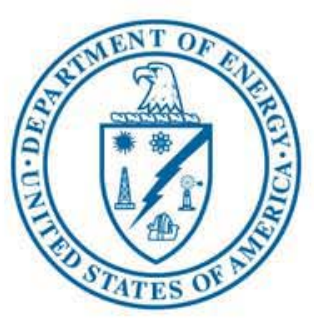

U.S. Department of Energy

Idaho Operations Office

Feasibility Assessment of the Water Energy Resources of the United States for New Low Power and Small Hydro Classes of Hydroelectric Plants

January 2006

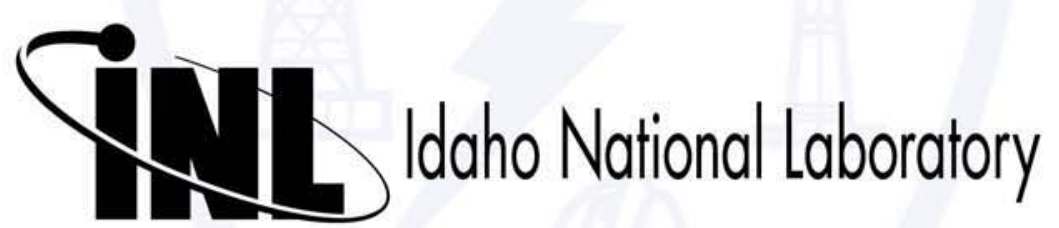




\section{Feasibility Assessment of the Water Energy Resources of the United States for New Low Power and Small Hydro Classes of Hydroelectric Plants}

Douglas G. Hall

January 2006

Prepared for the 
DOE-ID-11263

January 2006

Feasibility Assessment of the Water Energy Resources of the United States for New Low Power and Small Hydro Classes of Hydroelectric Plants

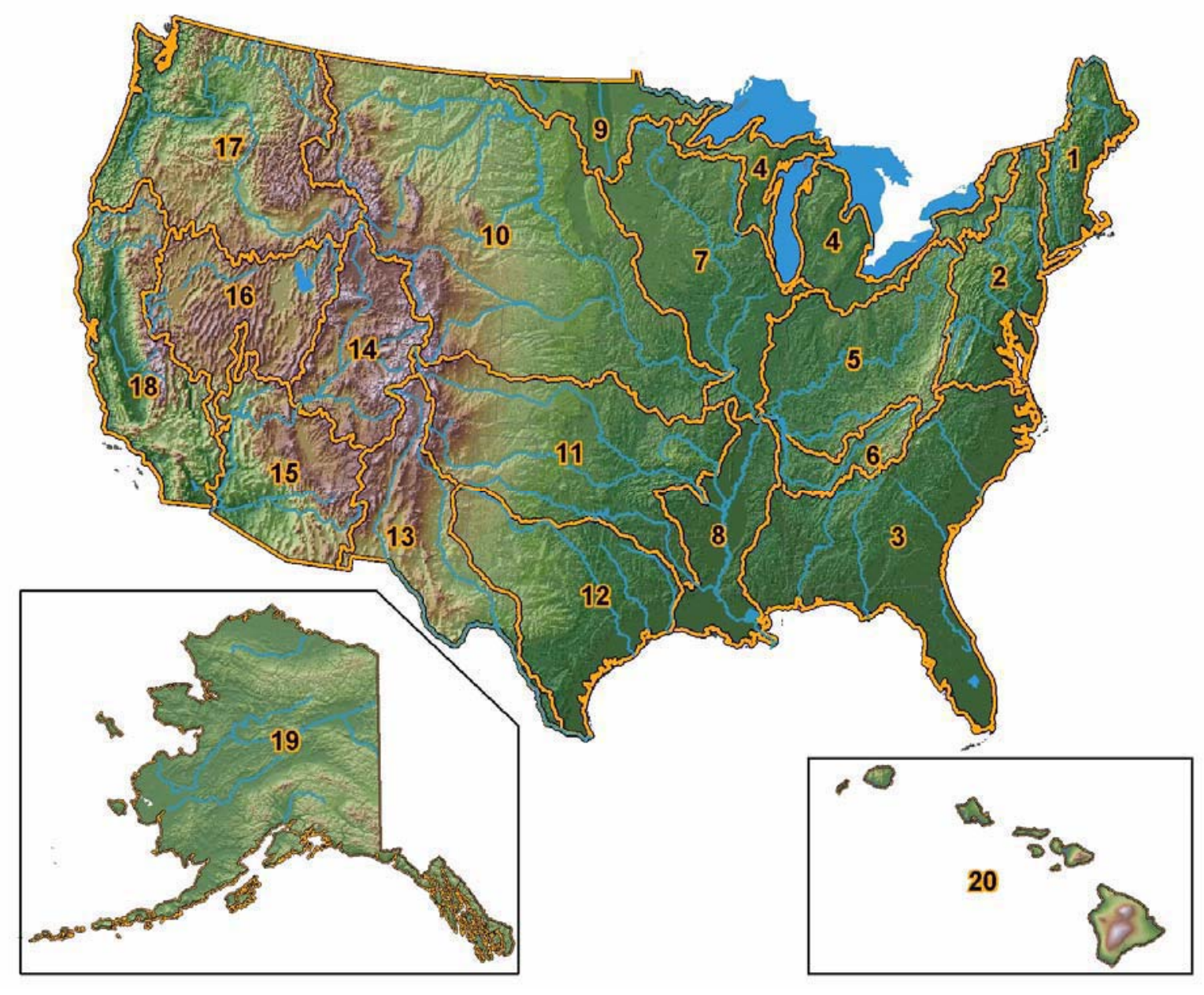

U.S. Department of Energy

Energy Efficiency and Renewable Energy

Wind and Hydropower Technologies 


\section{A Strong Energy Portfolio for a Strong America}

Energy efficiency and clean, renewable energy will mean a stronger economy, a cleaner environment, and greater energy independence for America. By investing in technology breakthroughs today, our nation can look forward to a more resilient economy and secure future.

Far-reaching technology changes will be essential to America's energy future. Working with a wide array of state, community, industry, and university partners, the U.S.

Department of Energy's Office of Energy Efficiency and Renewable Energy invests in a portfolio of energy technologies that will:

- $\quad$ Conserve energy in the residential, commercial, industrial, government, and transportation sectors

- Increase and diversify energy supply, with a focus on renewable domestic sources

- Upgrade our national energy infrastructure

- $\quad$ Facilitate the emergence of hydrogen technologies as a vital new "energy carrier."

To learn more, visit http://www.eere.energy.gov/

\section{NOTICE}

The information in this report is as accurate as possible within the limitations of the uncertainties of the basic data and methods used. The power potential quantities presented in the report were determined analytically. Document users need to ensure that the information in this report is adequate for their intended use. Battelle Energy Alliance, LLC makes no representation or warranty, expressed or implied, as to the completeness, accuracy, or usability of the data or information contained in this report.

The term "available" as used to refer to water energy resource sites or a category of power potential in this report denotes only that sites and their corresponding power potential are not located in a zone where hydropower development is unlikely and do not correspond to the location of an existing hydroelectric plant. The term does not denote any knowledge of the feasibility of developing or of any resource owner or agency having jurisdiction over a resource having an interest in developing or intent to develop any resource for the purpose of hydroelectric generation.

The term "feasible" as used to refer to water energy resource sites or a category of power potential in this report denotes only that sites and their corresponding power potential have met a limited set of feasibility criteria and been so designated via the methodology described in the report. Actual feasibility of a site for development as a hydroelectric plant must be determined by a site specific, comprehensive evaluation performed by the perspective developer.

\section{DISCLAIMER}

This information was prepared as an account of work sponsored by an agency of the U.S. Government. Neither the U.S. Government nor any agency thereof, nor any of their employees, makes any warranty, express or implied, or assumes any legal liability or responsibility for the accuracy, completeness, or usefulness of any information, apparatus, product, or process disclosed, or represents that its use would not infringe privately owned rights. References herein to any specific commercial product, process, or service by trade name, trademark, manufacturer, or otherwise, does not necessarily constitute or imply its endorsement, recommendation, or favoring by the U.S. Government or any agency thereof. The views and opinions of authors expressed herein do not necessarily state or reflect those of the U.S. Government or any agency thereof. 


\title{
Feasibility Assessment of the Water Energy Resources of the United States for New Low Power and Small Hydro Classes of Hydroelectric Plants
}

\author{
Douglas G. Hall, INL \\ Kelly S. Reeves, NPS \\ Julie Brizzee, INL \\ Randy D. Lee, INL \\ Gregory R. Carroll, BNI \\ Garold L. Sommers, INL, retired \\ IDAHO NATIONAL LABORATORY
}

Published January 2006

Prepared for the

U.S. Department of Energy

Office of Energy Efficiency and Renewable Energy

Wind and Hydropower Technologies Program

Idaho Operations Office 



\begin{abstract}
Water energy resource sites identified in the resource assessment study reported in Water Energy Resources of the United States with Emphasis on Low Head/Low Power Resources, DOE/ID-11111, April 2004 were evaluated to identify which could feasibly be developed using a set of feasibility criteria. The gross power potential of the sites estimated in the previous study was refined to determine the realistic hydropower potential of the sites using a set of development criteria assuming they are developed as low power (less than $1 \mathrm{MWa}$ ) or small hydro (between 1 and $30 \mathrm{MWa}$ ) projects. The methodologies for performing the feasibility assessment and estimating hydropower potential are described. The results for the country in terms of the number of feasible sites, their total gross power potential, and their total hydropower potential are presented. The spatial distribution of the feasible potential projects is presented on maps of the conterminous U.S. and Alaska and Hawaii. Results summaries for each of the 50 states are presented in an appendix. The results of the study are also viewable using a Virtual Hydropower Prospector geographic information system application accessible on the Internet at: http://hydropower.inl.gov/prospector.
\end{abstract}




\section{SUMMARY}

The U.S. Department of Energy (DOE) has an ongoing interest in assessing the water energy resources of the United States. Previous assessments have focused on potential projects having a capacity of $1 \mathrm{MW}$ and above. These assessments were also based on previously identified sites with a recognized, although varying, level of development potential.

The Idaho National Laboratory with the assistance of the U.S. Geological Survey completed water energy resource assessments of all 20 hydrologic regions in the United States in 2004 (reported in Water Energy Resources of the United States with Emphasis on Low Head/Low Power Resources, DOE/ID-11111, April 2004). In combination these results produced an assessment of the gross power potential of every natural stream in the United States. Parsing of the regional assessment results using geographic information system (GIS) tools produced assessment results for each of the 50 states.

In the present study, the water energy resource sites that were identified in the prior study were evaluated to determine the feasibility of their development using a set of feasibility criteria. These criteria considered site accessibility, load or transmission proximity, and land use or environmental sensitivities that would make development unlikely. Water energy resource sites that met the feasibility criteria were designated as feasible potential project sites. More realistic estimates of the power potential of these sites were determined by assuming a development model not requiring a dam obstructing the watercourse or the formation of a reservoir. The development model included a penstock running parallel to the stream, culminating in a powerhouse whose tailwater returned the working flow to the stream. It was assumed that only a low power $(<1 \mathrm{MWa})$ or small hydro ( $\geq 1 \mathrm{MWa}$ and $\leq 30 \mathrm{MWa}$ ) plant would be installed at the site. The working flow was restricted to half the stream flow rate at the site or sufficient flow to produce $30 \mathrm{MWa}$, whichever was less. Penstock lengths were limited by the lengths of penstocks of a majority of existing low power or small hydroelectric plants in the region. A methodology was employed to determine the optimum penstock length and location on the stream reach corresponding to the site based on yielding the maximum hydraulic head with the minimum length.

The population of water energy resource sites that was assessed was composed of slightly over 500,000 sites having a collective, gross power potential of slightly less than $300,000 \mathrm{MWa}$. The feasibility assessment identified approximately 130,000 sites meeting the feasibility criteria. These sites have a total gross power potential of nearly 100,000 MWa. Application of the development model with the associated limits on working flow and penstock length resulted in a total hydropower potential of 30,000 MWa. This amount of potential power is on the order of the total annual average power of the entire existing U.S. hydroelectric plant population. The approximately 5,400 sites that could potentially be developed as small hydro plants have a total hydropower potential of a little over 18,000 MWa. If developed, these projects would result in a greater than $50 \%$ increase in hydroelectric generation.

The regional results were parsed into results for the individual 50 states using GIS tools. Gross power potentials and hydropower potentials for feasible 
potential projects are presented for each state. Six western states, Alaska, Washington, California, Idaho, Oregon, and Montana, have the highest power potentials. From the perspective of the density of hydropower potential $(\mathrm{kWa} / \mathrm{sq} \mathrm{mi})$ that could feasibly be developed, Hawaii and Washington have the highest densities of feasibly developable resources. By comparing hydropower potential associated with feasible projects to the total annual average power of the existing hydroelectric plants in the state, it was found that 33 states could increase their hydropower generation by $100 \%$ or more and 41 states could realize increases of more than 50\%. A map showing the locations of the feasible potential project sites indicates that with the exceptions of part or most of eight states, potential projects are abundant throughout the country. Summaries of the gross and feasible potential in each state are provided in Appendix B.

It is concluded from the study results that there are a large number of opportunities for increasing U.S. hydroelectric generation throughout the country that are feasible based on an elementary set of feasibility criteria. These opportunities collectively represent a potential for approximately doubling U.S. hydroelectric generation (not including pumped storage), but more realistically offer the means to at least increase hydroelectric generation by more than $50 \%$. Compared to current in-state hydroelectric generation, nearly all of the states are underutilizing their natural stream water energy resources and could realize significant gains in generation from new hydroelectric plant development. Western states, including Alaska and Hawaii, have particularly large feasible hydropower potentials or densities of feasible hydropower potential. The majority of the identified feasible hydropower potential could be harnessed without constructing new dams, using existing techniques and technologies developed over the long and extensive history of installing small hydroelectric plants in the U.S.

The results of the prior assessment of water energy resources and this feasibility study have been incorporated into a GIS application accessible on the Internet at: http://hydropower.inl.gov/prospector. The application named the Virtual Hydropower Prospector (VHP) displays sites on hydrologic region maps. In addition to the sites, the user can select what context features are displayed, including hydrography, the power system, transportation, areas and places, and land use. Tools to select features and display their attributes are provided along with standard map navigation tools. The application has a print capability so that any map the user creates can be printed or incorporated into a document or slide show. VHP extends and enhances this report by providing detailed information about water energy resource sites and feasible potential projects and providing sufficient information for users to conduct specialized, preliminary feasibility assessments.

The last section in the report provides recommendations for additional studies. These include: refining the feasibility assessment by considering additional factors affecting feasibility and true hydropower potential; upgrading VHP by displaying high resolution topography and additional context feature sets; using the data produced in the prior and present study to produce customized reports of resources on military bases and tribal lands; performing natural stream resource and feasibility studies for other countries; performing similar assessments for other water energy resources such as ocean, tidal, and 
constructed waterways; and producing a catalog of technologies and cost estimating tools for small hydroelectric plants. These studies have the common objective of facilitating the planning and development of small hydroelectric plants with their attendant benefits using diverse technologies at locations around the globe.

For further information or comments, please contact:

Douglas G. Hall, Project Manager

Small Hydropower Resource Assessment and Technology Development Project Idaho National Laboratory

P.O. Box 1625, MS 3830

Idaho Falls, ID 83415-3830

Phone: (208) 526-9525

E-mail:ouglas.hall@inl.gov 


\section{ACKNOWLEDGMENTS}

The authors acknowledge and express their appreciation for the contributions to this study made by the U.S. Geological Survey: Earth Resources Observation Systems Data Center for producing the Elevation Derivatives for National Applications (EDNA) datasets for the 20 hydrologic regions of the United States, including high resolution synthetic hydrography, and programming and data processing, using the EDNA data in conjunction with climatic data to produce the basic power potential datasets and elevation annotated synthetic hydrography with particular recognition of the contributions of Ms. K. L. Verdin and Mr. M. Cast. The authors acknowledge and express their appreciation of project team member Ms. S. E. White, who produced the Virtual Hydropower Prospector GIS application that extends access to and the utility of the study results presented in this report. The authors acknowledge and express their appreciation for the technical editing and word processing of this document by Ms. J. K. Wright and Ms. D. R. Southwick, respectively. The authors acknowledge and express their appreciation for the technical guidance provided by members of the project technical advisory committee who are too numerous to mention by name. Particular acknowledgment and appreciation of Ms. P. A. Brookshier of the U.S. Department of Energy Idaho Operations Office is expressed for requesting the resource assessment research culminating in this report. 


\section{CONTENTS}

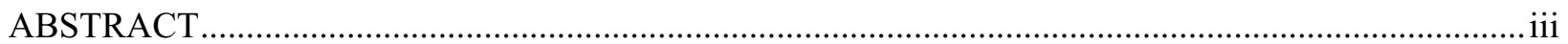

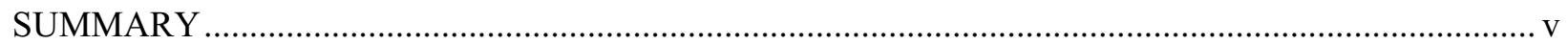

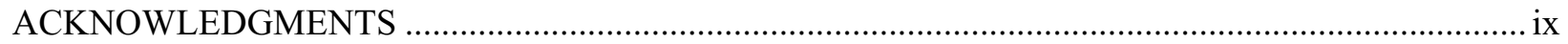

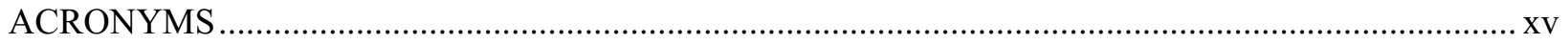

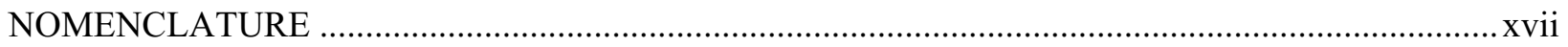

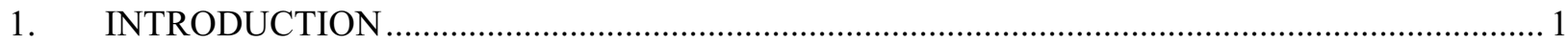

2. STUDY AREA-TWENTY HYDROLOGIC REGIONS OF THE UNITED STATES ................. 4

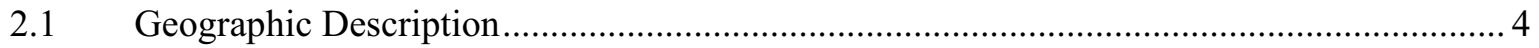

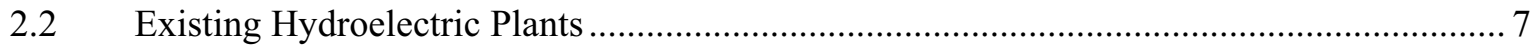

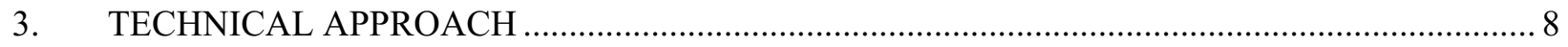

3.1 Water Energy Resource Site Population ..................................................................... 8

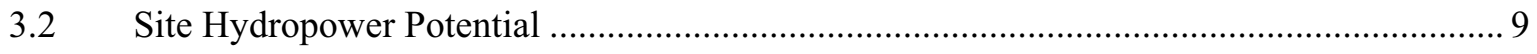

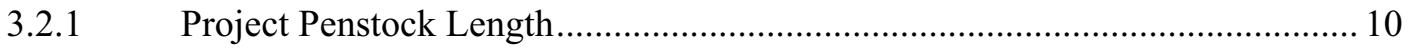

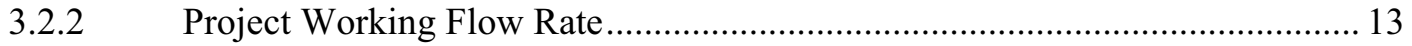

3.2.3 Logic for Selecting Site Development Parameters.......................................... 13

3.2.4 Summary of Site Development Criteria for Estimating Project Hydropower

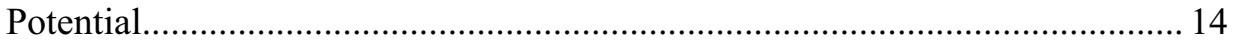

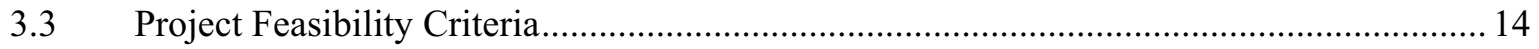

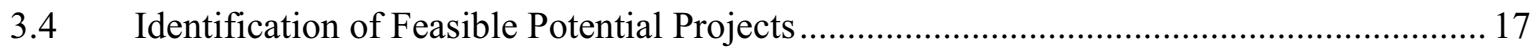

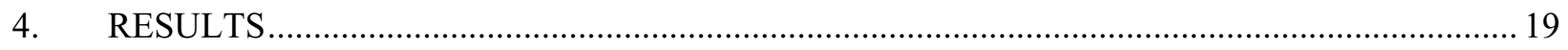

4.1 Power Category Distribution of Assessed Water Energy Resource Site Population .......... 19

4.2 Power and Technologies Class Distribution of Feasible Potential Projects ....................... 21

4.3 Spatial Distribution of Water Energy Resources and Potential Projects .......................... 24

4.4 Potential Project Location and Attributes Provided by the Virtual Hydropower

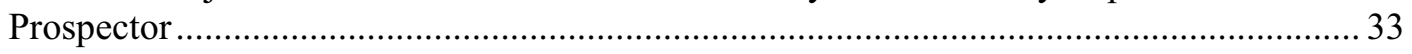

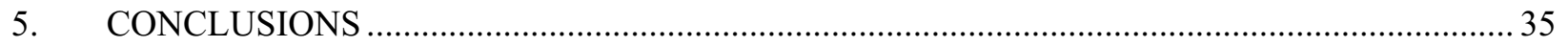

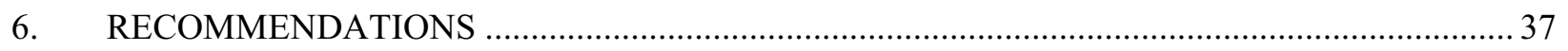

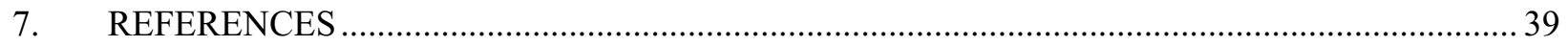




\section{FIGURES}

1. The 20 hydrologic regions (units) of the United States.............................................................. 5

2. Power class distribution of U.S. hydroelectric plants and their total average power. ...................... 7

3. Power class distributions of U.S. water energy resource sites by number and gross power

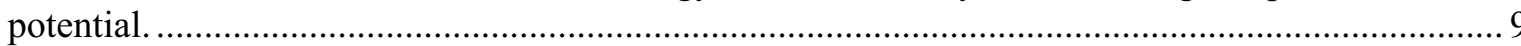

4. Penstock lengths of low power hydroelectric plants in the Pacific Northwest Region................... 10

5. Number of low power hydroelectric plants in the Pacific Northwest Region by penstock length interval and cumulative percentage of plants having penstocks of a given length or shorter.

6. Penstock lengths of small hydroelectric plants in the Pacific Northwest Region. 11

7. Number of small hydroelectric plants in the Pacific Northwest Region by penstock length interval and cumulative percentage of plants having penstocks of a given length or shorter.

8. Penstock length upper limits for low power and small hydro plants in 20 U.S. hydrologic regions.

9. Logic for determining whether a water energy resource site should be developed as a low power or small hydro project using development criteria thereby establishing working flow rate, penstock length, working hydraulic head, and hydropower potential.

10. a) Distribution of the distance of low power and small hydroelectric plants to a city or population center boundary. b) Cumulative distribution of the distance of low power and small hydroelectric plants to a city or population center boundary.

11. Power category distribution of water energy resource sites having gross power potentials greater than or equal to $10 \mathrm{kWa}$ and their associated total gross power potential.

12. Operating envelopes of three classes of low power technologies.

13. Power category distribution of feasible potential projects and their associated total hydropower potential with low power projects further divided by low power technology classes.

14. Distribution of (a) number and (b) group hydropower potential of U.S. low power potential projects.

15. Distribution of (a) number and (b) group hydropower potential of U.S. small hydro potential projects. 
16. Total gross power potential of water energy resources in the 50 states of the United States divided into feasible, other available, excluded, and developed power categories.

17. Total gross power potential density of water energy resources in the 50 states of the United States divided into feasible, other available, excluded, and developed power categories

18. Total hydropower potential of feasible low power and small hydro projects in the 50 states of the United States.

19. Total hydropower potential density of feasible low power and small hydro projects in the 50 states of the United States.

20. Existing hydroelectric plants and feasible potential hydropower projects in the United States.

21. Desktop of the Virtual Hydropower Prospect GIS application showing its areas for display and control.

\section{TABLES}

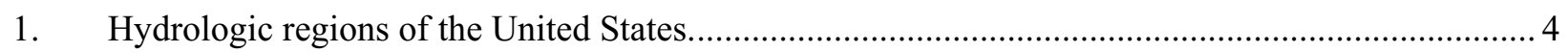

2. Penstock upper limits for low power and small hydro plants by hydrologic region. ..................... 13

3. Distances of $90 \%$ of low power and small hydro plants from cities and populated area boundaries in 20 hydrologic regions. 17

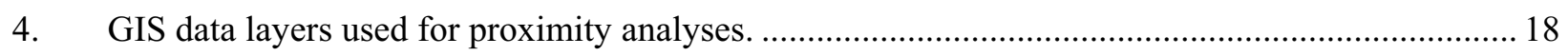

5. Water energy resource site attributes used in development feasibility assessment........................ 18

6. Power potential of U.S. water energy resource sites in power categories divided into power classes and low power technology classes.

7. Comparison of hydropower potential of feasible potential projects with total annual average power of hydroelectric plants in each of the 50 states of the United States. 


\section{ACRONYMS}

BNI Bechtel National, Incorporated

DEM digital elevation model

DOE U.S. Department of Energy

EDNA Elevation Derivatives for National Applications

An analytically derived, three-dimensional dataset in which hydrologic features have been determined based on elevation data from the National Elevation Dataset, resulting in three-dimensional representations of "synthetic streams" (stream path coordinates plus corresponding elevations) and an associated catchment boundary for each synthetic reach (based on 1:24K-scale data for the conterminous United States and 1:63,360-scale data for Alaska) (Note: EDNA synthetic stream reaches do not uniformly coincide with NHD reaches. Conflation of EDNA and NHD features to improve the quality of both datasets is a later phase EDNA development.) (http://edna.usgs.gov)

EROS Earth Resources Observation Systems

FERC Federal Energy Regulatory Commission

GIS geographic information system

A set of digital geographic information, such as map layers and elevation data layers, which can be analyzed using both standardized data queries as well as spatial query techniques.

HPRA Hydroelectric Power Resources Assessment

HUC hydrologic unit code

INL Idaho National Laboratory

NHD National Hydrography Dataset

A comprehensive set of digital spatial data that contains information about surface water features such as lakes, ponds, streams, rivers, springs, and wells. (http://nhd.usgs.gov)

NPS Nuclear Placement Services

USGS U.S. Geological Survey

VHP Virtual Hydropower Prospector 


\section{NOMENCLATURE}

Annual mean flow rate

Annual mean power

Attribute

Capacity

Catchment

Drainage area

Drainage basin

EDNA stream node

EDNA stream reach

Exclusion zone

Feasible potential project

Gross hydraulic head
The statistical mean of the flow rates occurring at a particular location during the course of 1 year. The annual mean flow rates were estimated using regional flow regression equations based on gauged stream flow rates that occurred over a period of many years. The annual mean flow rate in any given year will usually differ from the value predicted by the equations.

The statistical mean of the rate at which energy is produced over the course of 1 year. When based on the predicted annual mean flow rate and associated hydraulic head at a water energy resource site or based on working fractions of these quantities associated with a feasible potential project, the predicted annual mean power is the mean of the annual mean powers occurring over a period of many years. Such power values are denoted by units of "kWa" or "MWa". The actual annual mean power in a specific year will usually differ from the predicted value.

A power rating of a hydroelectric plant based on electricity generation at this rate throughout the course of a year would produce the average annual electricity generation of the plant; sometimes referred to as average megawatt power rating denoted in some usages by "MWa."

Characteristic information about a feature such as name or owner, or data describing it such as length or voltage.

Typically refers to the design power rating of a hydroelectric plant and are denoted by units of "MW. Considering all U.S. hydroelectric plants, the average ratio of capacity to annual mean power is a factor of two.

The local drainage area surrounding a stream reach that provides runoff to the reach as opposed to flow entering the reach at its upstream end resulting from runoff from upstream catchments.

The total surface area of the topography of a drainage basin.

The geographic area supplying runoff to a particular point on a stream equal to the area of all the catchments associated with upstream stream reaches supplying flow to the point.

Starting point of an EDNA synthetic stream, a confluence on it or point of reference, or its terminus where it enters a saltwater body or a sink.

That portion of an EDNA synthetic stream between two EDNA stream nodes. (Note: Each stream reach has an associated local catchment and an associated drainage basin.)

An area in which hydroelectric plant development is highly unlikely due to federal land use statutes or policies or environmental sensitivities.

A water energy resource site that has met a set of feasibility criteria, thus identifying it as feasible for development

The hydraulic head corresponding to the difference in the elevations at the upstream and downstream ends of a stream reach comprising a water energy resource site. 
Gross power potential

Hydraulic head

Hydropower potential

Map server

Penstock

Power category

Power class

(water energy

resource sites)
Ideal hydroelectric power based on an annual mean flow rate and an associated gross hydraulic head having units of MWa (average megawatts) in this report. The actual value in any given year will usually differ from the predicted value because of annual variations in annual mean flow rate. (Note: In the case of the developed power potential of an actual hydroelectric plant, annual mean power [average power] of the plant is used as the developed power potential.)

The elevation difference between the upstream and downstream ends of a column of water (such as in a penstock).

The power potential of a feasible potential project based on its working flow rate and working hydraulic head having units of MWa (average megawatts) in this report.

An internet-based application that displays geographic information on a map.

A pipe conducting water from the point of takeoff on a stream to a turbine.

The power category names used in this report to differentiate between categories of power potential are: "total," "developed," "excluded," "available" and "feasible." Total refers to all the power potential in a study area.

Developed refers to the power potential corresponding to the sum of the annual mean power of all the existing hydroelectric plants in a study area. Excluded refers to the power potential existing within zones in a study area where hydropower development is highly unlikely based on federal law or policy or known environmental sensitivities. Available refers to power potential corresponding to water energy resource sites that are not located in zones where hydropower development is unlikely and are not collocated with an existing hydroelectric plant. (Note: Available does not denote availability based on ownership or control.) Feasible refers to power potential corresponding to water energy resource sites that have met the limited set of feasibility criteria used in this study. (Note: The actual feasibility of a specific site must be determined by a comprehensive evaluation performed by a perspective developer.)

The power and technology classes into which water energy resource sites have been divided based on their power potential and gross hydraulic head:

\section{- High Head/High Power \\ - Low Head/High Power \\ - High Head/Low Power \\ - Convention Turbine \\ - Unconventional Systems \\ - Microhydro}

where high power refers to $\geq 1 \mathrm{MWA}$, low power refers to $<1 \mathrm{MWA}$, high head refers to $\geq 30 \mathrm{ft}$, and low head refers to $<30 \mathrm{ft}$. The conventional turbines, unconventional systems, and microhydro power technology classes are subclasses of the low power class defined by their operating envelopes as shown in the figure below. 
Power class (feasible potential projects)

Reach

Region

VHP desktop

Water energy resource site

Working flow rate

Working head

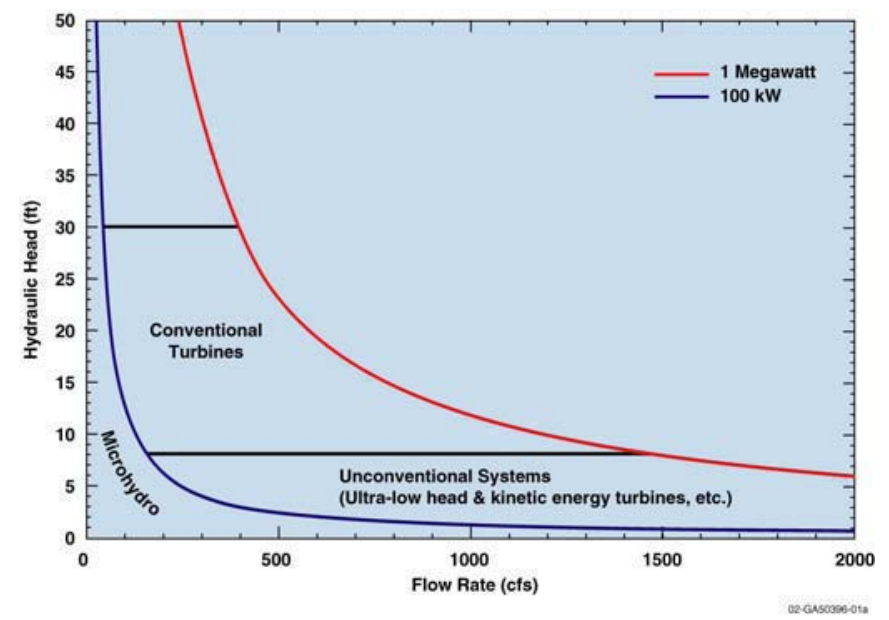

The power and technology classes into which feasible potential projects have been divided based on their hydropower potential and working hydraulic head:

\section{- Small Hydro \\ - Low Head-Convention Turbines \\ - Low Head-Unconventional Systems \\ - Microhydro}

where small hydro refers to hydropower potential $\geq 1$ MWA and $\leq 30$ MWA, and low power refers to hydropower potential $<1$ MWA. The conventional turbines, unconventional systems, and microhydro power technology classes are subclasses of the low power class defined by their operating envelopes as shown in the figure above except with no upper limit on hydraulic head for conventional turbines. When referring to the above figure for feasible potential projects, power ("1 Megawatt" or "100 kW") is hydropower potential, "Flow Rate" is working flow rate, and "Hydraulic Head" is working hydraulic head.

A stream segment often delineated by two successive confluences.

One of the 20 hydrologic regions into which the United States is divided, each composed of a set of drainage basins; in general, all flowing to the same stream or streams through which water flows out of the region. Regions are designated by hydrologic unit codes (HUC) from 1 through 20.

The Virtual Hydropower Prospector (VHP) GIS application desktop displayed in a single window and composed of the map view and controls for selecting the graphical and numerical information displayed by the application. (Note: Multiple windows each containing a complete VHP desktop devoted to a different hydrologic region may be open at the same time.)

A stream reach for which the values of hydraulic head, annual mean flow rate, and power potential have been estimated. The site location is taken as the longitudinal midpoint of the reach.

The rate of flow of water through a turbine.

The hydraulic head equal to the difference in the elevations of the entrance and exit of a penstock. 


\section{Feasibility Assessment of the Water Energy Resources of the United States for New Low Power and Small Hydro Classes of Hydroelectric Plants}

\section{INTRODUCTION}

In June 1989, the U.S. Department of Energy (DOE) initiated the development of a National Energy Strategy to identify the energy resources available to support the expanding demand for energy in the United States. Past efforts to identify and measure the undeveloped hydropower capacity in the United States have resulted in estimates ranging from about $70,000 \mathrm{MW}$ to almost 600,000 MW. The Federal Energy Regulatory Commission's (FERC's) capacity estimate was about 70,000 MW, and the U.S. Army Corps of Engineers' theoretical estimate was 580,000 MW. Public hearings conducted as part of the strategy development process indicated that the undeveloped hydropower resources were not well defined. One of the reasons was that no agency had previously estimated the undeveloped hydropower capacity based on site characteristics, stream flow data, and available hydraulic heads.

As a result, DOE established an interagency Hydropower Resources Assessment Team to ascertain the country's undeveloped hydropower potential. The team consisted of representatives from each power marketing administration (Alaska Power Administration, Bonneville Power Administration, Western Area Power Administration, Southwestern Power Administration, and Southeastern Power Administration), the Bureau of Reclamation, the Army Corps of Engineers, the FERC, the Idaho National Laboratory (INL), and the Oak Ridge National Laboratory. The interagency team drafted a preliminary assessment of potential hydropower resources in February 1990. This assessment estimated that $52,900 \mathrm{MW}$ of undeveloped hydropower capacity existed in the United States.

Partial analysis of the hydropower resource database by groups in the hydropower industry indicated that the hydropower data included redundancies and errors that reduced confidence in the published estimates of developable hydropower capacity. DOE has continued assessing hydropower resources to correct these deficiencies, improve estimates of developable hydropower, and determine future policy. An assessment of the opportunities for increased hydropower capacity in the United States identified 5,677 sites having a total capacity increase potential of about 70,000 MW (Connor et al. 1998). Consideration of environmental, legal, and institutional constraints resulted in an estimate of about 30,000 MW of viable opportunities to increase the United States hydropower capacity.

The previous resource assessment (Connor et al. 1998) was a site-based assessment, which evaluated the potential for obtaining increased hydropower capacity at previously identified sites. During the 2002 to 2004 timeframe, INL conducted regional assessments and then a national assessment of the power potential of all streams in the study area culminating in a report documenting the power potential of all United States natural streams (Hall et al. 2004). This comprehensive assessment conducted in conjunction with the U.S. Geological Survey (USGS) used state-of-the-art digital elevation models and geographic information system (GIS) tools to estimate the power potential of a mathematical analog of every stream segment in the country. Summing the estimated power potential of all stream segments provided an estimate of the total power potential of U.S. natural streams. The study only assessed water energy resources associated with natural water courses (constructed waterways, tides, waves, and ocean currents were not included).

While the gross power potential estimates in the 2004 report are useful, the greatest insight gained from the reported results is the relative magnitudes when power potentials are compared. 
Comparison of the magnitudes of state and regional power potentials and potential power densities shows those areas of the country having the most abundant and concentrated water energy resources. The spatial distribution maps included in the report also provide a visual measure of the relative concentration of water energy resources in the country. Comparison of developed, excluded, and available power potentials to the total power potential provides relative measures of these quantities that can be compared between areas to see the trends of past policy and development decisions and opportunities for future development. Comparison of power potential in the various power classes shows the relative abundance of water energy resources having certain hydraulic head and power characteristics, which can be used to guide future technology development.

Having completed the comprehensive assessment of the United States natural stream resources, the project addressed the ultimate resource questions:

- Which of the identified water energy resource sites can feasibly be developed?

- How much power can realistically be generated at the sites that are feasible?

- Where are the feasible potential project sites located?

The study reported in this document generated information that answers these questions. Feasibility criteria including exclusion of development, site accessibility, and transmission and load proximity were used to identify which water energy resource sites are locations for feasible potential projects. Development criteria regarding working flow rate and realistic penstock lengths were used to determine estimates of the realistic power potential of the feasible potential projects. The low power or small hydro project model that was used assumed power production without total stream impoundment or the creation of a reservoir. ${ }^{\text {a }}$ Since the project worked with georeferenced data from inception, the location of feasible potential projects was known once they were identified. While the report contains a distribution map showing the locations of feasible projects, this map is most valuable for detecting gross concentrations of projects. A companion GIS application called the Virtual Hydropower Prospector (VHP), which is available on the Internet (http://hydropower.inl.gov/prospector), was produced as a tool for locating water energy resource sites and feasible potential projects and performing customized, preliminary feasibility assessments.

As with the results in the predecessor report, the reader is cautioned about an important distinction that is made in the presentation of power results in this report. The assessment method that was used produced estimates of power potential as annual mean power. This parameter is not the same as hydropower capacity, which has been assessed in other assessment efforts. The difference lies in potential being based on estimates of annual mean flow rate or a working fraction thereof combined with gross or working hydraulic head to produce an estimate of annual mean power potential. In contrast, hydropower capacity is the design power capacity of a real or hypothetical hydroelectric plant. Plant design capacity is derived based on anticipated flow rates, which may not be natural stream flows, and may be determined by economic considerations, and other factors. Because the assessment results are power potential values rather than plant capacity values, total power potential values listed in this report will appear low when compared with the results of prior assessments, which are based on owners' selections of design capacity or an economic model that selects a design capacity. The values listed in this report are directly convertible to generation by multiplying them by the number of hours in a year without the need to apply a capacity factor.

a. The development plant model included entry of part of the stream flow into a penstock running parallel to the stream channel leading to a powerhouse downstream of which the water was returned to the stream. Entry to the penstock could be accomplished by water takeoff at a bend, obstructing a secondary channel to create a power channel, or the use of a submerged weir. 
This report is organized by presenting a description of the study area, details of the methods that were employed to perform the assessment, results of the assessments considering the study area at large, general conclusions based on the study results, and recommendations for additional related research. Appendix A describes the exclusion zones used in the study. Appendix B, which is a major fraction of the volume, contains summaries of the study results for each of the 50 states. 


\section{STUDY AREA - TWENTY HYDROLOGIC REGIONS OF THE UNITED STATES}

The United States is divided into 20 hydrologic regions designated by the USGS that are shown in Figure 1. The hydrologic regions have been numbered using a hydrologic unit code (HUC) of 1 through 20. For example, the North Atlantic Hydrologic Region has been assigned a hydrologic unit code of 1 and is sometimes referred to as "HUC 1." Eighteen hydrologic regions, HUC 1 through HUC 18, have been assigned to the conterminous United States. The remaining two hydrologic regions, HUC 19 and HUC 20, are assigned to Alaska and Hawaii, respectively. An additional region assigned to Puerto Rico, HUC 21, was not evaluated during this study. The hydrologic regions are listed by region or HUC number in Table 1.

Table 1. Hydrologic regions of the United States.

\begin{tabular}{|c|l|}
\hline $\begin{array}{c}\text { Region } \\
\text { (HUC) } \\
\text { No. }\end{array}$ & \multicolumn{1}{c|}{ Name } \\
\hline 1 & North Atlantic \\
\hline 2 & Mid-Atlantic \\
\hline 3 & South Atlantic-Gulf \\
\hline 4 & Great Lakes \\
\hline 5 & Ohio \\
\hline 6 & Tennessee \\
\hline 7 & Upper Mississippi \\
\hline 8 & Lower Mississippi \\
\hline 9 & Souris Red-Rainy \\
\hline 10 & Missouri \\
\hline 11 & Arkansas-White-Red \\
\hline 12 & Texas Gulf \\
\hline 13 & Rio Grande \\
\hline 14 & Upper Colorado \\
\hline 15 & Lower Colorado \\
\hline 16 & Great Basin \\
\hline 17 & Pacific Northwest \\
\hline 18 & California \\
\hline 19 & Alaska \\
\hline 20 & Hawaii \\
\hline & \\
\hline
\end{tabular}

\subsection{Geographic Description}

The conterminous United States from east to west consists of a coastal plain along the Atlantic, the Appalachian Mountains, a vast interior lowland, and the western Cordillera, which is a wide system of mountains and valleys extending to the Pacific Ocean. The Atlantic Coastal plain is narrow in the mid-Atlantic states, but gradually widens toward the south to form a broad coastal plain in the Carolinas and Georgia. Estuaries and bays form deep indentations in the coastal plain, especially Delaware Bay and Chesapeake Bay in Delaware, Maryland, and Virginia. Inland from the coastal plain, the Piedmont forms a gentle rolling upland that borders the eastern slope of the Appalachians. The Appalachian Mountains form a long southwest-northeast trending chain of mountains that extend from northern Alabama to New England. From New York southward, the Appalachians are composed of a long series of alternating ridges and valleys, created by folding and erosion of ancient rock layers. The mountains continue into New England, but the ridge and valley pattern is absent. Breaks in mountain ridges, known as "water gaps," allow several major rivers to cross part or all of this mountain chain, for example, the Connecticut River in New England, the Hudson River in New York, the Delaware River in Pennsylvania, the Susquehanna River in New York, Pennsylvania, and Maryland, and the Potomac River in Virginia, West Virginia, and Maryland.

West of the Appalachians lies a vast interior lowland that covers nearly half of the conterminous United States. It includes the drainage of the Mississippi River and its two major tributaries, the Ohio and Missouri rivers. The Mississippi River is the principal feature of this lowland, forming a major north-south waterway into the heartland of the United States. The lowland includes a wide coastal plain bordering the Gulf of Mexico, with rolling hills, river valleys, and extensive prairies lying north of the coastal plain. Dense deciduous woodlands 


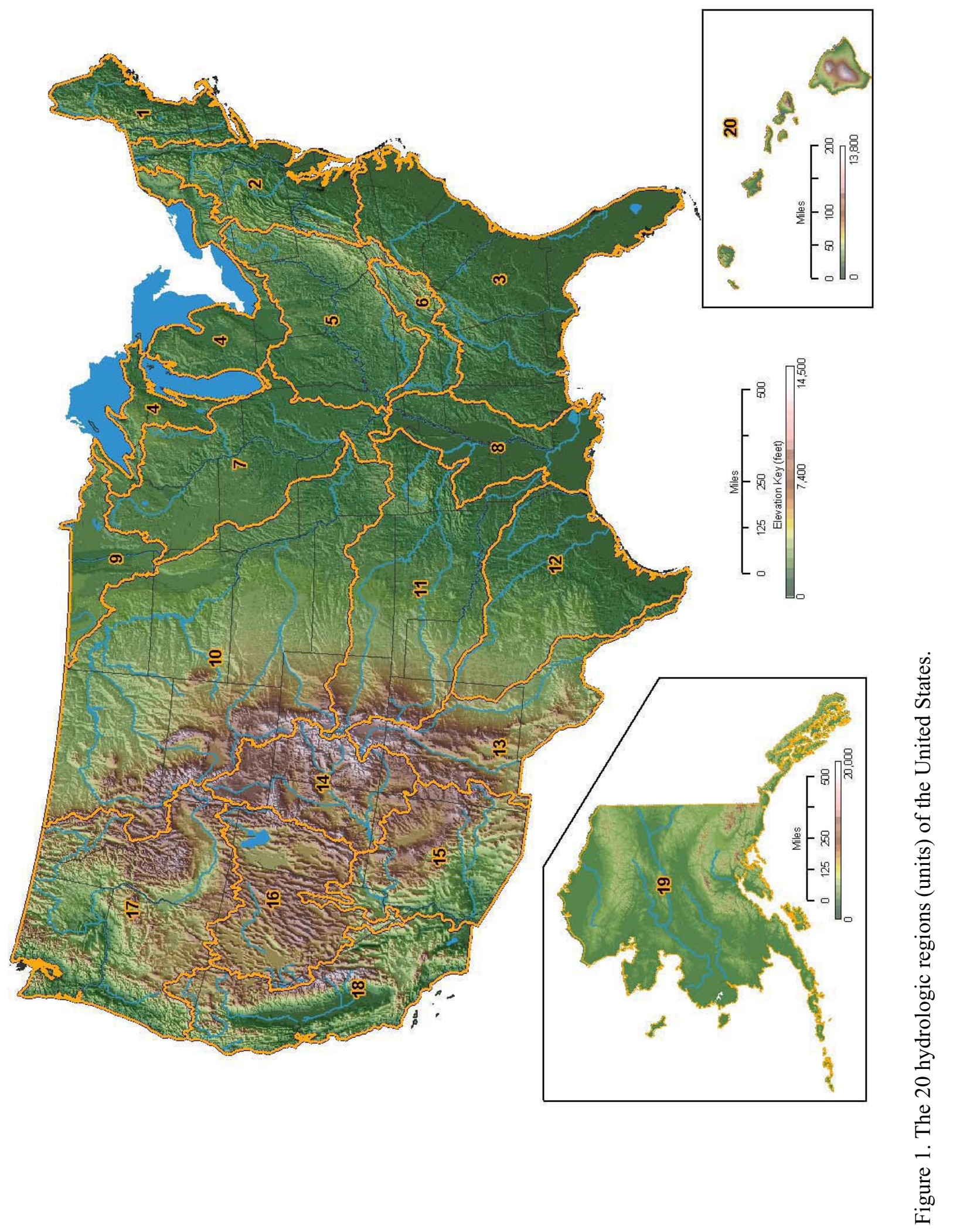


originally covered the eastern portion of the lowland, transitioning to pine forests in the south. Further west, the woodland gives way to prairie, a vast grassland mostly devoid of trees. Much of the woodland and prairie has been converted to agricultural use. The climate ranges from warm in the south to cold in the north, with precipitation decreasing toward the west.

A complex series of high mountain ranges, valleys, canyons, and plateaus create a spectacular landscape in the western United States. The Great Plains, which form the western portion of the interior lowlands, gradually rise thousands of feet in elevation to meet the abrupt eastern front of the Rocky Mountains. The Rocky Mountains are a chain of high mountain ranges extending from Mexico through the western United States into Canada. The crest of the Rocky Mountains forms the continental divide. Streams east of the continental divide flow to the Atlantic Ocean, the Gulf of Mexico, and the Hudson Bay. Most streams west of the continental divide flow to the Pacific Ocean or to the Gulf of California. However, streams in many areas west of the continental divide discharge into saline lakes or mud flats. These streams remain within the Great Basin, a series of semi-arid to arid mountains, valleys, and plains with no outlet to the sea. More high mountains are found in the West Coast states: the Cascades in Washington and Oregon and the Sierra Nevada in California. An additional set of mountain ranges, known as the Coast Ranges, borders the Pacific coastline of these three states.

The landscape varies greatly in the West. Cool, damp rainforests cover the slopes of the Coast Ranges in the Pacific Northwest. The Cascades and the Sierra Nevada have extensive coniferous forests due to abundant Pacific moisture. However, these ranges create a rain shadow that forms dry steppes and deserts immediately to their east. The two major rivers of the West, the Columbia River and the Colorado River, have been extensively developed for hydropower. The Grand Coulee Dam in Washington and the Hoover Dam on the Nevada-Arizona border are the best known of the West's hydropower mega-projects. Interior valleys have fertile soils suitable for farming, including the Great Central Valley of California, the
Willamette Valley of Oregon, and the Snake River Plain in Idaho. In many places, irrigation water from mountains or rivers is imported to water crops in arid areas. Water is also imported for hundreds of miles to supply the domestic needs of major coastal cities in California.

Alaska, the largest, northernmost, and least densely populated state, extends from temperate rainforests on the southeastern panhandle, to arctic tundra on the arid North Slope. High coastal and near-coastal mountain ranges receive abundant Pacific moisture as snow and ice to create the largest glaciated area outside of Antarctica and Greenland. Further inland, the Alaska Range reaches elevations exceeding 20,000 feet on Mt. McKinley, the highest point in North America. Approximately one-third of the state lies north of the Arctic Circle.

A large interior lowland, extending across the central portion of the state, is drained primarily by the Yukon River and its tributaries. Rivers and streams in this area are typically braided and are subject to intense season flooding due to rapid melting of snow and ice during the spring/summer thaw. The east-west trending Brooks Range lies north of this lowland. North of the Arctic Circle, the North Slope, a flat, arid plain slopes northward from the Brooks Range to the Arctic Ocean. Permafrost and tundra dominate the North Slope, home to the Arctic National Wildlife Refuge, as well as some of the United States' most productive oil fields.

Hawaii, a chain of eight volcanic islands, lies near the center of the Pacific Ocean, approximately 2,200 miles from the U.S. mainland. The island chain was formed by motion of the Pacific Plate over a stationary volcanic hot spot that extrudes molten rock to create a series of volcanic islands. The islands nearest to the hot spot, Hawaii and Maui, have active volcanoes and are the largest islands in the chain. Islands further from the hot spot no longer contain active volcanoes and are generally smaller due to subsidence and erosion. Islands with northern and eastern exposures to the Pacific receive abundant moisture up to several hundred inches per year. The opposite southern and western slopes lie in a rain shadow, where arid conditions predominate. 
Some of the smaller islands are relatively dry because they lie entirely within the rain shadow of larger islands.

The Hawaiian Islands lack the large watersheds found on the U.S. mainland. Instead, streams on the islands generally run outward in a radial pattern from volcanic summits and mountain ridges toward the sea. The largest streams with the highest flow levels are found on the wetter northern and eastern slopes of the major islands.

\subsection{Existing Hydroelectric Plants}

The Hydroelectric Power Resources Assessment (HPRA) Database (FERC 1998) lists 2,378 hydroelectric plants in the United States (not including pumped storage plants). The distribution of these plants by power class is shown in Figure 2. The power classes are defined on the basis of annual average power $\left[\mathrm{P}_{\mathrm{a}}=\right.$ Annual Generation/Annual Hours $(8,760 \mathrm{hr})]$ rather than by design capacity. They include:

- Low power: $\mathrm{P}_{\mathrm{a}}<1 \mathrm{MWa}$

- Small hydro: $1 \mathrm{MWa} \leq \mathrm{P}_{\mathrm{a}} \leq 30 \mathrm{MWa}$

- Large hydro: $\mathrm{P}_{\mathrm{a}}>30 \mathrm{MWa}$.

The plant population produces energy at a total annual average rate of 35,432 MWa based on the average annual generation data in the HPRA Database. The 192 large hydro plants, which are only $8 \%$ of the plant population, produce $80 \%$ of the annual average power. On the other hand, 2,184 low power and small hydro plants constitute $92 \%$ of the plant population and produces the remaining $20 \%$ of the annual average power. Clearly, the public perception of hydroelectric plants is based on a small percentage of the plant population almost certainly without recognition that the vast majority of hydroelectric plants are small or very small plants.

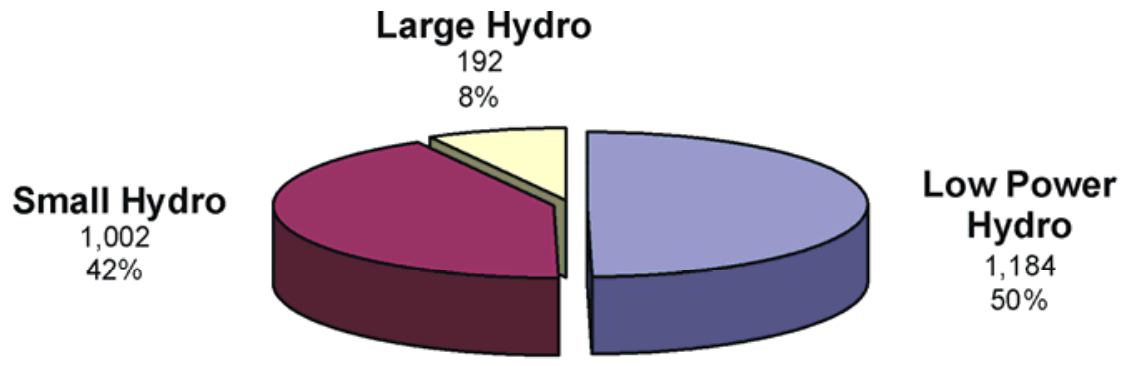

\section{2,378 Plants}

Large Hydro

$28,345 \mathrm{MWa}$

$80 \%$

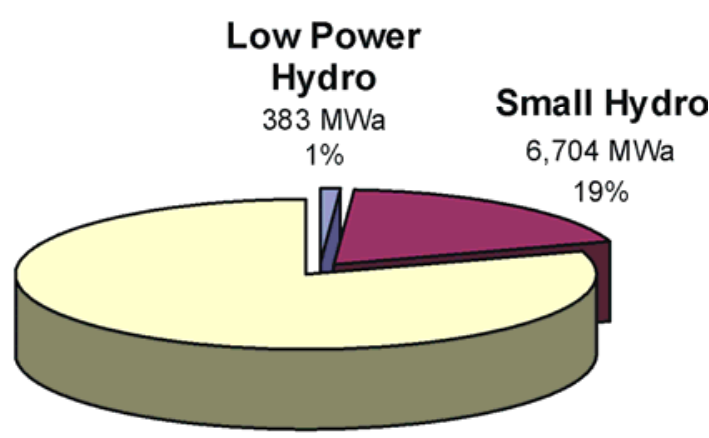

Total Average Power
35,432 MWa

Figure 2. Power class distribution of U.S. hydroelectric plants and their total average power. 


\section{TECHNICAL APPROACH}

Water energy resource sites in each of 20 hydrologic regions identified in the assessment of U.S. water energy resources (Hall et al. 2004) were assessed with regard to the feasibility of their development and the power potential of feasible sites considering development constraints. The feasibility assessment thus had two components:

- Selection of sites based on project feasibility criteria

- Estimation of power potential using realistic development criteria.

The technical approach as originally envisioned was first to identify sites that could feasibly be developed and then estimate the power potential of these sites using a development model with associated, realistic development constraints. During the evolution of the technical approach, it was determined that it would be necessary to first estimate the realistic power potential of all the sites and then determine the feasibility of their development. This approach was required because the assessment methodology that was finally employed required knowing the ultimate power class (low power or small hydro) of a potential project based on realistic development criteria as a prerequisite for applying one of the load/transmission proximity feasibility criteria.

The detailed description of the technical approach addresses:

- The population of U.S. water energy resource sites that were assessed

- Estimation of the power potential of these sites based on a development model with associated development constraints

- Identification of feasible potential projects based on a set of feasibility criteria.

Some of the feasibility and development criteria were selected based on engineering judgment. The rationale for each of these selections is provided in the discussion. Others were derived from characteristics of the existing hydroelectric plant population in each region.

The feasibility assessment was performed on a region by region basis. The results for the
20 hydrologic regions were combined to obtain nationwide results. Results for each of the 50 states were obtained by intersecting regional data with state boundaries. This was possible because of the water energy resource site data produced in the prior resource assessment and further attributed in the present study was georeferenced.

\subsection{Water Energy Resource Site Population}

The water energy resource sites that were assessed for development feasibility corresponded to all the validated stream reaches in the country having a gross power potential greater than $10 \mathrm{kWa}$. Validated stream reaches were segments of synthetic streams having an associated catchment area that contained a part of a stream in the National Hydrography Dataset (NHD). The validated reaches averaged 2 miles in length. The longitudinal midpoint of the reach was used as the geographic location of the water energy resource site.

The site population on which the feasibility assessment was performed numbered approximately 500,000 sites having gross power potentials greater than $10 \mathrm{kWa}$. The total number of sites countrywide was over one million. The distribution of water energy resource sites by the number of sites in each of three power classes (see Subsection 2.2 for power class definitions) and the corresponding, total, gross power potential of the sites is shown in Figure 3.

The site population assessed represented a total gross power potential of nearly 300,000 MWa. Figure 3 shows that over $99 \%$ of the feasibility assessed, water energy resource site population are low power and small hydro sites corresponding to $74 \%$ of the total gross power potential. There are a relatively small number of large hydro sites (874) that correspond to the remaining $26 \%$ of the total gross power potential if found to be feasible. The large hydro sites could be developed as low power or small hydro plants through partial use of the resource. 


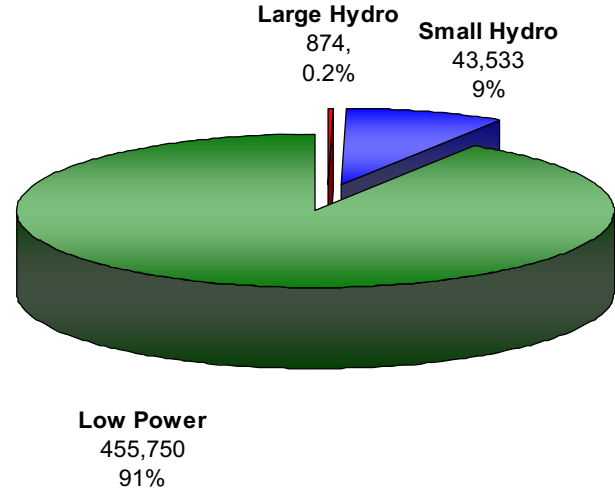

500,157 sites

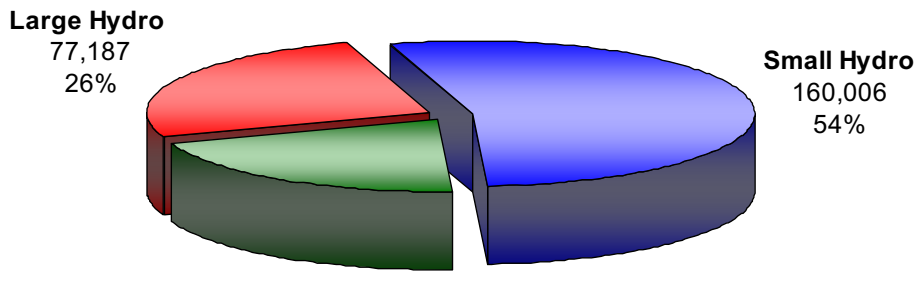

Low Power

60,243

$20 \%$

Total Gross Power Potential 297,436 MWa

Figure 3. Power class distributions of U.S. water energy resource sites by number and gross power potential.

\subsection{Site Hydropower Potential}

The gross power potential of each water energy resource site was defined by the annual mean flow rate of the associated reach and gross hydraulic head equal to the elevation difference between the upstream and downstream ends of the reach. Use of the entire reach flow and installations of penstocks of $10,000 \mathrm{ft}$ long on average, which was the average reach length, are not realistic for most low power and small hydro plants. It was, therefore, necessary to define a basic model for site development incorporating limitations on both the usable flow and the penstock length to estimate the true hydropower potential of the site.

The basic development model assumed was a hydroelectric plant producing power at an annual average rate of $30 \mathrm{MWa}$ or less. The plant configuration did not include a dam obstructing the main stream channel and did not include water impoundment in its operation. The most simplistic version of the working model includes a water takeoff point on the stream bank at which water enters a penstock running parallel to the stream channel terminating at a powerhouse containing a single turbine-generator set. Downstream of the powerhouse, the water is returned to the stream channel. Induction of the water into the penstock may be by means of the takeoff point being at a natural bend in the stream channel or use of a submerged diversion structure. It is also possible that a secondary branch of the stream is obstructed to produce a power channel from which water enters the penstock. Depending on the path of the stream channel, it is also possible that the penstock could run transverse to the stream channel terminating at a powerhouse located at a lower elevation beside the stream. However, this configuration was not considered in the feasibility assessments.

The realistic power potential of each water energy resource site was estimated by assigning limitations on working flow rate and penstock length within the context of the basic development model. A realistic optimum penstock length and location on the stream reach was determined for each site and followed by the determination of a working flow rate. The combination of working hydraulic head corresponding to the optimum penstock and the working flow rate provided the estimate of true hydropower potential power. The term "hydropower potential" is used to denote the power potential of a site with the development constraints applied as opposed to "gross potential," which denotes a site's power potential based solely on the associated stream reach flow rate and difference in the elevations at the upstream and downstream ends of the reach (gross hydraulic head). In either case, the power value is 
annual mean power, which is directly convertible to annual generation, as opposed to the design capacity of the plant.

\subsubsection{Project Penstock Length}

The methodology for determining penstock lengths for water energy resource sites in a region involved several steps:

Step 1: Penstock lengths of existing low power and small hydro plants (FERC 1998) located in the region were reviewed to gain an understanding of realistic lengths. ${ }^{\mathrm{b}}$ This review was used to establish upper limits for penstock lengths for low power and small hydro plants, respectively.

Step 2: The location on the stream reach where the maximum elevation difference was obtained using the upper limits of the low power, and small hydro penstock lengths or the reach length were established.

Step 3: Beginning with penstock lengths on the order of $30 \mathrm{~m}$ long, the optimal locations of penstocks of successive lengths up to the maximums were determined; each providing a corresponding hydraulic head.

Step 4: The optimum low power penstock and small hydro penstock lengths and their locations on the stream reach were identified as being those of the shortest length that captured $90 \%$ of the hydraulic head captured by using the respective upper limit penstocks optimally located on the reach. At this point in the hydropower potential estimation, it was not known whether the site was a low power or small hydro site based on its hydropower potential, because the working flow rate for the site had not been established.

The determination of optimal penstock locations and lengths required specialized, regional datasets from the Elevation Derivative for National Applications (EDNA), which was provided by the Earth Resources Observation System (EROS) Data Center. In these datasets, the elevation annotation of the synthetic stream reaches was expanded beyond having elevations

b. Plants having "Conduit Types" in the HPRA Database of Canal, Concrete Flume, Pipeline and/or Conduit, and Other were not included. only at the beginning and ending nodes of the reach. In these datasets, elevation data were available at every vertex along the reach. Because most of the synthetic hydrography was derived using 30-m digital elevation models, this meant that elevations were available every 30 or $42 \mathrm{~m}$ along the reach.

For the upper limit penstock lengths determined based on a regional plant population (Step 2 above), the optimal locations of penstocks of these lengths were determined by applying these lengths starting at successive nodes. The location yielding the maximum hydraulic head was the optimal location. When searching for the optimal penstock location and length (Steps 3 and 4 above), the location and corresponding hydraulic head of penstocks composed of every combination of contiguous nodes on the stream reach were evaluated up to the penstock length limits. The optimal low power and small hydro penstocks at a site were those combinations of location and minimum length that provided $90 \%$ of the hydraulic head obtained by optimal placement of penstocks having the low power and small hydro upper limit lengths.

The Pacific Northwest Region (HUC 17) is used to illustrate how upper limit low power and small hydro penstock lengths were determined. Penstock lengths for low power plants in the region are shown in Figure 4. The figure shows there are a large number of plants having penstock lengths less than $5,000 \mathrm{ft}$ with the remainder having penstock lengths, ranging from 5,000 to $21,000 \mathrm{ft}$. The plants with the longer penstocks are most likely conduit installations associated with

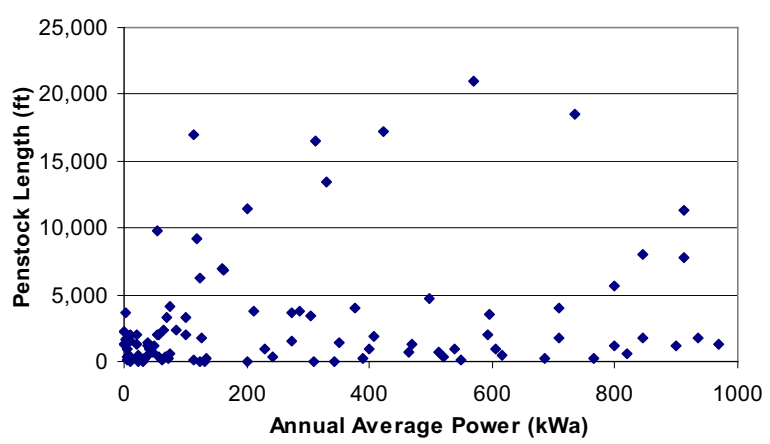

Figure 4. Penstock lengths of low power hydroelectric plants in the Pacific Northwest Region. 
water delivery systems and are not typical for the natural stream installations, which are the subject of this study. It is also noteworthy that there is no correlation of penstock length with plant annual average power.

The number of plants having penstocks in 1,000 -ft intervals ranging from 1,000 to $22,000 \mathrm{ft}$ is shown in Figure 5. The figure also includes the cumulative percentage of plants having penstocks of a given length or less. There is a rapid rise in the percentage of the sample plant population as penstock length increases up to a penstock length of 4,000 ft. Eighty percent of the low power plants have penstocks of this length or less. For this reason, the upper limit of penstocks for potential low power projects in Region 17 was chosen to be $4,000 \mathrm{ft}$.

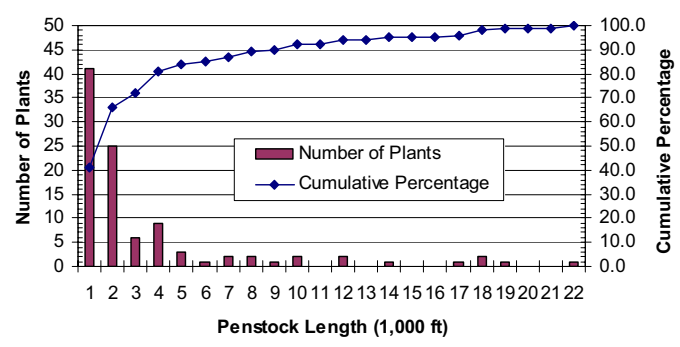

Figure 5. Number of low power hydroelectric plants in the Pacific Northwest Region by penstock length interval and cumulative percentage of plants having penstocks of a given length or shorter.

Penstock lengths for a sample of small hydropower plants in the region varied similarly to those for low power plants as shown in Figure 6. Most of the plants in this power class had penstocks less than 10,000 $\mathrm{ft}$ long with the remainder having penstock lengths ranging from 10,000 to $28,000 \mathrm{ft}$.

The number of plants having penstocks in 1,000 -ft intervals ranging from 1,000 to $22,000 \mathrm{ft}$ is shown in Figure 7 along with the cumulative percentage of plants having penstocks of a given length or less. Significant increases in the cumulative percentage of plants having penstocks of a given length or less occur up to a penstock length of $8,000 \mathrm{ft}$. Nearly $95 \%$ of the small hydro plants have penstocks of this length or less. For this reason, the upper limit of penstocks for potential small hydro projects in Region 17 was chosen to be $8,000 \mathrm{ft}$.

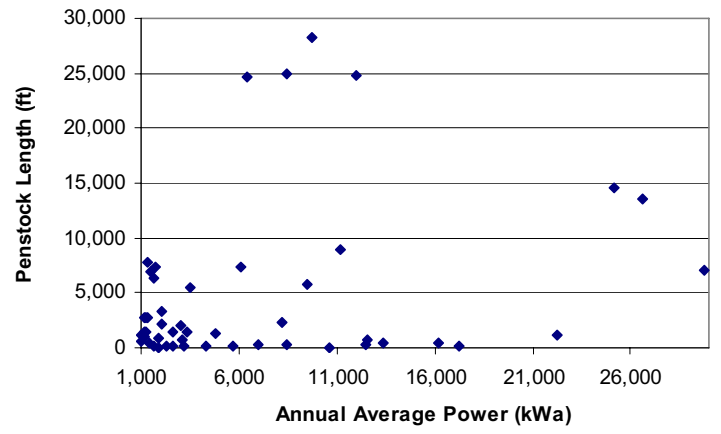

Figure 6. Penstock lengths of small hydroelectric plants in the Pacific Northwest Region.

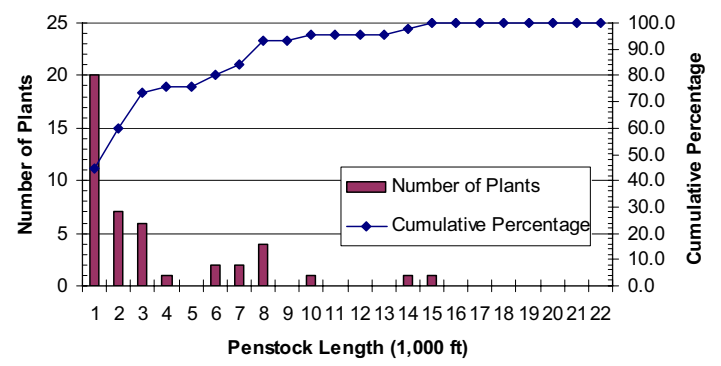

Figure 7. Number of small hydroelectric plants in the Pacific Northwest Region by penstock length interval and cumulative percentage of plants having penstocks of a given length or shorter.

Similar evaluations of the penstock lengths of low power and small hydro plants were carried out for each of the regions for which data were available. Upper limit penstock lengths for regions for which data were not available were determined based on values in neighboring regions considering topography, climate, and hydrology similarities and differences. Figure 8 shows the upper limit penstock lengths by region that are also given in Table 2 along with the rationale for assumed values.

The choice of whether the low power or small hydro penstock applied to the site was determined by the logic described in Subsection 3.3. This choice was dependent on the applicable working flow rate.

An interesting feature of the data shown in Figure 8 and presented in Table 2 is that while the penstocks of most of the low power plants are shorter than those of small hydro plants for regions on the East and West coasts, the relationship is 


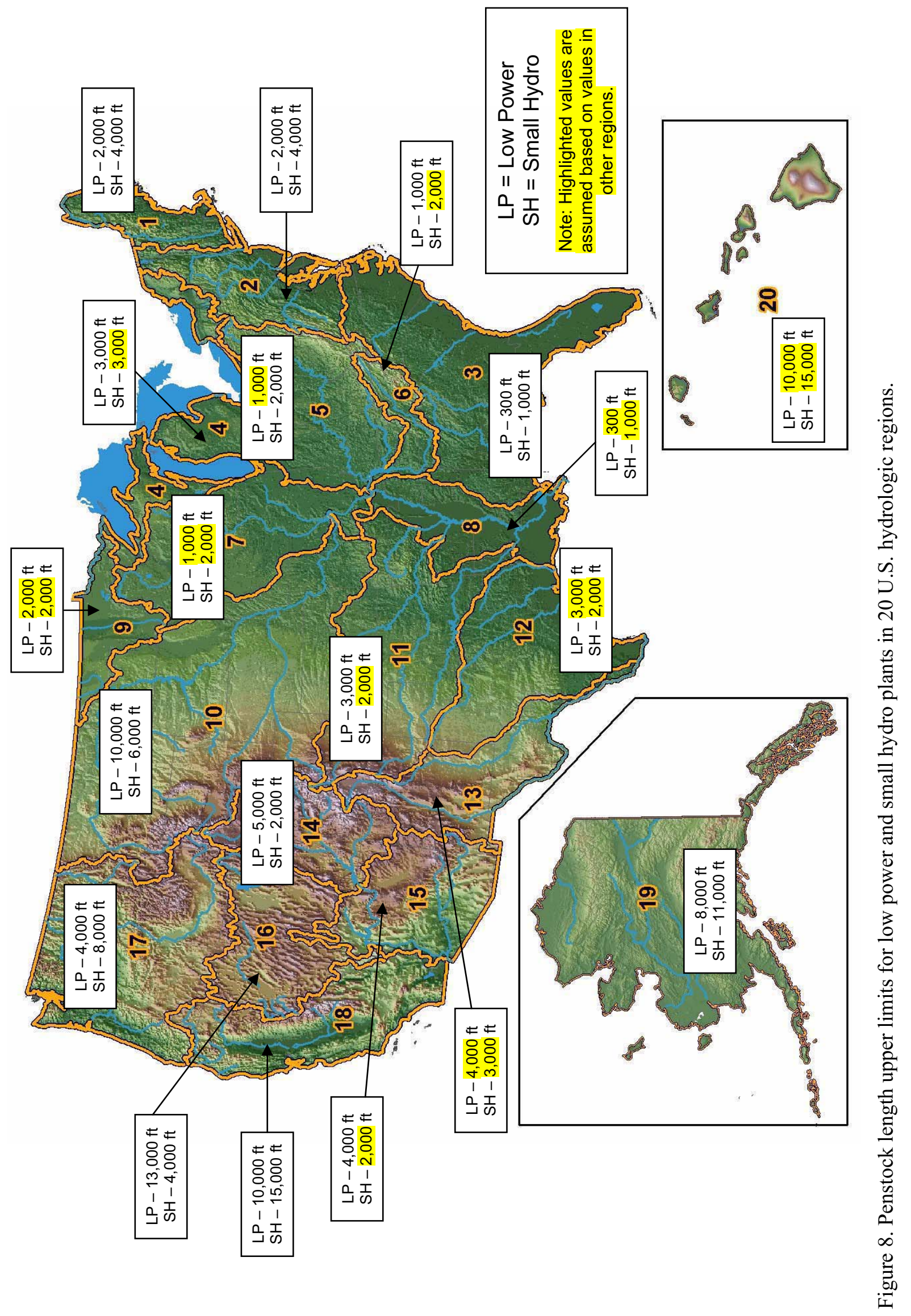


Table 2. Penstock upper limits for low power and small hydro plants by hydrologic region.

\begin{tabular}{|c|c|c|c|c|c|}
\hline \multirow[b]{2}{*}{ Region } & \multicolumn{2}{|c|}{ Low Power } & \multicolumn{2}{|c|}{ Small Hydro } & \multirow[b]{2}{*}{ Assumption Rationale } \\
\hline & $\begin{array}{l}\text { No. of } \\
\text { Plants }\end{array}$ & $\begin{array}{l}\text { Penstock } \\
\text { Length } \\
\text { Upper } \\
\text { Limit }\end{array}$ & $\begin{array}{l}\text { No. of } \\
\text { Plants }\end{array}$ & $\begin{array}{l}\text { Penstock } \\
\text { Length } \\
\text { Upper } \\
\text { Limit }\end{array}$ & \\
\hline 1 & 111 & 2,000 & 27 & 4,000 & \\
\hline 2 & 44 & 2,000 & 37 & 4,000 & \\
\hline 3 & 15 & 300 & 9 & 1,000 & \\
\hline 4 & 28 & 3,000 & 37 & 3,000 & \\
\hline 5 & 0 & 1,000 & 6 & 2,000 & LP based on HUC 6 - similar topography, climate, and hydrology \\
\hline 6 & 4 & 1,000 & 0 & 2,000 & SH based on HUC 5 - similar topography, climate, and hydrology \\
\hline 7 & 0 & 1,000 & 0 & 2,000 & LP \& SH based on HUCs 1-4 considering hydrology differences \\
\hline 8 & 0 & 300 & 0 & 1,000 & LP \& SH based on HUC 3 - similar topography, climate, and hydrology \\
\hline 9 & 0 & 2,000 & 0 & 2,000 & LP \& SH based on HUC 4 - considering hydrology differences \\
\hline 10 & 17 & 10,000 & 7 & 6,000 & \\
\hline 11 & 4 & 3,000 & 0 & 2,000 & SH based on HUC 10 using LP proportionality \\
\hline 12 & 0 & 3,000 & 0 & 2,000 & LP \& SH based on HUC 11 - similar topography, climate, and hydrology \\
\hline 13 & 0 & 4,000 & 0 & 3,000 & LP \& SH based on HUC 15 - similar topography and climate with hydrology differences \\
\hline 14 & 11 & 5,000 & 6 & 2,000 & \\
\hline 15 & 4 & 4,000 & 0 & 2,000 & SH based on HUC 14 - similar topography, climate, and hydrology \\
\hline 16 & 32 & 13,000 & 13 & 4,000 & \\
\hline 17 & 100 & 4,000 & 49 & 8,000 & \\
\hline 18 & 93 & 10,000 & 57 & 15,000 & \\
\hline 19 & 8 & 8,000 & 11 & 11,000 & \\
\hline 20 & 0 & 10,000 & 0 & 15,000 & LP \& SH based on HUC 18 - similar topography and stream flows \\
\hline Total & 471 & & 259 & & \\
\hline
\end{tabular}

Note: Values highlighted in yellow indicate assumed values based on values in another region or regions selected using the rationale stated.

reversed for mid-West and Southwest regions. The former situation follows intuitive understanding that the higher power small hydro plants would require higher hydraulic heads and, therefore, longer penstocks. The reverse situation may be the result of insufficient data. It could also be the result of low power plants being sited on streams with relatively small flow rates, thus requiring long penstocks to obtain sufficient hydraulic head. Conversely, the small hydro plants in these regions tend to be located on the larger streams; therefore, being capable of producing more power without the need for long penstocks.

\subsubsection{Project Working Flow Rate}

Limitations were placed on working flow rates to estimate the hydropower potential of sites. The working flow rate was limited to the lesser of:

- Half the annual mean flow rate of the stream reach associated with the site

- The flow rate required to produce an annual average power of 30 MWA using the hydraulic head corresponding to the optimal small hydro penstock length and location.
In most cases, if the working flow rate was less than half the reach flow rate, it was because half the reach flow rate in combination with the hydraulic head corresponding to the optimal small hydro penstock for the site resulted in a hydropower potential greater than 30 MWA. Because this development of the site would no longer produce a small hydro plant, the flow rate was restricted so that the project hydropower potential would be 30 MWA. However, there were instances in Regions 10 through 16 where the working flow rate was reduced to less than half the reach flow rate even for low power projects as will be discussed in the next subsection.

\subsubsection{Logic for Selecting Site Development Parameters}

A logic scheme was used to determine whether a site would be developed as a low power or small hydro project. Optimal low power and small hydro penstock lengths and locations were determined as described in Subsection 3.2.1. Working flow limitations were adopted as described in the previous subsection. This information was combined to determine the power class of the project and associated development 
parameters. The logic for this process is shown in Figure 9. The basic approach was first to try and develop the site as a small hydro project using half the reach flow rate and the optimal small hydro penstock for the site. This either resulted in reduction of the working flow rate to limit the project to being a small hydropower project, confirmation that the project could be developed as a small hydro project, or determination that there was not sufficient hydropower potential at the site, indicating a low power project development. If a low power project development was indicated, the only remaining step was to resolve an ambiguity that occurred in Regions 10 through 16. In these regions, it was possible for the optimum low power penstock for a site to be longer and, therefore, have more corresponding hydraulic head than the optimum small hydro penstock. It was thus possible to have the working flow rate equal to half the reach flow rate in combination with the small hydro penstock indicate a low power project and yet the working flow rate in combination with the low power penstock indicate a small hydro project. This ambiguity was resolved by arbitrarily reducing the working flow rate in combination with the optimum low power penstock and corresponding hydraulic head such that hydropower potential of the project was slightly less than 1 MWA, ensuring that it was a low power project. This approach was taken as opposed to reducing the low power penstock length to take the most conservative approach with regard to use of the stream resource.

\subsubsection{Summary of Site Development Criteria for Estimating Project Hydropower Potential}

The site development criteria that were used to estimate project hydropower potential were:

- Project location - optimal based on hydraulic head capture

- Penstock length

- Low power project - optimal based on capturing $90 \%$ of hydraulic head captured with longest, typical penstock length based on existing low power plants in the region

- Small hydro project - optimal based on capturing $90 \%$ of hydraulic head captured with longest, typical penstock length based on existing small hydro plants in the region.

- Flow rate-lesser of:

- Half the stream reach flow rate

- Flow rate required to produce an annual average power of $30 \mathrm{MWa}$ using hydraulic head corresponding to optimal small hydro penstock.

These assumptions are conservative for some sites for one or a combination of reasons. It was assumed that the penstock paralleled the stream for all projects. Depending on the topography and the stream path, it may be possible to capture more of the reach hydraulic head if the penstock is run transverse rather than parallel to the stream if it has a serpentine path. There may be instances in which more of stream flow can be used for power production than dictated by the development criteria. Flow rates have also been limited to that required to produce $30 \mathrm{MWa}$ because of the focus of this study. Larger working flows and subsequently larger hydropower potentials exist at some sites and may be available for development. Finally, the hydropower model that has been used in this study is a potential energy conversion model. If a kinetic energy model consisting of one or a group of kinetic turbines had been applied to stream reaches having little power potential by virtue of little hydraulic head, but having adequate stream velocities, significant additional hydropower potential may well have been identified.

\subsection{Project Feasibility Criteria}

The project feasibility criteria that were used to identify feasible potential project sites addressed the likelihood of development based on land use and environmental sensitivities, prior development, site access, and load and transmission proximity. Specifically, the feasibility criteria applied to each water energy resource site were:

- Hydropower potential $\geq 10 \mathrm{kWa}$

- Does not lie within a zone in which development is excluded by federal law or policy 


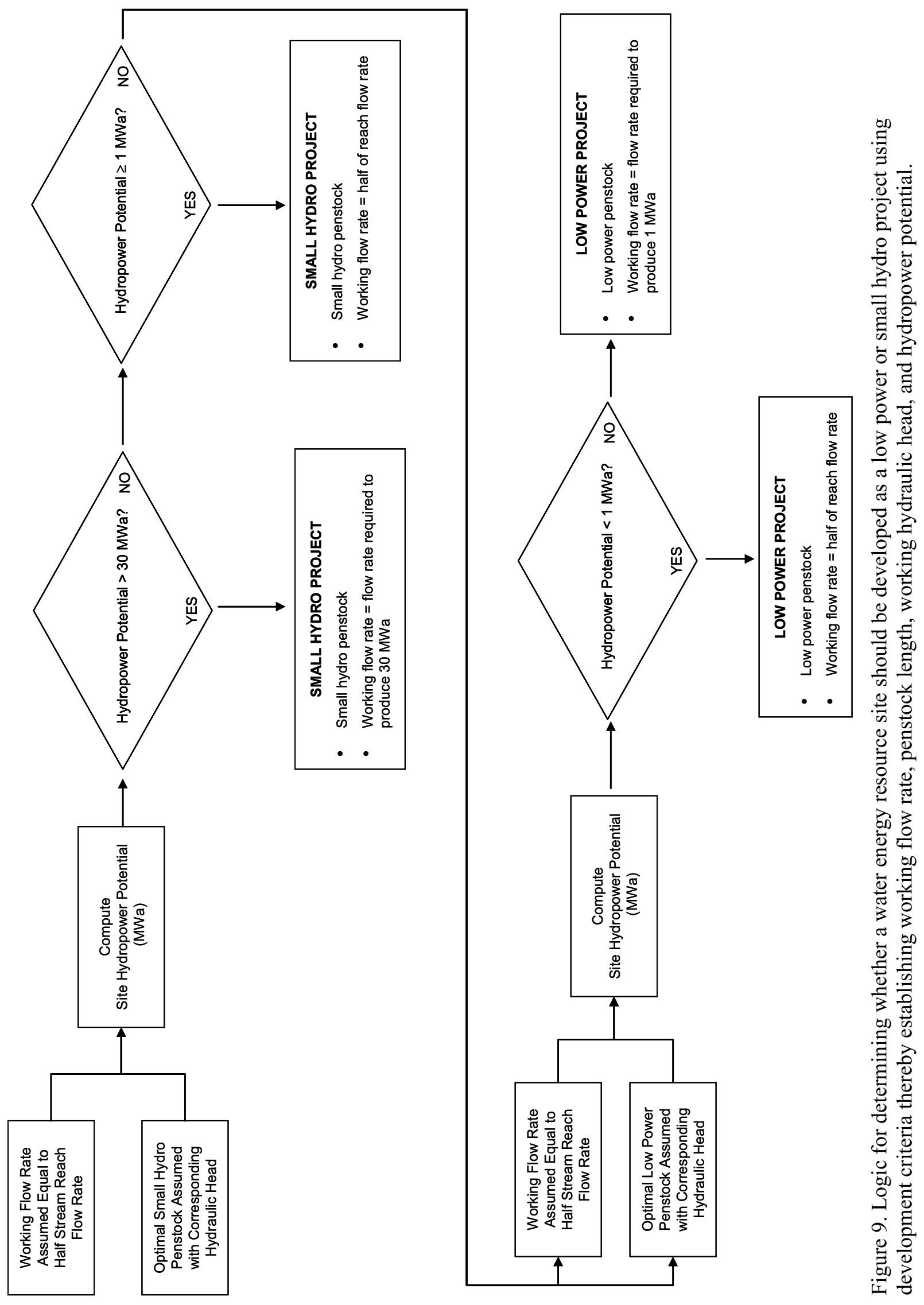


- Does not lie within a zone that makes development highly unlikely because of land use designations

- Does not coincide with an existing hydroelectric plant

- Is within 1 mile of a road

- Is within 1 mile of part of the power infrastructure (power plant, power line, or substation) $\mathbf{O R}$ is within a typical distance from a populated area for plants of the same power class in the region.

The question of whether site development was highly unlikely due to federal land use designation or environmental sensitivities was answered by intersecting the stream reaches corresponding to water energy resource sites with the polygons corresponding to the exclusion zones using GIS tools. (Descriptions of the exclusion zones used in this study are provided in Appendix A.) If any point on the reach fell within the exclusion zone, site development was considered to be unfeasible. On the other hand, a site could be very close to the exclusion zone boundary and not be disqualified based on the exclusion criterion (all parts of stream reach outside the boundary).

Sites that have already been developed into a hydroelectric plant were identified using a 2-mile search radius from the plant location to identify the water energy resource site that most nearly matched the head and annual average power of the plant. A search radius of this size was required, because it was found that some plant locations based on their geographic coordinates differed by this much and sometimes more from their obvious location at the head of a reservoir. Only hydroelectric plant locations were used, so it is possible that an existing dam without a power house is located at the feasible project site. Hydroelectric plant locations were provided by by a combination of locations in the HPRA Database (FERC 1998), locations in ENERmap's power system data layer (ENERmap 2005), and manual corrections by matching plant locations to water features using GIS tools.

The accessibility criterion of the site being within 1 mile of a road was chosen because it was reasoned that particularly a low power hydroelectric project could not afford construction of a road longer than 1 mile and be economically viable. This criterion was not found to be very restrictive, because proximity analysis revealed that $84 \%$ of the available resource sites were within 1 mile of a road. The ESRI Streetmap (ESRI 2004) GIS layer of roads was used in the proximity analysis.

The feasibility criterion for proximity to a part of the power infrastructure was also chosen to be 1 mile considering low power project funding constraints to construct a powerline to connect to existing power infrastructure. The feasibility analysis did not account for the voltage of the nearby powerlines or consider the affordability of the transformer required to connect the potential project to the grid. The power infrastructure was geographically represented by geospatical data provided by ENERmap, LLC (ENERmap 2005).

The feasibility criterion for proximity to cities and population centers was based on the distance of most of the existing hydroelectric plants in each power class (low power or small hydro) to a city or population center. Two GIS layers were required for this part of the proximity analysis. It was found that very small towns were best represented by a discrete city location. Larger populated areas were best represented by polygons corresponding to the boundary of the populated area. The feasibility criterion in this case was based on actual locations of hydroelectric plants rather than an assumed economic limitation as with the construction of an access road or hook up to a transmission line. It was reasoned that municipalities have local electrical lines extending beyond their boundaries that have made low power and small hydropower projects viable at some distance from the densely populated area. These lower voltage electrical lines were generally not represented in the electrical transmission GIS layer used in the analysis.

The distribution of low power and small hydroelectric plants to populated areas in the Pacific Northwest Region shown in Figure 10 is typical of most of the regions. The distributions for low power and small hydroelectric plants considered separately were sufficiently similar to the combined distribution shown in Figure 10 making it unnecessary to define separate criteria 
for each power class. For this region, the distributions show that $90 \%$ of the low power and small hydro plants were within 10 miles of a city center or population center boundary.

The distances that $90 \%$ of the low power and small hydro plants are from a city or populated area boundary are shown in Table 3 for each of the 20 hydrologic regions. Application of the criterion for proximity to a city or populated area required knowing whether a water energy resource site would be developed as a low power or small hydro plant so that the correct proximity criterion could be used. It is for this reason that the hydropower potential and thus power class of each water energy resource site, if it was developed, was evaluated as described in Subsection 3.2 prior to the feasibility evaluation using the criteria described in this subsection.

\subsection{Identification of Feasible Potential Projects}

Evaluation of the water energy resource sites using the feasibility criteria described in the previous subsection required the water energy resource sites to be attributed with proximity data for each of the parameters addressed in the feasibility criteria. Proximity analyses were performed using GIS tools and the GIS data layers listed in Table 4. The results of the hydropower

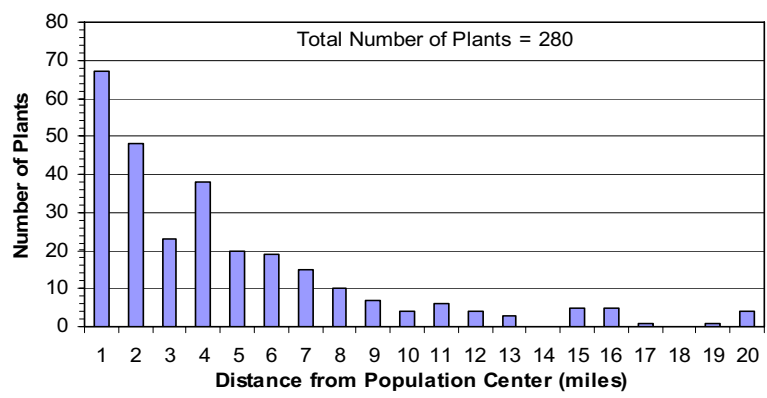

(a) potential assessment and the proximity analyses were entered into an Access database containing the attribute data for all water energy resource sites. The attributes used in the feasibility assessment are listed in Table 5. ${ }^{\mathrm{C}}$ Queries on the database implementing the feasibility criteria resulted in identification of water energy resource sites that are the sites of feasible potential projects.

Table 3. Distances of $90 \%$ of low power and small hydro plants from cities and populated area boundaries in 20 hydrologic regions.

\begin{tabular}{|c|c|c|}
\hline Region & $\begin{array}{c}\text { Low Power } \\
\text { Plant } \\
\text { Distance in } \\
\text { Miles }\end{array}$ & $\begin{array}{c}\text { Small Hydro } \\
\text { Plant } \\
\text { Distance in } \\
\text { Miles }\end{array}$ \\
\hline 1 & 4 & 4 \\
\hline 2 & 5 & 5 \\
\hline 3 & 5 & 5 \\
\hline 4 & 4 & 7 \\
\hline 5 & 2 & 6 \\
\hline 6 & 5 & 5 \\
\hline 7 & 4 & 4 \\
\hline 8 & 4 & 4 \\
\hline 9 & 1 & 1 \\
\hline 10 & 7 & 7 \\
\hline 11 & 7 & 4 \\
\hline 12 & 3 & 8 \\
\hline 13 & 4 & 4 \\
\hline 14 & 7 & 7 \\
\hline 15 & 5 & 10 \\
\hline 16 & 6 & 4 \\
\hline 17 & 10 & 10 \\
\hline 18 & 8 & 8 \\
\hline 19 & 10 & 10 \\
\hline 20 & 2 & 2 \\
\hline
\end{tabular}

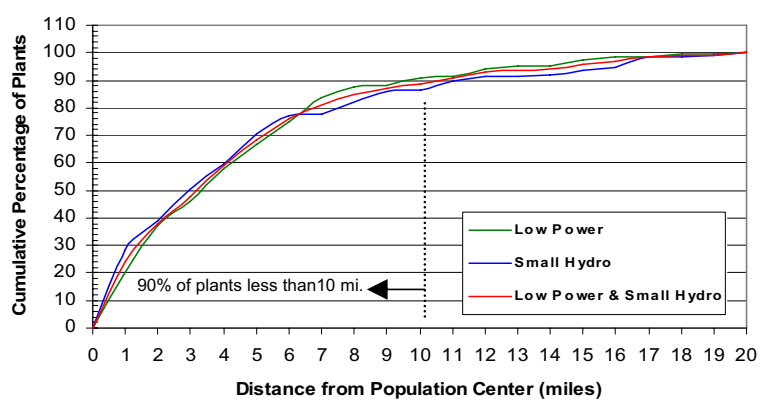

(b)

Figure 10. a) Distribution of the distance of low power and small hydroelectric plants to a city or population center boundary. b) Cumulative distribution of the distance of low power and small hydroelectric plants to a city or population center boundary.

c. The attributes listed in Table 5 are only those that were required to perform the feasibility assessment to identify feasible potential projects. 
Table 4. GIS data layers used for proximity analyses.

\begin{tabular}{|c|c|c|c|}
\hline Feature & Source & $\begin{array}{c}\text { Data } \\
\text { Vintage }\end{array}$ & Source Website \\
\hline $\begin{array}{l}\text { Federal Exclusion } \\
\text { Zones }\end{array}$ & $\begin{array}{l}\text { National Atlas of the United } \\
\text { States } \\
\text { Federal \& Indian Lands } \\
\text { Parkways \& Scenic Rivers }\end{array}$ & 2002 & $\begin{array}{l}\text { http://nationalatlas.gov/natlas/Natlass } \\
\underline{\text { tart.asp }}\end{array}$ \\
\hline $\begin{array}{l}\text { Environmental } \\
\text { Exclusion Zones }\end{array}$ & Conservation Biology Institute & 2005 & http://www.consbio.org/ \\
\hline Roads & $\begin{array}{l}\text { Environmental Systems } \\
\text { Research Institute (ESRI) } \\
\text { (Streetmap) }\end{array}$ & 2004 & $\begin{array}{l}\text { http://www.esri.com/data/index.h } \\
\underline{\operatorname{tml}}\end{array}$ \\
\hline Power Infrastructure & Global Energy Decisions & 2004 & http://www.globalenergy.com/ \\
\hline \multicolumn{4}{|l|}{ Transmission lines } \\
\hline \multicolumn{4}{|l|}{ Substations } \\
\hline \multicolumn{4}{|l|}{ Power plants } \\
\hline Cities & $\begin{array}{l}\text { Environmental Systems } \\
\text { Research Institute (ESRI) } \\
\text { (cities_dtl) }\end{array}$ & 2000 & http://www.esri.com/data/index.html \\
\hline Populated Places & $\begin{array}{l}\text { Environmental Systems } \\
\text { Research Institute (ESRI) } \\
\text { (placeply) }\end{array}$ & 2000 & http://www.esri.com/data/index.html \\
\hline
\end{tabular}

Table 5. Water energy resource site attributes used in development feasibility assessment.

\begin{tabular}{|c|c|c|}
\hline Name & Description & Units \\
\hline PEN_POWER_KW & Hydropower potential & $\mathrm{kWa}$ \\
\hline PEN_TECH & Technology classification (LP or SH) & \\
\hline FED_EXCLUDED & Stream reach intersects federal exclusion area $(\mathrm{Y}=$ yes, $\mathrm{N}=$ no $)$ & \\
\hline GAP_EXCLUDED ${ }^{1}$ & $\begin{array}{l}\text { Stream reach intersects a GAP area with GAP value of } 1 \text { or } 2(\mathrm{Y}=\text { yes, } \mathrm{N}= \\
\text { no) }\end{array}$ & \\
\hline DEVELOPED & $\begin{array}{l}\text { Stream reach is likely the site of an existing hydroelectric plant }(\mathrm{Y}=\text { yes, } \mathrm{N} \\
=\text { no) }\end{array}$ & \\
\hline ROAD_DIST_M & Distance to nearest road. & $\mathrm{m}$ \\
\hline PLANT_DIST_M & Distance to nearest existing power plant. & $\mathrm{m}$ \\
\hline SUBST_DIST_M $^{2}$ & Distance to nearest substation. & $\mathrm{m}$ \\
\hline PWRLN_DIST_M ${ }^{1}$ & Distance to nearest power line. & $\mathrm{m}$ \\
\hline POP_DIST_M & Distance to boundary of nearest populated area or city center. & $\mathrm{m}$ \\
\hline
\end{tabular}




\section{RESULTS}

The discussion of results begins with an overview of the water energy resource site population that was assessed to identify feasible potential projects. This overview is followed by a discussion of the feasibility assessment results for the country presented in terms of numbers of feasible potential projects and their corresponding hydropower potential divided into power classes and into project size as designated by ranges of power potential. The results are then discussed from the perspective of their spatial distribution across the country by comparing results for each state and viewing the potential projects on a map. The last subsection discusses how the reader can access additional information about potential projects using a GIS application on the Internet called the VHP.

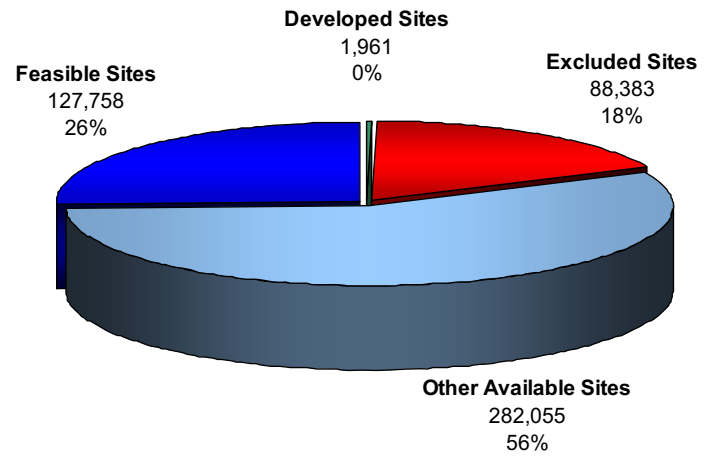

\subsection{Power Category Distribution of Assessed Water Energy Resource Site Population}

The water energy resource site population on which the feasibility assessment was performed included 500,157 sites representing a total gross power potential of 297,436 MWa. The distribution of these sites and their associated gross power potential on the basis of four categories:

- Developed

- Excluded

- Feasible

- Other available.

is shown in Figure 11. This figure shows that 127,758 sites having a total gross power potential

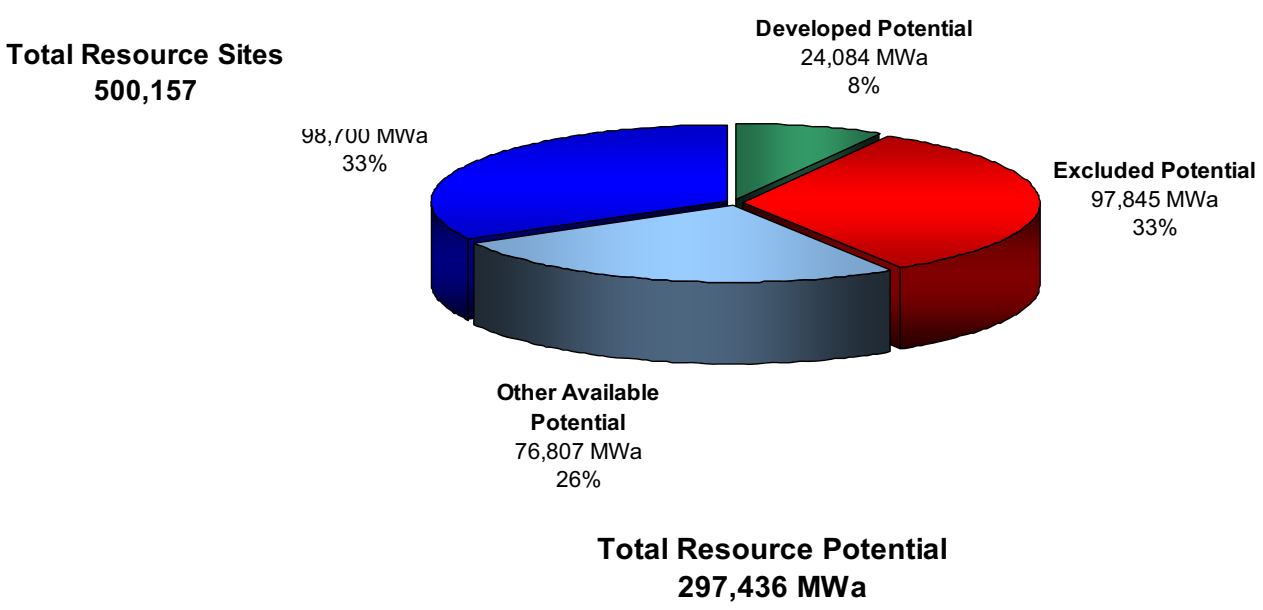

Figure 11. Power category distribution of water energy resource sites having gross power potentials greater than or equal to $10 \mathrm{kWa}$ and their associated total gross power potential. 
of 98,700 MWa were identified by the feasibility assessment as being sites for feasible potential projects. These sites constitute $26 \%$ of the site population and $33 \%$ of the total gross power, respectively.

The total power and its distribution shown in Figure 11 differ somewhat from results reported from the predecessor study (Hall et al. 2004). The total resource potential of $297,436 \mathrm{MWa}$ is approximately 8,000 MWa higher than previously reported. This is the result of data refinements in the basic reach used in present study. The amount of excluded power increased in the present study by approximately 9,000 MWa because of the inclusion of environmentally sensitive areas, which added to the total area of zones in which hydropower development is unlikely. The amount of developed potential reported in the present study is approximately 10,000 MWa less than in the previous study. The methods of obtaining this value were different in the two studies. In the previous study, total average power for the U.S. hydroelectric plant population was used. This value was derived using the estimated average annual generation of each plant in the HPRA Database (FERC 1998), dividing this generation by the number of hours in a year to obtain plant average power, and summing all the plant values. In the present study, developed potential was determined by spatially relating water energy resource sites with existing hydroelectric plants, thereby identifying the gross power potential of sites corresponding to plant locations as developed potential.

Both methods of identifying developed potential have significant uncertainties. The estimated average annual generation in the HPRA Database is taken from the plant license application, if these data are provided. The value is the licensee's estimate of annual average generation at the time of application. Actual annual average generation could differ significantly over the period from when the application was filed to the present. If the average annual generation is not provided in the application, the value entered in the database is calculated from the nameplate capacity, assuming a capacity factor of 1.0 - clearly an overestimation.

The uncertainty in developed potential derived in the present study stems from at least two known sources. Identifying water energy resource sites as developed based on collocation with a hydroelectric plant depends on having accurate plant geographic coordinates. It was found in many cases that these coordinates were not sufficiently accurate for this purpose. Large plant locations were manually verified to the extent possible using GIS tools to ensure the plant location was on a stream or located at the head of a reservoir. Still a search radius had to be used, and the nearest stream reach whose gross power potential and hydraulic head most closely matched the plant average power (derived from estimated average annual generation as stated above) and hydraulic head was considered the corresponding developed site and its potential the developed potential. It was also possible to miss developed potential for plants having reservoirs that extended for many miles upstream. These plants take advantage of elevation change occurring over miles of stream path, concentrating this elevation change at the dam to produce localized hydraulic head. Ideally, the existence of the reservoir is captured in the digital elevation model (DEM) that was used to derive the synthetic hydrography, which provided the hydraulic head and consequently the gross power potential for a water energy site in our study. If the presence of the reservoir is included in the DEM, a synthetic stream reach will have the local elevation change at the dam. However, if the DEM does not reflect the presence of the reservoir or its full extent, but rather reflects the topography underlying the reservoir, some of the upstream stream reaches that should have been flagged developed will be missed and thus reduce the total developed potential. Considering the uncertainties in both methods, it is best to consider values from the two methods as upper and lower bounds of the developed potential. In a worst case, the total available potential (feasible and other available) of $175,507 \mathrm{MWa}$ would be reduced by 10,000 MWa. 


\subsection{Power and Technologies Class Distribution of Feasible Potential Projects}

The nearly 130,000 feasible potential projects identified in the study were classified as either low power (hydropower potential less than $1 \mathrm{MWa}$ ) or small hydro (hydropower potential greater than or equal to $1 \mathrm{MWa}$, but less than or equal to $30 \mathrm{MWa}$ ). The low power projects were further subdivided using the operating envelopes of classes of low power technologies shown in Figure 12. The hydropower potential and working hydraulic head of the potential project were used to assign technologies class. The unconventional systems class of technologies, which is delineated by the working hydraulic head being less than $8 \mathrm{ft}$, is intended to show that if the potential is going to be realized, it will require the use of an ultra low head turbine or hydrokinetic technology. It is not known from the assessment performed whether there is sufficient velocity at the site to make a hydrokinetic installation viable.

The power potential of U.S. water energy resource sites is presented in power categories and is divided by power classes and classes of low power hydropower technologies in Table 6 . The power values listed for the power categories "Total" through "Feasible" are total gross power potential values for a group of water energy resource sites. The values listed for each power category "Developed" through "Feasible" for a particular power class ${ }^{\text {d }}$ (e.g., "Small Hydro") correspond to a subset of the water energy resource sites whose total gross power potential is listed under the "Total" power category. The sites corresponding to the values listed in the "Feasible" category are a subset of those corresponding to the values listed under the "Available" category.

The power values listed under "Potential Projects" are hydropower potential values. They

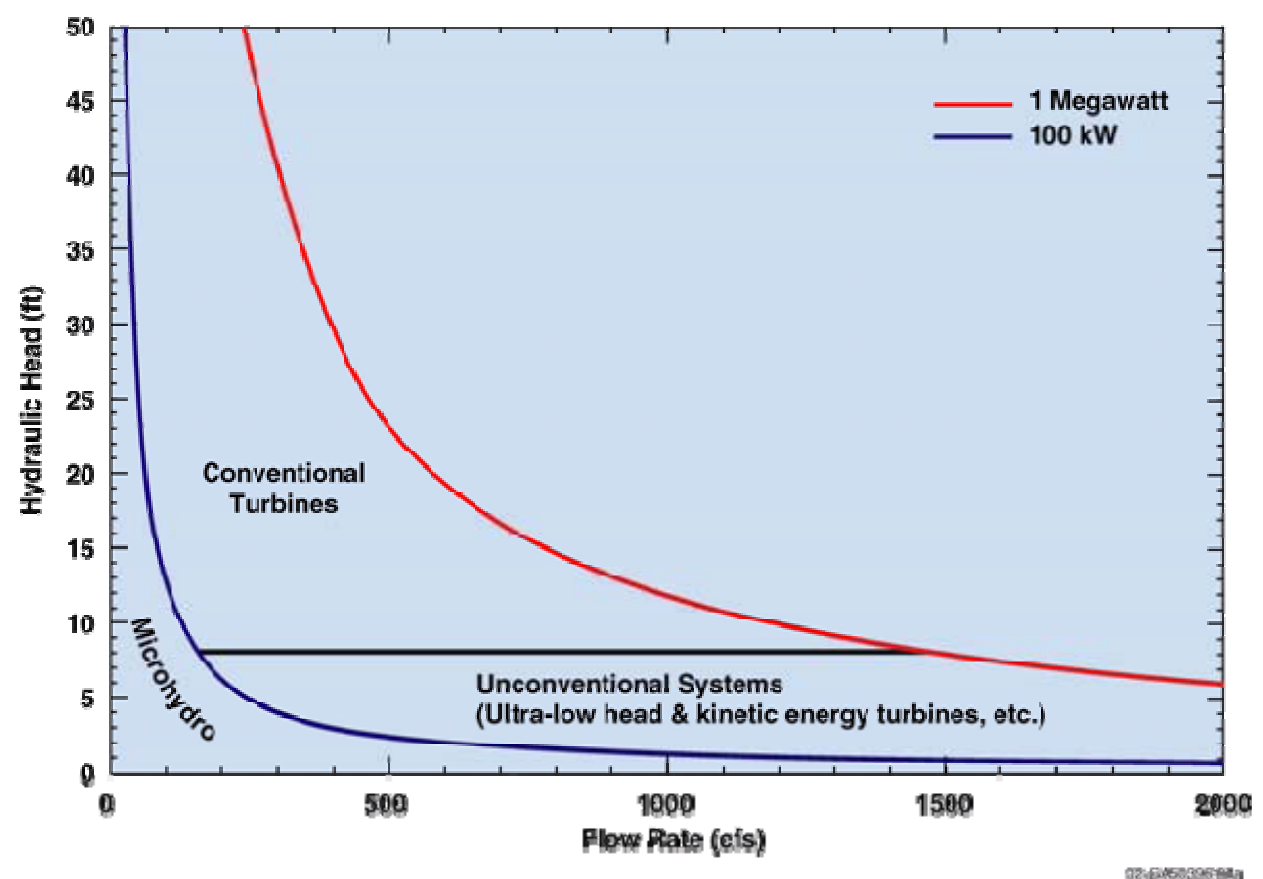

Figure 12. Operating envelopes of three classes of low power technologies.

d. The low power technology classes were assigned to water energy resource sites and their cumulative power potential by using the operating envelopes shown in Figure 12, but were based on reach hydraulic head and full flow rate rather than working hydraulic head and flow rate, which were used to classify low power potential projects. 
Table 6. Power potential of U.S. water energy resource sites in power categories divided into power classes and low power technology classes.

\begin{tabular}{|c|c|c|c|c|c|c|c|}
\hline $\begin{array}{c}\text { Annual Mean Power } \\
\text { (MWa) }\end{array}$ & Total & Developed & $\begin{array}{l}\text { Federally } \\
\text { Excluded }\end{array}$ & $\begin{array}{c}\text { GAP } \\
\text { Excluded }\end{array}$ & Available ${ }^{a}$ & Feasible $^{b}$ & $\begin{array}{l}\text { Potential } \\
\text { Projects }^{\circ}\end{array}$ \\
\hline Total Power & 297,436 & 24,084 & 84,682 & 13,163 & 175,507 & 98,700 & 29,438 \\
\hline Total High Power & 237,193 & 23,786 & 73,591 & 10,097 & 129,719 & 75,853 & 18,450 \\
\hline Large Hydro & 77,187 & 19,380 & 17,600 & 2,307 & 37,900 & 21,691 & 0 \\
\hline Small Hydro & 160,006 & 4,406 & 55,991 & 7,790 & 91,819 & 54,161 & 18,450 \\
\hline Total Low Power & 60,243 & 298 & 11,091 & 3,066 & 45,788 & 22,848 & 10,988 \\
\hline Conventional Turbines & 45,208 & 241 & 9,517 & 2,426 & 33,024 & 17,729 & 6,297 \\
\hline Unconventional Systems & 3,986 & 37 & 520 & 187 & 3,243 & 2,355 & 1,640 \\
\hline Microhydro & 11,049 & 20 & 1,054 & 453 & 9,522 & 2,763 & 3,052 \\
\hline \multicolumn{8}{|c|}{$\begin{array}{l}\text { Note: Power potential in power categories "Total" through "Feasible" are gross potential. Power potential in "Potential Projects" category is hy } \\
\text { potential based on development criteria. } \\
\text { a "Available" only indicates net gross power potential after subtracting developed and excluded potentials from total potential. } \\
\text { b "Feasible" is gross power potential of water energy resource sites that are feasibly developable based on stated feasibility criteria. } \\
\text { "Potential Projects" is hydropower potential based on development criteria being applied to feasibly developable water energy resource sites. }\end{array}$} \\
\hline
\end{tabular}

do not correspond to a subset of the water energy resource sites reflected in the "Total" power category for a given power or technology class. This is because application of the development criteria produced hydropower potential values that were significantly less than the gross power values. Thus, water energy resource sites that were power classed based on their gross power potential were not necessarily in the same power class based on their hydropower potential. For example, all the sites that were classed as "Large Hydro" based on their gross potential became "Small Hydro" or "Low Power" potential projects.

The distribution of feasible potential project sites and their associated hydropower potential is shown in Figure 13. This figure shows the results of applying the development criteria to obtain better estimates of hydropower potential. The nearly 130,000 feasible project sites, which had a total gross power potential of nearly

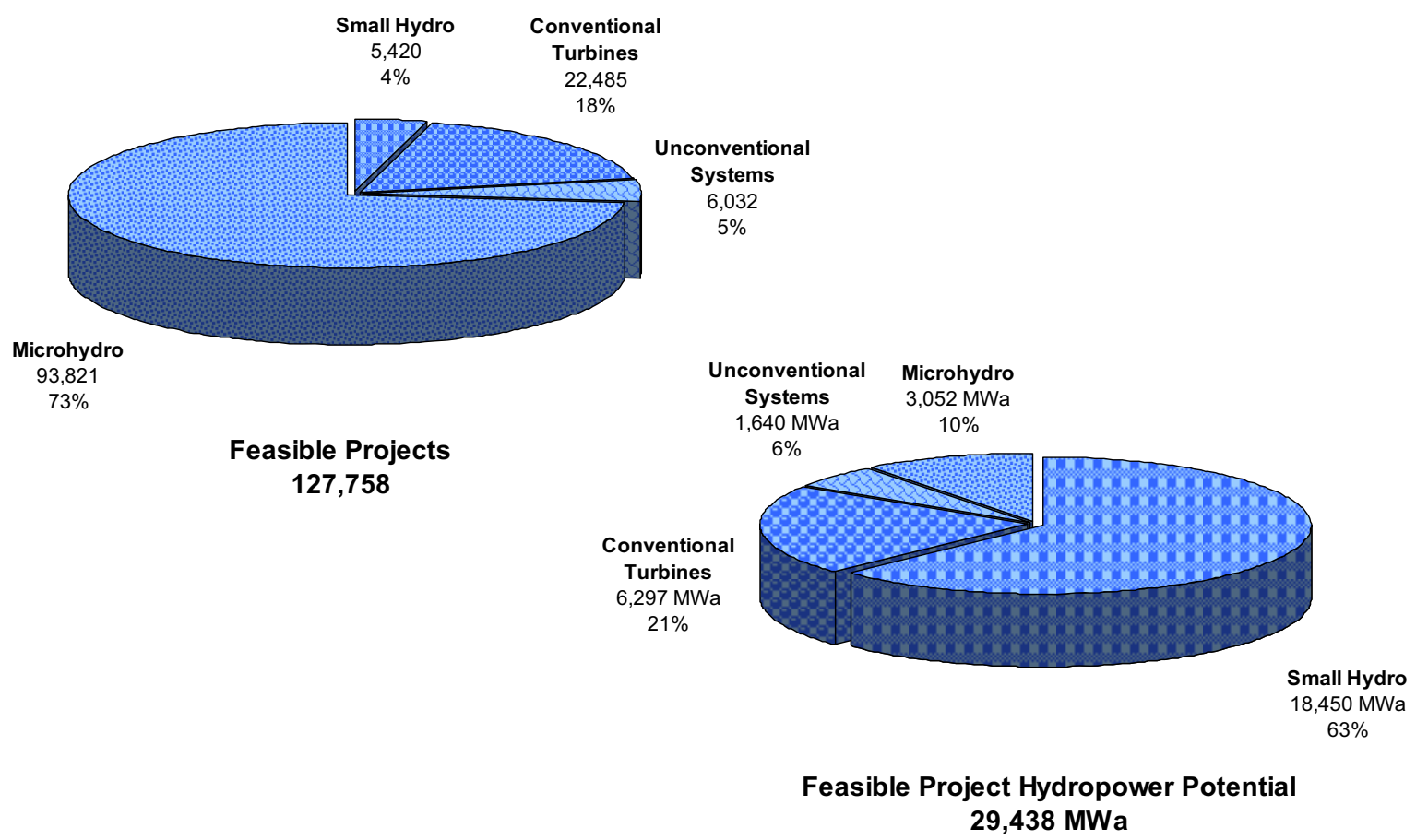

Figure 13. Power category distribution of feasible potential projects and their associated total hydropower potential with low power projects further divided by low power technology classes. 
$100,000 \mathrm{MWa}$, were found to realistically offer $30,000 \mathrm{MWa}$ of hydropower potential. This is not surprising considering that the development criteria of using half the site's flow or less resulted in at least halving of the possible amount of hydropower potential compared to the gross power potential. The working flow rate restriction may be overly conservative resulting in more total hydropower potential than that estimated by the study. The methodology used in the study also did not explicitly evaluate hydrokinetic potential at sites where there may be little or no elevation difference, but sufficient velocity and stream depth to support energy extraction using hydrokinetic technologies.

It is essential that the total hydropower potential of approximately 30,000 MWa not be interpreted to be same as 30,000 MW of likely capacity increase potential identified in a sitebased resource assessment conducted during the 1990s by INL (Connor et al. 1998). While the numerical values are the same, the units and associated generation potential are not. The hydropower potential estimated by the present study is annual mean power. This power value translates directly to generation power when multiplied by the number of hours in a year $(8760 \mathrm{hr})$. In contrast, the total capacity increase potential identified in the prior study requires the application of a capacity factor to estimate the corresponding potential generation. Considering that the average capacity factor for the U.S. plant population is $50 \%$, the capacity increase potential corresponds to a 15,000-MWa increase when viewed as annual average power. Conversely, the 30,000 MWa identified in the present study could imply a 60,000-MW increase in capacity. It is not

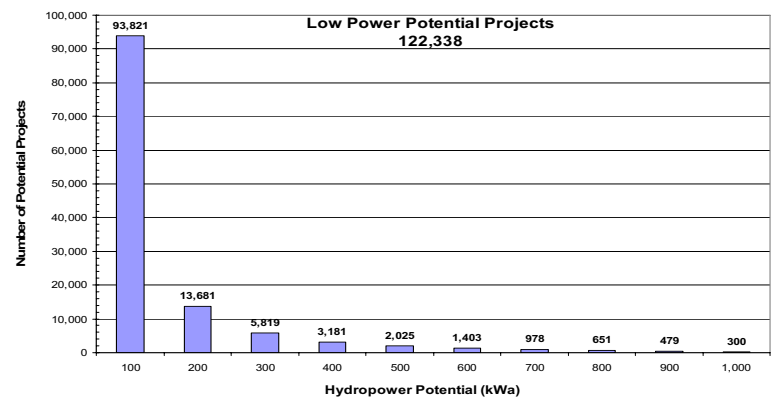

(a) anticipated that this large an increase in capacity would be required in light of the development assumption of only using part of the stream flow, which would allow the identified potential projects to operate at higher capacity factors.

The information shown in Figure 13 is put in perspective by comparison with information about the present U.S. plant population shown in Figure 2. The 30,000 MWa of hydropower potential estimated by this study is comparable to the total average power of the existing plant population, which is between 25,000 and 35,000 MWa as discussed above. However, considering that the present plant population numbers on the order of 2,400 plants (not counting pumped storage plants), it is clear that 130,000 projects will not get built in the foreseeable future, which would double U.S. annual hydropower generation. The fact that the study identified this many feasible projects does indicate a significant number of opportunities for new hydropower development. Development that is more realistic is represented by the 5,400 new small hydro projects identified by the study as shown in Figure 13. These potential projects represent nearly 20,000 MWa of hydropower potential, which would increase in U.S. annual hydropower generation by more than $50 \%$, if they were developed.

The distribution of potential low power projects on the basis of the number of projects and their corresponding hydropower potential in $100-\mathrm{kWa}$ bins ranging from 100 to $1,000 \mathrm{kWa}$ is shown in Figure 14. Most of the 122,338 potential projects in this power class are microhydro projects (hydropower potential less than $100 \mathrm{kWa}$ )

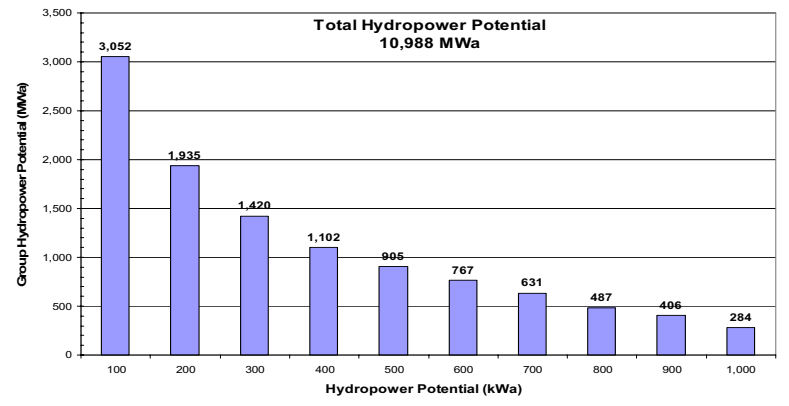

(b)

Figure 14. Distribution of (a) number and (b) group hydropower potential of U.S. low power potential projects. 
representing approximately $30 \%$ of the total hydropower potential for this class of potential projects. The remaining 28,517 potential projects representing approximately 8,000 MWa of hydropower potential have power potentials between 100 and $1000 \mathrm{kWa}$.

Similar distributions for small hydro potential projects are shown in Figure 15 in which the bins are $2 \mathrm{MWa}$, ranging from 2 to $30 \mathrm{MWa}$. Again, the potential projects at the lower end of the power class constitute most of the population. There are 4,375 potential small hydro projects or $80 \%$ of the population having hydropower potentials in the range from 1 to $4 \mathrm{MWa}$. These projects represent slightly over $40 \%$ of the total small hydro hydropower potential. The remaining hydropower potential of 13,000 MWa corresponds to 1,045 potential projects ranging from 6 to $30 \mathrm{MWa}$. At the upper end of the power class, 78 potential projects having hydropower potentials between 28 and $30 \mathrm{MWa}$ represent a total hydropower potential of 2,330 MWa. Most of these projects correspond to using just enough flow rate to produce $30 \mathrm{MWa}$ from larger streams where use of half the flow rate would result in development of a large hydro class project. The approximately 5,000 potential small hydro projects identified in the study represent the group of projects that would most efficiently increase U.S. hydropower generation.

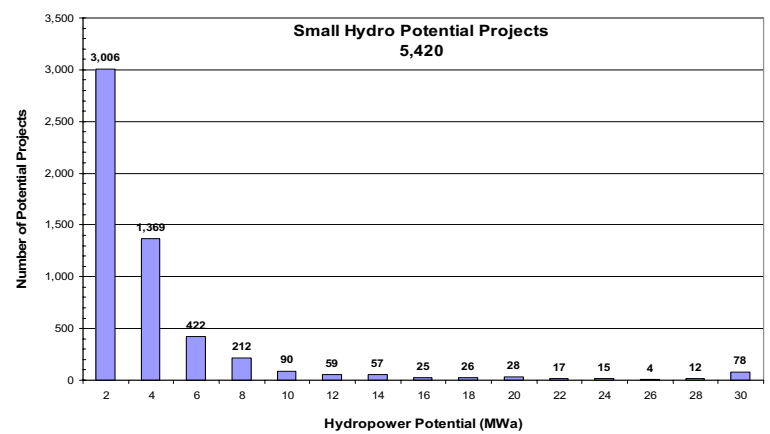

(a)

\subsection{Spatial Distribution of Water Energy Resources and Potential Projects}

The total gross power potential of water energy resource sites in each of the 50 states of the United States is shown in Figure 16. The total state gross power potential is divided into the potential that could feasibly be developed, other available potential that has not been developed and is not excluded from development, potential that is excluded from development either because it is in a zone where federal land use or environmental sensitivity make development unlikely, and potential that has already been developed corresponding to existing hydroelectric plants. This figure shows that six western states, Alaska, Washington, California, Idaho, Oregon, and Montana, have significantly more gross power potential that the other 44 states. For the vast majority of the states (42) the feasible gross potential is more than half of the available gross potential. The average percentage of available gross potential that is feasible is $71 \%$.

Alaska is outstanding both because of it vast power potential (on the order of three times any other state) and because its feasible gross potential is only $14 \%$ of that available. Nearly half of the state's power potential lies within zones where development is unlikely. These characteristics of the state's water energy resources are understandable in light of its large area, extent of mountainous terrain, prevalence of protected areas, and remote location of many resources.

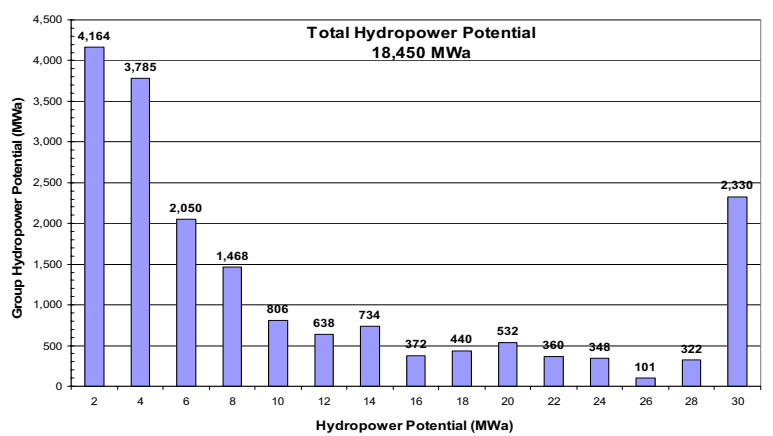

(b)

Figure 15. Distribution of (a) number and (b) group hydropower potential of U.S. small hydro potential projects. 

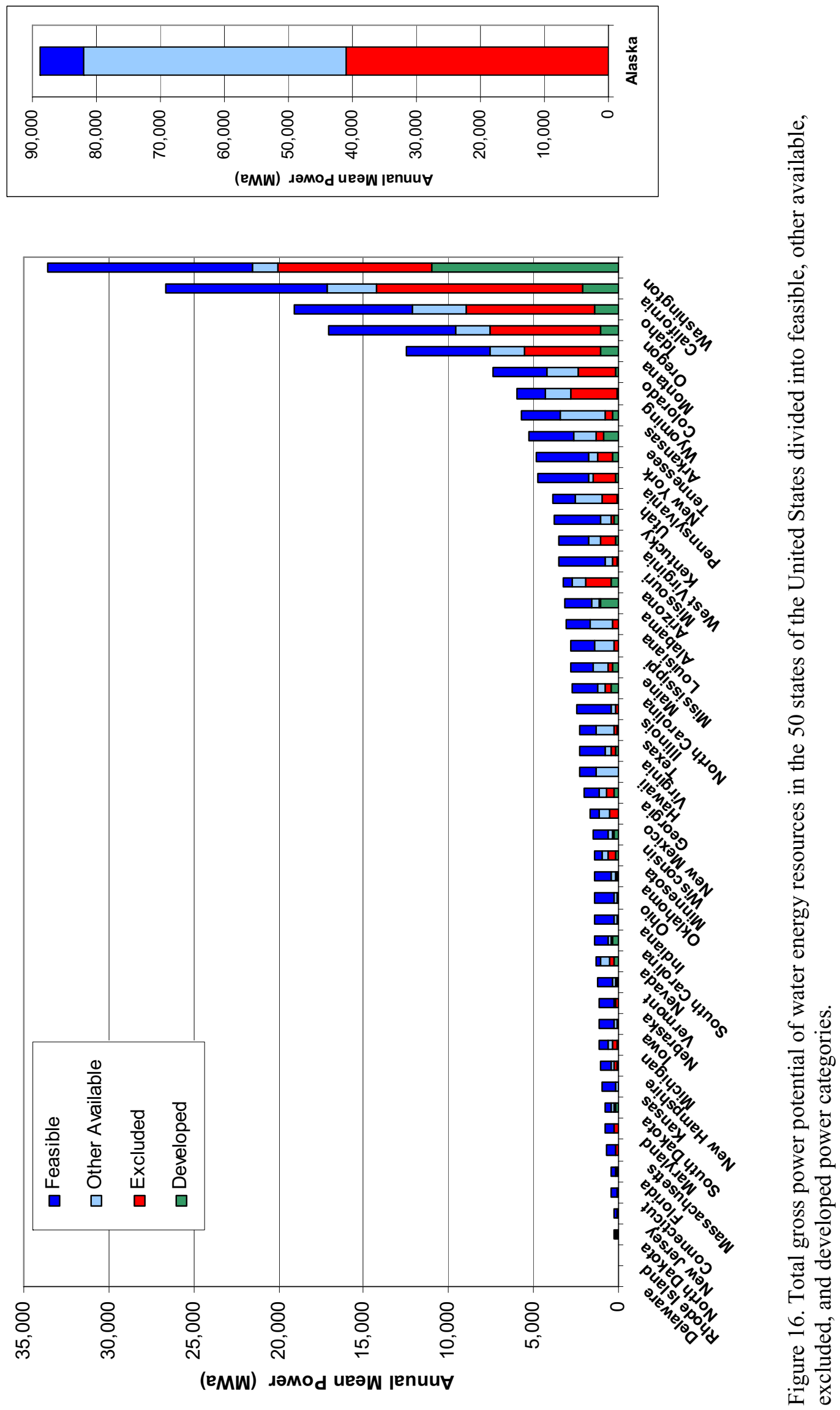
The gross power potential for each state shown in Figure 16 can also be viewed from the perspective of power density by dividing each state's gross power potential by its planimetric area. The result shown in Figure 17 provides an indication of the density of water energy resources in the state. From this perspective, Washington and Hawaii have significantly higher power densities than the other 48 states. This is the result of high rainfall coupled with significant elevation differences in the topography.

The total hydropower potential of feasible potential projects in each of the 50 states of the United States is shown in Figure 18. The total hydropower potential of each state is divided into that corresponding to low power and small hydro potential projects. The same six western states that were found to have the most gross power potential were found to have the most hydropower potential, but not in the same order. While Alaska had by far the most gross power potential, California was found to have the most hydropower potential when feasibility is considered. For most states, most of the hydropower potential was associated with potential small hydro projects (on average $63 \%$ of the total hydropower potential compared to the remaining $37 \%$ associated with potential low power projects).

The hydropower potential of feasible potential projects in each state is put in perspective by comparing to the total average power of the existing hydroelectric plants in the state. Table 7 provides this comparison and shows what percentage increase in generation would be achieved if all the potential projects identified in the state were developed. For this comparison, the higher estimates of annual average power derived from the estimated annual generation listed in the HPRA Database (FERC 1998) were used to be conservative. The data in Table 7 show that 33 states would increase their hydropower generation by $100 \%$ or more and 41 states would increase their generation by more than $50 \%$ if all the potential projects identified in the state were developed.

As with gross power potential, it is useful to know what states have the highest concentrations of hydropower potential. This view is provided by Figure 19. The same two states, Washington and Hawaii, that have outstanding concentrations of gross power potential, also have outstanding concentrations of hydropower potential, but in reverse order. Hawaii has the distinction of having the highest concentration of hydropower potential, followed closely by Washington. Seven states: Idaho, Vermont, California, Oregon, Connecticut, Pennsylvania, and West Virginia make up the next tier of states having power densities greater than $20 \mathrm{kWa} / \mathrm{sq}$ mi with Idaho being the only one of this group that exceeded $25 \mathrm{kWa} / \mathrm{sq}$ mi.

The locations of the 127,758 potential project sites are shown on the map in Figure 20. Project sites are differentiated by whether they are small hydro or low power sites. The low power sites are further differentiated by low power technology class. The 2,391 existing hydroelectric plants are

Table 7. Comparison of hydropower potential of feasible potential projects with total annual average power of hydroelectric plants in each of the 50 states of the United States.

\begin{tabular}{|c|c|c|c|c|c|c|c|c|c|c|c|}
\hline State Name & $\begin{array}{c}\text { Developed } \\
\text { Hydropower } \\
\text { (MWa) }\end{array}$ & $\begin{array}{c}\text { Feasible } \\
\text { Potential } \\
\text { Hydropower } \\
\text { (MWa) }\end{array}$ & $\begin{array}{l}\text { Potential } \\
\text { Hydropower } \\
\text { Increase }\end{array}$ & State Name & $\begin{array}{c}\text { Developed } \\
\text { Hydropower } \\
\text { (MWa) }\end{array}$ & $\begin{array}{c}\text { Feasible } \\
\text { Potential } \\
\text { Hydropower } \\
\text { (MWa) }\end{array}$ & $\begin{array}{l}\text { Potential } \\
\text { Hydropower } \\
\text { Increase }\end{array}$ & State Name & $\begin{array}{c}\text { Developed } \\
\text { Hydropower } \\
\text { (MWa) }\end{array}$ & $\begin{array}{c}\text { Feasible } \\
\text { Potential } \\
\text { Hydropower } \\
\text { (MWa) }\end{array}$ & $\begin{array}{l}\text { Potential } \\
\text { Hydropower } \\
\text { Increase }\end{array}$ \\
\hline \begin{tabular}{|l} 
Delaware \\
\end{tabular} & 0 & 6 & $\infty$ & Utah & 135 & 401 & $297 \%$ & New Hampshire & 187 & 174 & $93 \%$ \\
\hline \begin{tabular}{|l} 
Mississippi \\
\end{tabular} & 0 & 298 & $\infty$ & Virginia & 147 & 418 & $284 \%$ & California & 4699 & 3,425 & $73 \%$ \\
\hline \begin{tabular}{|l} 
Kansas \\
\end{tabular} & 1 & 295 & $29451 \%$ & \begin{tabular}{|l|l|} 
Florida \\
\end{tabular} & 32 & 79 & $245 \%$ & Michigan & 209 & 133 & $64 \%$ \\
\hline Illinois & 27 & 568 & $2103 \%$ & Nebraska & 152 & 354 & $233 \%$ & Oregon & 3271 & 2,072 & $63 \%$ \\
\hline Alaska & 171 & 2,694 & $1575 \%$ & Connecticut & 55 & 105 & $191 \%$ & Tennessee & 1082 & 655 & $61 \%$ \\
\hline Hawaii & 20 & 280 & $1400 \%$ & Texas & 189 & 328 & $174 \%$ & North Carolina & 610 & 348 & $57 \%$ \\
\hline New Jersey & 6 & 63 & $1057 \%$ & Vermont & 128 & 217 & $170 \%$ & Georgia & 429 & 230 & $54 \%$ \\
\hline \begin{tabular}{|l} 
Missouri \\
\end{tabular} & 129 & 798 & $618 \%$ & $\mid$\begin{tabular}{|l|} 
Idaho \\
\end{tabular} & 1288 & 2,122 & $165 \%$ & South Carolina & 428 & 211 & $49 \%$ \\
\hline New Mexico & 30 & 156 & $519 \%$ & Rhode Island & 4 & 7 & $163 \%$ & Maryland & 203 & 91 & $45 \%$ \\
\hline Ohio & 63 & 319 & $506 \%$ & Arkansas & 405 & 590 & $146 \%$ & Alabama & 1113 & 462 & $41 \%$ \\
\hline \begin{tabular}{|l|} 
Indiana \\
\end{tabular} & 67 & 305 & $455 \%$ & Oklahoma & 239 & 345 & $144 \%$ & Nevada & 263 & 95 & $36 \%$ \\
\hline Wyoming & 117 & 507 & $433 \%$ & \begin{tabular}{|l|} 
Montana \\
\end{tabular} & 1192 & 1,669 & $140 \%$ & Washington & 11470 & 3,106 & $27 \%$ \\
\hline \begin{tabular}{|l|} 
Colorado \\
\end{tabular} & 246 & 891 & $362 \%$ & Kentucky & 383 & 518 & $135 \%$ & New York & 2861 & 757 & $26 \%$ \\
\hline \begin{tabular}{|l|} 
lowa \\
\end{tabular} & 95 & 329 & $347 \%$ & Minnesota & 128 & 140 & $109 \%$ & South Dakota & 622 & 119 & $19 \%$ \\
\hline West Virginia & 140 & 484 & $346 \%$ & Massachusetts & 126 & 136 & $108 \%$ & \begin{tabular}{|l|} 
Arizona \\
\end{tabular} & 928 & 150 & $16 \%$ \\
\hline \begin{tabular}{|l} 
Louisiana \\
\end{tabular} & 89 & 306 & $343 \%$ & \begin{tabular}{|l|} 
Maine \\
\end{tabular} & 432 & 432 & $100 \%$ & North Dakota & 270 & 40 & $15 \%$ \\
\hline \begin{tabular}{|l|} 
Pennsylvania \\
\end{tabular} & 284 & 953 & $336 \%$ & Wisconsin & 264 & 259 & $98 \%$ & & & & \\
\hline
\end{tabular}




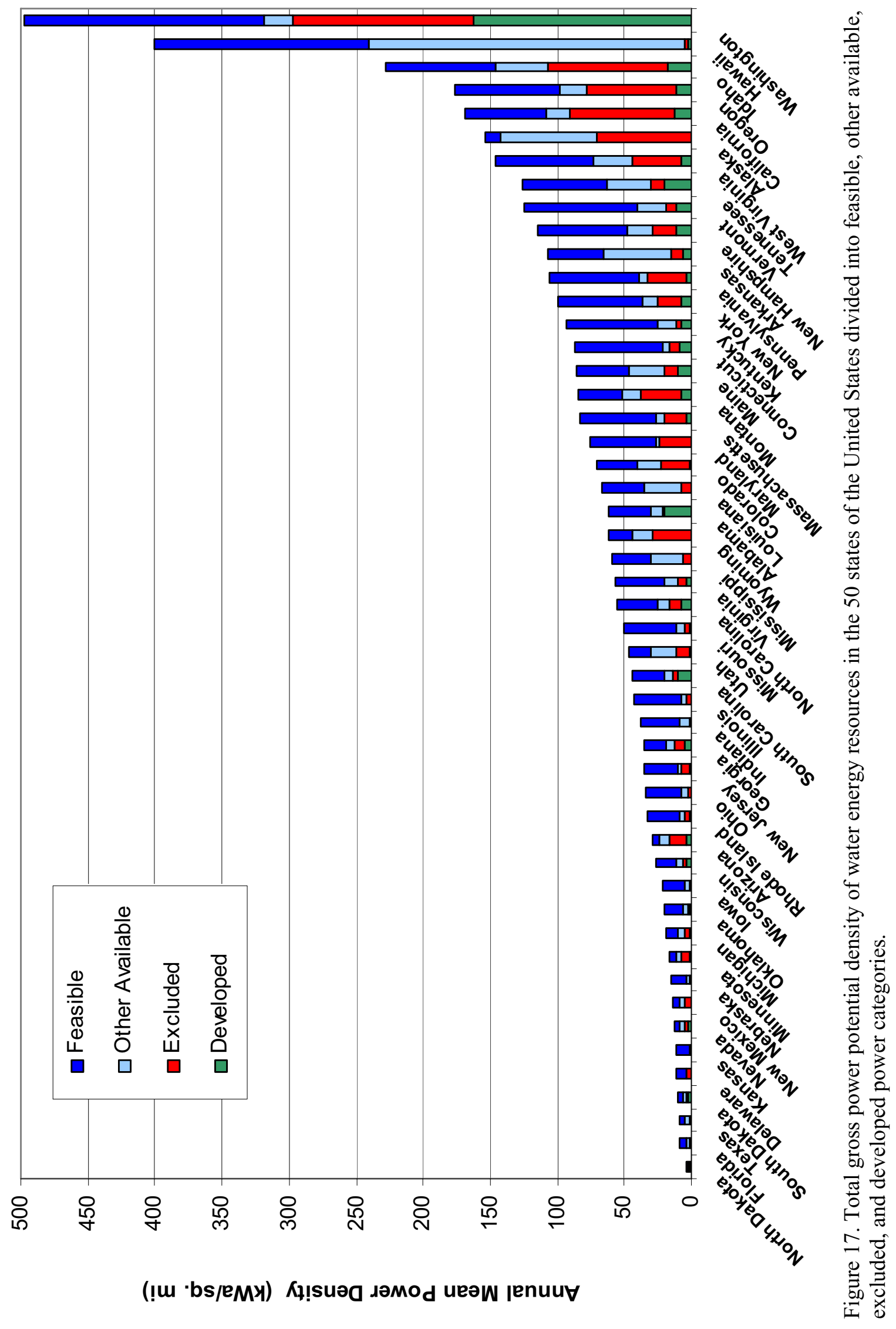



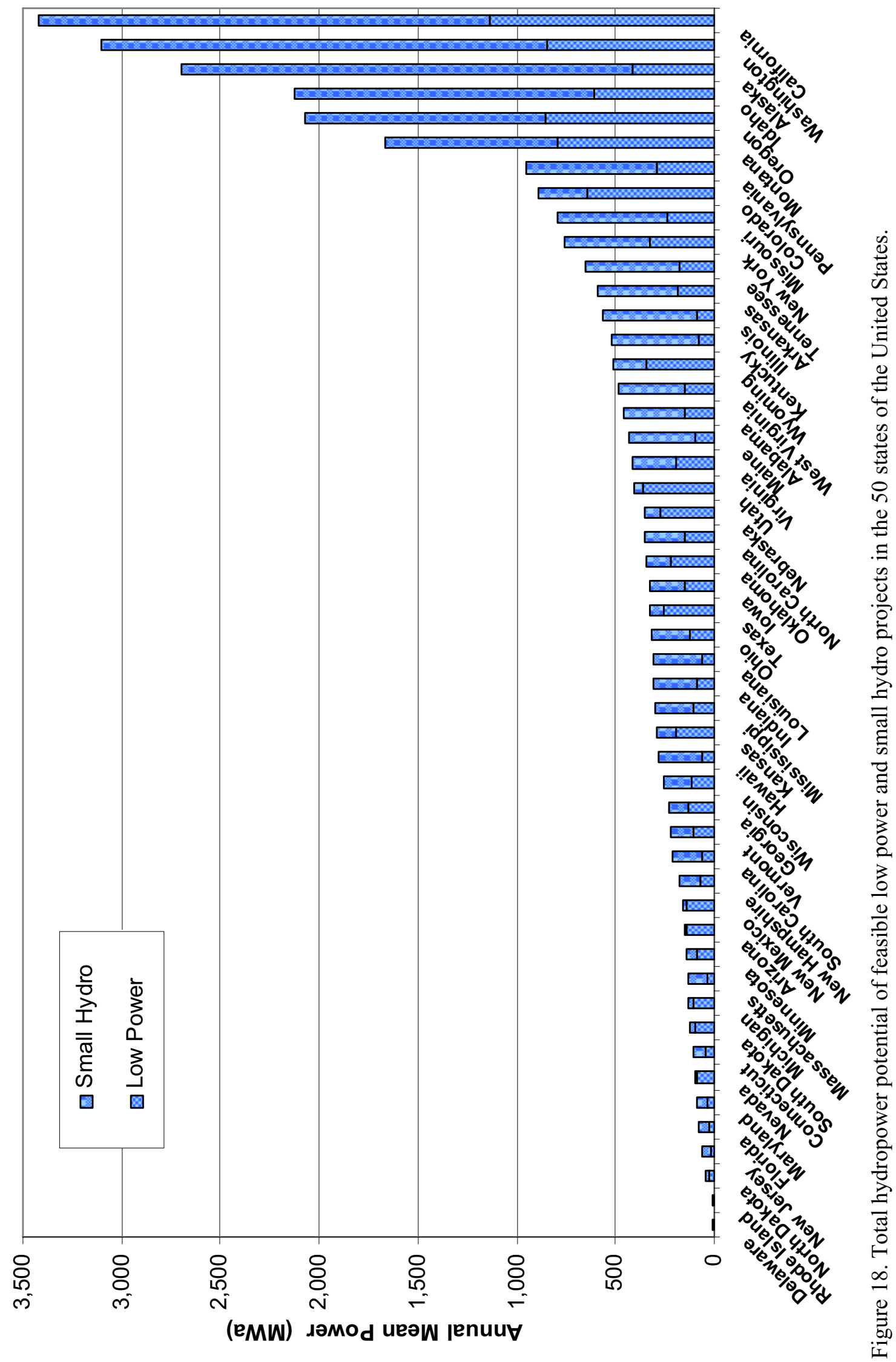

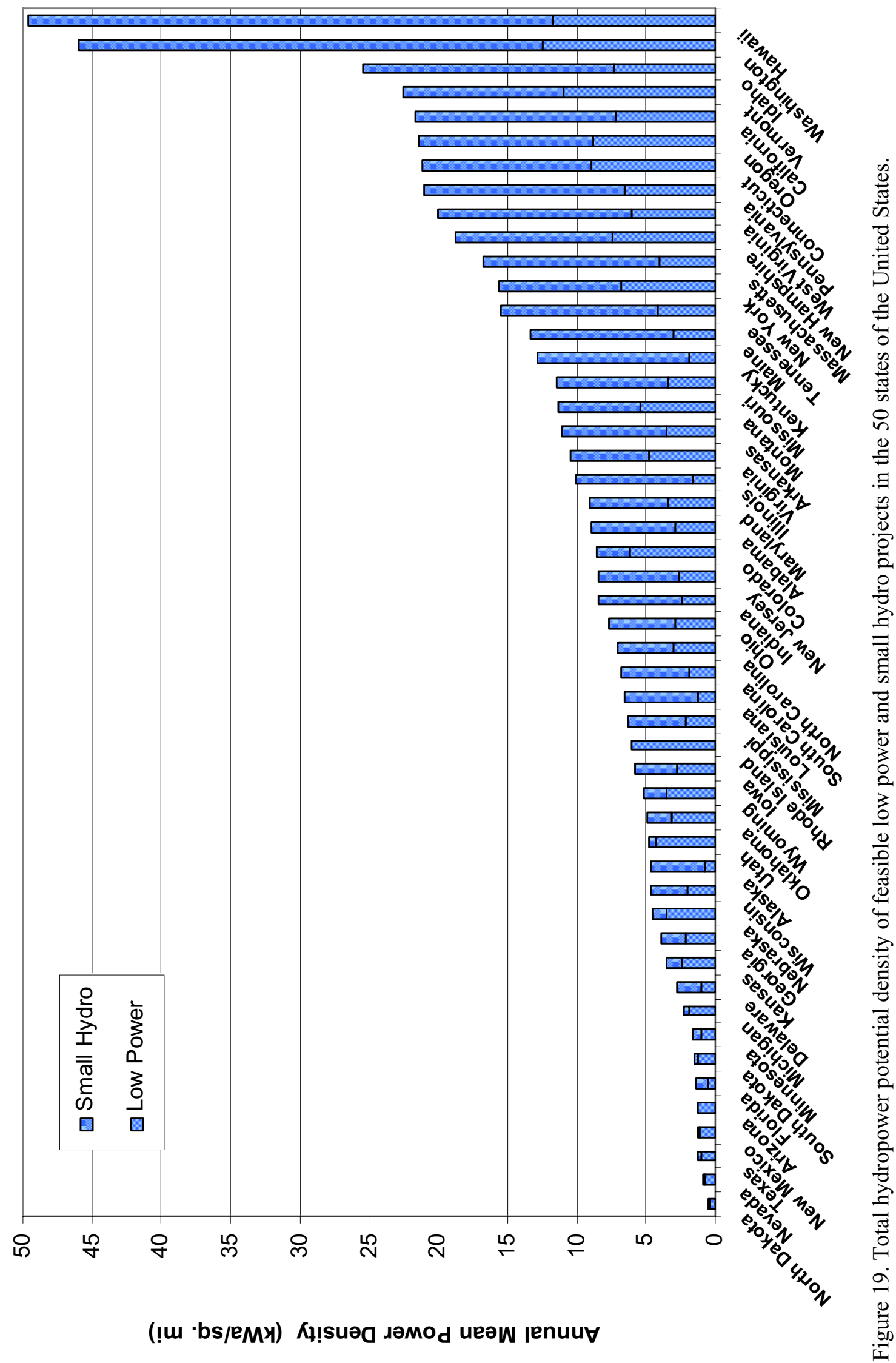

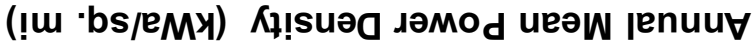




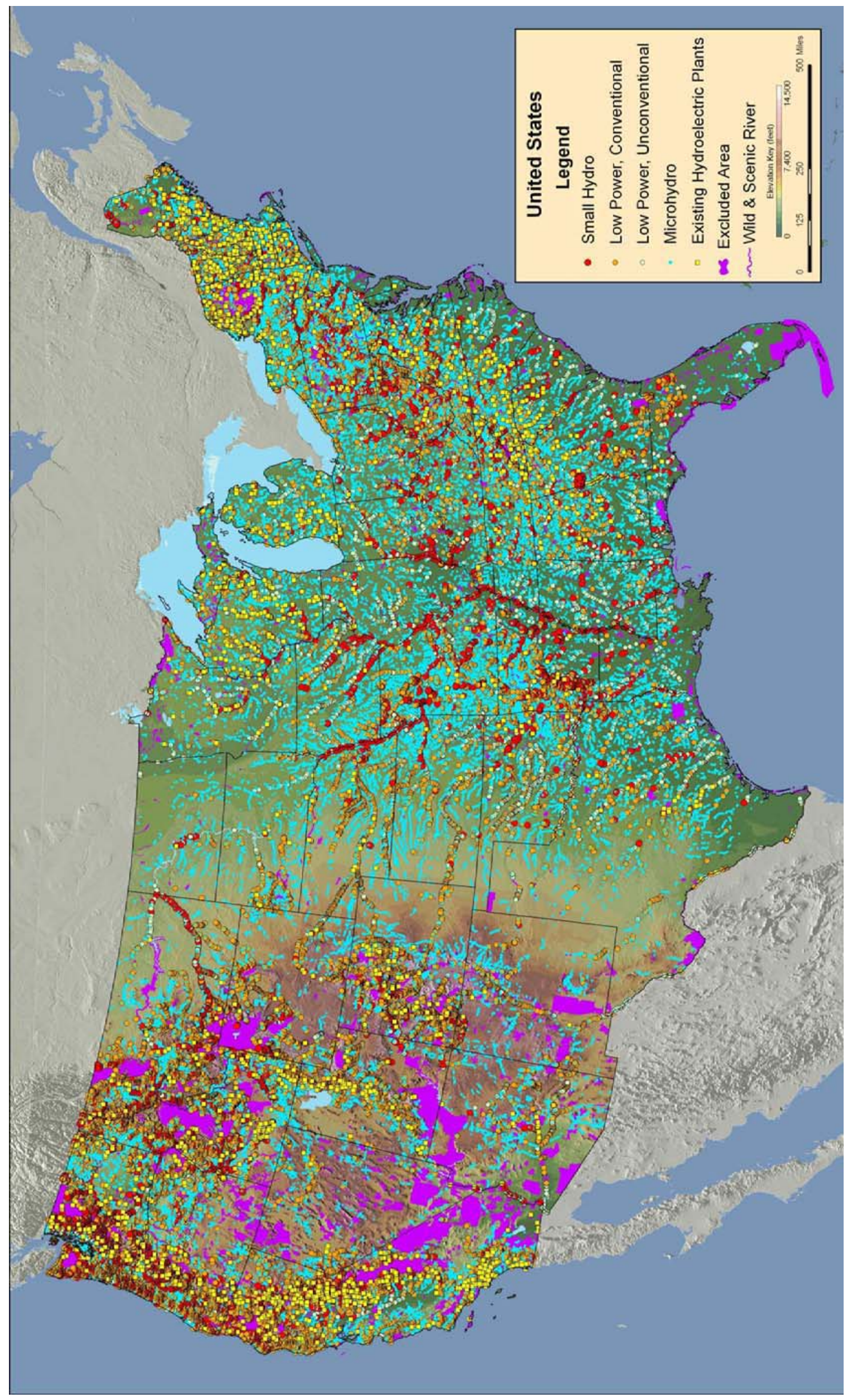


also shown on the map. Figure 20 provides an indication of the location of the project sites and visual image of their concentration. Every state contains some potential project sites. It is clear from the map and Figure 19 that eight states, North Dakota, Nevada, Texas, New Mexico, Arizona, Florida, South Dakota, and Minnesota, have notably low concentrations of project sites in at least part of the state. Other than these states, most states have significant numbers and concentrations of potential project sites including Texas, whose potential projects happened to be concentrated in the eastern part of the state. Considering only small hydro and low power, conventional turbine project sites, the map shows that sites abound East of the Mississippi River particularly in the Appalachian Mountains, on tributaries of the Mississippi River, in the Rocky Mountains, in the Sierra Mountains, and in the Coastal Ranges in California, Oregon, and Washington.

Summaries addressing the water energy resources and feasible potential projects in each state are provided in Appendix B. These summaries include tabular data and graphical presentations of the gross power potential of state water energy resources by power category and the hydropower potential of potential projects by power class. Distributions of the number and group hydropower of low power and small hydro potential projects are presented in ranges of hydropower potential. These distributions show relative numbers of projects of various sizes and their contribution to the total, power class, hydropower potential. Each summary concludes with a state map showing the locations of low power and small hydro potential projects.

\subsection{Potential Project Location and Attributes Provided by the Virtual Hydropower Prospector}

In order to go beyond the summary data presented in this report and present information about individual water energy resource sites and potential projects, the data used and produced in this study were incorporated into a GIS application and made publicly available on the Internet. This application is called the VHP, and it is accessible at http://hydropower.inl.gov/prospector/. The VHP desktop displaying a map of the Pacific Northwest Region is shown in Figure 21. Its purpose is not only to display water energy resource sites and potential projects on regional maps and provide extensive attribute information about them, but also to show sufficient context features so that the application user can perform preliminary, customized feasibility assessments. For this purpose, the user can elect to display the following context features:

- Hydrography

- Power system (hydroelectric plants, other power plants, transmission lines, and substations)

- Transportation (roads and railroads)

- Areas and places (city centers; populated areas; county, state, and hydrologic region boundaries)

- Land Use (exclusion zones based on federal and statutes and policies and environmental sensitivities; and land that is the purview of federal agencies including: Bureau of Indian Affairs, Bureau of Land Management, Bureau of Reclamation, Department of Defense, U.S. Forest Service, U.S. Fish \& Wildlife Service, U.S. Park Service).

In addition to displaying these features on the map, attribute information about them is also provided by the application. 


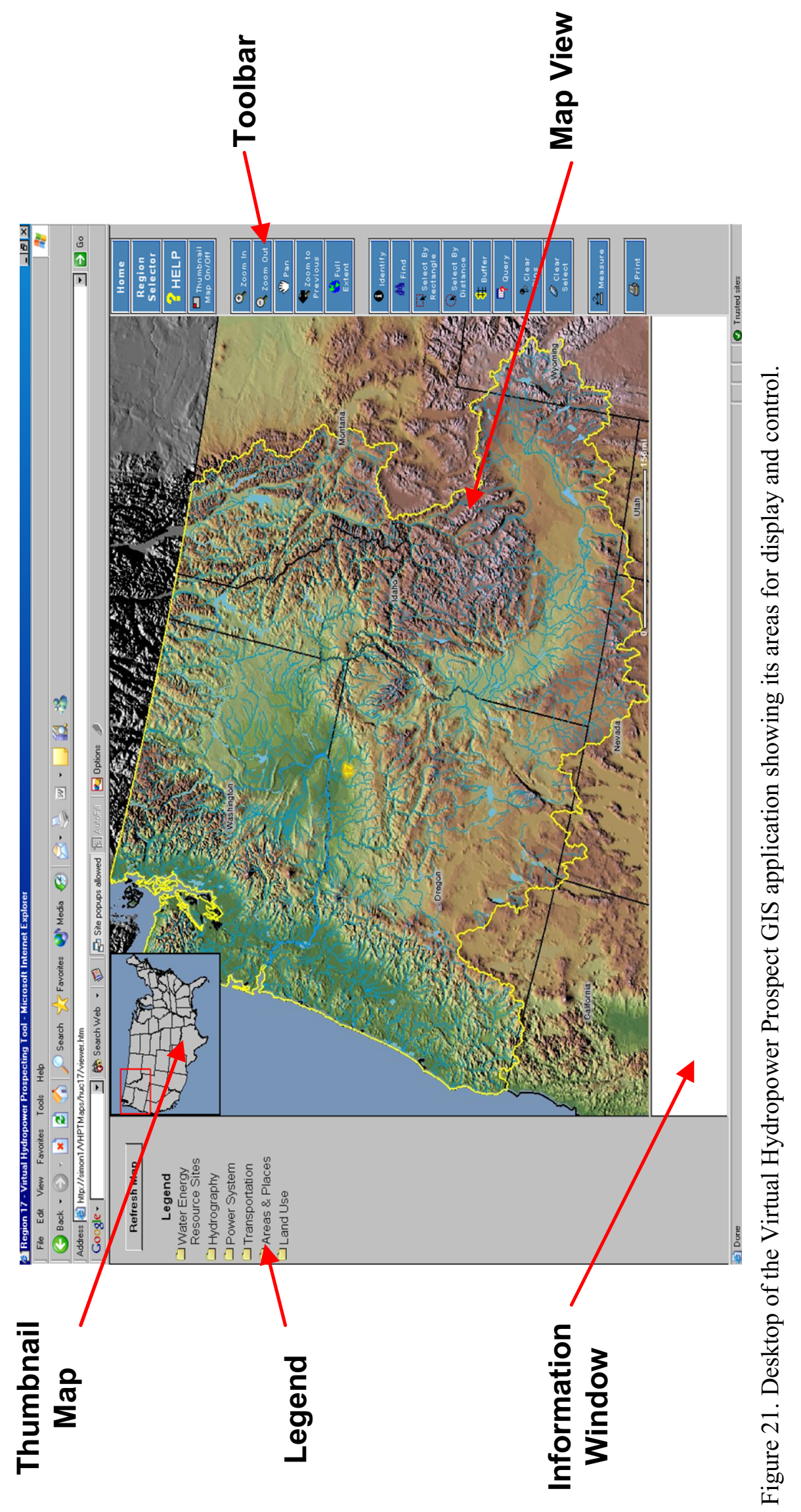




\section{CONCLUSIONS}

This study has refined the results of the previous assessment of the water energy resources of the United States (Hall et al. 2004) by accounting for environmentally sensitive areas as zones in which hydropower development is unlikely. It has extended the previous study by identifying water energy resource sites that are feasible to develop and estimated their hydropower potential based on a realistic development model and associated development constraints. Of the approximately $300,000 \mathrm{MWa}$ of total, gross power potential of U.S. natural stream water energy resources, only about $10 \%$ has been developed. About 30\% are located in zones where development is unlikely. The remaining $60 \%$ of over $170,000 \mathrm{MWa}$ have not been developed and are not restricted from development based on information sources used in the assessment. Of this potential, it was found that nearly 100,000 MWa of gross power potential could feasibly be developed. This feasible potential corresponds to nearly 130,000 potential low power and small hydro projects. Estimation of the hydropower potential of these sites indicates $30,000 \mathrm{MWa}$ of new power supply could feasibly be developed in the United States.

There are a large number of feasible potential projects to choose from, and they are located such that most states could benefit from a significant amount of additional renewable energy if they were developed. Development of the 5,400 feasible small hydro projects alone would provide more than a $50 \%$ increase in U.S. hydroelectric generation. Six western states, California, Washington, Alaska, Idaho, Oregon, and Montana, have potential project sites representing particularly high amounts of hydropower potential. With the exception of Washington, which already has the highest amount of hydroelectric generation among the states by a wide margin, these states have sufficient hydropower potential to increase their generation by between 60 and $1600 \%$. Alaska has sufficient hydropower potential to increase its hydroelectric generation by nearly a factor of 16 . Hawaii is also noteworthy, because it has the highest density of potential projects, which if developed, would also increase its hydroelectric generation by more than a factor of ten. Beneficial increases are not limited to just the western states.
This study has shown that 41 states distributed around the country have sufficient potential to increase their generation by at least $50 \%$. These facts illustrate that beneficial renewable water energy resources are under utilized throughout most of the country.

The development model used to assess hydropower potential is a configuration not requiring a total obstruction of the water course or the creation of a reservoir. Eighty-four percent of the identified hydropower potential could be developed using existing technology. Of the current U.S. hydroelectric plant population, 92\% are small hydro or low power plants based on their annual average power. These facts illustrate that while research and development may lead to new configurations, use of new materials, and increased efficiencies, significant gains in generation can be achieved without large research and development investments or the need to demonstrate that low power and small hydro plants are technologically feasible.

Water energy resource sites were designated as being feasible for development in this study based on a set of feasibility criteria. Local land use, policies, and environmental sensitivities not accounted for in the study may render some of the identified potential projects unfeasible. Economic factors may also affect the development viability of some sites. The study also did not include a comprehensive assessment of the economic viability of the identified potential projects. An elementary consideration was given to acceptable costs of site accessibility and power transmission. However, the costs of licensing, construction, mitigation, operation and maintenance, availability of financing, and the potential income from purchased power were not evaluated. Current trends may make projects that are not economically viable now become viable in the future. These trends include: the rising cost of fossils fuels, the establishment of state renewable portfolio standards, carbon credits, transmission grid load and energy security considerations favoring distributed generation, and federal incentives to promote sustainable energy production and U.S. energy independence. 
The hydropower potential of feasible potential projects was based on a development model and restrictions on working flow rate and hydraulic head. Equipment efficiency and penstock pressure losses were not included, which would reduce estimated hydropower potentials. While annual mean flow rates were used to estimate power potential, water availability based on flow duration was not. Some sites could be rendered unfeasible when equipment related power losses and water availability are included in the feasibility assessment. Counterbalancing these power potential reducing factors are the facts that more than half the stream flow may be available for power generation at some sites, thus increasing both power potential and availability. Dams may exist at some sites, increasing the power potential because of the existence of more hydraulic head than was estimated and increasing the likelihood of development due to previously mitigated environmental concerns and significantly reduced development costs.
This study and the companion development of a publicly available GIS application on the Internet has shown that the value of research can be enhanced and extended by providing access to detailed information and tools for individuals to further research the subject matter from their perspective. The ultimate value of the study is the conclusion that sufficient, untapped power potential from water energy resources exists in most places in the United States to warrant further evaluation as sources of sustainable energy production and has shown the most likely locations meriting further evaluation. The Virtual Hydropower Prospector GIS application on the Internet provides a tool for customized preliminary site evaluations. However, site specific evaluations of development feasibility and power potential considering engineering and economic aspects of the potential project are essential. 


\section{RECOMMENDATIONS}

The feasibility assessment that has been performed could be further refined to address additional factors including:

- Equipment efficiencies and energy losses

- Resource duration and availability

- Local land use and environmental sensitivities

- Economic feasibility considering development costs and incentives, power marketing, and available financing.

Incorporation of these additional factors for all the potential projects identified by the screening performed in the present study would require significant funding. As with any federally funded research and development, there is the question of at what point research that could not be funded by industry has been completed and sufficient information has been provided to enable industry to explore and develop specific opportunities. The need for federally funded refinement of the feasibility assessment is not clear. Such refinements are possible, but are probably dependent on an expression of industry need.

The usefulness of VHP GIS application could be enhanced by several upgrades. At present, the application displays color-coded, shaded relief only when a large area is displayed. The relief is turned off when the user zooms into a local area because the relief is based on $1 \mathrm{~km}$ DEMs, resulting in distracting pixilation beyond a certain level of zoom. The relief display could be upgraded using GIS data layers based on at most $90 \mathrm{~m}$ DEMS, allowing the user to view the topography of local areas and be better able to evaluate topographic implications affecting development. Additional feature sets and references that could be added include:

- Locations and attributes of all existing U.S. dams from the National Inventory of Dams

- Reference added to site and potential project attributes to access the Bureau of Land Management's hydropower site surveys

- Locations and attributes of protected areas as defined by the Northwest Power and Conservation Council.
Canvassing hydropower stakeholders would no doubt lead to the identification of other feature sets that should be made available for display and reference.

Entities controlling large land holdings, such as the U.S. military and Indian tribes, would benefit from customized versions of the assessment studies that have been performed. Such assessments would present subsets of the countrywide information to identify water energy resources and potential projects on the land under their purview. This would assist them in planning and securing funding, and if implemented, would provide energy security while providing electricity for their residents and operations.

The tools and techniques that have been developed for assessing the United States natural stream resources could be applied anywhere in the world. Other developed countries and particularly developing countries would benefit from an assessment of their resources, the identification of promising development sites, and a GIS tool to assist in site evaluation and planning development of water energy resources.

The resource assessment and subsequent feasibility assessment that have been performed were limited to natural stream, potential energy, water energy resources. The United States has other abundant sources of water energy that could be harnessed including:

- Locations on natural streams with little or no elevation difference, but sufficient velocity and depth to accommodate hydrokinetic turbines

- Constructed waterways

- Tidal estuaries

- Ocean currents

- Ocean waves.

Efficient development of these resources would be aided by determining the spatial distribution of their gross power potential, identifying feasible development sites, and estimating the realistic power potential at these sites. All stakeholders and particularly developers would greatly benefit from a GIS application addressing these resources like 
the VHP. Such a tool would not only provide information about resources, but would help to ensure that investment is not made in areas where development is unlikely to succeed.

Small hydropower developers would benefit from two information resources: a catalog of small hydropower technologies and a cost estimating guide that would assist them in making preliminary estimates of development costs. A pilot technology catalog (Hall \& Dalton 2004) was published, but was not fully developed. A catalog of this type would serve the obvious function of informing developers of equipment available for their project. Because it was envisioned that the catalog would also contain technologies that have not reached the commercial stage of development, it would have the benefits of exposing promising technologies to additional development and revealing gaps where new technologies are needed. In addition to knowing what technologies are available, developers need to be able to get preliminary estimates of development costs including: licensing, construction, mitigation, and operations and maintenance. A previous study (Hall et al. 2004) provided cost estimating tools for these costs, but was limited to projects having nameplate capacities of $1 \mathrm{MW}$ or greater. A reference that focused on low power and small hydro projects would provide greater applicability to these power classes of hydropower projects. 


\section{REFERENCES}

Connor, A. M., J. E. Frankfort, and B. N. Rinehart, 1998, U.S. Hydropower Resource Assessment Final Report, DOE/ID-10430.2, December 1998. ${ }^{\mathrm{e}}$

ENERmap, 2005, U.S. power system GIS data layer purchased from ENERmap, LLC January 2005.

ESRI, 2004, Environmental Systems Research Institute (ESRI) StreetMap data layer, 2004.

Federal Energy Regulatory Commission, 1998, Hydroelectric Power Resources Assessment (HPRA) Database.

Hall, D. G., R. T. Hunt, K. S. Reeves, and G. R. Carroll, 2003, Estimation of Economic Parameters of U.S. Hydropower Resources, INEEL/EXT-03-00662, June 2003. ${ }^{\mathrm{e}}$

Hall, D. G., S. J. Cherry, K. S. Reeves, R. D. Lee, G. R. Carroll, G. L. Sommers, and K. L. Verdin 2004, Water Energy Resources of the United States with Emphasis on Low Head/Low Power Resources, DOE/ID-11111, April 2004.
Hall, D. G. and J. L. Dalton, 2004, Catalog of Low Power Hydropower Technologies, DOE/NE-11181, October 2004.

Verdin, K., and S. Jenson, 1996, "Development of Continental Scale DEMs and Extraction of Hydrographic Features," Proceedings of the Third International Conference/Workshop on Integrating GIS and Environmental Modeling, Santa Fe, New Mexico, January 21-26, 1996. (CD-ROM available from National Center for Geographic Information and Analysis, Santa Barbara, California, 93106, USA).

Vogel, R. M., I. Wilson, and C. Daly, 1999, "Regional Regression Models of Annual Streamflow for the United States," Journal of Irrigation and Drainage Engineering, May/June 1999, pp. 148-157.

e. This report is accessible in pdf format on the Internet at: http://hydropower.inl.gov/resourceassessment/ 
Appendix A

\section{Description of Exclusion Zones}


A-2 


\section{Appendix A}

\section{Description of Exclusion Zones}

In this study, exclusion zones were areas in which development of new hydroelectric plants is highly unlikely either because of land use designated by federal statutes and policies or because of known environmental sensitivities. These zones were used to apply the feasibility criteria stipulating that a water energy resource site must not be located in an exclusion zone if it is to be designated as a feasible potential project. Geographic information system (GIS) tools were used to determine whether any part of a stream reach corresponding to a water energy resource site intersected the polygon area representing the exclusion zone. If any part of the reach intersected the zone, the site was designated as unfeasible for development. However, if no part of the reach intersected the zone, no matter how close to the zone boundary it is, the exclusion zone feasibility criteria were considered to be met affirmatively. The two sections of this appendix each describe one of the two types of exclusion zones used in the study and the data that was used for analysis.

States, regional jurisdictions, and local jurisdictions have also designated protected areas that are most likely excluded from hydropower development. However, information regarding these protected areas is scattered among numerous state, regional, and local government agencies. Much of this information is not yet in digital format, and much of the digital data are not available online.

Determining the boundaries of lands protected by nonfederal agencies would have entailed contacting a large number of agencies in the country and collecting and digitizing multiple paper datasets in a variety of formats. Such an effort was beyond the scope of the study. It is fortunate that the Conservation Biology Institute provides georeferenced data for environmentally sensitive areas as is discussed in Section A-2.

\section{A-1. Federal Exclusion Zones}

Two GIS data layers from the National Atlas of the United States were used to locate federal exclusion zones. The first layer, "Federal and Indian Lands," contains the boundaries of all federal lands in the United States, subdivided into categories such as national parks, national monuments, Indian reservations, military bases, and DOE sites. The second layer, "Parkways and Scenic Rivers," contains federally protected linear features such as National Wild and Scenic Rivers and National Parkways. Both GIS data layers are available online from the National Atlas of the United States website at http://www.nationalatlas.gov/atlasftp.html.

The categories of federal lands listed in the GIS dataset "Federal and Indian Lands" were reviewed to determine categories corresponding to areas in which hydropower development is highly likely to be excluded. Based on this review, the following categories of federal lands were selected as exclusion zones:

- National battlefields

- National historic parks

- National parks

- National parkways

- National monuments

- National preserves

- National wildlife refuges

- Wildlife management areas

- National wilderness areas.

All the federal lands in these categories were used to create an "excluded federal lands" GIS data layer. Similarly, all national wild and scenic rivers were extracted from the National Wild and Scenic Rivers and National Parkways data 
layer to create a GIS data layer composed exclusively of Wild and Scenic Rivers. Because the "wild and scenic rivers data layer" contained only the rivers themselves, but no adjoining land, all land within one kilometer of a wild and scenic river reach was designated as an excluded area. These areas were combined with excluded federal lands to create a final "federal exclusion zone" GIS data layer that contains the boundaries of all lands and shorelines excluded from hydropower development.

\section{A-2. Environmentally Sensitive Exclusion Zones}

The Conservation Biology Institute

(http://www.consbio.org/) provides a GIS data layer containing environmentally sensitive areas designated by four gap analysis program (GAP) categories with GAP-1 being the most restrictive and GAP-4 being the least restrictive. The definitions of the GAP categories are given in Table A-1.

For the purposes of this study, areas designated with GAP codes 1 and 2 were considered to be exclusion zones in which new hydropower development is highly unlikely. The types of land use areas designated as GAP-1 and GAP-2 are enumerated in Tables A-2 and A-3, respectively. Many of the same types of land use areas appear in both lists, but were apparently discriminated based on the specific use restrictions for each individual area. Many of the exclusion zones based on GAP-1 and GAP-2 areas from the Conservation Biology Institute are coincident with areas that were considered federally designated exclusion zones. No individual area use restrictions were considered for federal exclusion zones. 
Table A-1. GAP codes used by the Conservation Biology Institute to designate land use restrictions based on environmental sensitivities.

\begin{tabular}{|c|l|}
\cline { 2 - 3 } \multicolumn{1}{c|}{} & \multicolumn{1}{c|}{ GAP Code Description } \\
\hline GAP Code 1 & $\begin{array}{l}\text { An area having permanent protection from conversion of natural land cover and a } \\
\text { mandated management plan in operation to maintain a natural state within which } \\
\text { disturbance events (of natural type, frequency, intensity, and legacy) are allowed to } \\
\text { proceed without interference or are mimicked through management. Gap Code 1 } \\
\text { examples include national parks, wilderness areas, and nature preserves. }\end{array}$ \\
\hline GAP Code 2 & $\begin{array}{l}\text { An area having permanent protection from conversion of natural land cover and a } \\
\text { mandated management plan in operation to maintain a primarily natural state, but } \\
\text { which may receive uses or management practices that degrade the quality of existing } \\
\text { natural communities, including suppression of natural disturbance. Gap Code } 2 \\
\text { examples include state and provincial parks, wildlife refuges, and national recreation } \\
\text { areas. }\end{array}$ \\
\hline GAP Code 3 & $\begin{array}{l}\text { An area having permanent protection from conversion of natural land cover for the } \\
\text { majority of the area, but subject to extractive uses of either a broad, low-intensity type } \\
\text { (e.g., logging) or localized intense type(e.g., mining). It also confers protection to } \\
\text { federally listed endangered and threatened species throughout the area. Gap Code 3 } \\
\text { examples include national forests, wildlife management areas, and Bureau of Land } \\
\text { Management lands. }\end{array}$ \\
\hline GAP Code 4 & $\begin{array}{l}\text { There are no known public or private institutional mandates or legally recognized } \\
\text { easements or deed restrictions held by the managing entity to prevent conversion of } \\
\text { natural habitat types to anthropogenic habitat types. The area generally allows } \\
\text { conversion to unnatural land cover throughout. }\end{array}$ \\
\hline
\end{tabular}


Table A-2. Types of land use areas designated as GAP Code 1 by the Conservation Biology Institute.

\begin{tabular}{|l||l||l|}
\hline Adaptive Management Area & National Recreation Area & Research Natural Area \\
\hline Administratively Withdrawn & National Reserve & Scenic Recreation Area \\
\hline $\begin{array}{l}\text { Area of Critical Environmental } \\
\text { Concern }\end{array}$ & National Scenic-Research Area & Scenic Research Area \\
\hline Botanical Reserve (SIA) & National Volcanic Monument & Special Designation \\
\hline Congressionally Withdrawn & National Wildlife Refuge & Special Interest Area \\
\hline Conservation Land & Natural Area & State Park \\
\hline Ecological Reserve & Nature Conservancy Preserve & State Proposed Research Natural Area \\
\hline Geologic Area & Nature Preserve & State Scenic Waterway \\
\hline Late Successional Reserve & Open Water & State Wildlife Reserve \\
\hline Management Plan Area & OSPRSSW/Deschutes & Tribal Primitive Area \\
\hline National Forest & Other BLM Land & Tribal Wilderness \\
\hline National Grassland & Other COE Land & Water \\
\hline National Historic Park & Other National Park Land & Wild and Scenic Area \\
\hline National Historical Park & Private Conservation Land & Wild and Scenic River \\
\hline National Memorial Parkway & Private Institution Managed for & Wilderness \\
\hline National Monument & Biodiversity & Wilderness Area \\
\hline \begin{tabular}{|l} 
National Outstanding Natural \\
Area
\end{tabular} & Private Land & Wilderness Study Area \\
\hline National Park & Proposed Research Natural Area & Wildlife Habitat Management Area \\
\hline
\end{tabular}

Table A-3. Types of land use areas designated as GAP Code 2 by the Conservation Biology Institute.

\begin{tabular}{|c|c|c|}
\hline Area of Critical Environmental Concern & Natl River \& Wild \& Scenic Riverway & Research Natural Area \\
\hline BLM Holding & Natural Area & Special Designation \\
\hline BLM/National Wildlife Refuge PW & Natural scenic area & Special Interest Area \\
\hline BLM/Protective Withdrawal (PW) & Open Water & State Lands \\
\hline Botanical Area & Other BLM Land & State Lease \\
\hline Botanical Emphasis Area & Other COE Land & State Memorial \\
\hline Conservation Easement & Other Federal Land & State Natural Area \\
\hline Corporate easement & Other Federal Lands & State Park \\
\hline Ducks Unlimited Managed & Other ODFW Land & State Recreation Area \\
\hline Fish \& Game Access Area & Other USFWS & State RNA \\
\hline Fish \& Game Management Area & Other USFWS Land & State Scenic Waterway \\
\hline Game Management Area & Park Land & State Wildlife Recreation Area \\
\hline Game Range & Preservation Easement & TNC Easement \\
\hline Instant Study Area & Primitive Area & Tribal Wilderness Buffer Zone \\
\hline Lease & Primitive State Park & USFS/Protective Withdrawal (PW) \\
\hline Local Land Trust Preserve/Easement & Privately owned, DU managed CE & Water \\
\hline Military Reservation & Privately owned, Fvlt managed CE & Wayside \\
\hline National Conservation Area & Privately owned, MLR managed & Wild and Scenic Area \\
\hline National Forest & Privately owned, MLR managed CE & Wild and Scenic River \\
\hline National Grassland & Privately owned, MLR managed, PW & Wild River/Wilderness Area \\
\hline National Monument & Privately owned, TNC managed & Wilderness Area \\
\hline National Park & Privately owned, TNC managed CE & Wilderness Study Area \\
\hline National Recreation Area & Privately owned, TNC managed other & Wildlife Area \\
\hline National Scenic Area & Privately owned, TNC managed regis & Wildlife Habitat Management Area \\
\hline National Wild \& Scenic River & Proposed Natural Area & Wildlife Management Area \\
\hline National Wildlife Refuge & Proposed Research Natural Area & \\
\hline Native American Lands & Proposed RNA & \\
\hline
\end{tabular}


Appendix B

Assessment Results by State 
B-2 


\section{Appendix B}

\section{Assessment Results by State}

This appendix contains the results of feasibility assessments of the 50 states of the United States. The state results are summarized in tables, Tables B-1 and B-2, to facilitate lookup of power potential values and comparison of these values among the states. Table B-1 presents power potentials in three groups. The first group includes the gross power potential and its subdivisions by power categories: developed, excluded, and available. The second group includes the total hydropower potential of feasible projects and its subdivisions into low power and small hydro power classes. The third group includes subdivisions of the low power hydropower potential into power classes corresponding to classes of low power technologies.

Table B-2 presents information corresponding to that presented in Table B-1 but as percentages of total values. In the first group of data, total gross power potential for the state is presented as a percentage of the total gross power potential for the country. This percentage is followed by values for developed, excluded, and available power categories as percentages of the state total gross power potential. In the second group of data, the first value is the total hydropower potential of feasible projects as a percentage of the gross available power potential. This value is followed by values for low power and small hydro feasible projects as percentages of the total hydropower potential of all feasible projects. The third group includes values for the three power classes of low power feasible projects as percentages of the total, low power, hydropower potential. Bolded values in this table indicate values higher than the national average, and values highlighted in blue indicate the largest subdivision.

The summary information in Tables B-1 and B-2 is followed by 50 sections, each devoted to a particular state. Each section has the same format, which includes the following tables and figures:

- Table of total, developed, federally excluded, environmentally excluded and other excluded, and available gross power potential by power class
- Pie charts showing the developed, excluded, and available fractions of the water energy resource site population and the corresponding fractions of the total gross power potential

- Table of gross power potential of available sites, gross power potential of feasible sites, and hydropower potential of feasible sites by power class

- Pie charts showing fractions of the feasible project population and the corresponding fractions of the total hydropower potential by power class

- Bar charts showing the distribution of the low power feasible project population and corresponding hydropower potential by hydropower ranges

- Bar charts showing the distribution of the small hydro feasible project population and corresponding hydropower potential by hydropower ranges

- Feasible project distribution map showing the locations of existing hydroelectric power plants and feasible project sites differentiated by power class.

The term "available" used in the tables and figures in this appendix only denotes the net amount of power potential after subtracting the amounts of developed and excluded power potential from the gross amount of power potential. The term "feasible" used in the tables and figures in this appendix refers to water energy resource sites and their corresponding gross power potential or hydropower potential as determined using the feasibility criteria and assessment methodology as described in Section 3, Technical Approach. 


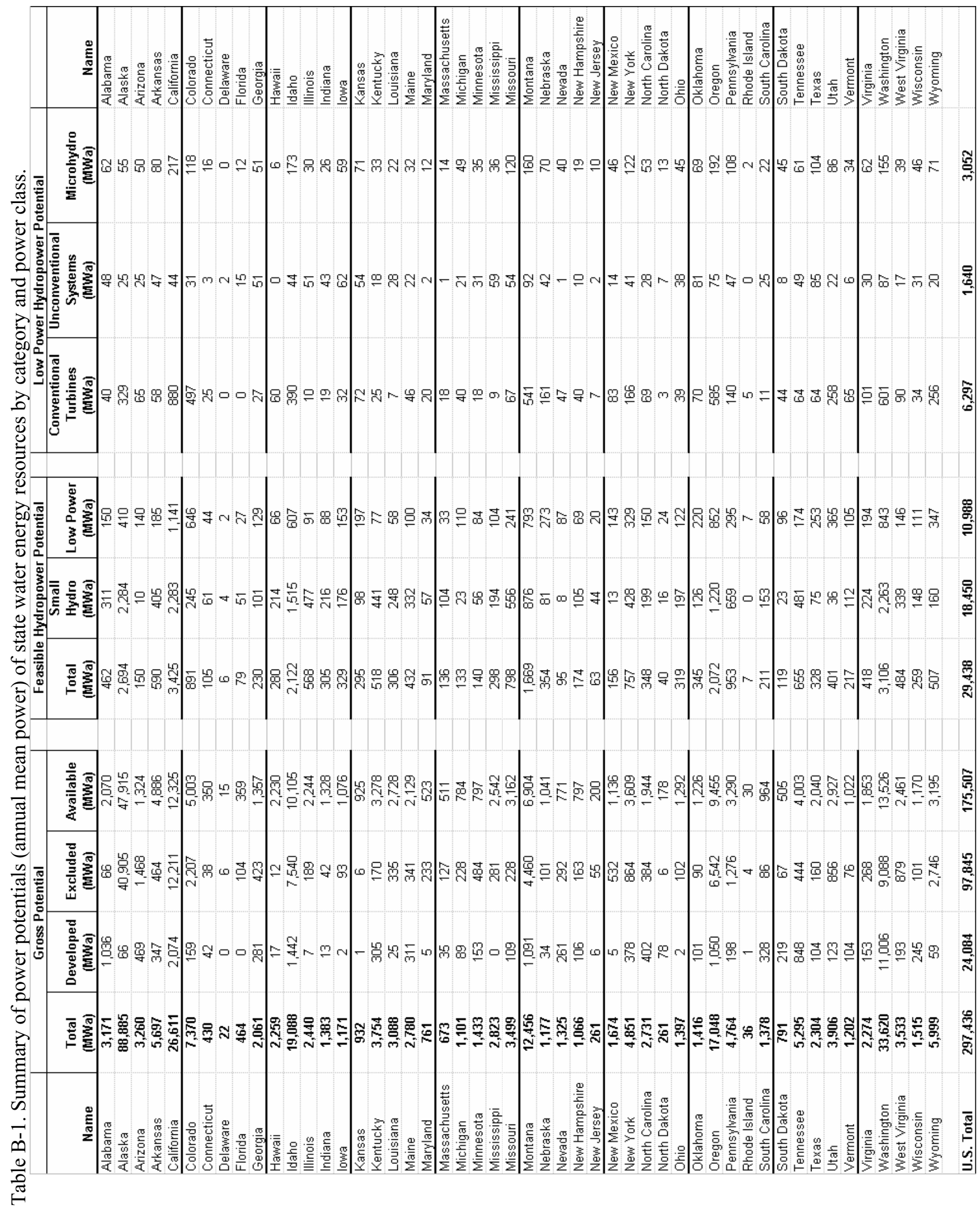




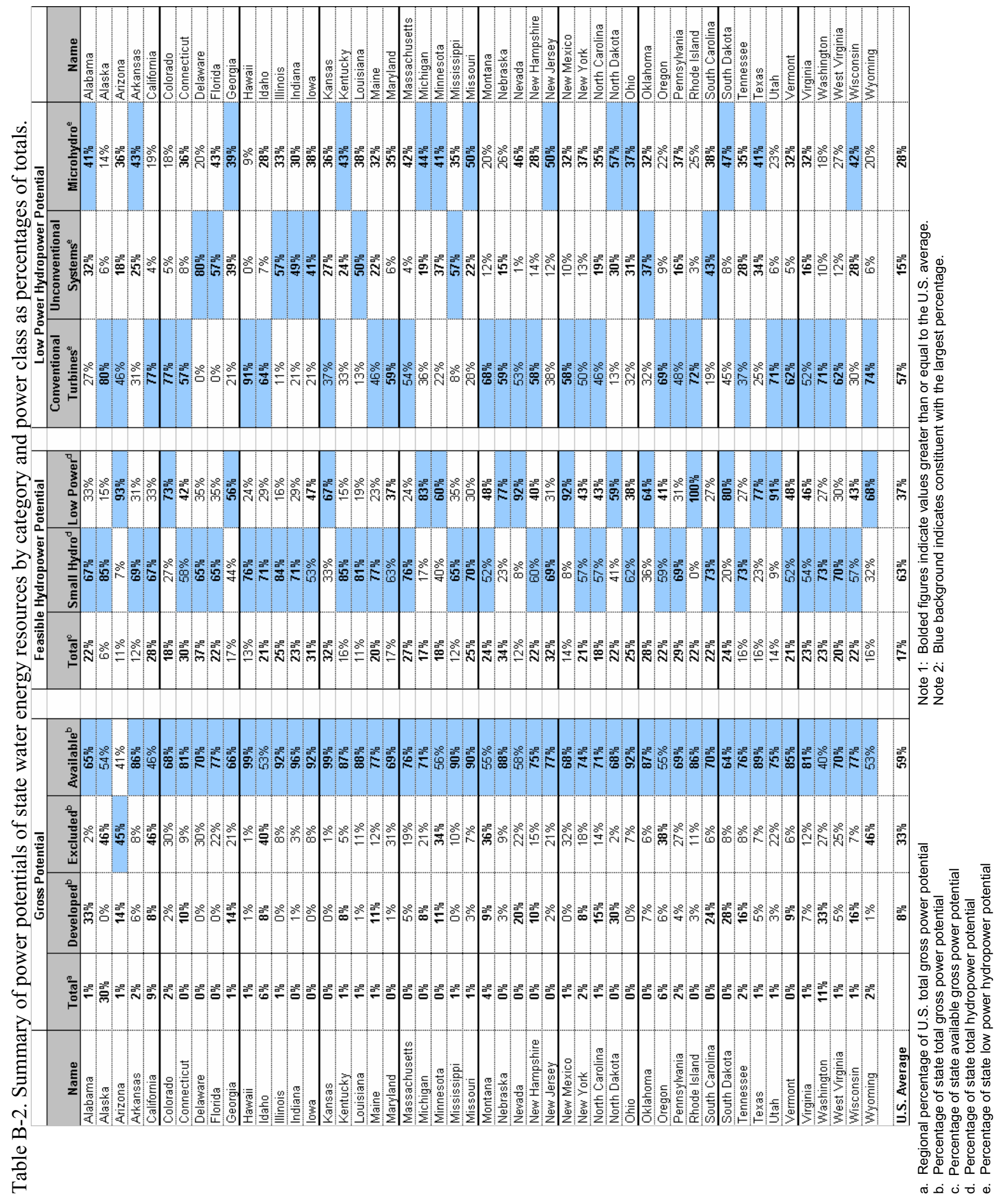


Intentionally left blank

B-6 


\section{B.1 Alabama}

Table B-3. Summary of results of water energy resource assessment of Alabama.

\begin{tabular}{|c|c|c|c|c|c|}
\hline Power Class & $\begin{array}{l}\text { Total } \\
\text { (MWa) }\end{array}$ & $\begin{array}{c}\text { Developed } \\
\text { (MWa) }\end{array}$ & $\begin{array}{c}\text { Federally } \\
\text { Excluded } \\
\text { (MWa) }\end{array}$ & $\begin{array}{c}\text { Other } \\
\text { Excluded } \\
\text { (MWa) }\end{array}$ & $\begin{array}{c}\text { Available } \\
\text { (MWa) }\end{array}$ \\
\hline Total Power & 3,171 & 1,036 & 42 & 24 & 2,070 \\
\hline Total High Power & 2,332 & 1,032 & 31 & 18 & 1,250 \\
\hline Large Hydro & 1,404 & 957 & 0 & 0 & 446 \\
\hline Small Hydro & 929 & 75 & 31 & 18 & 804 \\
\hline Total Low Power & 839 & 3 & 10 & 6 & 820 \\
\hline Conventional Turbines & 490 & 2 & 7 & 4 & 478 \\
\hline Unconventional Systems & 93 & 1 & 1 & 0 & 90 \\
\hline Microhydro & 256 & 0 & 2 & 2 & 252 \\
\hline
\end{tabular}

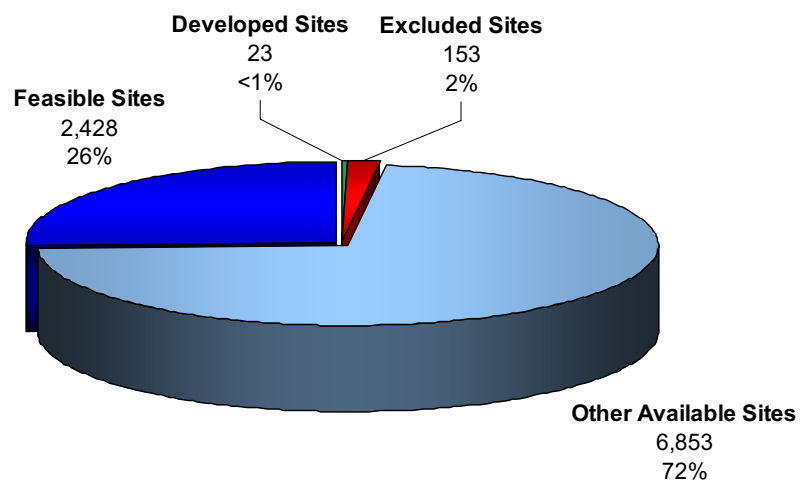

(a) Total Resource Sites 9,457

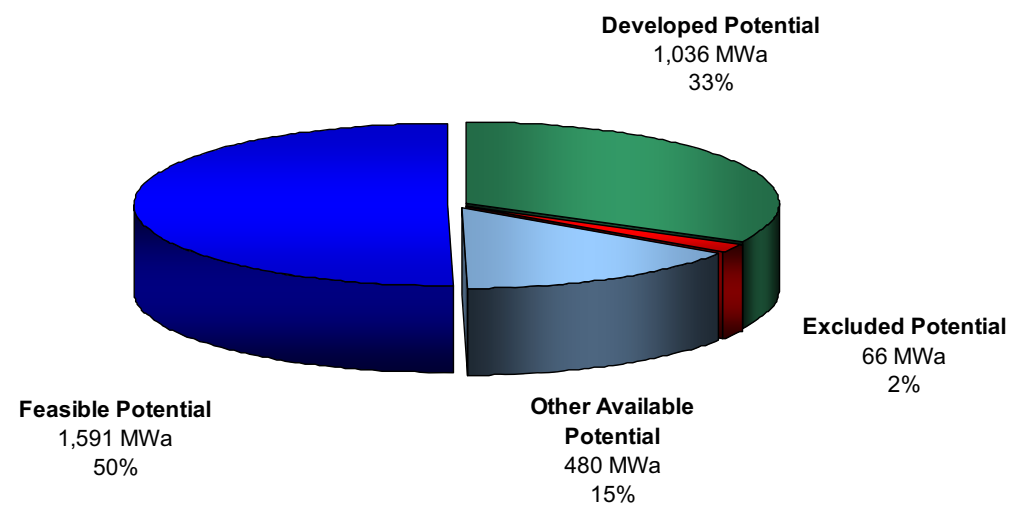

(b) Total Resource Potential 3,171 MWa

Figure B-1. Power category distribution of the (a) number and (b) total power potential of the water energy resource sites in Alabama. 
Table B-4. Summary of results of feasibility assessment of water energy resources in Alabama.

\begin{tabular}{|c|c|}
\hline Power Class & $\begin{array}{c}\text { Available } \\
\text { (MWa) }\end{array}$ \\
\hline Total Power & 2,070 \\
\hline & \\
\hline Total High Power & 1,250 \\
\hline Large Hydro & 446 \\
\hline Small Hydro & 804 \\
\hline & \\
\hline Total Low Power & 820 \\
\hline Conventional Turbines & 478 \\
\hline Unconventional Systems & 90 \\
\hline Microhydro & 252 \\
\hline
\end{tabular}
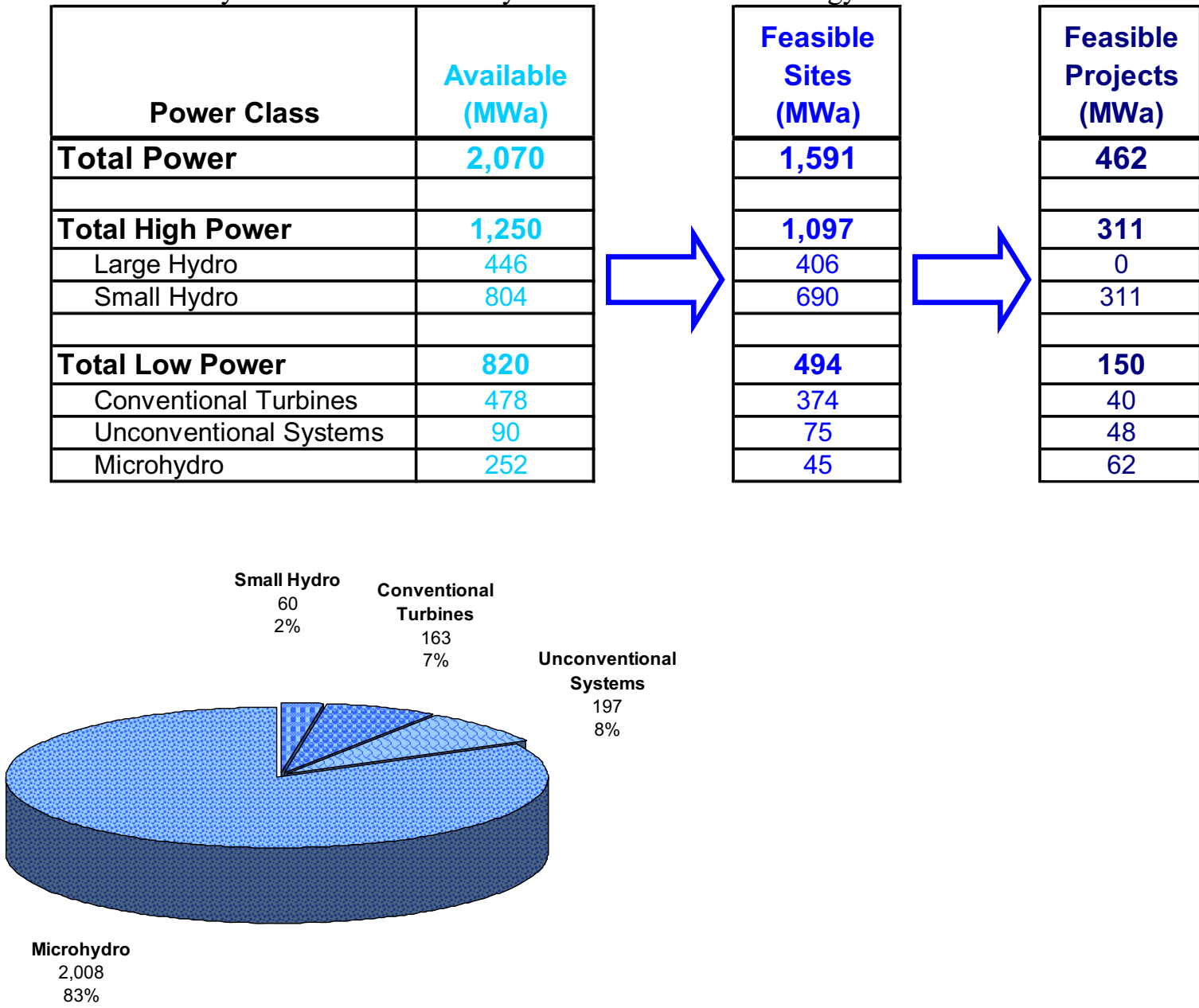

(a) Total Feasible Projects

$$
2,428
$$

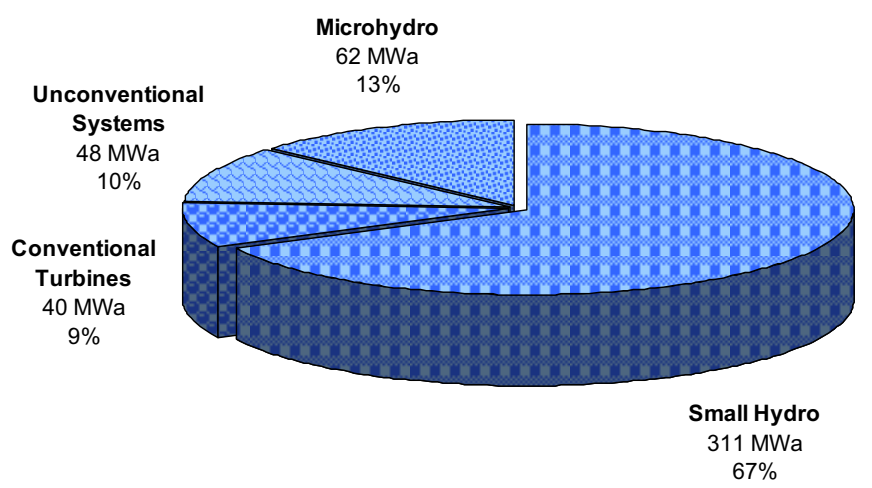

(b) Total Feasible Project Hydropower Potential $462 \mathrm{MWa}$

Figure B-2. Distribution of the (a) number and (b) total hydropower potential of the low power and small hydropower feasible projects in Alabama with the low power projects divided into technology classes. 

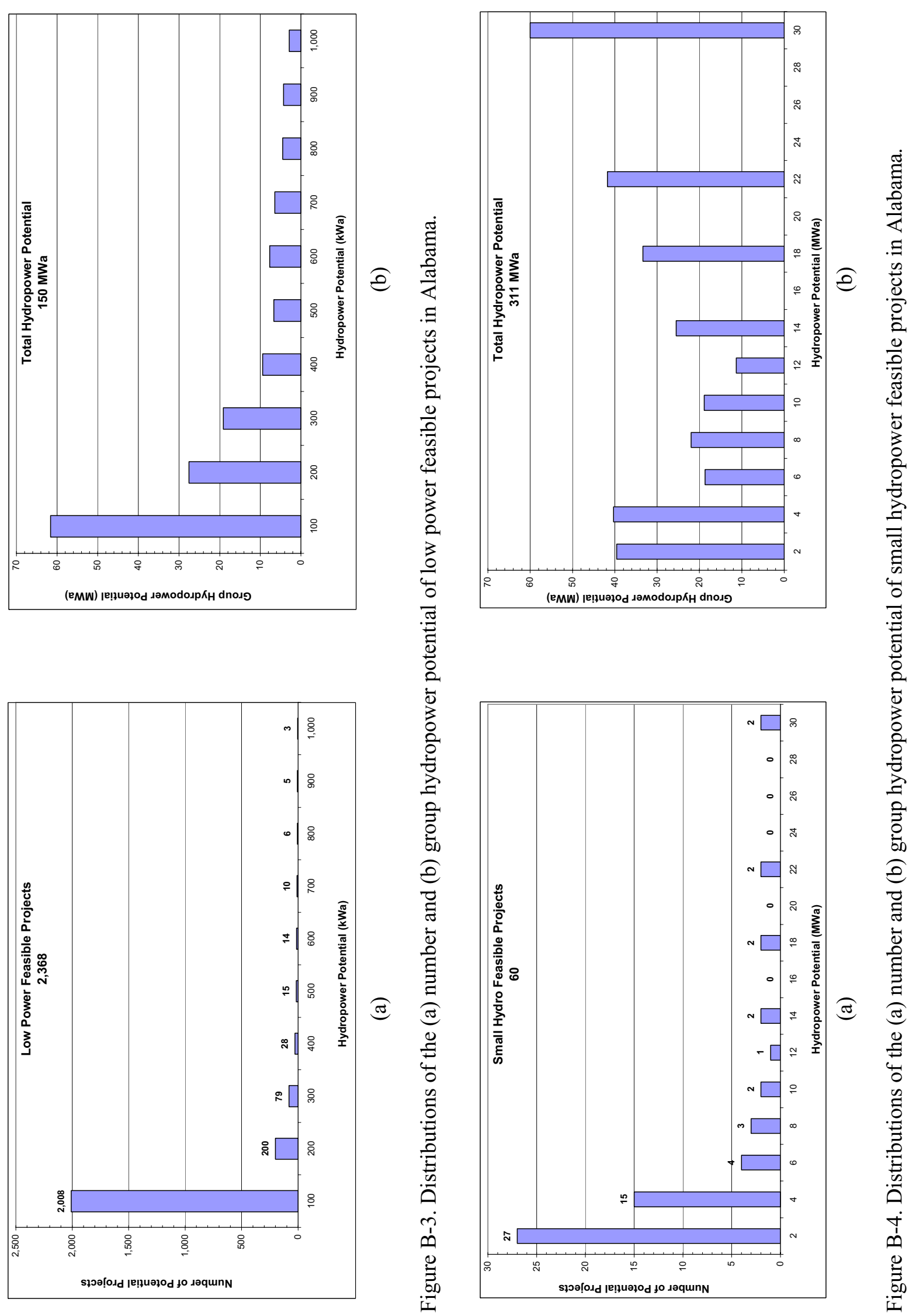


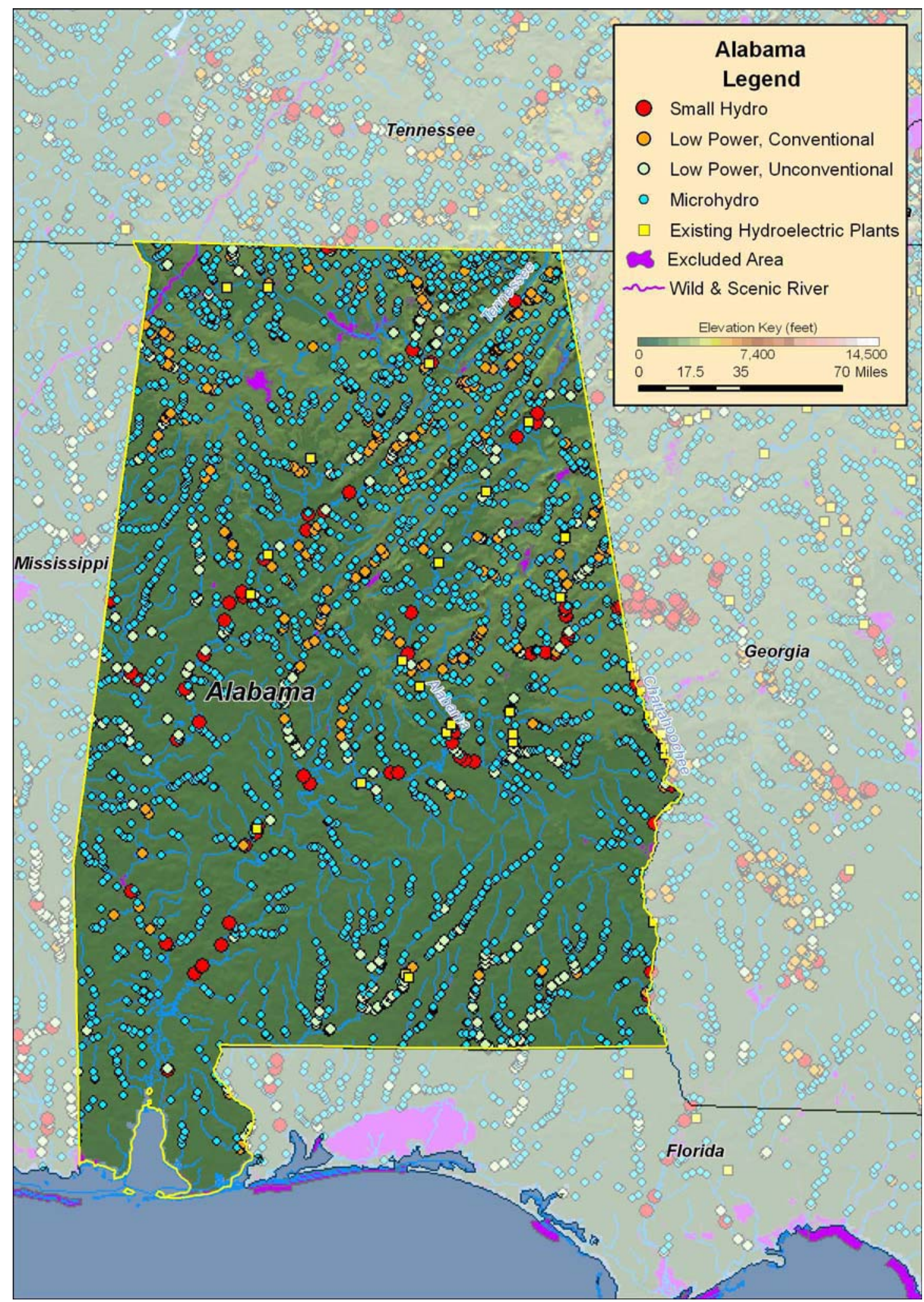

Figure B-5. Low power and small hydropower feasible projects, and existing hydroelectric plants in Alabama. 


\section{B.2 Alaska}

Table B-5. Summary of results of water energy resource assessment of Alaska.

\begin{tabular}{|c|c|c|c|c|c|}
\hline Power Class & $\begin{array}{l}\text { Total } \\
\text { (MWa) }\end{array}$ & $\begin{array}{c}\text { Developed } \\
\text { (MWa) }\end{array}$ & $\begin{array}{c}\text { Federally } \\
\text { Excluded } \\
\text { (MWa) }\end{array}$ & $\begin{array}{c}\text { Other } \\
\text { Excluded } \\
\text { (MWa) }\end{array}$ & $\begin{array}{c}\text { Available } \\
\text { (MWa) }\end{array}$ \\
\hline Total Power & 88,885 & 66 & 39,125 & 1,780 & 47,915 \\
\hline Total High Power & 74,329 & 60 & 33,086 & 1,678 & 39,505 \\
\hline Large Hydro & 25,131 & 0 & 11,860 & 1,006 & 12,266 \\
\hline Small Hydro & 49,197 & 60 & 21,226 & 672 & 27,239 \\
\hline Total Low Power & 14,556 & 5 & 6,039 & 102 & 8,410 \\
\hline Conventional Turbines & 11,858 & 5 & 5,089 & 82 & 6,682 \\
\hline Unconventional Systems & 694 & 0 & 269 & 4 & 420 \\
\hline Microhydro & 2,005 & 0 & 681 & 16 & 1,307 \\
\hline
\end{tabular}

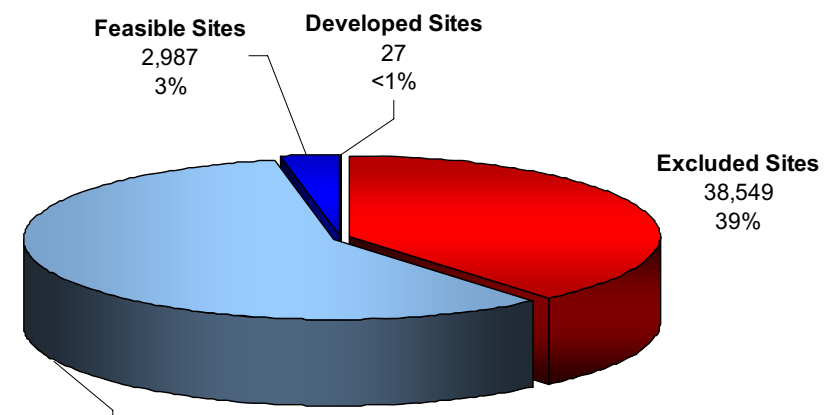

Other Available Sites

57,833

$58 \%$

(a) Total Resource Sites

99,396

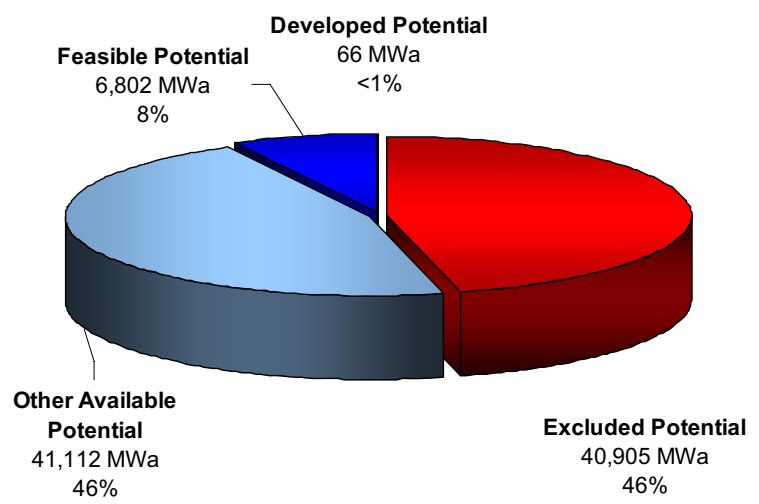

(b) Total Resource Potential 88,885 MWa

Figure B-6. Power category distribution of the (a) number and (b) total power potential of the water energy resource sites in Alaska. 
Table B-6. Summary of results of feasibility assessment of water energy resources in Alaska.

\begin{tabular}{|c|c|c|c|}
\hline Power Class & $\begin{array}{c}\text { Available } \\
\text { (MWa) }\end{array}$ & $\begin{array}{c}\text { Feasible } \\
\text { Sites } \\
(\mathrm{MWa})\end{array}$ & $\begin{array}{c}\text { Feasible } \\
\text { Projects } \\
\text { (MWa) }\end{array}$ \\
\hline Total Power & 47,915 & 6,802 & 2,694 \\
\hline Total High Power & 39,505 & 6,275 & 2,284 \\
\hline Large Hydro & 12,266 & 2,331 & 0 \\
\hline Small Hydro & 27,239 & 3,944 & 2,284 \\
\hline Total Low Power & 8,410 & 527 & 410 \\
\hline Conventional Turbines & 6,682 & 444 & 329 \\
\hline Unconventional Systems & 420 & 34 & 25 \\
\hline Microhydro & 1,307 & 49 & 55 \\
\hline
\end{tabular}

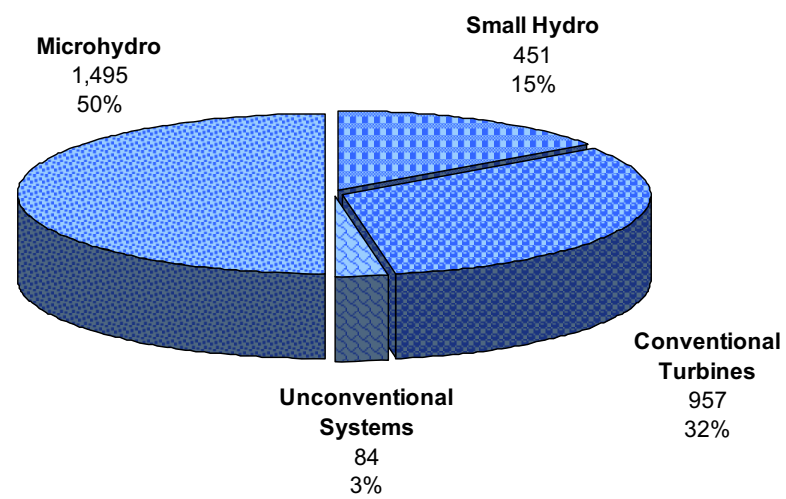

(a) Total Feasible Projects 2,987

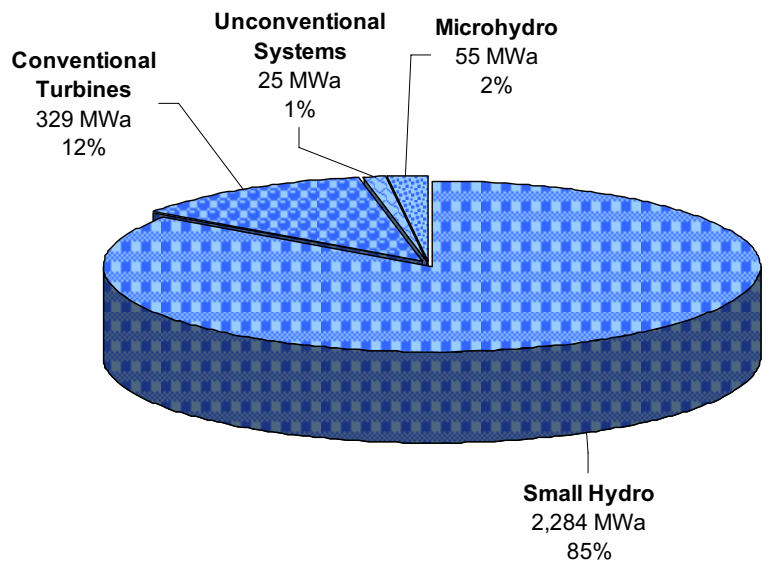

(b) Total Feasible Project Hydropower Potential 2,694 MWa

Figure B-7. Distribution of the (a) number and (b) total hydropower potential of the low power and small hydropower feasible projects in Alaska with the low power projects divided into technology classes. 

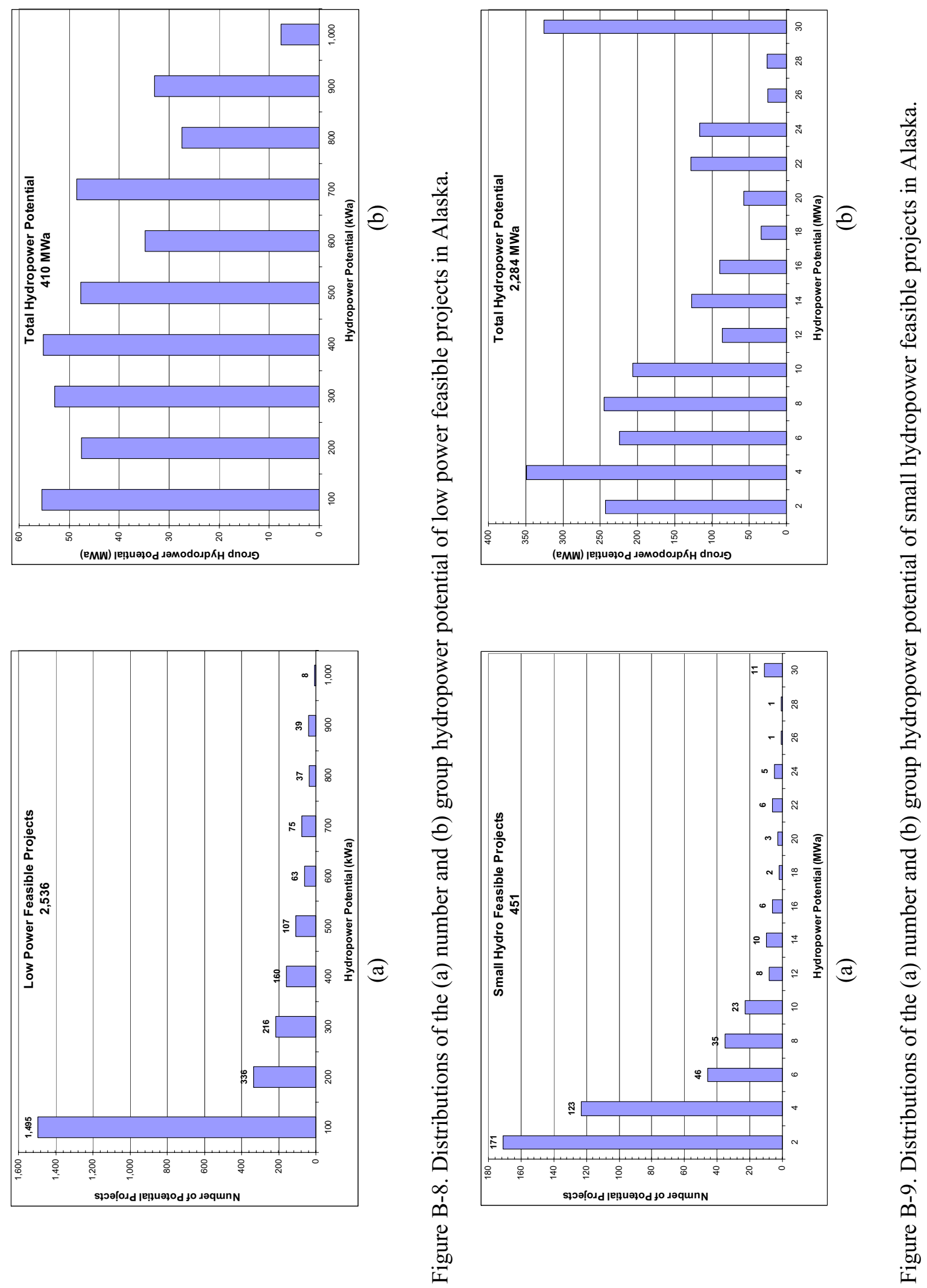

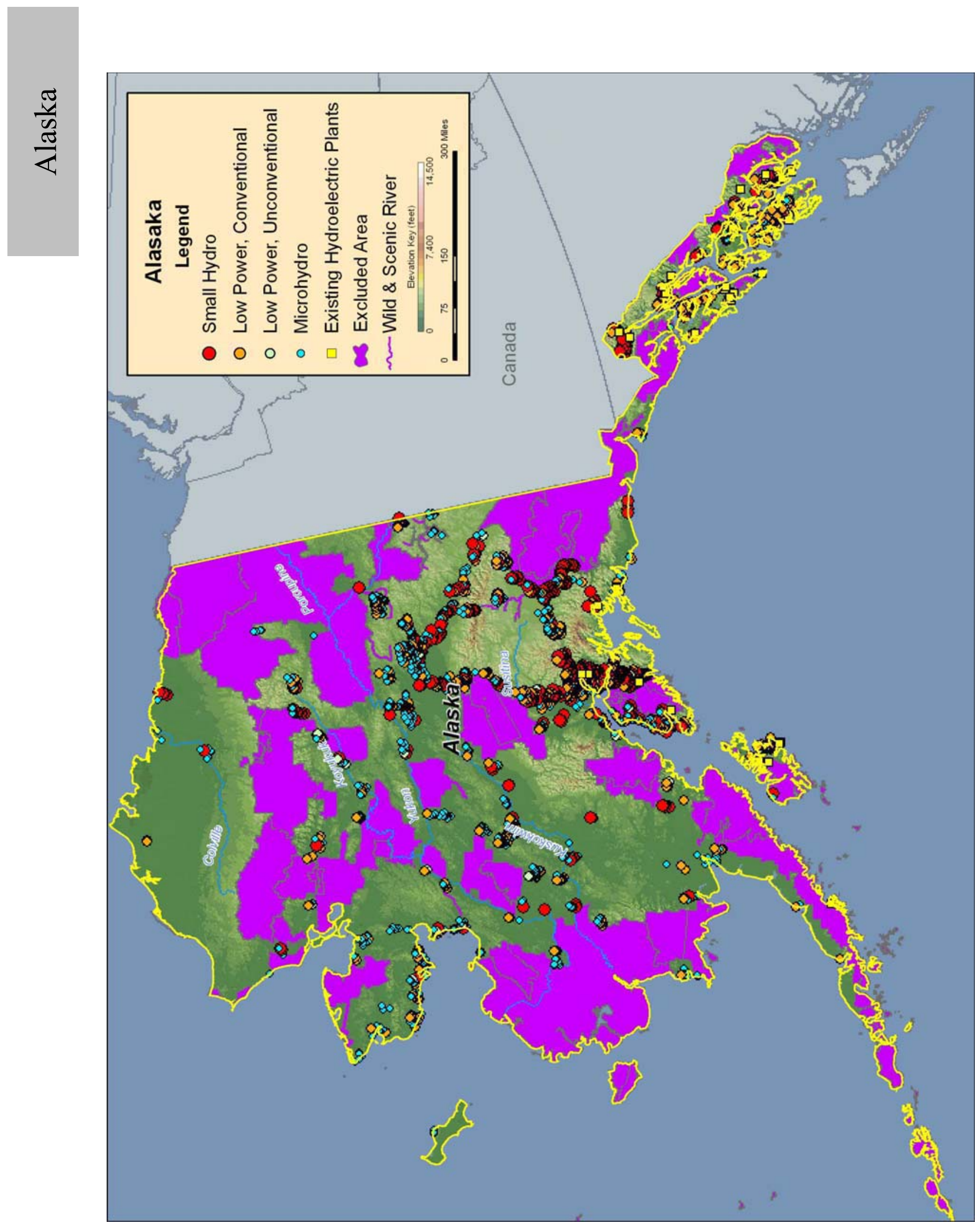

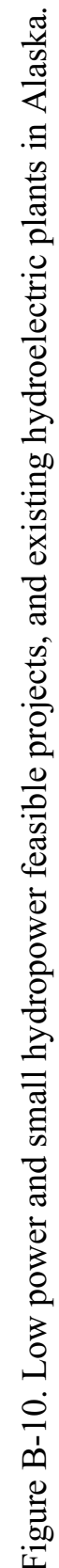




\section{B.3 Arizona}

Table B-7. Summary of results of water energy resource assessment of Arizona.

\begin{tabular}{|c|c|c|c|c|c|}
\hline \multicolumn{1}{|c|}{ Power Class } & $\begin{array}{c}\text { Total } \\
\mathbf{( M W a )}\end{array}$ & $\begin{array}{c}\text { Developed } \\
(\mathrm{MWa})\end{array}$ & $\begin{array}{c}\text { Federally } \\
\text { Excluded } \\
(\mathbf{M W a})\end{array}$ & $\begin{array}{c}\text { Other } \\
\text { Excluded } \\
(\mathbf{M W a})\end{array}$ & $\begin{array}{c}\text { Available } \\
(\mathrm{MWa})\end{array}$ \\
\hline Total Power & $\mathbf{3 , 2 6 0}$ & $\mathbf{4 6 9}$ & $\mathbf{1 , 2 0 0}$ & $\mathbf{2 6 8}$ & 1,324 \\
\hline & & & & & \\
\hline Total High Power & $\mathbf{2 , 1 0 9}$ & $\mathbf{4 6 6}$ & $\mathbf{9 8 8}$ & $\mathbf{2 0 0}$ & 454 \\
\hline Large Hydro & $\mathbf{5 9 4}$ & 441 & 35 & 118 & 0 \\
\hline Small Hydro & 1,515 & 25 & 953 & 82 & 454 \\
\hline & & & & & \\
\hline Total Low Power & $\mathbf{1 , 1 5 2}$ & $\mathbf{2}$ & $\mathbf{2 1 2}$ & $\mathbf{6 8}$ & 869 \\
\hline Conventional Turbines & 814 & 2 & 164 & 51 & 597 \\
\hline Unconventional Systems & 49 & 0 & 10 & 4 & 35 \\
\hline Microhydro & $\mathbf{2 8 8}$ & 0 & 38 & 13 & 237 \\
\hline
\end{tabular}

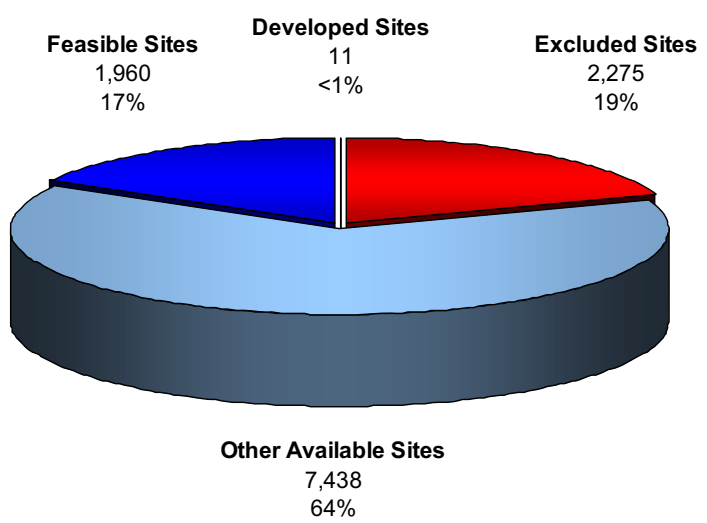

(a) Total Resource Sites 11,684

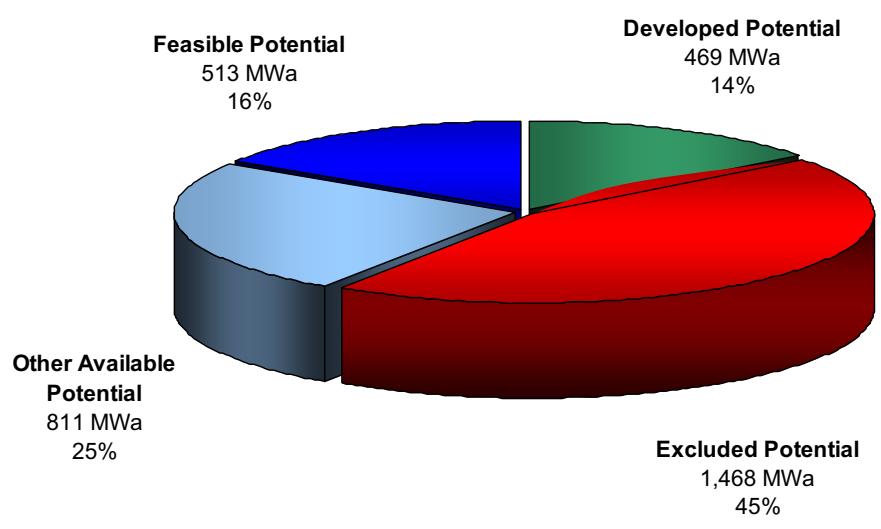

(b) Total Resource Potential 3,260 MWa

Figure B-11. Power category distribution of the (a) number and (b) total power potential of the water energy resource sites in Arizona. 
Table B-8. Summary of results of feasibility assessment of water energy resources in Arizona.

\begin{tabular}{|c|c|}
\hline Power Class & $\begin{array}{c}\text { Available } \\
\text { (MWa) }\end{array}$ \\
\hline Total Power & 1,324 \\
\hline & \\
\hline Total High Power & 454 \\
\hline Large Hydro & 0 \\
\hline Small Hydro & 454 \\
\hline & \\
\hline Total Low Power & 869 \\
\hline Conventional Turbines & 597 \\
\hline Unconventional Systems & 35 \\
\hline Microhydro & 237 \\
\hline
\end{tabular}

\begin{tabular}{|c|c|}
\hline $\begin{array}{c}\text { Feasible } \\
\text { Sites } \\
\text { (MWa) }\end{array}$ & $\begin{array}{c}\text { Feasible } \\
\text { Projects } \\
\text { (MWa) }\end{array}$ \\
\hline 513 & 150 \\
\hline 170 & 10 \\
\hline 0 & 0 \\
\hline 170 & 10 \\
\hline 343 & 140 \\
\hline 265 & 65 \\
\hline 28 & 25 \\
\hline 50 & 50 \\
\hline
\end{tabular}

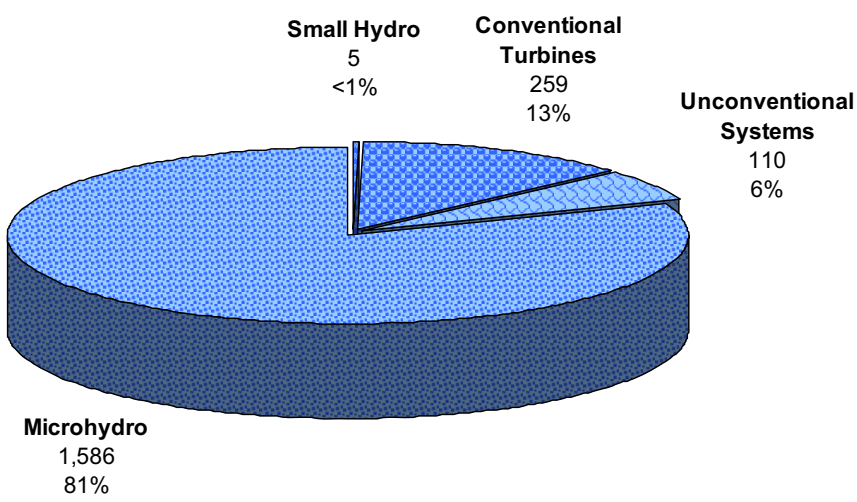

(a) Total Feasible Projects 1,960

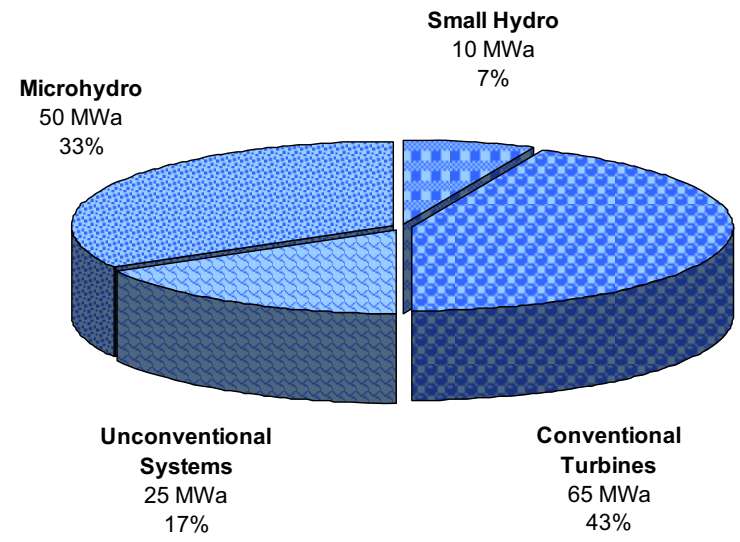

(b) Total Feasible Project Hydropower Potential $150 \mathrm{MWa}$

Figure B-12. Distribution of the (a) number and (b) total hydropower potential of the low power and small hydropower feasible projects in Arizona with the low power projects divided into technology classes. 

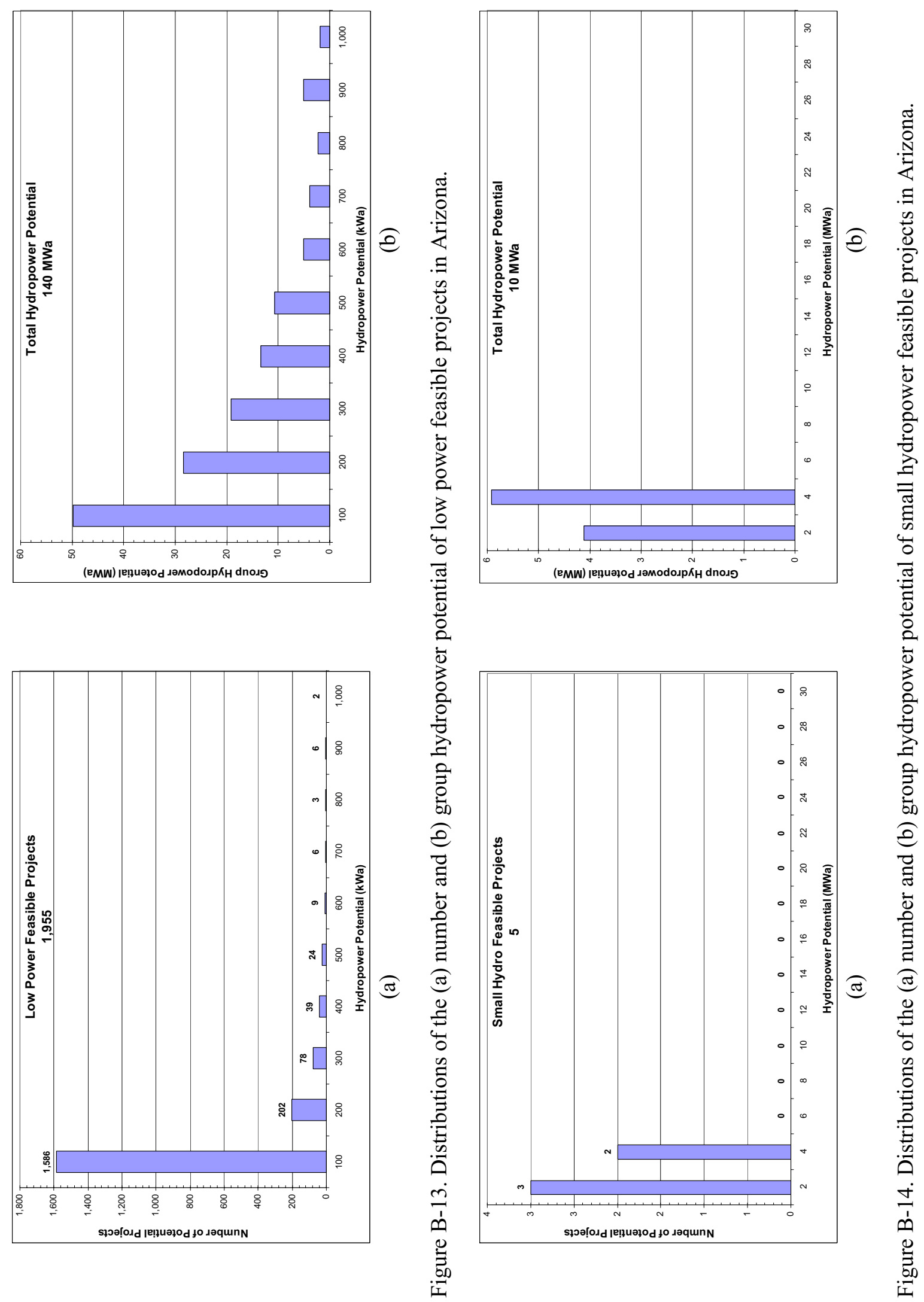

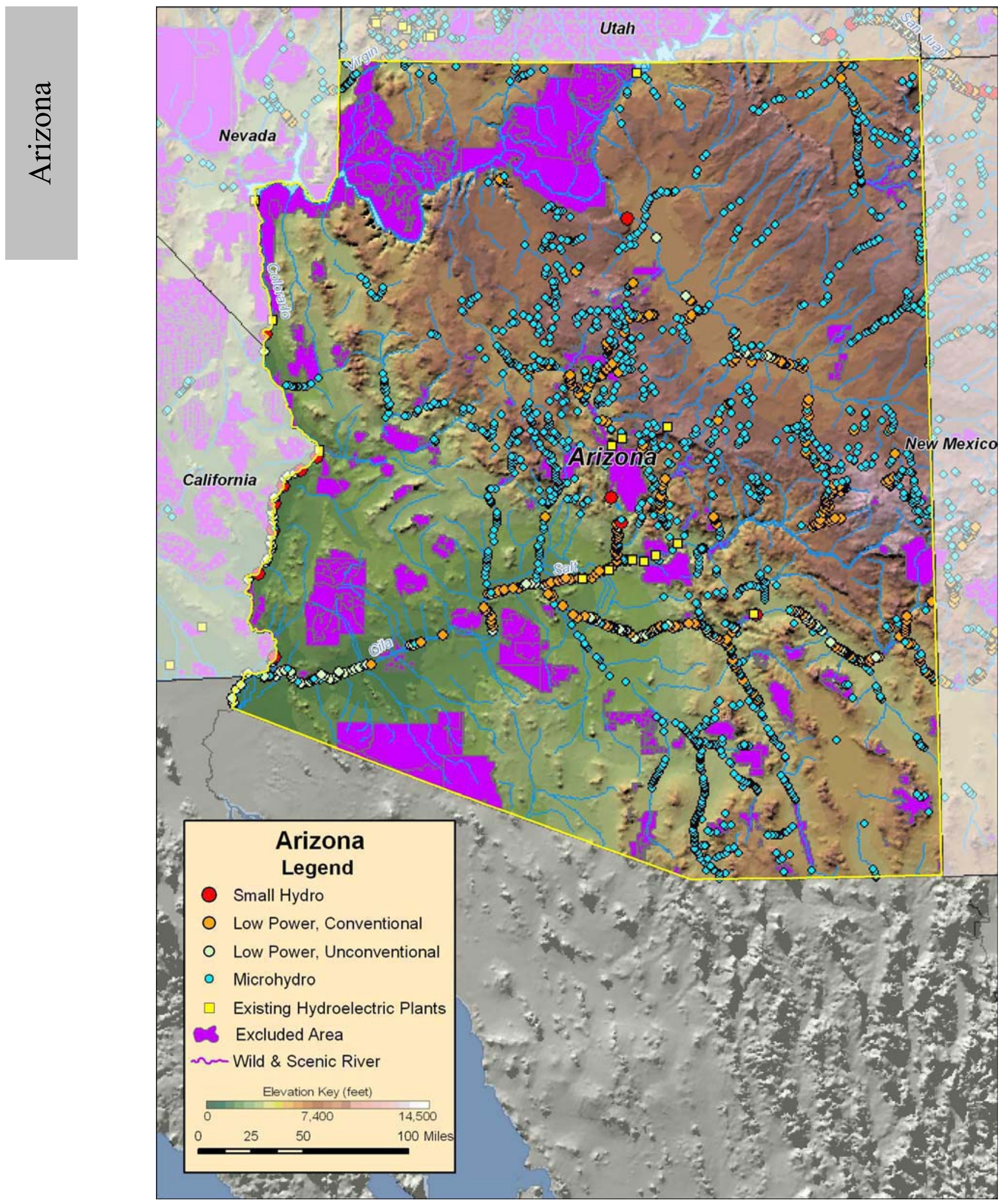

Figure B-15. Low power and small hydropower feasible projects, and existing hydroelectric plants in Arizona. 


\section{B.4 Arkansas}

Table B-9. Summary of results of water energy resource assessment of Arkansas.

\begin{tabular}{|c|c|c|c|c|c|}
\hline \multicolumn{1}{|c|}{ Power Class } & $\begin{array}{c}\text { Total } \\
\text { (MWa) }\end{array}$ & $\begin{array}{c}\text { Developed } \\
(\mathrm{MWa})\end{array}$ & $\begin{array}{c}\text { Federally } \\
\text { Excluded } \\
(\mathbf{M W a})\end{array}$ & $\begin{array}{c}\text { Other } \\
\text { Excluded } \\
(\mathrm{MWa})\end{array}$ & $\begin{array}{c}\text { Available } \\
(\mathrm{MWa})\end{array}$ \\
\hline Total Power & $\mathbf{5 , 6 9 7}$ & $\mathbf{3 4 7}$ & $\mathbf{3 8 5}$ & $\mathbf{7 9}$ & 4,886 \\
\hline Total High Power & & & & & \\
\hline Large Hydro & $\mathbf{4 , 8 1 9}$ & 347 & $\mathbf{3 0 7}$ & $\mathbf{5 5}$ & 4,110 \\
\hline Small Hydro & 3,607 & 230 & 166 & 0 & 3,211 \\
\hline & 1,212 & 117 & 141 & 55 & 899 \\
\hline Total Low Power & & & & & \\
\hline Conventional Turbines & $\mathbf{8 7 8}$ & 0 & $\mathbf{7 8}$ & $\mathbf{2 4}$ & 776 \\
\hline Unconventional Systems & $\mathbf{5 4 7}$ & 0 & 63 & 11 & 473 \\
\hline Microhydro & 117 & 0 & 7 & 9 & 101 \\
\hline
\end{tabular}

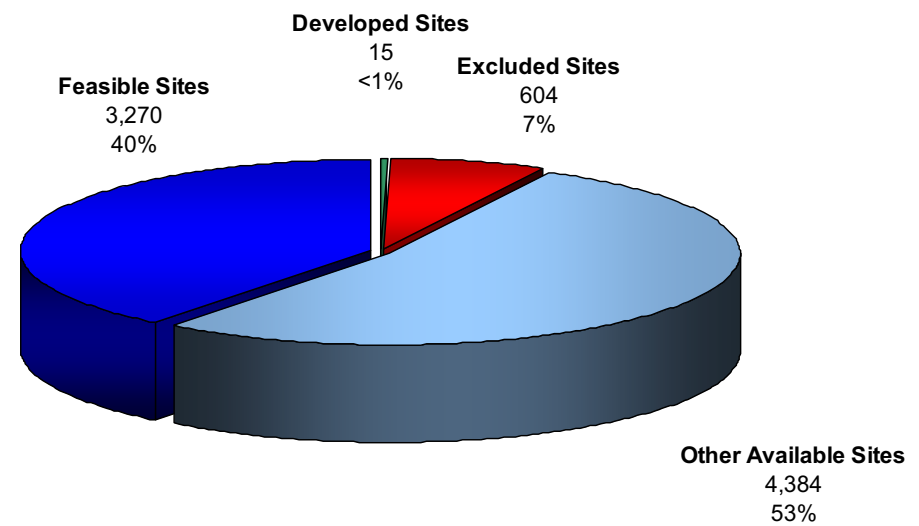

(a) Total Resource Sites 8,273

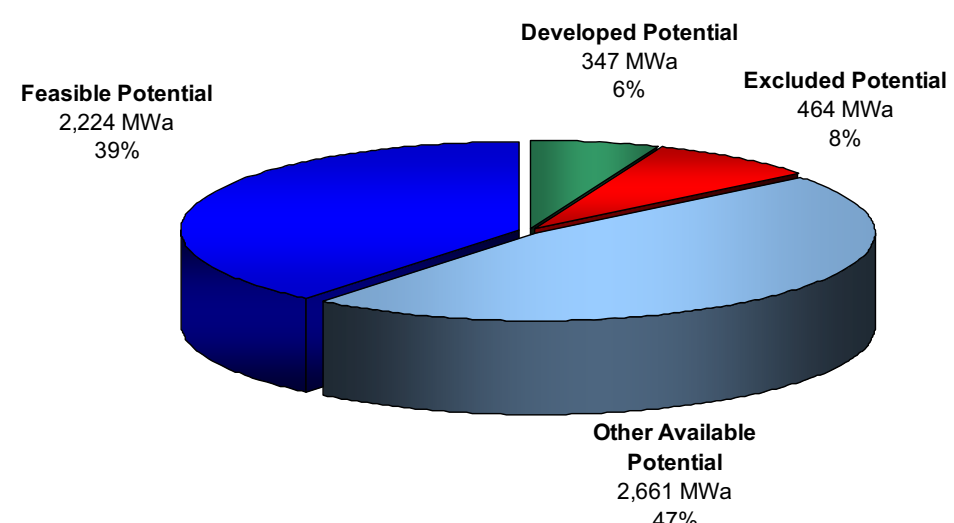

(b) Total Resource Potential $5,697 \mathrm{MWa}$

Figure B-16. Power category distribution of the (a) number and (b) total power potential of the water energy resource sites in Arkansas. 
Table B-10. Summary of results of feasibility assessment of water energy resources in Arkansas.

\begin{tabular}{|c|c|}
\hline Power Class & $\begin{array}{c}\text { Available } \\
\text { (MWa) }\end{array}$ \\
\hline Total Power & 4,886 \\
\hline & \\
\hline Total High Power & 4,110 \\
\hline Large Hydro & 3,211 \\
\hline Small Hydro & 899 \\
\hline & \\
\hline Total Low Power & 776 \\
\hline Conventional Turbines & 473 \\
\hline Unconventional Systems & 101 \\
\hline Microhydro & 202 \\
\hline
\end{tabular}

\begin{tabular}{|c|c|}
\hline $\begin{array}{c}\text { Feasible } \\
\text { Sites } \\
\text { (MWa) }\end{array}$ & $\begin{array}{c}\text { Feasible } \\
\text { Projects } \\
\text { (MWa) }\end{array}$ \\
\hline 2,224 & 590 \\
\hline 1,660 & 405 \\
\hline 996 & 0 \\
\hline 665 & 405 \\
\hline 564 & 185 \\
\hline 407 & 58 \\
\hline 76 & 47 \\
\hline 81 & 80 \\
\hline
\end{tabular}

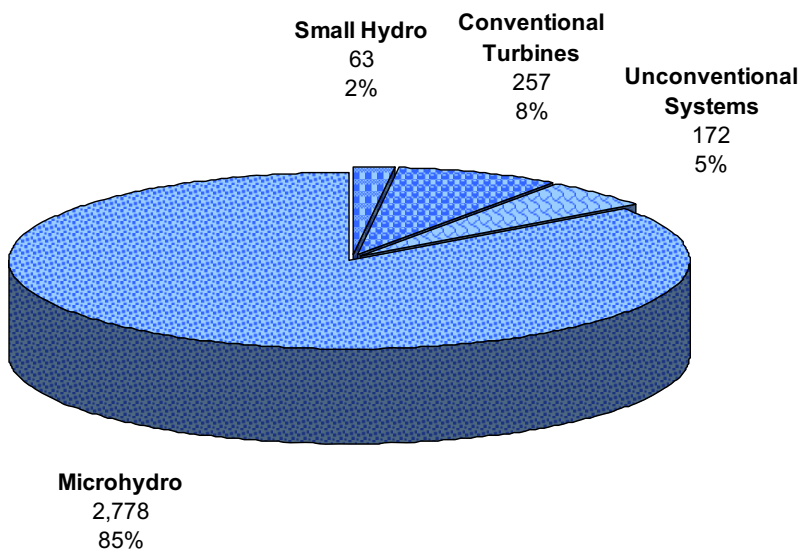

(a) Total Feasible Projects 3,270

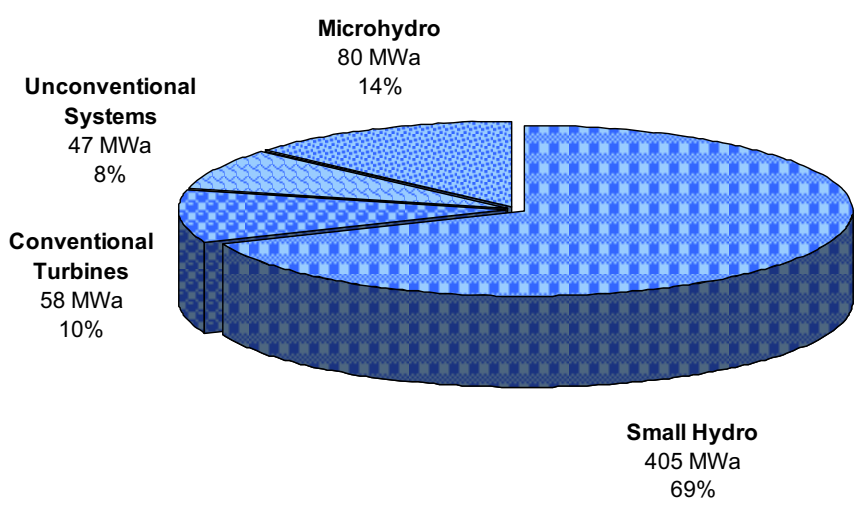

(b) Total Feasible Project Hydropower Potential $590 \mathrm{MWa}$

Figure B-17. Distribution of the (a) number and (b) total hydropower potential of the low power and small hydropower feasible projects in Arkansas with the low power projects divided into technology classes. 

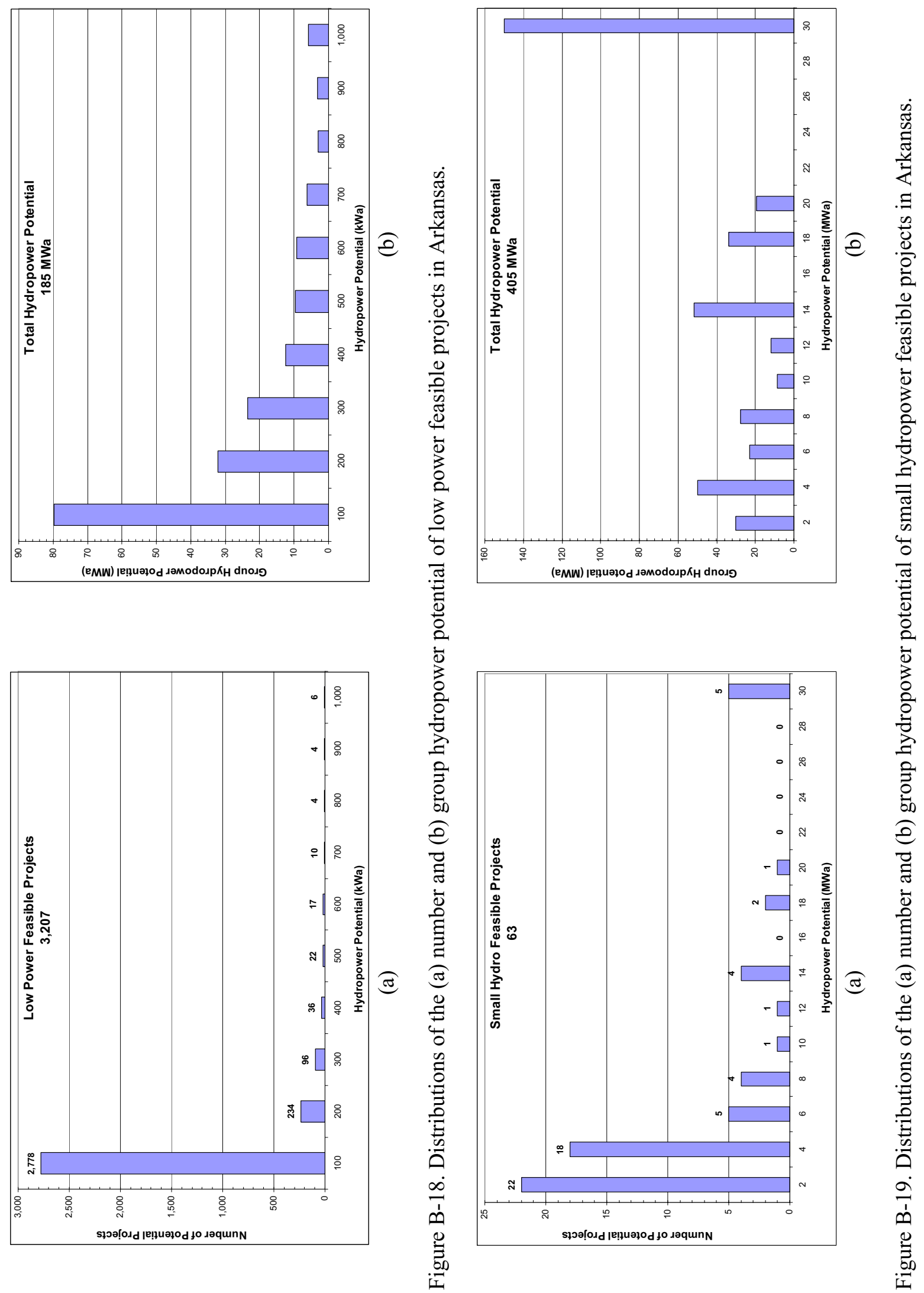

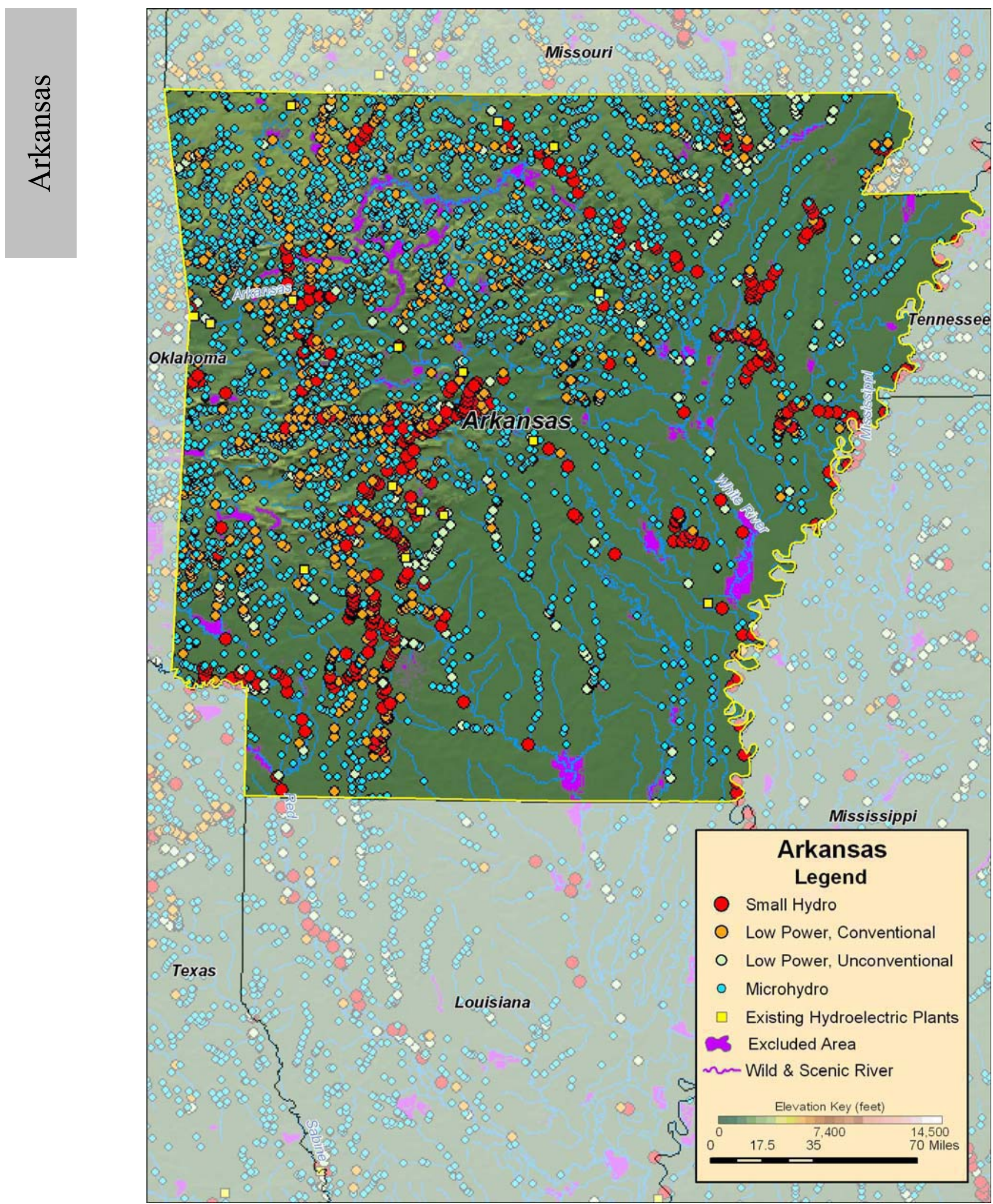

Figure B-20. Low power and small hydropower feasible projects, and existing hydroelectric plants in Arkansas. 


\section{B.5 California}

Table B-11. Summary of results of water energy resource assessment of California.

\begin{tabular}{|c|c|c|c|c|c|}
\hline Power Class & $\begin{array}{c}\text { Total } \\
\text { (MWa) }\end{array}$ & $\begin{array}{c}\text { Developed } \\
\text { (MWa) }\end{array}$ & $\begin{array}{c}\text { Federally } \\
\text { Excluded } \\
\text { (MWa) }\end{array}$ & $\begin{array}{c}\text { Other } \\
\text { Excluded } \\
(\mathbf{M W a})\end{array}$ & $\begin{array}{c}\text { Available } \\
\text { (MWa) }\end{array}$ \\
\hline Total Power & $\mathbf{2 6 , 6 1 1}$ & $\mathbf{2 , 0 7 4}$ & $\mathbf{1 1 , 0 5 6}$ & $\mathbf{1 , 1 5 5}$ & 12,325 \\
\hline Total High Power & & & & & \\
\hline Large Hydro & $\mathbf{2 2 , 9 3 7}$ & $\mathbf{2 , 0 3 0}$ & $\mathbf{1 0 , 1 2 6}$ & $\mathbf{9 7 6}$ & 9,806 \\
\hline Small Hydro & 4,816 & 1,155 & 1,598 & 407 & 1,656 \\
\hline & 18,122 & 875 & 8,528 & 568 & 8,151 \\
\hline Total Low Power & & & & & \\
\hline Conventional Turbines & $\mathbf{3 , 6 7 4}$ & $\mathbf{4 5}$ & $\mathbf{9 3 0}$ & $\mathbf{1 8 0}$ & 2,519 \\
\hline Unconventional Systems & $\mathbf{3 , 1 6 1}$ & 39 & 839 & 148 & 2,134 \\
\hline Microhydro & 101 & 2 & 22 & 6 & 71 \\
\hline
\end{tabular}

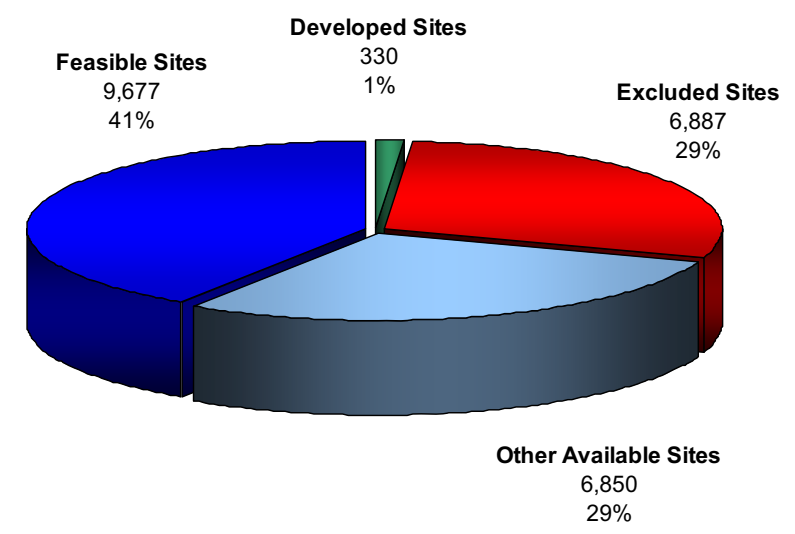

(a) Total Resource Sites 23,744

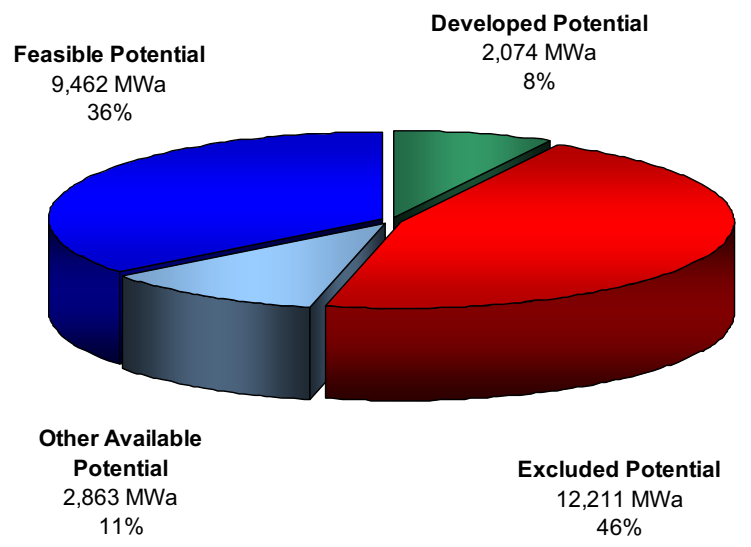

(b) Total Resource Potential 26,611 MWa

Figure B-21. Power category distribution of the (a) number and (b) total power potential of the water energy resource sites in California. 
Table B-12. Summary of results of water energy resource assessment of California.

\begin{tabular}{|c|c|c|c|}
\hline Power Class & $\begin{array}{c}\text { Available } \\
\text { (MWa) }\end{array}$ & $\begin{array}{c}\text { Feasible } \\
\text { Sites } \\
\text { (MWa) }\end{array}$ & $\begin{array}{c}\text { Feasible } \\
\text { Projects } \\
\text { (MWa) }\end{array}$ \\
\hline Total Power & 12,325 & 9,462 & 3,425 \\
\hline Total High Power & 9,806 & 7,679 & 2,283 \\
\hline Large Hydro & 1,656 & 1,465 & 0 \\
\hline Small Hydro & 8,151 & 6,214 & 2,283 \\
\hline Total Low Power & 2,519 & 1,783 & 1,141 \\
\hline Conventional Turbines & 2,134 & 1,529 & 880 \\
\hline Unconventional Systems & 71 & 67 & 44 \\
\hline Microhydro & 314 & 187 & 217 \\
\hline
\end{tabular}

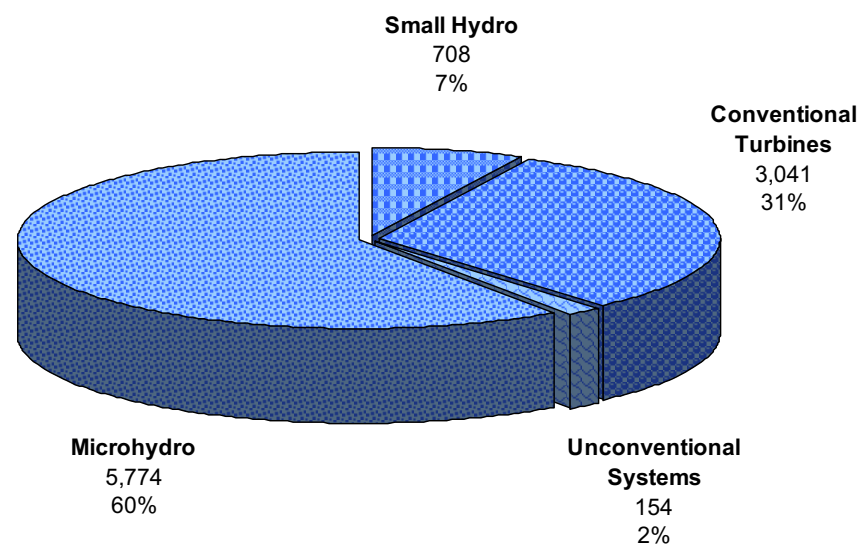

(a) Total Feasible Projects 9,677

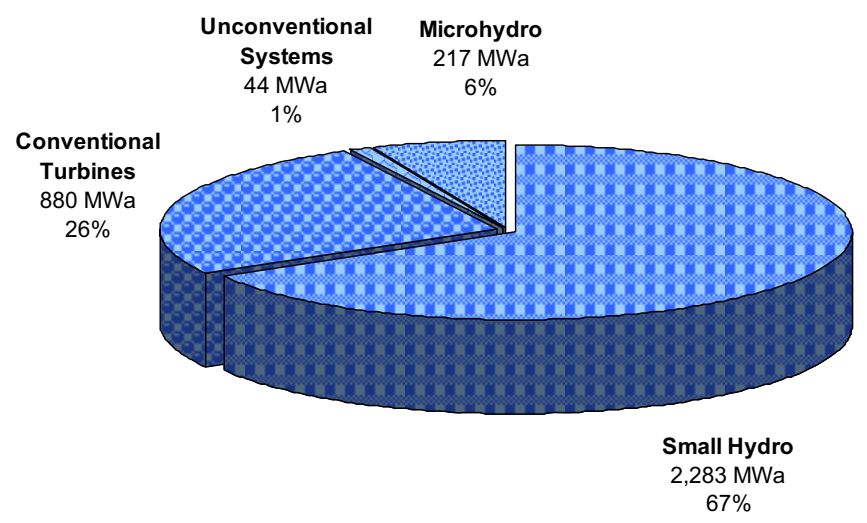

(b) Total Feasible Project Hydropower Potential $3,425 \mathrm{MWa}$

Figure B-22. Distribution of the (a) number and (b) total hydropower potential of the low power and small hydropower feasible projects in California with the low power projects divided into technology classes. 

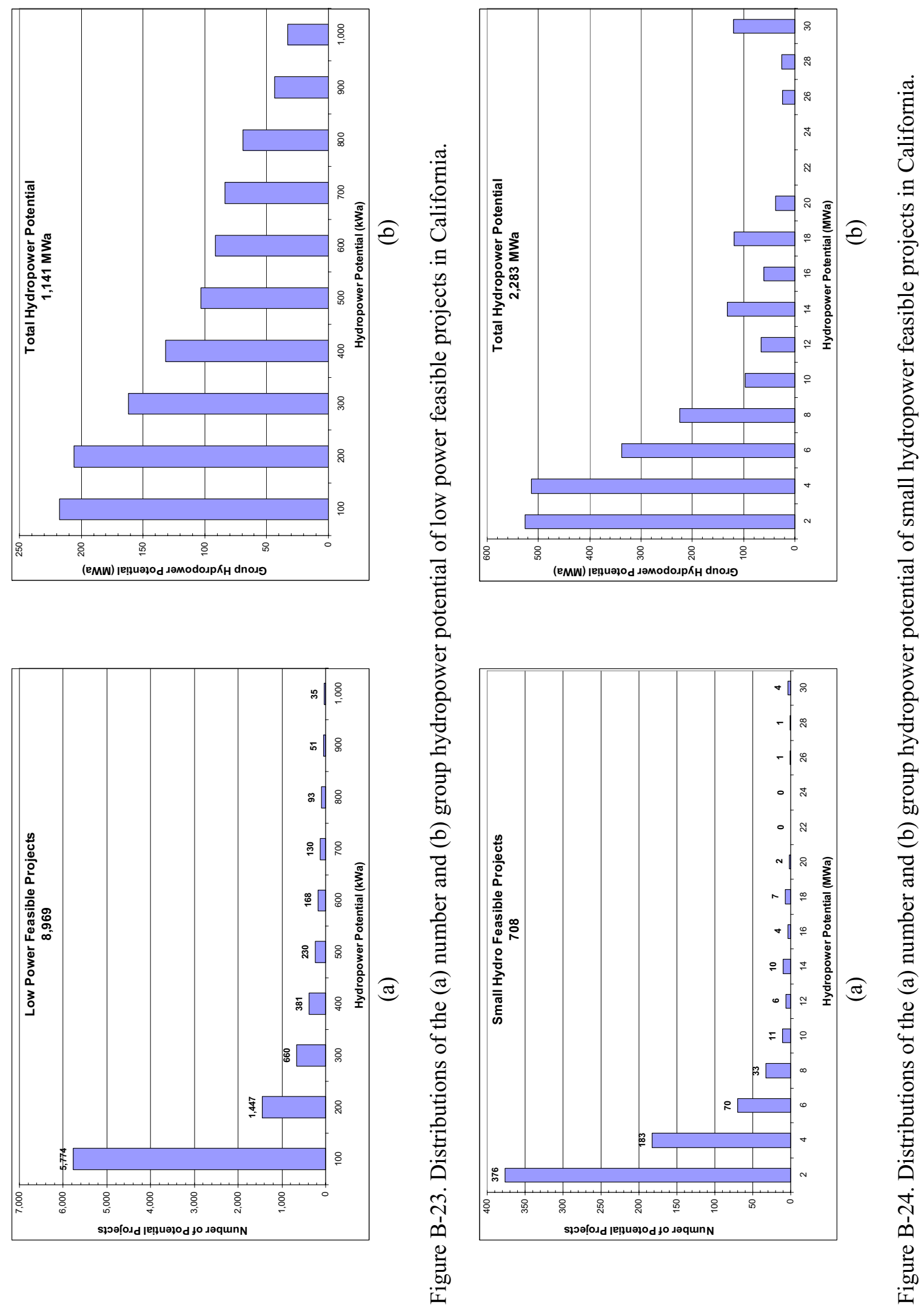


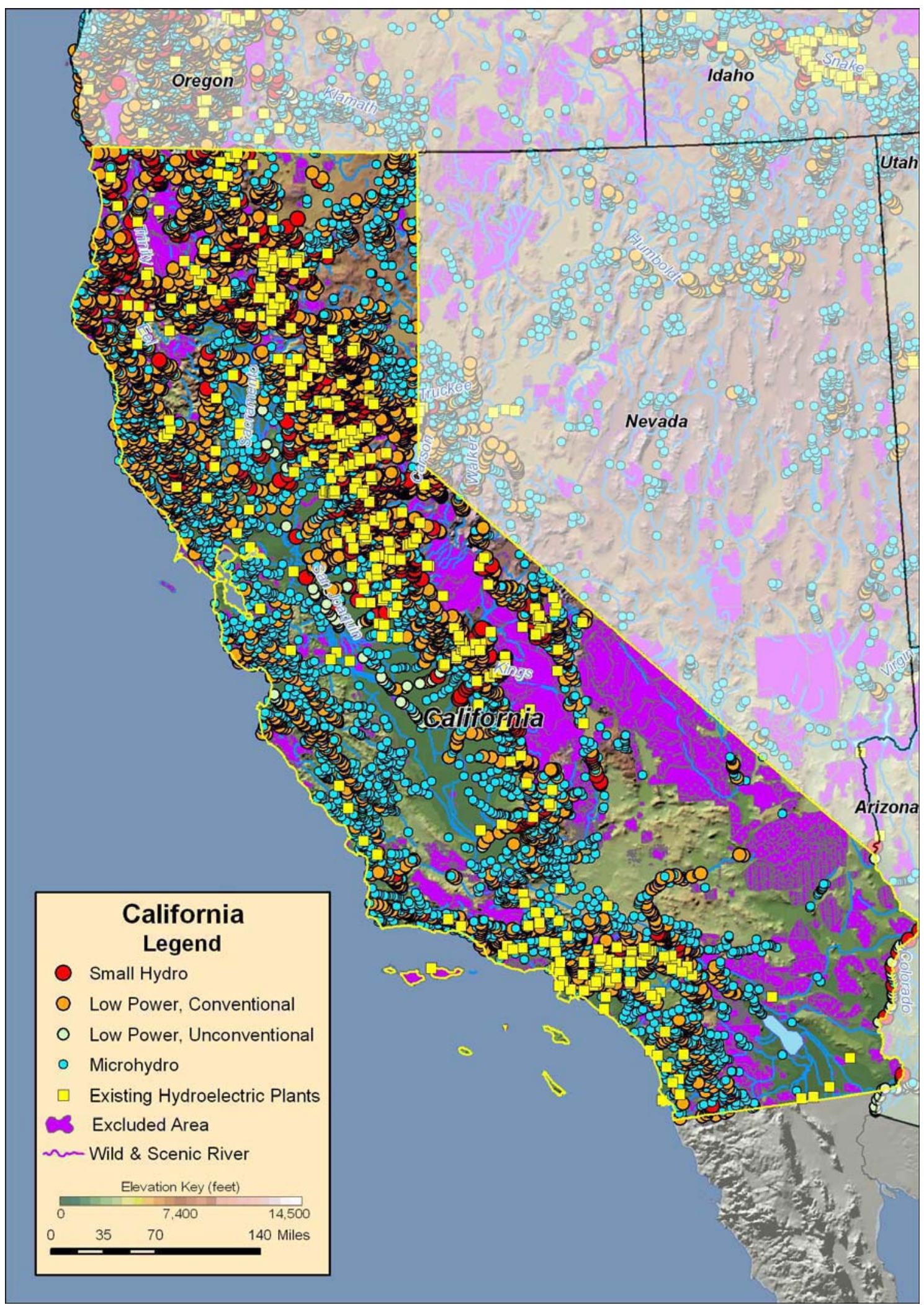

Figure B-25. Low power and small hydropower feasible projects, and existing hydroelectric plants in California. 


\section{B.6 Colorado}

Table B-13. Summary of results of water energy resource assessment of Colorado.

\begin{tabular}{|c|c|c|c|c|c|}
\hline Power Class & $\begin{array}{c}\text { Total } \\
\mathbf{( M W a )}\end{array}$ & $\begin{array}{c}\text { Developed } \\
(\mathrm{MWa})\end{array}$ & $\begin{array}{c}\text { Federally } \\
\text { Excluded } \\
(\mathbf{M W a})\end{array}$ & $\begin{array}{c}\text { Other } \\
\text { Excluded } \\
(\mathbf{M W a})\end{array}$ & $\begin{array}{c}\text { Availlable } \\
(\mathrm{MWa})\end{array}$ \\
\hline Total Power & $\mathbf{7 , 3 7 0}$ & 159 & $\mathbf{1 , 8 1 7}$ & $\mathbf{3 9 1}$ & 5,003 \\
\hline Total High Power & & & & & \\
\hline Large Hydro & $\mathbf{4 , 9 3 0}$ & 149 & $\mathbf{1 , 4 2 0}$ & $\mathbf{2 6 3}$ & 3,099 \\
\hline Small Hydro & $\mathbf{2 6 1}$ & 80 & 180 & 0 & 0 \\
\hline & 4,670 & 68 & 1,240 & 263 & 3,099 \\
\hline Total Low Power & & & & & \\
\hline Conventional Turbines & $\mathbf{2 , 4 3 9}$ & 11 & 397 & 128 & 1,904 \\
\hline Unconventional Systems & 2,090 & 10 & 375 & 104 & 1,600 \\
\hline Microhydro & 64 & 0 & 6 & 9 & 49 \\
\hline
\end{tabular}

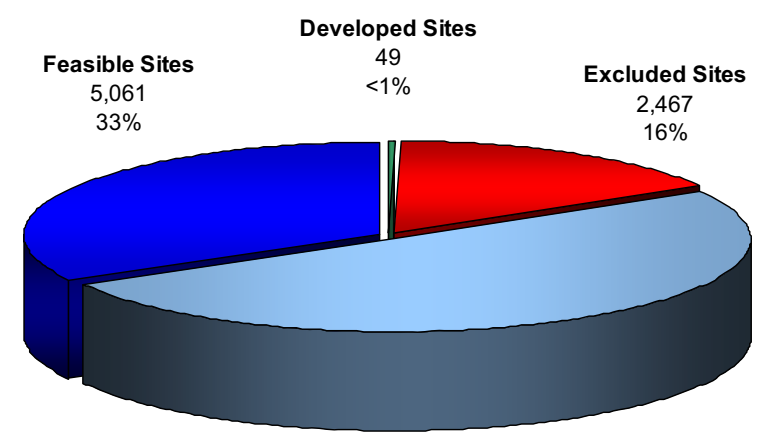

Other Available Sites

7,722

$50 \%$

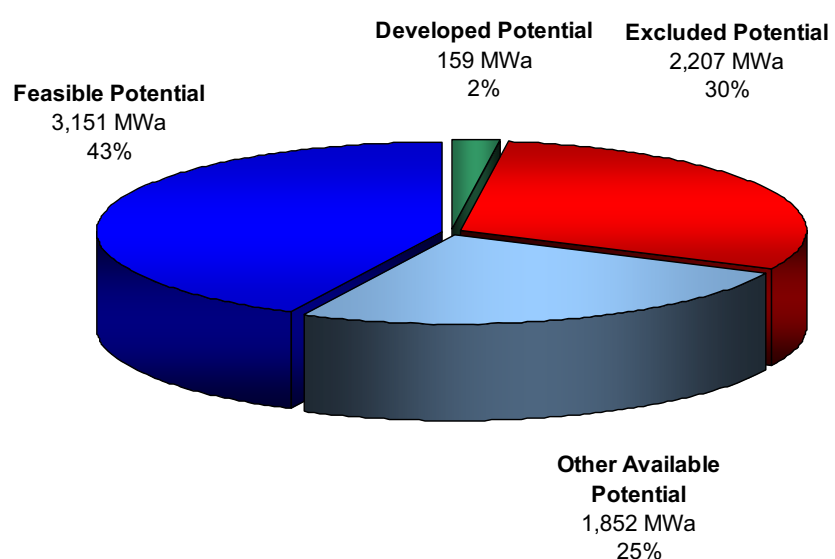

(b) Total Resource Potential 7,370 MWa

Figure B-26. Power category distribution of the (a) number and (b) total power potential of the water energy resource sites in Colorado. 
Table B-14. Summary of results of feasibility assessment of water energy resources in Colorado.

\begin{tabular}{|c|c|}
\hline Power Class & $\begin{array}{c}\text { Available } \\
\text { (MWa) }\end{array}$ \\
\hline Total Power & 5,003 \\
\hline & \\
\hline Total High Power & 3,099 \\
\hline Large Hydro & 0 \\
\hline Small Hydro & 3,099 \\
\hline & \\
\hline Total Low Power & 1,904 \\
\hline Conventional Turbines & 1,600 \\
\hline Unconventional Systems & 49 \\
\hline Microhydro & 255 \\
\hline
\end{tabular}

\begin{tabular}{|c|c|}
\hline $\begin{array}{c}\text { Feasible } \\
\text { Sites } \\
\text { (MWa) }\end{array}$ & $\begin{array}{c}\text { Feasible } \\
\text { Projects } \\
\text { (MWa) }\end{array}$ \\
\hline 3,151 & 891 \\
\hline 2,130 & 245 \\
\hline 0 & 0 \\
\hline 2,130 & 245 \\
\hline 1,021 & 646 \\
\hline 887 & 497 \\
\hline 43 & 31 \\
\hline 91 & 118 \\
\hline
\end{tabular}

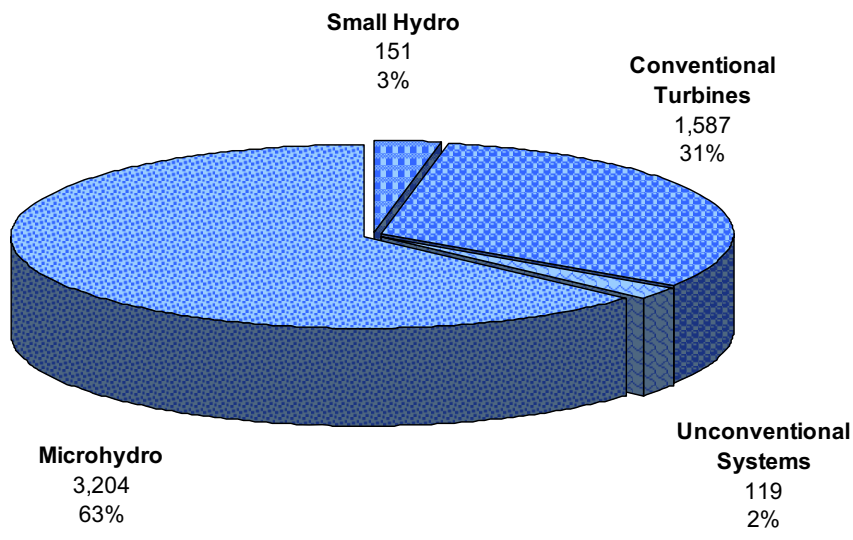

(a) Total Feasible Projects 5,061

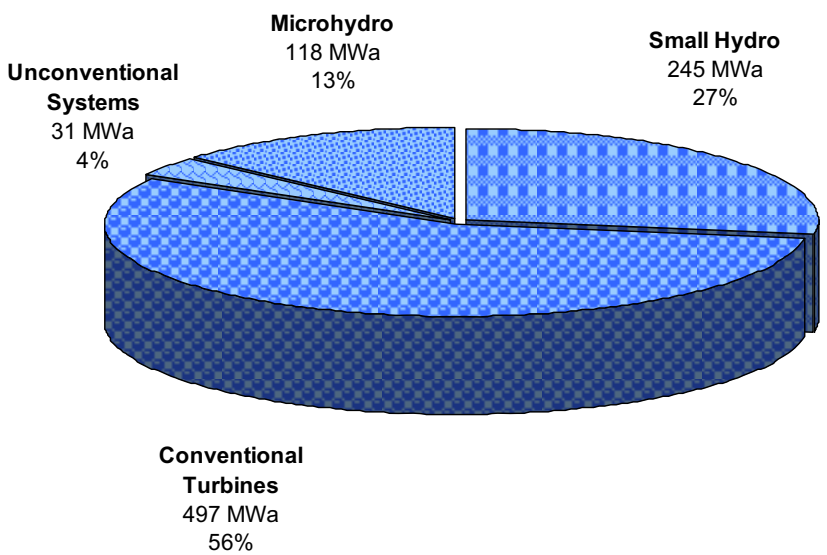

(b) Total Feasible Project Hydropower Potential $891 \mathrm{MWa}$

Figure B-27. Distribution of the (a) number and (b) total hydropower potential of the low power and small hydropower feasible projects in Colorado with the low power projects divided into technology classes. 

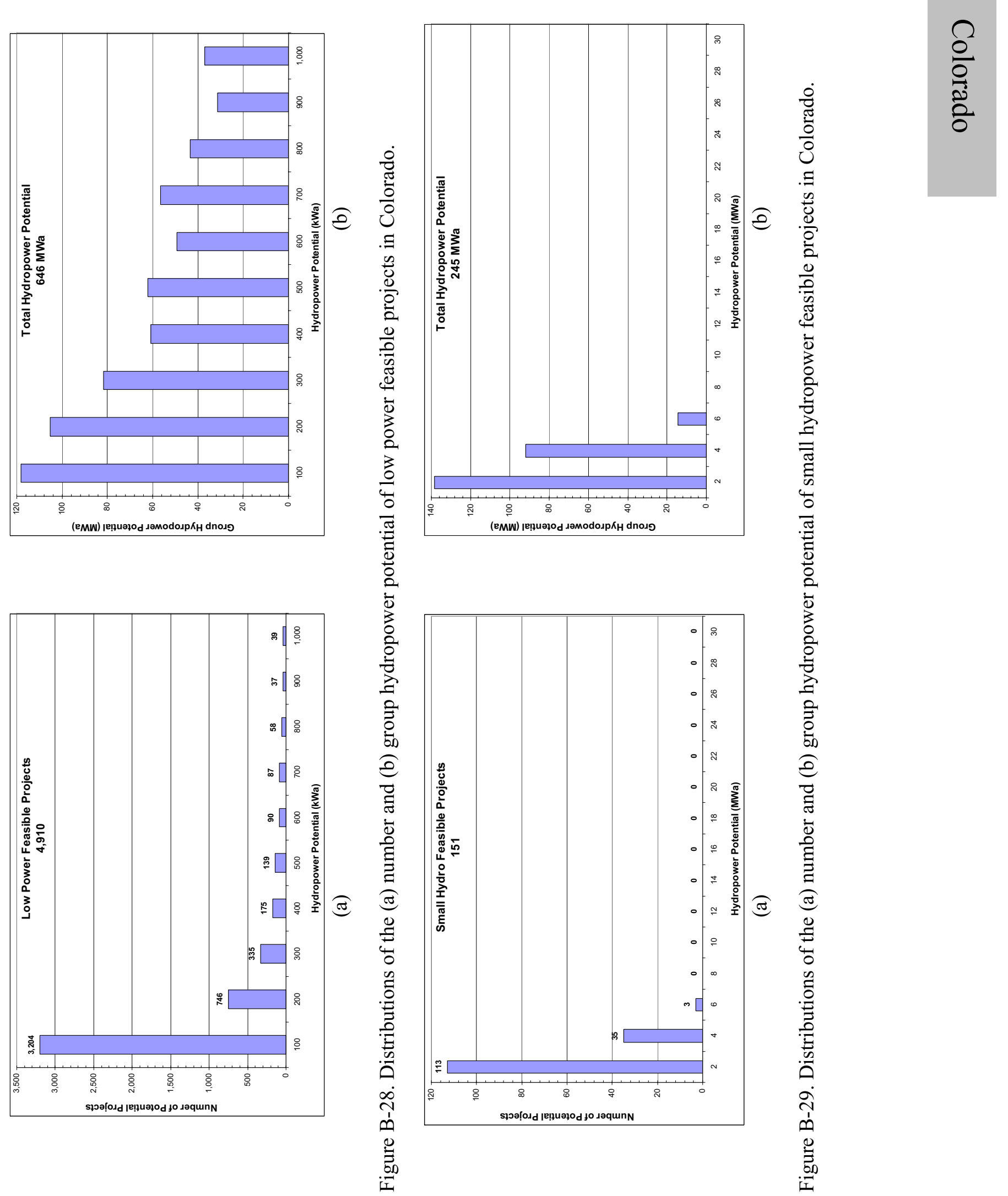

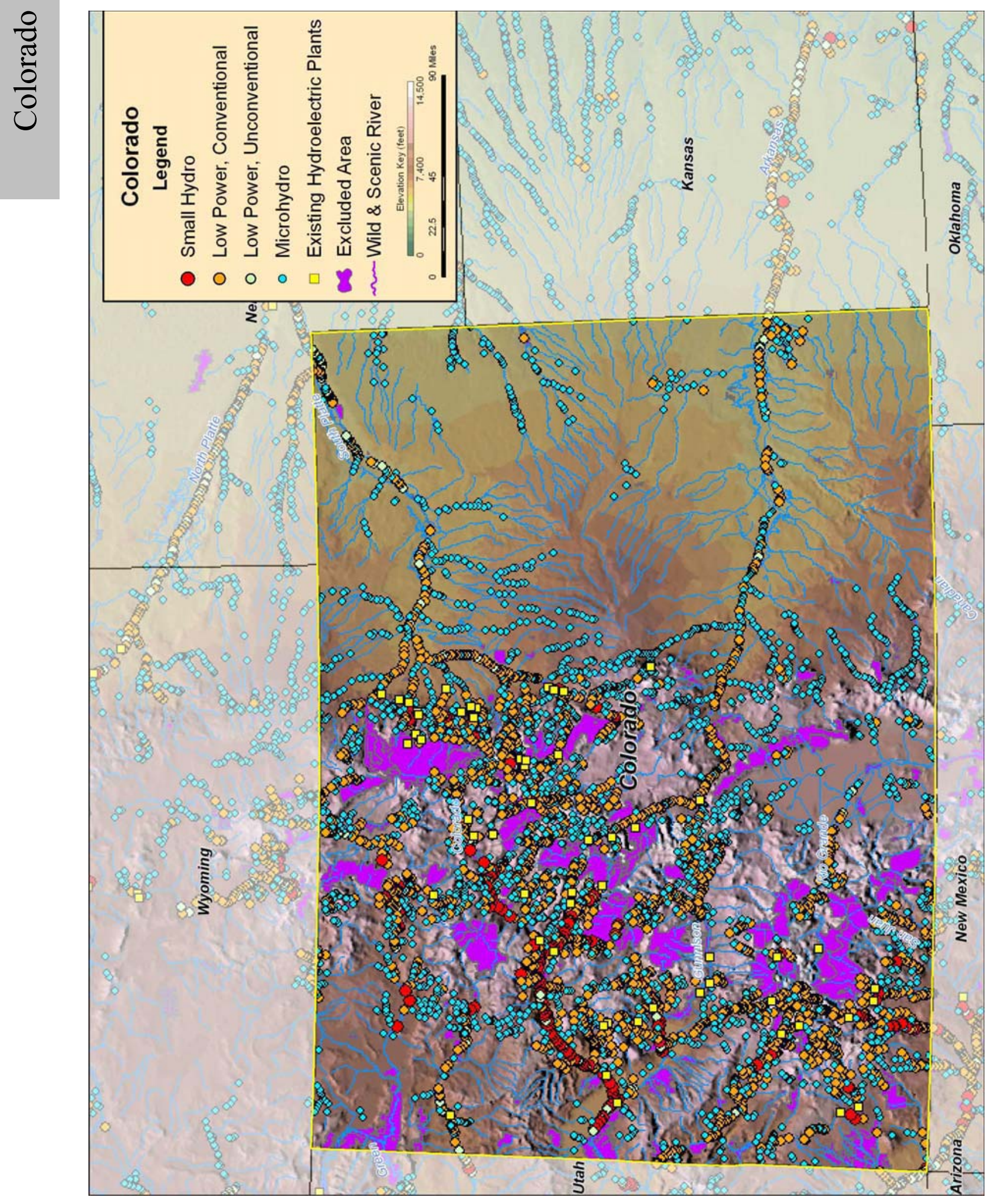

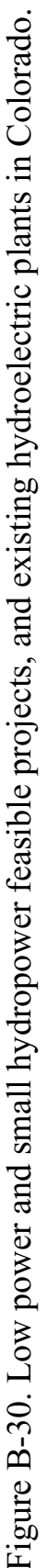




\section{B.7 Connecticut}

Table B-15. Summary of results of water energy resource assessment of Connecticut.

\begin{tabular}{|c|c|c|c|c|c|}
\hline Power Class & $\begin{array}{l}\text { Total } \\
\text { (MWa) }\end{array}$ & $\begin{array}{l}\text { Developed } \\
\text { (MWa) }\end{array}$ & $\begin{array}{c}\text { Federally } \\
\text { Excluded } \\
\text { (MWa) }\end{array}$ & $\begin{array}{c}\text { Other } \\
\text { Excluded } \\
(\mathrm{MWa})\end{array}$ & $\begin{array}{c}\text { Available } \\
\text { (MWa) }\end{array}$ \\
\hline Total Power & 430 & 42 & 13 & 25 & 350 \\
\hline Total High Power & 273 & 37 & 12 & 11 & 213 \\
\hline Large Hydro & 0 & 0 & 0 & 0 & 0 \\
\hline Small Hydro & 273 & 37 & 12 & 11 & 213 \\
\hline Total Low Power & 157 & 5 & 1 & 14 & 137 \\
\hline Conventional Turbines & 122 & 3 & 1 & 12 & 105 \\
\hline Unconventional Systems & 11 & 2 & 0 & 1 & 8 \\
\hline Microhydro & 25 & 0 & 0 & 1 & 23 \\
\hline
\end{tabular}

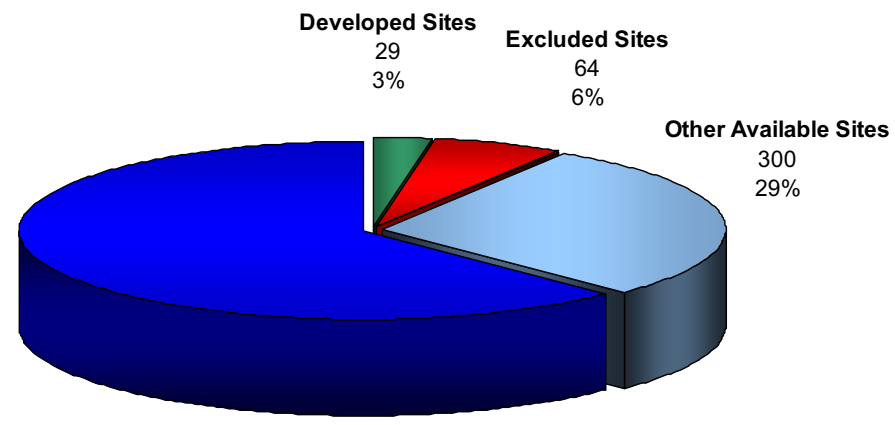

Feasible Sites 656

$63 \%$

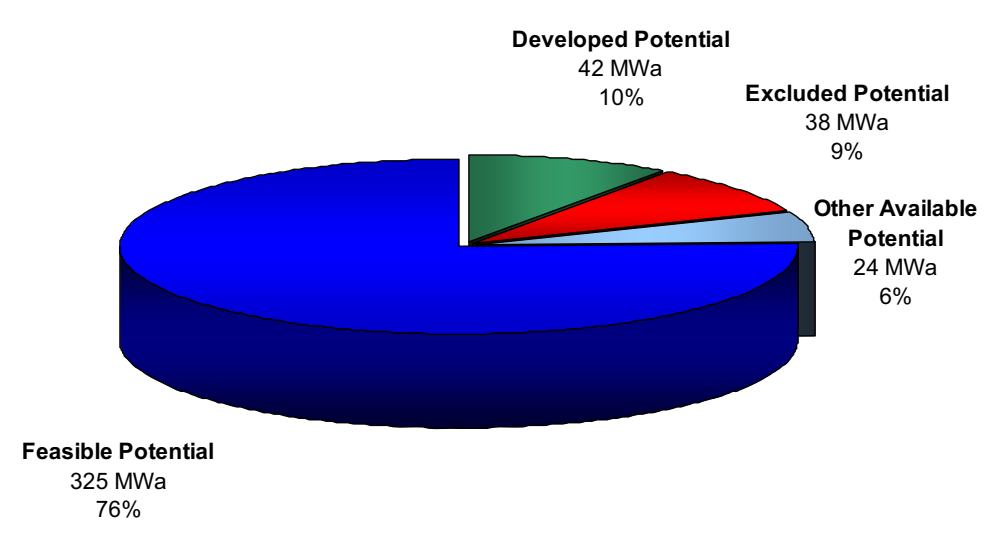

(a) Total Resource Sites 1,049

(b) Total Resource Potential $430 \mathrm{MWa}$

Figure B-31. Power category distribution of the (a) number and (b) total power potential of the water energy resource sites in Connecticut. 
Table B-16. Summary of results of water energy resource assessment of Connecticut.

\begin{tabular}{|c|c|c|c|}
\hline Power Class & $\begin{array}{c}\text { Available } \\
\text { (MWa) }\end{array}$ & $\begin{array}{c}\text { Feasible } \\
\text { Sites } \\
\text { (MWa) }\end{array}$ & $\begin{array}{c}\text { Feasible } \\
\text { Projects } \\
\text { (MWa) }\end{array}$ \\
\hline Total Power & 350 & 325 & 105 \\
\hline Total High Power & 213 & 204 & 61 \\
\hline Large Hydro & 0 & 0 & 0 \\
\hline Small Hydro & 213 & 204 & 61 \\
\hline Total Low Power & 137 & 121 & 44 \\
\hline Conventional Turbines & 105 & 98 & 25 \\
\hline Unconventional Systems & 8 & 8 & 3 \\
\hline Microhydro & 23 & 15 & 16 \\
\hline
\end{tabular}

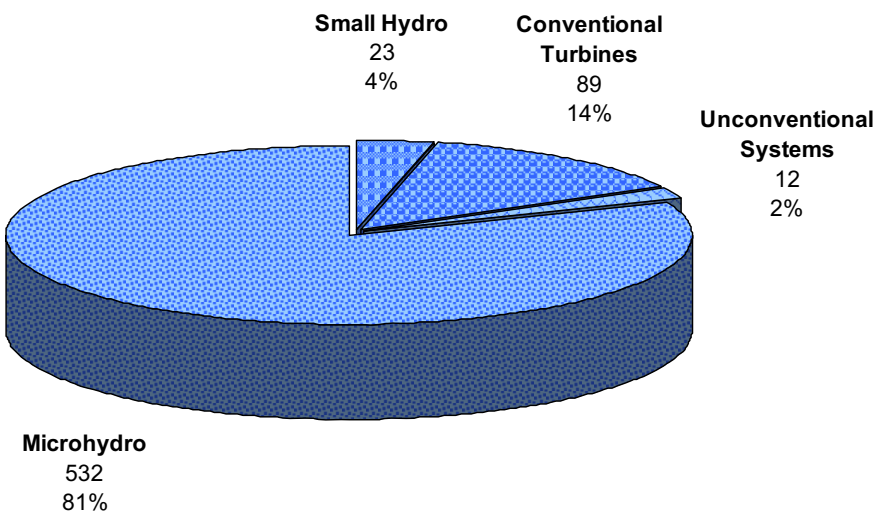

(a) Total Feasible Projects 656

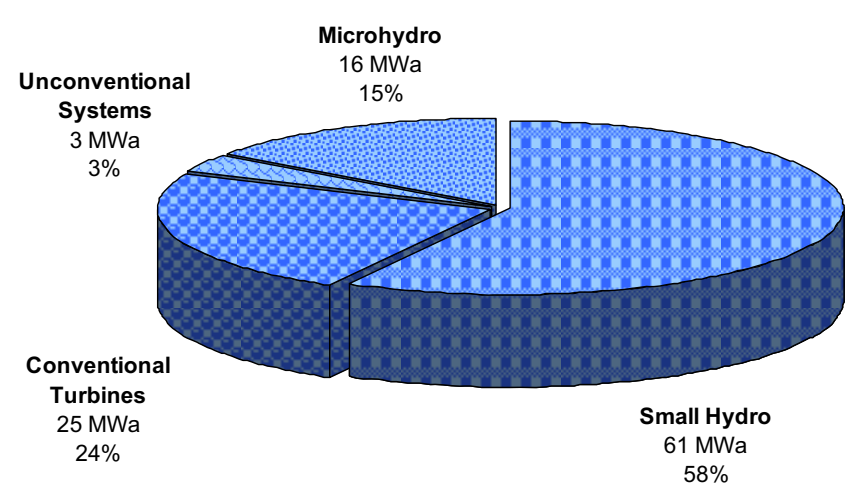

(b) Total Feasible Project Hydropower Potential $105 \mathrm{MWa}$

Figure B-32. Distribution of the (a) number and (b) total hydropower potential of the low power and small hydropower feasible projects in Connecticut with the low power projects divided into technology classes. 

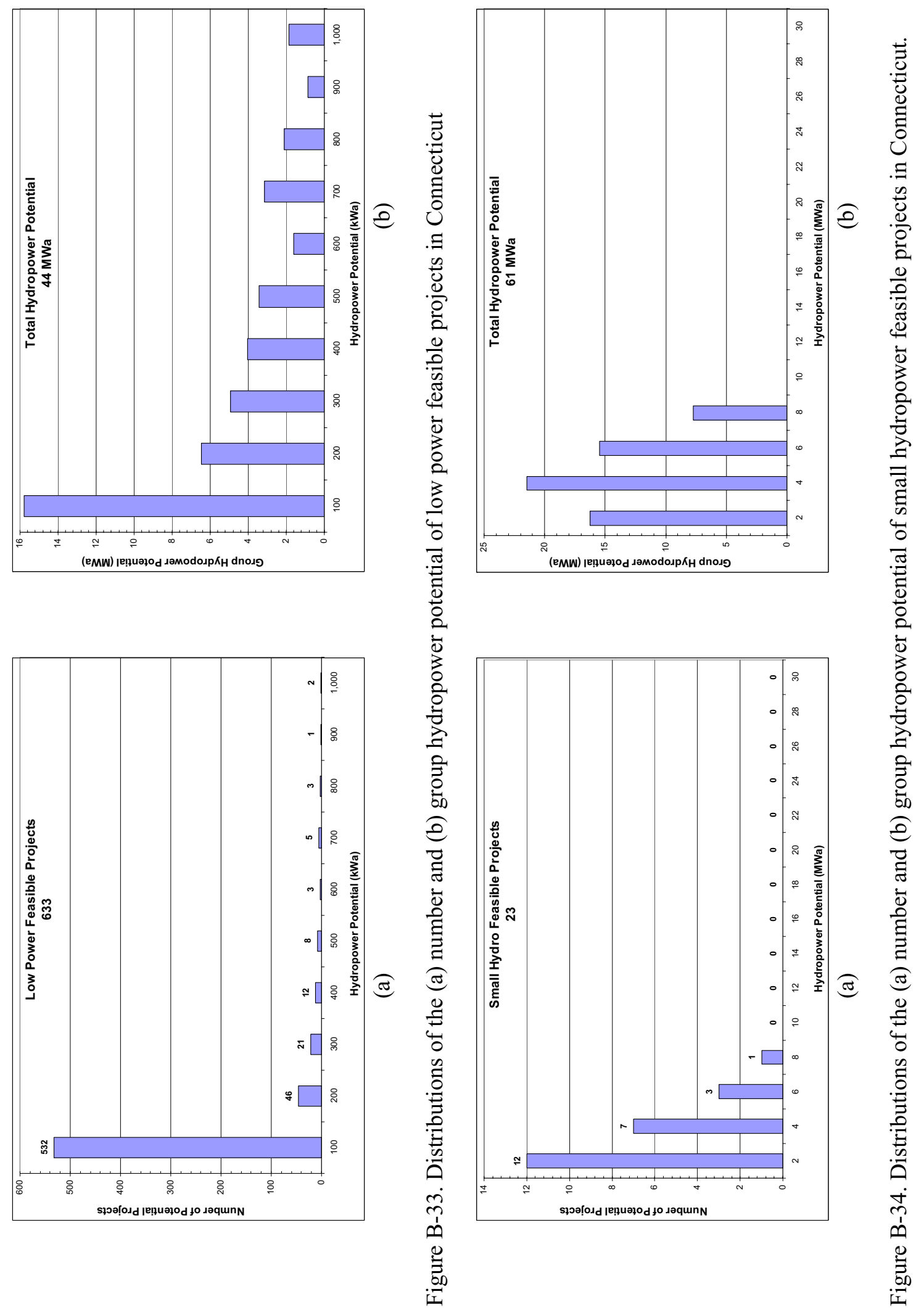

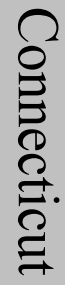
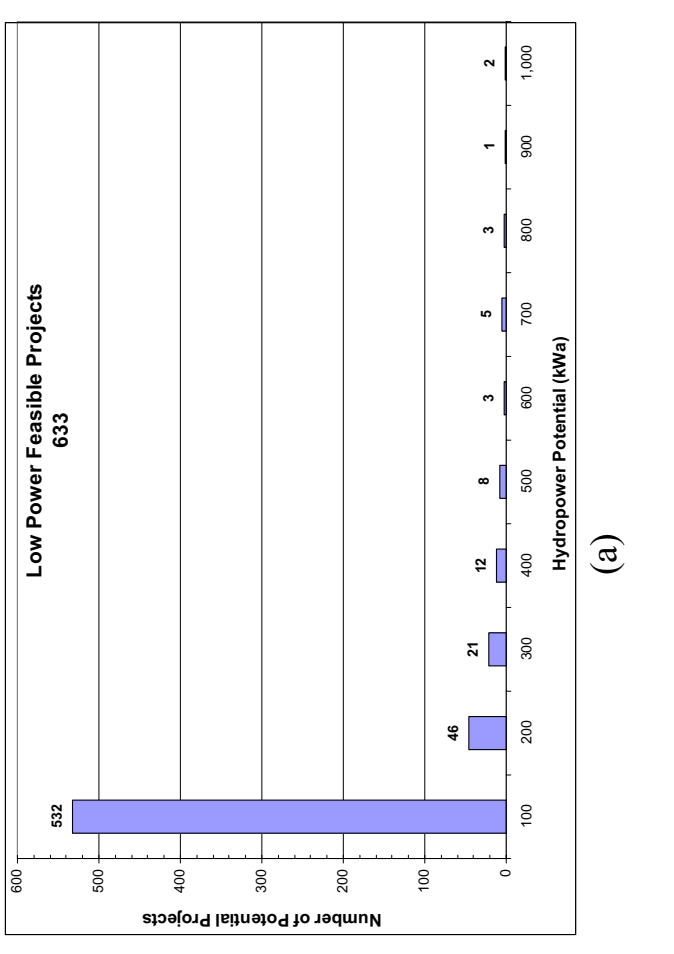


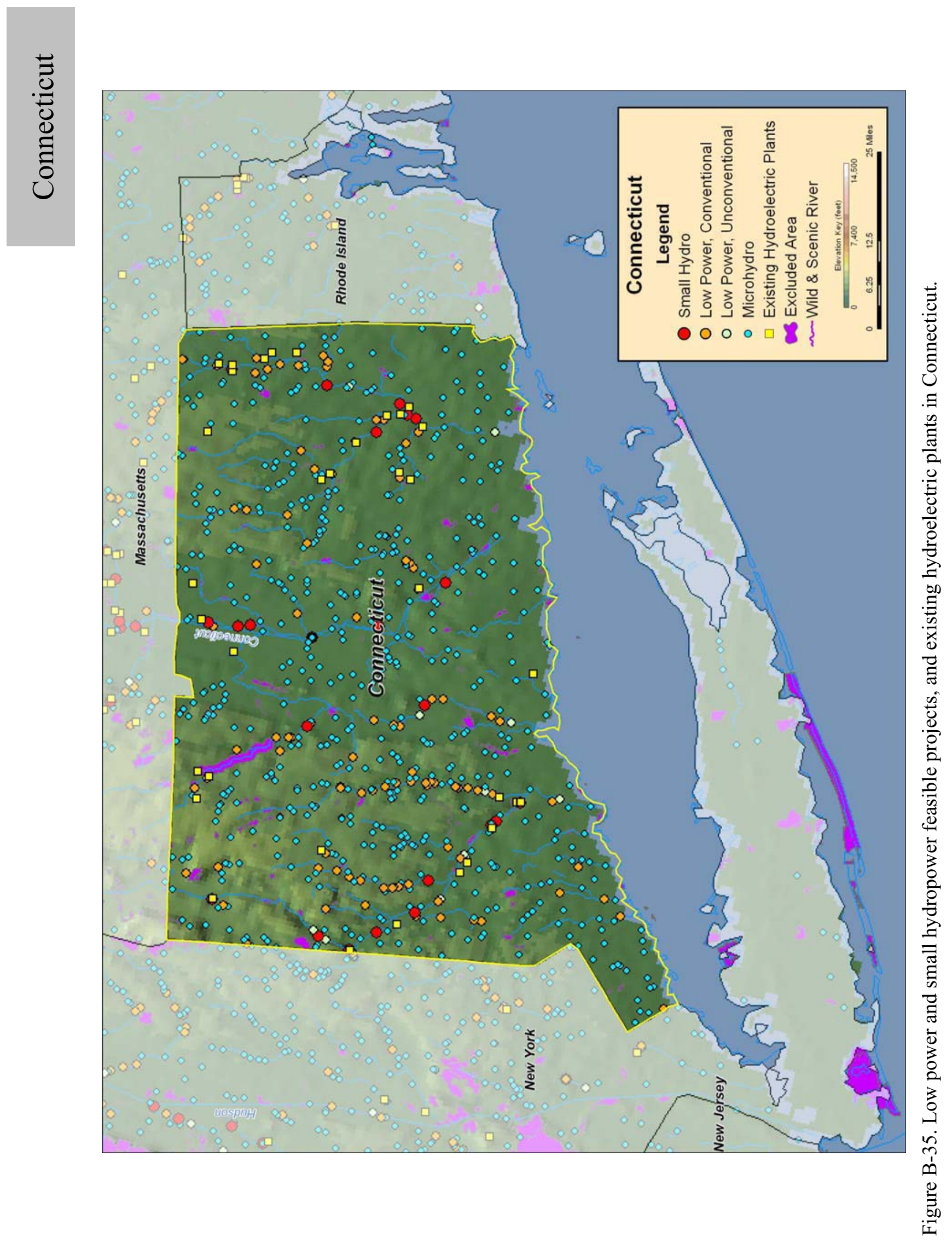




\section{B.8 Delaware}

Table B-17. Summary of results of water energy resource assessment of Delaware.

\begin{tabular}{|c|c|c|c|c|c|}
\hline Power Class & $\begin{array}{c}\text { Total } \\
(\mathbf{M W a})\end{array}$ & $\begin{array}{c}\text { Developed } \\
(\mathrm{MWa})\end{array}$ & $\begin{array}{c}\text { Federally } \\
\text { Excluded } \\
(\mathrm{MWa})\end{array}$ & $\begin{array}{c}\text { Other } \\
\text { Excluded } \\
(\mathrm{MWa})\end{array}$ & $\begin{array}{c}\text { Available } \\
(\mathrm{MWa})\end{array}$ \\
\hline Total Power & $\mathbf{2 2}$ & $\mathbf{0}$ & $\mathbf{0}$ & $\mathbf{6}$ & 15 \\
\hline & & & & & \\
\hline Total High Power & $\mathbf{1 4}$ & 0 & $\mathbf{0}$ & $\mathbf{5}$ & 10 \\
\hline Large Hydro & 0 & 0 & 0 & 0 & 0 \\
\hline Small Hydro & 14 & 0 & 0 & 5 & 10 \\
\hline Total Low Power & & & & & \\
\hline Conventional Turbines & $\mathbf{7}$ & 0 & $\mathbf{0}$ & $\mathbf{2}$ & 5 \\
\hline Unconventional Systems & $\mathbf{3}$ & 0 & 0 & 1 & 2 \\
\hline Microhydro & $\mathbf{3}$ & 0 & 0 & 0 & 1 \\
\hline
\end{tabular}

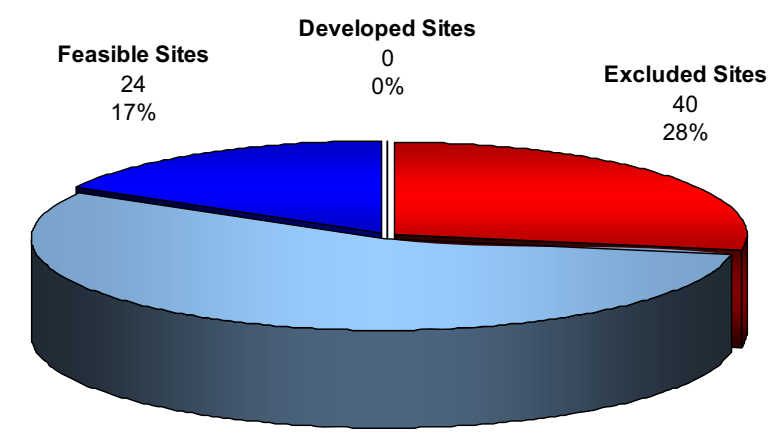

Other Available Sites

80

$56 \%$

(a) Total Resource Sites 144

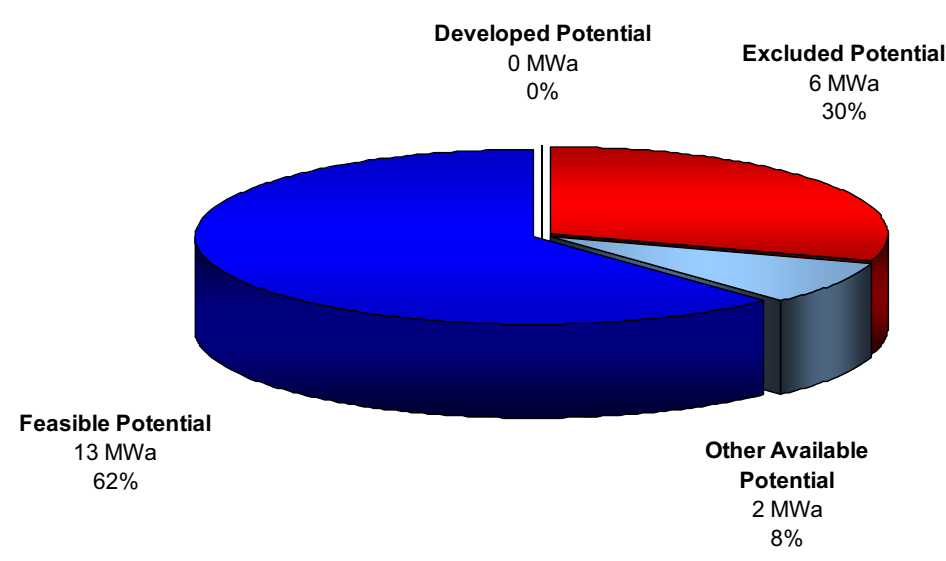

(b) Total Resource Potential $22 \mathrm{MWa}$

Figure B-36. Power category distribution of the (a) number and (b) total power potential of the water energy resource sites in Delaware. 
Table B-18. Summary of results of feasibility assessment of water energy resources in Delaware.

\begin{tabular}{|c|c|c|c|}
\hline Power Class & $\begin{array}{c}\text { Available } \\
\text { (MWa) }\end{array}$ & $\begin{array}{c}\text { Feasible } \\
\text { Sites } \\
\text { (MWa) }\end{array}$ & $\begin{array}{c}\text { Feasible } \\
\text { Projects } \\
\text { (MWa) }\end{array}$ \\
\hline Total Power & 15 & 13 & 6 \\
\hline Total High Power & 10 & 10 & 4 \\
\hline Large Hydro & 0 & 0 & 0 \\
\hline Small Hydro & 10 & 10 & 4 \\
\hline Total Low Power & 5 & 3 & 2 \\
\hline Conventional Turbines & 2 & 2 & 0 \\
\hline Unconventional Systems & 1 & 1 & 2 \\
\hline Microhydro & 2 & 0 & 0 \\
\hline
\end{tabular}

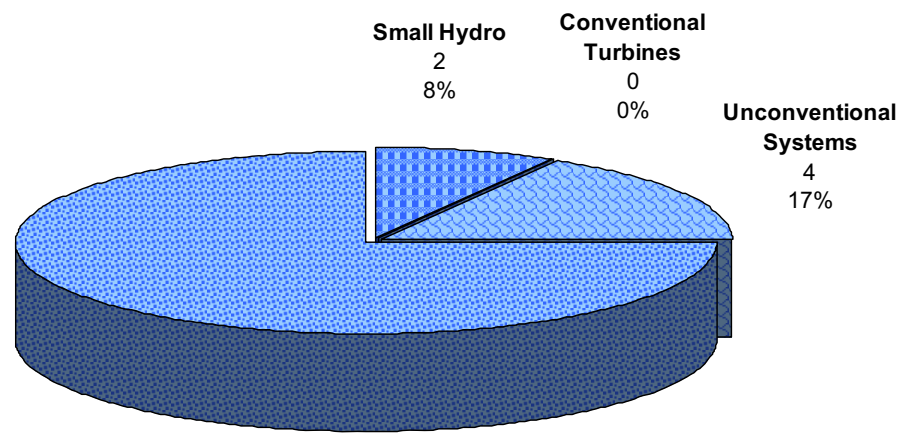

Microhydro
18
$75 \%$

(a) Total Feasible Projects

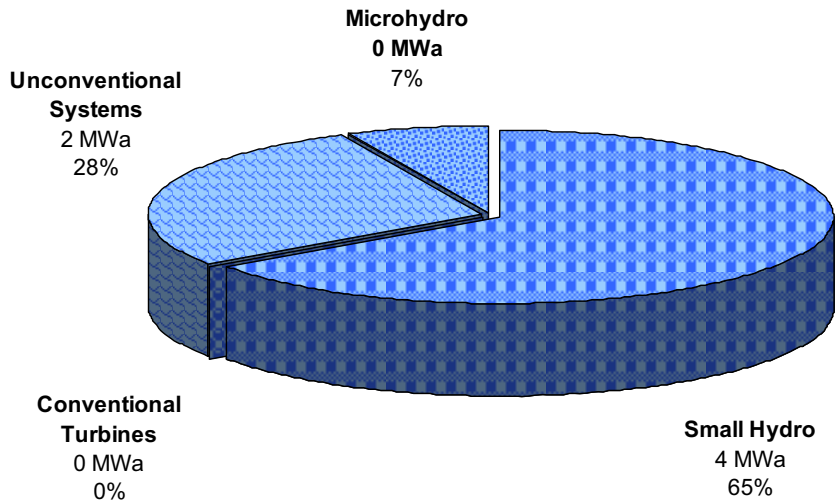

(b) Total Feasible Project Hydropower Potential $6 \mathrm{MWa}$

Figure B-37. Distribution of the (a) number and (b) total hydropower potential of the low power and small hydropower feasible projects in Delaware with the low power projects divided into technology classes. 

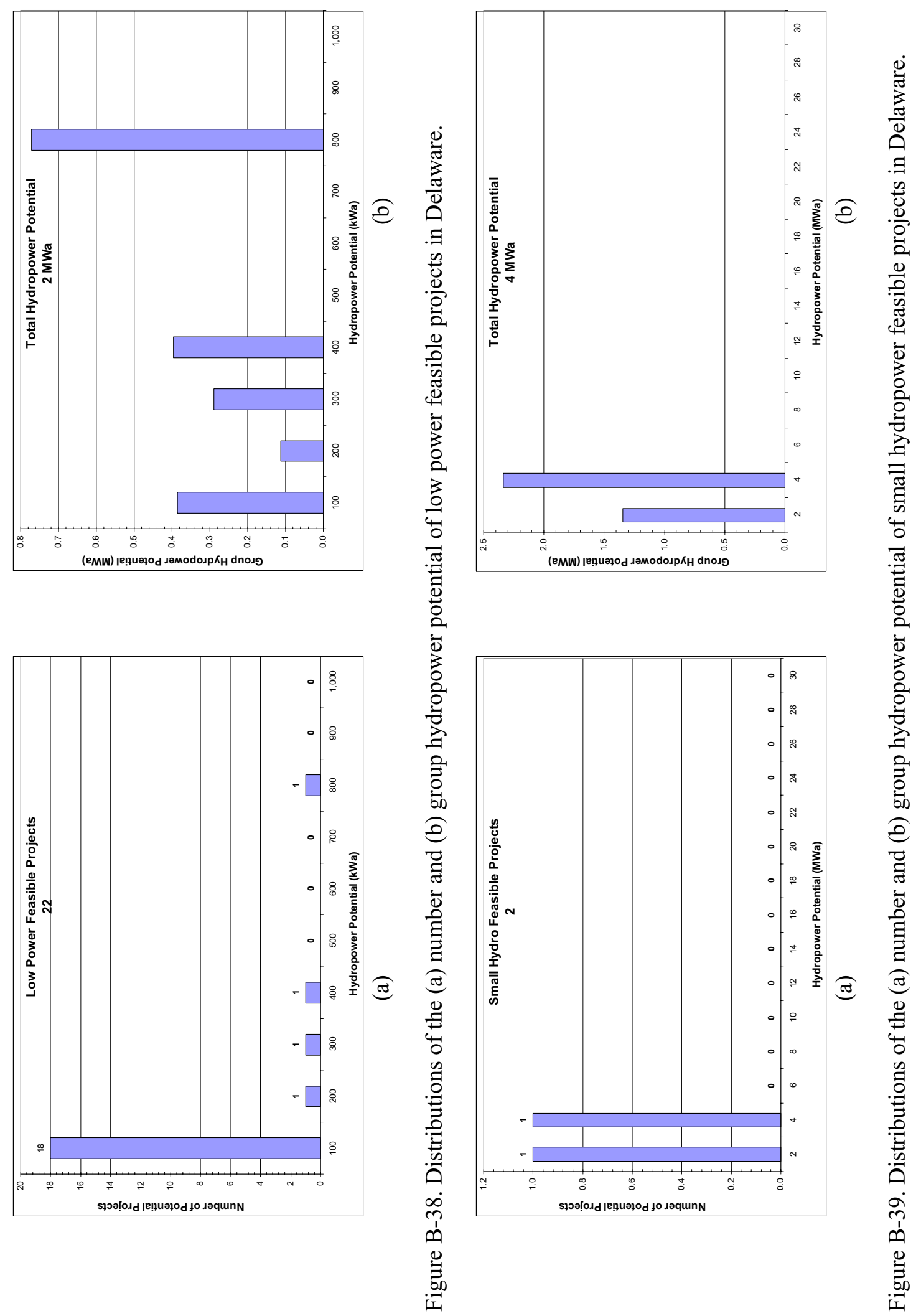


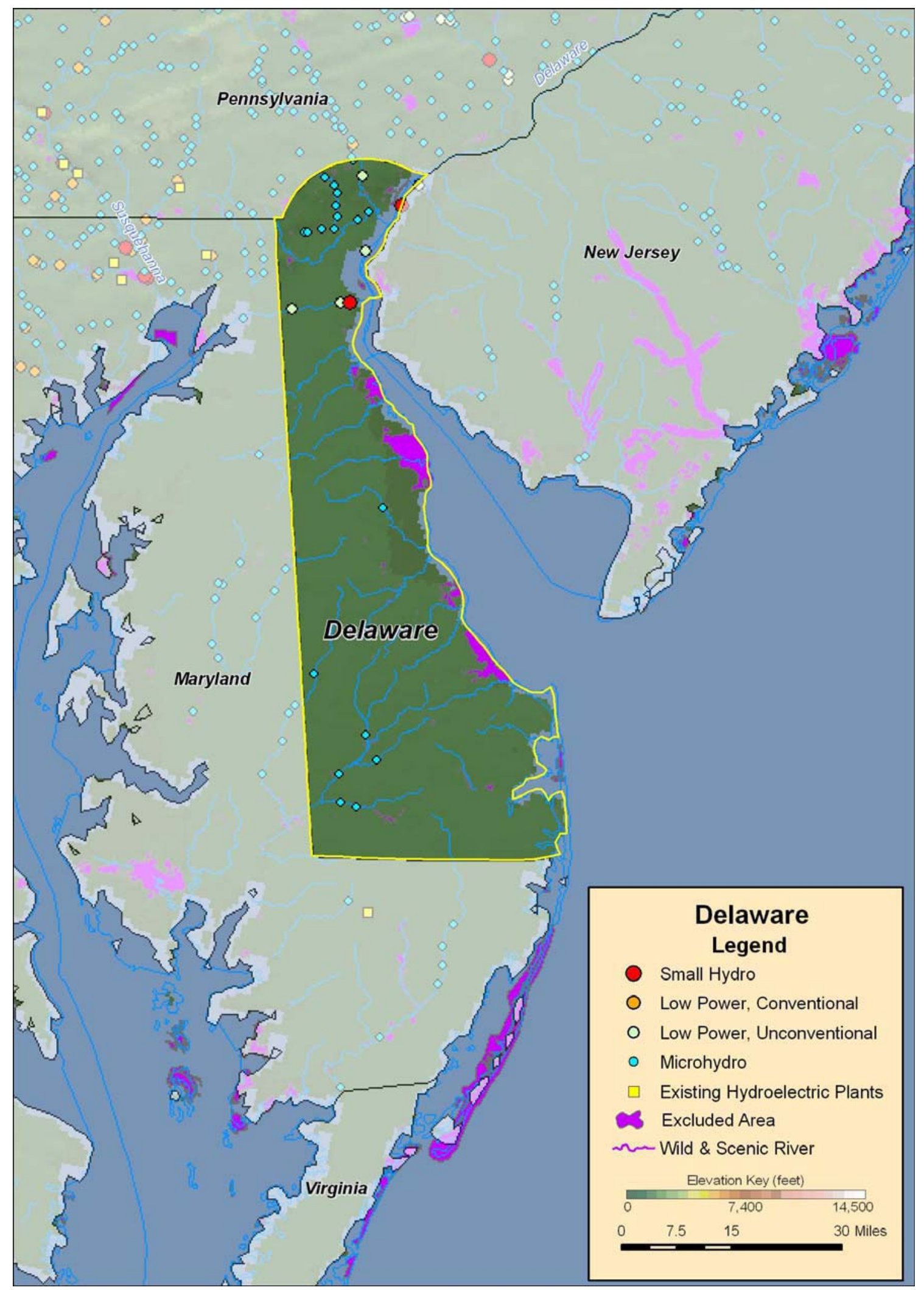

Figure B-40. Low power and small hydropower feasible projects, and existing hydroelectric plants in Delaware. 


\section{B.9 Florida}

Table B-19. Summary of results of water energy resource assessment of Florida.

\begin{tabular}{|c|c|c|c|c|c|}
\hline Power Class & $\begin{array}{c}\text { Total } \\
\text { (MWa) }\end{array}$ & $\begin{array}{c}\text { Developed } \\
(\mathrm{MWa})\end{array}$ & $\begin{array}{c}\text { Federally } \\
\text { Excluded } \\
(\mathbf{M W a})\end{array}$ & $\begin{array}{c}\text { Other } \\
\text { Excluded } \\
(\mathrm{MWa})\end{array}$ & $\begin{array}{c}\text { Available } \\
(\mathrm{MWa})\end{array}$ \\
\hline Total Power & $\mathbf{4 6 4}$ & $\mathbf{0}$ & $\mathbf{1 4}$ & $\mathbf{9 0}$ & 359 \\
\hline Total High Power & $\mathbf{2 5 0}$ & 0 & & & \\
\hline Large Hydro & 36 & 0 & 0 & $\mathbf{4 2}$ & 201 \\
\hline Small Hydro & $\mathbf{2 1 3}$ & 0 & 6 & 42 & 36 \\
\hline & & & & & 165 \\
\hline Total Low Power & $\mathbf{2 1 4}$ & 0 & $\mathbf{8}$ & $\mathbf{4 8}$ & 158 \\
\hline Conventional Turbines & 55 & 0 & 2 & 9 & 44 \\
\hline Unconventional Systems & $\mathbf{7 3}$ & 0 & 4 & 23 & 47 \\
\hline Microhydro & $\mathbf{8 5}$ & 0 & 2 & 16 & 68 \\
\hline
\end{tabular}

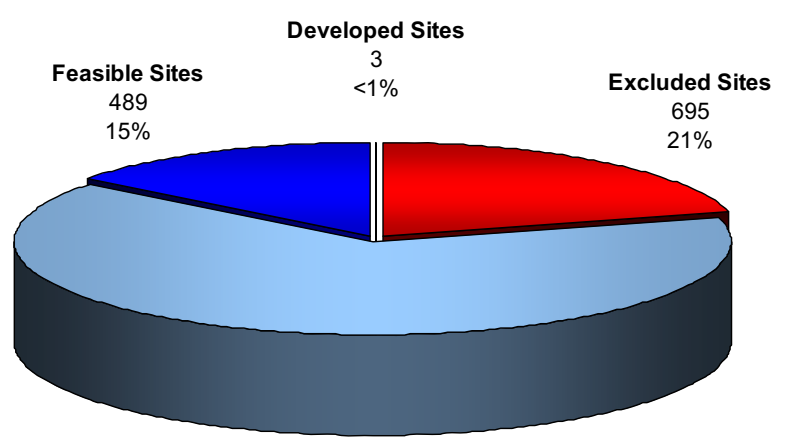

Other Available Sites

2,168
$65 \%$

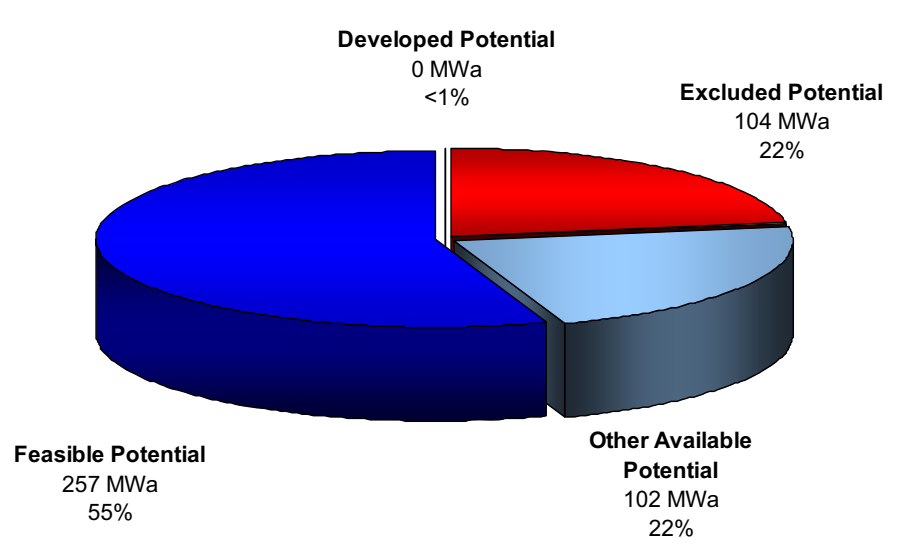

(a) Total Resource Sites

3,355

(a) Total Resource Potential $464 \mathrm{MWa}$

Figure B-41. Power category distribution of the (a) number and (b) total power potential of the water energy resource sites in Florida. 
Table B-20. Summary of results of feasibility assessment of water energy resources in Florida.

\begin{tabular}{|c|c|}
\hline Power Class & $\begin{array}{c}\text { Available } \\
\text { (MWa) }\end{array}$ \\
\hline Total Power & 359 \\
\hline & \\
\hline Total High Power & 201 \\
\hline Large Hydro & 36 \\
\hline Small Hydro & 165 \\
\hline & \\
\hline Total Low Power & 158 \\
\hline Conventional Turbines & 44 \\
\hline Unconventional Systems & 47 \\
\hline Microhydro & 68 \\
\hline
\end{tabular}

\begin{tabular}{|c|c|}
\hline $\begin{array}{c}\text { Feasible } \\
\text { Sites } \\
\text { (MWa) }\end{array}$ & $\begin{array}{c}\text { Feasible } \\
\text { Projects } \\
\text { (MWa) }\end{array}$ \\
\hline 257 & 79 \\
\hline 180 & 51 \\
\hline 36 & 0 \\
\hline 143 & 51 \\
\hline 77 & 27 \\
\hline 30 & 0 \\
\hline 36 & 15 \\
\hline 11 & 12 \\
\hline
\end{tabular}

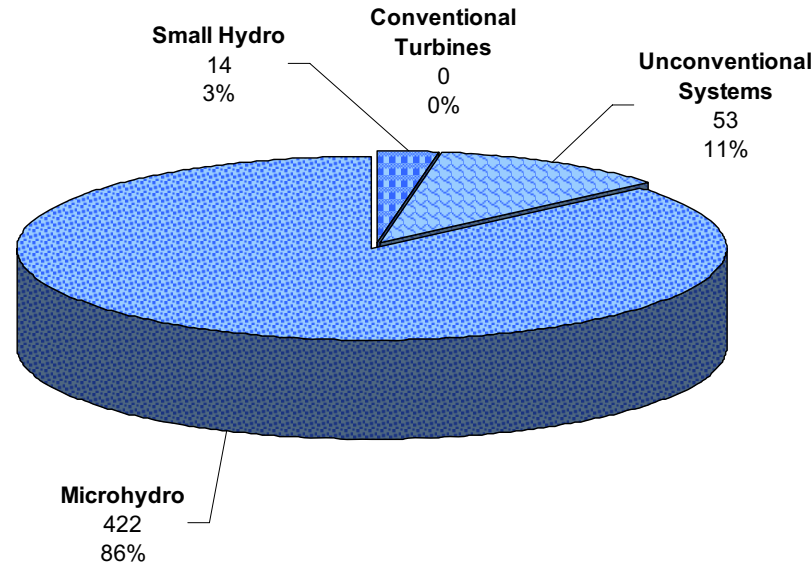

(a) Total Feasible Projects 489

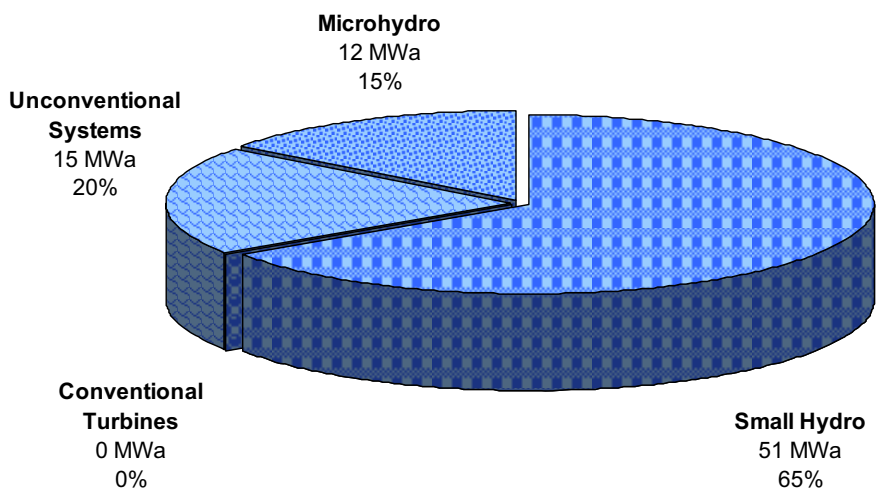

(b) Total Feasible Project Hydropower Potential $79 \mathrm{MWa}$

Figure B-42. Distribution of the (a) number and (b) total hydropower potential of the low power and small hydropower feasible projects in Florida with the low power projects divided into technology classes. 

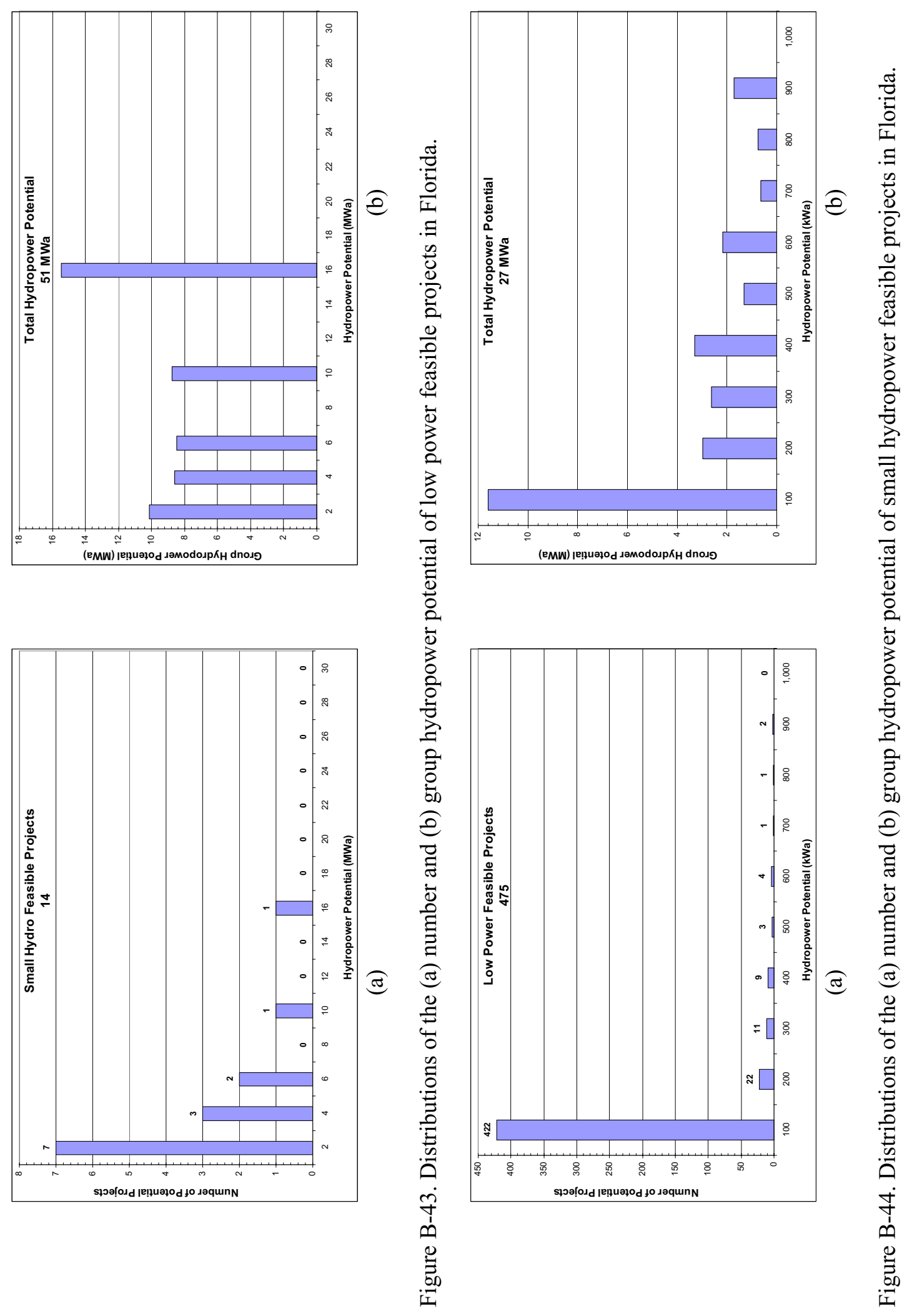

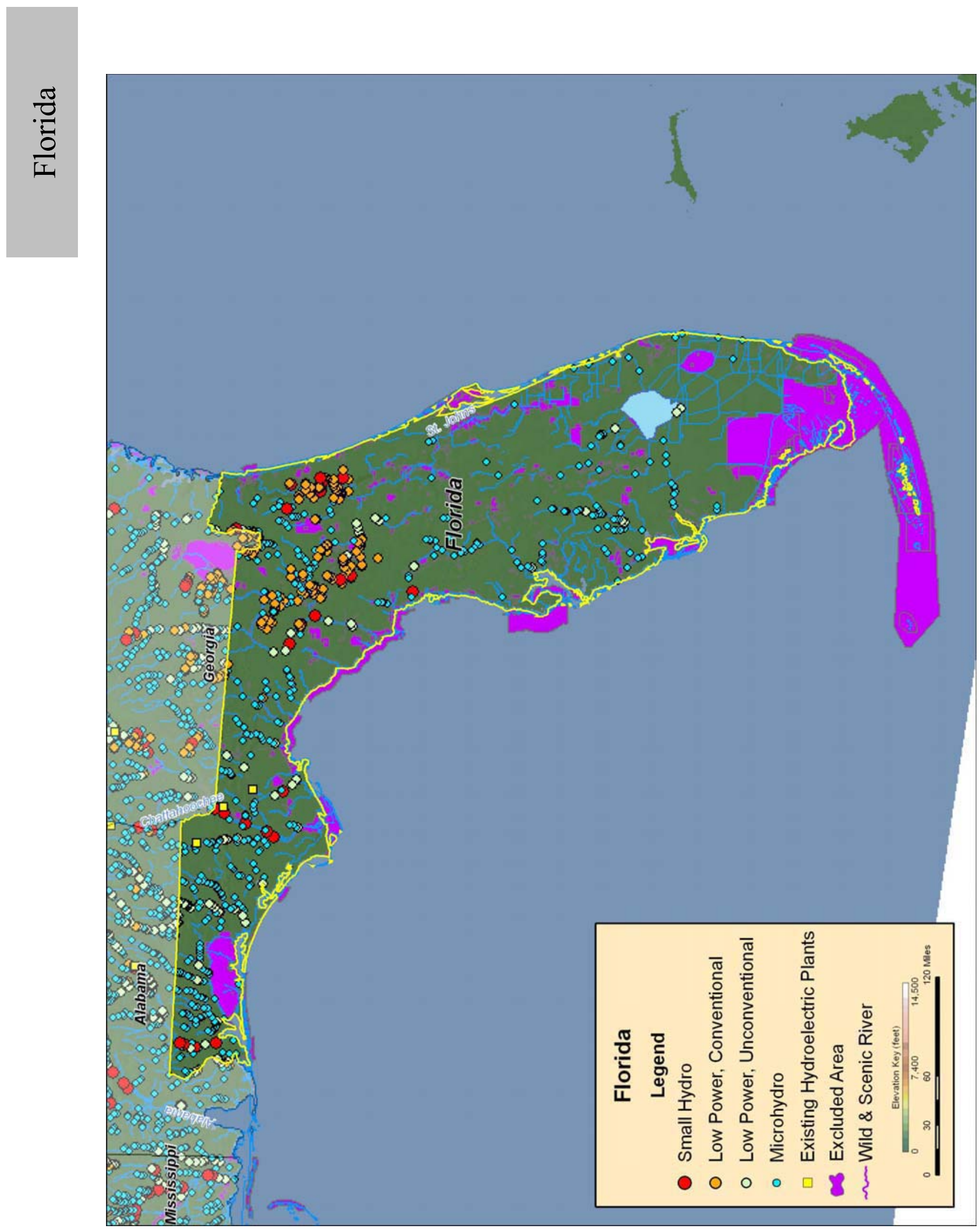

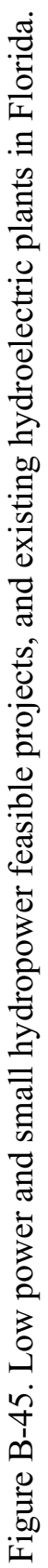




\section{B.10 Georgia}

Table B-21. Summary of results of water energy resource assessment of Georgia.

\begin{tabular}{|c|c|c|c|c|c|}
\hline Power Class & $\begin{array}{c}\text { Total } \\
\mathbf{( M W a )}\end{array}$ & $\begin{array}{c}\text { Developed } \\
(\mathbf{M W a})\end{array}$ & $\begin{array}{c}\text { Federally } \\
\text { Excluded } \\
(\mathbf{M W a})\end{array}$ & $\begin{array}{c}\text { Other } \\
\text { Excluded } \\
(\mathbf{M W a})\end{array}$ & $\begin{array}{c}\text { Available } \\
(\mathrm{MWa})\end{array}$ \\
\hline Total Power & $\mathbf{2 , 0 6 1}$ & $\mathbf{2 8 1}$ & $\mathbf{1 9 0}$ & $\mathbf{2 3 3}$ & 1,357 \\
\hline Total High Power & & & & & \\
\hline Large Hydro & $\mathbf{1 , 2 7 2}$ & $\mathbf{2 7 7}$ & $\mathbf{1 7 2}$ & $\mathbf{1 6 5}$ & 658 \\
\hline Small Hydro & $\mathbf{2 2 2}$ & 142 & 42 & 0 & 37 \\
\hline Total Low Power & 1,050 & 134 & 130 & 165 & 621 \\
\hline Conventional Turbines & & & & & \\
\hline Unconventional Systems & $\mathbf{7 8 9}$ & $\mathbf{5}$ & $\mathbf{1 8}$ & $\mathbf{6 8}$ & 699 \\
\hline Microhydro & $\mathbf{4 4 4}$ & 4 & 13 & 44 & 383 \\
\hline
\end{tabular}

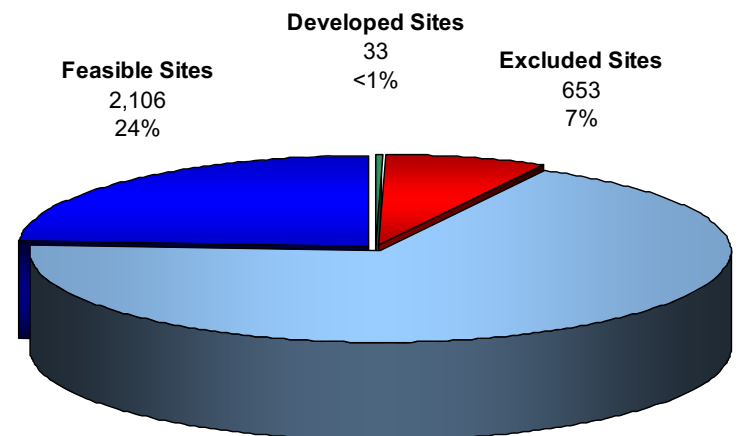

Other Available Sites

6,035

Feasible Potential

$930 \mathrm{MWa}$

$45 \%$
Developed Potential

$281 \mathrm{MWa}$

$14 \%$

(a) Total Resource Sites

8,827

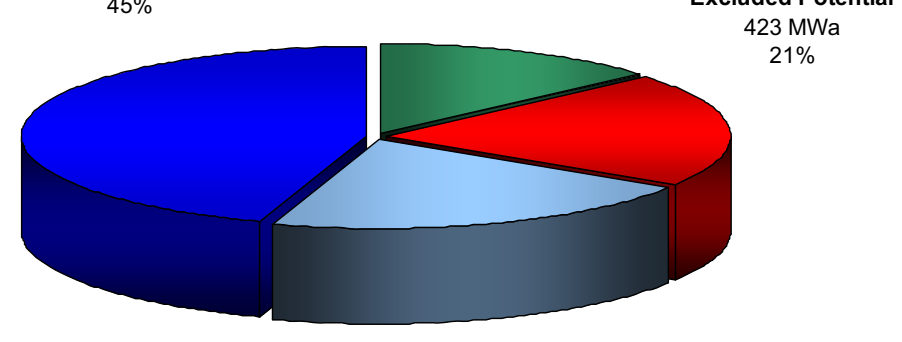

Other Available

Potential

$427 \mathrm{MWa}$

$21 \%$

(b) Total Resource Potential 2,061 MWa

Figure B-46. Power category distribution of the (a) number and (b) total power potential of the water energy resource sites in Georgia. 
Table B-22. Summary of results of feasibility assessment of water energy resources in Georgia.

\begin{tabular}{|c|c|}
\hline Power Class & $\begin{array}{c}\text { Available } \\
\text { (MWa) }\end{array}$ \\
\hline Total Power & 1,357 \\
\hline Total High Power & 658 \\
\hline Large Hydro & 37 \\
\hline Small Hydro & 621 \\
\hline & \\
\hline Total Low Power & 699 \\
\hline Conventional Turbines & 383 \\
\hline Unconventional Systems & 107 \\
\hline Microhydro & 209 \\
\hline
\end{tabular}

\begin{tabular}{|c|c|}
\hline $\begin{array}{c}\text { Feasible } \\
\text { Sites } \\
\text { (MWa) }\end{array}$ & $\begin{array}{c}\text { Feasible } \\
\text { Projects } \\
\text { (MWa) }\end{array}$ \\
\hline 930 & 230 \\
\hline 514 & 101 \\
\hline 37 & 0 \\
\hline 477 & 101 \\
\hline 416 & 129 \\
\hline 284 & 27 \\
\hline 91 & 51 \\
\hline 41 & 51 \\
\hline
\end{tabular}

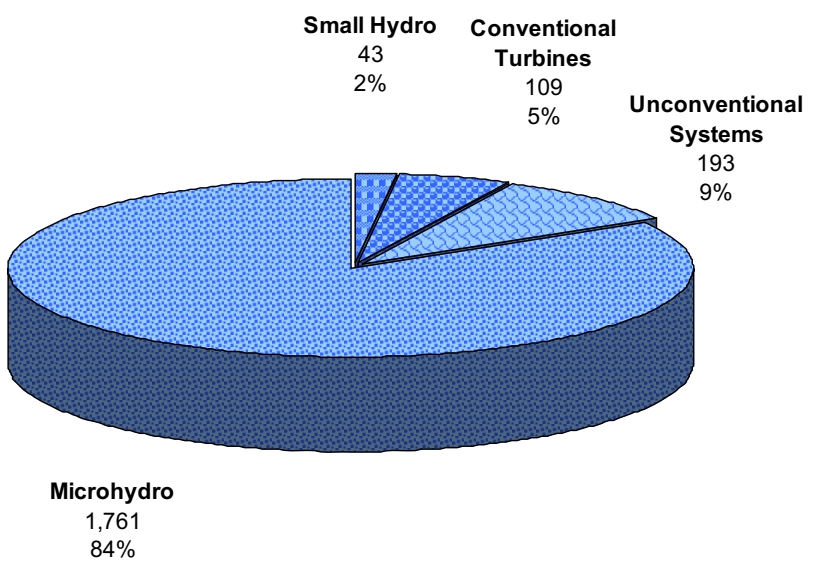

(a) Total Feasible Projects 2,106

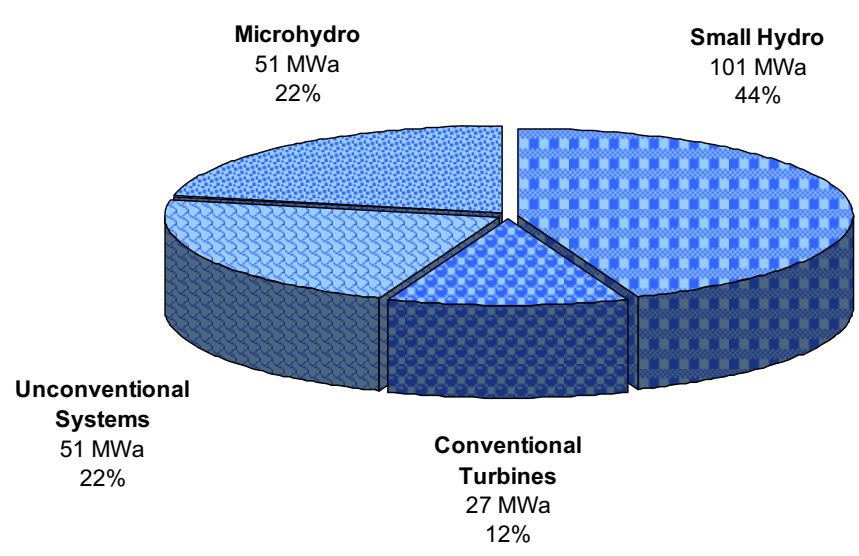

(b) Total Feasible Project Hydropower Potential $230 \mathrm{MWa}$

Figure B-47. Distribution of the (a) number and (b) total hydropower potential of the low power and small hydropower feasible projects in Georgia with the low power projects divided into technology classes. 

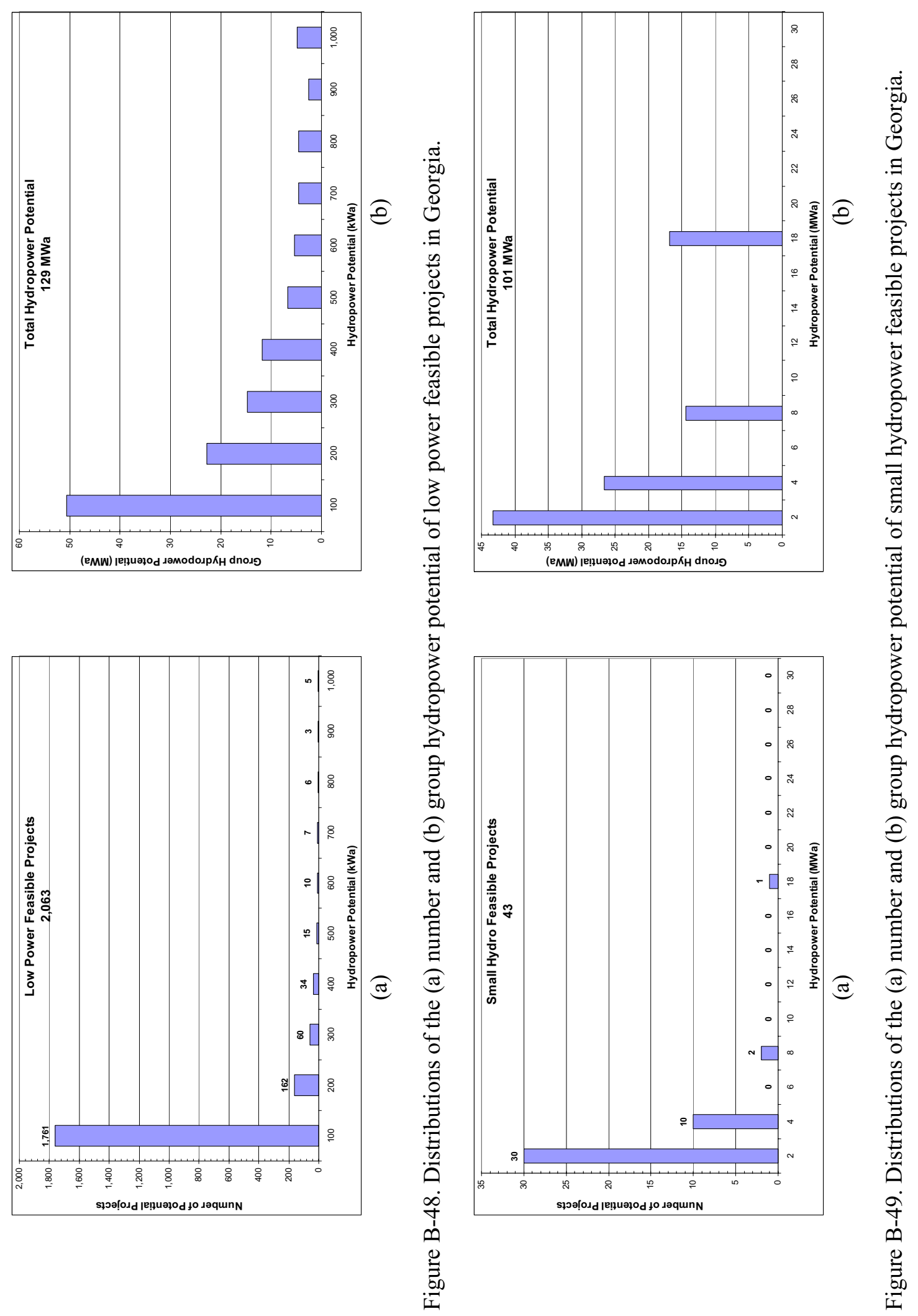

๑ิ

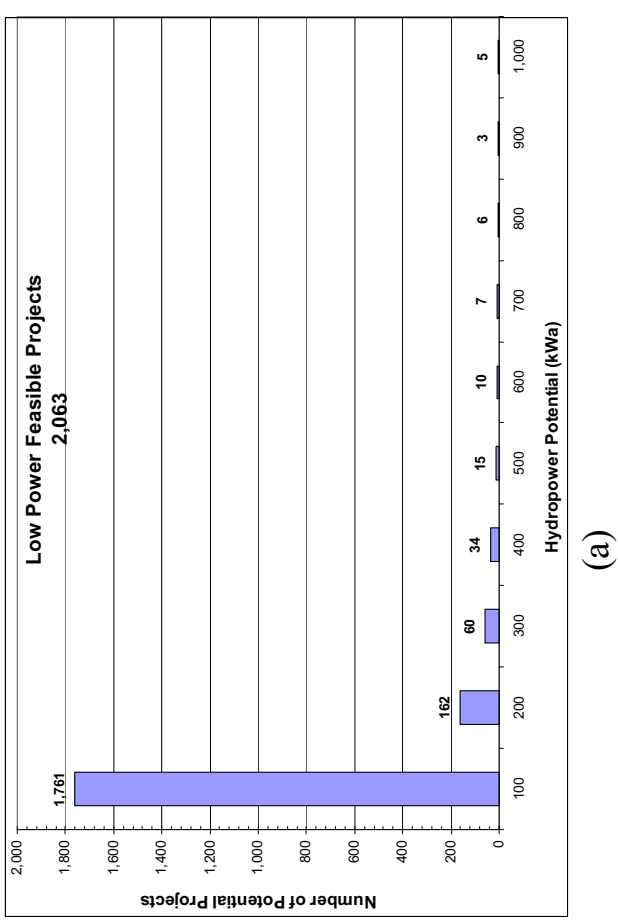




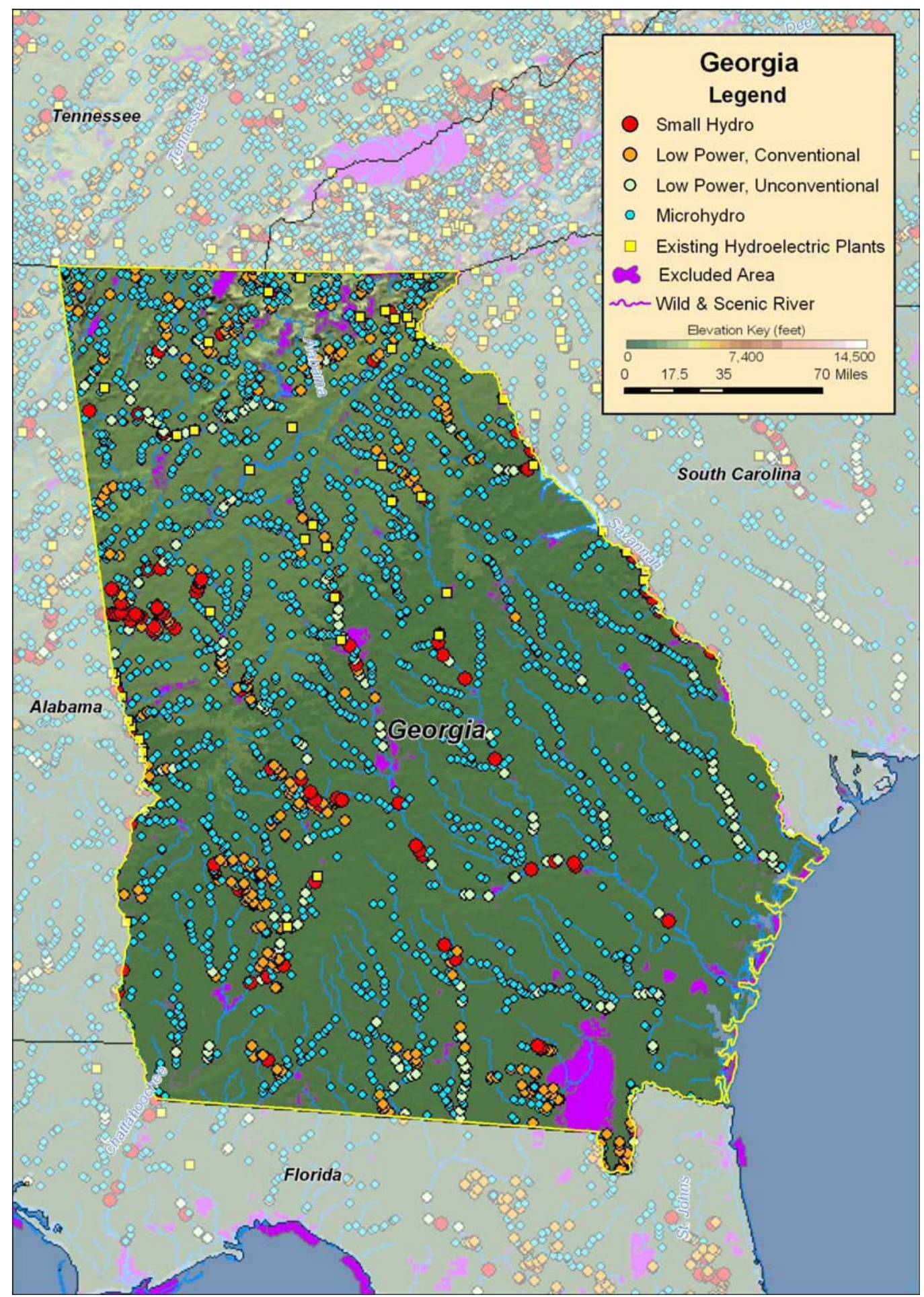

Figure B-50. Low power and small hydropower feasible projects, and existing hydroelectric plants in Georgia. 


\section{B.11 Hawaii}

Table B-23. Summary of results of water energy resource assessment of Hawaii.

\begin{tabular}{|c|c|c|c|c|c|}
\hline \multicolumn{1}{|c|}{ Power Class } & $\begin{array}{c}\text { Total } \\
\mathbf{( M W a )}\end{array}$ & $\begin{array}{c}\text { Developed } \\
(\mathrm{MWa})\end{array}$ & $\begin{array}{c}\text { Federally } \\
\text { Excluded } \\
(\mathbf{M W a})\end{array}$ & $\begin{array}{c}\text { Other } \\
\text { Excluded } \\
(\mathbf{M W a})\end{array}$ & $\begin{array}{c}\text { Available } \\
(\mathrm{MWa})\end{array}$ \\
\hline Total Power & $\mathbf{2 , 2 5 9}$ & $\mathbf{1 7}$ & $\mathbf{1 2}$ & $\mathbf{0}$ & 2,230 \\
\hline & & & & & \\
\hline Total High Power & $\mathbf{2 , 1 0 2}$ & 15 & 11 & $\mathbf{0}$ & 2,077 \\
\hline Large Hydro & 382 & 0 & 0 & 0 & 382 \\
\hline Small Hydro & 1,720 & 15 & 11 & 0 & 1,695 \\
\hline & & & & & \\
\hline Total Low Power & $\mathbf{1 5 7}$ & $\mathbf{2}$ & $\mathbf{1}$ & $\mathbf{0}$ & 154 \\
\hline Conventional Turbines & 149 & 2 & 1 & 0 & 147 \\
\hline Unconventional Systems & 0 & 0 & 0 & 0 & 0 \\
\hline Microhydro & $\mathbf{7}$ & 0 & 0 & 0 & 7 \\
\hline
\end{tabular}

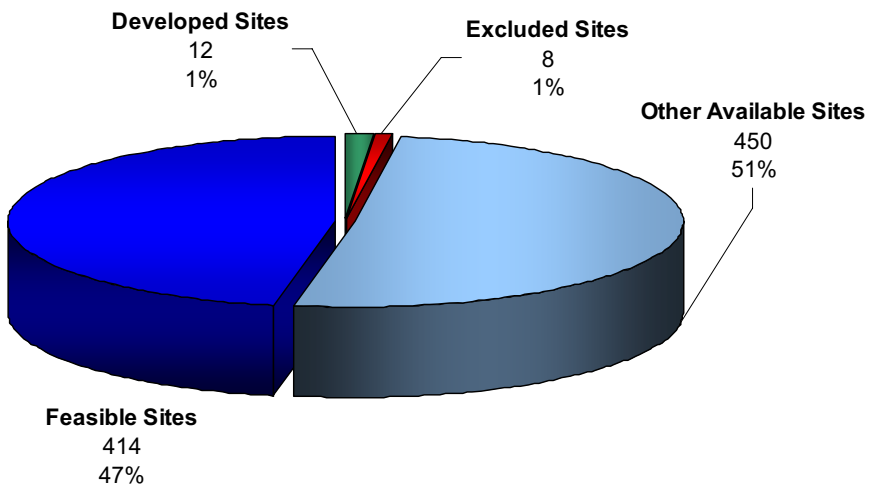

(a) Total Resource Sites 884

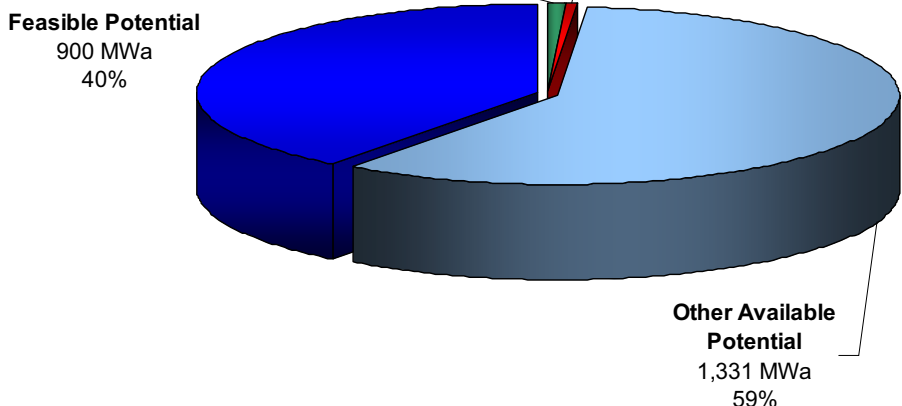

(b) Total Resource Potential 2,259 MWa

Figure B-51. Power category distribution of the (a) number and (b) total power potential of the water energy resource sites in Hawaii. 
Table B-24. Summary of results of feasibility assessment of water energy resources in Hawaii.

\begin{tabular}{|c|c|}
\hline Power Class & $\begin{array}{c}\text { Available } \\
(\mathrm{MWa})\end{array}$ \\
\hline Total Power & 2,230 \\
\hline & \\
\hline Total High Power & 2,077 \\
\hline Large Hydro & 382 \\
\hline Small Hydro & 1,695 \\
\hline & \\
\hline Total Low Power & 154 \\
\hline Conventional Turbines & 147 \\
\hline Unconventional Systems & 0 \\
\hline Microhydro & 7 \\
\hline
\end{tabular}
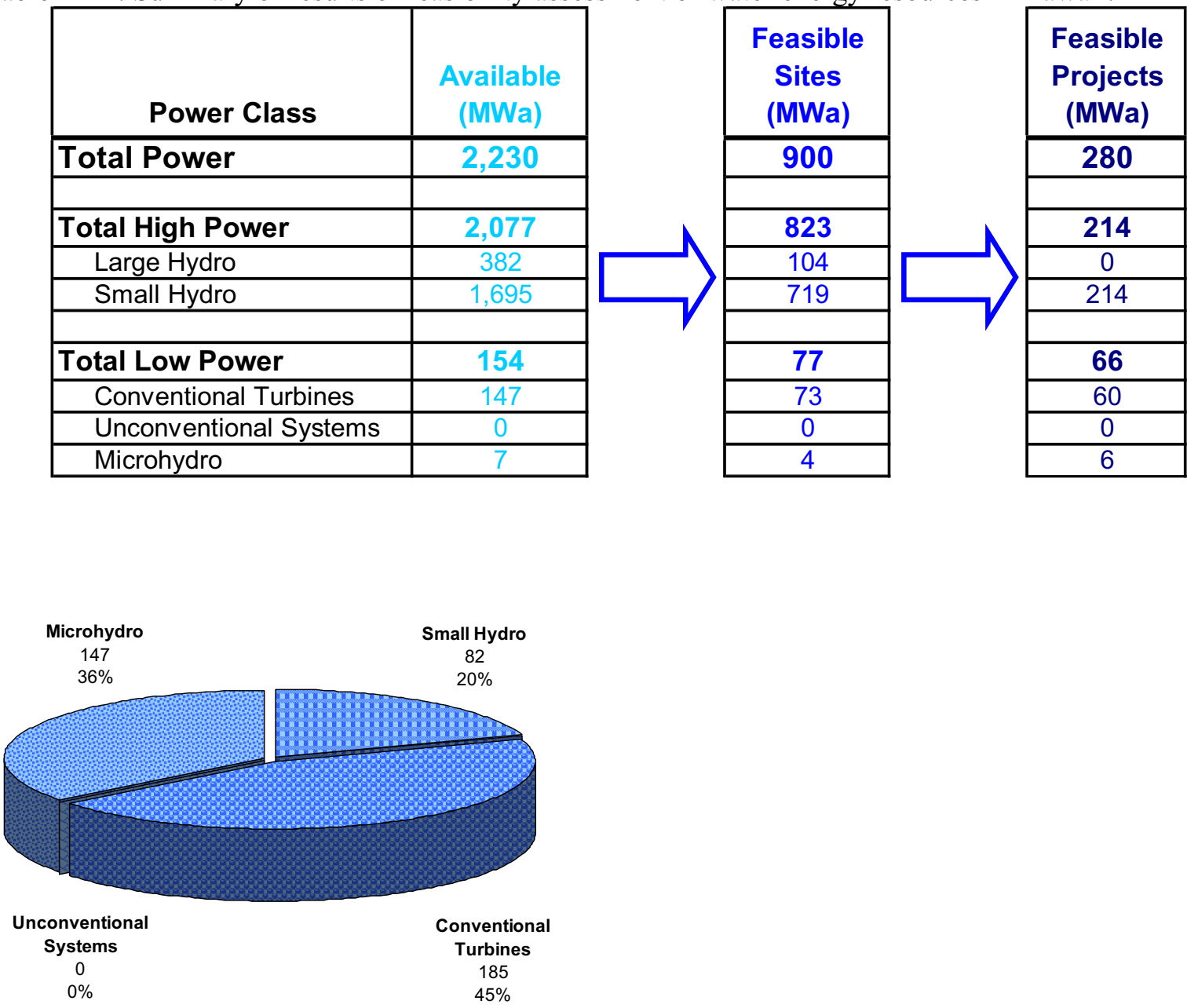

(a) Total Feasible Projects 414

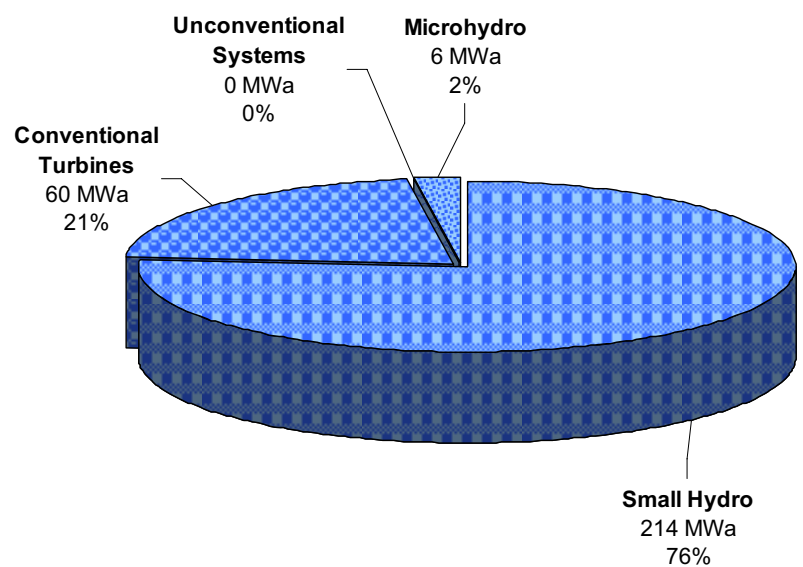

(b) Total Feasible Project Hydropower Potential $280 \mathrm{MWa}$

Figure B-52. Distribution of the (a) number and (b) total hydropower potential of the low power and small hydropower feasible projects in Hawaii with the low power projects divided into technology classes. 

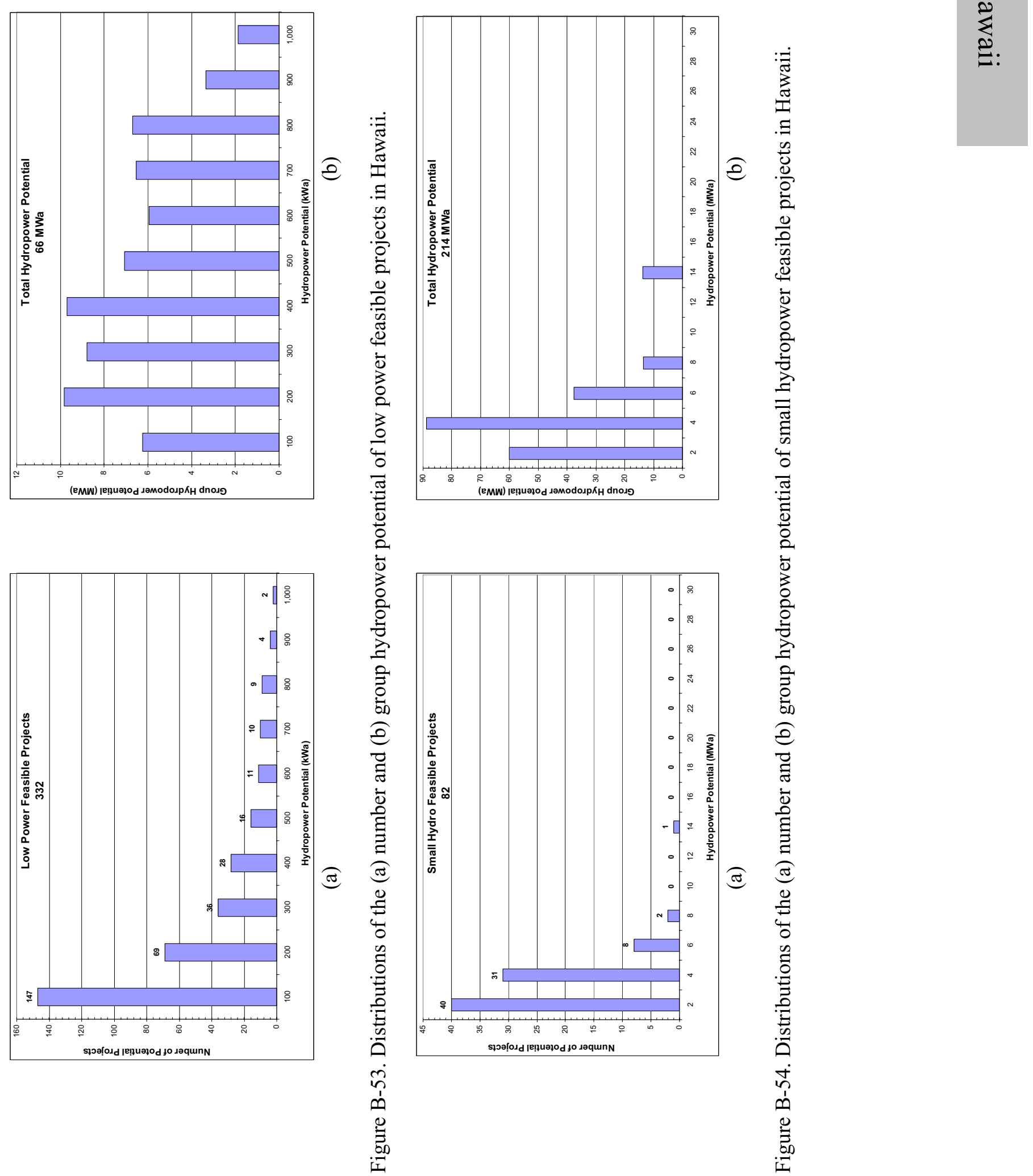


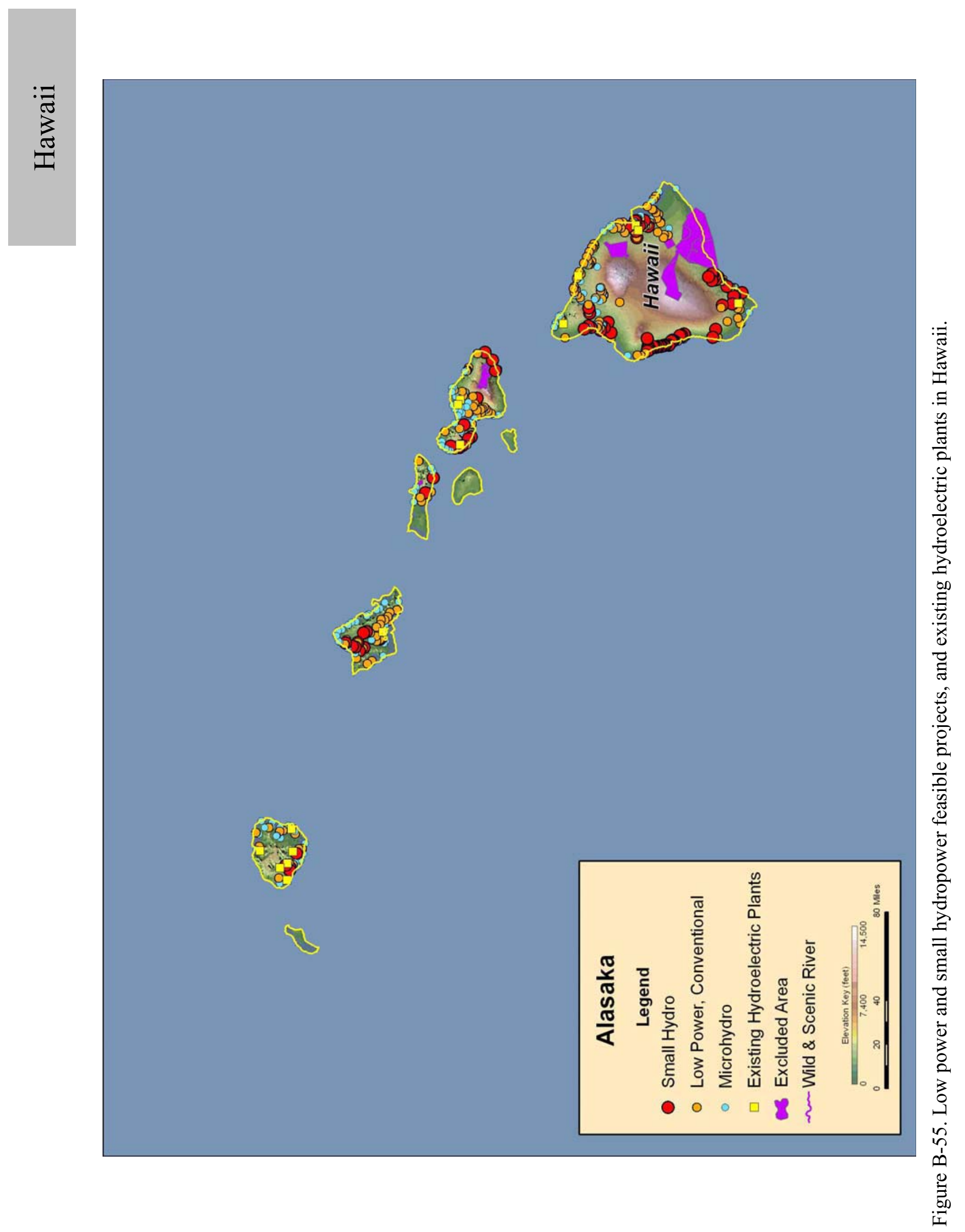




\section{B.12 Idaho}

Table B-25. Summary of results of water energy resource assessment of Idaho.

\begin{tabular}{|c|c|c|c|c|c|}
\hline \multicolumn{1}{|c|}{ Power Class } & $\begin{array}{c}\text { Total } \\
(\mathbf{M W a})\end{array}$ & $\begin{array}{c}\text { Developed } \\
(\mathrm{MWa})\end{array}$ & $\begin{array}{c}\text { Federally } \\
\text { Excluded } \\
(\mathbf{M W a})\end{array}$ & $\begin{array}{c}\text { Other } \\
\text { Excluded } \\
(\mathbf{M W a})\end{array}$ & $\begin{array}{c}\text { Available } \\
(\mathrm{MWa})\end{array}$ \\
\hline Total Power & $\mathbf{1 9 , 0 8 8}$ & $\mathbf{1 , 4 4 2}$ & $\mathbf{5 , 5 1 1}$ & $\mathbf{2 , 0 2 9}$ & 10,105 \\
\hline & & & & & \\
\hline Total High Power & $\mathbf{1 5 , 9 9 6}$ & $\mathbf{1 , 4 2 8}$ & $\mathbf{4 , 9 9 4}$ & $\mathbf{1 , 7 6 2}$ & 7,812 \\
\hline Large Hydro & $\mathbf{4 , 2 3 8}$ & 1,181 & 1,023 & 339 & 1,695 \\
\hline Small Hydro & 11,758 & 247 & 3,971 & 1,423 & 6,117 \\
\hline Total Low Power & & & & & \\
\hline Conventional Turbines & $\mathbf{3 , 0 9 2}$ & $\mathbf{1 4}$ & $\mathbf{5 1 7}$ & $\mathbf{2 6 8}$ & 2,293 \\
\hline Unconventional Systems & $\mathbf{2 , 7 1 7}$ & 12 & 485 & 236 & 1,985 \\
\hline Microhydro & $\mathbf{8 7}$ & 2 & 17 & 8 & 60 \\
\hline
\end{tabular}

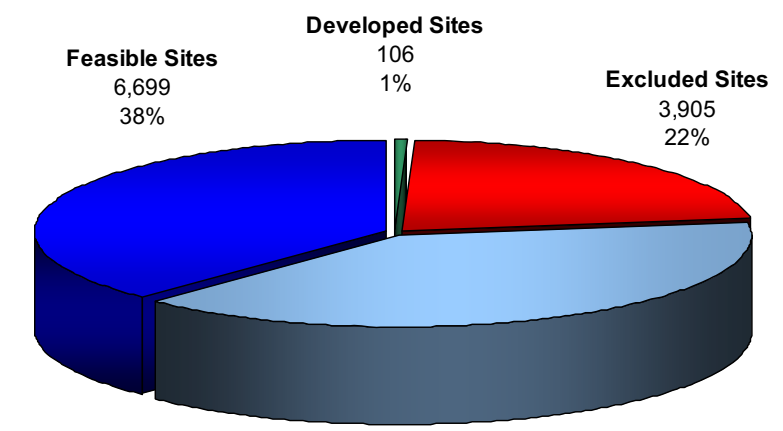

Other Available Sites 6,964

$39 \%$

(a) Total Resource Sites 17,674

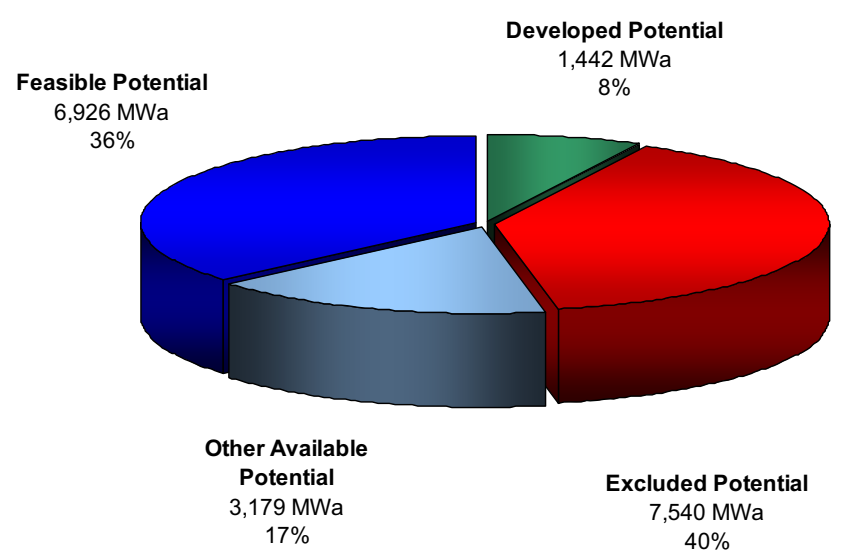

(b) Total Resource Potential $19,088 \mathrm{MWa}$

Figure B-56. Power category distribution of the (a) number and (b) total power potential of the water energy resource sites in Idaho. 
Table B-26. Summary of results of feasibility assessment of water energy resources in Idaho.

\begin{tabular}{|c|c|c|c|}
\hline Power Class & $\begin{array}{c}\text { Available } \\
\text { (MWa) }\end{array}$ & $\begin{array}{c}\text { Feasible } \\
\text { Sites } \\
\text { (MWa) }\end{array}$ & $\begin{array}{c}\text { Feasible } \\
\text { Projects } \\
\text { (MWa) }\end{array}$ \\
\hline Total Power & 10,105 & 6,926 & 2,122 \\
\hline Total High Power & 7,812 & 5,573 & 1,515 \\
\hline Large Hydro & 1,695 & 1,657 & 0 \\
\hline Small Hydro & 6,117 & 3,916 & 1,515 \\
\hline Total Low Power & 2,293 & 1,353 & 607 \\
\hline Conventional Turbines & 1,985 & 1,182 & 390 \\
\hline Unconventional Systems & 60 & 54 & 44 \\
\hline Microhydro & 248 & 117 & 173 \\
\hline
\end{tabular}

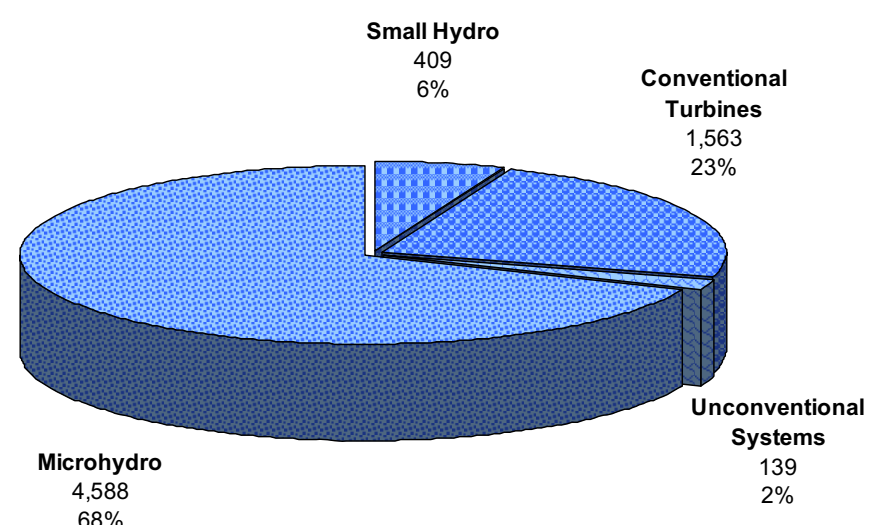

(a) Total Feasible Projects 6,699

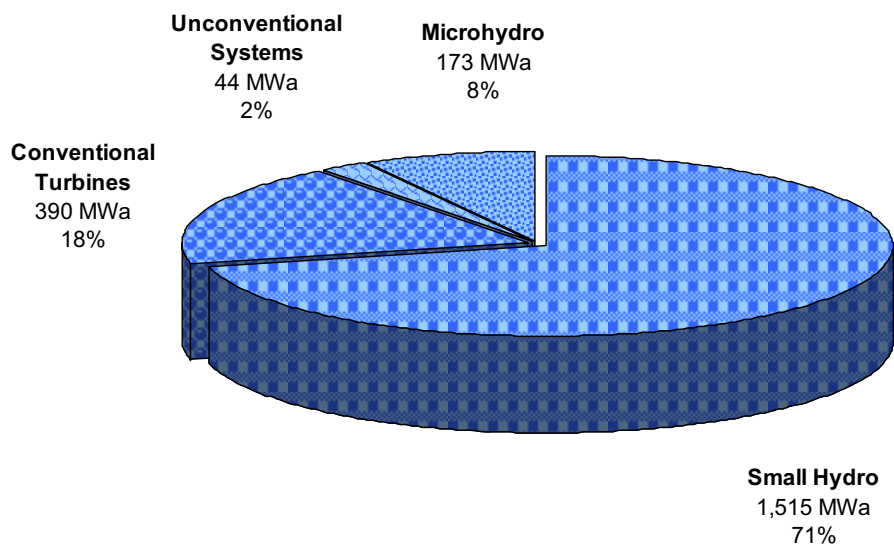

(b) Total Feasible Project Hydropower Potential 2,122 MWa

Figure B-57. Distribution of the (a) number and (b) total hydropower potential of the low power and small hydropower feasible projects in Idaho with the low power projects divided into technology classes. 

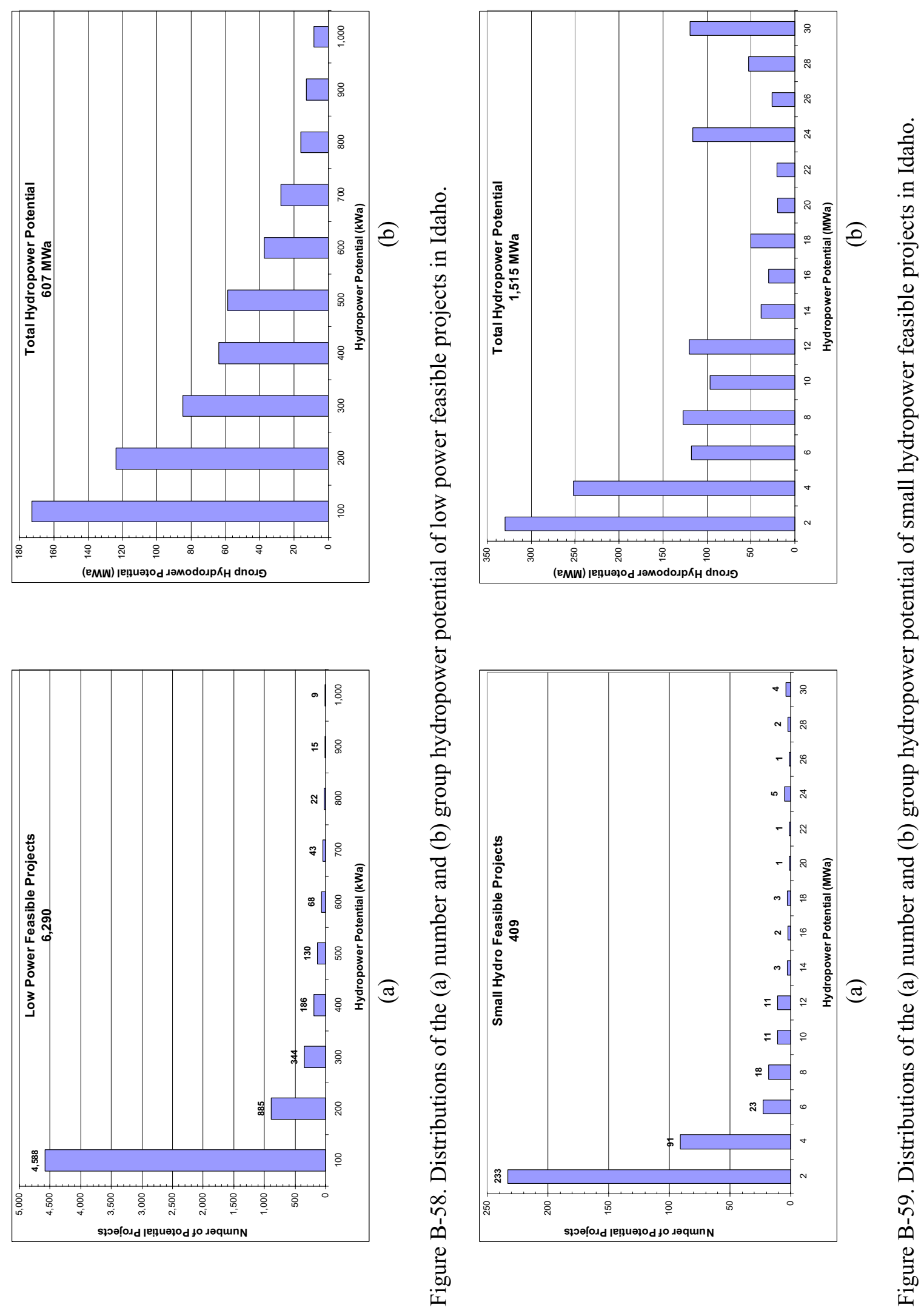


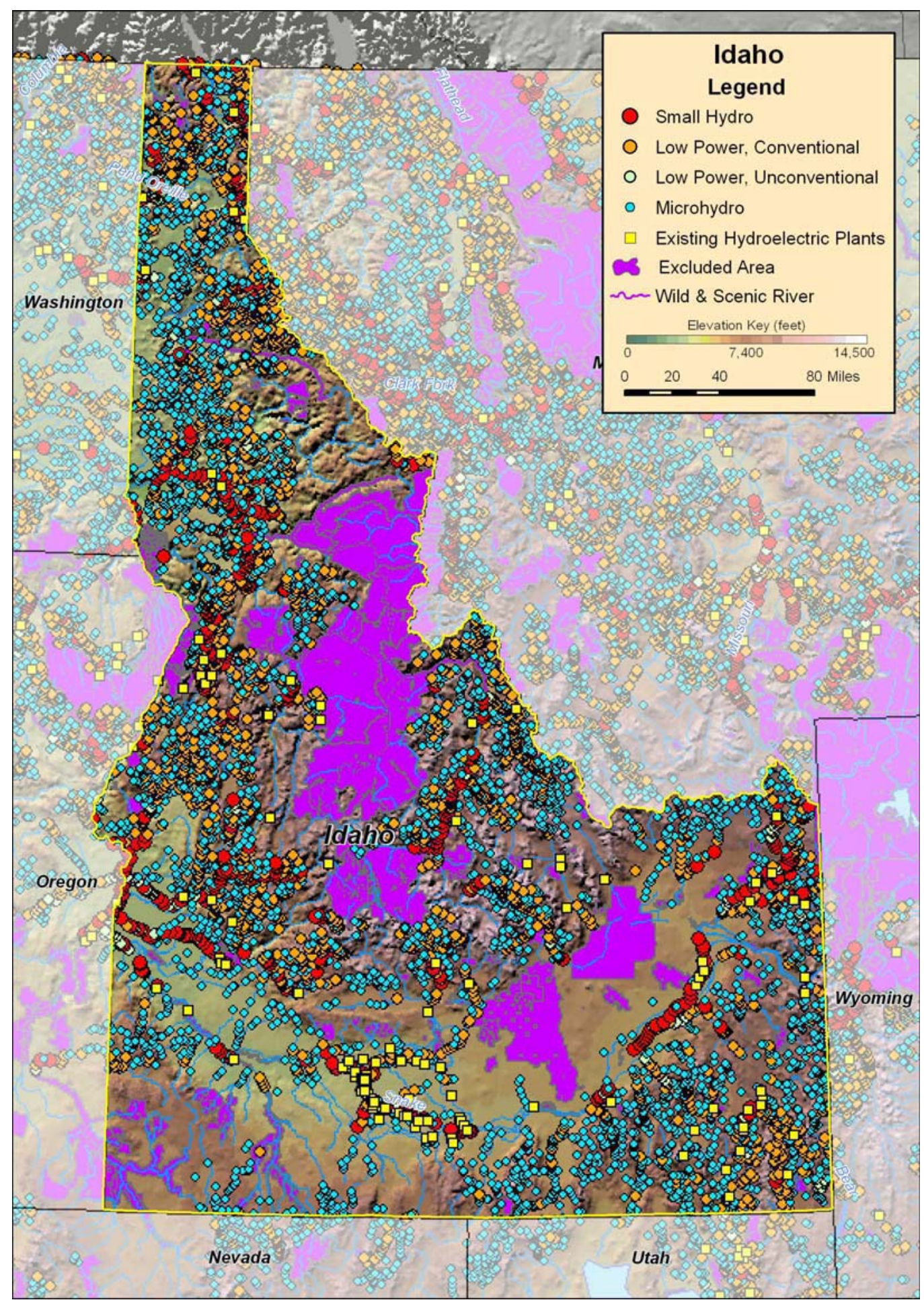

Figure B-60. Low power and small hydropower feasible projects, and existing hydroelectric plants in Idaho. 


\section{B.13 Illinois}

Table B-27. Summary of results of water energy resource assessment of Illinois.

\begin{tabular}{|c|c|c|c|c|c|}
\hline \multicolumn{1}{|c|}{ Power Class } & $\begin{array}{c}\text { Total } \\
\mathbf{( M W a )}\end{array}$ & $\begin{array}{c}\text { Developed } \\
(\mathrm{MWa})\end{array}$ & $\begin{array}{c}\text { Federally } \\
\text { Excluded } \\
(\mathbf{M W a})\end{array}$ & $\begin{array}{c}\text { Other } \\
\text { Excluded } \\
(\mathbf{M W a})\end{array}$ & $\begin{array}{c}\text { Available } \\
(\mathrm{MWa})\end{array}$ \\
\hline Total Power & $\mathbf{2 , 4 4 0}$ & $\mathbf{7}$ & $\mathbf{1 0 1}$ & $\mathbf{8 8}$ & 2,244 \\
\hline Total High Power & & & & & \\
\hline Large Hydro & $\mathbf{2 , 0 2 8}$ & $\mathbf{6}$ & $\mathbf{9 0}$ & $\mathbf{4 2}$ & 1,891 \\
\hline Small Hydro & 1,647 & 0 & 75 & 0 & 1,572 \\
\hline & 381 & 6 & 15 & 42 & 318 \\
\hline Total Low Power & & & & & \\
\hline Conventional Turbines & $\mathbf{4 1 2}$ & 1 & $\mathbf{1 1}$ & $\mathbf{4 7}$ & 353 \\
\hline Unconventional Systems & 150 & 1 & 6 & 19 & 124 \\
\hline Microhydro & 100 & 0 & 2 & 18 & 79 \\
\hline
\end{tabular}

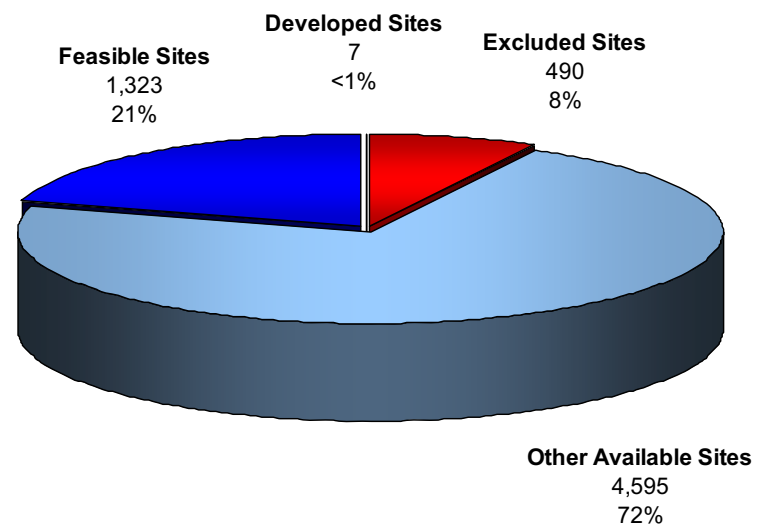

(a) Total Resource Sites 6,415

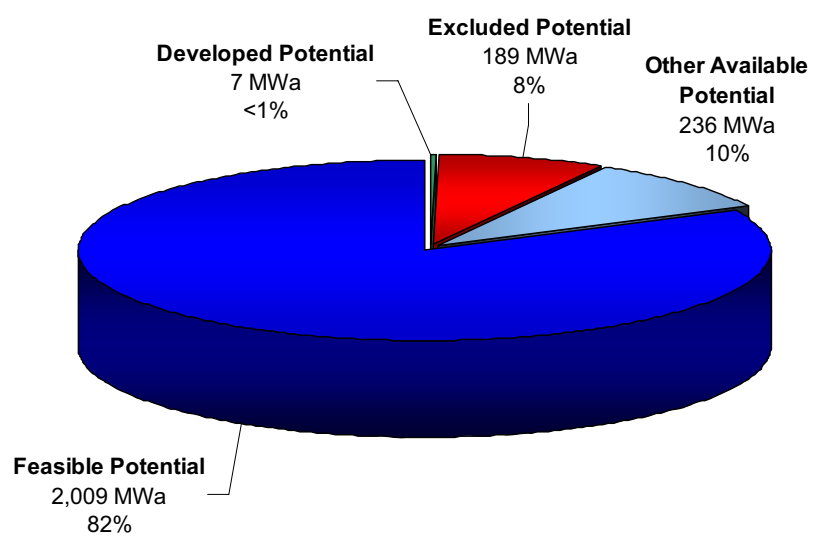

(b) Total Resource Potential 2,440 MWa

Figure B-61. Power category distribution of the (a) number and (b) total power potential of the water energy resource sites in Illinois. 
Table B-28. Summary of results of feasibility assessment of water energy resources in Illinois.

\begin{tabular}{|c|c|}
\hline Power Class & $\begin{array}{c}\text { Available } \\
(\mathrm{MWa})\end{array}$ \\
\hline Total Power & 2,244 \\
\hline & \\
\hline Total High Power & 1,891 \\
\hline Large Hydro & 1,572 \\
\hline Small Hydro & 318 \\
\hline & \\
\hline Total Low Power & 353 \\
\hline Conventional Turbines & 124 \\
\hline Unconventional Systems & 79 \\
\hline Microhydro & 150 \\
\hline
\end{tabular}

\begin{tabular}{|c|c|}
\hline $\begin{array}{c}\text { Feasible } \\
\text { Sites } \\
\text { (MWa) }\end{array}$ & $\begin{array}{c}\text { Feasible } \\
\text { Projects } \\
\text { (MWa) }\end{array}$ \\
\hline 2,009 & 568 \\
\hline 1,810 & 477 \\
\hline 1,506 & 0 \\
\hline 304 & 477 \\
\hline 198 & 91 \\
\hline 99 & 10 \\
\hline 64 & 51 \\
\hline 36 & 30 \\
\hline
\end{tabular}

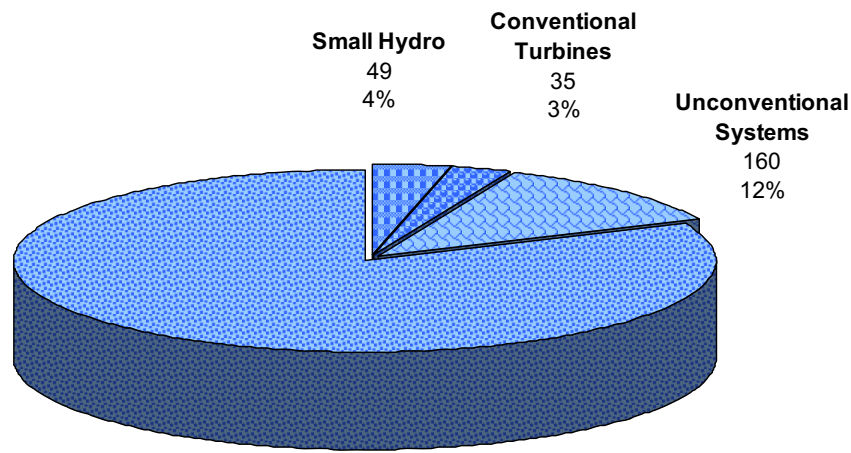

Microhydro

1,07

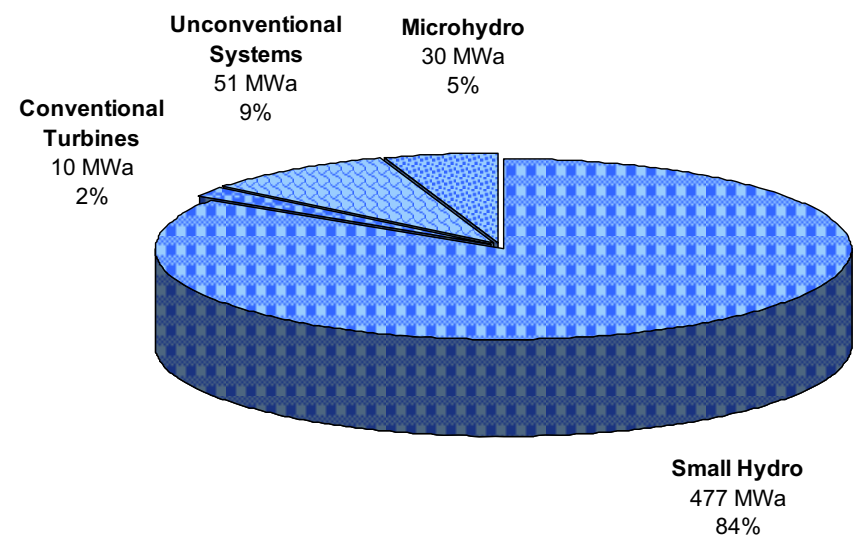

(a) Total Feasible Projects 1,323

(b) Total Feasible Project Hydropower Potential $568 \mathrm{MWa}$

Figure B-62. Distribution of the (a) number and (b) total hydropower potential of the low power and small hydropower feasible projects in Illinois with the low power projects divided into technology classes. 

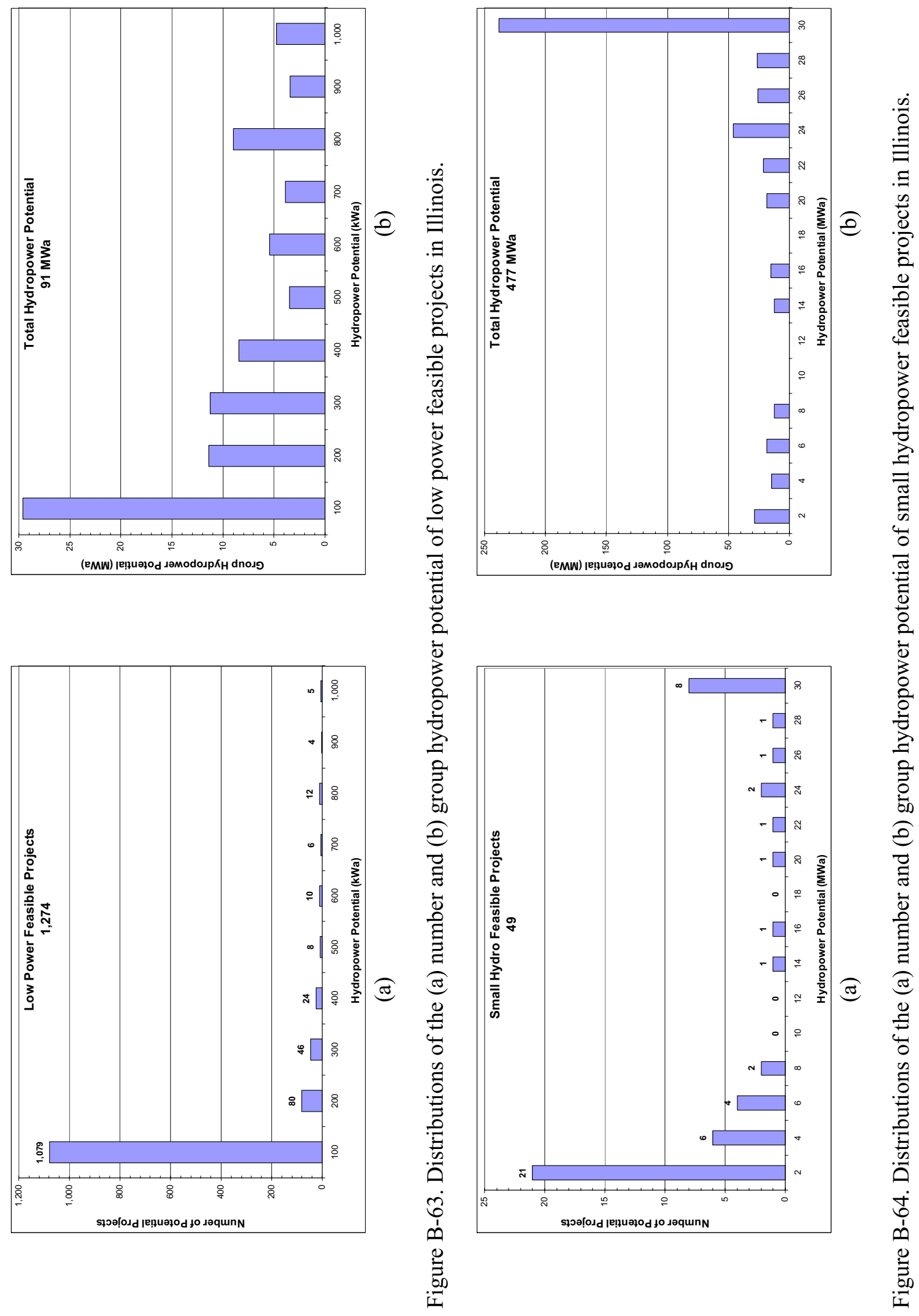

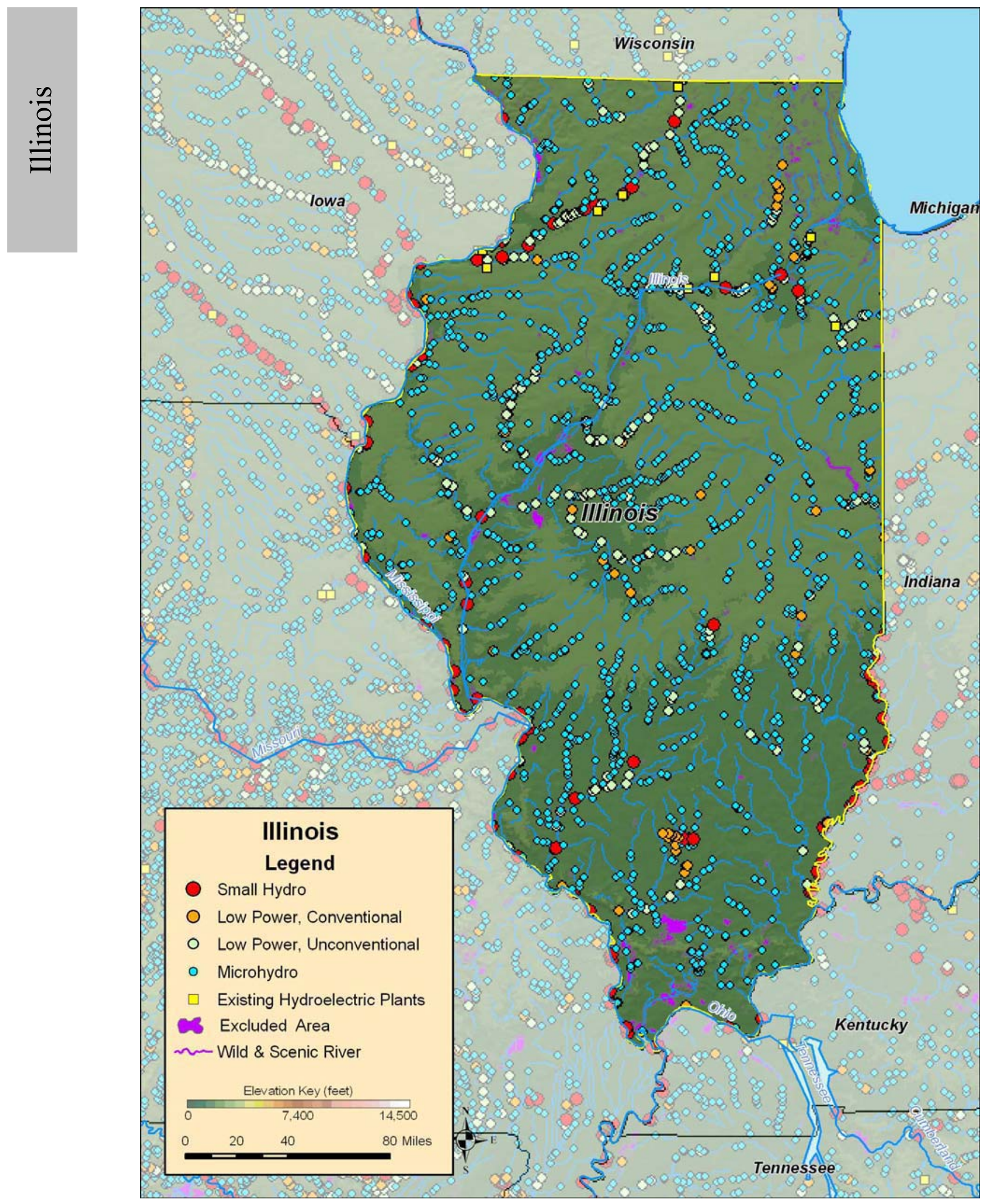

Figure B-65. Low power and small hydropower feasible projects, and existing hydroelectric plants in Illinois. 


\section{B.14 Indiana}

Table B-29. Summary of results of water energy resource assessment of Indiana.

\begin{tabular}{|c|c|c|c|c|c|}
\hline \multicolumn{1}{|c|}{ Power Class } & $\begin{array}{c}\text { Total } \\
\mathbf{( M W a )}\end{array}$ & $\begin{array}{c}\text { Developed } \\
(\mathrm{MWa})\end{array}$ & $\begin{array}{c}\text { Federally } \\
\text { Excluded } \\
(\mathbf{M W a})\end{array}$ & $\begin{array}{c}\text { Other } \\
\text { Excluded } \\
(\mathbf{M W a})\end{array}$ & $\begin{array}{c}\text { Available } \\
(\mathrm{MWa})\end{array}$ \\
\hline Total Power & $\mathbf{1 , 3 8 3}$ & $\mathbf{1 3}$ & $\mathbf{2}$ & $\mathbf{4 0}$ & 1,328 \\
\hline & & & & & \\
\hline Total High Power & $\mathbf{9 9 1}$ & $\mathbf{1 2}$ & $\mathbf{0}$ & $\mathbf{1 7}$ & 962 \\
\hline Large Hydro & $\mathbf{3 9 6}$ & 0 & 0 & 0 & 396 \\
\hline Small Hydro & 596 & 12 & 0 & 17 & 566 \\
\hline & & & & & \\
\hline Total Low Power & $\mathbf{3 9 2}$ & 0 & $\mathbf{2}$ & $\mathbf{2 4}$ & 366 \\
\hline Conventional Turbines & $\mathbf{2 0 4}$ & 0 & 0 & 16 & 188 \\
\hline Unconventional Systems & 66 & 0 & 1 & 3 & 62 \\
\hline Microhydro & 122 & 0 & 1 & 5 & 116 \\
\hline
\end{tabular}

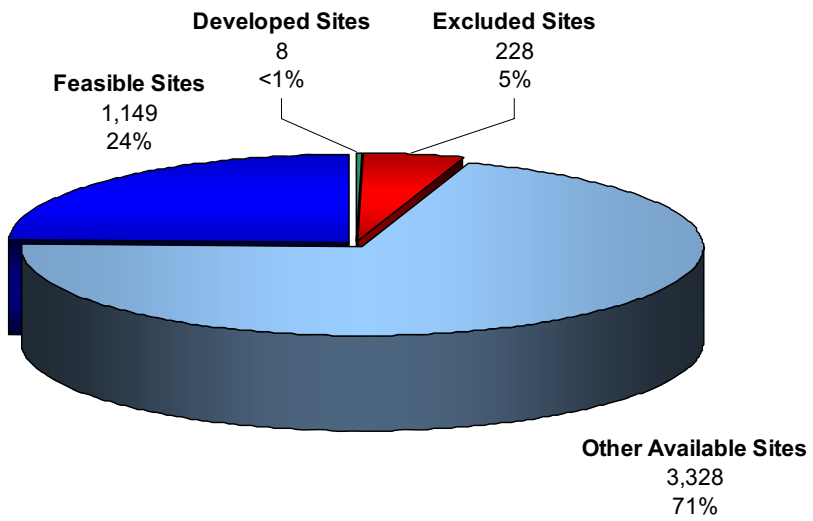

(a) Total Resource Sites

4,713

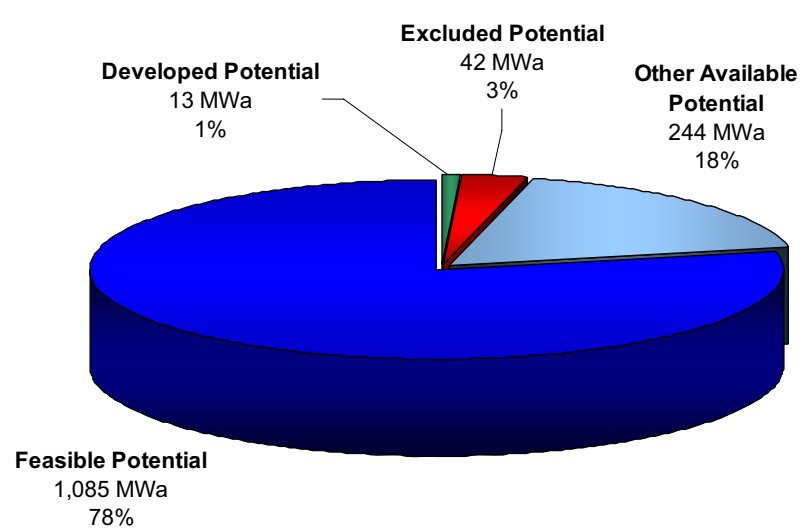

(b) Total Resource Potential $1,383 \mathrm{MWa}$

Figure B-66. Power category distribution of the (a) number and (b) total power potential of the water energy resource sites in Indiana. 
Table B-30. Summary of results of feasibility assessment of water energy resources in Indiana.

\begin{tabular}{|c|c|}
\hline Power Class & $\begin{array}{c}\text { Available } \\
\text { (MWa) }\end{array}$ \\
\hline Total Power & 1,328 \\
\hline & \\
\hline Total High Power & 962 \\
\hline Large Hydro & 396 \\
\hline Small Hydro & 566 \\
\hline & \\
\hline Total Low Power & 366 \\
\hline Conventional Turbines & 188 \\
\hline Unconventional Systems & 62 \\
\hline Microhydro & 116 \\
\hline
\end{tabular}

\begin{tabular}{|c|c|}
\hline $\begin{array}{c}\text { Feasible } \\
\text { Sites } \\
\text { (MWa) }\end{array}$ & $\begin{array}{c}\text { Feasible } \\
\text { Projects } \\
\text { (MWa) }\end{array}$ \\
\hline 1,085 & 305 \\
\hline 881 & 216 \\
\hline 396 & 0 \\
\hline 486 & 216 \\
\hline 204 & 88 \\
\hline 129 & 19 \\
\hline 48 & 43 \\
\hline 27 & 26 \\
\hline
\end{tabular}

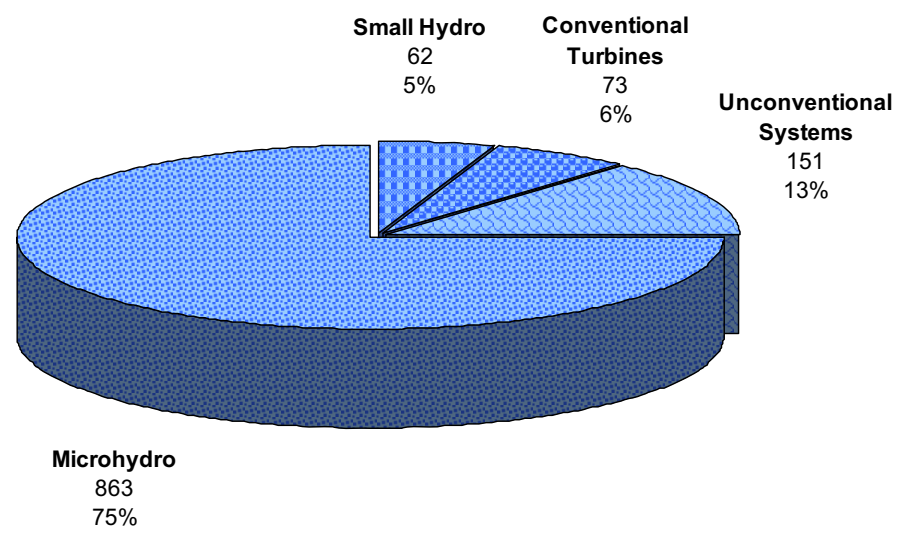

(a) Total Feasible Projects 1,149

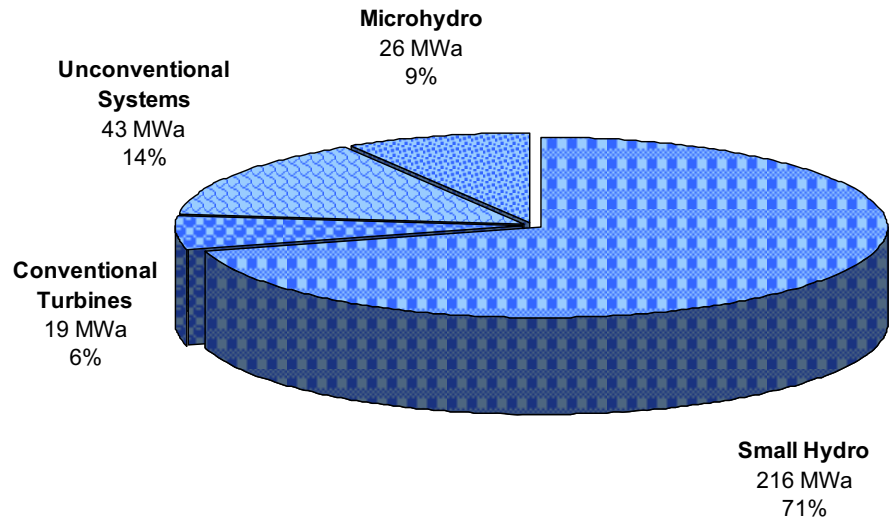

(a) Total Feasible Project Hydropower Potential $305 \mathrm{MWa}$

Figure B-67. Distribution of the (a) number and (b) total hydropower potential of the low power and small hydropower feasible projects in Indiana with the low power projects divided into technology classes. 

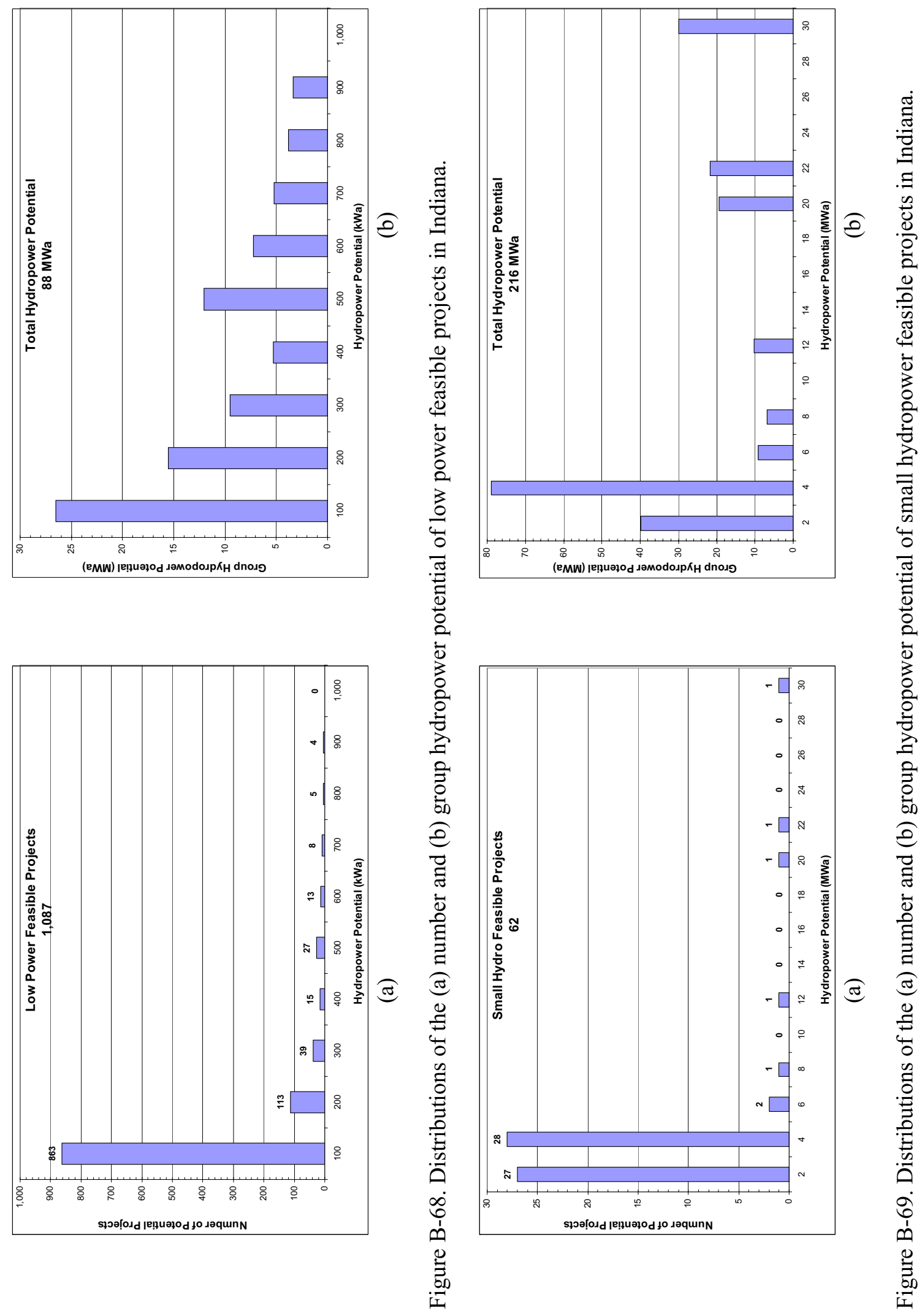


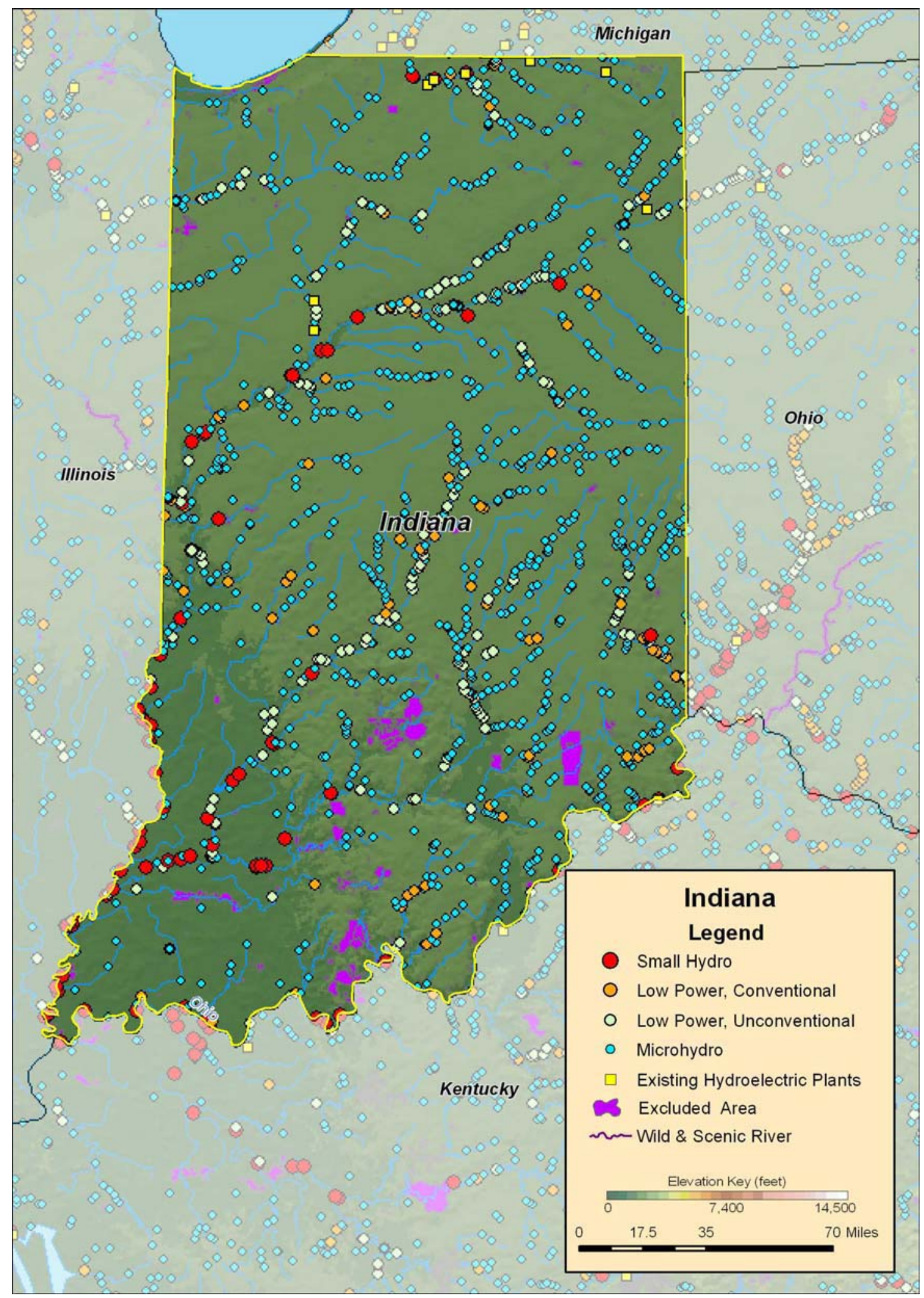

Figure B-70. Low power and small hydropower feasible projects, and existing hydroelectric plants in Indiana. 


\section{B.15 lowa}

Table B-31. Summary of results of water energy resource assessment of Iowa.

\begin{tabular}{|c|c|c|c|c|c|}
\hline Power Class & $\begin{array}{c}\text { Total } \\
\mathbf{( M W a )}\end{array}$ & $\begin{array}{c}\text { Developed } \\
(\mathrm{MWa})\end{array}$ & $\begin{array}{c}\text { Federally } \\
\text { Excluded } \\
(\mathbf{M W a})\end{array}$ & $\begin{array}{c}\text { Other } \\
\text { Excluded } \\
(\mathrm{MWa})\end{array}$ & $\begin{array}{c}\text { Available } \\
(\mathrm{MWa})\end{array}$ \\
\hline Total Power & $\mathbf{1 , 1 7 1}$ & $\mathbf{2}$ & $\mathbf{8 3}$ & $\mathbf{1 0}$ & 1,076 \\
\hline Total High Power & & & & & \\
\hline Large Hydro & $\mathbf{6 5 0}$ & $\mathbf{0}$ & $\mathbf{7 7}$ & $\mathbf{5}$ & 568 \\
\hline Small Hydro & 42 & 0 & 0 & 0 & 42 \\
\hline & 608 & 0 & 77 & 5 & 526 \\
\hline Total Low Power & & & & & \\
\hline Conventional Turbines & $\mathbf{5 2 0}$ & $\mathbf{2}$ & $\mathbf{6}$ & $\mathbf{5}$ & 507 \\
\hline Unconventional Systems & $\mathbf{2 3 4}$ & 1 & 1 & 4 & 228 \\
\hline Microhydro & 114 & 1 & 4 & 1 & 108 \\
\hline
\end{tabular}

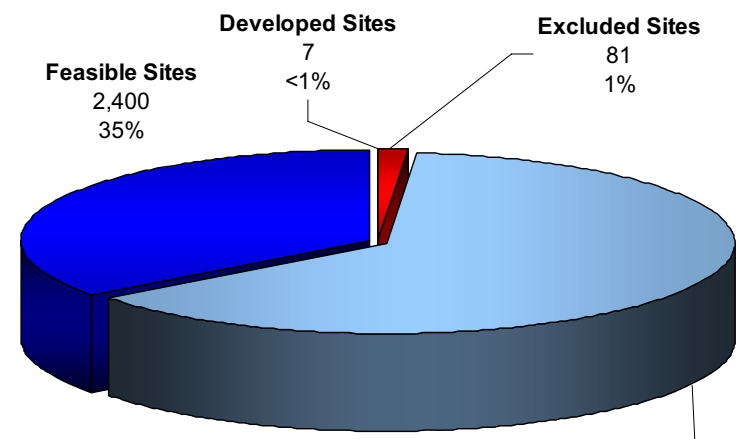

Other Available Sites

$$
4,327
$$

(a) Total Resource Sites

$63 \%$

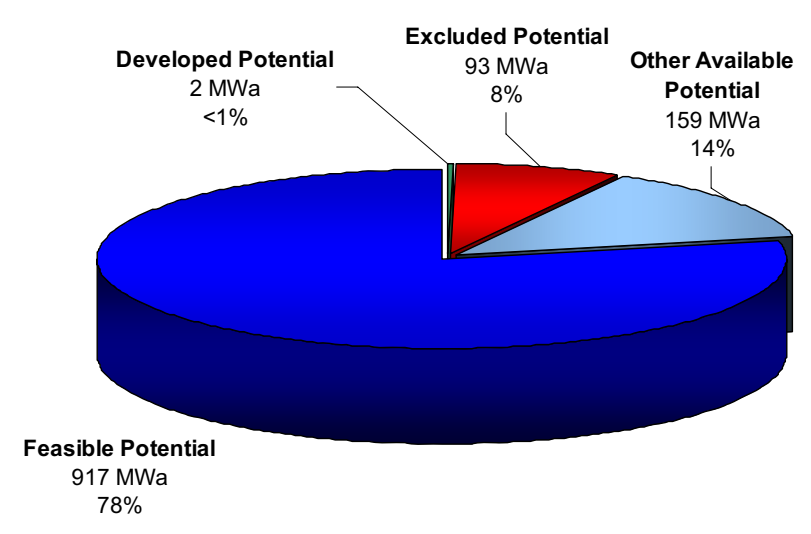

(b) Total Resource Potential $1,171 \mathrm{MWa}$

Figure B-71. Power category distribution of the (a) number and (b) total power potential of the water energy resource sites in Iowa. 
Table B-32. Summary of results of feasibility assessment of water energy resources in Iowa.

\begin{tabular}{|c|c|}
\hline Power Class & $\begin{array}{c}\text { Available } \\
\text { (MWa) }\end{array}$ \\
\hline Total Power & 1,076 \\
\hline & \\
\hline Total High Power & 568 \\
\hline Large Hydro & 42 \\
\hline Small Hydro & 526 \\
\hline & \\
\hline Total Low Power & 507 \\
\hline Conventional Turbines & 228 \\
\hline Unconventional Systems & 108 \\
\hline Microhydro & 171 \\
\hline
\end{tabular}

\begin{tabular}{|c|c|}
\hline $\begin{array}{c}\text { Feasible } \\
\text { Sites } \\
\text { (MWa) }\end{array}$ & $\begin{array}{c}\text { Feasible } \\
\text { Projects } \\
\text { (MWa) }\end{array}$ \\
\hline 917 & 329 \\
\hline 544 & 176 \\
\hline 42 & 0 \\
\hline 501 & 176 \\
\hline 373 & 153 \\
\hline 203 & 32 \\
\hline 102 & 62 \\
\hline 68 & 59 \\
\hline
\end{tabular}

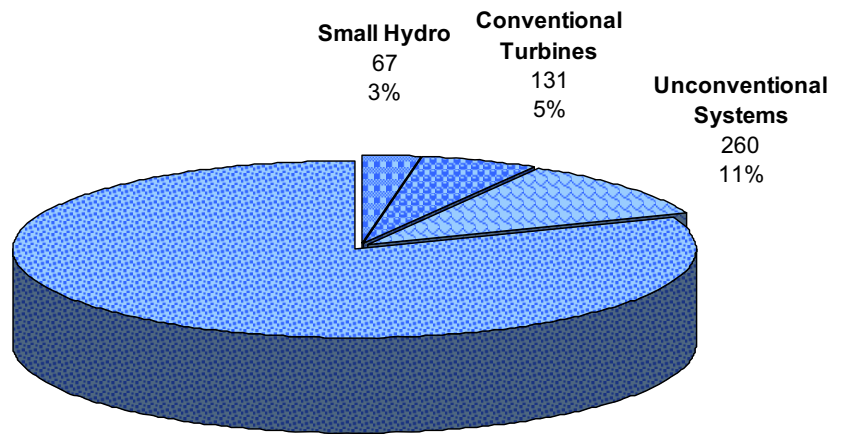

\footnotetext{
Microhydro

1,942

$81 \%$
}

(a) Total Feasible Projects

2,400

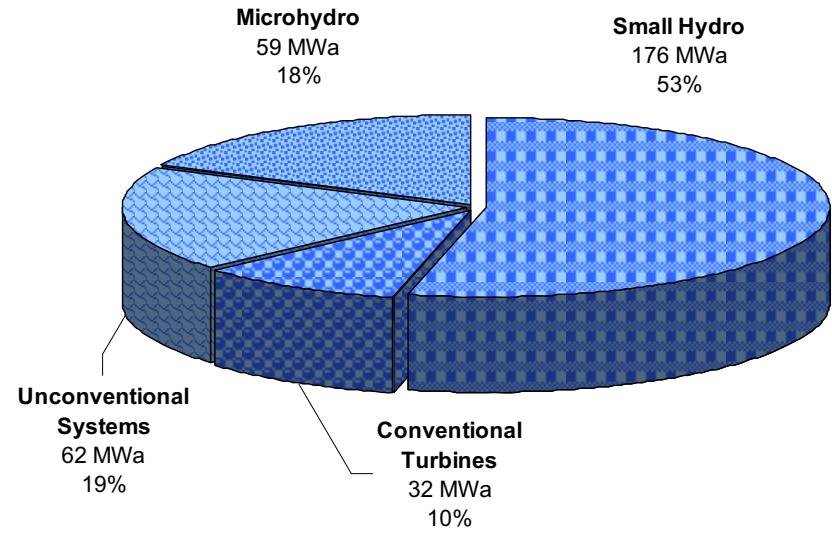

(b) Total Feasible Project Hydropower Potential $329 \mathrm{MWa}$

Figure B-72. Distribution of the (a) number and (b) total hydropower potential of the low power and small hydropower feasible projects in Iowa with the low power projects divided into technology classes. 

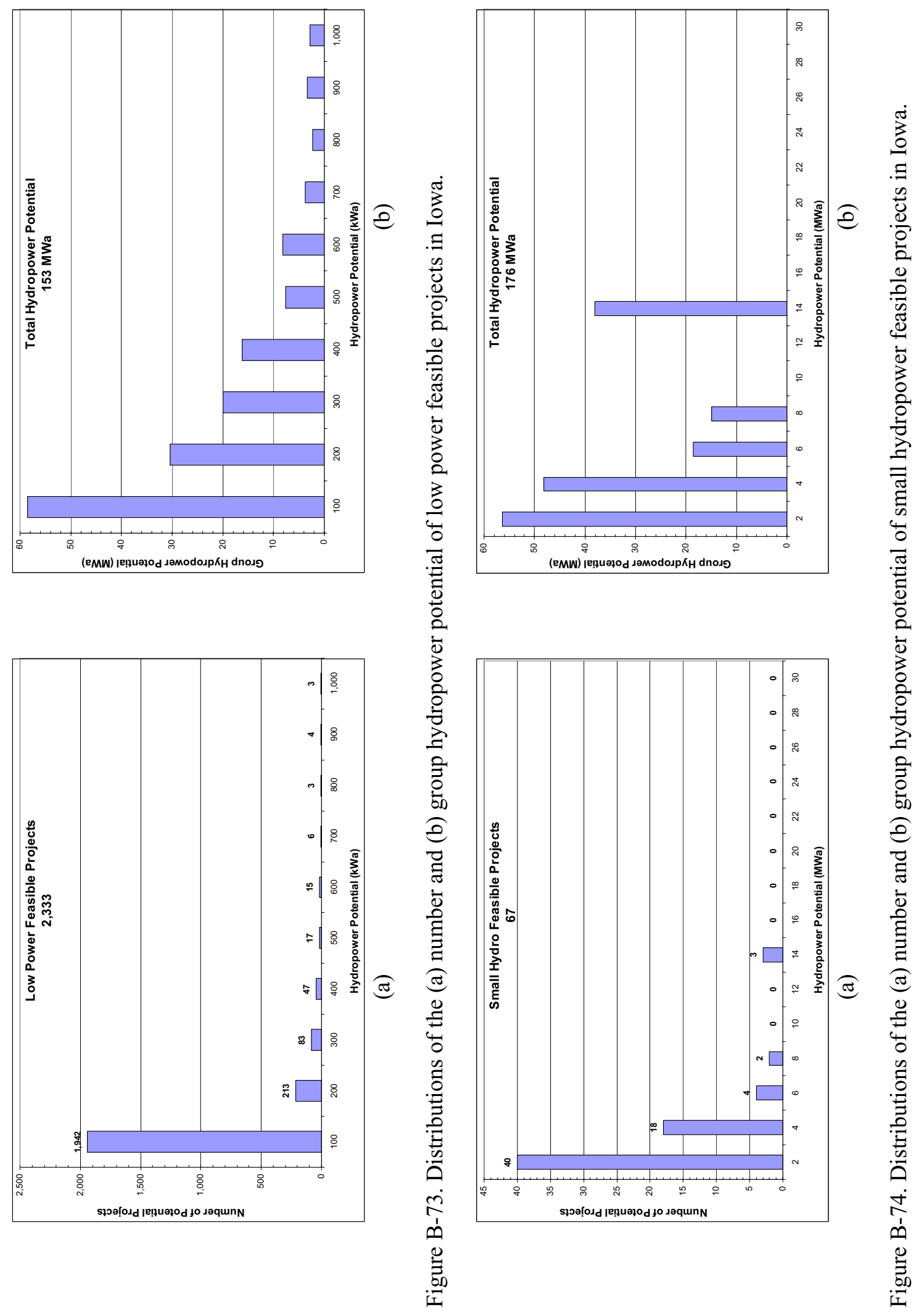


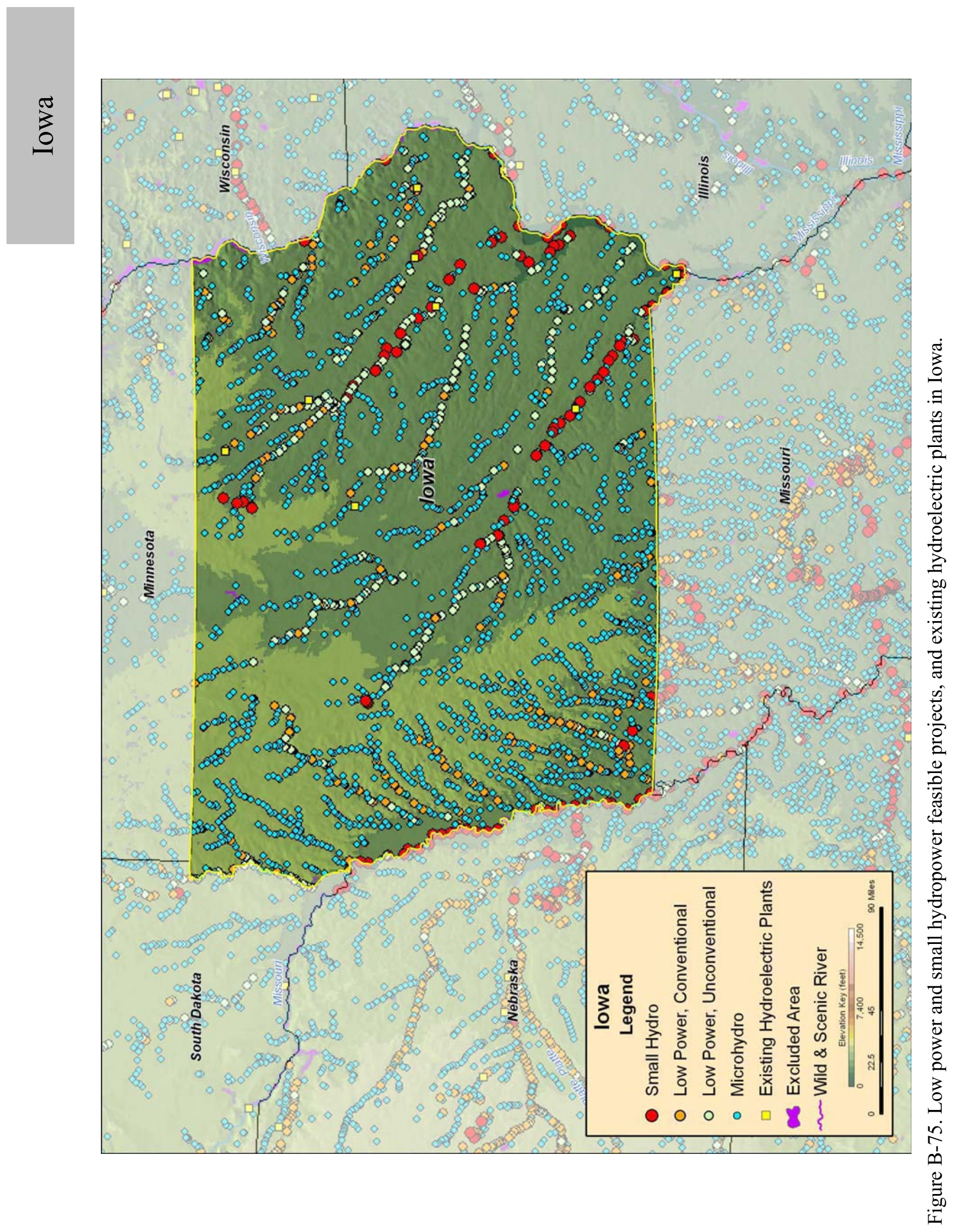




\section{B.16 Kansas}

Table B-33. Summary of results of water energy resource assessment of Kansas.

\begin{tabular}{|c|c|c|c|c|c|}
\hline Power Class & $\begin{array}{c}\text { Total } \\
\text { (MWa) }\end{array}$ & $\begin{array}{c}\text { Developed } \\
(\mathrm{MWa})\end{array}$ & $\begin{array}{c}\text { Federally } \\
\text { Excluded } \\
(\mathbf{M W a})\end{array}$ & $\begin{array}{c}\text { Other } \\
\text { Excluded } \\
(\mathrm{MWa})\end{array}$ & $\begin{array}{c}\text { Available } \\
(\mathrm{MWa})\end{array}$ \\
\hline Total Power & $\mathbf{9 3 2}$ & $\mathbf{1}$ & $\mathbf{3}$ & $\mathbf{3}$ & 925 \\
\hline & & & & & \\
\hline Total High Power & $\mathbf{4 0 5}$ & 0 & 0 & 0 & 405 \\
\hline Large Hydro & 0 & 0 & 0 & 0 & 0 \\
\hline Small Hydro & 405 & 0 & 0 & 0 & 405 \\
\hline Total Low Power & & & & & \\
\hline Conventional Turbines & $\mathbf{5 2 7}$ & 1 & 3 & 3 & 520 \\
\hline Unconventional Systems & $\mathbf{2 3 0}$ & 0 & 2 & 2 & 227 \\
\hline Microhydro & 80 & 1 & 1 & 0 & 77 \\
\hline
\end{tabular}

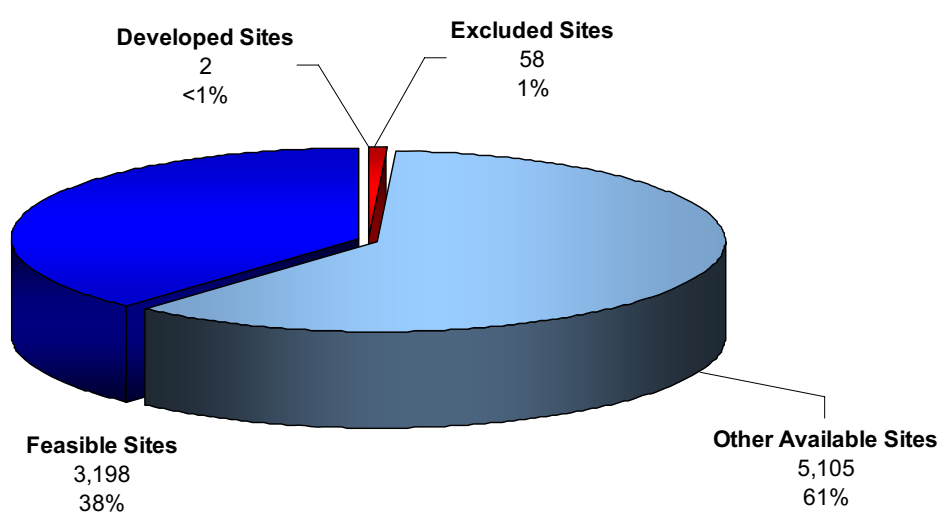

(a) Total Resource Sites 8,363

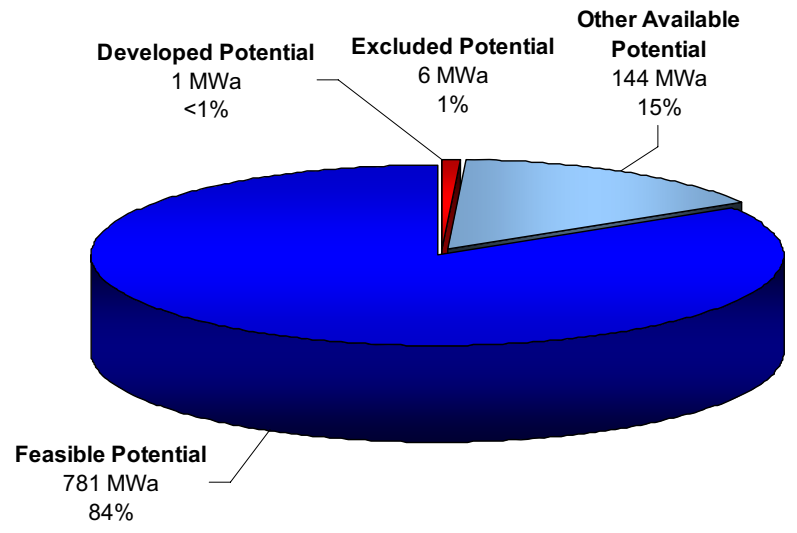

(b) Total Resource Potential $932 \mathrm{MWa}$

Figure B-76. Power category distribution of the (a) number and (b) total power potential of the water energy resource sites in Kansas. 
Table B-34. Summary of results of feasibility assessment of water energy resources in Kansas.

\begin{tabular}{|c|c|}
\hline Power Class & $\begin{array}{c}\text { Available } \\
\text { (MWa) }\end{array}$ \\
\hline Total Power & 925 \\
\hline Total High Power & 405 \\
\hline Large Hydro & 0 \\
\hline Small Hydro & 405 \\
\hline & \\
\hline Total Low Power & 520 \\
\hline Conventional Turbines & 227 \\
\hline Unconventional Systems & 77 \\
\hline Microhydro & 216 \\
\hline
\end{tabular}

\begin{tabular}{|c|c|}
\hline $\begin{array}{c}\text { Feasible } \\
\text { Sites } \\
\text { (MWa) }\end{array}$ \\
\hline $\mathbf{7 8 1}$ \\
\hline \\
\hline $\mathbf{4 0 3}$ \\
\hline 0 \\
\hline 403 \\
\hline \\
\hline $\mathbf{3 7 8}$ \\
\hline 196 \\
\hline 76 \\
\hline 106 \\
\hline
\end{tabular}
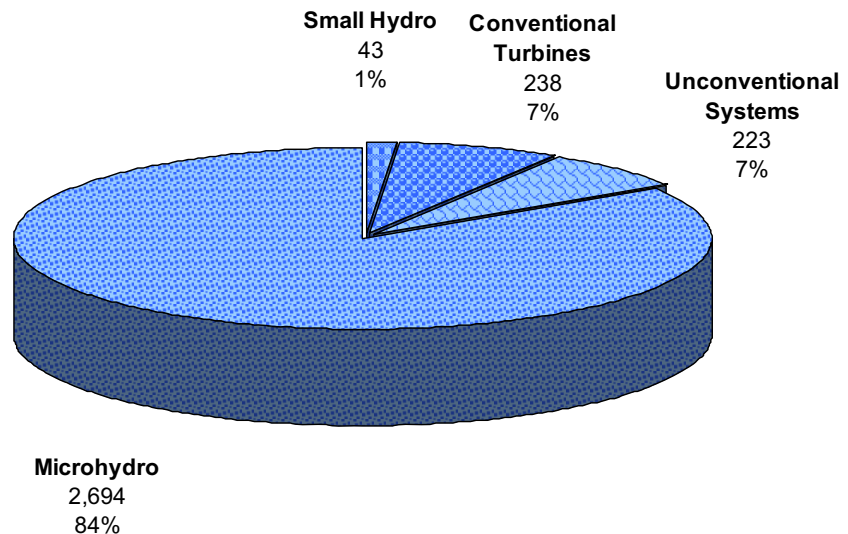

(a) Total Feasible Projects 3,198

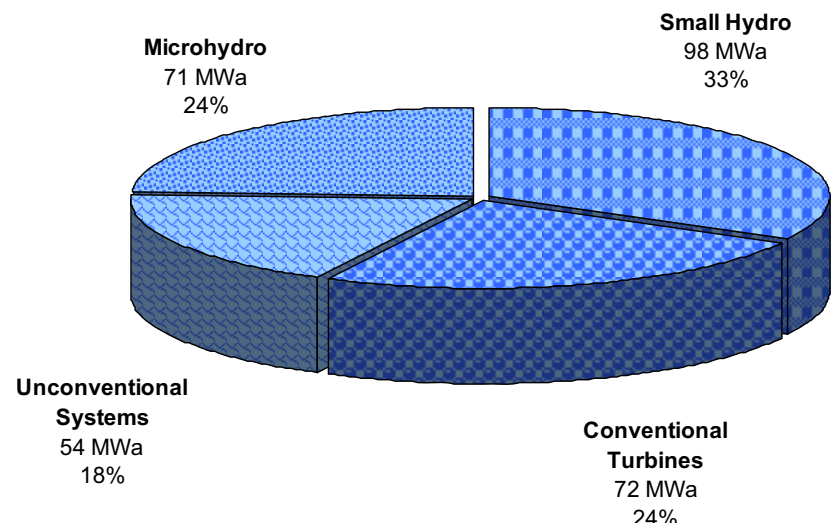

(b) Total Feasible Project Hydropower Potential $295 \mathrm{MWa}$

Figure B-77. Distribution of the (a) number and (b) total hydropower potential of the low power and small hydropower feasible projects in Kansas with the low power projects divided into technology classes. 

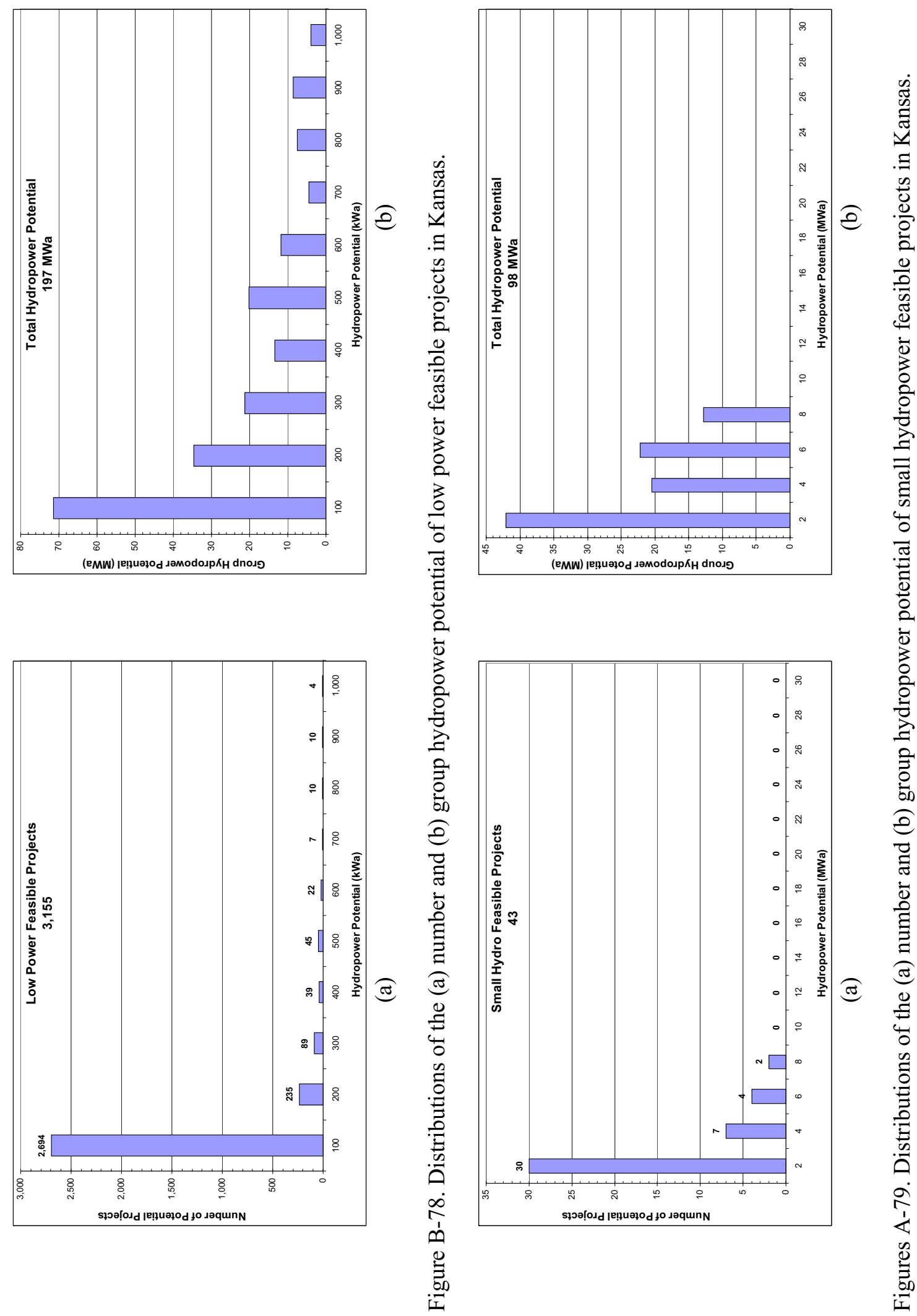


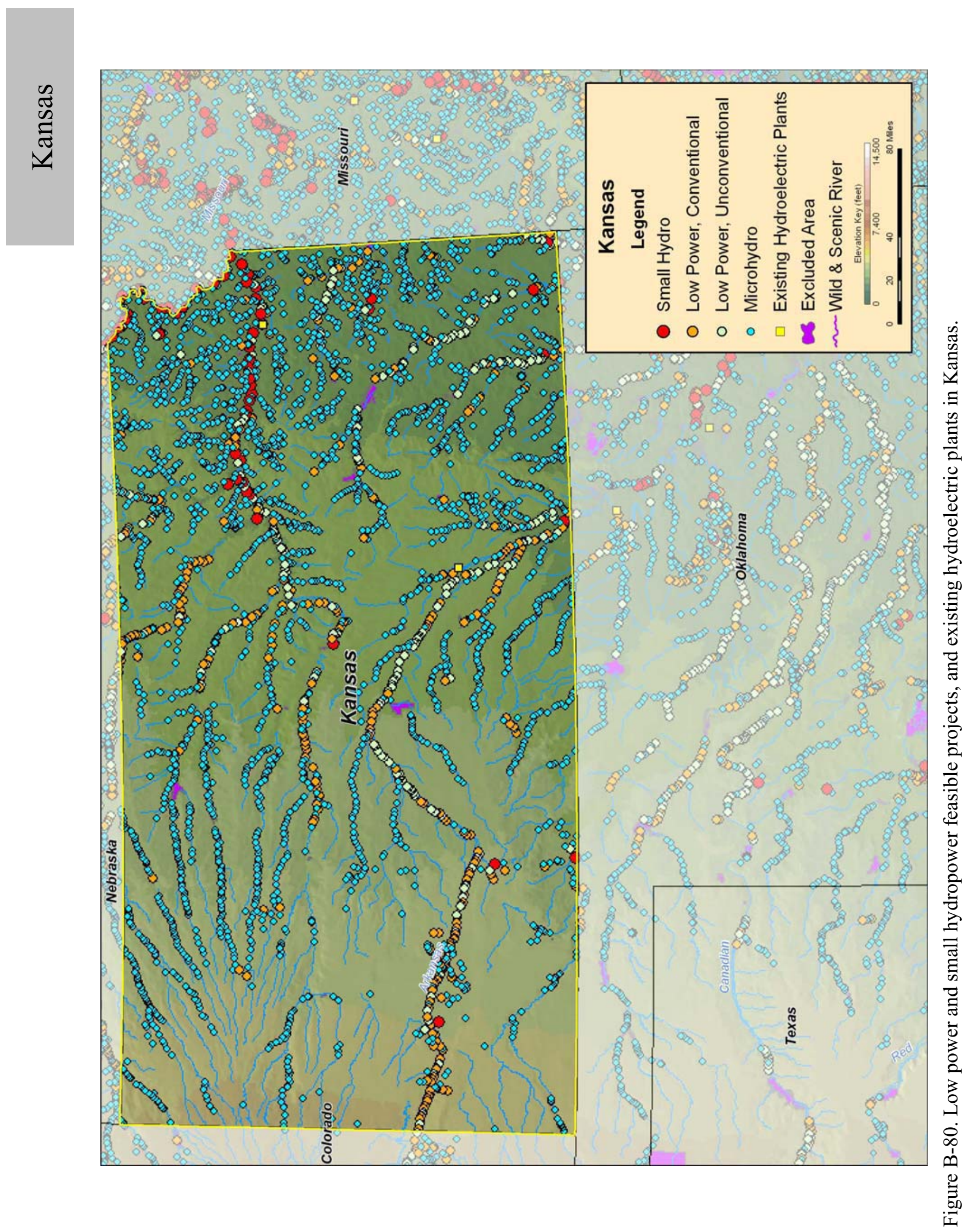




\section{B.17 Kentucky}

Table B-35. Summary of results of water energy resource assessment of Kentucky.

\begin{tabular}{|c|c|c|c|c|c|}
\hline Power Class & $\begin{array}{c}\text { Total } \\
(\mathbf{M W a})\end{array}$ & $\begin{array}{c}\text { Developed } \\
(\mathrm{MWa})\end{array}$ & $\begin{array}{c}\text { Federally } \\
\text { Excluded } \\
(\mathbf{M W a})\end{array}$ & $\begin{array}{c}\text { Other } \\
\text { Excluded } \\
(\mathbf{M W a})\end{array}$ & $\begin{array}{c}\text { Available } \\
(\mathrm{MWa})\end{array}$ \\
\hline Total Power & $\mathbf{3 , 7 5 4}$ & $\mathbf{3 0 5}$ & $\mathbf{4 4}$ & $\mathbf{1 2 7}$ & 3,278 \\
\hline Total High Power & & & & & \\
\hline Large Hydro & $\mathbf{3 , 1 7 8}$ & $\mathbf{3 0 5}$ & $\mathbf{3 3}$ & $\mathbf{7 7}$ & 2,763 \\
\hline Small Hydro & 2,518 & 285 & 0 & 0 & 2,233 \\
\hline & 661 & 21 & 33 & 77 & 530 \\
\hline Total Low Power & & & & & \\
\hline Conventional Turbines & $\mathbf{5 7 6}$ & 0 & 11 & $\mathbf{4 9}$ & 515 \\
\hline Unconventional Systems & $\mathbf{3 4 1}$ & 0 & 7 & 31 & 303 \\
\hline Microhydro & 49 & 0 & 2 & 7 & 40 \\
\hline
\end{tabular}

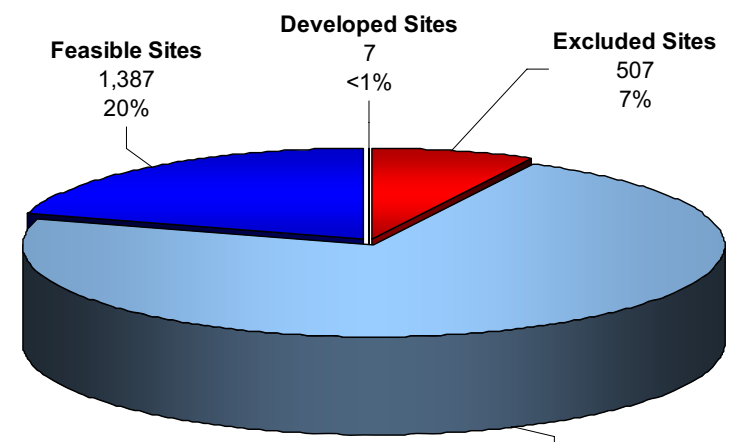

Other Available Sites

$$
\begin{gathered}
4,904 \\
72 \%
\end{gathered}
$$

Developed Potential

$305 \mathrm{MWa}$

8\% Excluded Potential

$170 \mathrm{MWa}$

$5 \%$ Other Available

6,805

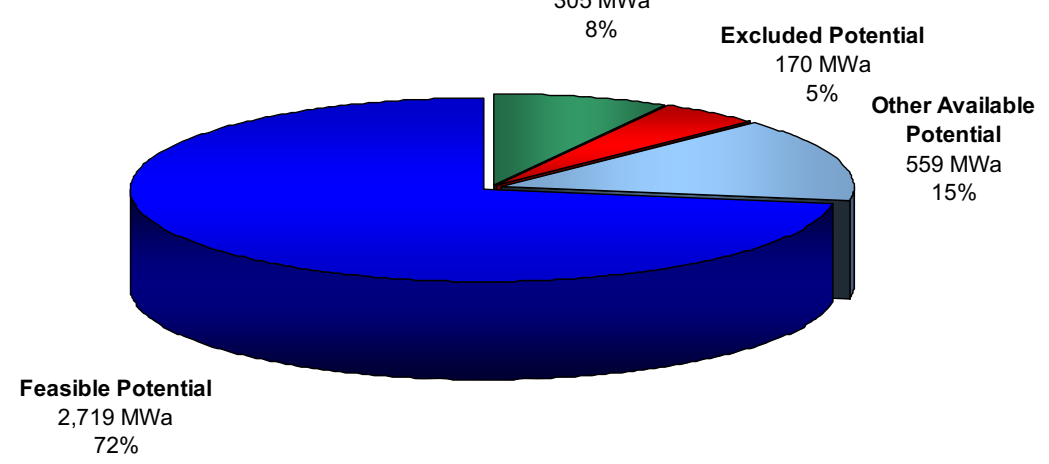

(a) Total Resource Potential $3,754 \mathrm{MWa}$

Figure B-81. Power category distribution of the (a) number and (b) total power potential of the water energy resource sites in Kentucky. 
Table B-36. Summary of results of feasibility assessment of water energy resources in Kentucky.

\begin{tabular}{|c|c|}
\hline Power Class & $\begin{array}{c}\text { Available } \\
\text { (MWa) }\end{array}$ \\
\hline Total Power & 3,278 \\
\hline & \\
\hline Total High Power & 2,763 \\
\hline Large Hydro & 2,233 \\
\hline Small Hydro & 530 \\
\hline & \\
\hline Total Low Power & 515 \\
\hline Conventional Turbines & 303 \\
\hline Unconventional Systems & 40 \\
\hline Microhydro & 172 \\
\hline
\end{tabular}
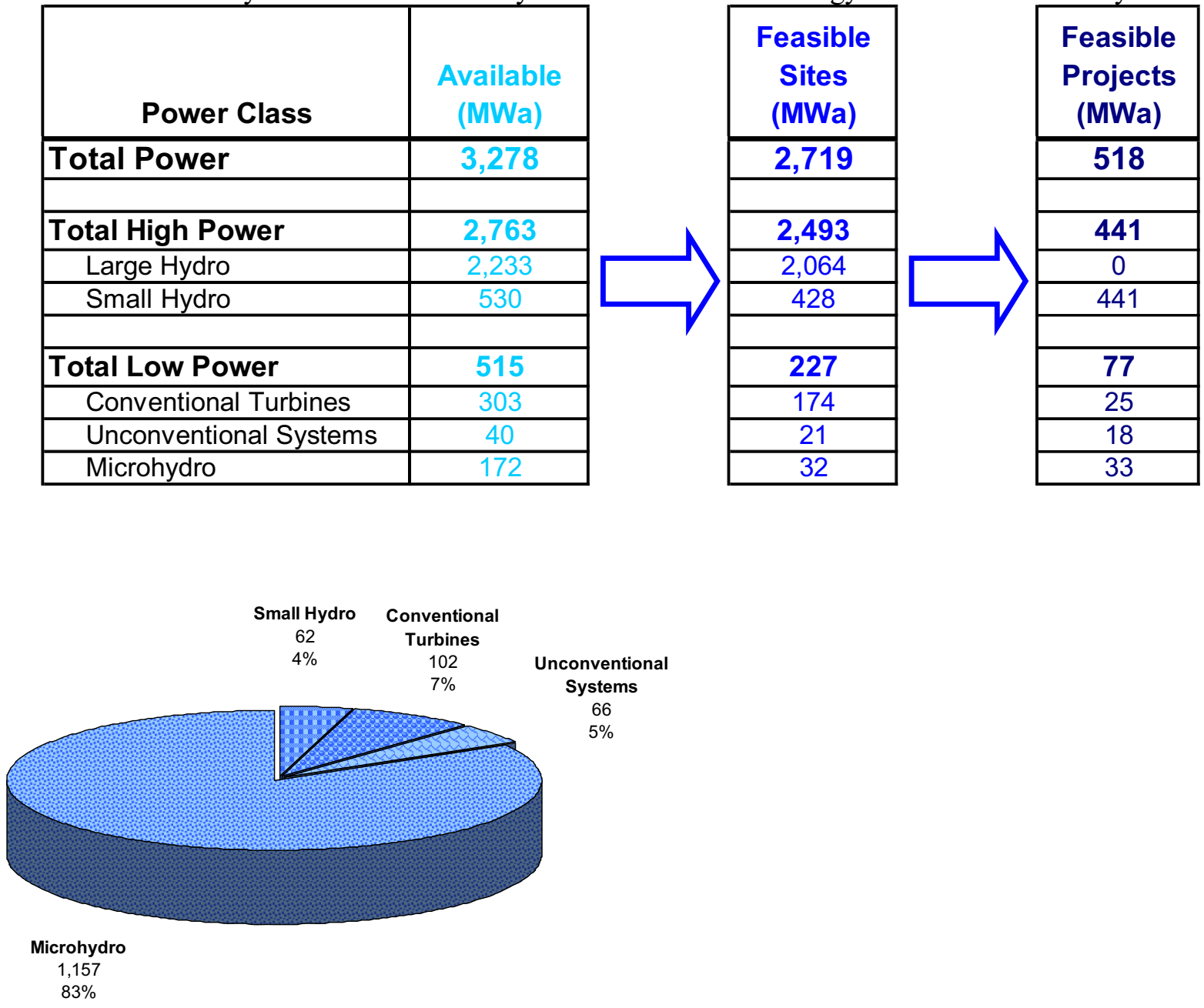

(a) Total Feasible Projects 1,387

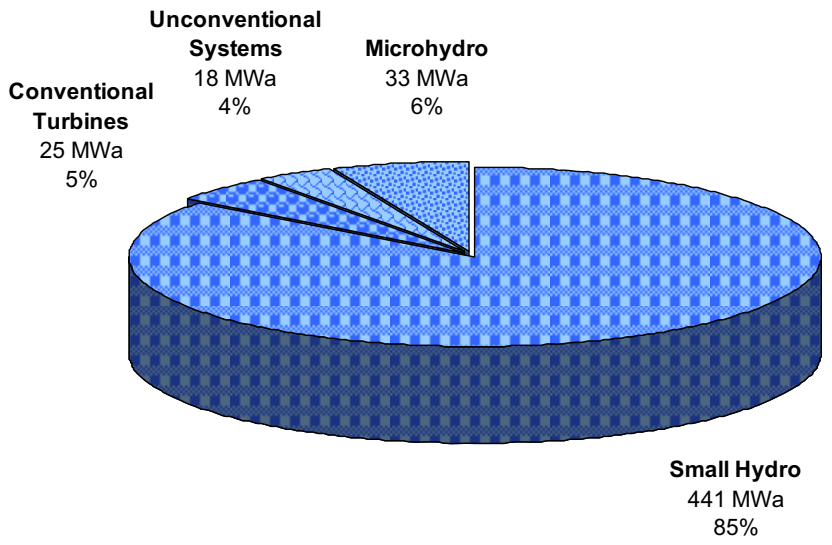

(b) Total Feasible Project Hydropower Potential $518 \mathrm{MWa}$

Figure B-82. Distribution of the (a) number and (b) total hydropower potential of the low power and small hydropower feasible projects in Kentucky with the low power projects divided into technology classes. 

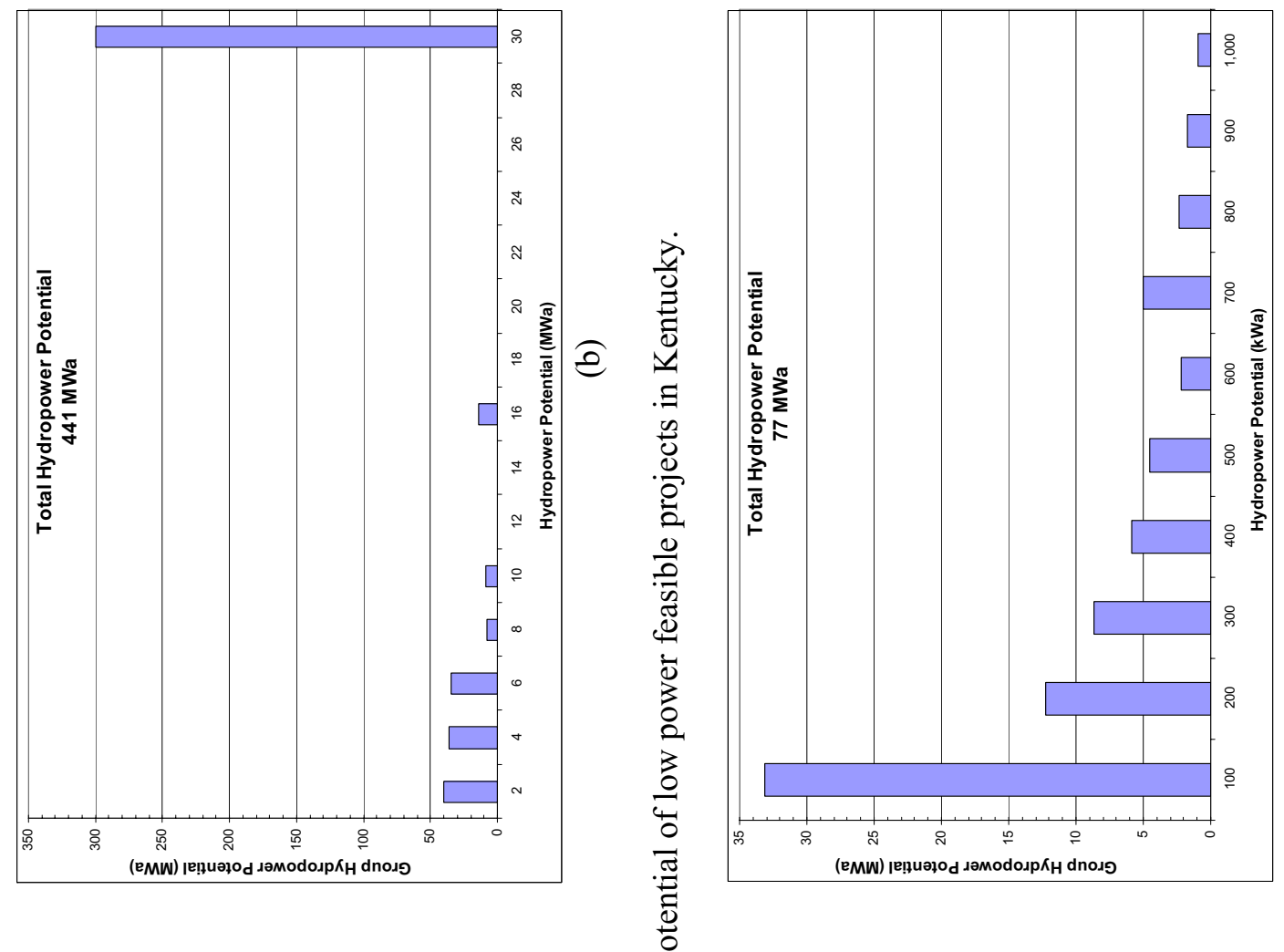

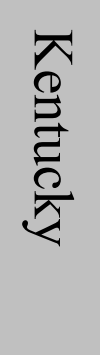
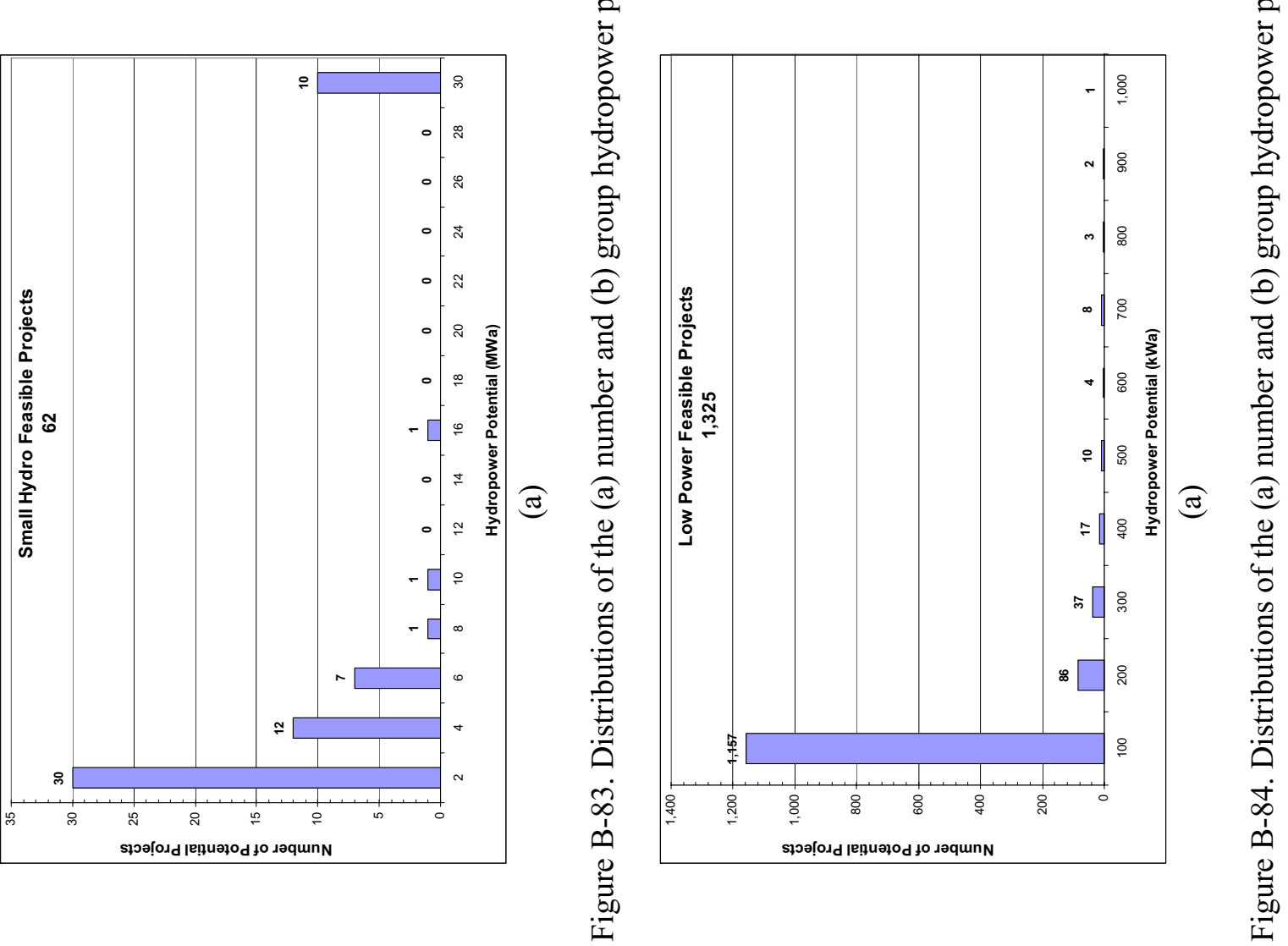

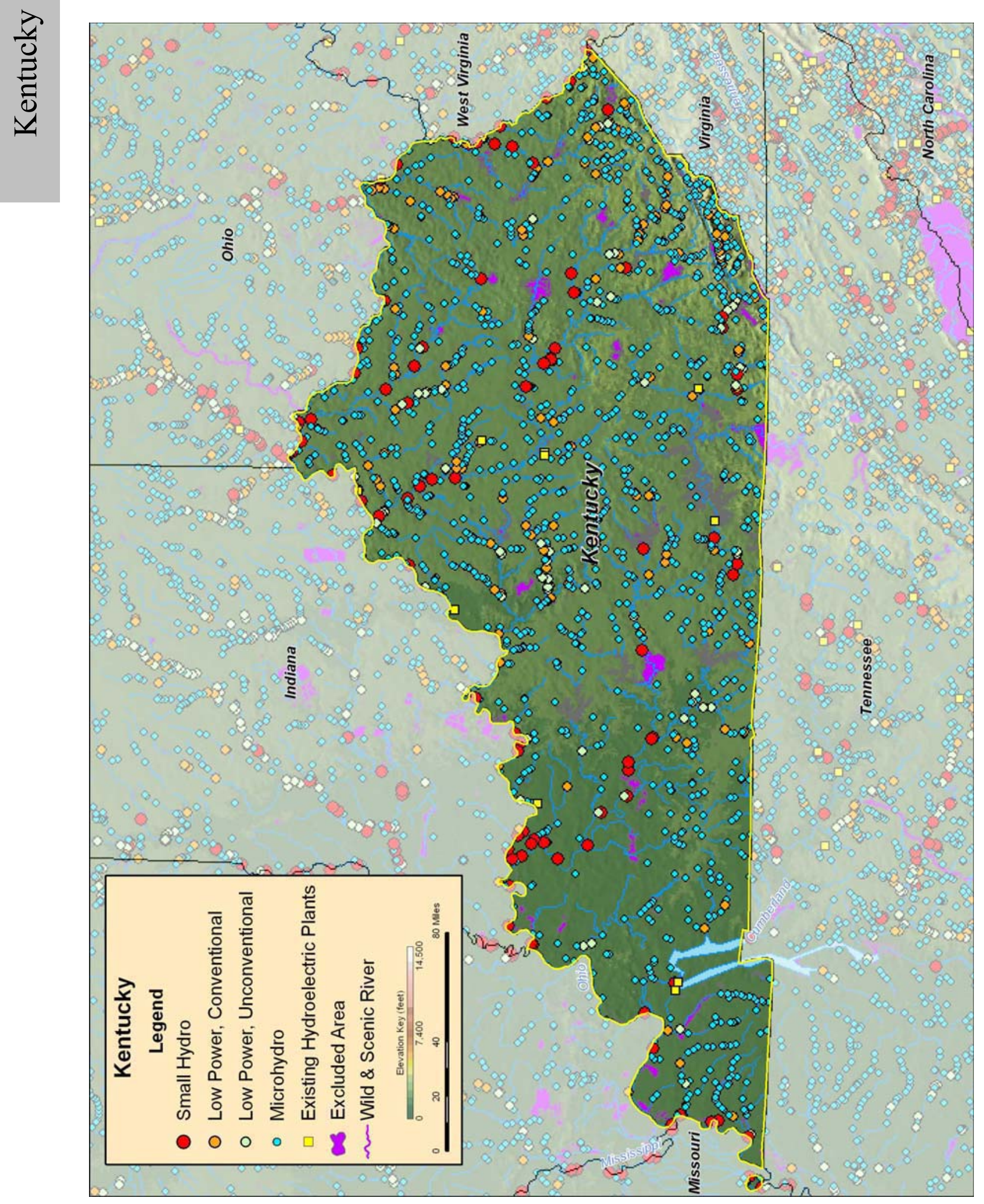

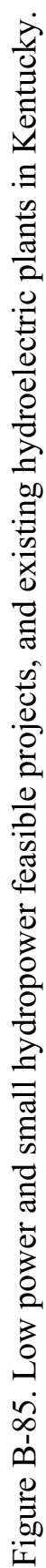




\section{B.18 Louisiana}

Table B-37. Summary of results of water energy resource assessment of Louisiana.

\begin{tabular}{|c|c|c|c|c|c|}
\hline Power Class & $\begin{array}{c}\text { Total } \\
\mathbf{( M W a )}\end{array}$ & $\begin{array}{c}\text { Developed } \\
(\mathrm{MWa})\end{array}$ & $\begin{array}{c}\text { Federally } \\
\text { Excluded } \\
(\mathbf{M W a})\end{array}$ & $\begin{array}{c}\text { Other } \\
\text { Excluded } \\
(\mathrm{MWa})\end{array}$ & $\begin{array}{c}\text { Available } \\
(\mathrm{MWa})\end{array}$ \\
\hline Total Power & $\mathbf{3 , 0 8 8}$ & $\mathbf{2 5}$ & $\mathbf{3 3 1}$ & $\mathbf{4}$ & 2,728 \\
\hline Total High Power & & & & & \\
\hline Large Hydro & $\mathbf{2 , 8 0 1}$ & $\mathbf{2 5}$ & $\mathbf{3 2 3}$ & $\mathbf{0}$ & 2,453 \\
\hline Small Hydro & 2,416 & 0 & 287 & 0 & 2,129 \\
\hline & 385 & 25 & 37 & 0 & 323 \\
\hline Total Low Power & & & & & \\
\hline Conventional Turbines & $\mathbf{2 8 7}$ & 0 & $\mathbf{7}$ & $\mathbf{4}$ & 276 \\
\hline Unconventional Systems & $\mathbf{9 8}$ & 0 & 0 & 2 & 96 \\
\hline Microhydro & $\mathbf{8 4}$ & 0 & 5 & 1 & 78 \\
\hline
\end{tabular}

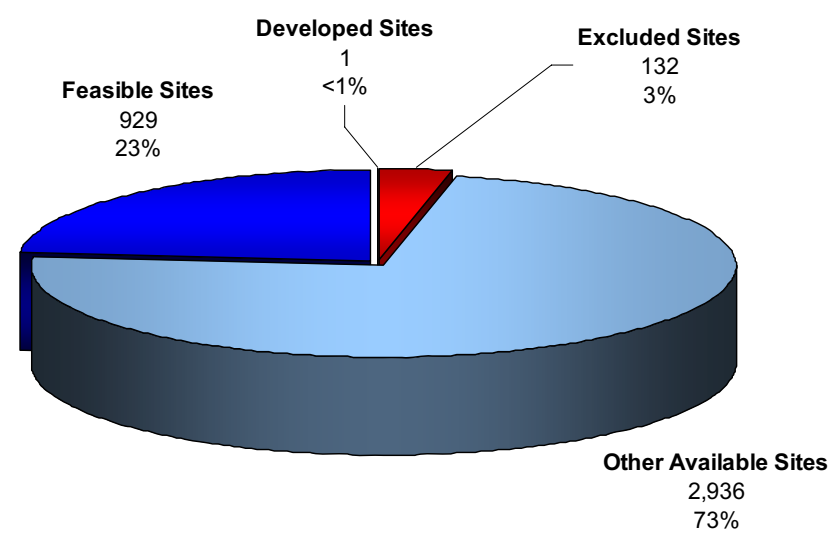

(a) Total Resource Sites 3,998

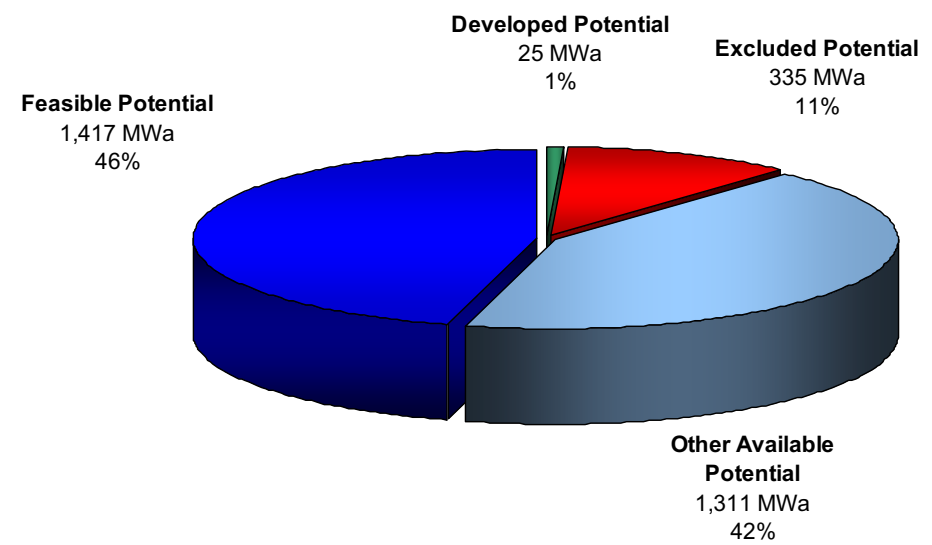

(b) Total Resource Potential $3,088 \mathrm{MWa}$

Figure B-86. Power category distribution of the (a) number and (b) total power potential of the water energy resource sites in Louisiana. 
Table B-38. Summary of results of feasibility assessment of water energy resources in Louisiana.

\begin{tabular}{|c|c|}
\hline Power Class & $\begin{array}{c}\text { Available } \\
(\mathrm{MWa})\end{array}$ \\
\hline Total Power & 2,728 \\
\hline Total High Power & 2,453 \\
\hline Large Hydro & 2,129 \\
\hline Small Hydro & 323 \\
\hline & \\
\hline Total Low Power & 276 \\
\hline Conventional Turbines & 96 \\
\hline Unconventional Systems & 78 \\
\hline Microhydro & 101 \\
\hline
\end{tabular}
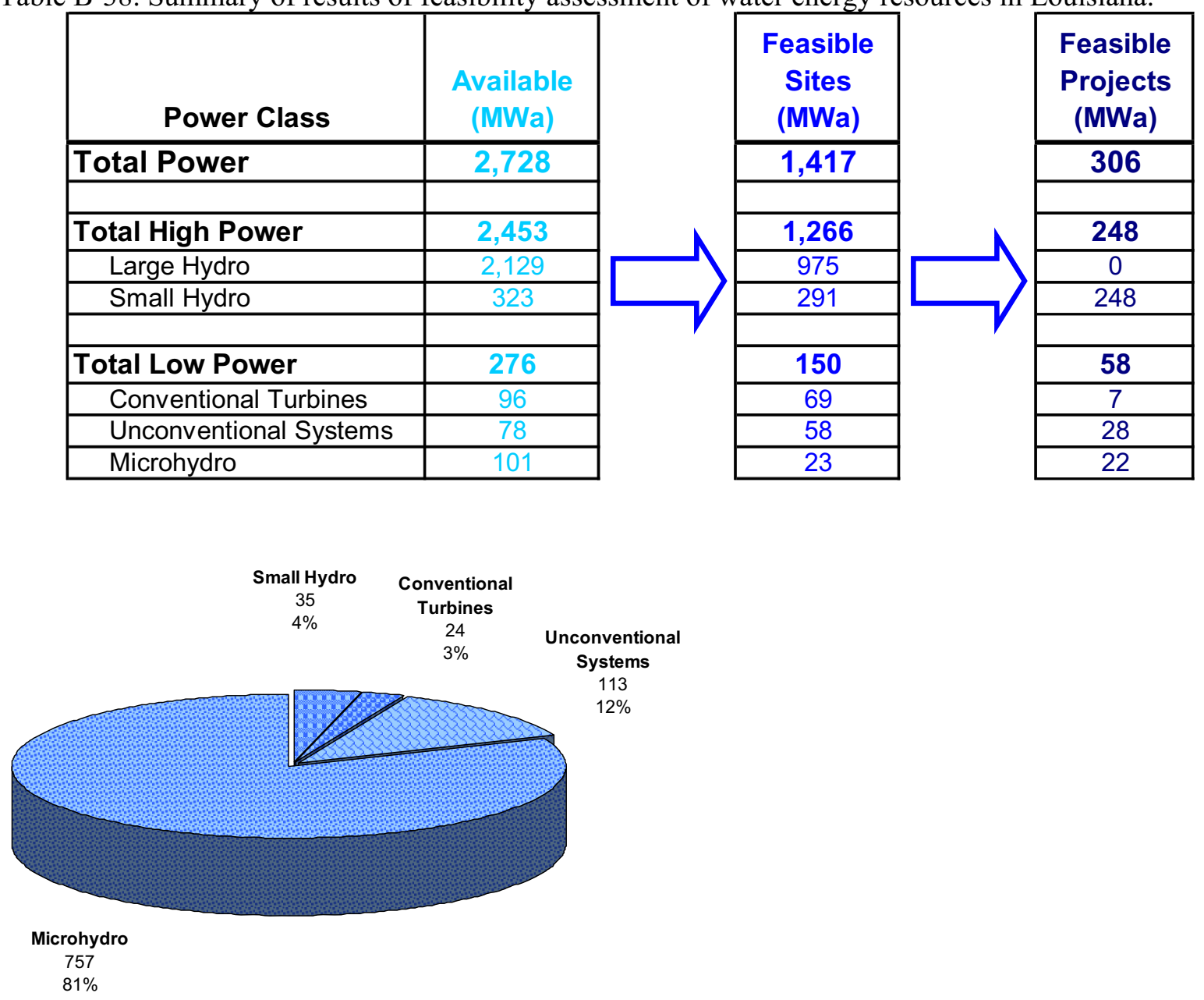

(a) Total Feasible Projects

929

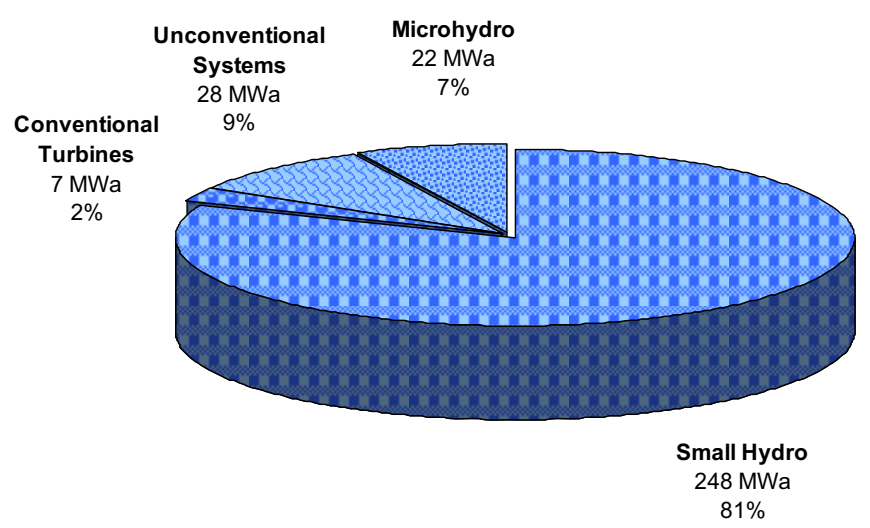

(b) Total Feasible Project Hydropower Potential $306 \mathrm{MWa}$

Figures A-87. Distribution of the (a) number and (b) total hydropower potential of the low power and small hydropower feasible projects in Louisiana with the low power projects divided into technology classes. 

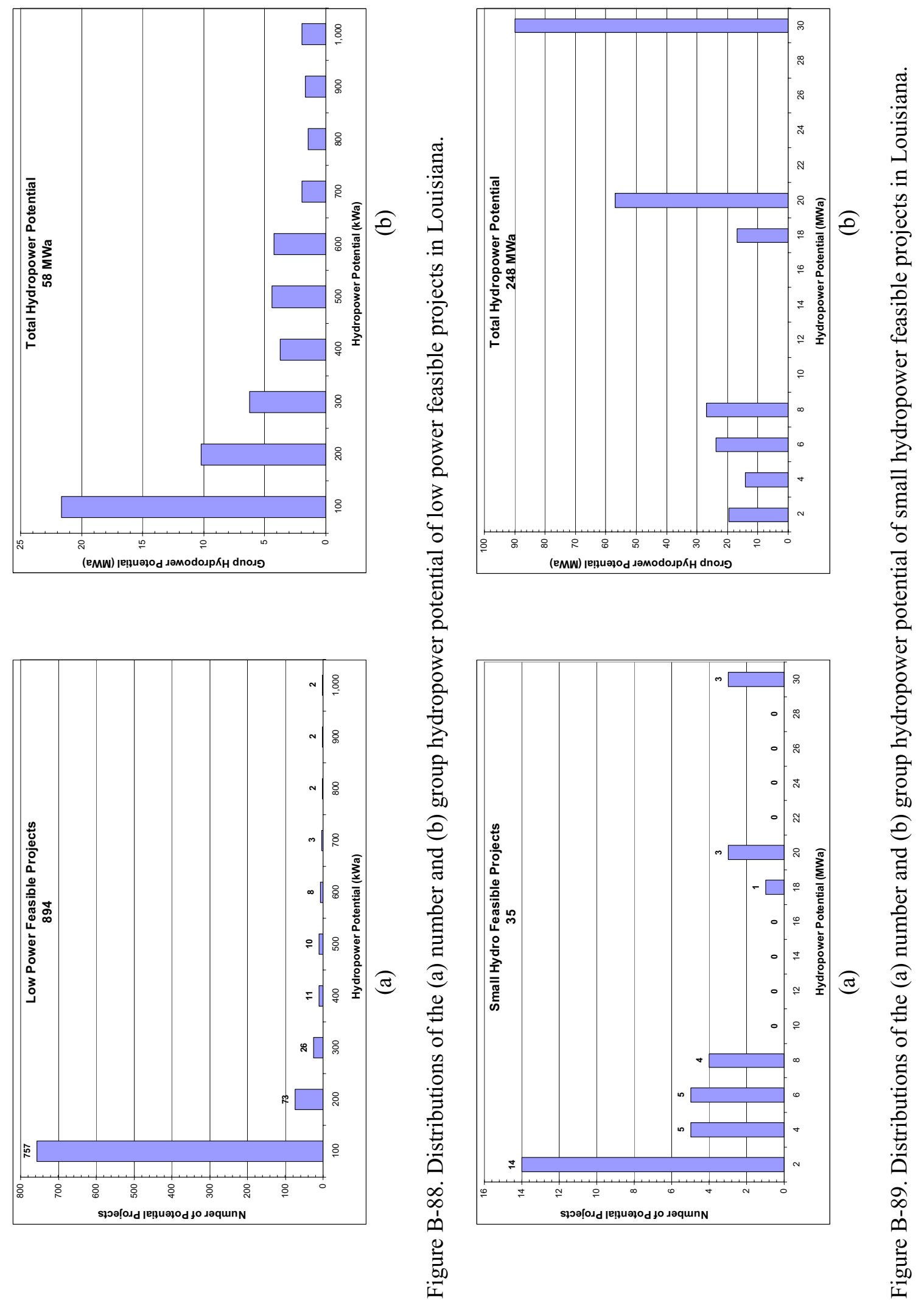


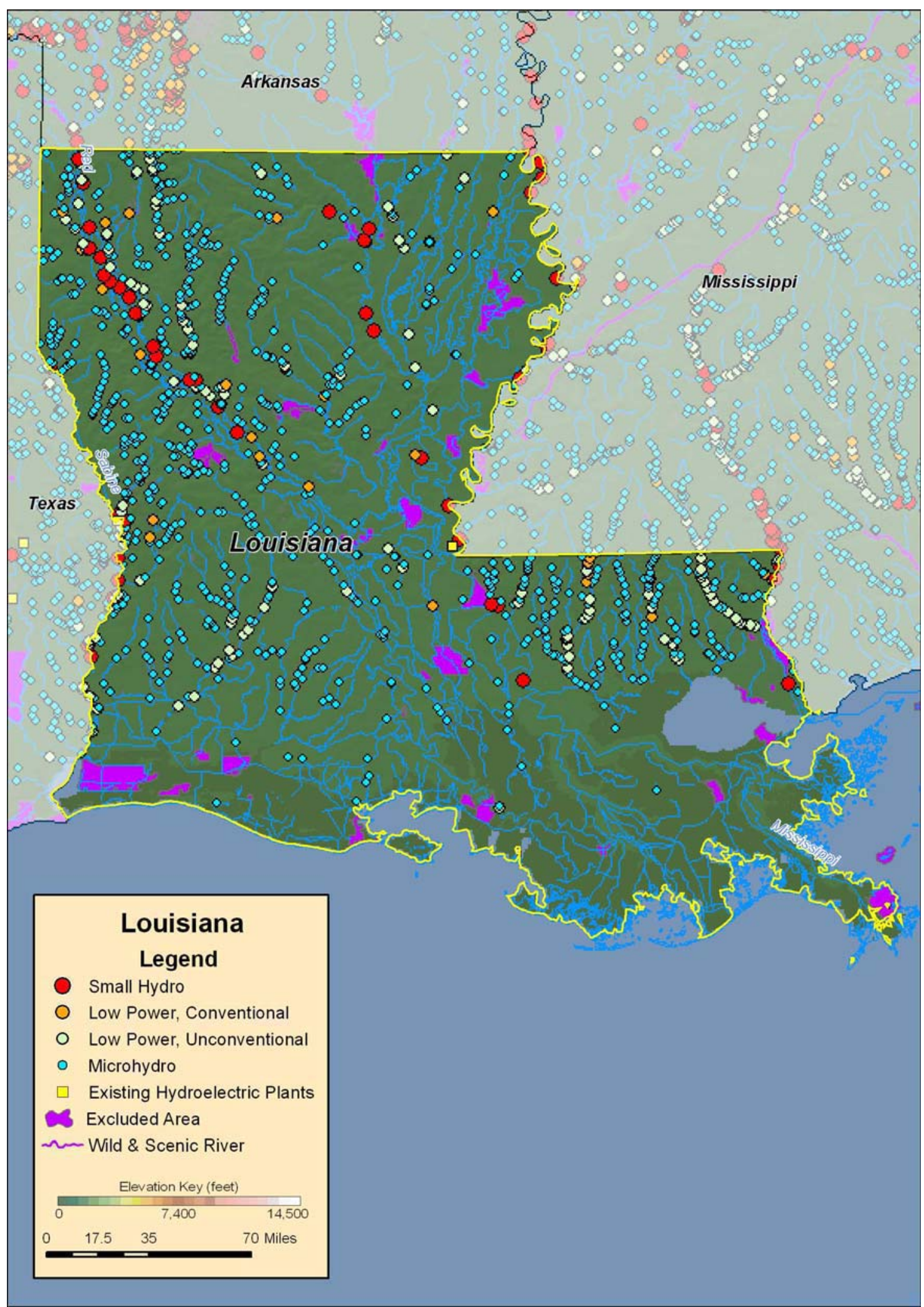

Figure B-90. Low power and small hydropower feasible projects, and existing hydroelectric plants in Louisiana. 


\section{B.19 Maine}

Table B-39. Summary of results of water energy resource assessment of Maine.

\begin{tabular}{|c|c|c|c|c|c|}
\hline Power Class & $\begin{array}{c}\text { Total } \\
\mathbf{( M W a )}\end{array}$ & $\begin{array}{c}\text { Developed } \\
(\mathbf{M W a})\end{array}$ & $\begin{array}{c}\text { Federally } \\
\text { Excluded } \\
(\mathbf{M W a})\end{array}$ & $\begin{array}{c}\text { Other } \\
\text { Excluded } \\
(\mathbf{M W a})\end{array}$ & $\begin{array}{c}\text { Available } \\
(\mathrm{MWa})\end{array}$ \\
\hline Total Power & $\mathbf{2 , 7 8 0}$ & $\mathbf{3 1 1}$ & $\mathbf{6 3}$ & $\mathbf{2 7 7}$ & $\mathbf{2}, 129$ \\
\hline & & & & & \\
\hline Total High Power & $\mathbf{1 , 9 8 9}$ & $\mathbf{2 9 7}$ & $\mathbf{4 2}$ & $\mathbf{2 1 1}$ & 1,439 \\
\hline Large Hydro & 315 & 89 & 0 & 47 & 179 \\
\hline Small Hydro & 1,675 & 208 & 42 & 164 & 1,260 \\
\hline & & & & & \\
\hline Total Low Power & $\mathbf{7 9 1}$ & 14 & $\mathbf{2 1}$ & $\mathbf{6 6}$ & 689 \\
\hline Conventional Turbines & 607 & 11 & 15 & 53 & 529 \\
\hline Unconventional Systems & 44 & 2 & 4 & 4 & 35 \\
\hline Microhydro & 139 & 2 & 2 & 9 & 126 \\
\hline
\end{tabular}

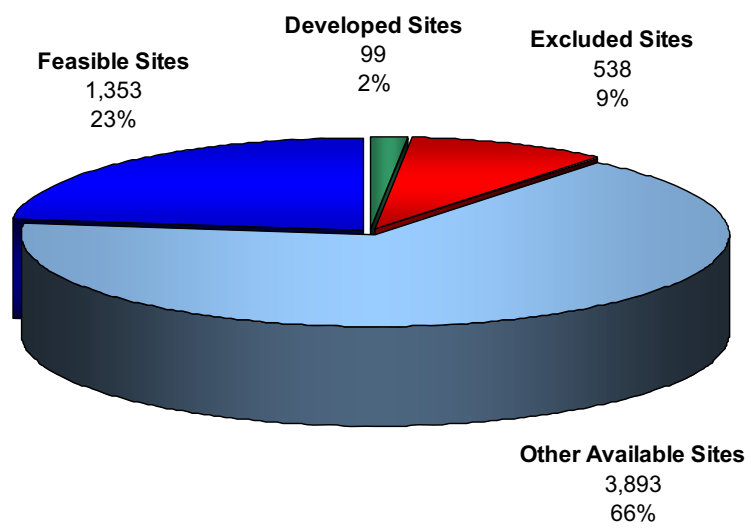

(a) Total Resource Sites 5,883

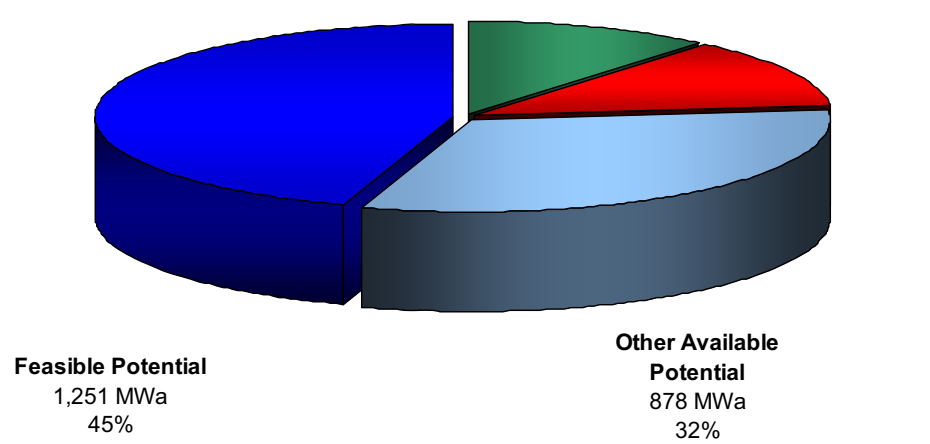

(a) Total Resource Potential $2,780 \mathrm{MWa}$

Figure B-91. Power category distribution of the (a) number and (b) total power potential of the water energy resource sites in Maine. 
Table B-40. Summary of results of feasibility assessment of water energy resources in Maine.

\begin{tabular}{|c|c|c|c|}
\hline Power Class & $\begin{array}{c}\text { Available } \\
\text { (MWa) }\end{array}$ & $\begin{array}{c}\text { Feasible } \\
\text { Sites } \\
(\mathrm{MWa})\end{array}$ & $\begin{array}{c}\text { Feasible } \\
\text { Projects } \\
\text { (MWa) }\end{array}$ \\
\hline Total Power & 2,129 & 1,251 & 432 \\
\hline Total High Power & 1,439 & 1,015 & 332 \\
\hline Large Hydro & 179 & 135 & 0 \\
\hline Small Hydro & 1,260 & 881 & 332 \\
\hline Total Low Power & 689 & 236 & 100 \\
\hline Conventional Turbines & 529 & 187 & 46 \\
\hline Unconventional Systems & 35 & 21 & 22 \\
\hline Microhydro & 126 & 28 & 32 \\
\hline
\end{tabular}

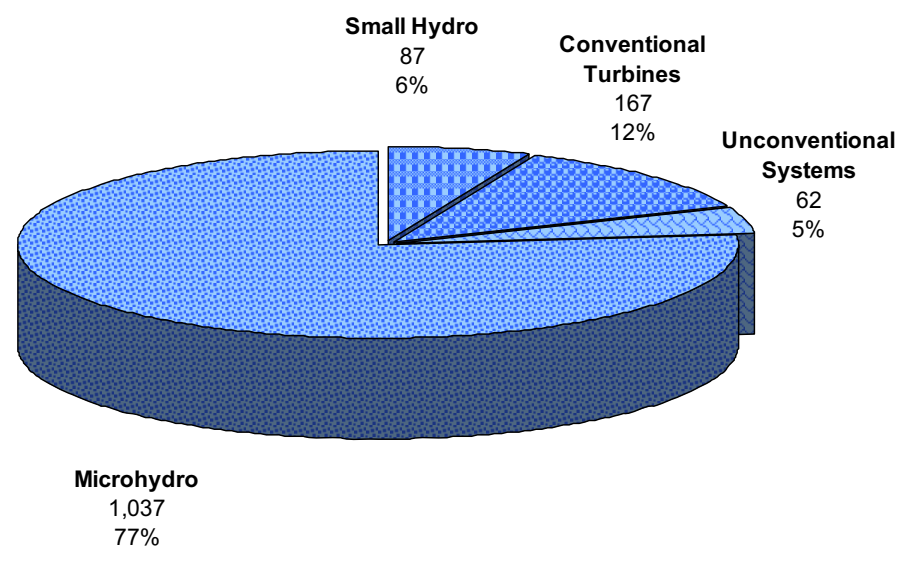

(a) Total Feasible Projects 1,353

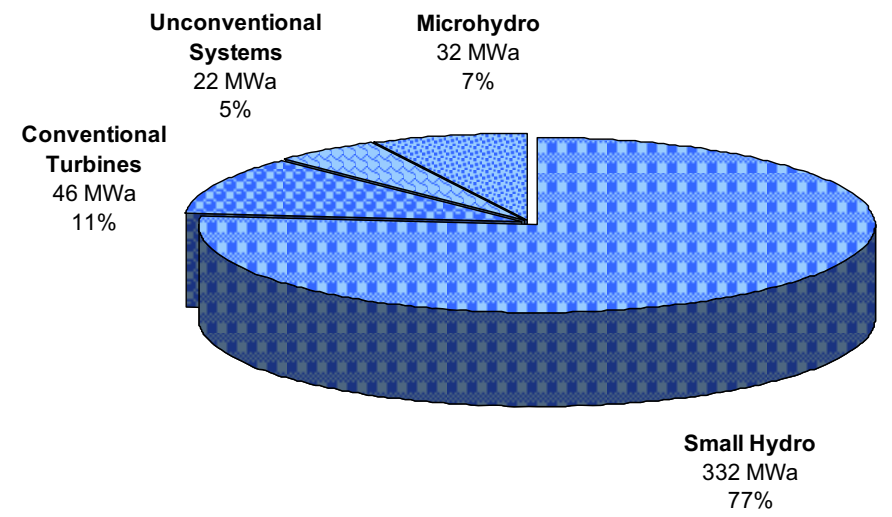

(b) Total Feasible Project Hydropower Potential $432 \mathrm{MWa}$

Figure B-92. Distribution of the (a) number and (b) total hydropower potential of the low power and small hydropower feasible projects in Maine with the low power projects divided into technology classes. 

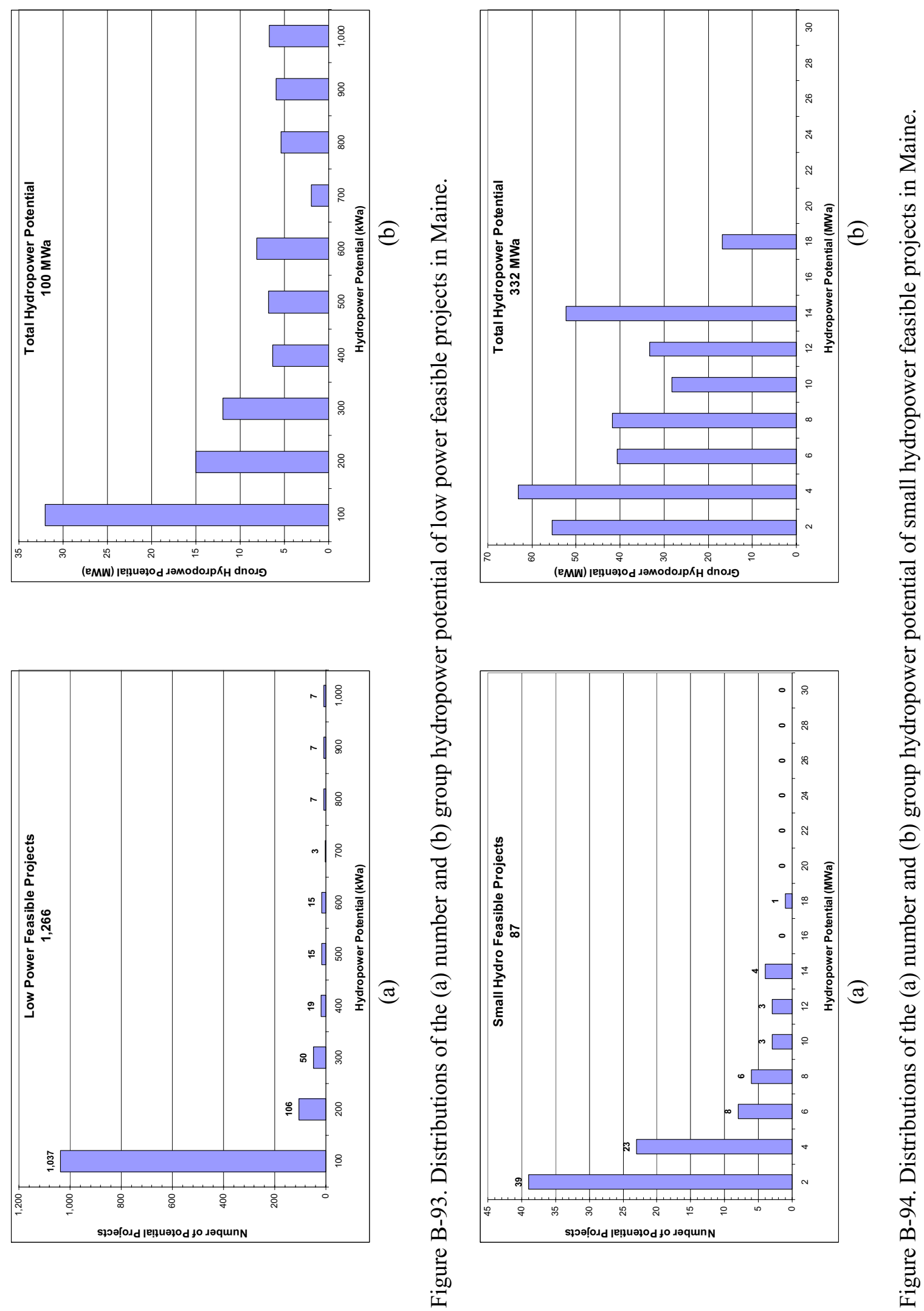

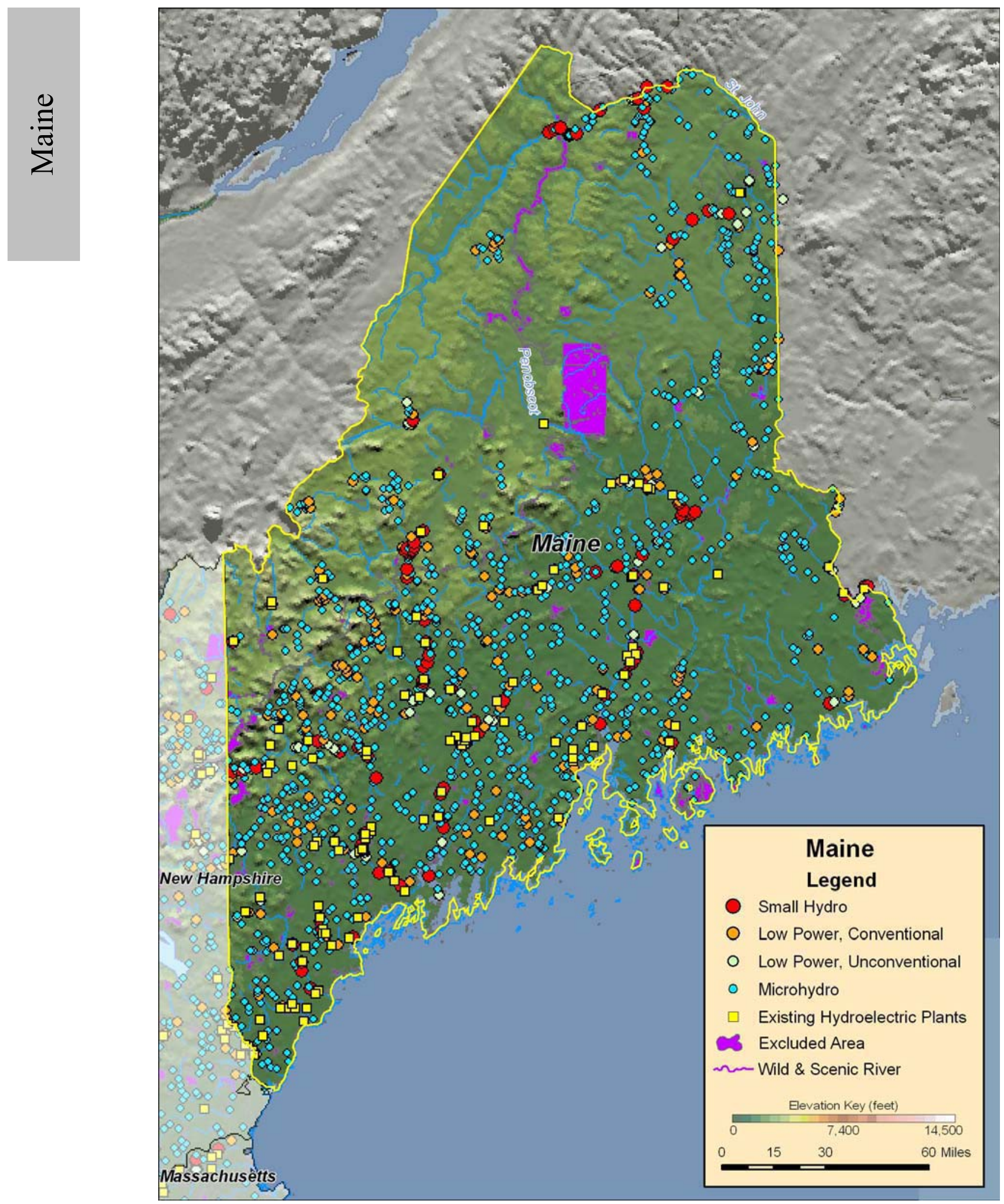

Figure B-95. Low power and small hydropower feasible projects, and existing hydroelectric plants in Maine. 


\section{B.20 Maryland}

Table B-41. Summary of results of water energy resource assessment of Maryland.

\begin{tabular}{|c|c|c|c|c|c|}
\hline \multicolumn{1}{|c|}{ Power Class } & $\begin{array}{c}\text { Total } \\
(\mathbf{M W a})\end{array}$ & $\begin{array}{c}\text { Developed } \\
(\mathrm{MWa})\end{array}$ & $\begin{array}{c}\text { Federally } \\
\text { Excluded } \\
(\mathrm{MWa})\end{array}$ & $\begin{array}{c}\text { Other } \\
\text { Excluded } \\
(\mathrm{MWa})\end{array}$ & $\begin{array}{c}\text { Available } \\
(\mathrm{MWa})\end{array}$ \\
\hline Total Power & $\mathbf{7 6 1}$ & $\mathbf{5}$ & $\mathbf{1 9 3}$ & $\mathbf{4 0}$ & 523 \\
\hline & & & & & \\
\hline Total High Power & $\mathbf{6 1 5}$ & $\mathbf{3}$ & $\mathbf{1 8 2}$ & $\mathbf{1 5}$ & 415 \\
\hline Large Hydro & 336 & 0 & 69 & 0 & 268 \\
\hline Small Hydro & $\mathbf{2 7 9}$ & 3 & 113 & 15 & 147 \\
\hline & & & & & \\
\hline Total Low Power & $\mathbf{1 4 6}$ & 1 & $\mathbf{1 2}$ & $\mathbf{2 5}$ & 108 \\
\hline Conventional Turbines & 108 & 1 & 9 & 20 & 77 \\
\hline Unconventional Systems & 4 & 0 & 0 & 0 & 3 \\
\hline Microhydro & 34 & 0 & 2 & 4 & 28 \\
\hline
\end{tabular}

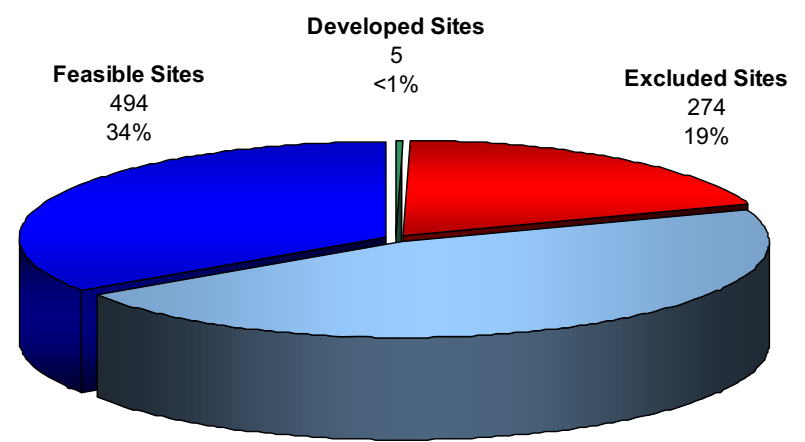

Other Available Sites

665

$46 \%$

(a) Total Resource Sites

1,438

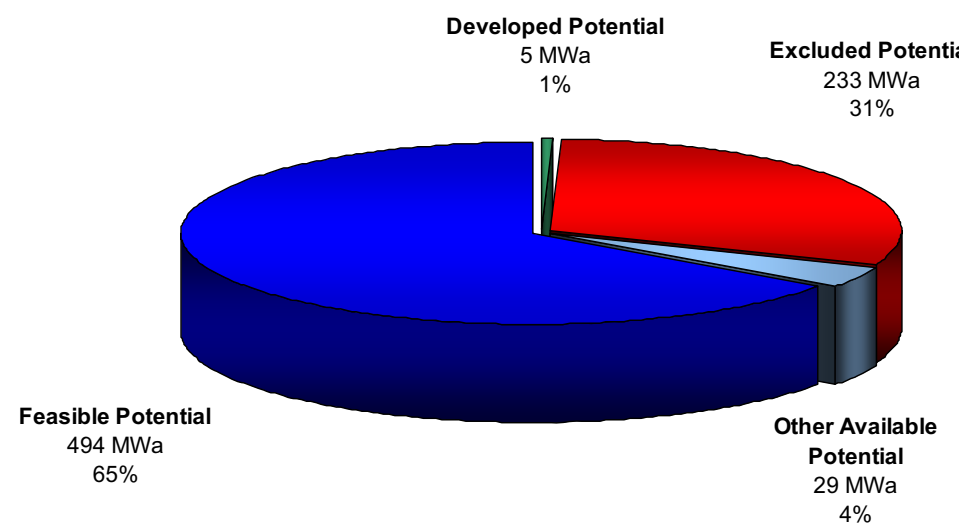

(a) Total Resource Potential $761 \mathrm{MWa}$

Figure B-96. Power category distribution of the (a) number and (b) total power potential of the water energy resource sites in Maryland. 
Table B-42. Summary of results of feasibility assessment of water energy resources in Maryland.

\begin{tabular}{|c|c|c|c|}
\hline Power Class & $\begin{array}{c}\text { Available } \\
\text { (MWa) }\end{array}$ & $\begin{array}{c}\text { Feasible } \\
\text { Sites } \\
\text { (MWa) }\end{array}$ & $\begin{array}{c}\text { Feasible } \\
\text { Projects } \\
\text { (MWa) }\end{array}$ \\
\hline Total Power & 523 & 494 & 91 \\
\hline Total High Power & 415 & 411 & 57 \\
\hline Large Hydro & 268 & 268 & 0 \\
\hline Small Hydro & 147 & 143 & 57 \\
\hline Total Low Power & 108 & 83 & 34 \\
\hline Conventional Turbines & 77 & 69 & 20 \\
\hline Unconventional Systems & 3 & 3 & 2 \\
\hline Microhydro & 28 & 11 & 12 \\
\hline
\end{tabular}

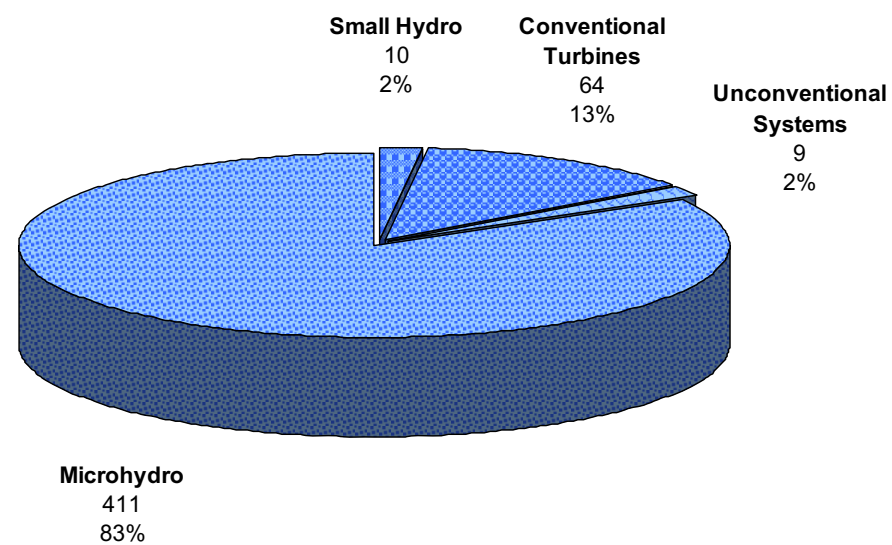

(a) Total Feasible Projects 494

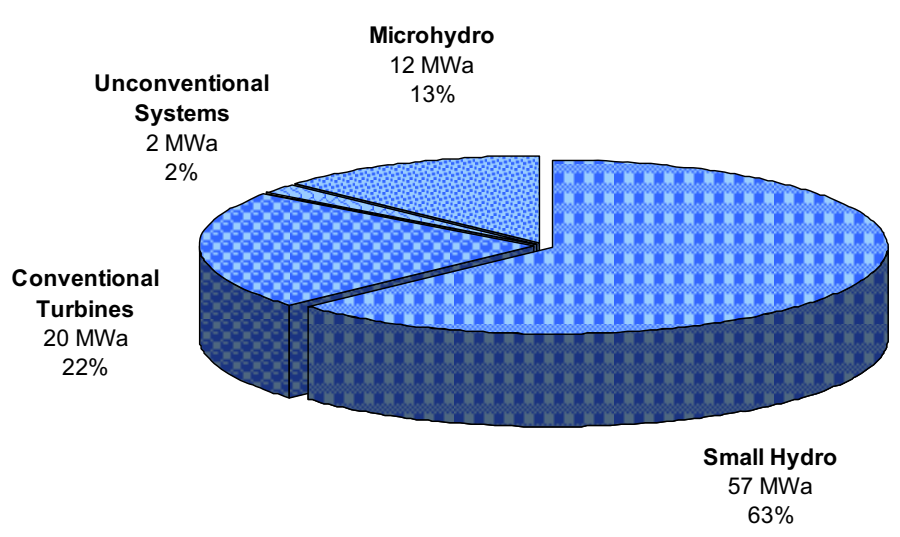

(a) Total Feasible Project Hydropower Potential $91 \mathrm{MWa}$

Figure B-97. Distribution of the (a) number and (b) total hydropower potential of the low power and small hydropower feasible projects in Maryland with the low power projects divided into technology classes. 

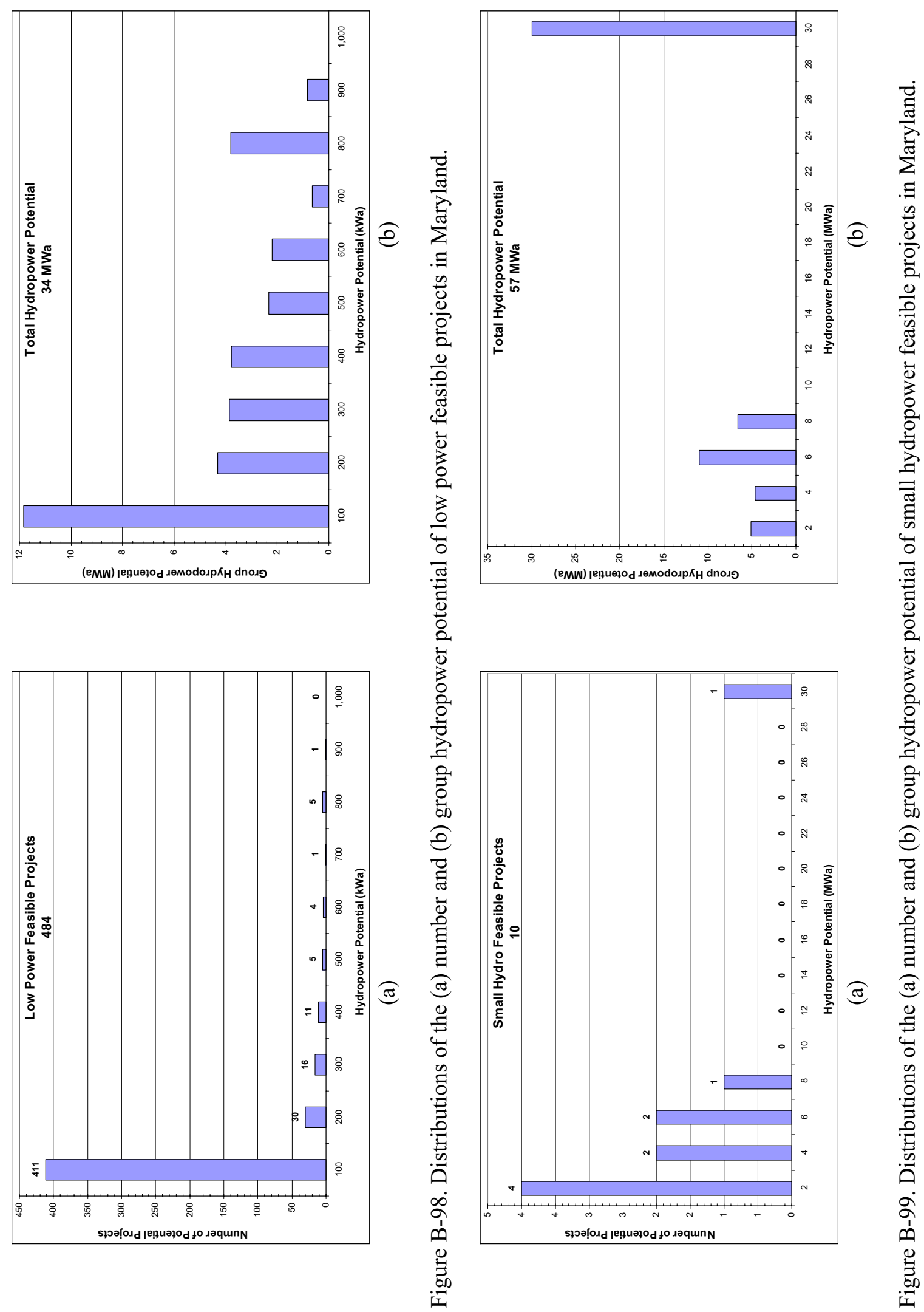

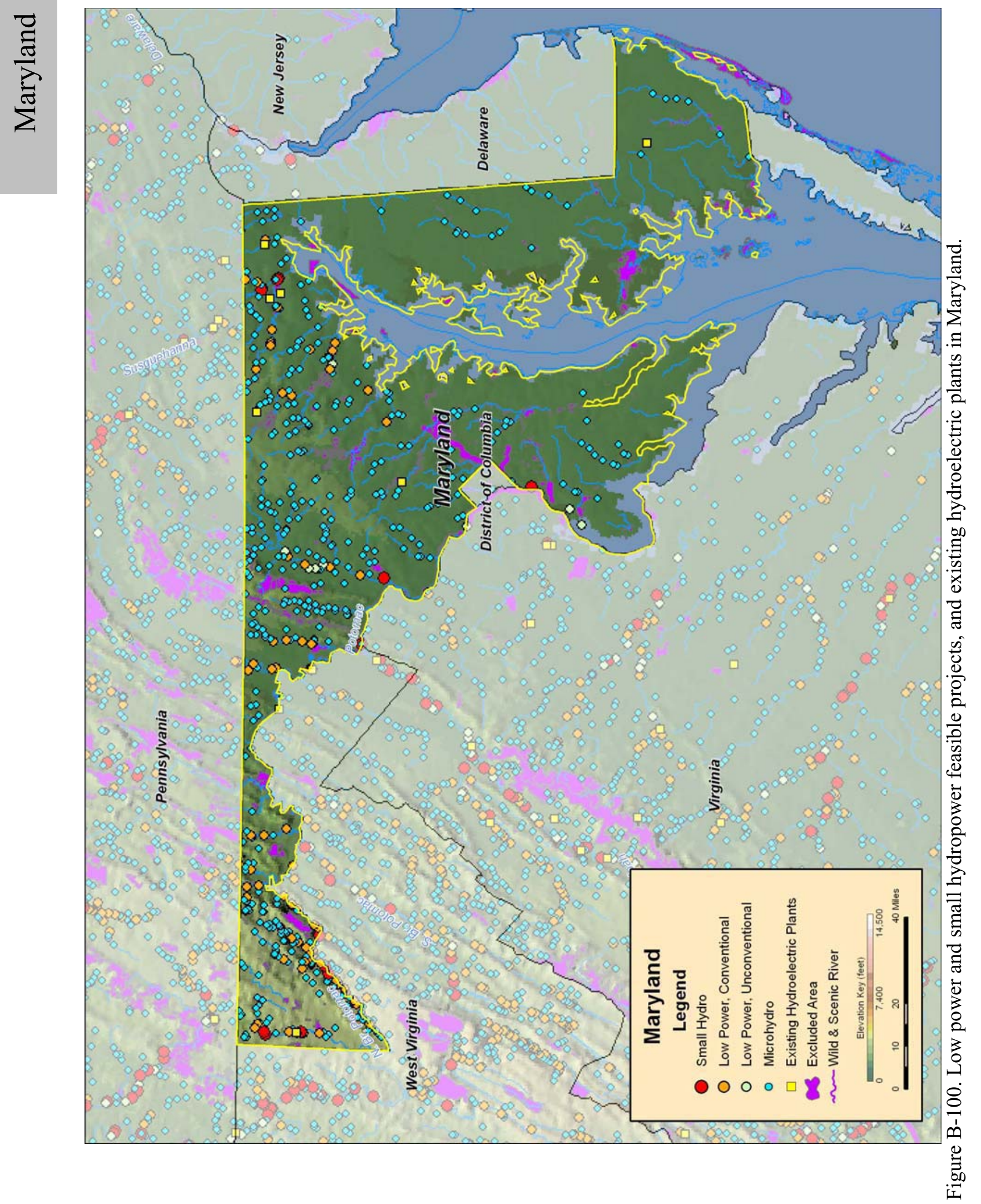


\section{B.21 Massachusetts}

Table B-43. Summary of results of water energy resource assessment of Massachusetts.

\begin{tabular}{|c|c|c|c|c|c|}
\hline Power Class & $\begin{array}{c}\text { Total } \\
(\mathbf{M W a})\end{array}$ & $\begin{array}{c}\text { Developed } \\
(\mathrm{MWa})\end{array}$ & $\begin{array}{c}\text { Federally } \\
\text { Excluded } \\
(\mathbf{M W a})\end{array}$ & $\begin{array}{c}\text { Other } \\
\text { Excluded } \\
(\mathrm{MWa})\end{array}$ & $\begin{array}{c}\text { Available } \\
(\mathrm{MWa})\end{array}$ \\
\hline Total Power & $\mathbf{6 7 3}$ & $\mathbf{3 5}$ & $\mathbf{2 9}$ & $\mathbf{9 8}$ & 511 \\
\hline Total High Power & $\mathbf{4 7 8}$ & $\mathbf{2 9}$ & $\mathbf{1 1}$ & $\mathbf{5 7}$ & 381 \\
\hline Large Hydro & 136 & 0 & 0 & 0 & 136 \\
\hline Small Hydro & 343 & 29 & 11 & 57 & 246 \\
\hline Total Low Power & & & & & \\
\hline Conventional Turbines & $\mathbf{1 9 5}$ & $\mathbf{6}$ & $\mathbf{1 8}$ & $\mathbf{4 1}$ & 130 \\
\hline Unconventional Systems & 155 & 5 & 17 & 31 & 101 \\
\hline Microhydro & 6 & 0 & 0 & 2 & 4 \\
\hline
\end{tabular}

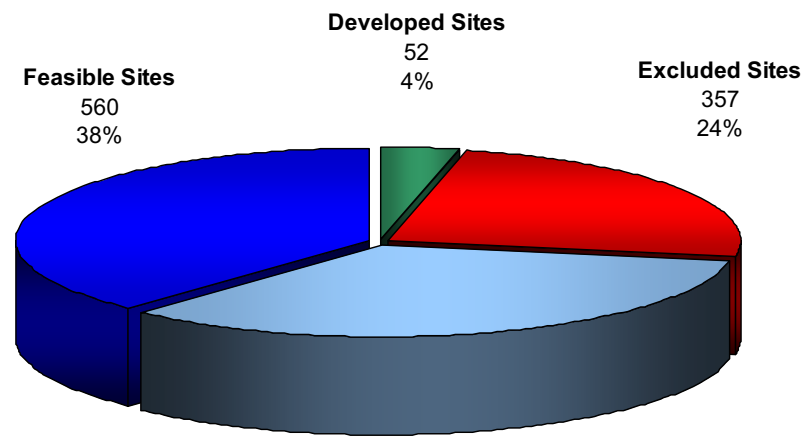

Other Available Sites

506

$34 \%$

(a) Total Resource Sites

1,475

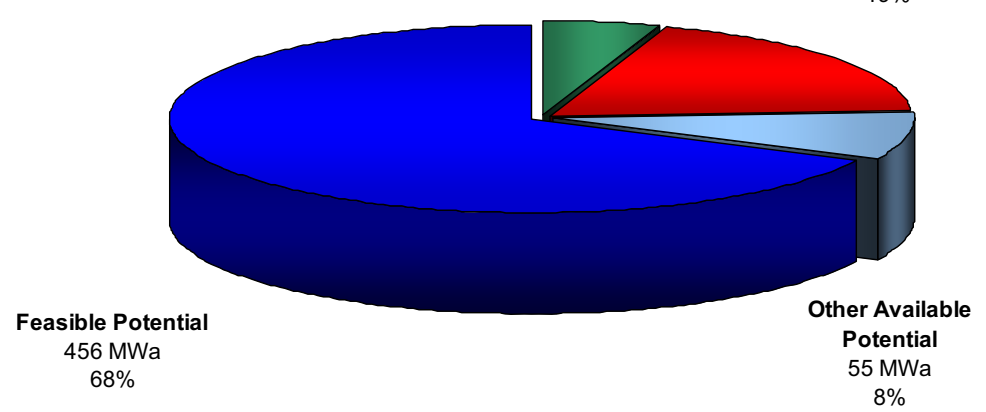

(b) Total Resource Potential $673 \mathrm{MWa}$

Figures A-101. Power category distribution of the (a) number and (b) total power potential of the water energy resource sites in Massachusetts. 
Table B-44. Summary of results of feasibility assessment of water energy resources in Massachusetts.

\begin{tabular}{|c|c|c|c|}
\hline Power Class & $\begin{array}{c}\text { Available } \\
\text { (MWa) }\end{array}$ & $\begin{array}{c}\text { Feasible } \\
\text { Sites } \\
\text { (MWa) }\end{array}$ & $\begin{array}{c}\text { Feasible } \\
\text { Projects } \\
\text { (MWa) }\end{array}$ \\
\hline Total Power & 511 & 456 & 136 \\
\hline Total High Power & 381 & 360 & 104 \\
\hline Large Hydro & 136 & 136 & 0 \\
\hline Small Hydro & 246 & 225 & 104 \\
\hline Total Low Power & 130 & 96 & 33 \\
\hline Conventional Turbines & 101 & 80 & 18 \\
\hline Unconventional Systems & 4 & 3 & 1 \\
\hline Microhydro & 25 & 13 & 14 \\
\hline
\end{tabular}

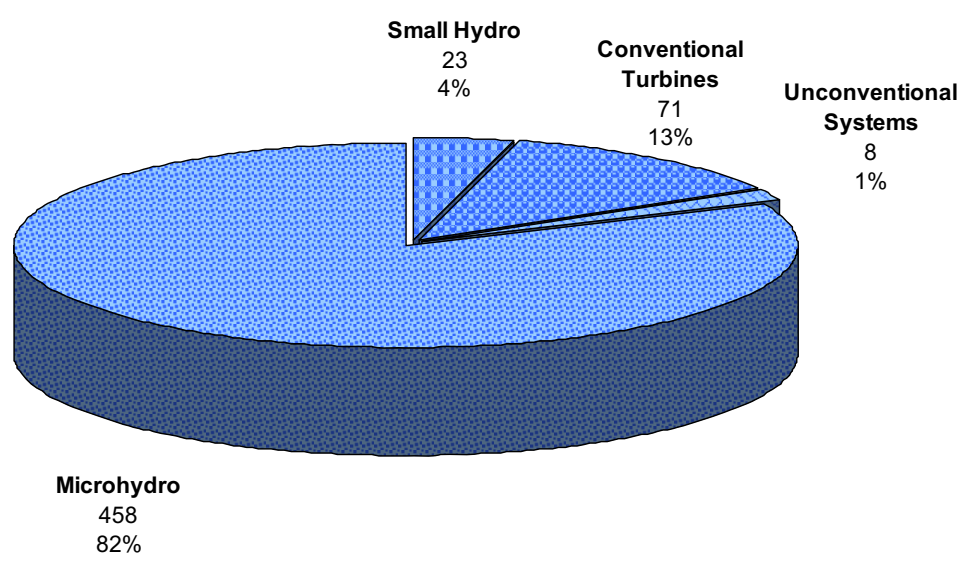

(a) Total Feasible Projects

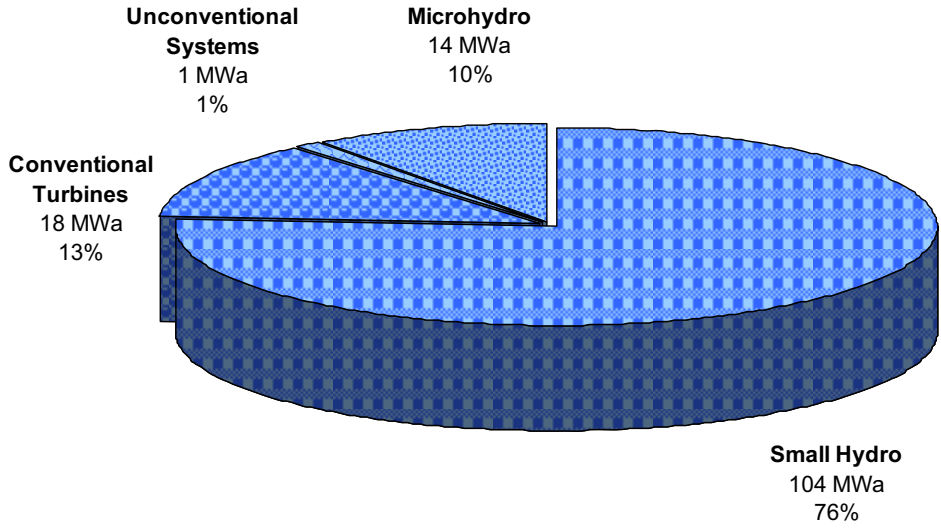

(b) Total Feasible Project Hydropower Potential $136 \mathrm{MWa}$

Figure B-102. Distribution of the (a) number and (b) total hydropower potential of the low power and small hydropower feasible projects in Massachusetts with the low power projects divided into technology classes. 

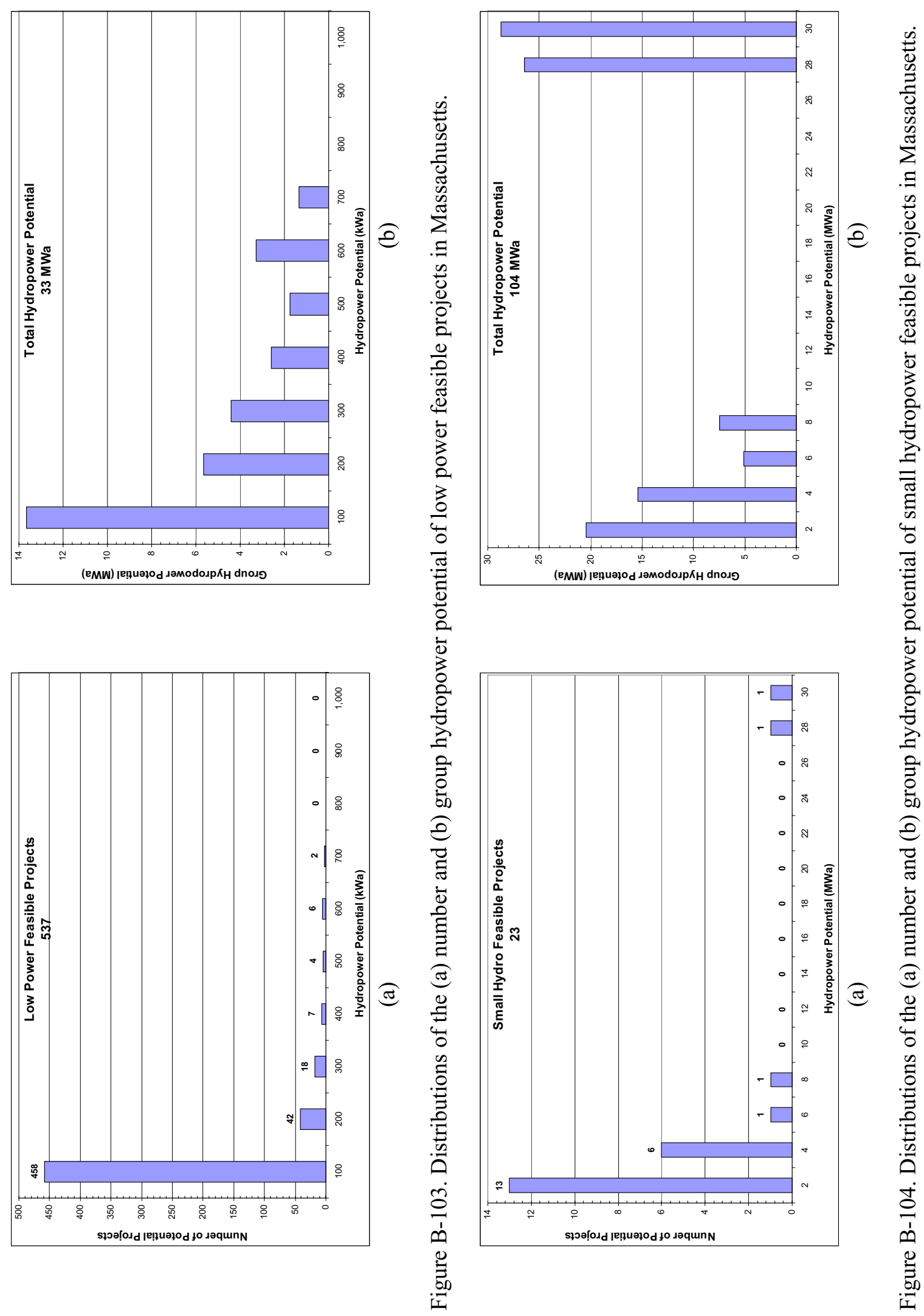


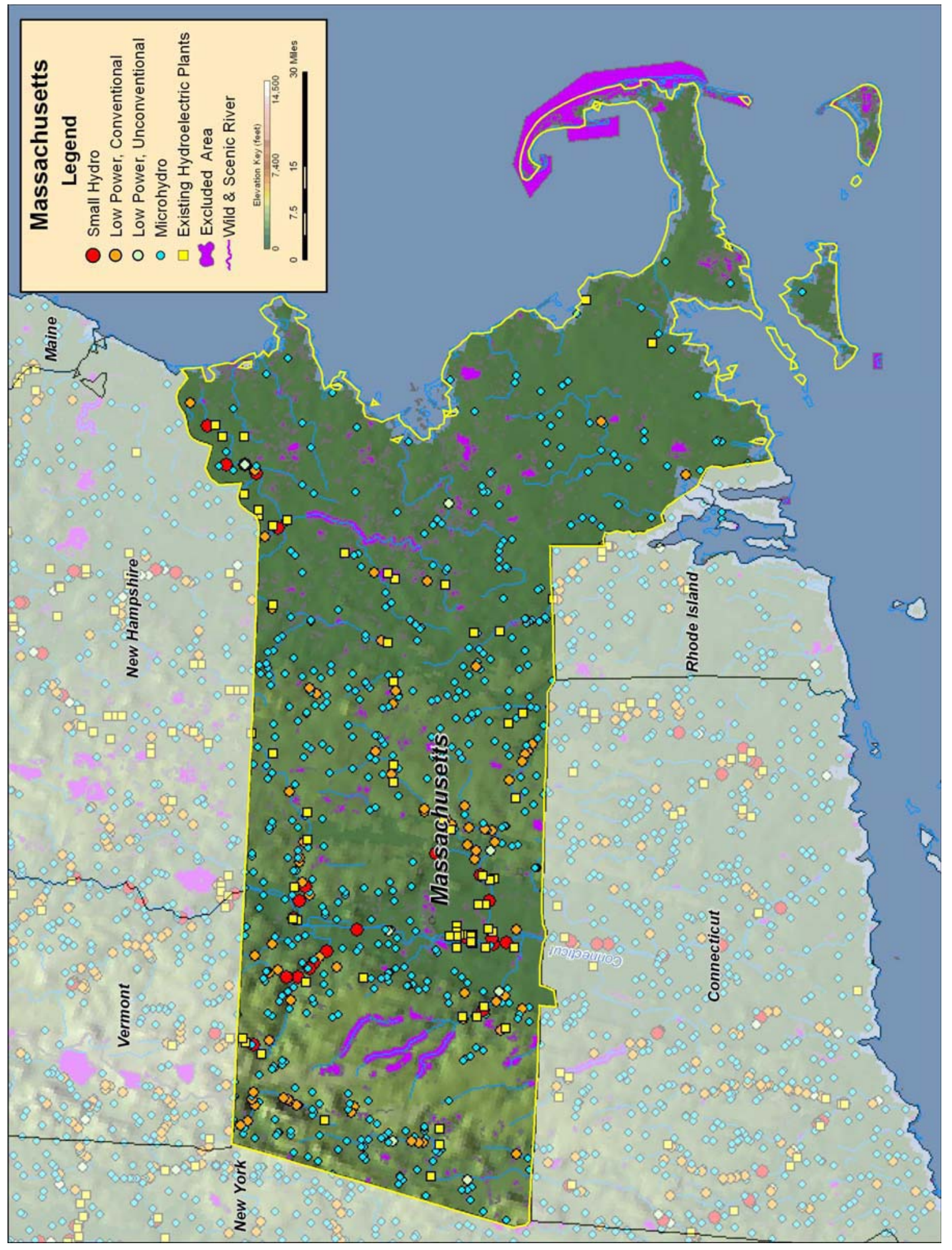

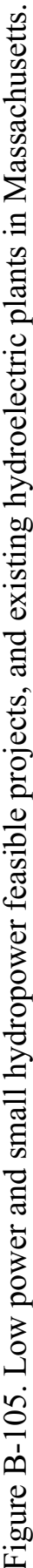




\section{B.22 Michigan}

Table B-45. Summary of results of water energy resource assessment of Michigan.

\begin{tabular}{|c|c|c|c|c|c|}
\hline Power Class & $\begin{array}{c}\text { Total } \\
\text { (MWa) }\end{array}$ & $\begin{array}{c}\text { Developed } \\
\text { (MWa) }\end{array}$ & $\begin{array}{c}\text { Federally } \\
\text { Excluded } \\
(\mathrm{MWa})\end{array}$ & $\begin{array}{c}\text { Other } \\
\text { Excluded } \\
(\mathrm{MWa})\end{array}$ & $\begin{array}{c}\text { Available } \\
\text { (MWa) }\end{array}$ \\
\hline Total Power & 1,101 & 89 & 200 & 27 & 784 \\
\hline Total High Power & 434 & 75 & 124 & 12 & 224 \\
\hline Large Hydro & 0 & 0 & 0 & 0 & 0 \\
\hline Small Hydro & 434 & 75 & 124 & 12 & 224 \\
\hline Total Low Power & 666 & 15 & 77 & 15 & 560 \\
\hline Conventional Turbines & 409 & 12 & 57 & 8 & 332 \\
\hline Unconventional Systems & 59 & 2 & 9 & 3 & 46 \\
\hline Microhydro & 198 & 1 & 11 & 4 & 182 \\
\hline
\end{tabular}

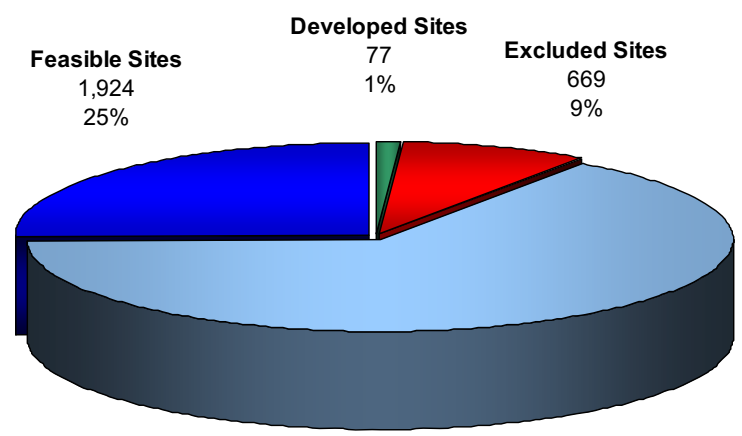

Other Available Sites

4,958

$65 \%$

Developed Potential $89 \mathrm{MWa}$

8\% Excluded Potential $228 \mathrm{MWa}$

Feasible Potential $484 \mathrm{MWa}$ $44 \%$
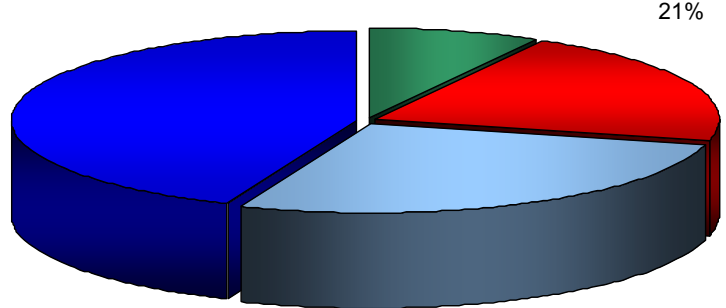

Other Available

Potential

$300 \mathrm{MWa}$

$27 \%$

(b) Total Resource Potential 1,101 MWa

Figure B-106. Power category distribution of the (a) number and (b) total power potential of the water energy resource sites in Michigan. 
Table B-46. Summary of results of feasibility assessment of water energy resources in Michigan.

\begin{tabular}{|c|c|c|c|}
\hline Power Class & $\begin{array}{c}\text { Available } \\
\text { (MWa) }\end{array}$ & $\begin{array}{c}\text { Feasible } \\
\text { Sites } \\
\text { (MWa) }\end{array}$ & $\begin{array}{c}\text { Feasible } \\
\text { Projects } \\
\text { (MWa) }\end{array}$ \\
\hline Total Power & 784 & 484 & 133 \\
\hline Total High Power & 224 & 187 & 23 \\
\hline Large Hydro & 0 & 0 & 0 \\
\hline Small Hydro & 224 & 187 & 23 \\
\hline Total Low Power & 560 & 297 & 110 \\
\hline Conventional Turbines & 332 & 208 & 40 \\
\hline Unconventional Systems & 46 & 34 & 21 \\
\hline Microhydro & 182 & 54 & 49 \\
\hline
\end{tabular}

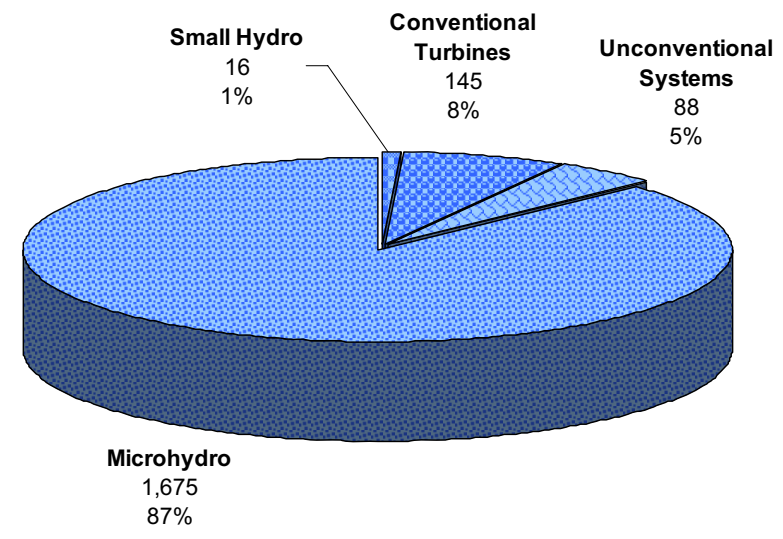

(a) Total Feasible Projects 1,924

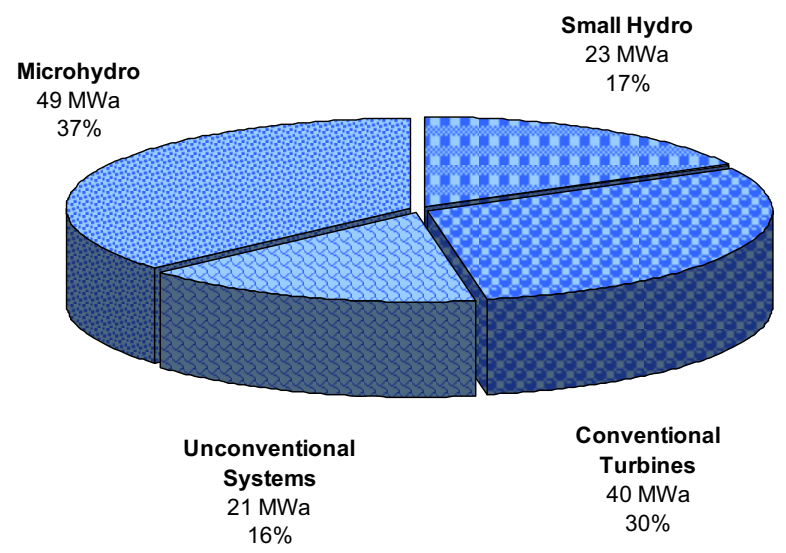

(b) Total Feasible Project Hydropower Potential $133 \mathrm{MWa}$

Figure B-107. Distribution of the (a) number and (b) total hydropower potential of the low power and small hydropower feasible projects in Michigan with the low power projects divided into technology classes. 

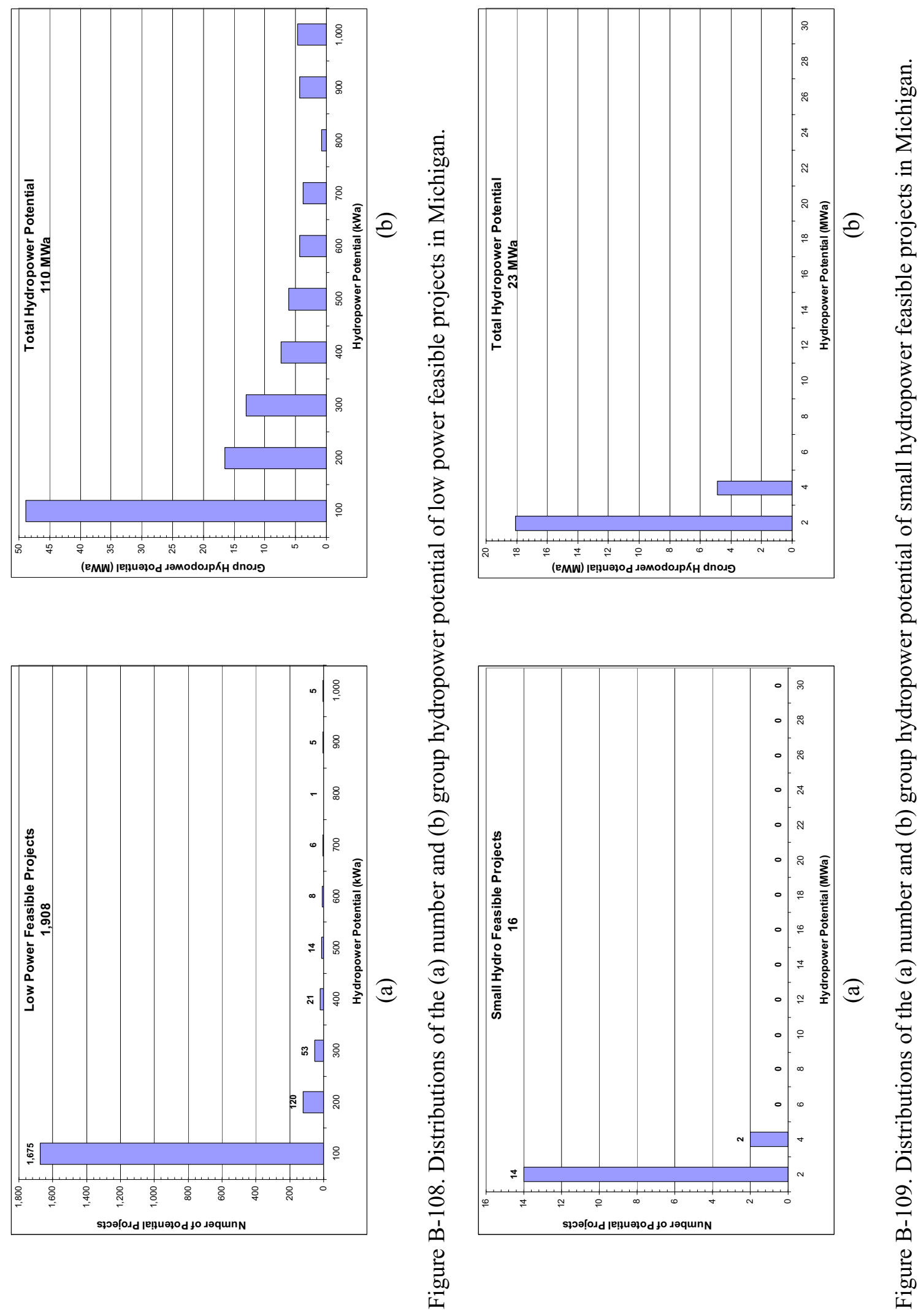

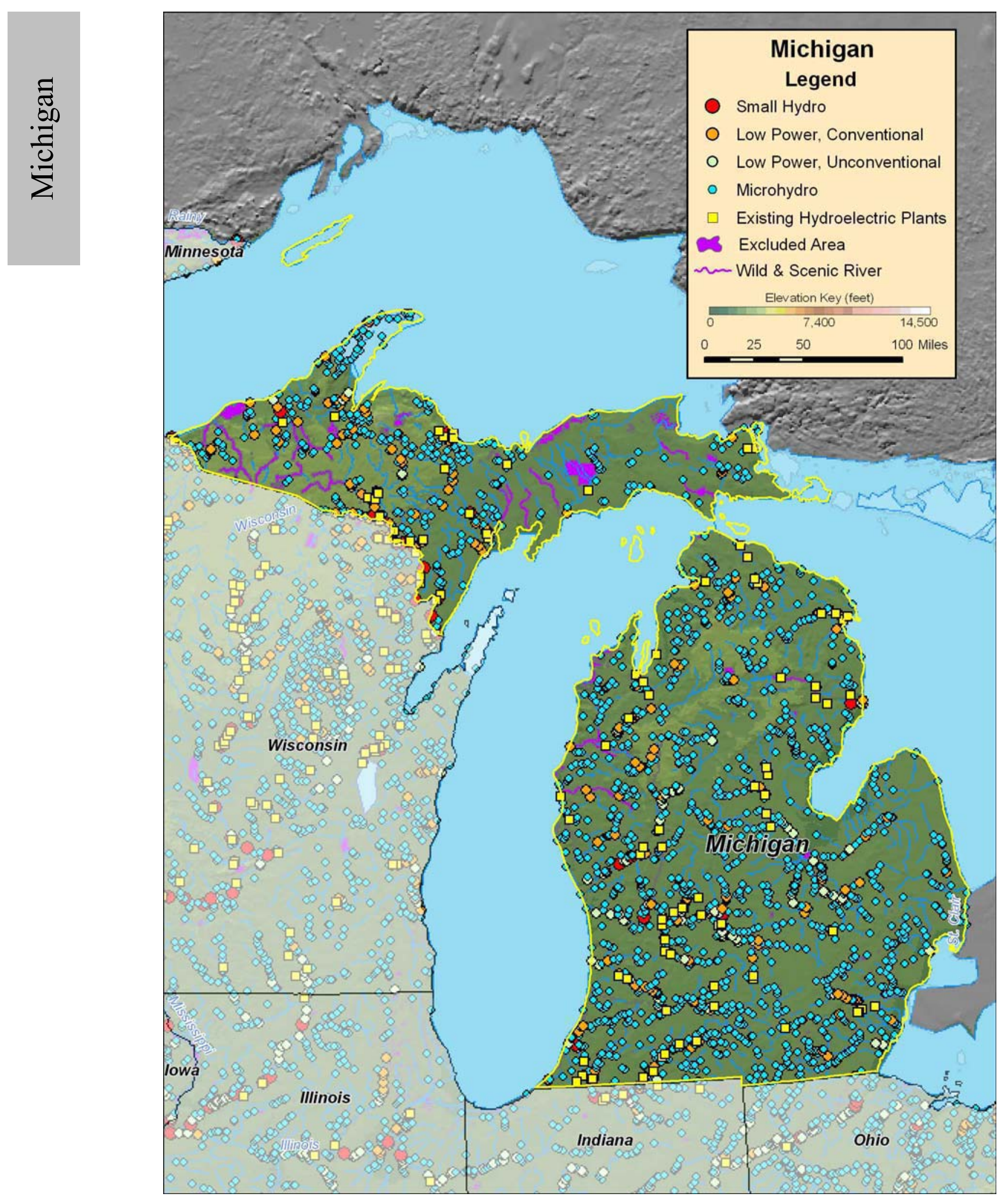

Figure B-110. Low power and small hydropower feasible projects, and existing hydroelectric plants in Michigan. 


\section{B.23 Minnesota}

Table B-47. Summary of results of water energy resource assessment of Minnesota.

\begin{tabular}{|c|c|c|c|c|c|}
\hline Power Class & $\begin{array}{c}\text { Total } \\
\mathbf{( M W a )}\end{array}$ & $\begin{array}{c}\text { Developed } \\
(\mathrm{MWa})\end{array}$ & $\begin{array}{c}\text { Federally } \\
\text { Excluded } \\
(\mathbf{M W a})\end{array}$ & $\begin{array}{c}\text { Other } \\
\text { Excluded } \\
(\mathbf{M W a})\end{array}$ & $\begin{array}{c}\text { Availlable } \\
(\mathrm{MWa})\end{array}$ \\
\hline Total Power & $\mathbf{1 , 4 3 3}$ & 153 & $\mathbf{3 1 1}$ & $\mathbf{1 7 3}$ & 797 \\
\hline Total High Power & & & & & \\
\hline Large Hydro & $\mathbf{8 1 1}$ & 147 & $\mathbf{2 5 0}$ & $\mathbf{1 1 2}$ & 302 \\
\hline Small Hydro & 123 & 74 & 48 & 0 & 0 \\
\hline & 688 & 73 & 201 & 112 & 302 \\
\hline Total Low Power & & & & & \\
\hline Conventional Turbines & $\mathbf{6 2 2}$ & 6 & 61 & $\mathbf{6 1}$ & 495 \\
\hline Unconventional Systems & 349 & 3 & 39 & 34 & 274 \\
\hline Microhydro & 85 & 2 & 11 & 11 & 60 \\
\hline
\end{tabular}

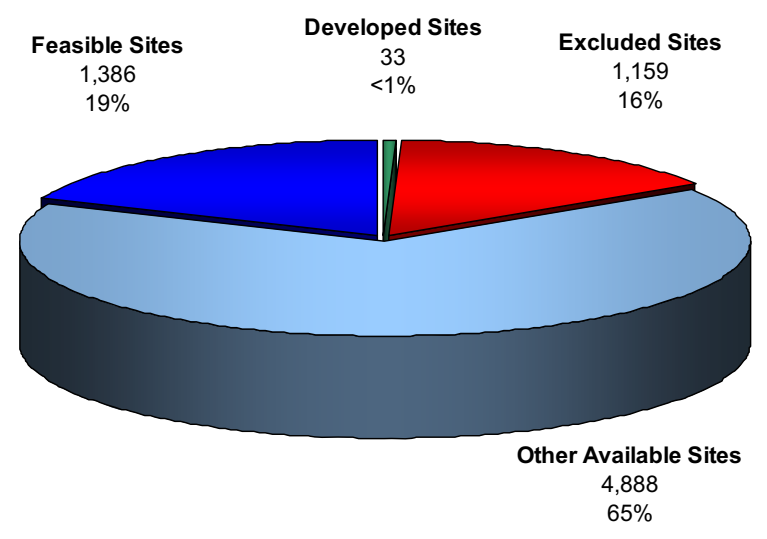

(a) Total Resource Sites 7,466

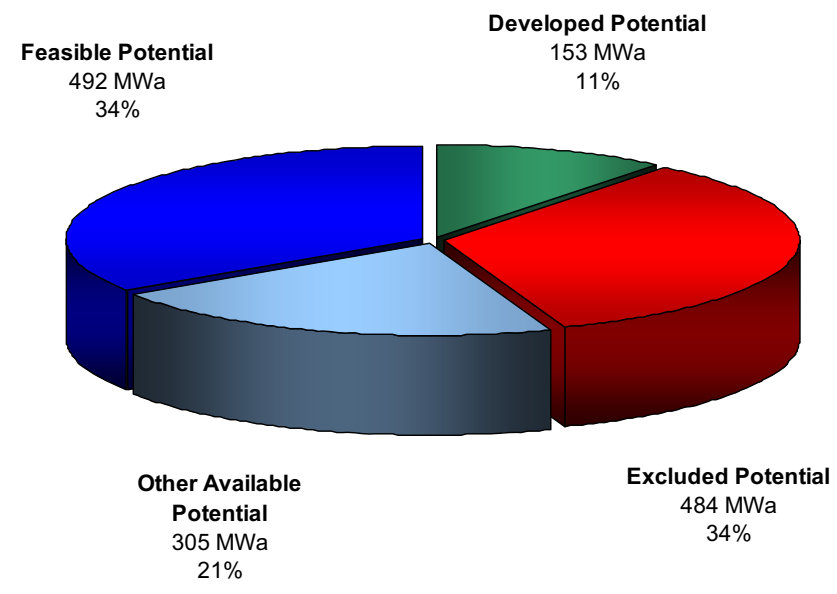

(b) Total Resource Potential $1,433 \mathrm{MWa}$

Figure B-111. Power category distribution of the (a) number and (b) total power potential of the water energy resource sites in Minnesota. 
Table B-48. Summary of results of feasibility assessment of water energy resources in Minnesota.

\begin{tabular}{|c|c|}
\hline Power Class & $\begin{array}{c}\text { Available } \\
\text { (MWa) }\end{array}$ \\
\hline Total Power & 797 \\
\hline & \\
\hline Total High Power & 302 \\
\hline Large Hydro & 0 \\
\hline Small Hydro & 302 \\
\hline & \\
\hline Total Low Power & 495 \\
\hline Conventional Turbines & 274 \\
\hline Unconventional Systems & 60 \\
\hline Microhydro & 161 \\
\hline
\end{tabular}

\begin{tabular}{|c|c|}
\hline $\begin{array}{c}\text { Feasible } \\
\text { Sites } \\
\text { (MWa) }\end{array}$ \\
\hline $\mathbf{4 9 2}$ \\
\hline \\
\hline $\mathbf{2 5 0}$ \\
\hline 0 \\
\hline 250 \\
\hline \\
\hline $\mathbf{2 4 2}$ \\
\hline 161 \\
\hline 46 \\
\hline 36 \\
\hline
\end{tabular}

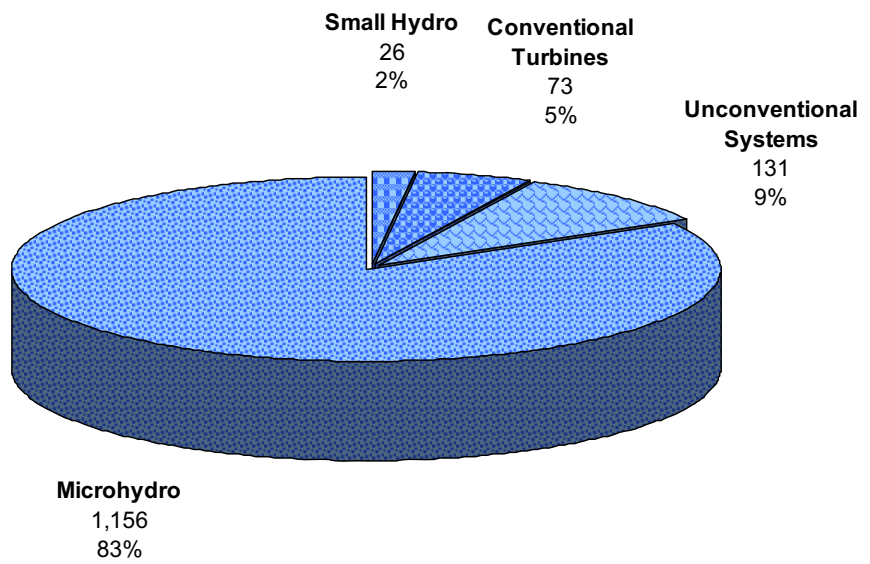

(a) Total Feasible Projects 1,386

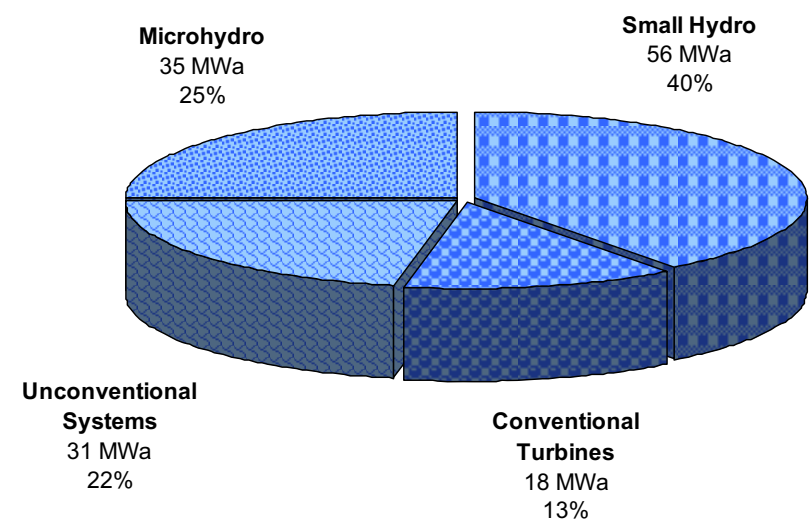

(b) Total Feasible Project Hydropower Potential $140 \mathrm{MWa}$

Figure B-112. Distribution of the (a) number and (b) total hydropower potential of the low power and small hydropower feasible projects in Minnesota with the low power projects divided into technology classes. 

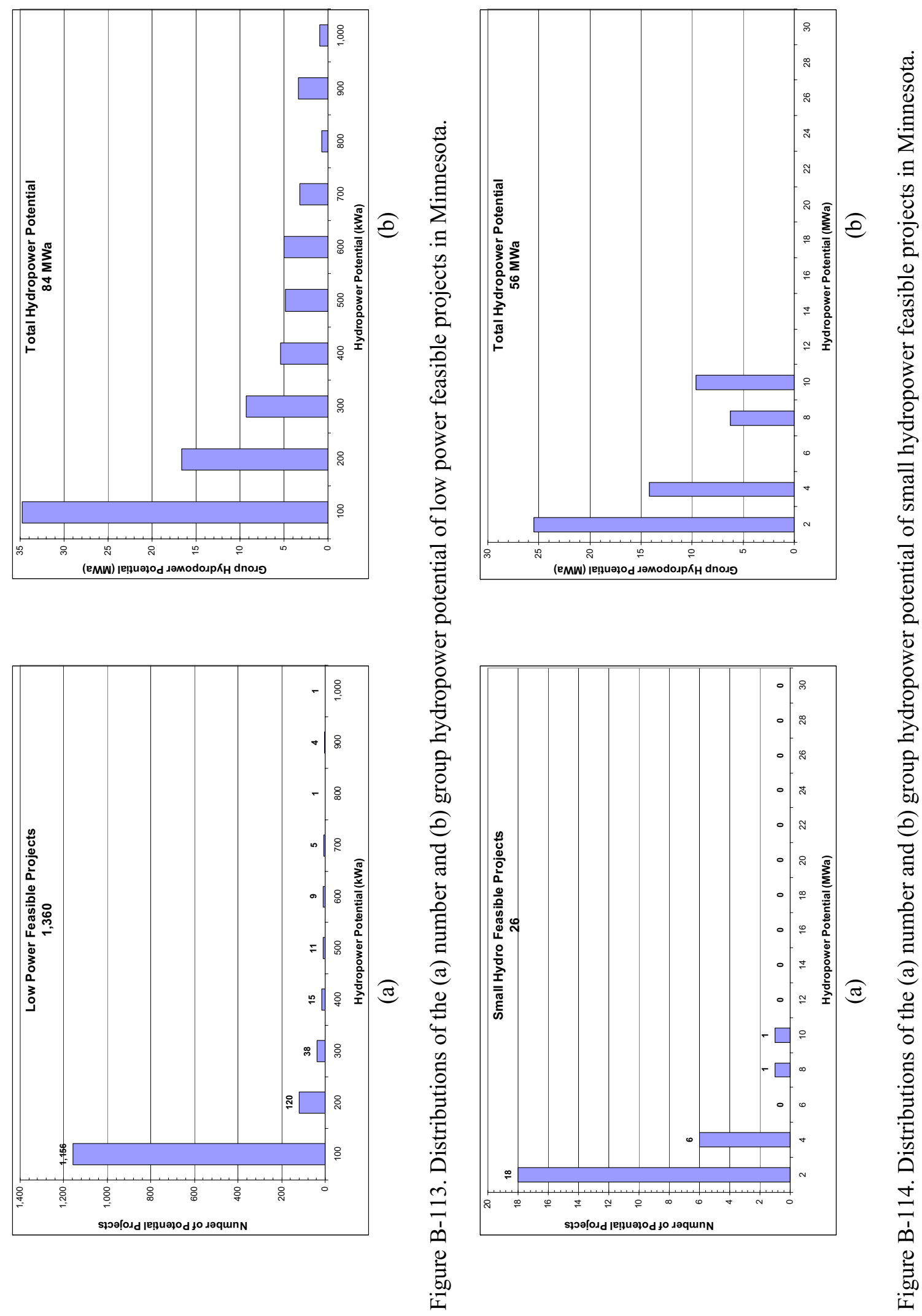
$\pi$
0
0
0
0
$\vdots$
$\Sigma$

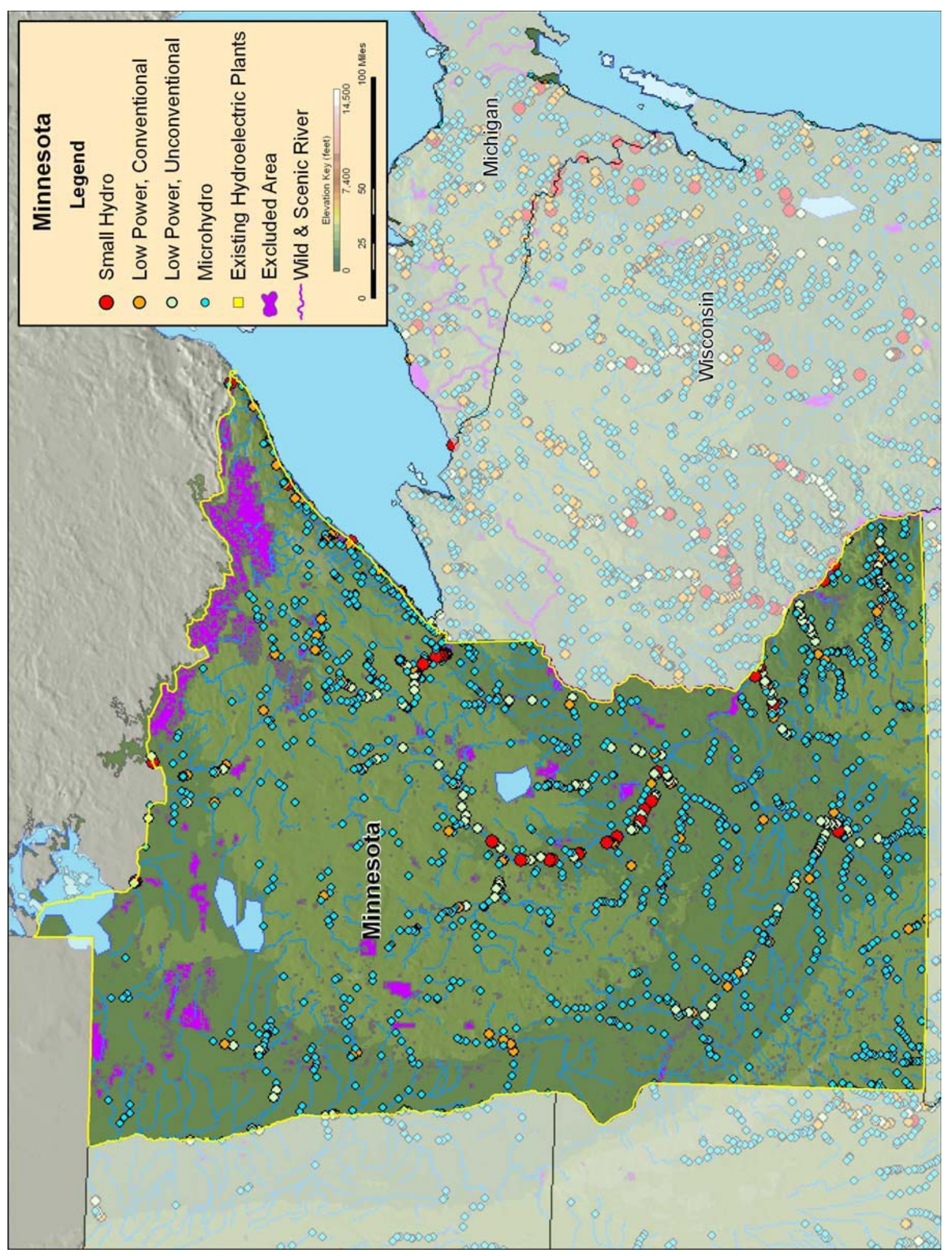

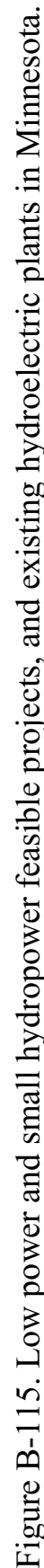




\section{B.24 Mississippi}

Table B-49. Summary of results of water energy resource assessment of Mississippi.

\begin{tabular}{|c|c|c|c|c|c|}
\hline Power Class & $\begin{array}{c}\text { Total } \\
(\mathbf{M W a})\end{array}$ & $\begin{array}{c}\text { Developed } \\
(\mathrm{MWa})\end{array}$ & $\begin{array}{c}\text { Federally } \\
\text { Excluded } \\
(\mathbf{M W a})\end{array}$ & $\begin{array}{c}\text { Other } \\
\text { Excluded } \\
(\mathrm{MWa})\end{array}$ & $\begin{array}{c}\text { Available } \\
(\mathrm{MWa})\end{array}$ \\
\hline Total Power & $\mathbf{2 , 8 2 3}$ & $\mathbf{0}$ & $\mathbf{2 6 5}$ & $\mathbf{1 6}$ & 2,542 \\
\hline Total High Power & $\mathbf{2 , 2 3 5}$ & 0 & $\mathbf{2 3 3}$ & $\mathbf{1 2}$ & 1,990 \\
\hline Large Hydro & 1,684 & 0 & 182 & 0 & 1,502 \\
\hline Small Hydro & $\mathbf{5 5 2}$ & 0 & 51 & 12 & 489 \\
\hline & & & & & \\
\hline Total Low Power & $\mathbf{5 8 8}$ & 0 & 31 & $\mathbf{4}$ & 552 \\
\hline Conventional Turbines & $\mathbf{2 4 8}$ & 0 & 15 & 1 & 232 \\
\hline Unconventional Systems & 137 & 0 & 7 & 2 & 128 \\
\hline Microhydro & $\mathbf{2 0 2}$ & 0 & 9 & 1 & 192 \\
\hline
\end{tabular}

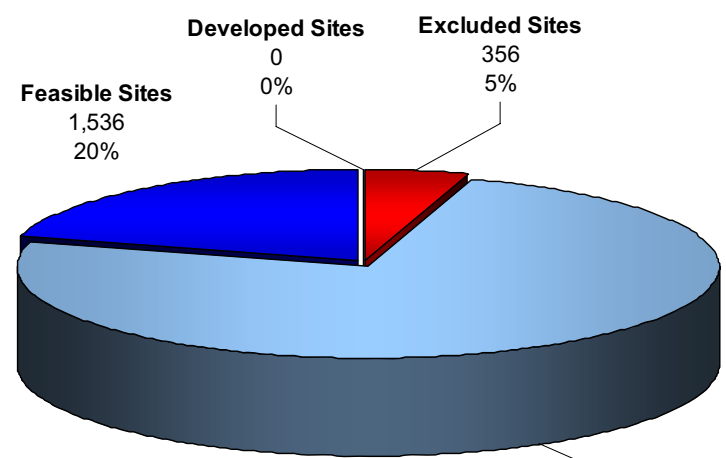

Other Available Sites

$$
5,605
$$

(a) Total Resource Sites

7,497

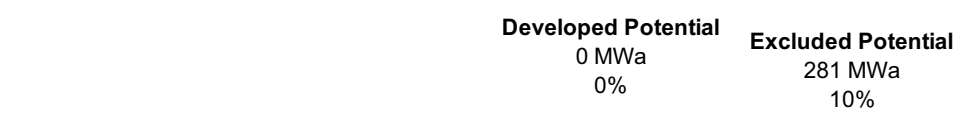

Feasible Potential $1,406 \mathrm{MWa}$ $50 \%$
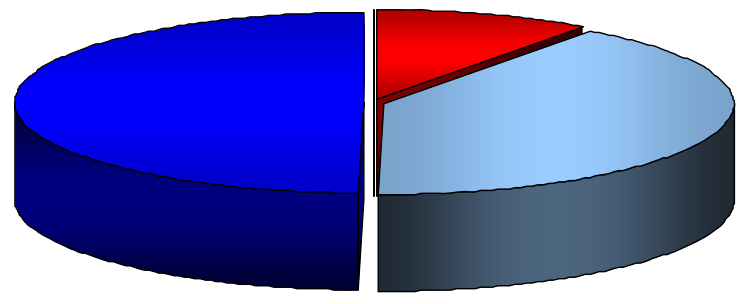

Other Available

Potential

$1,137 \mathrm{MWa}$ $40 \%$

(b) Total Resource Potential 2,823 MWa

Figure B-116. Power category distribution of the (a) number and (b) total power potential of the water energy resource sites in Mississippi. 
Table B-50. Summary of results of feasibility assessment of water energy resources in Mississippi.

\begin{tabular}{|c|c|}
\hline Power Class & $\begin{array}{c}\text { Available } \\
(\mathrm{MWa})\end{array}$ \\
\hline Total Power & $\mathbf{2 , 5 4 2}$ \\
\hline Total High Power & 1,990 \\
\hline Large Hydro & 1,502 \\
\hline Small Hydro & 489 \\
\hline & \\
\hline Total Low Power & 552 \\
\hline Conventional Turbines & 232 \\
\hline Unconventional Systems & 128 \\
\hline Microhydro & 192 \\
\hline
\end{tabular}

\begin{tabular}{|c|c|}
\hline $\begin{array}{c}\text { Feasible } \\
\text { Sites } \\
\text { (MWa) }\end{array}$ & $\begin{array}{c}\text { Feasible } \\
\text { Projects } \\
\text { (MWa) }\end{array}$ \\
\hline 1,406 & 298 \\
\hline 1,121 & 194 \\
\hline 736 & 0 \\
\hline 386 & 194 \\
\hline 284 & 104 \\
\hline 162 & 9 \\
\hline 92 & 59 \\
\hline 31 & 36 \\
\hline
\end{tabular}

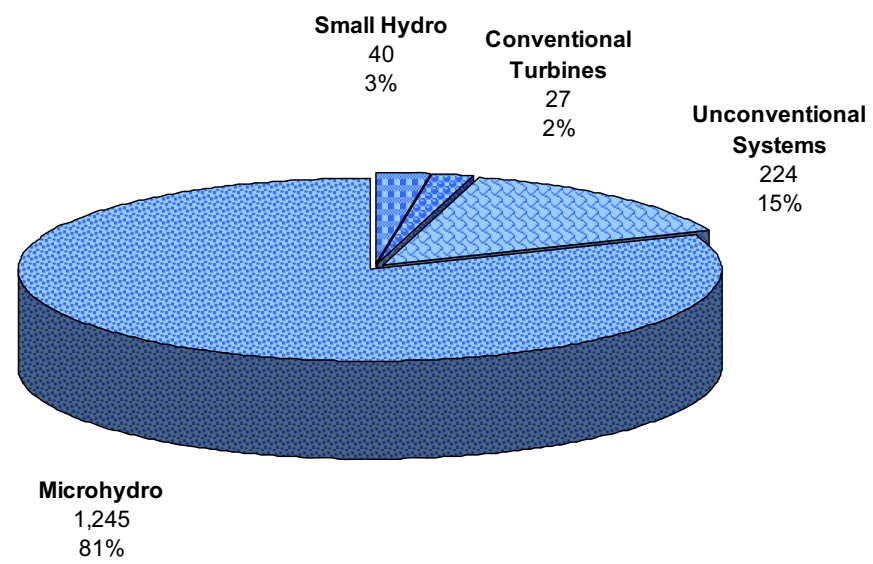

(a) Total Feasible Projects 1,536

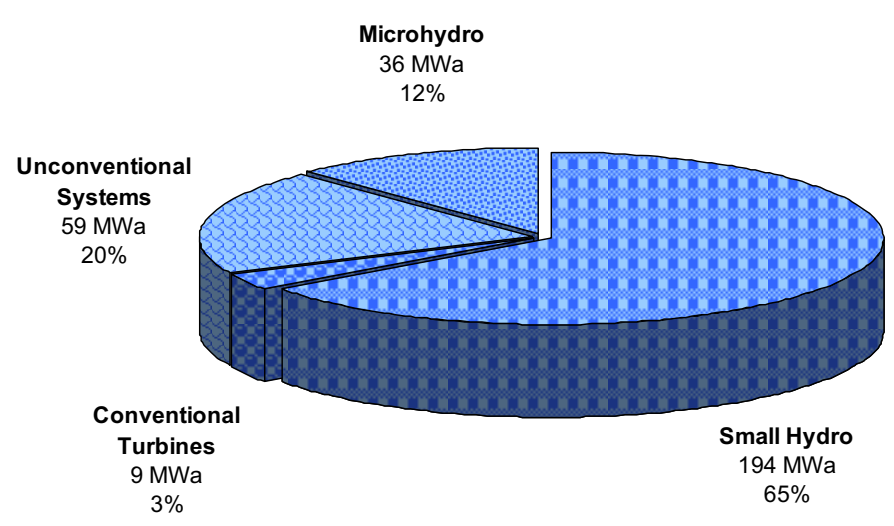

(a) Total Feasible Project Hydropower Potential $298 \mathrm{MWa}$

Figure B-117. Distribution of the (a) number and (b) total hydropower potential of the low power and small hydropower feasible projects in Mississippi with the low power projects divided into technology classes Mississippi. 

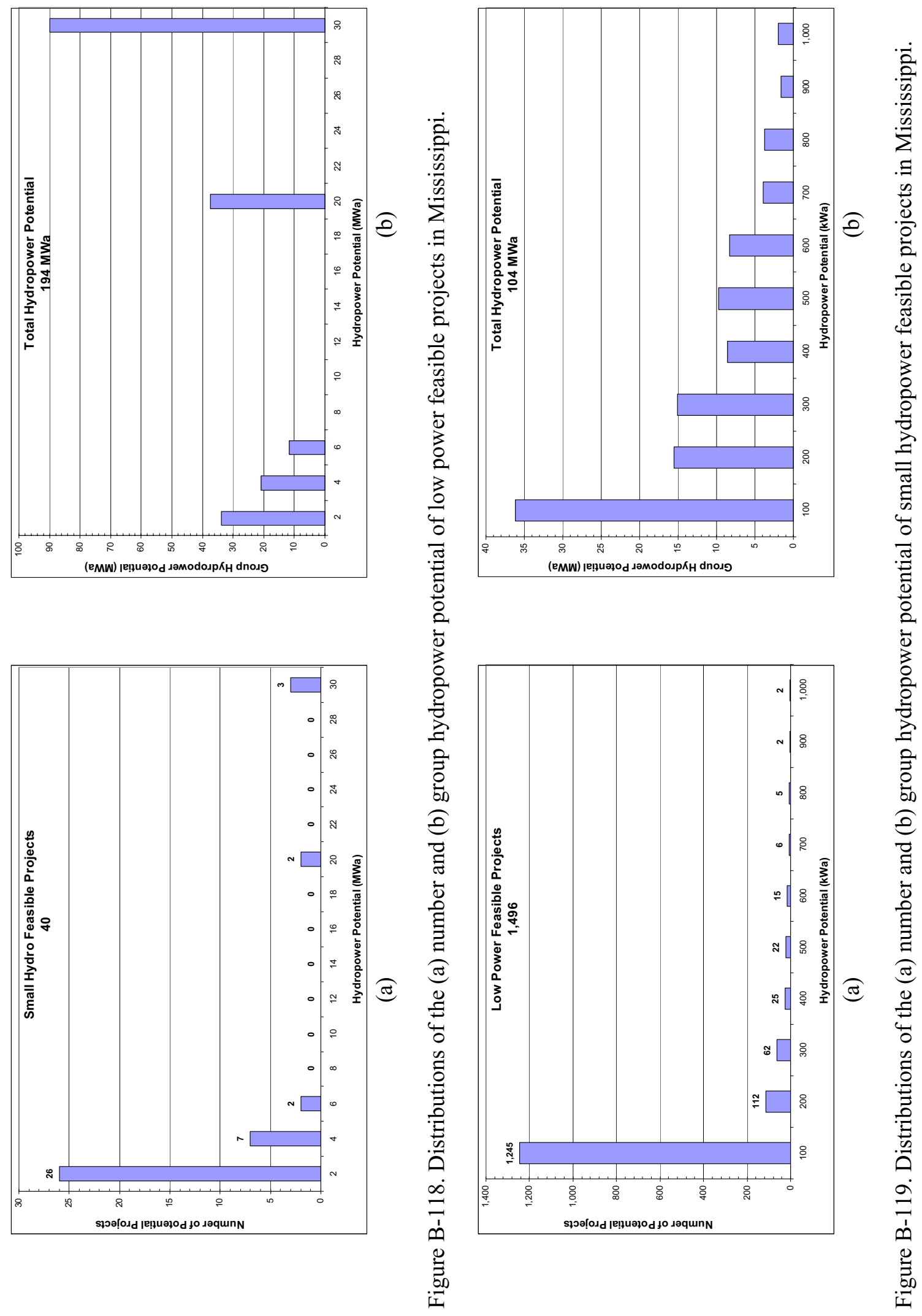

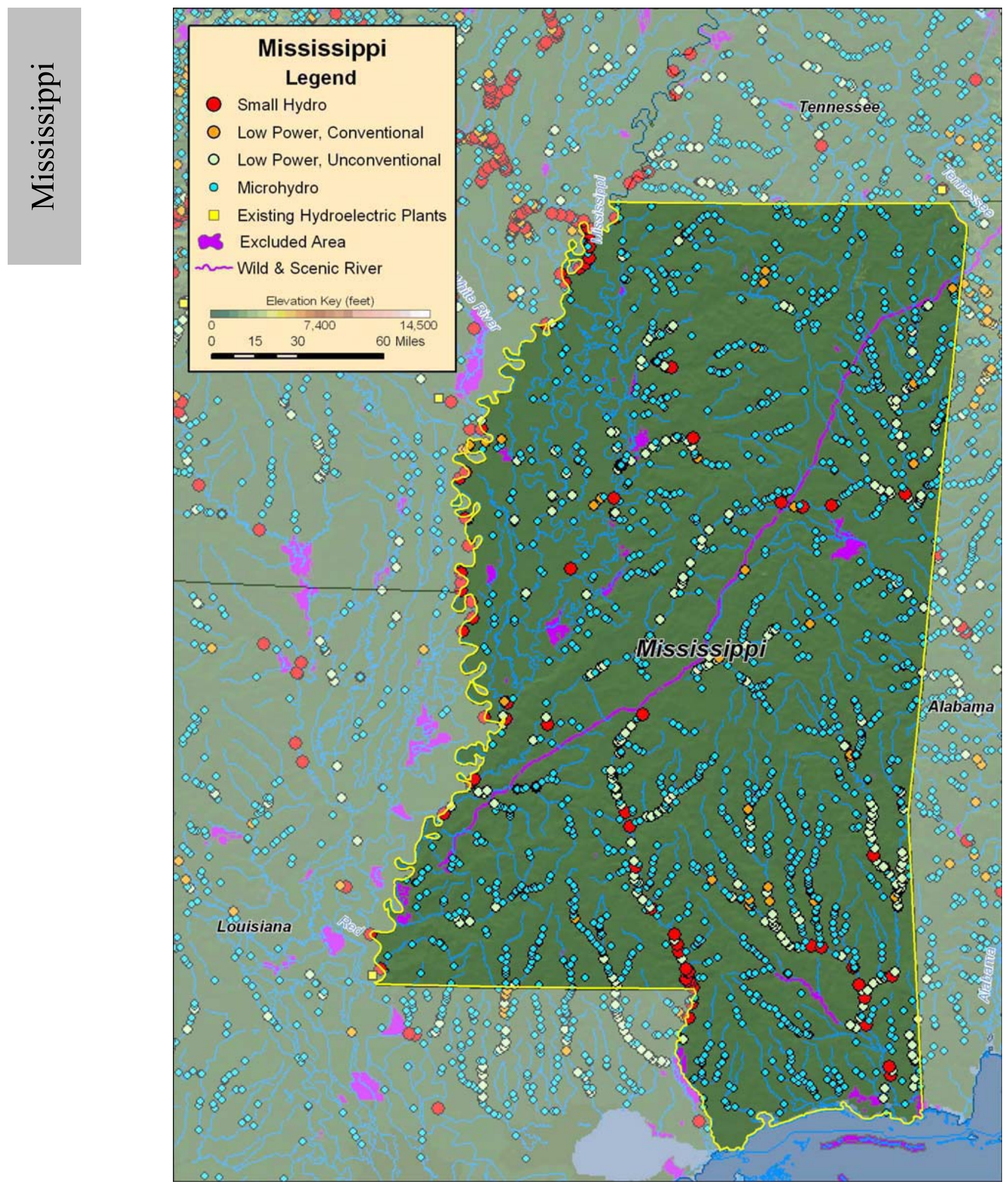

Figure B-120. Low power and small hydropower feasible projects, and existing hydroelectric plants in Mississippi. 


\section{B.25 Missouri}

Table B-51. Summary of results of water energy resource assessment of Missouri.

\begin{tabular}{|c|c|c|c|c|c|}
\hline Power Class & $\begin{array}{c}\text { Total } \\
\mathbf{( M W a )}\end{array}$ & $\begin{array}{c}\text { Developed } \\
(\mathrm{MWa})\end{array}$ & $\begin{array}{c}\text { Federally } \\
\text { Excluded } \\
(\mathbf{M W a})\end{array}$ & $\begin{array}{c}\text { Other } \\
\text { Excluded } \\
(\mathbf{M W a})\end{array}$ & $\begin{array}{c}\text { Available } \\
(\mathrm{MWa})\end{array}$ \\
\hline Total Power & $\mathbf{3 , 4 9 9}$ & 109 & 111 & 117 & 3,162 \\
\hline Total High Power & & & & & \\
\hline Large Hydro & $\mathbf{2 , 5 6 3}$ & 107 & $\mathbf{6 4}$ & $\mathbf{6 9}$ & 2,323 \\
\hline Small Hydro & 1,571 & 63 & 0 & 0 & 1,508 \\
\hline & $\mathbf{9 9 2}$ & 45 & 64 & 69 & 814 \\
\hline Total Low Power & & & & & \\
\hline Conventional Turbines & $\mathbf{9 3 6}$ & $\mathbf{2}$ & $\mathbf{4 7}$ & $\mathbf{4 8}$ & 839 \\
\hline Unconventional Systems & $\mathbf{4 9 9}$ & 2 & 31 & 36 & 431 \\
\hline Microhydro & 110 & 0 & 10 & 5 & 95 \\
\hline
\end{tabular}

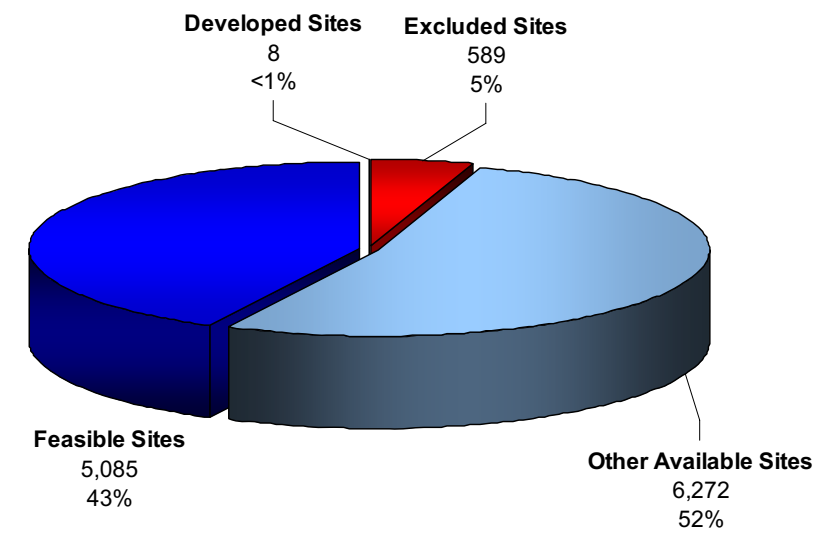

(a) Total Resource Sites 11,954

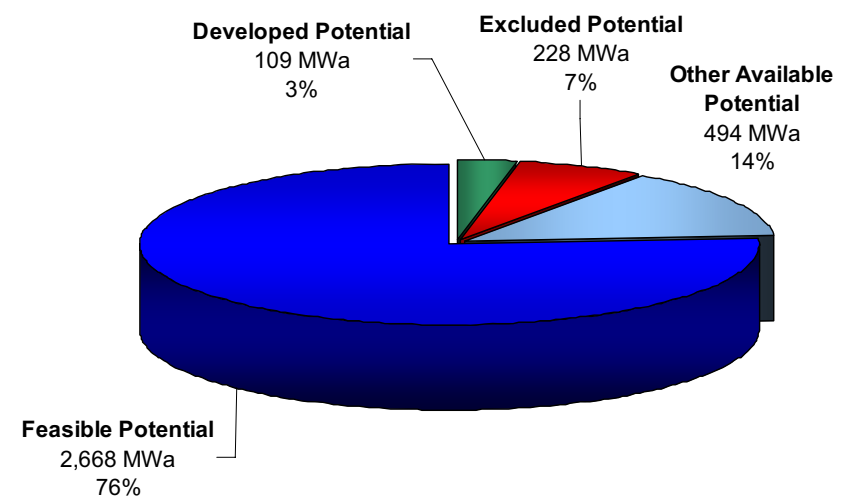

(b) Total Resource Potential 3,499 MWa

Figure B-121. Power category distribution of the (a) number and (b) total power potential of the water energy resource sites in Missouri. 
Table B-52. Summary of results of feasibility assessment of water energy resources in Missouri.

\begin{tabular}{|c|c|}
\hline Power Class & $\begin{array}{c}\text { Available } \\
(\mathrm{MWa})\end{array}$ \\
\hline Total Power & 3,162 \\
\hline Total High Power & 2,323 \\
\hline Large Hydro & 1,508 \\
\hline Small Hydro & 814 \\
\hline & \\
\hline Total Low Power & 839 \\
\hline Conventional Turbines & 431 \\
\hline Unconventional Systems & 95 \\
\hline Microhydro & 314 \\
\hline
\end{tabular}
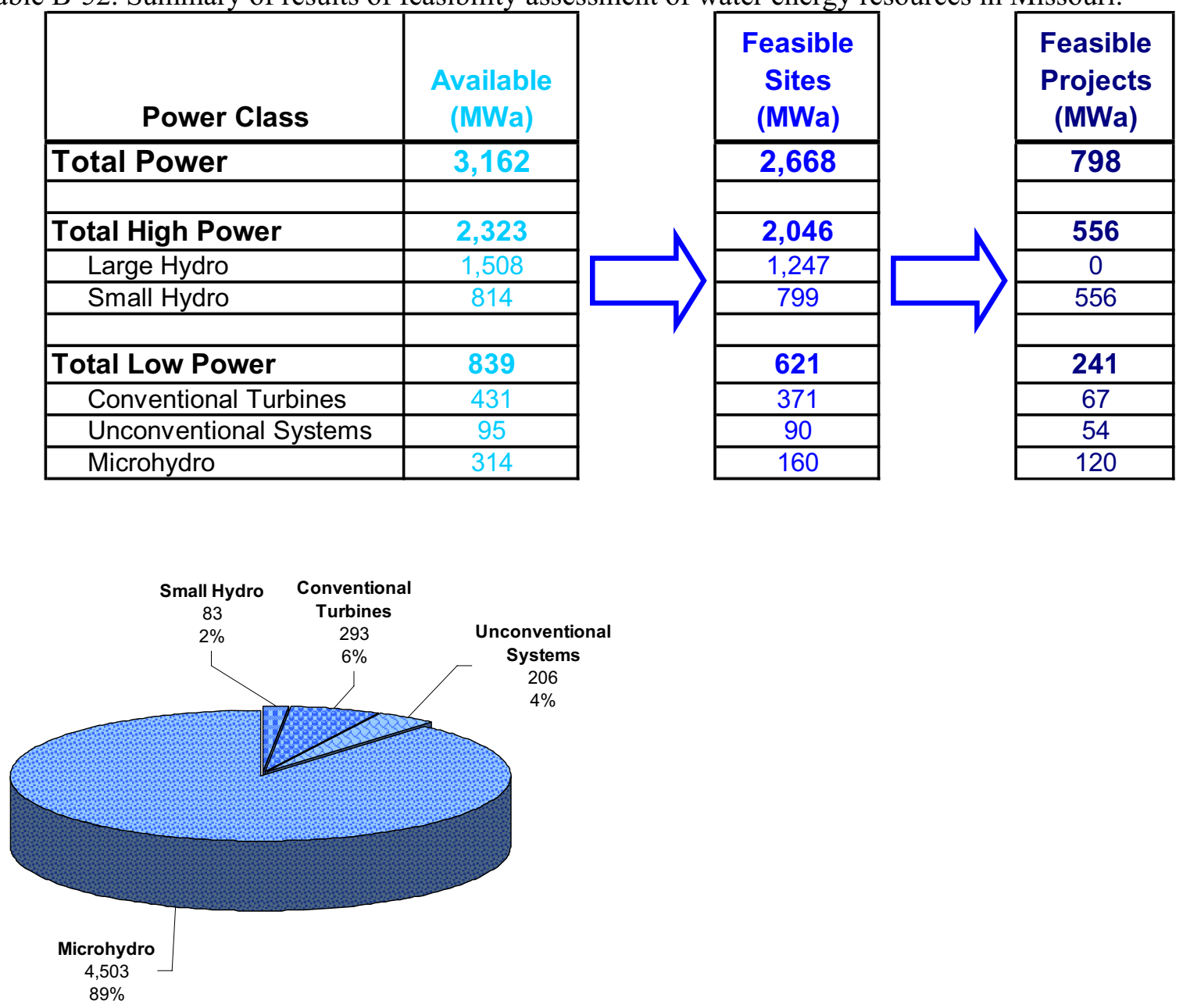

(a) Total Feasible Projects 5,085

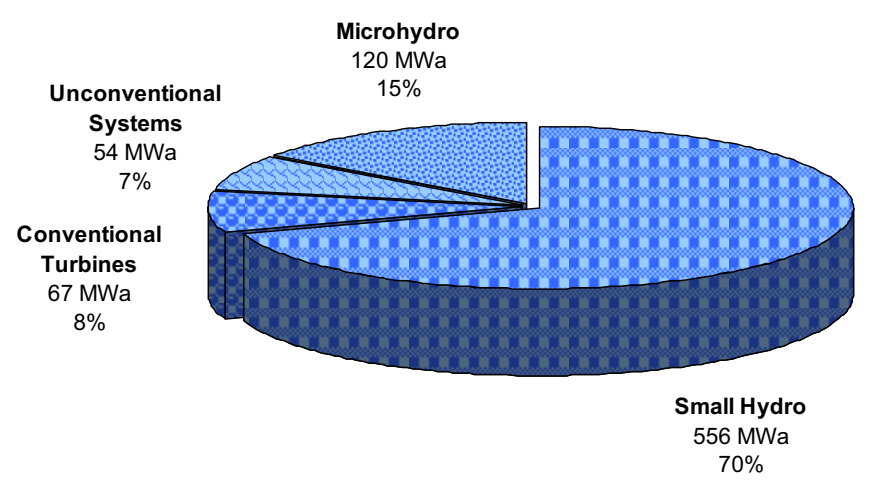

(b) Total Feasible Project Hydropower Potential $798 \mathrm{MWa}$

Figure B-122. Distribution of the (a) number and (b) total hydropower potential of the low power and small hydropower feasible projects in Missouri with the low power projects divided into technology classes. 

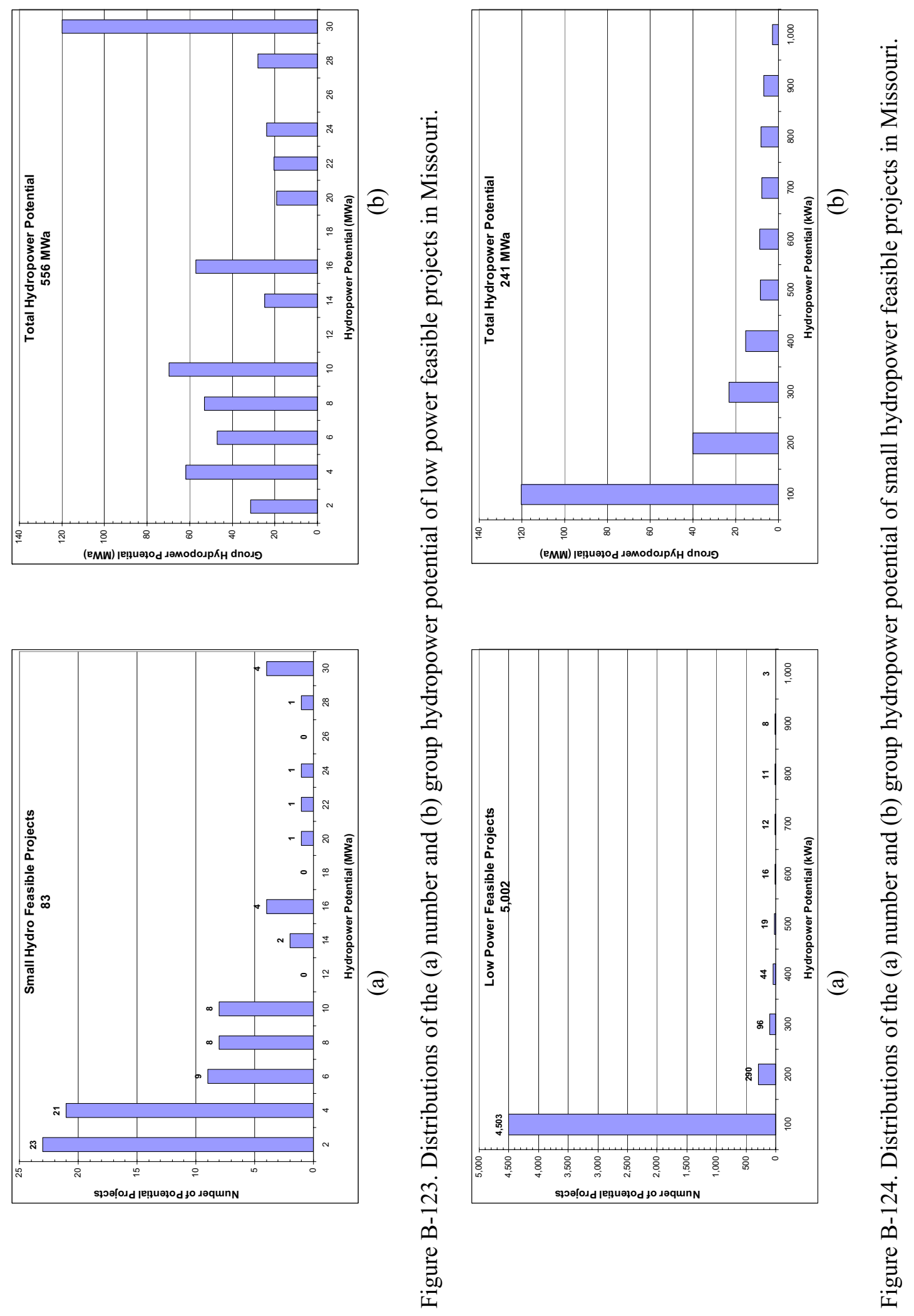


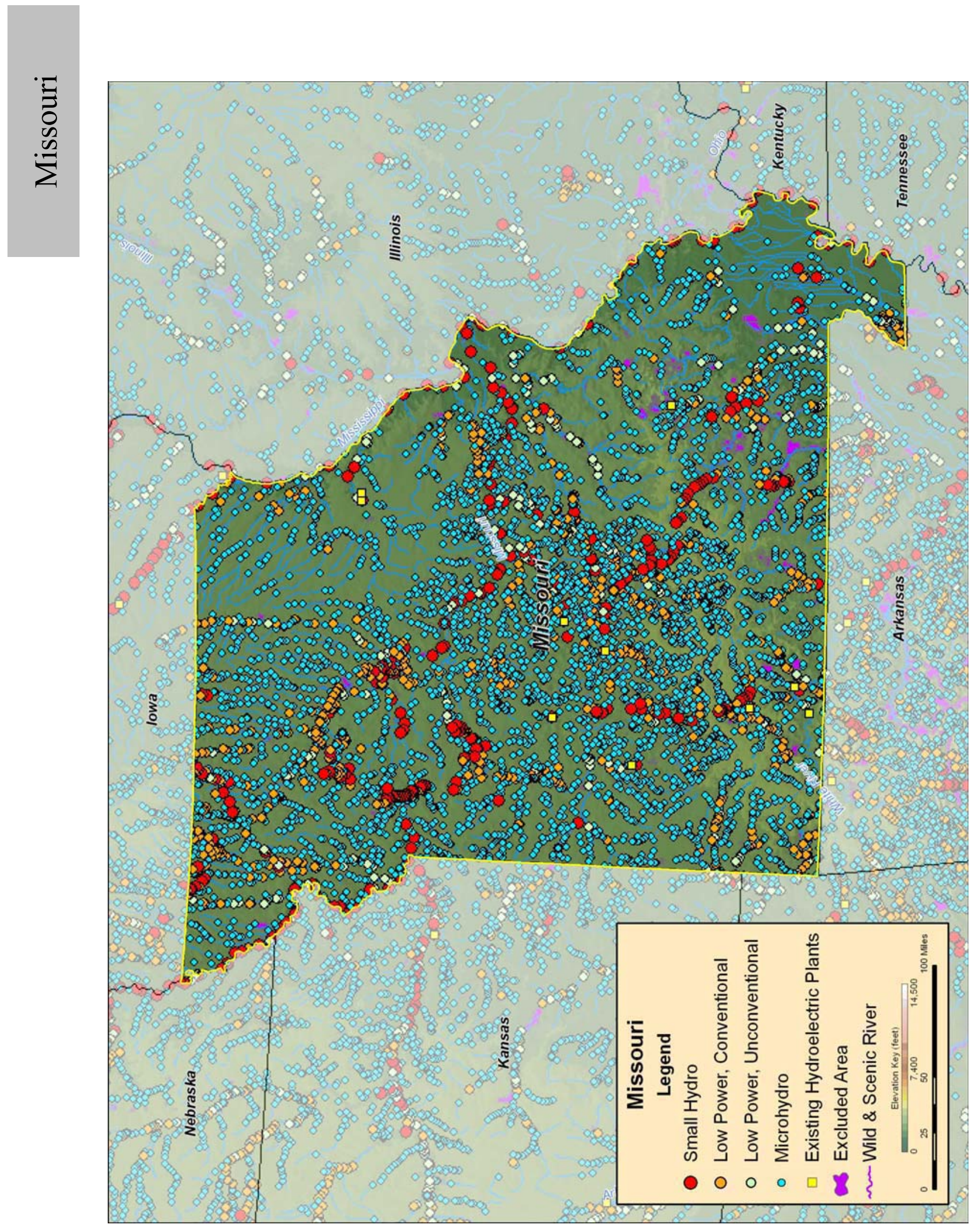

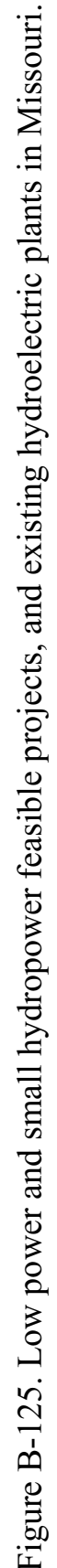




\section{B.26 Montana}

Table B-53. Summary of results of water energy resource assessment of Montana.

\begin{tabular}{|l|c|c|c|c|c|}
\hline \multicolumn{1}{|c|}{ Power Class } & $\begin{array}{c}\text { Total } \\
\mathbf{( M W a )}\end{array}$ & $\begin{array}{c}\text { Developed } \\
(\mathbf{M W a})\end{array}$ & $\begin{array}{c}\text { Federally } \\
\text { Excluded } \\
(\mathbf{M W a})\end{array}$ & $\begin{array}{c}\text { Other } \\
\text { Excluded } \\
(\mathbf{M W a})\end{array}$ & $\begin{array}{c}\text { Available } \\
(\mathrm{MWa})\end{array}$ \\
\hline Total Power & $\mathbf{1 2 , 4 5 6}$ & $\mathbf{1 , 0 9 1}$ & $\mathbf{3 , 4 0 6}$ & $\mathbf{1 , 0 5 4}$ & 6,904 \\
\hline Total High Power & & & & & \\
\hline Large Hydro & $\mathbf{9 , 4 4 6}$ & $\mathbf{1 , 0 8 7}$ & $\mathbf{2 , 9 1 5}$ & $\mathbf{7 9 3}$ & 4,650 \\
\hline Small Hydro & 1,280 & 901 & 104 & 33 & 241 \\
\hline & $\mathbf{8 , 1 6 6}$ & 186 & 2,811 & 760 & 4,408 \\
\hline Total Low Power & & & & & \\
\hline Conventional Turbines & $\mathbf{3 , 0 1 0}$ & $\mathbf{4}$ & $\mathbf{4 9 1}$ & $\mathbf{2 6 1}$ & 2,254 \\
\hline Unconventional Systems & $\mathbf{2 , 5 1 9}$ & 4 & 453 & 239 & 1,822 \\
\hline Microhydro & 141 & 0 & 23 & 5 & 113 \\
\hline
\end{tabular}

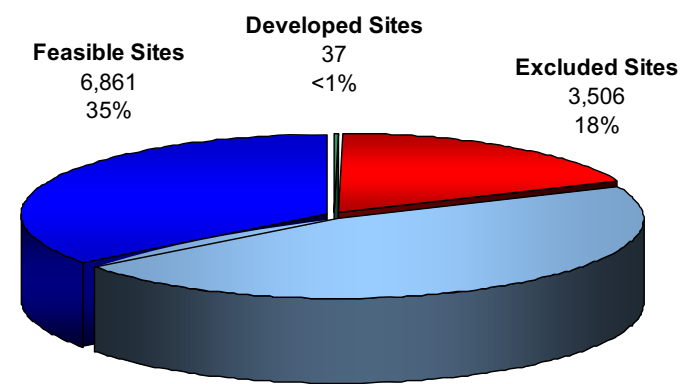

Other Available Sites 8,981

(a) Total Resource Sites 19,385

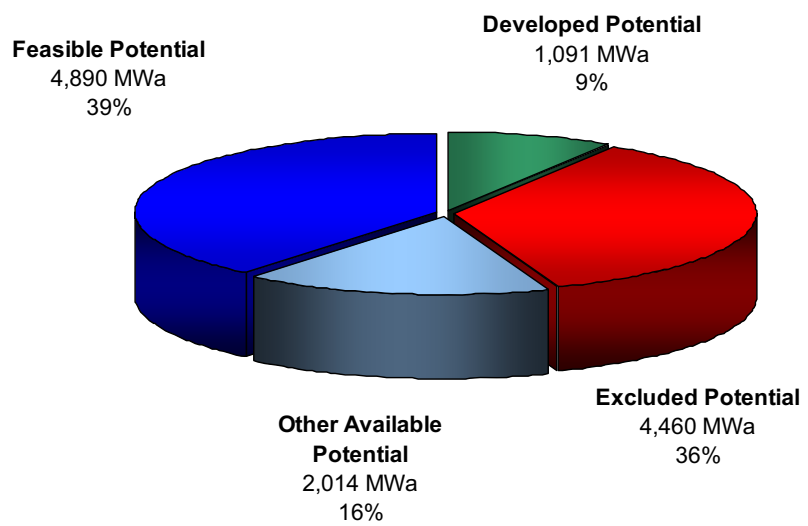

(b) Total Resource Potential 12,456 MWa

Figure B-126. Power category distribution of the (a) number and (b) total power potential of the water energy resource sites in Montana. 
Table B-54. Summary of results of feasibility assessment of water energy resources in Montana.

\begin{tabular}{|c|c|}
\hline Power Class & $\begin{array}{c}\text { Available } \\
\text { (MWa) }\end{array}$ \\
\hline Total Power & 6,904 \\
\hline Total High Power & 4,650 \\
\hline Large Hydro & 241 \\
\hline Small Hydro & 4,408 \\
\hline & \\
\hline Total Low Power & 2,254 \\
\hline Conventional Turbines & 1,822 \\
\hline Unconventional Systems & 113 \\
\hline Microhydro & 319 \\
\hline
\end{tabular}

\begin{tabular}{|c|c|}
\hline $\begin{array}{c}\text { Feasible } \\
\text { Sites } \\
\text { (MWa) }\end{array}$ \\
\hline $\mathbf{4 , 8 9 0}$ \\
\hline \\
\hline $\mathbf{3 , 6 1 7}$ \\
\hline 241 \\
\hline 3,375 \\
\hline \\
\hline $\mathbf{1 , 2 7 4}$ \\
\hline 1,045 \\
\hline 94 \\
\hline 134 \\
\hline
\end{tabular}

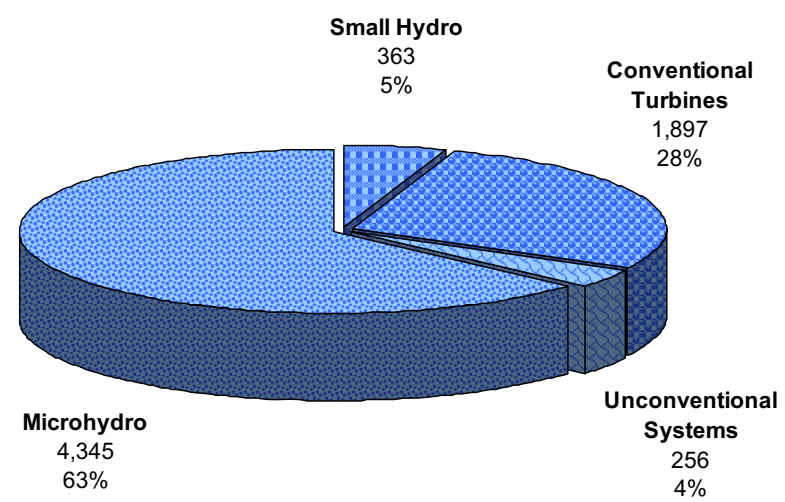

(a) Total Feasible Projects

6,861

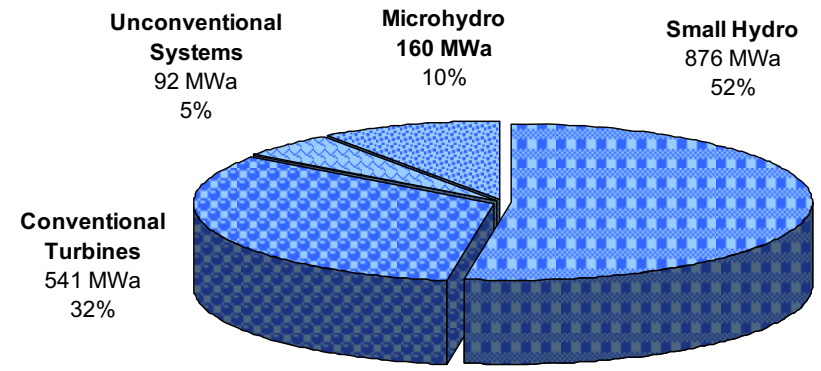

(b) Total Feasible Project Hydropower Potential $1,669 \mathrm{MWa}$

Figure B-127. Distribution of the (a) number and (b) total hydropower potential of the low power and small hydropower feasible projects in Montana with the low power projects divided into technology classes. 

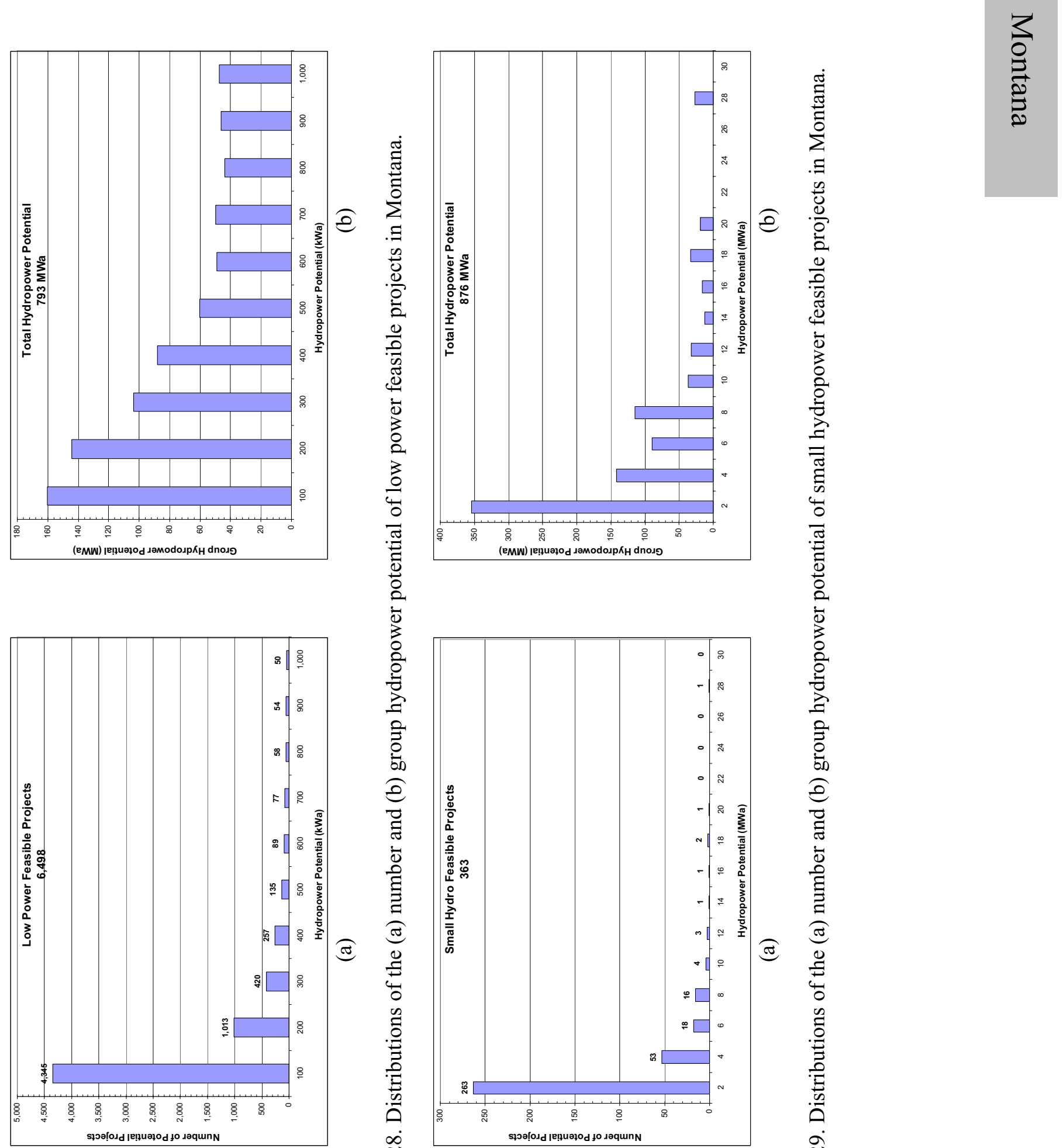

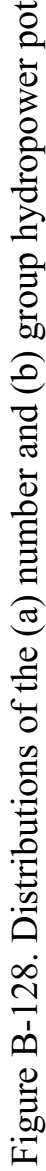

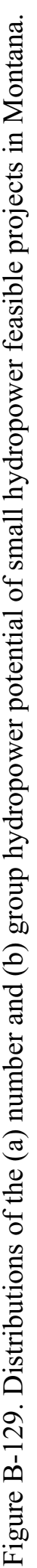




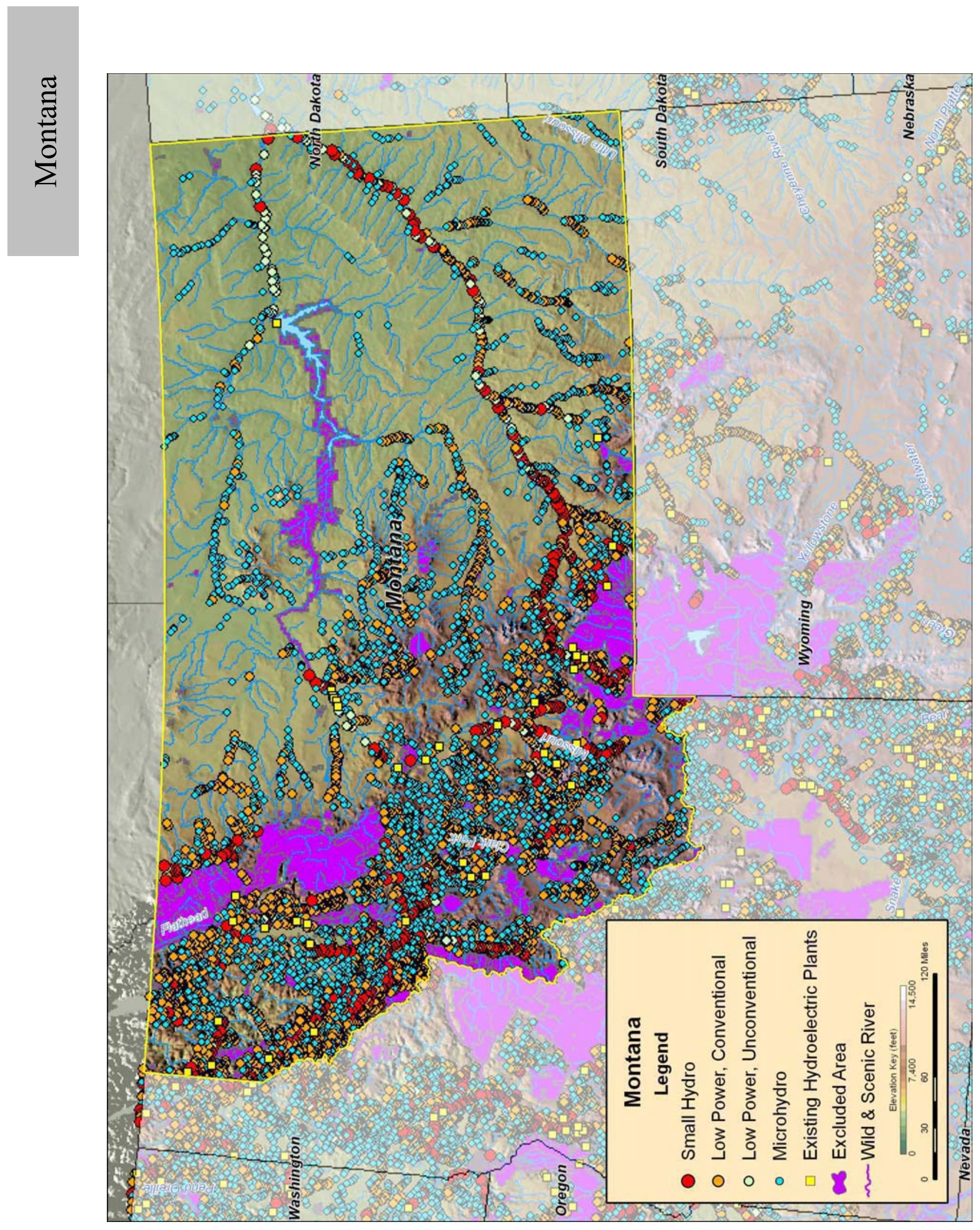

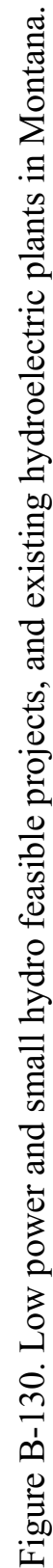




\section{B.27 Nebraska}

Table B-55. Summary of results of water energy resource assessment of Nebraska.

\begin{tabular}{|c|c|c|c|c|c|}
\hline Power Class & $\begin{array}{c}\text { Total } \\
(\mathbf{M W a})\end{array}$ & $\begin{array}{c}\text { Developed } \\
(\mathrm{MWa})\end{array}$ & $\begin{array}{c}\text { Federally } \\
\text { Excluded } \\
(\mathbf{M W a})\end{array}$ & $\begin{array}{c}\text { Other } \\
\text { Excluded } \\
(\mathbf{M W a})\end{array}$ & $\begin{array}{c}\text { Available } \\
(\mathrm{MWa})\end{array}$ \\
\hline Total Power & $\mathbf{1 , 1 7 7}$ & $\mathbf{3 4}$ & $\mathbf{6 8}$ & $\mathbf{3 3}$ & 1,041 \\
\hline Total High Power & & & & & \\
\hline Large Hydro & $\mathbf{5 5 4}$ & 33 & 33 & $\mathbf{2 6}$ & 462 \\
\hline Small Hydro & 0 & 0 & 0 & 0 & 0 \\
\hline Total Low Power & 554 & 33 & 33 & 26 & 462 \\
\hline Conventional Turbines & & & & & \\
\hline Unconventional Systems & $\mathbf{6 2 3}$ & 1 & 35 & $\mathbf{7}$ & 579 \\
\hline Microhydro & $\mathbf{3 7 5}$ & 1 & 26 & 5 & 343 \\
\hline
\end{tabular}

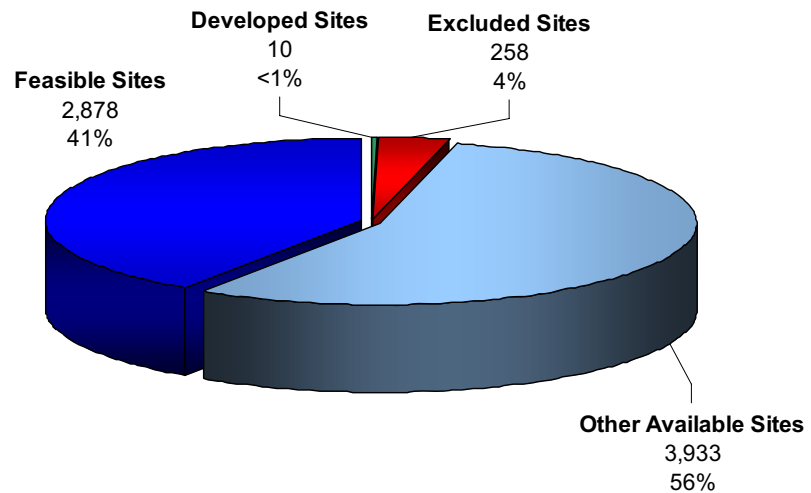

(a) Total Resource Sites 7,079

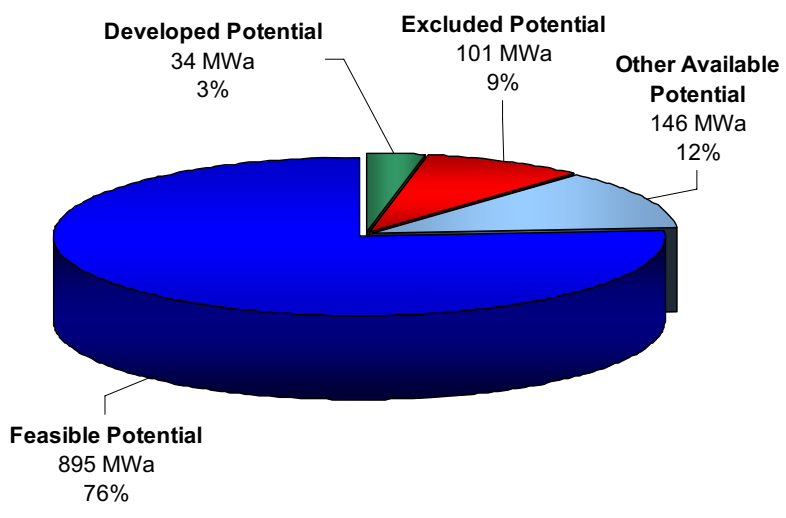

(b) Total Resource Potential $1,177 \mathrm{MWa}$

Figure B-131. Power category distribution of the (a) number and (b) total power potential of the water energy resource sites in Nebraska. 
Table B-56. Summary of results of feasibility assessment of water energy resources in Nebraska.

\begin{tabular}{|c|c|c|c|}
\hline Power Class & $\begin{array}{c}\text { Available } \\
\text { (MWa) }\end{array}$ & $\begin{array}{c}\text { Feasible } \\
\text { Sites } \\
\text { (MWa) }\end{array}$ & $\begin{array}{c}\text { Feasible } \\
\text { Projects } \\
\text { (MWa) }\end{array}$ \\
\hline Total Power & 1,041 & 895 & 354 \\
\hline Total High Power & 462 & 451 & 81 \\
\hline Large Hydro & 0 & 0 & 0 \\
\hline Small Hydro & 462 & 451 & 81 \\
\hline Total Low Power & 579 & 444 & 273 \\
\hline Conventional Turbines & 343 & 293 & 161 \\
\hline Unconventional Systems & 72 & 69 & 42 \\
\hline Microhydro & 164 & 82 & 70 \\
\hline
\end{tabular}

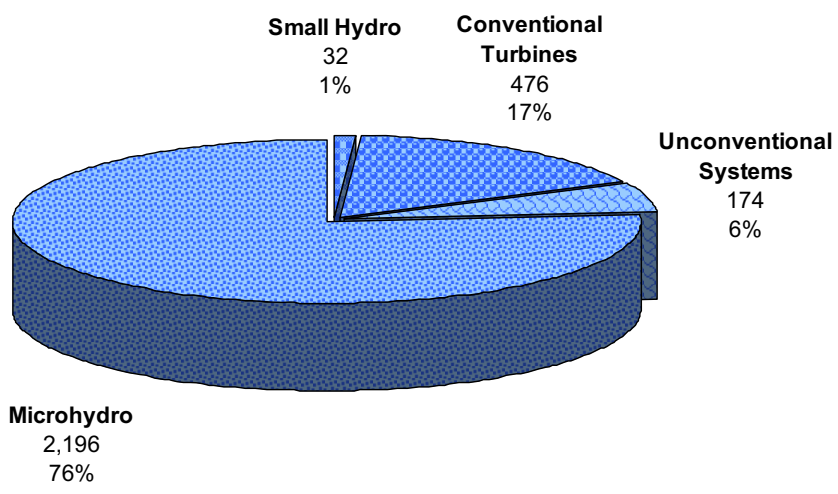

(a) Total Feasible Projects

2,878

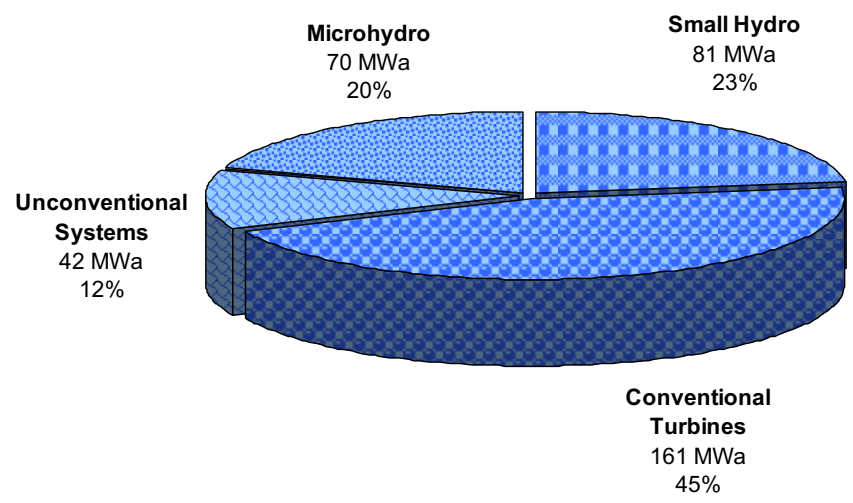

(b) Total Feasible Project Hydropower Potential $354 \mathrm{MWa}$

Figure B-132. Distribution of the (a) number and (b) total hydropower potential of the low power and small hydropower feasible projects in Nebraska with the low power projects divided into technology classes. 

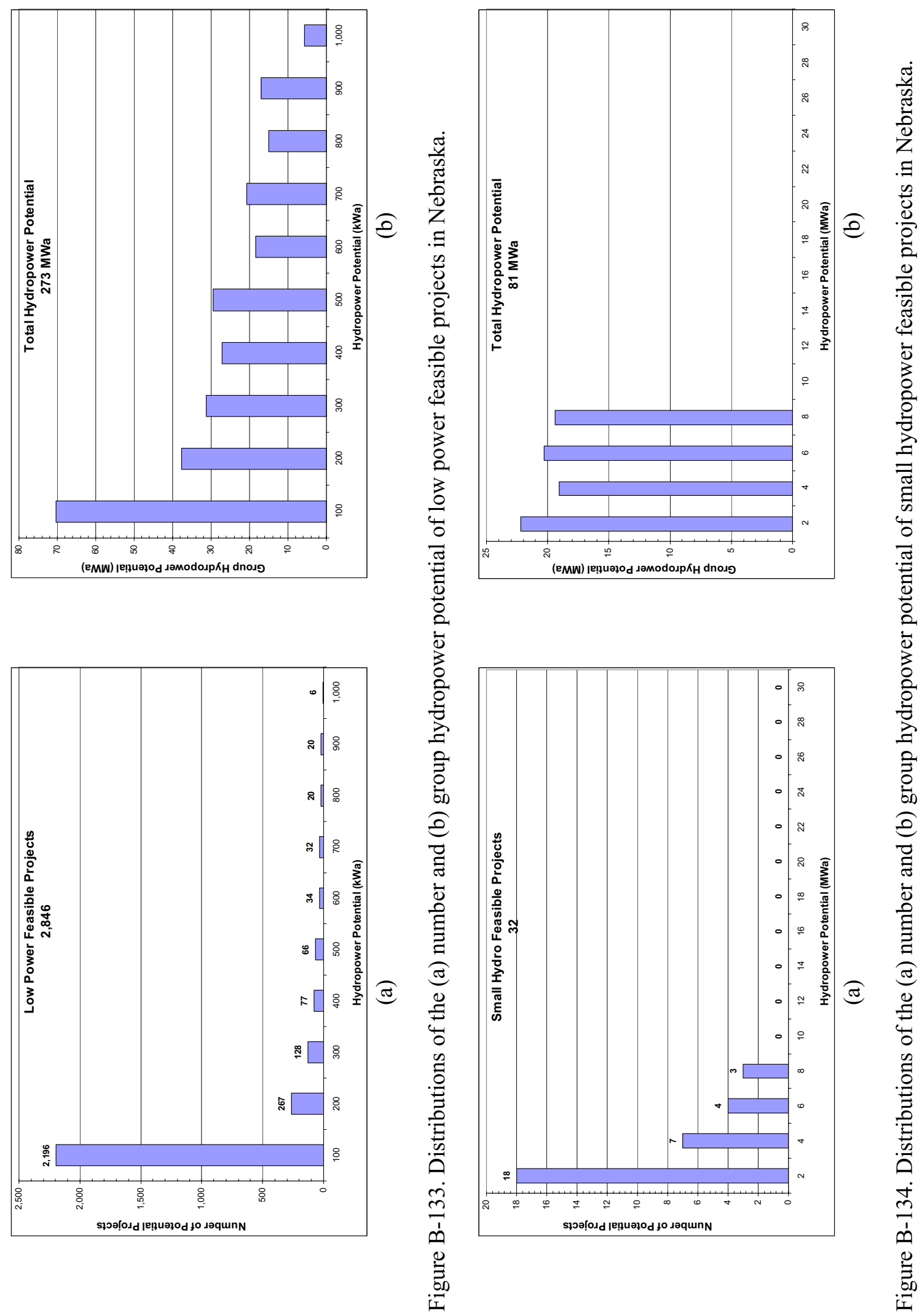


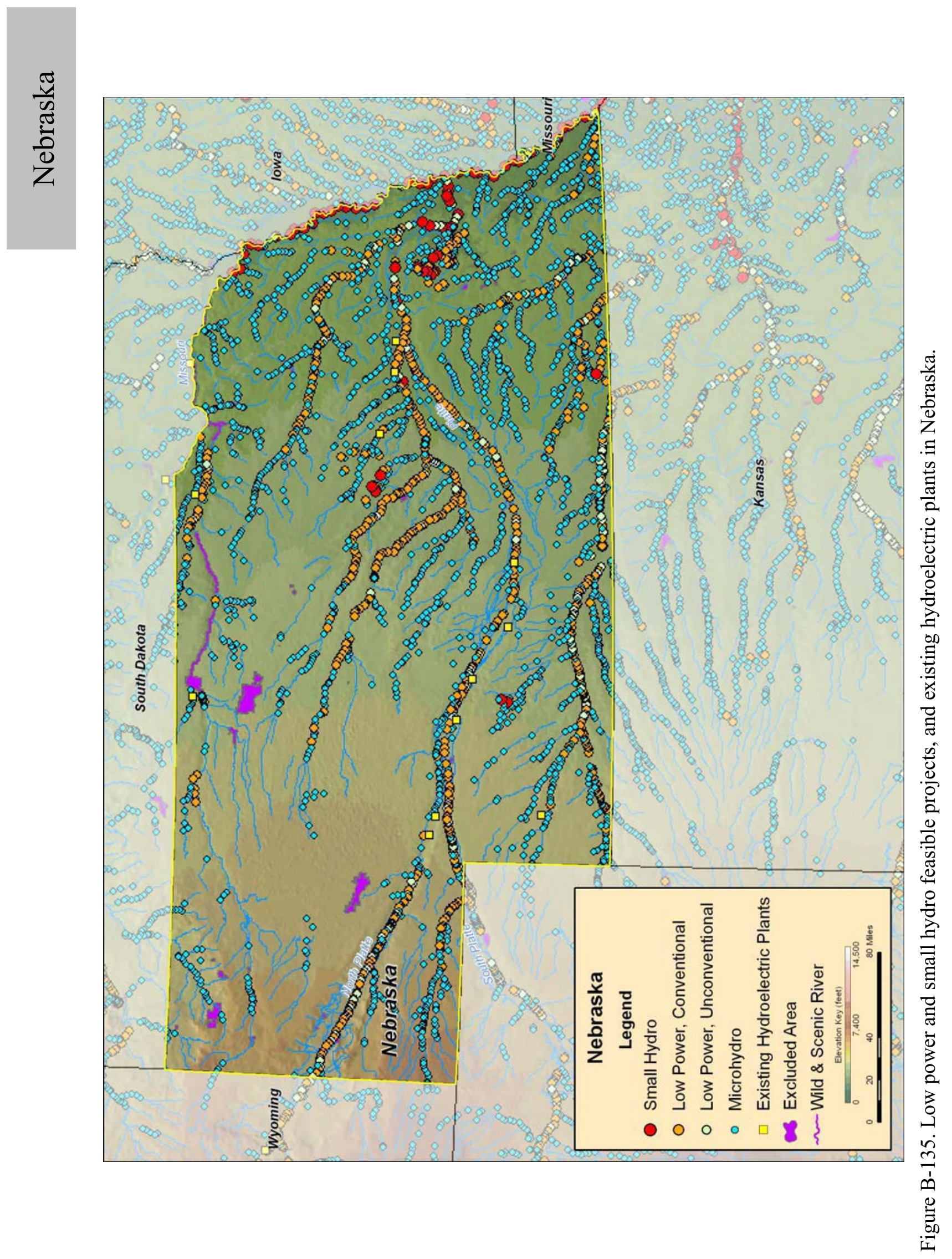




\section{B.28 Nevada}

Table B-57. Summary of results of water energy resource assessment of Nevada.

\begin{tabular}{|c|c|c|c|c|c|}
\hline Power Class & $\begin{array}{c}\text { Total } \\
(\mathbf{M W a})\end{array}$ & $\begin{array}{c}\text { Developed } \\
(\mathrm{MWa})\end{array}$ & $\begin{array}{c}\text { Federally } \\
\text { Excluded } \\
(\mathbf{M W a})\end{array}$ & $\begin{array}{c}\text { Other } \\
\text { Excluded } \\
(\mathbf{M W a})\end{array}$ & $\begin{array}{c}\text { Available } \\
(\mathrm{MWa})\end{array}$ \\
\hline Total Power & $\mathbf{1 , 3 2 5}$ & $\mathbf{2 6 1}$ & $\mathbf{1 4 7}$ & $\mathbf{1 4 5}$ & $\mathbf{7 7 1}$ \\
\hline Total High Power & & & & & \\
\hline Large Hydro & $\mathbf{4 5 5}$ & 260 & $\mathbf{5 6}$ & $\mathbf{2 7}$ & 112 \\
\hline Small Hydro & 257 & 257 & 0 & 0 & 0 \\
\hline & 198 & 3 & 56 & 27 & 112 \\
\hline Total Low Power & & & & & \\
\hline Conventional Turbines & $\mathbf{8 7 0}$ & 1 & 91 & 118 & 659 \\
\hline Unconventional Systems & 540 & 1 & 72 & 79 & 389 \\
\hline Microhydro & 9 & 0 & 1 & 0 & 8 \\
\hline
\end{tabular}

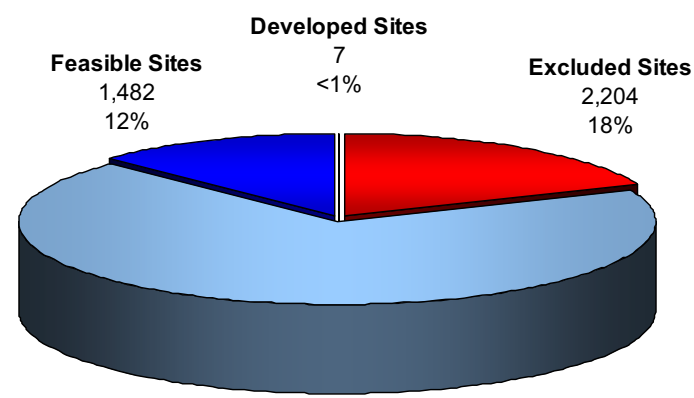

Other Available Sites

8,243

$69 \%$

(a) Total Resource Sites

11,936

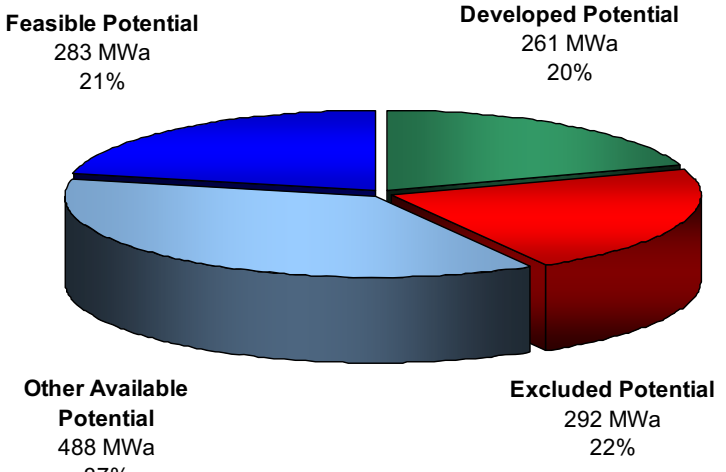

(b) Total Resource Potential $1,325 \mathrm{MWa}$

Figure B-136. Power category distribution of the (a) number and (b) total power potential of the water energy resource sites in Nevada. 
Table B-58. Summary of results of feasibility assessment of water energy resources in Nevada.

\begin{tabular}{|c|c|}
\hline \multicolumn{1}{|c|}{ Power Class } & $\begin{array}{c}\text { Available } \\
(\mathrm{MWa})\end{array}$ \\
\hline Total Power & 771 \\
\hline & \\
\hline Total High Power & 112 \\
\hline Large Hydro & 0 \\
\hline Small Hydro & 112 \\
\hline & \\
\hline Total Low Power & 659 \\
\hline Conventional Turbines & 389 \\
\hline Unconventional Systems & 8 \\
\hline Microhydro & 263 \\
\hline
\end{tabular}
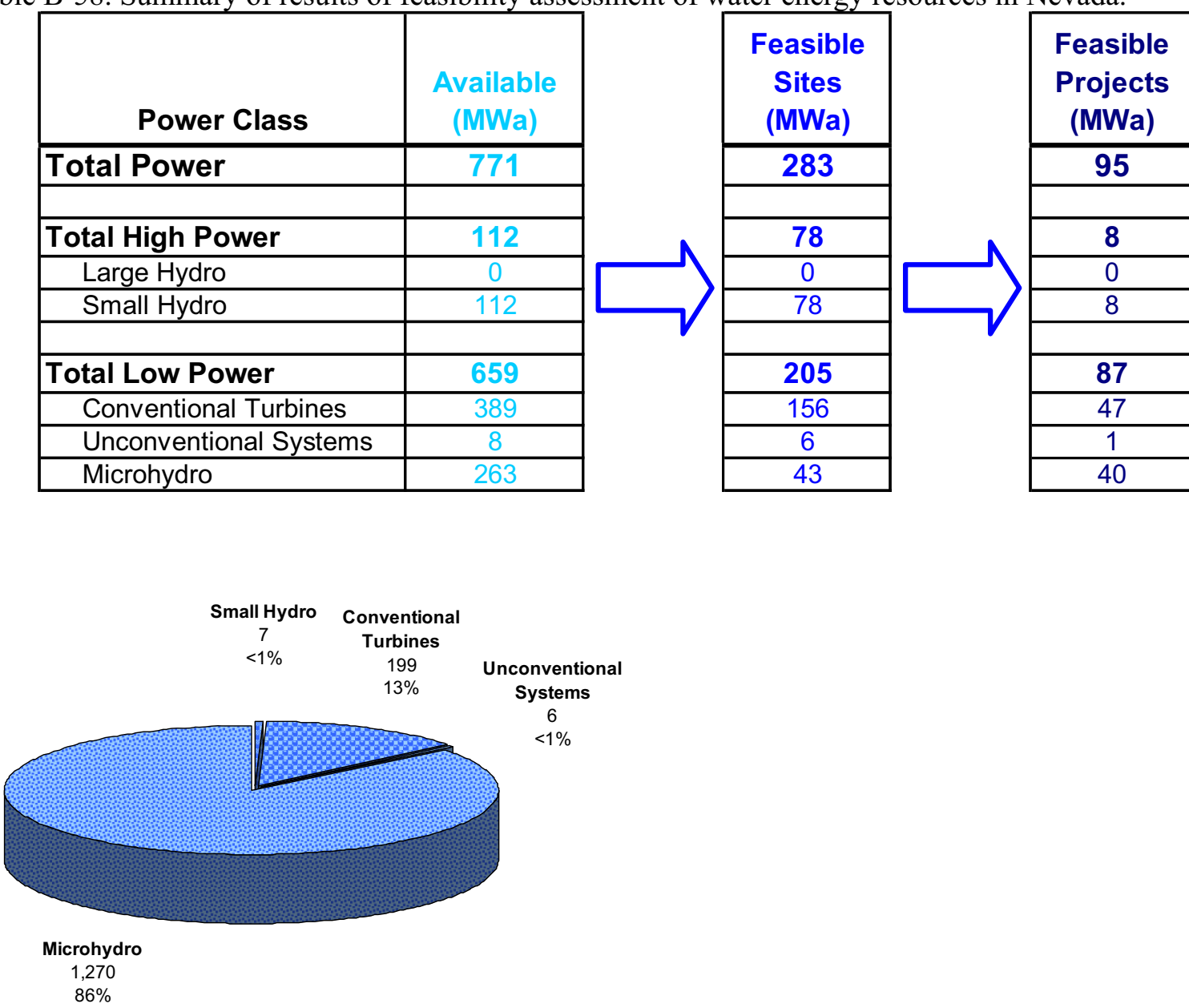

(a) Total Feasible Projects

1,482

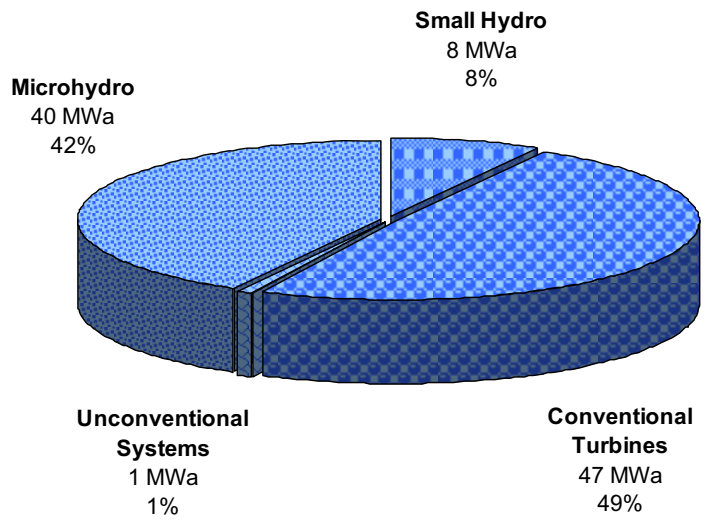

(b) Total Feasible Project Hydropower Potential $95 \mathrm{MWa}$

Figure B-137. Distribution of the (a) number and (b) total hydropower potential of the low power and small hydropower feasible projects in Nevada with the low power projects divided into technology classes. 

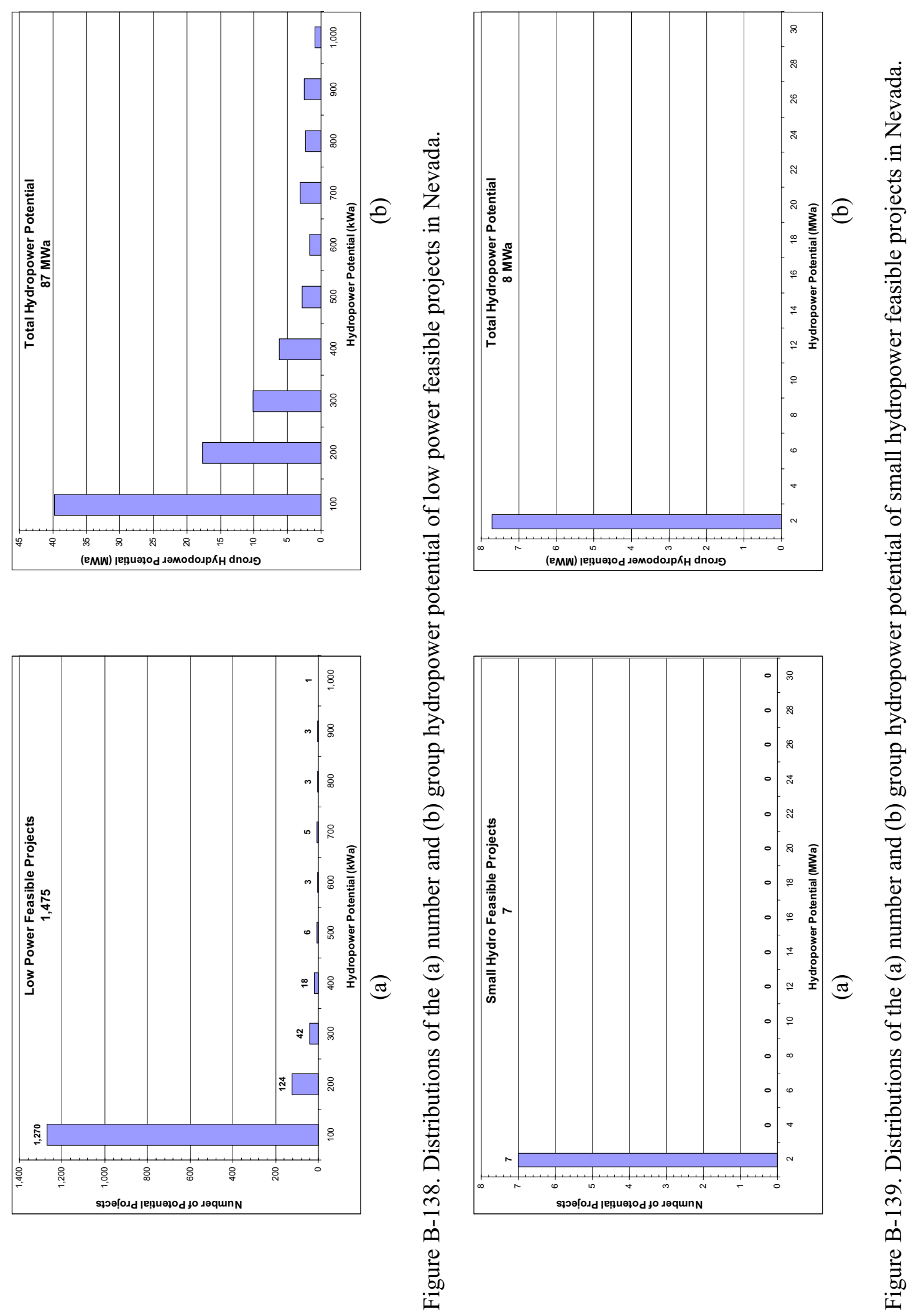

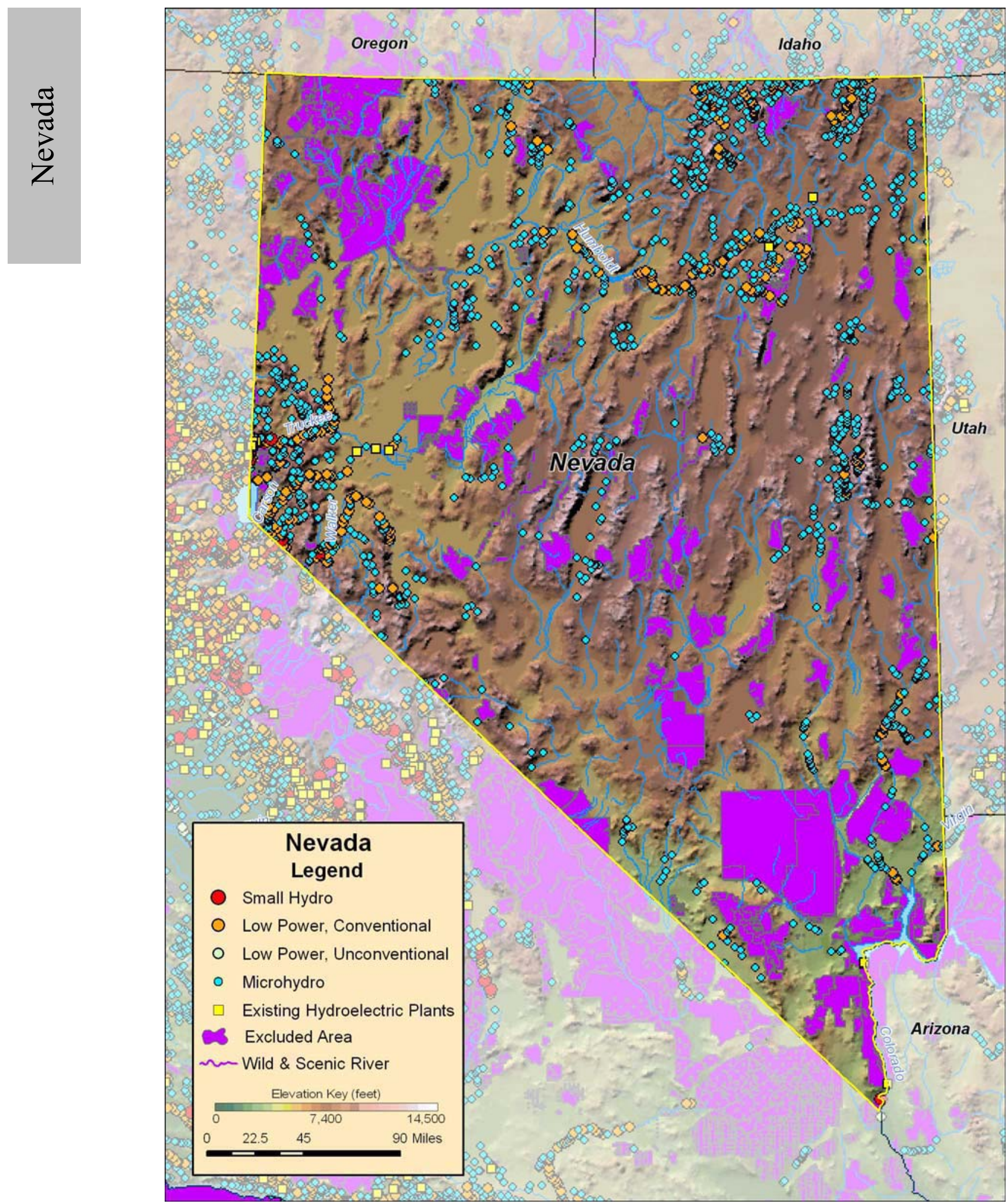

Figure B-140. Low power and small hydro feasible projects, and existing hydroelectric plants in Nevada. 


\section{B.29 New Hampshire}

Table B-59. Summary of results of water energy resource assessment of New Hampshire.

\begin{tabular}{|c|c|c|c|c|c|}
\hline Power Class & $\begin{array}{c}\text { Total } \\
\text { (MWa) }\end{array}$ & $\begin{array}{c}\text { Developed } \\
\text { (MWa) }\end{array}$ & $\begin{array}{c}\text { Federally } \\
\text { Excluded } \\
(\mathrm{MWa})\end{array}$ & $\begin{array}{c}\text { Other } \\
\text { Excluded } \\
(\mathrm{MWa})\end{array}$ & $\begin{array}{c}\text { Available } \\
\text { (MWa) }\end{array}$ \\
\hline Total Power & 1,066 & 106 & 54 & 110 & 797 \\
\hline Total High Power & 695 & 94 & 39 & 48 & 515 \\
\hline Large Hydro & 50 & 0 & 0 & 0 & 50 \\
\hline Small Hydro & 645 & 94 & 39 & 48 & 465 \\
\hline Total Low Power & 371 & 13 & 15 & 62 & 282 \\
\hline Conventional Turbines & 318 & 10 & 14 & 55 & 239 \\
\hline Unconventional Systems & 15 & 1 & 0 & 1 & 13 \\
\hline Microhydro & 38 & 1 & 0 & 6 & 31 \\
\hline
\end{tabular}

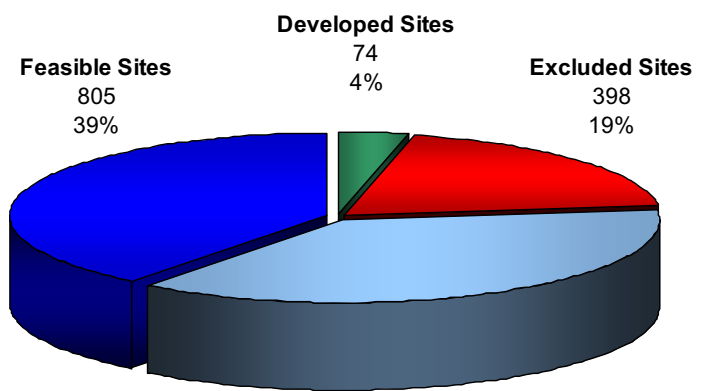

Other Available Sites

769

(a) Total Resource Sites

2,046

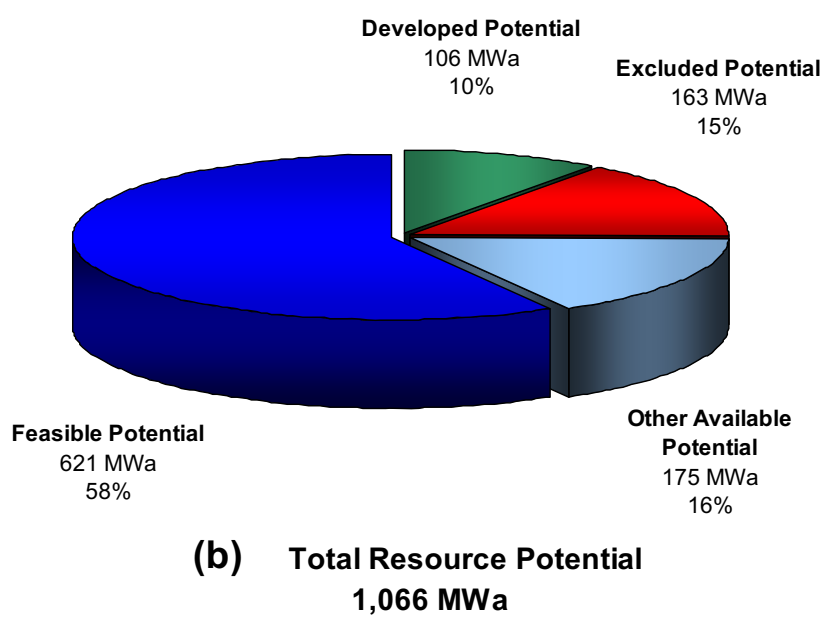

Figure B-141. Power category distribution of the (a) number and (b) total power potential of the water energy resource sites in New Hampshire. 
Table B-60. Summary of results of feasibility assessment of water energy resources in New Hampshire.

\begin{tabular}{|c|c|}
\hline Power Class & $\begin{array}{c}\text { Available } \\
\text { (MWa) }\end{array}$ \\
\hline Total Power & 797 \\
\hline & \\
\hline Total High Power & 515 \\
\hline Large Hydro & 50 \\
\hline Small Hydro & 465 \\
\hline & \\
\hline Total Low Power & 282 \\
\hline Conventional Turbines & 239 \\
\hline Unconventional Systems & 13 \\
\hline Microhydro & 31 \\
\hline
\end{tabular}
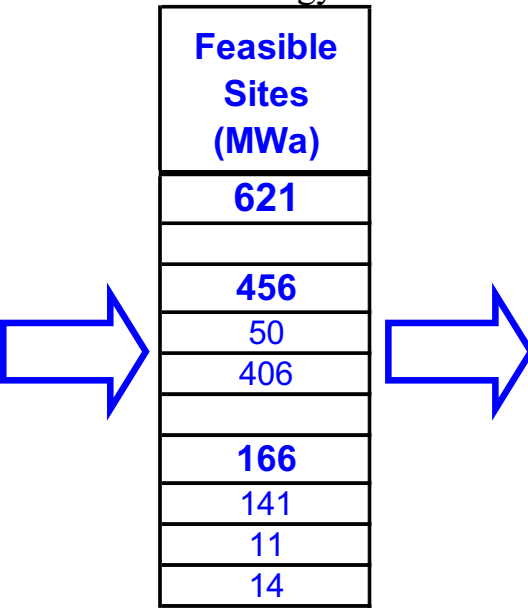

Feasible

Projects

(MWa)

174

\begin{tabular}{|c|}
\hline 105 \\
\hline 0 \\
\hline 105 \\
\hline \\
\hline 69 \\
\hline 40 \\
\hline 10 \\
\hline 19 \\
\hline
\end{tabular}

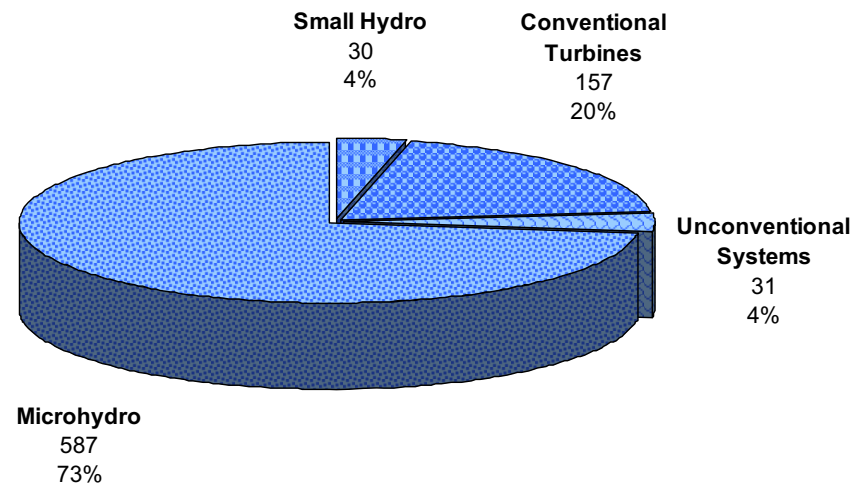

(a) Total Feasible Projects

805

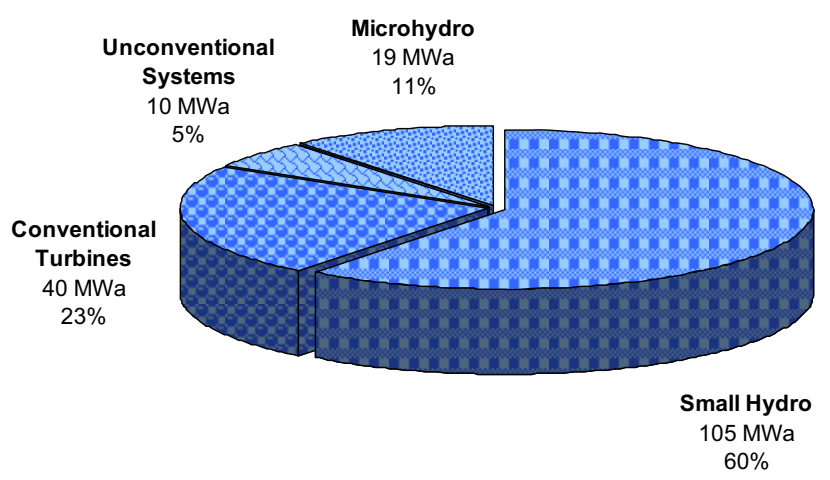

(b) Total Feasible Project Hydropower Potential $174 \mathrm{MWa}$

Figure B-142. Distribution of the (a) number and (b) total hydropower potential of the low power and small hydropower feasible projects in New Hampshire with the low power projects divided into technology classes. 

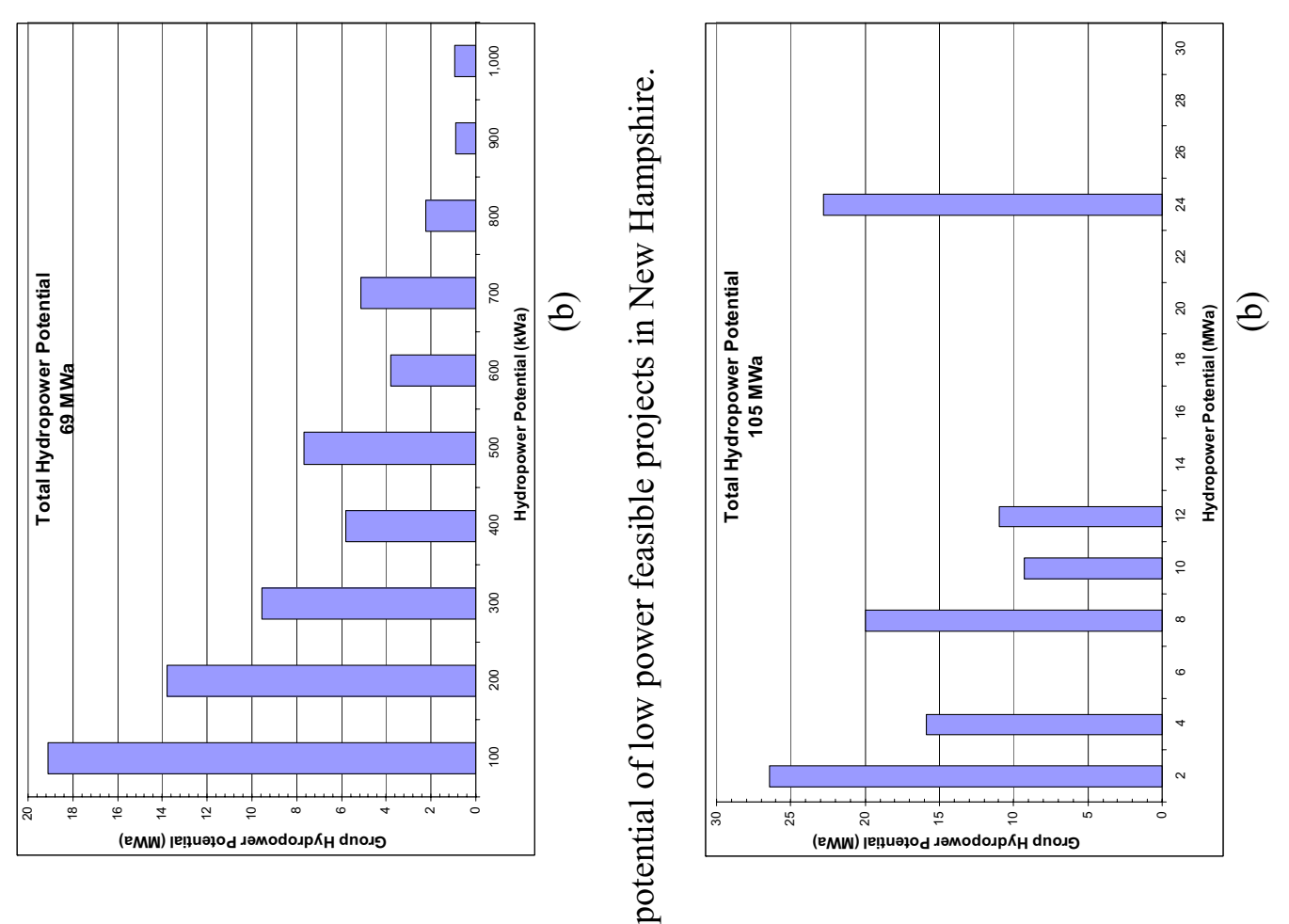

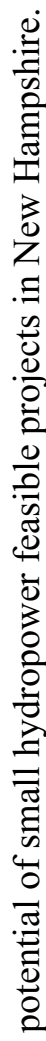

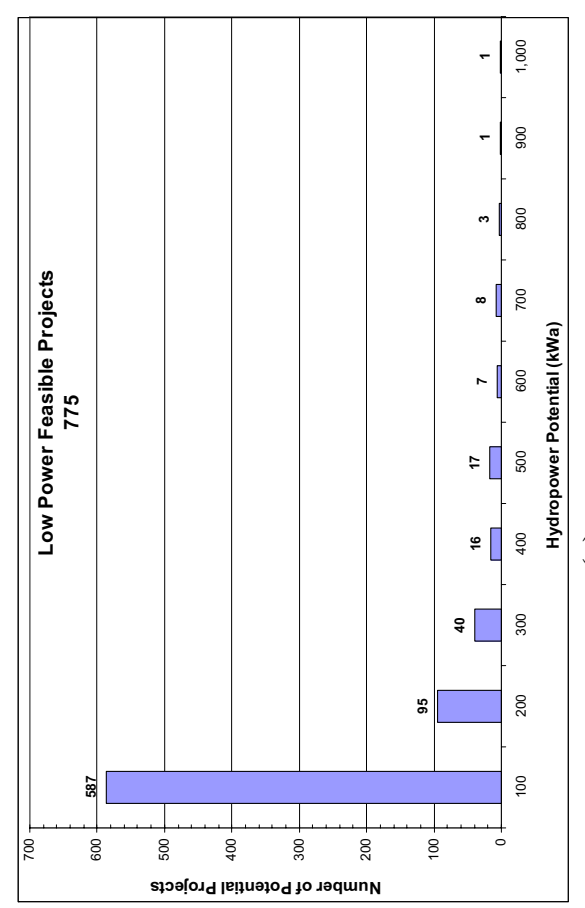

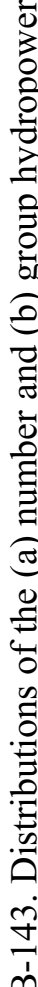

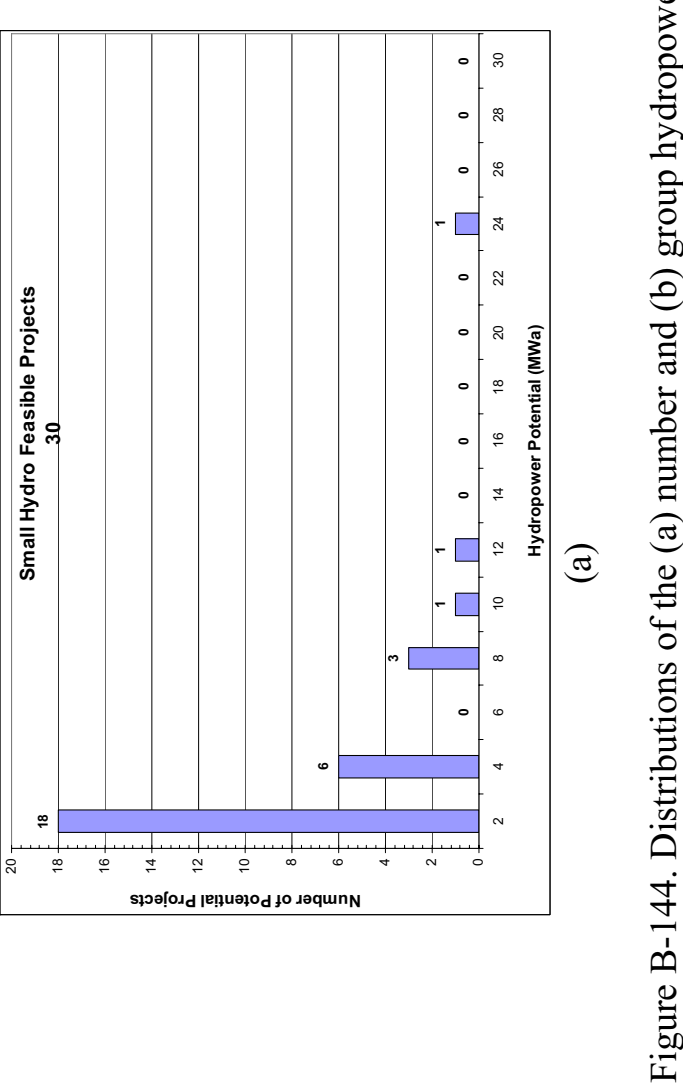




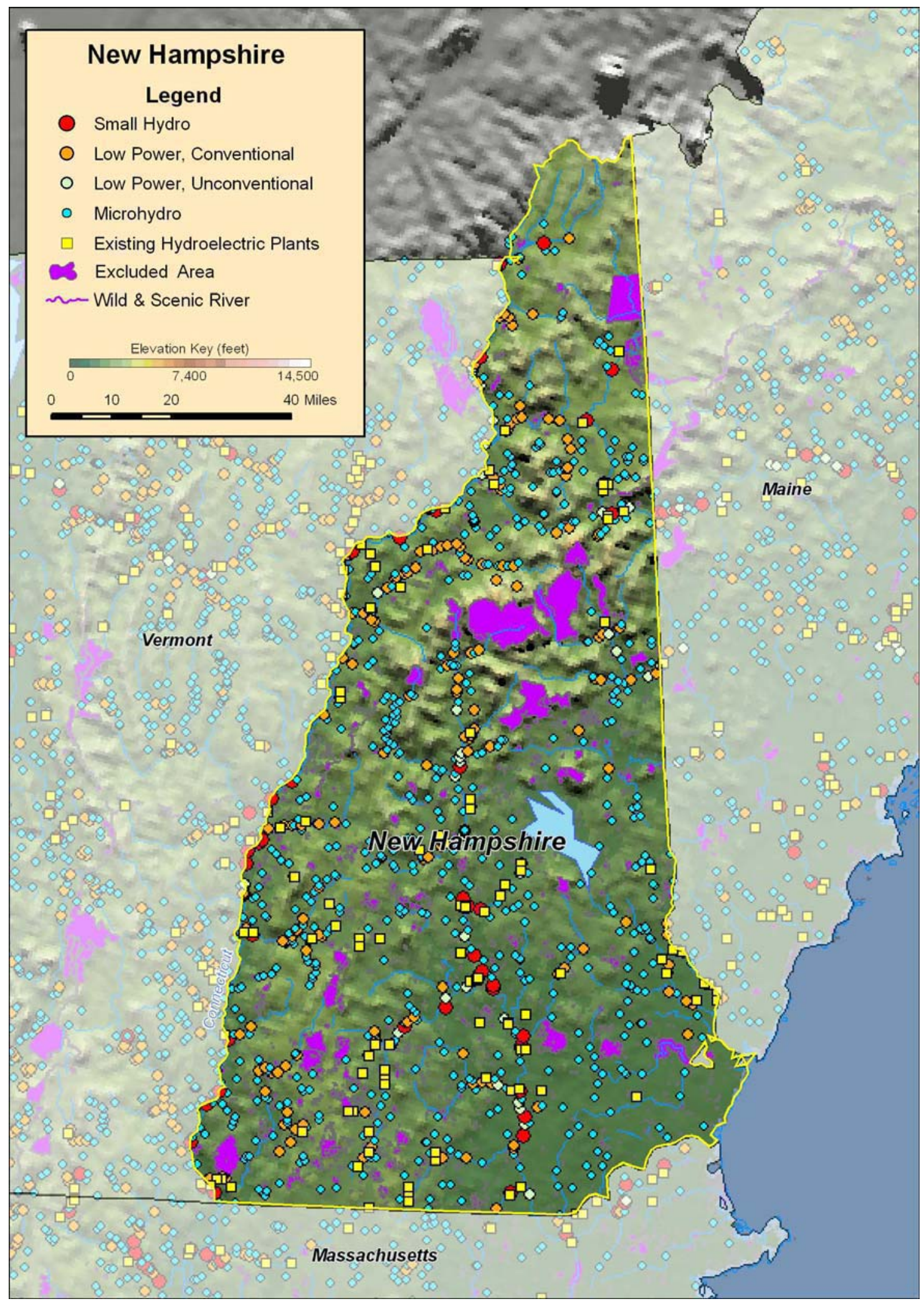

Figure B-145. Low power and small hydropower feasible projects, and existing hydroelectric plants in New Hampshire. 


\section{B.30 New Jersey}

Table B-61. Summary of results of water energy resource assessment of New Jersey.

\begin{tabular}{|c|c|c|c|c|c|}
\hline Power Class & $\begin{array}{l}\text { Total } \\
\text { (MWa) }\end{array}$ & $\begin{array}{c}\text { Developed } \\
\text { (MWa) }\end{array}$ & $\begin{array}{c}\text { Federally } \\
\text { Excluded } \\
\text { (MWa) }\end{array}$ & $\begin{array}{c}\text { Other } \\
\text { Excluded } \\
\text { (MWa) }\end{array}$ & $\begin{array}{c}\text { Available } \\
\text { (MWa) }\end{array}$ \\
\hline Total Power & 261 & 6 & 15 & 41 & 200 \\
\hline Total High Power & 167 & 5 & 7 & 29 & 125 \\
\hline Large Hydro & 0 & 0 & 0 & 0 & 0 \\
\hline Small Hydro & 167 & 5 & 7 & 29 & 125 \\
\hline Total Low Power & 94 & 1 & 7 & 11 & 75 \\
\hline Conventional Turbines & 62 & 1 & 4 & 9 & 49 \\
\hline Unconventional Systems & 6 & 0 & 1 & 1 & 4 \\
\hline Microhydro & 26 & 0 & 2 & 2 & 23 \\
\hline
\end{tabular}

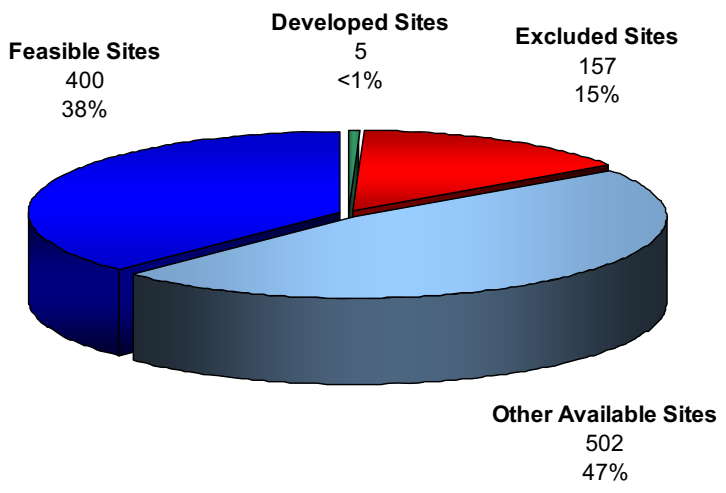

(a) Total Resource Sites 1,064

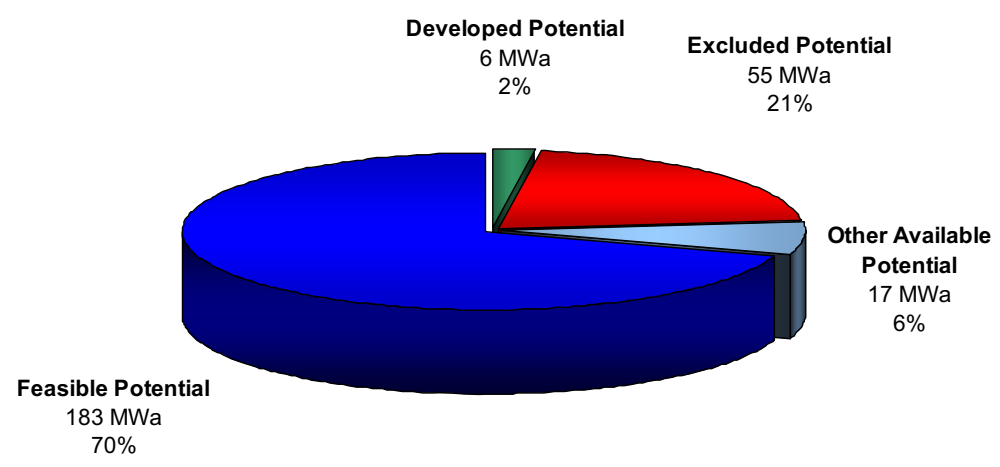

(b) Total Resource Potential $261 \mathrm{MWa}$

Figure B-146. Power category distribution of the (a) number and (b) total power potential of the water energy resource sites in New Jersey. 
Table B-62. Summary of results of feasibility assessment of water energy resources in New Jersey.

\begin{tabular}{|c|c|}
\hline Power Class & $\begin{array}{c}\text { Available } \\
\text { (MWa) }\end{array}$ \\
\hline Total Power & 200 \\
\hline Total High Power & 125 \\
\hline Large Hydro & 0 \\
\hline Small Hydro & 125 \\
\hline & \\
\hline Total Low Power & 75 \\
\hline Conventional Turbines & 49 \\
\hline Unconventional Systems & 4 \\
\hline Microhydro & 23 \\
\hline
\end{tabular}
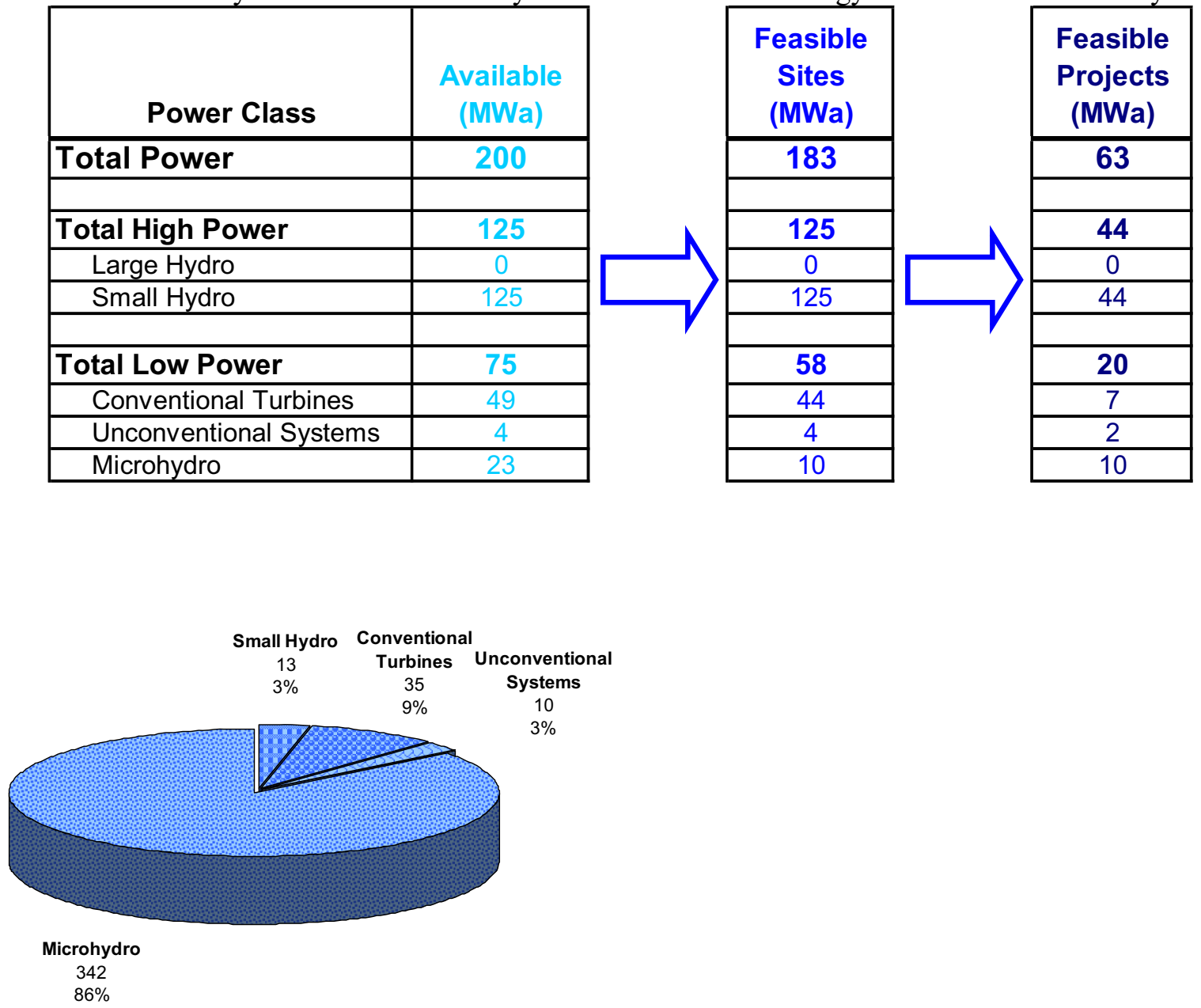

(a) Total Feasible Projects 400

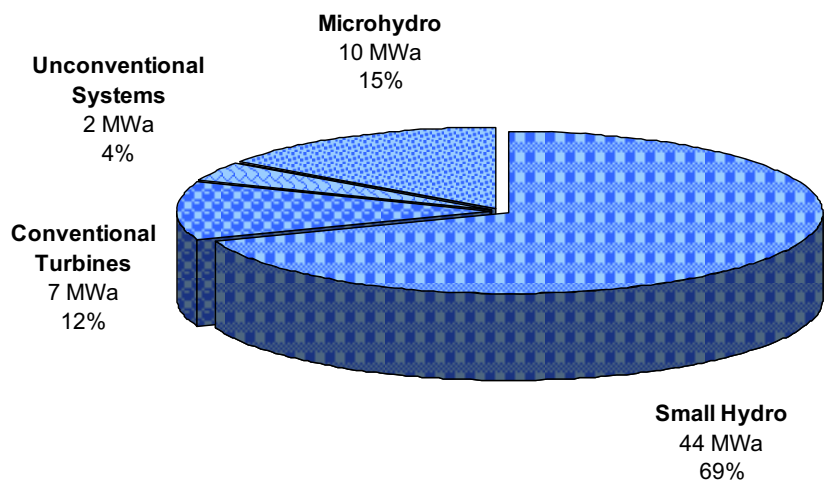

(b) Total Feasible Project Hydropower Potential $63 \mathrm{MWa}$

Figure B-147. Distribution of the (a) number and (b) total hydropower potential of the low power and small hydropower feasible projects in New Jersey with the low power projects divided into technology classes. 

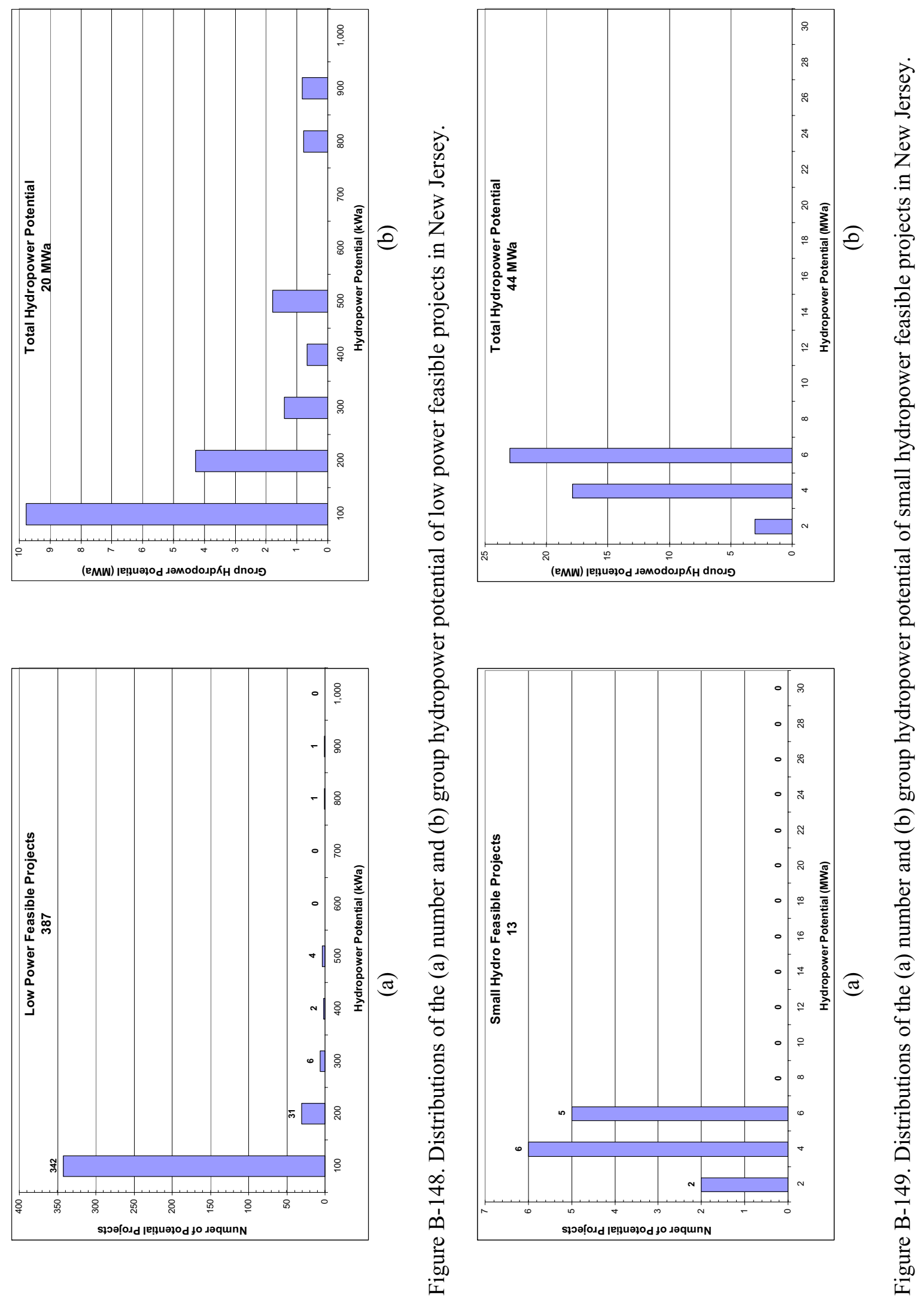

B-125 


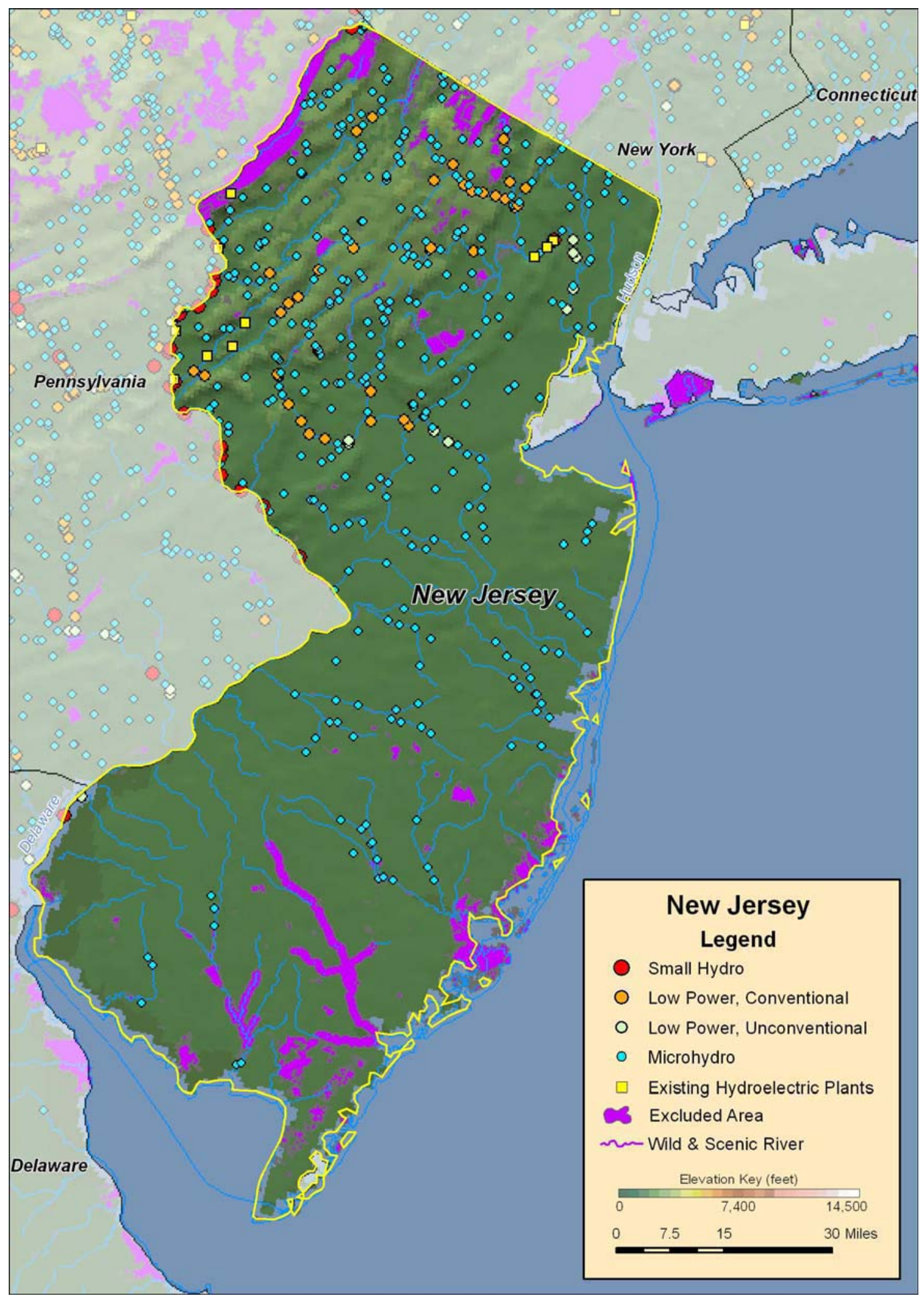

Figure B-150. Low power and small hydro feasible projects, and existing hydroelectric plants in New Jersey. 


\section{B.31 New Mexico}

Table B-63. Summary of results of water energy resource assessment of New Mexico.

\begin{tabular}{|c|c|c|c|c|c|}
\hline Power Class & $\begin{array}{c}\text { Total } \\
\mathbf{( M W a )}\end{array}$ & $\begin{array}{c}\text { Developed } \\
(\mathrm{MWa})\end{array}$ & $\begin{array}{c}\text { Federally } \\
\text { Excluded } \\
(\mathbf{M W a})\end{array}$ & $\begin{array}{c}\text { Other } \\
\text { Excluded } \\
(\mathbf{M W a})\end{array}$ & $\begin{array}{c}\text { Availlable } \\
(\mathrm{MWa})\end{array}$ \\
\hline Total Power & $\mathbf{1 , 6 7 4}$ & $\mathbf{5}$ & $\mathbf{3 1 5}$ & $\mathbf{2 1 7}$ & 1,136 \\
\hline Total High Power & $\mathbf{5 8 6}$ & $\mathbf{5}$ & $\mathbf{1 7 1}$ & $\mathbf{1 0 6}$ & 304 \\
\hline Large Hydro & 36 & 0 & 0 & 36 & 0 \\
\hline Small Hydro & 551 & 5 & 171 & 70 & 304 \\
\hline Total Low Power & & & & & \\
\hline Conventional Turbines & $\mathbf{1 , 0 8 7}$ & 0 & 144 & 111 & 832 \\
\hline Unconventional Systems & $\mathbf{7 5 5}$ & 0 & 123 & 86 & 545 \\
\hline Microhydro & 40 & 0 & 3 & 2 & 34 \\
\hline
\end{tabular}

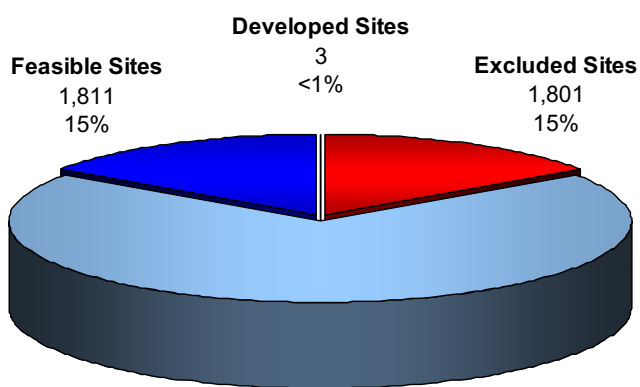

Other Available Sites

8,277

$70 \%$

(a) Total Resource Sites

11,892

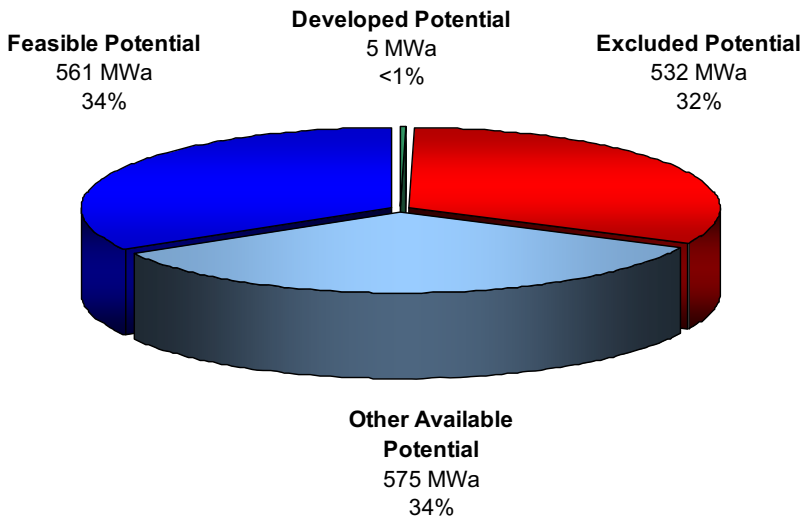

(b) Total Resource Potential $1,674 \mathrm{MWa}$

Figure B-151. Power category distribution of the (a) number and (b) total power potential of the water energy resource sites in New Mexico. 
Table B-64. Summary of results of feasibility assessment of water energy resources in New Mexico.

\begin{tabular}{|c|c|}
\hline Power Class & $\begin{array}{c}\text { Available } \\
\text { (MWa) }\end{array}$ \\
\hline Total Power & 1,136 \\
\hline Total High Power & 304 \\
\hline Large Hydro & 0 \\
\hline Small Hydro & 304 \\
\hline & \\
\hline Total Low Power & 832 \\
\hline Conventional Turbines & 545 \\
\hline Unconventional Systems & 34 \\
\hline Microhydro & 252 \\
\hline
\end{tabular}

\begin{tabular}{|c|c|}
\hline $\begin{array}{c}\text { Feasible } \\
\text { Sites } \\
\text { (MWa) }\end{array}$ & $\begin{array}{c}\text { Feasible } \\
\text { Projects } \\
\text { (MWa) }\end{array}$ \\
\hline 561 & 156 \\
\hline 229 & 13 \\
\hline 0 & 0 \\
\hline 229 & 13 \\
\hline 332 & 143 \\
\hline 259 & 83 \\
\hline 31 & 14 \\
\hline 42 & 46 \\
\hline
\end{tabular}

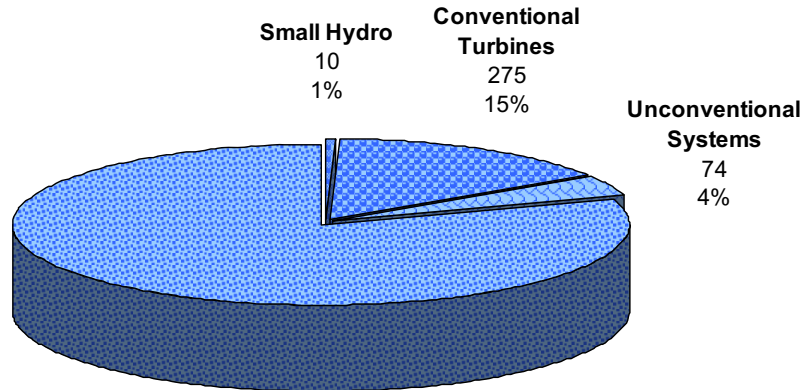

Microhydro

1,452

(a) Total Feasible Projects

1,811

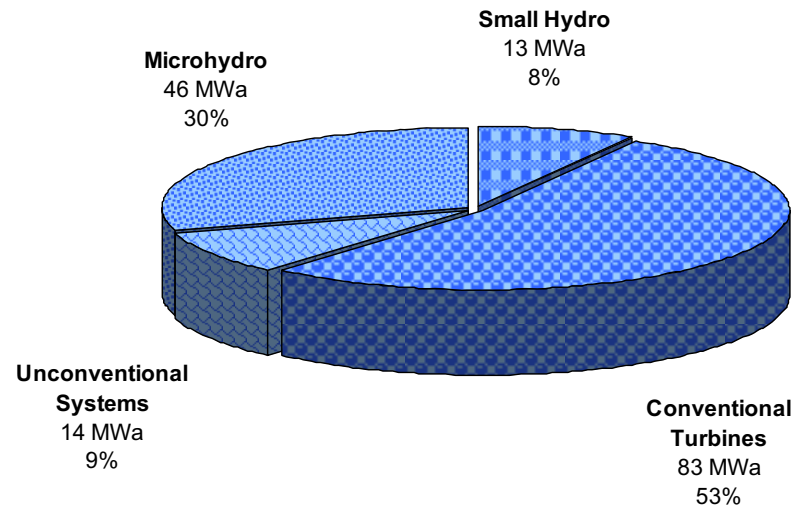

(b) Total Feasible Project Hydropower Potential $156 \mathrm{MWa}$

Figure B-152. Distribution of the (a) number and (b) total hydropower potential of the low power and small hydropower feasible projects in New Mexico with the low power projects divided into technology classes. 

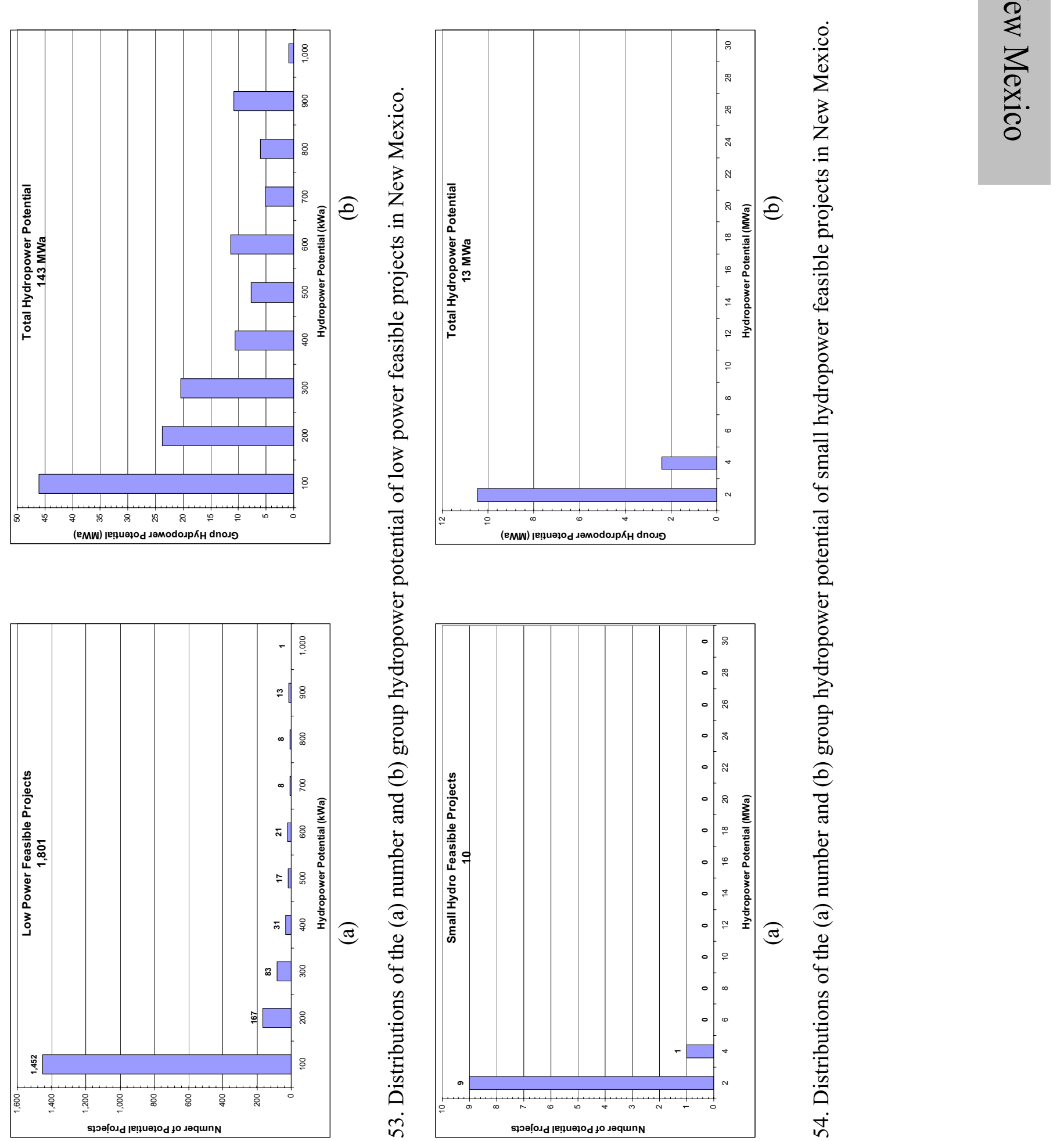


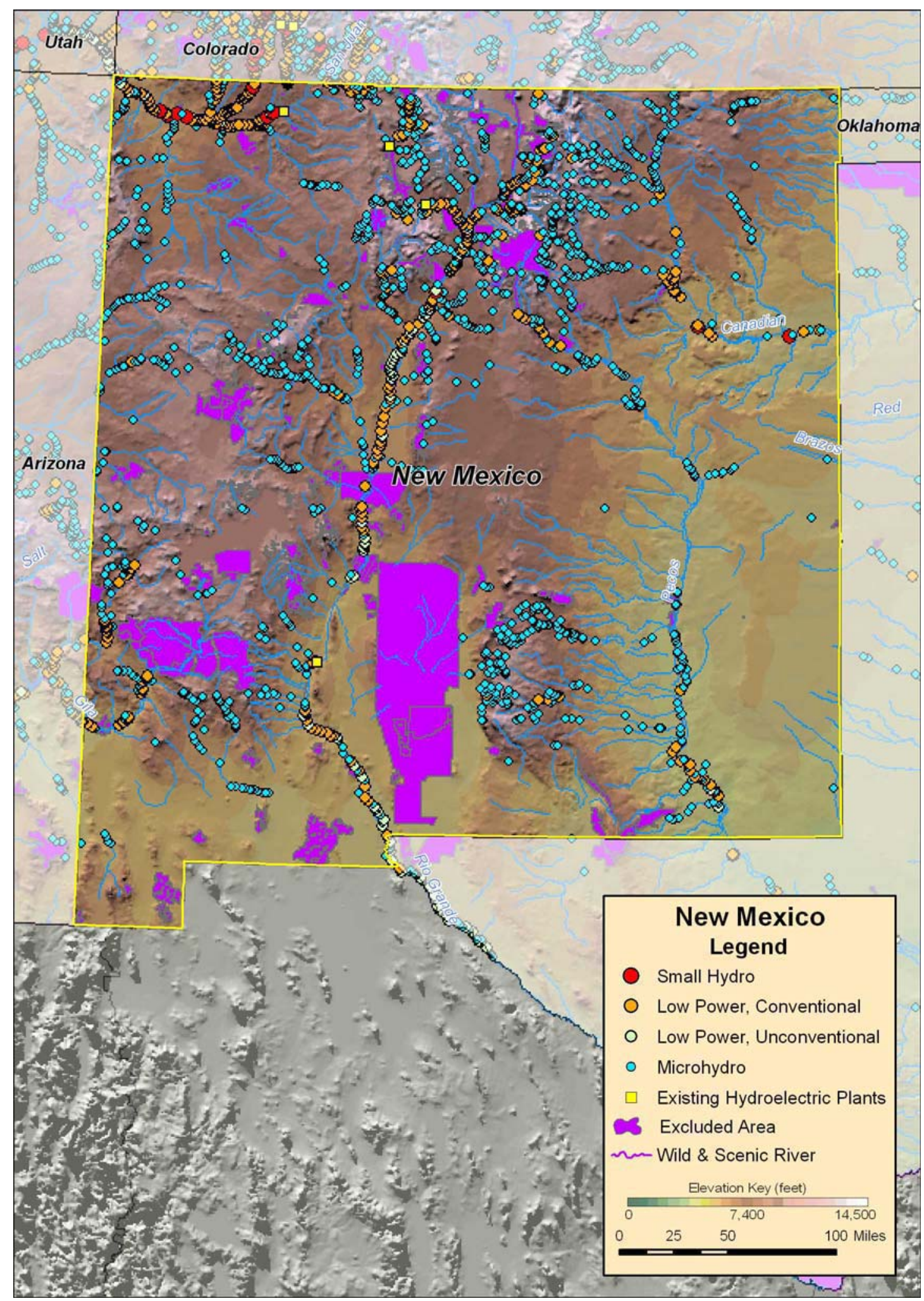

Figure B-155. Low power and small hydro feasible projects, and existing hydroelectric plants in New Mexico. 


\section{B.32 New York}

Table B-65. Summary of results of water energy resource assessment of New York.

\begin{tabular}{|c|c|c|c|c|c|}
\hline Power Class & $\begin{array}{c}\text { Total } \\
\mathbf{( M W a )}\end{array}$ & $\begin{array}{c}\text { Developed } \\
(\mathrm{MWa})\end{array}$ & $\begin{array}{c}\text { Federally } \\
\text { Excluded } \\
(\mathbf{M W a})\end{array}$ & $\begin{array}{c}\text { Other } \\
\text { Excluded } \\
(\mathbf{M W a})\end{array}$ & $\begin{array}{c}\text { Availlable } \\
(\mathrm{MWa})\end{array}$ \\
\hline Total Power & $\mathbf{4 , 8 5 1}$ & $\mathbf{3 7 8}$ & $\mathbf{9 8}$ & $\mathbf{7 6 7}$ & 3,609 \\
\hline Total High Power & & & & & \\
\hline Large Hydro & $\mathbf{3 , 3 0 8}$ & $\mathbf{3 4 6}$ & $\mathbf{8 8}$ & $\mathbf{5 0 9}$ & 2,365 \\
\hline Small Hydro & 481 & 83 & 0 & 0 & 399 \\
\hline Total Low Power & 2,827 & 263 & 88 & 509 & 1,967 \\
\hline Conventional Turbines & & & & & \\
\hline Unconventional Systems & $\mathbf{1 , 5 4 3}$ & $\mathbf{3 2}$ & $\mathbf{1 0}$ & $\mathbf{2 5 8}$ & 1,244 \\
\hline Microhydro & $\mathbf{1 , 2 5 6}$ & 26 & 8 & 235 & 987 \\
\hline
\end{tabular}

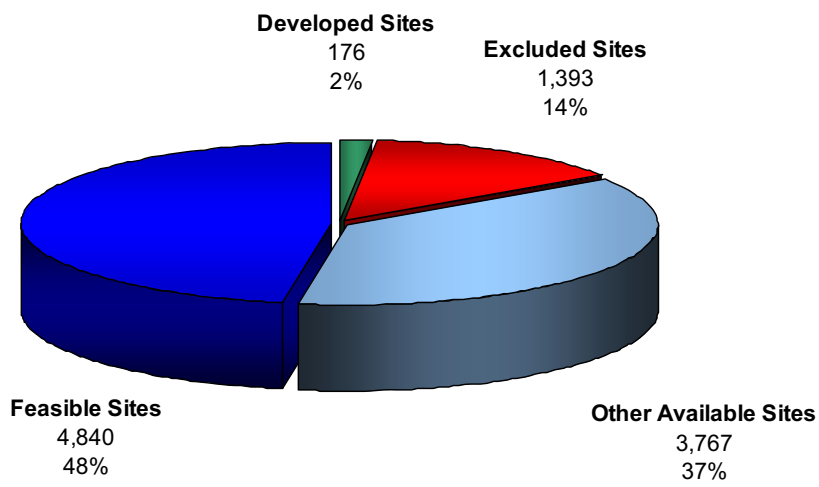

(a) Total Resource Sites 10,176

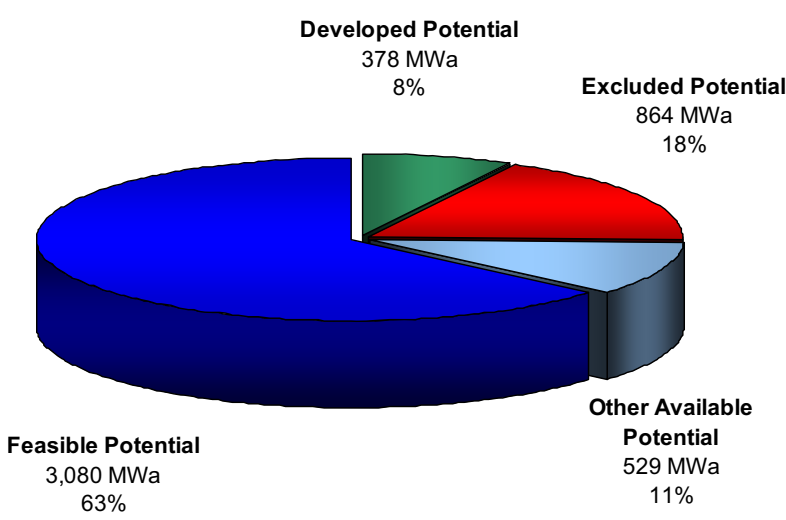

(a) Total Resource Potential $4,851 \mathrm{MWa}$

Figure B-156. Power category distribution of the (a) number and (b) total power potential of the water energy resource sites in New York. 
Table B-66. Summary of results of feasibility assessment of water energy resources in New York.

\begin{tabular}{|c|c|}
\hline Power Class & $\begin{array}{c}\text { Available } \\
\text { (MWa) }\end{array}$ \\
\hline Total Power & 3,609 \\
\hline Total High Power & 2,365 \\
\hline Large Hydro & 399 \\
\hline Small Hydro & 1,967 \\
\hline & \\
\hline Total Low Power & 1,244 \\
\hline Conventional Turbines & 987 \\
\hline Unconventional Systems & 63 \\
\hline Microhydro & 194 \\
\hline
\end{tabular}
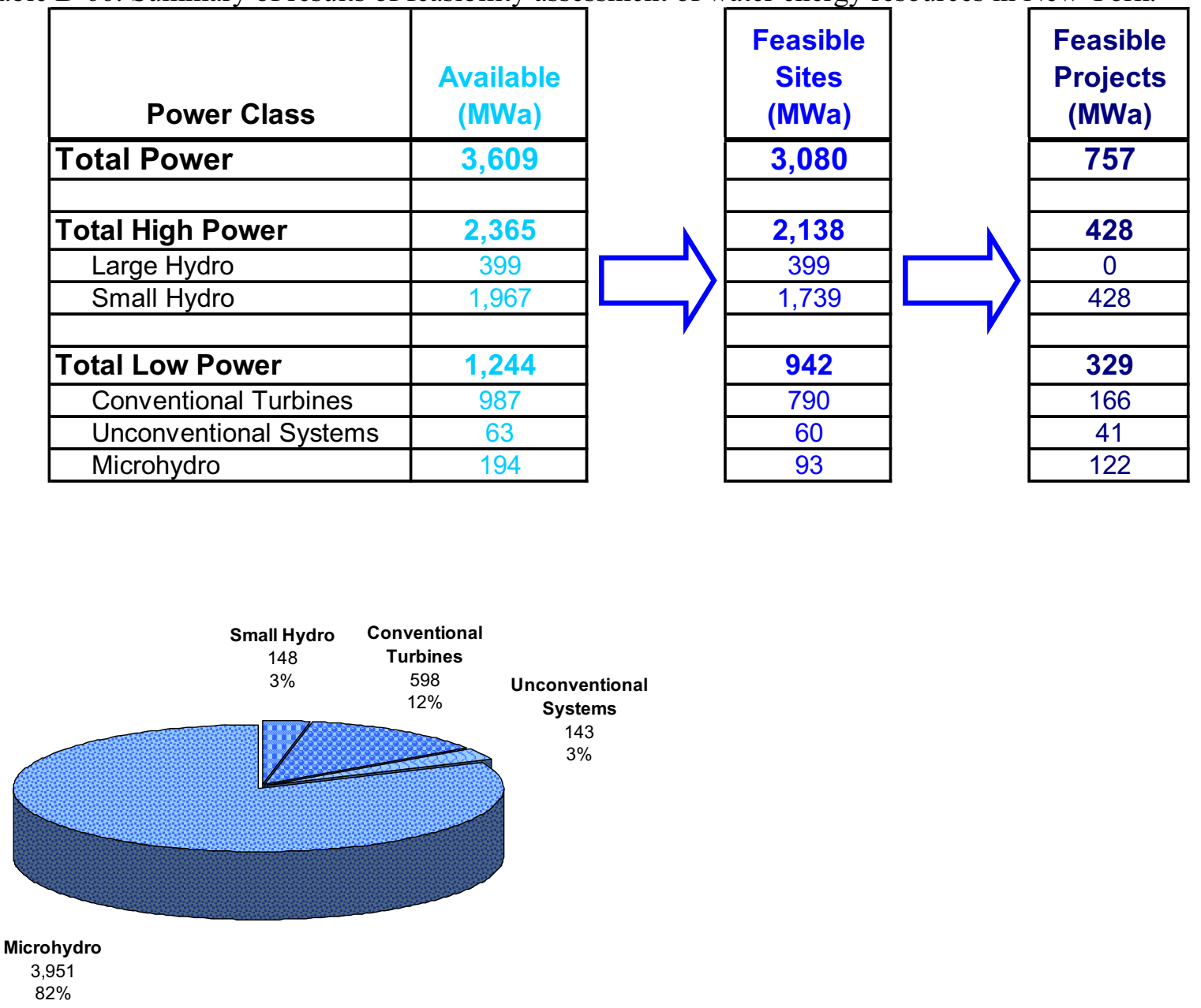

(a) Total Feasible Projects

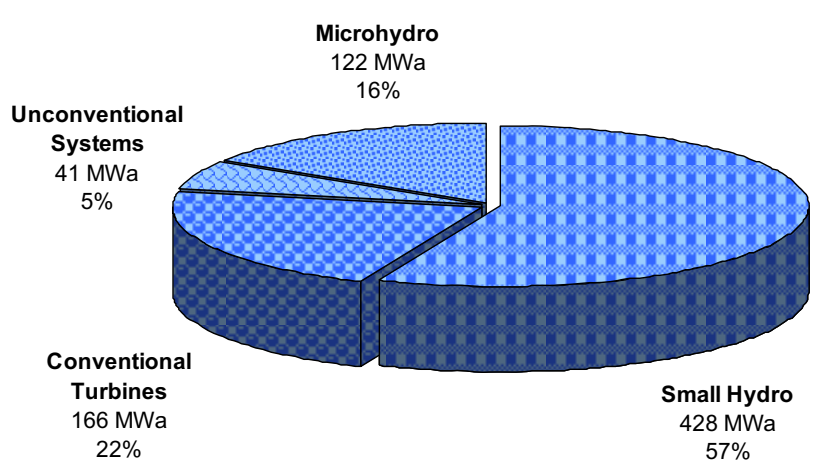

(b) Total Feasible Project Hydropower Potential $757 \mathrm{MWa}$

Figure B-157. Distribution of the (a) number and (b) total hydropower potential of the low power and small hydropower feasible projects in New York with the low power projects divided into technology classes. 

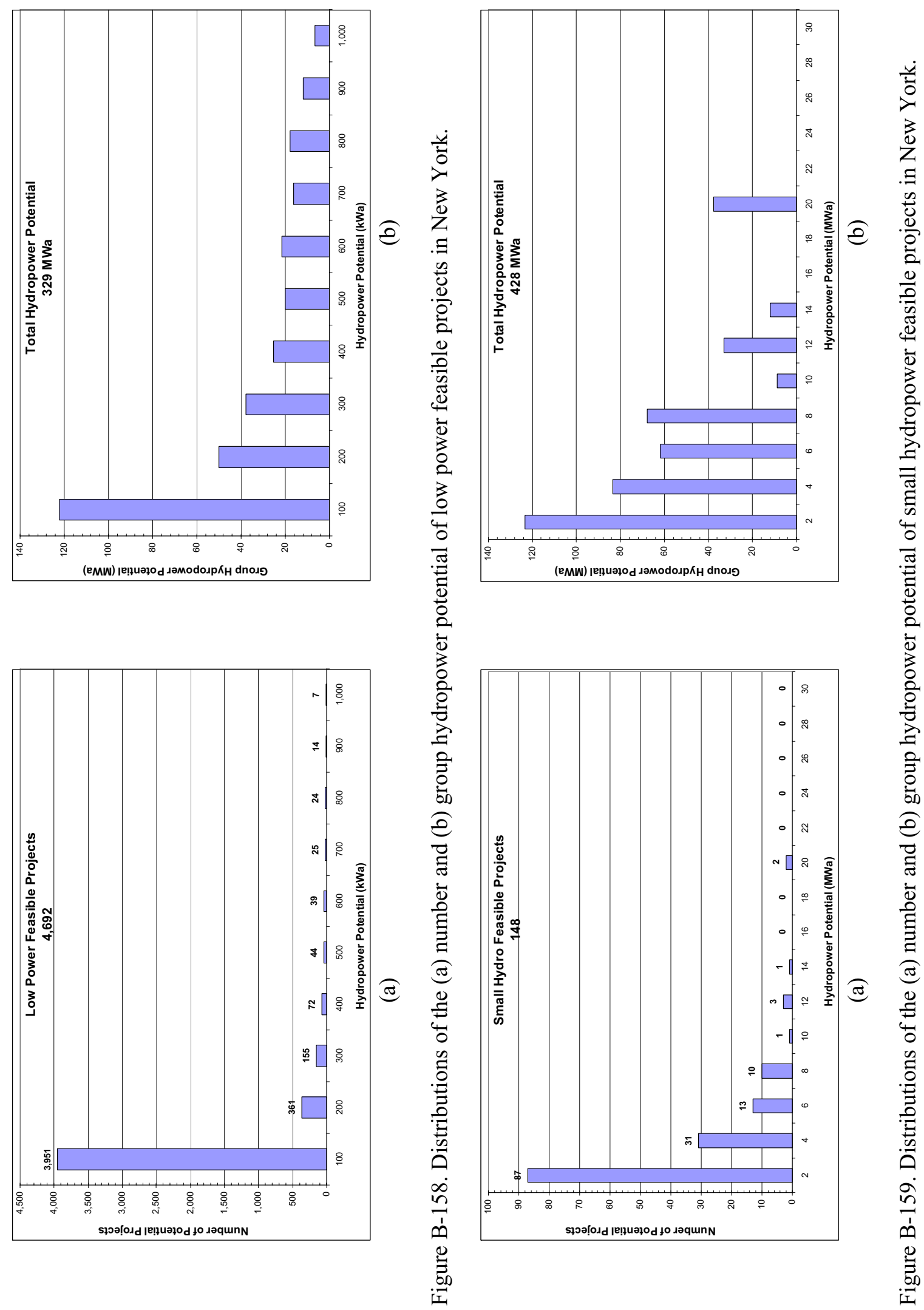

B-133 


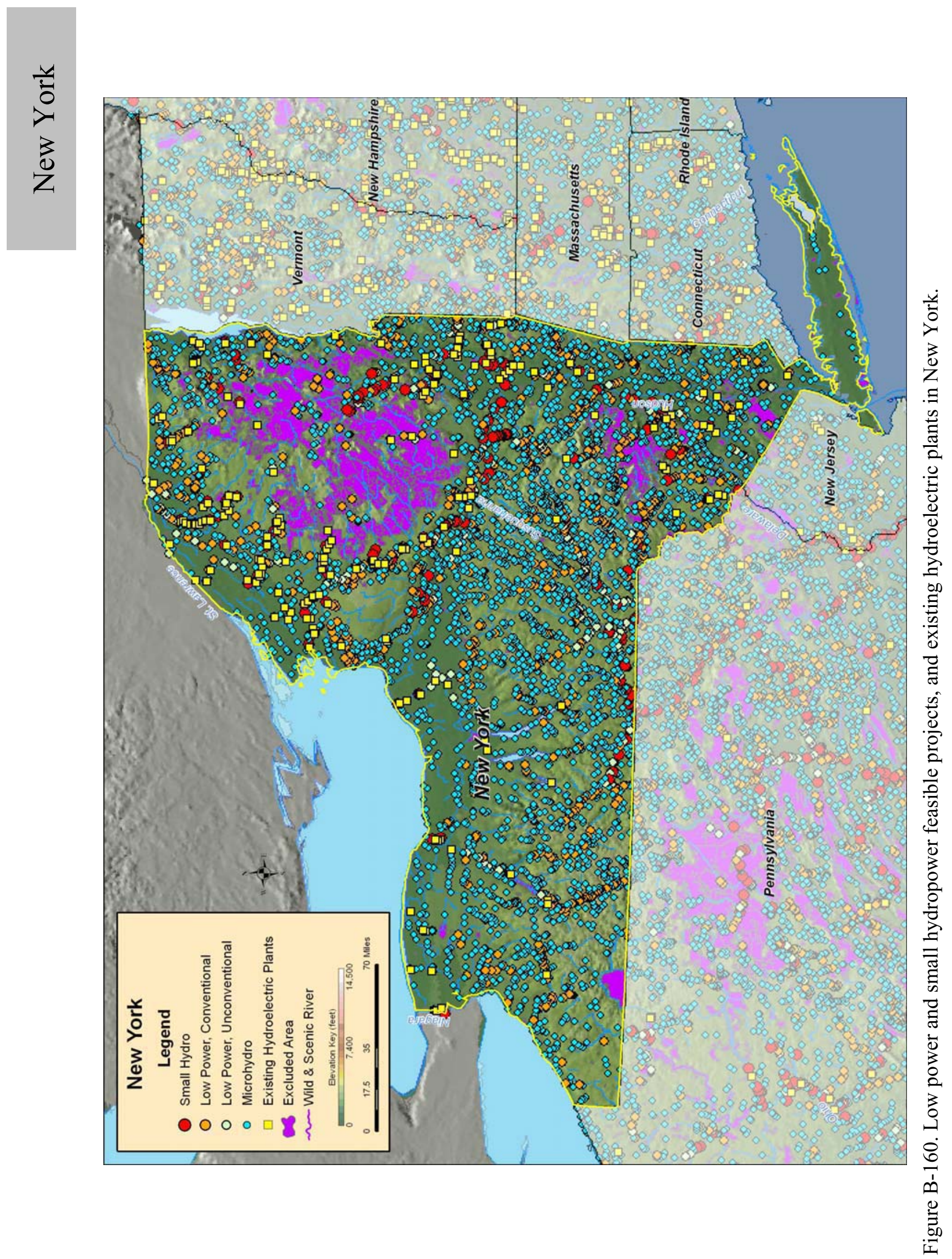




\section{B.33 North Carolina}

Table B-67. Summary of results of water energy resource assessment of North Carolina.

\begin{tabular}{|c|c|c|c|c|c|}
\hline Power Class & $\begin{array}{c}\text { Total } \\
\mathbf{( M W a )}\end{array}$ & $\begin{array}{c}\text { Developed } \\
(\mathrm{MWa})\end{array}$ & $\begin{array}{c}\text { Federally } \\
\text { Excluded } \\
(\mathbf{M W a})\end{array}$ & $\begin{array}{c}\text { Other } \\
\text { Excluded } \\
(\mathbf{M W a})\end{array}$ & $\begin{array}{c}\text { Available } \\
\text { (MWa) }\end{array}$ \\
\hline Total Power & $\mathbf{2 , 7 3 1}$ & $\mathbf{4 0 2}$ & $\mathbf{2 5 6}$ & $\mathbf{1 2 9}$ & 1,944 \\
\hline Total High Power & & & & & \\
\hline Large Hydro & $\mathbf{1 , 8 9 6}$ & $\mathbf{3 8 8}$ & $\mathbf{1 8 6}$ & $\mathbf{8 9}$ & 1,234 \\
\hline Small Hydro & $\mathbf{4 0 3}$ & 181 & 0 & 0 & 222 \\
\hline & 1,493 & 206 & 186 & 89 & 1,012 \\
\hline Total Low Power & & & & & \\
\hline Conventional Turbines & $\mathbf{8 3 5}$ & $\mathbf{1 5}$ & $\mathbf{7 0}$ & $\mathbf{3 9}$ & 711 \\
\hline Unconventional Systems & $\mathbf{5 9 9}$ & 13 & 64 & 27 & 496 \\
\hline Microhydro & $\mathbf{7 4}$ & 1 & 3 & 5 & 66 \\
\hline
\end{tabular}

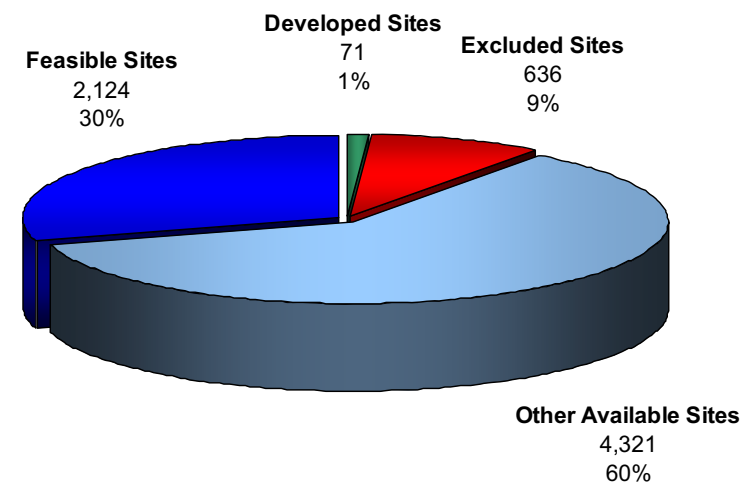

(a) Total Resource Sites 7,152

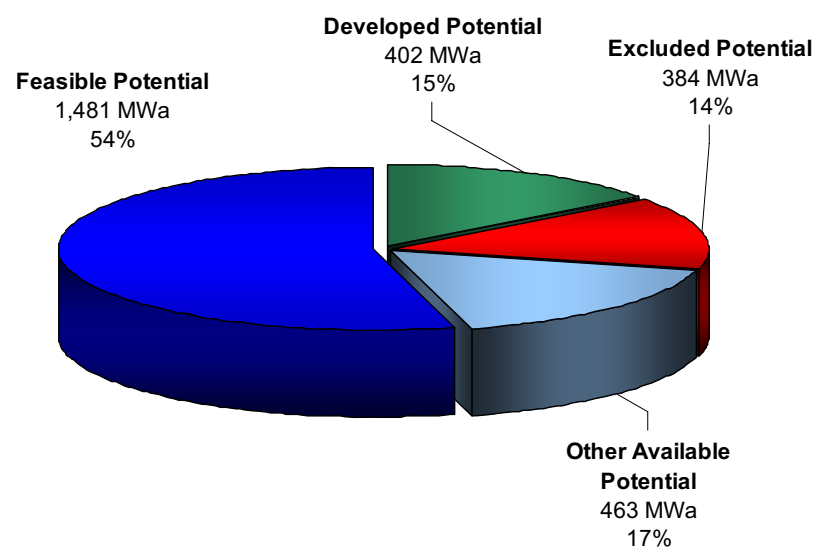

(b) Total Resource Potential $2,731 \mathrm{MWa}$

Figure B-161. Power category distribution of the (a) number and (b) total power potential of the water energy resource sites in North Carolina. 
Table B-68. Summary of results of feasibility assessment of water energy resources in North Carolina.

\begin{tabular}{|c|c|}
\hline Power Class & $\begin{array}{c}\text { Available } \\
(\mathrm{MWa})\end{array}$ \\
\hline Total Power & 1,944 \\
\hline Total High Power & 1,234 \\
\hline Large Hydro & 222 \\
\hline Small Hydro & 1,012 \\
\hline & \\
\hline Total Low Power & 711 \\
\hline Conventional Turbines & 496 \\
\hline Unconventional Systems & 66 \\
\hline Microhydro & 149 \\
\hline
\end{tabular}
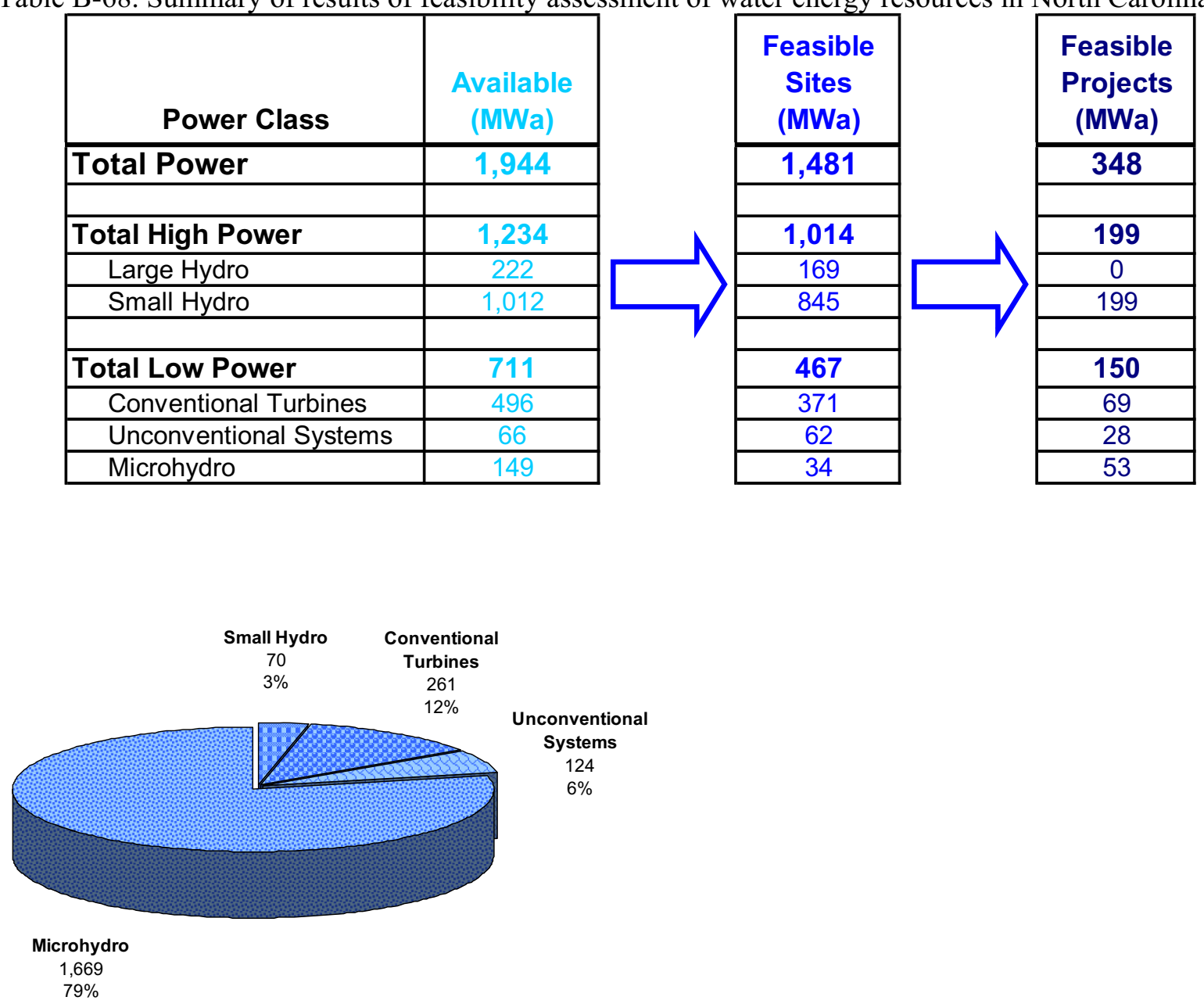

(a) Total Feasible Projects

2,124

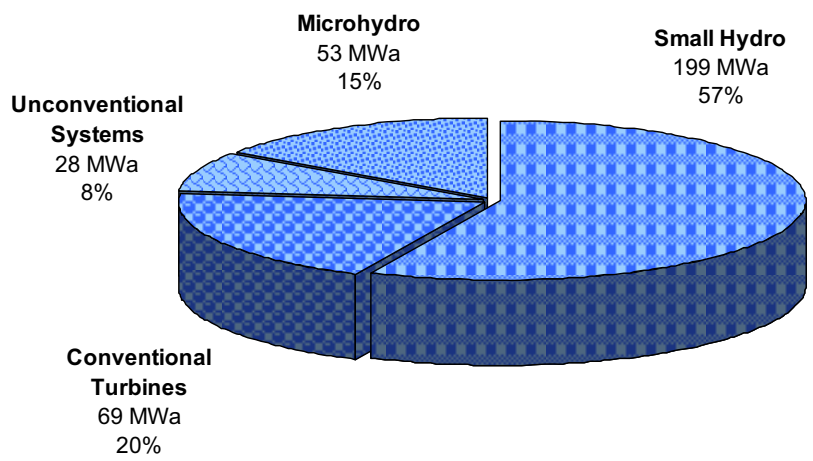

(b) Total Feasible Project Hydropower Potential $348 \mathrm{MWa}$

Figure B-162. Distribution of the (a) number and (b) total hydropower potential of the low power and small hydropower feasible projects in North Carolina with the low power projects divided into technology classes. 

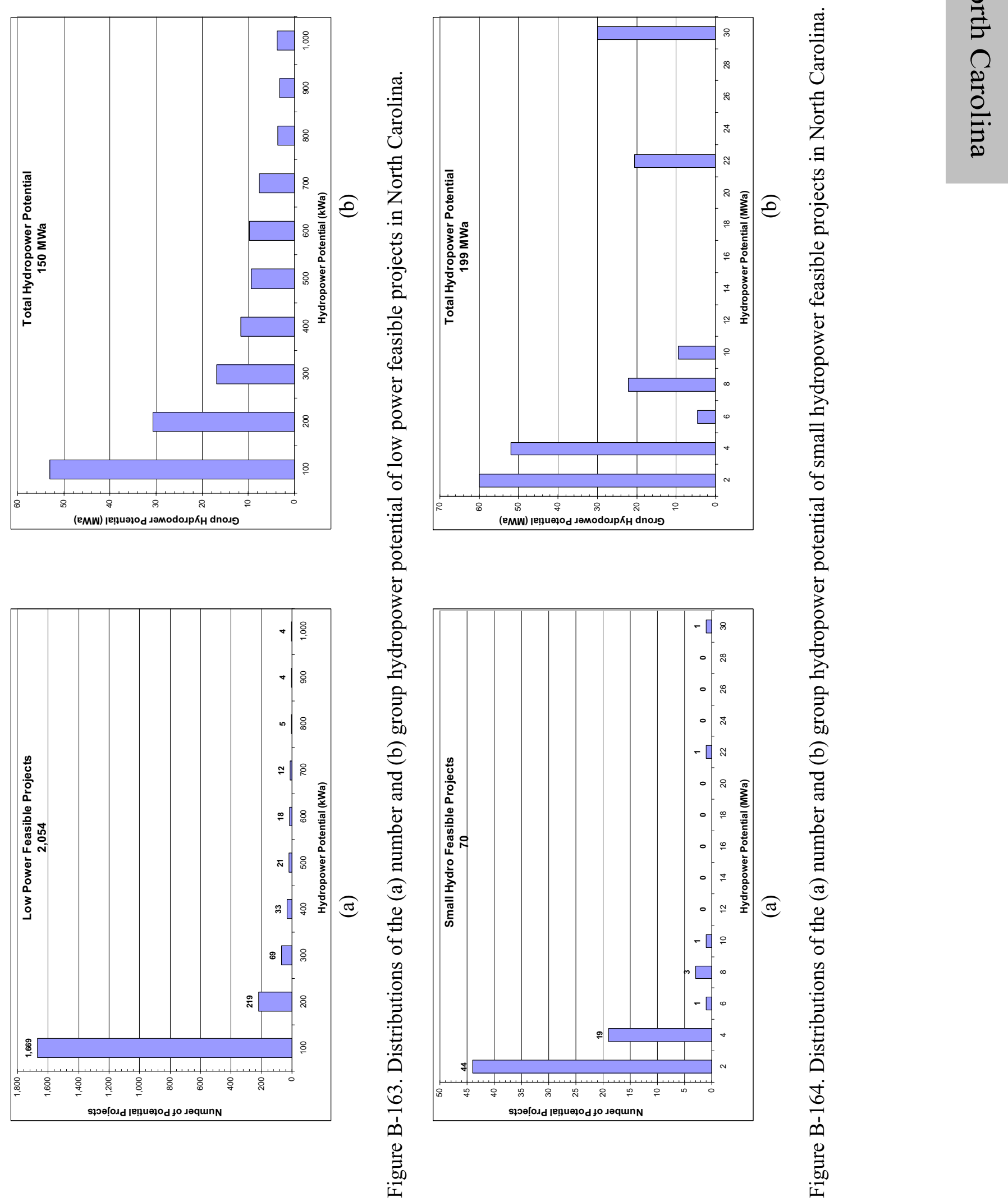


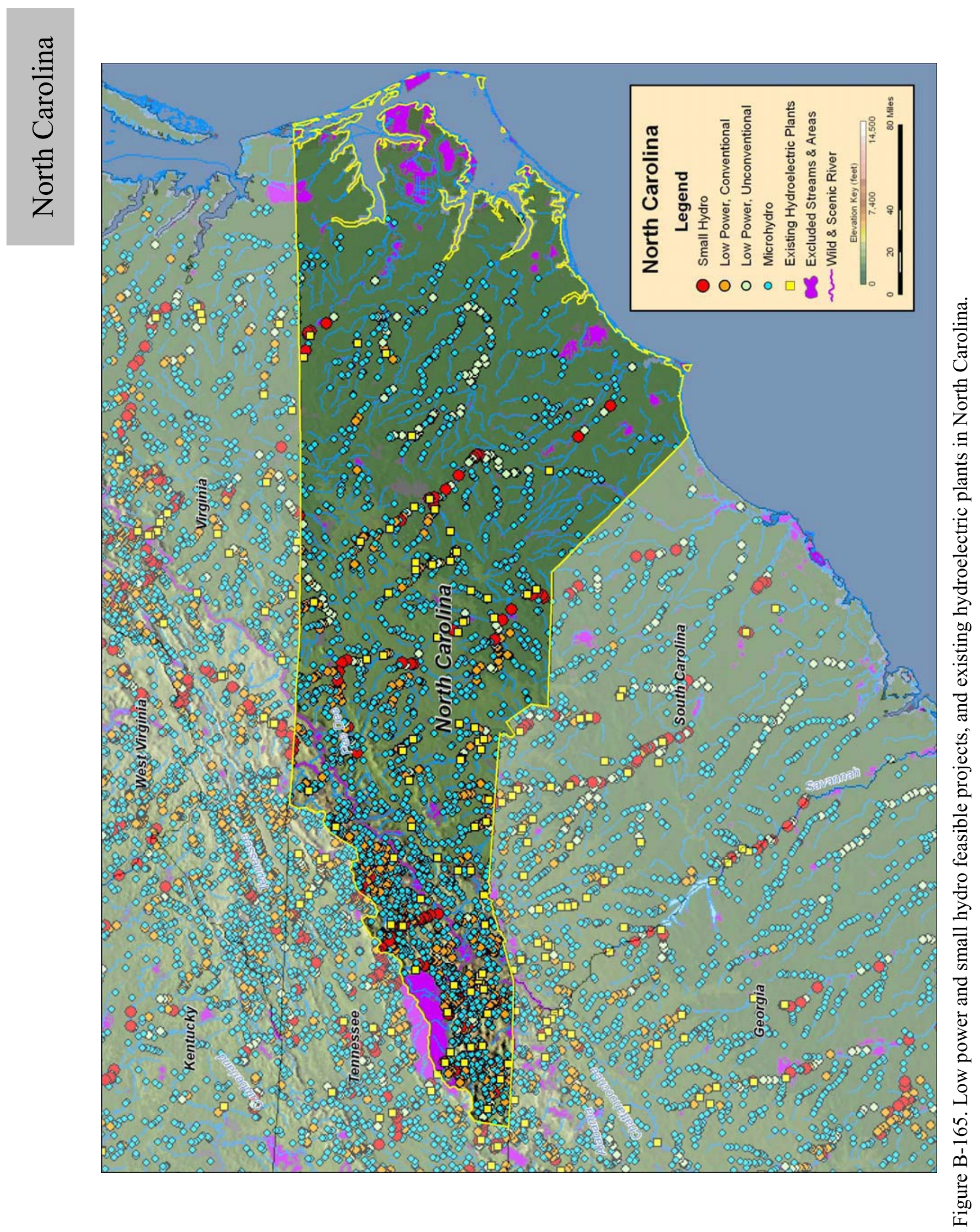




\section{B.34 North Dakota}

Table B-69. Summary of results of water energy resource assessment of North Dakota.

\begin{tabular}{|c|c|c|c|c|c|}
\hline Power Class & $\begin{array}{c}\text { Total } \\
(\mathbf{M W a})\end{array}$ & $\begin{array}{c}\text { Developed } \\
(\mathrm{MWa})\end{array}$ & $\begin{array}{c}\text { Federally } \\
\text { Excluded } \\
(\mathbf{M W a})\end{array}$ & $\begin{array}{c}\text { Other } \\
\text { Excluded } \\
(\mathbf{M W a})\end{array}$ & $\begin{array}{c}\text { Available } \\
(\mathrm{MWa})\end{array}$ \\
\hline Total Power & $\mathbf{2 6 1}$ & $\mathbf{7 8}$ & $\mathbf{5}$ & $\mathbf{1}$ & 178 \\
\hline Total High Power & & & & & \\
\hline Large Hydro & $\mathbf{1 3 2}$ & $\mathbf{7 8}$ & $\mathbf{1}$ & $\mathbf{0}$ & 53 \\
\hline Small Hydro & 78 & 78 & 0 & 0 & 0 \\
\hline & 54 & 0 & 1 & 0 & 53 \\
\hline Total Low Power & & & & & \\
\hline Conventional Turbines & $\mathbf{1 3 0}$ & 0 & 3 & 1 & 125 \\
\hline Unconventional Systems & $\mathbf{5 4}$ & 0 & 2 & 0 & 52 \\
\hline Microhydro & 10 & 0 & 0 & 0 & 10 \\
\hline
\end{tabular}

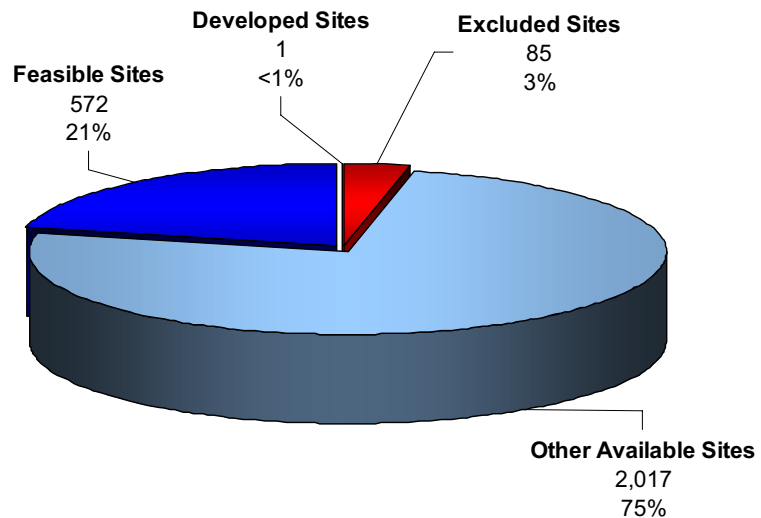

(a) Total Resource Sites 2,675

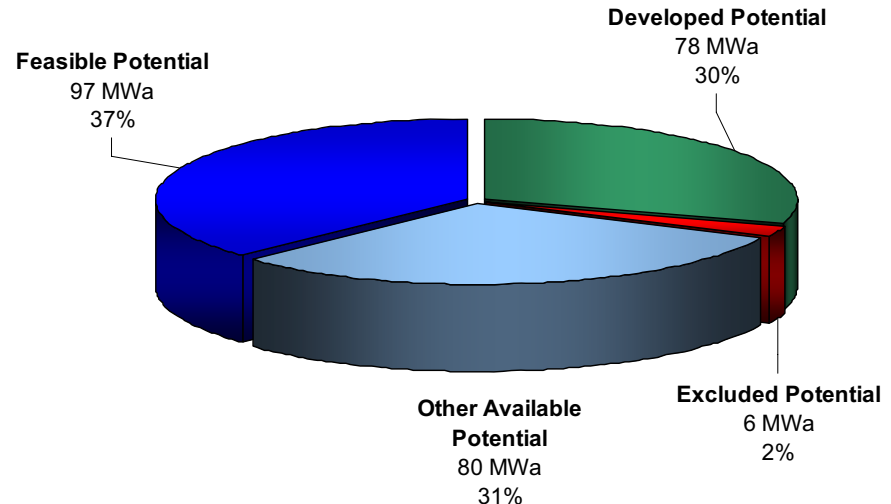

(b) Total Resource Potential $261 \mathrm{MWa}$

Figure B-166. Power category distribution of the (a) number and (b) total power potential of the water energy resource sites in North Dakota. 
Table B-70. Summary of results of feasibility assessment of water energy resources in North Dakota.

\begin{tabular}{|c|c|}
\hline Power Class & $\begin{array}{c}\text { Available } \\
\text { (MWa) }\end{array}$ \\
\hline Total Power & 178 \\
\hline Total High Power & 53 \\
\hline Large Hydro & 0 \\
\hline Small Hydro & 53 \\
\hline & \\
\hline Total Low Power & 125 \\
\hline Conventional Turbines & 52 \\
\hline Unconventional Systems & 10 \\
\hline Microhydro & 63 \\
\hline
\end{tabular}
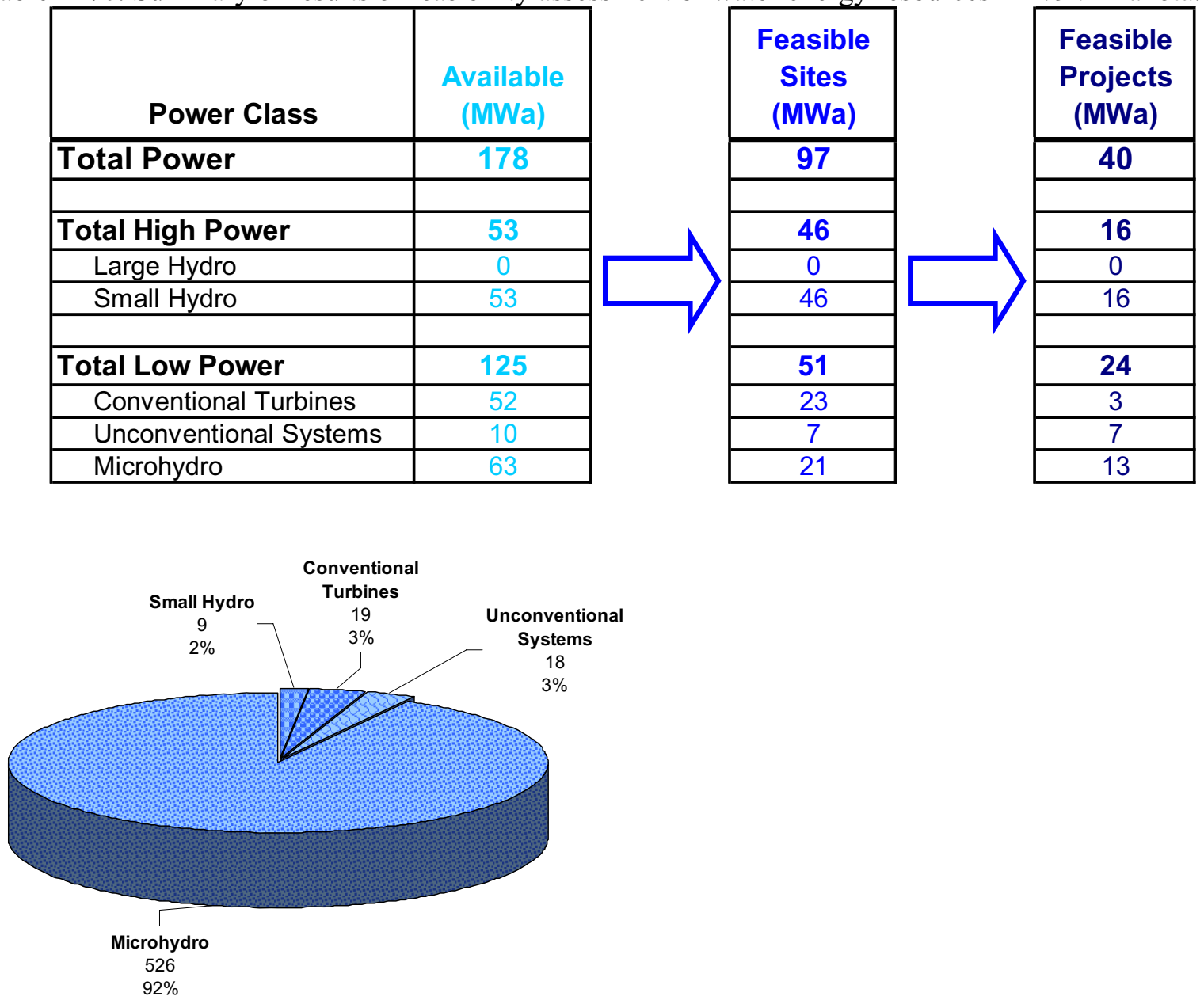

(a) Total Feasible Projects

572

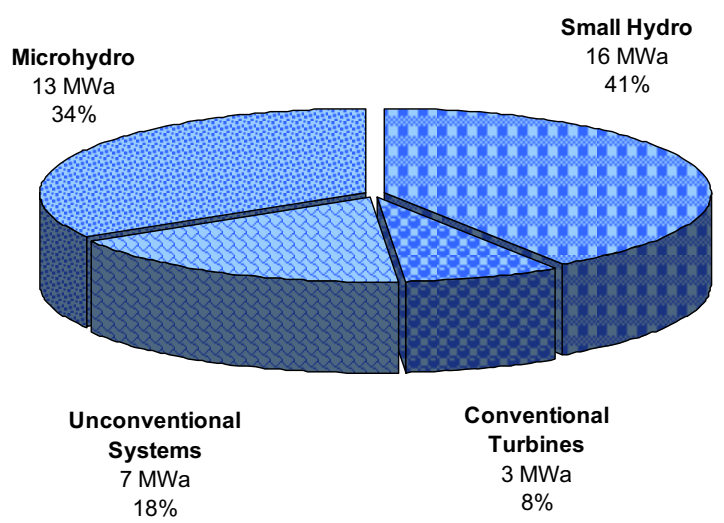

(b) Total Feasible Project Hydropower Potential $40 \mathrm{MWa}$

Figure B-167. Distribution of the (a) number and (b) total hydropower potential of the low power and small hydropower feasible projects in North Dakota with the low power projects divided into technology classes. 

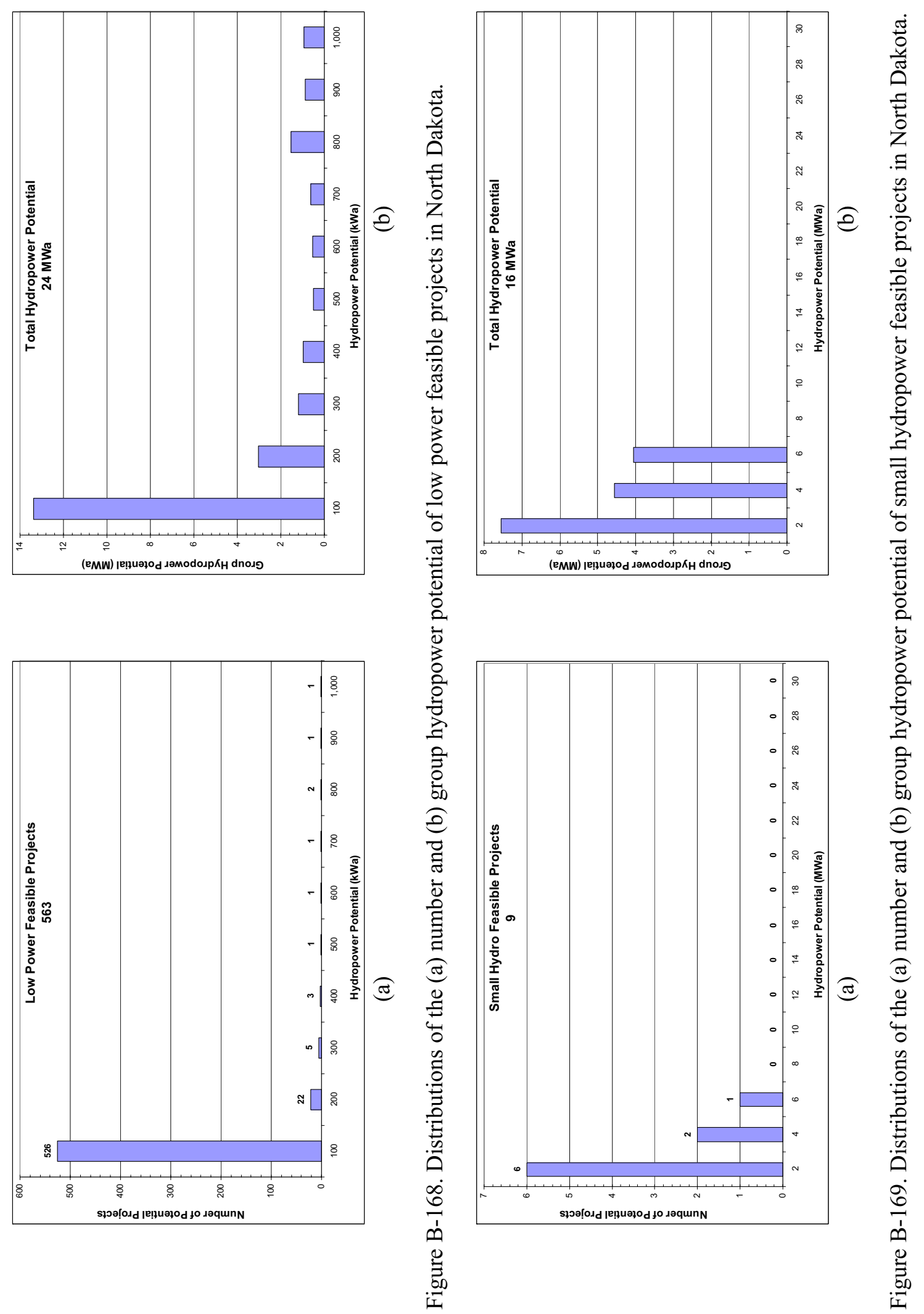


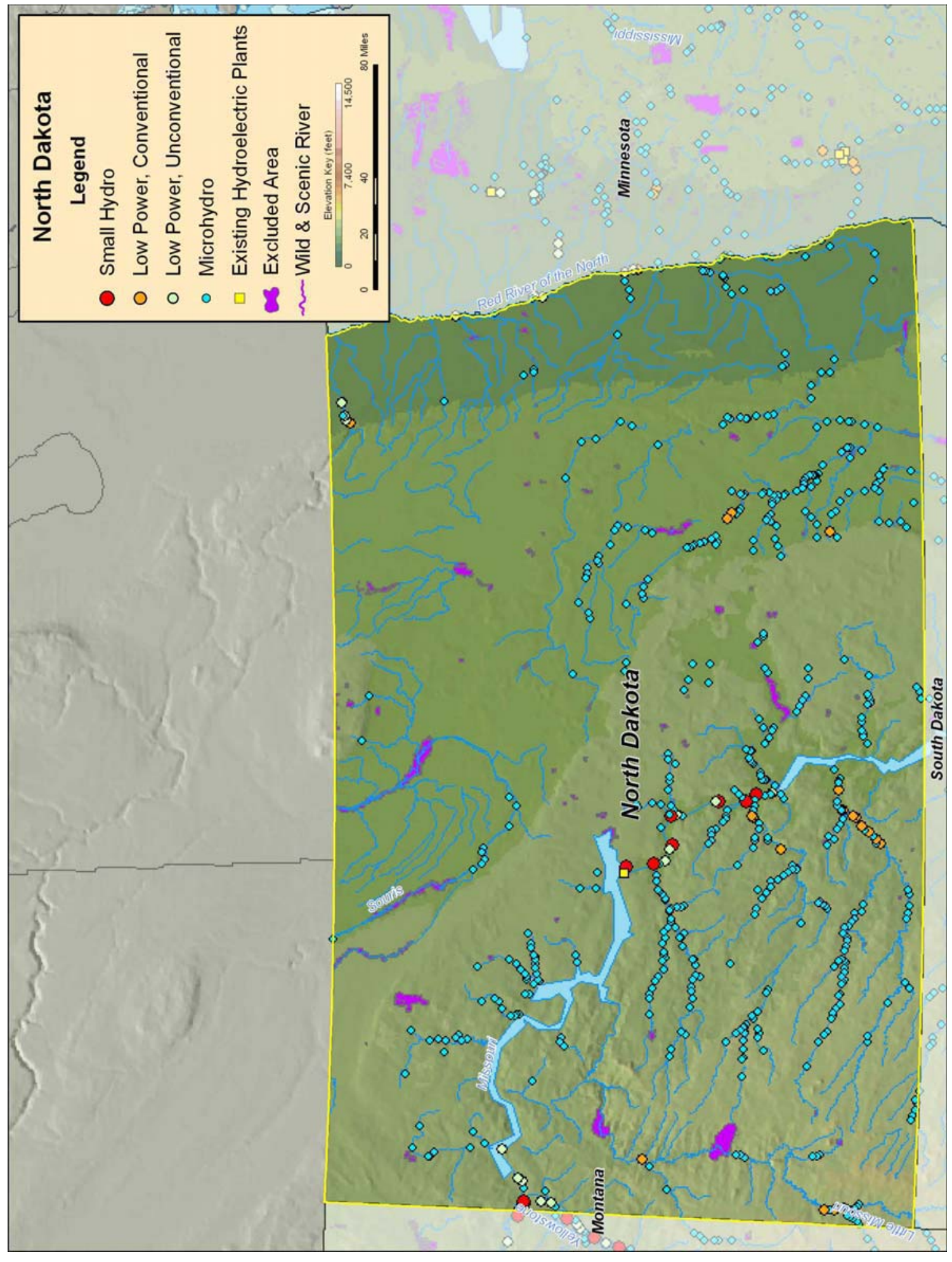

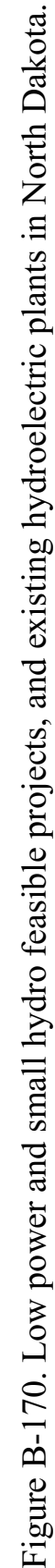




\section{B.35 Ohio}

Table B-71. Summary of results of water energy resource assessment of Ohio.

\begin{tabular}{|c|c|c|c|c|c|}
\hline Power Class & $\begin{array}{c}\text { Total } \\
\mathbf{( M W a )}\end{array}$ & $\begin{array}{c}\text { Developed } \\
(\mathrm{MWa})\end{array}$ & $\begin{array}{c}\text { Federally } \\
\text { Excluded } \\
(\mathbf{M W a})\end{array}$ & $\begin{array}{c}\text { Other } \\
\text { Excluded } \\
(\mathbf{M W a})\end{array}$ & $\begin{array}{c}\text { Available } \\
(\mathrm{MWa})\end{array}$ \\
\hline Total Power & $\mathbf{1 , 3 9 7}$ & $\mathbf{2}$ & $\mathbf{7 0}$ & $\mathbf{3 3}$ & 1,292 \\
\hline & & & & & \\
\hline Total High Power & $\mathbf{8 5 6}$ & $\mathbf{2}$ & $\mathbf{4 0}$ & $\mathbf{1 4}$ & 799 \\
\hline Large Hydro & $\mathbf{3 6 6}$ & 0 & 0 & 0 & 366 \\
\hline Small Hydro & $\mathbf{4 9 0}$ & 2 & 40 & 14 & 434 \\
\hline & & & & & \\
\hline Total Low Power & $\mathbf{5 4 1}$ & 1 & $\mathbf{2 9}$ & $\mathbf{1 8}$ & 492 \\
\hline Conventional Turbines & 315 & 0 & 21 & 11 & 283 \\
\hline Unconventional Systems & 56 & 0 & 3 & 2 & 51 \\
\hline Microhydro & 170 & 0 & 5 & 6 & 158 \\
\hline
\end{tabular}

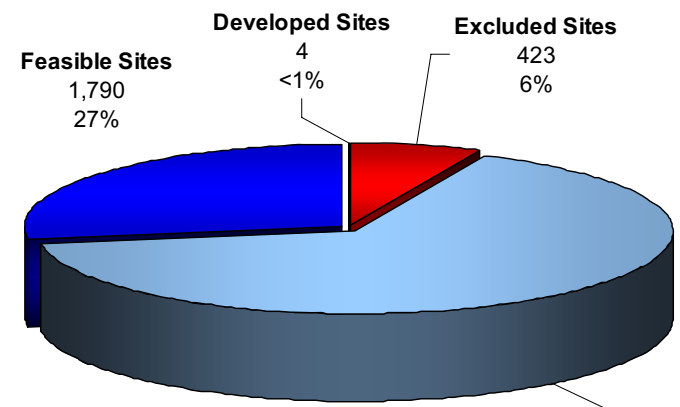

Other Available Sites

$$
4,319
$$

(a) Total Resource Sites

6,536

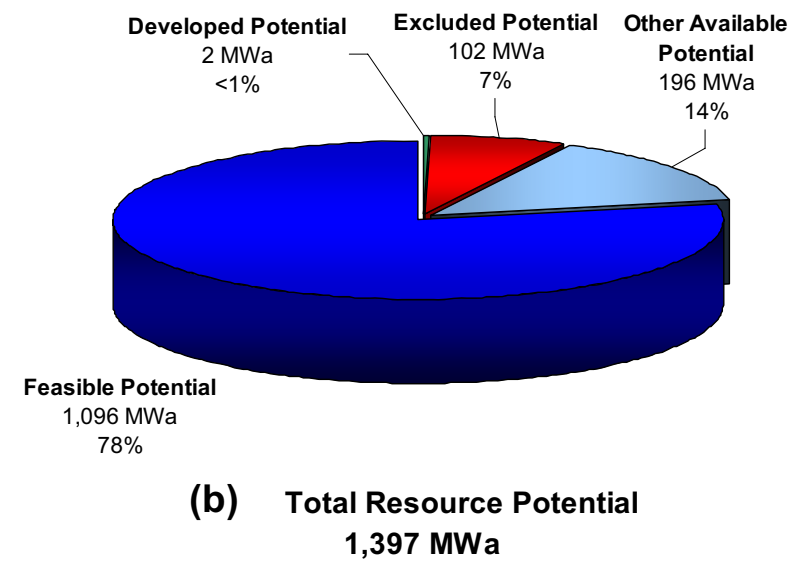

Figure B-171. Power category distribution of the (a) number and (b) total power potential of the water energy resource sites in Ohio. 
Table B-72. Summary of results of feasibility assessment of water energy resources in Ohio.

\begin{tabular}{|c|c|c|c|}
\hline Power Class & $\begin{array}{c}\text { Available } \\
\text { (MWa) }\end{array}$ & $\begin{array}{c}\text { Feasible } \\
\text { Sites } \\
\text { (MWa) }\end{array}$ & $\begin{array}{c}\text { Feasible } \\
\text { Projects } \\
(\mathrm{MWa})\end{array}$ \\
\hline Total Power & 1,292 & 1,096 & 319 \\
\hline Total High Power & 799 & 780 & 197 \\
\hline Large Hydro & 366 & 366 & 0 \\
\hline Small Hydro & 434 & 414 & 197 \\
\hline Total Low Power & 492 & 316 & 122 \\
\hline Conventional Turbines & 283 & 227 & 39 \\
\hline Unconventional Systems & 51 & 46 & 38 \\
\hline Microhydro & 158 & 43 & 45 \\
\hline
\end{tabular}

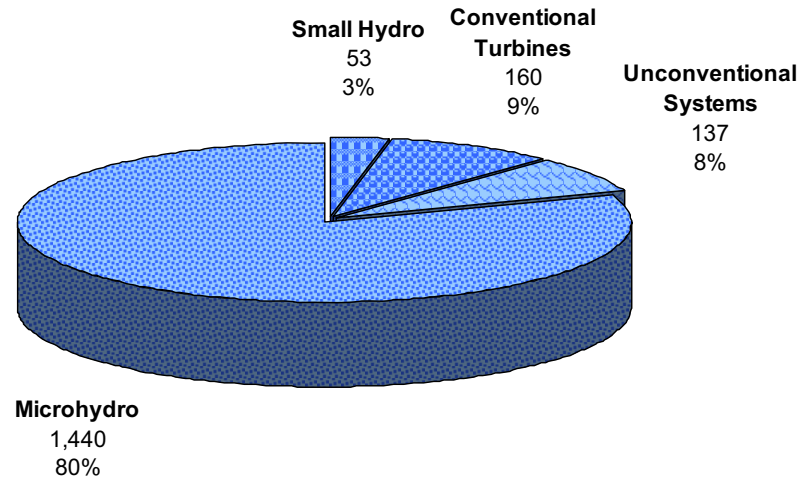

(a) Total Feasible Projects

1,790

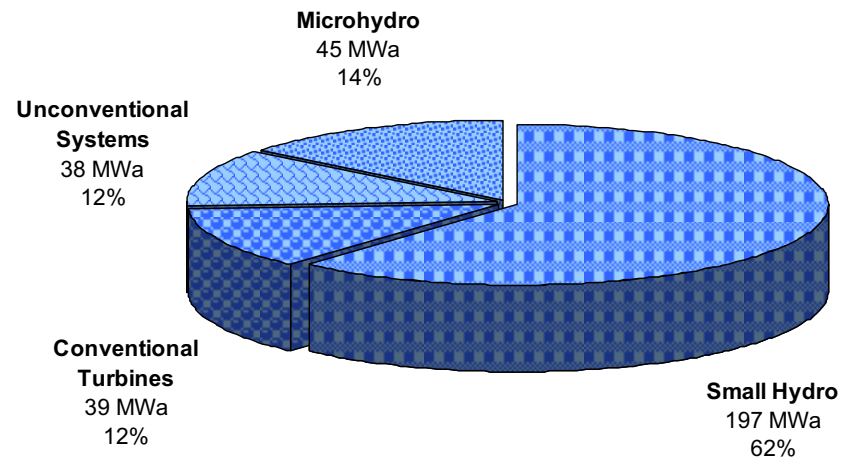

(b) Total Feasible Project Hydropower Potential $319 \mathrm{MWa}$

Figure B-172. Distribution of the (a) number and (b) total hydropower potential of the low power and small hydropower feasible projects in Ohio with the low power projects divided into technology classes. 

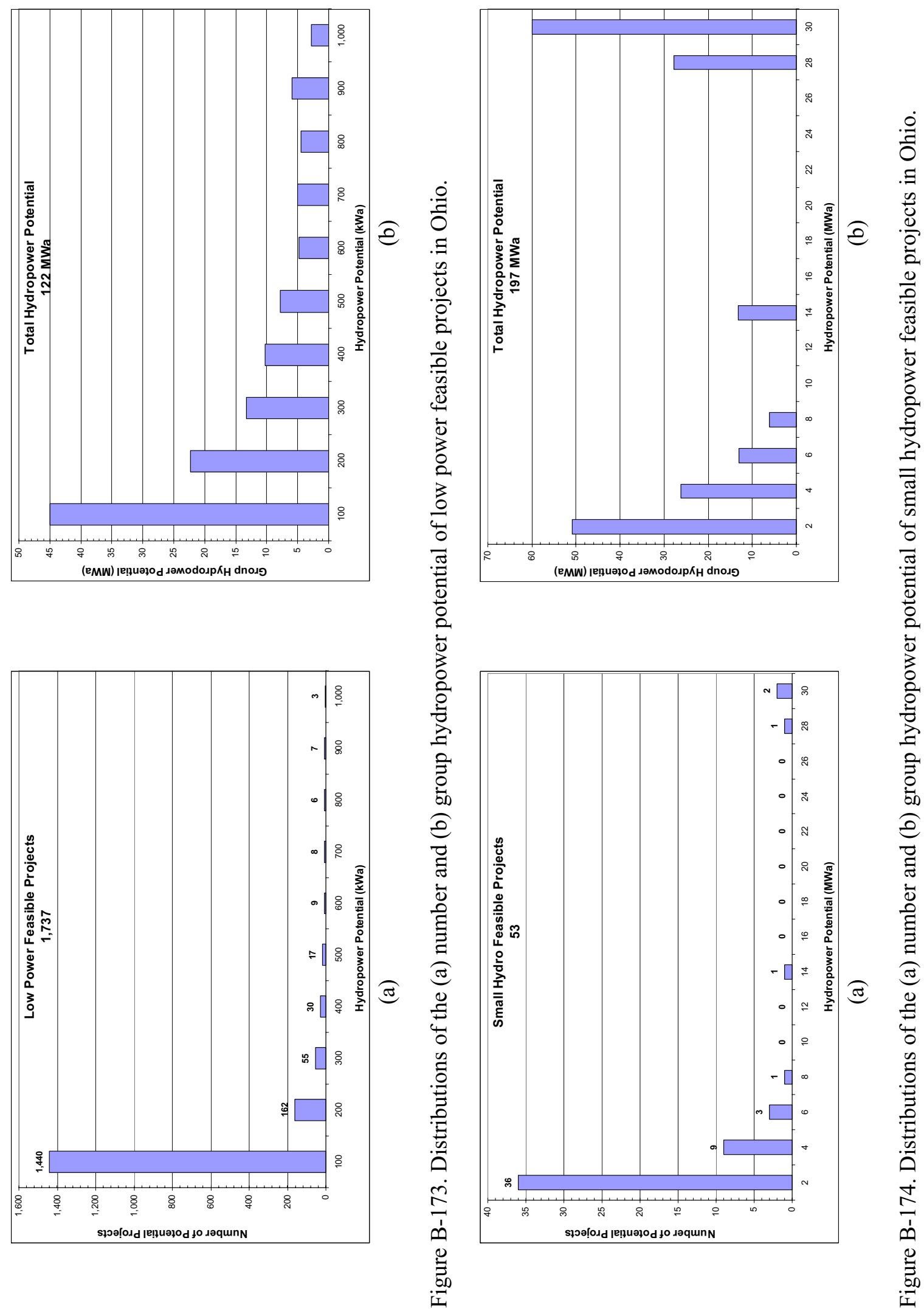

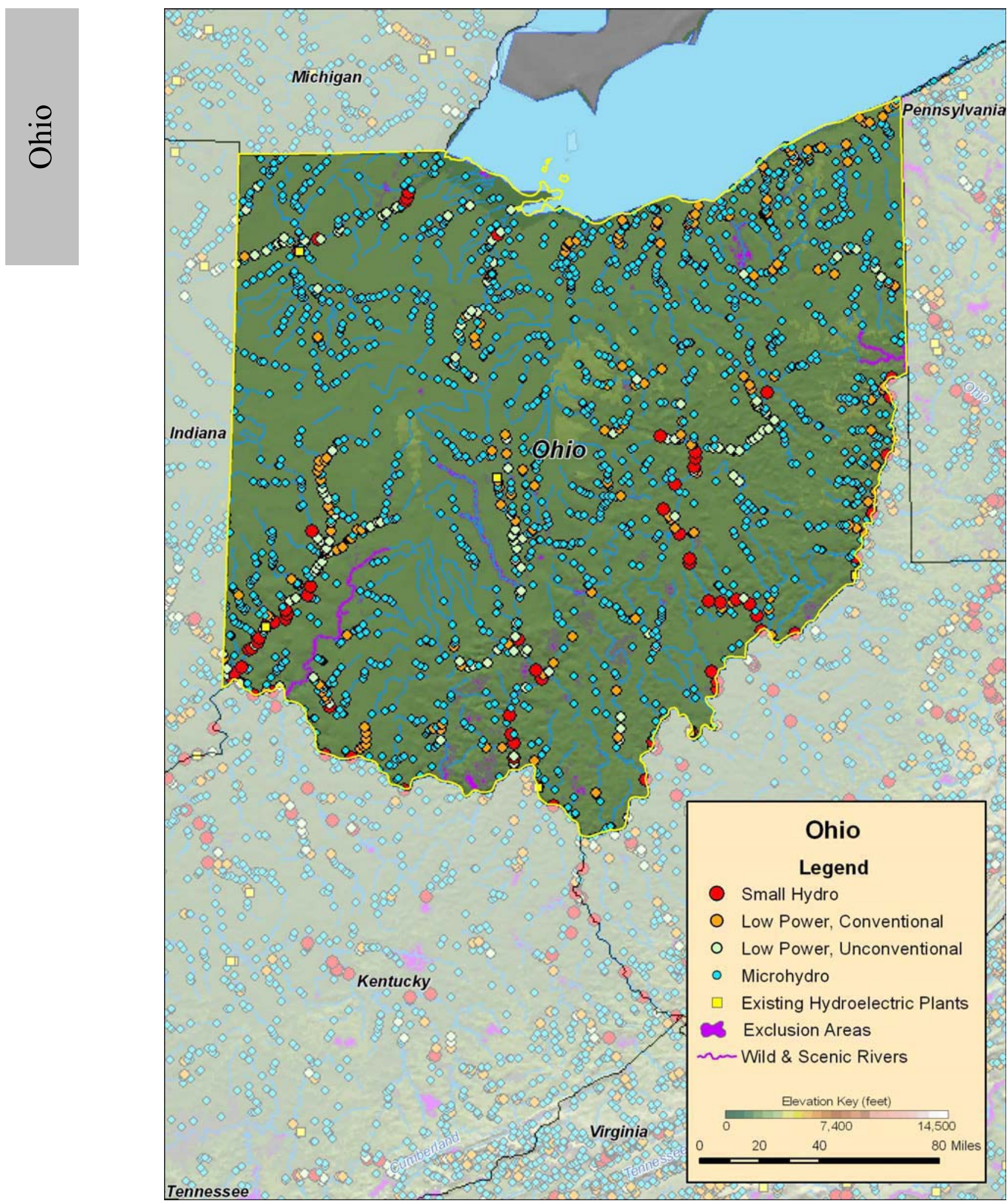

Figure B-175. Low power and small hydro feasible projects, and existing hydroelectric plants in Ohio. 


\section{B.36 Oklahoma}

Table B-73. Summary of results of water energy resource assessment of Oklahoma.

\begin{tabular}{|c|c|c|c|c|c|}
\hline Power Class & $\begin{array}{c}\text { Total } \\
\mathbf{( M W a )}\end{array}$ & $\begin{array}{c}\text { Developed } \\
(\mathrm{MWa})\end{array}$ & $\begin{array}{c}\text { Federally } \\
\text { Excluded } \\
(\mathbf{M W a})\end{array}$ & $\begin{array}{c}\text { Other } \\
\text { Excluded } \\
(\mathbf{M W a})\end{array}$ & $\begin{array}{c}\text { Availlable } \\
(\mathrm{MWa})\end{array}$ \\
\hline Total Power & $\mathbf{1 , 4 1 6}$ & 101 & $\mathbf{1 8}$ & $\mathbf{7 2}$ & 1,226 \\
\hline Total High Power & $\mathbf{6 5 9}$ & 100 & $\mathbf{5}$ & $\mathbf{3 0}$ & 524 \\
\hline Large Hydro & 157 & 68 & 0 & 0 & 88 \\
\hline Small Hydro & 502 & 32 & 5 & 30 & 436 \\
\hline Total Low Power & & & & & \\
\hline Conventional Turbines & $\mathbf{7 5 7}$ & 1 & 13 & $\mathbf{4 2}$ & 702 \\
\hline Unconventional Systems & $\mathbf{4 1 3}$ & 0 & 6 & 25 & 381 \\
\hline Microhydro & 157 & 0 & 5 & 6 & 145 \\
\hline
\end{tabular}

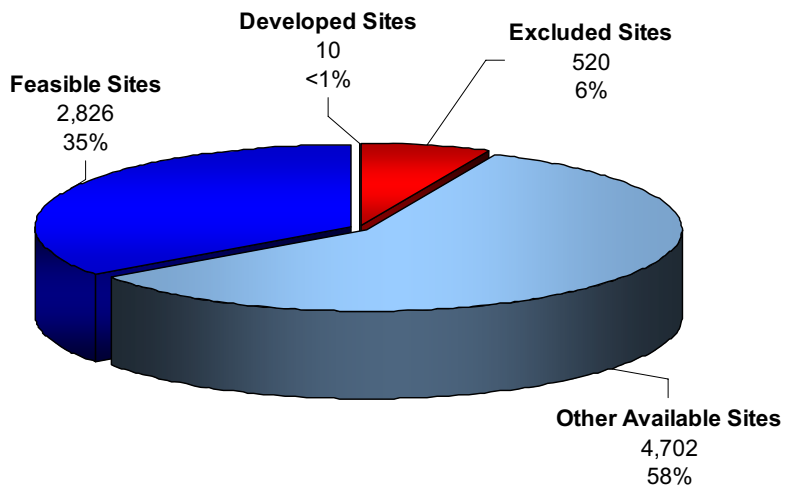

(a) Total Resource Sites 8,058

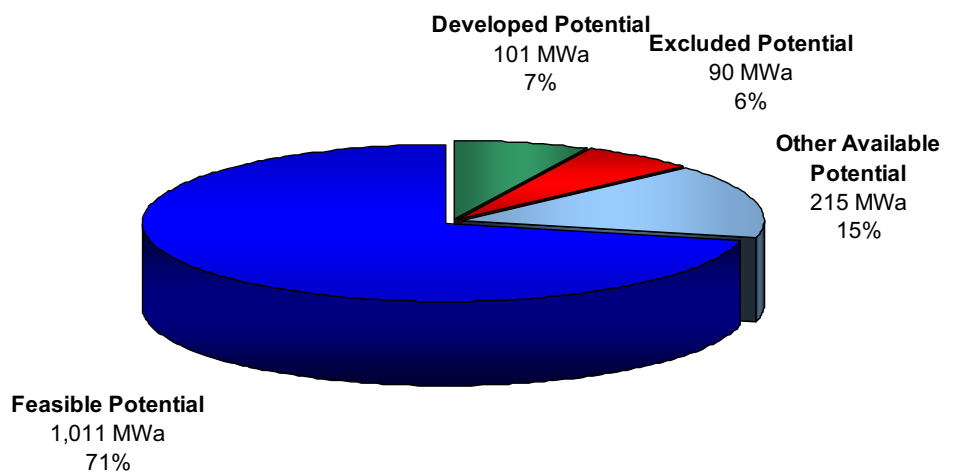

(b) Total Resource Potential $1,416 \mathrm{MWa}$

Figure B-176. Power category distribution of the (a) number and (b) total power potential of the water energy resource sites in Oklahoma. 
Table B-74. Summary of results of feasibility assessment of water energy resources in Oklahoma.

\begin{tabular}{|c|c|}
\hline Power Class & $\begin{array}{c}\text { Available } \\
\text { (MWa) }\end{array}$ \\
\hline Total Power & 1,226 \\
\hline Total High Power & 524 \\
\hline Large Hydro & 88 \\
\hline Small Hydro & 436 \\
\hline & \\
\hline Total Low Power & 702 \\
\hline Conventional Turbines & 381 \\
\hline Unconventional Systems & 145 \\
\hline Microhydro & 175 \\
\hline
\end{tabular}

\begin{tabular}{|c|c|}
\hline $\begin{array}{c}\text { Feasible } \\
\text { Sites } \\
\text { (MWa) }\end{array}$ & $\begin{array}{c}\text { Feasible } \\
\text { Projects } \\
\text { (MWa) }\end{array}$ \\
\hline 1,011 & 345 \\
\hline 482 & 126 \\
\hline 88 & 0 \\
\hline 394 & 126 \\
\hline 529 & 220 \\
\hline 331 & 70 \\
\hline 128 & 81 \\
\hline 69 & 69 \\
\hline
\end{tabular}

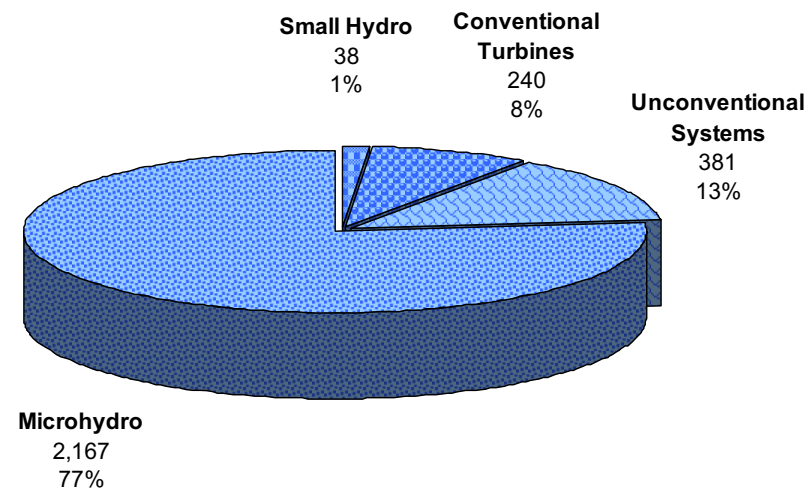

(a) Total Feasible Projects 2,826

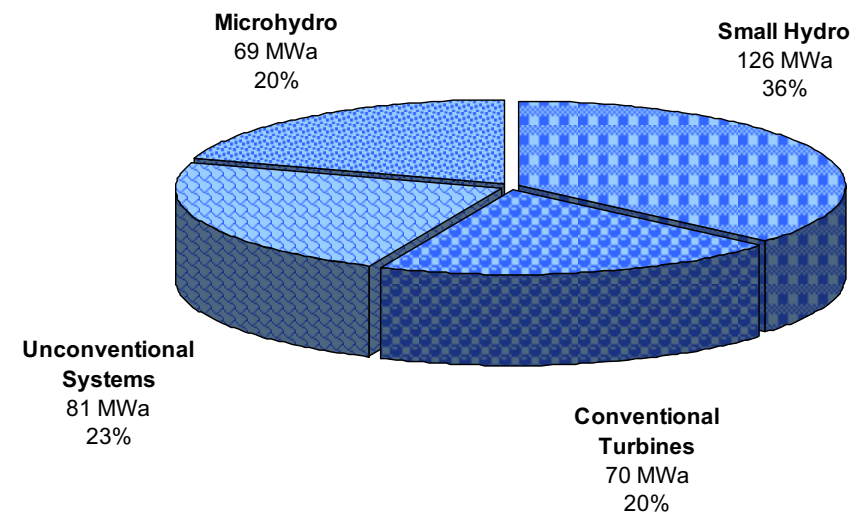

(b) Total Feasible Project Hydropower Potential $345 \mathrm{MWa}$

Figure B-177. Distribution of the (a) number and (b) total hydropower potential of the low power and small hydropower feasible projects in Oklahoma with the low power projects divided into technology classes. 

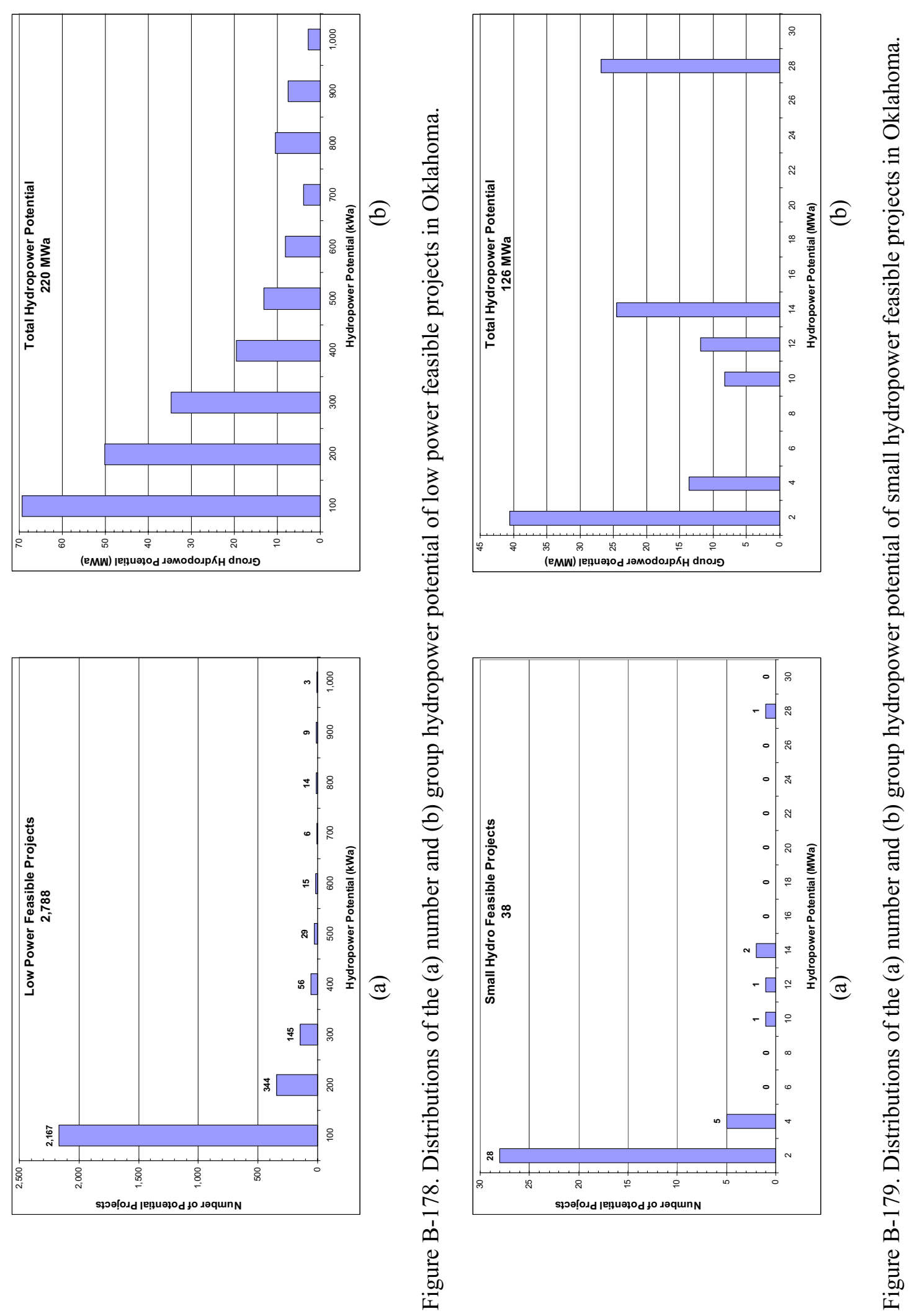

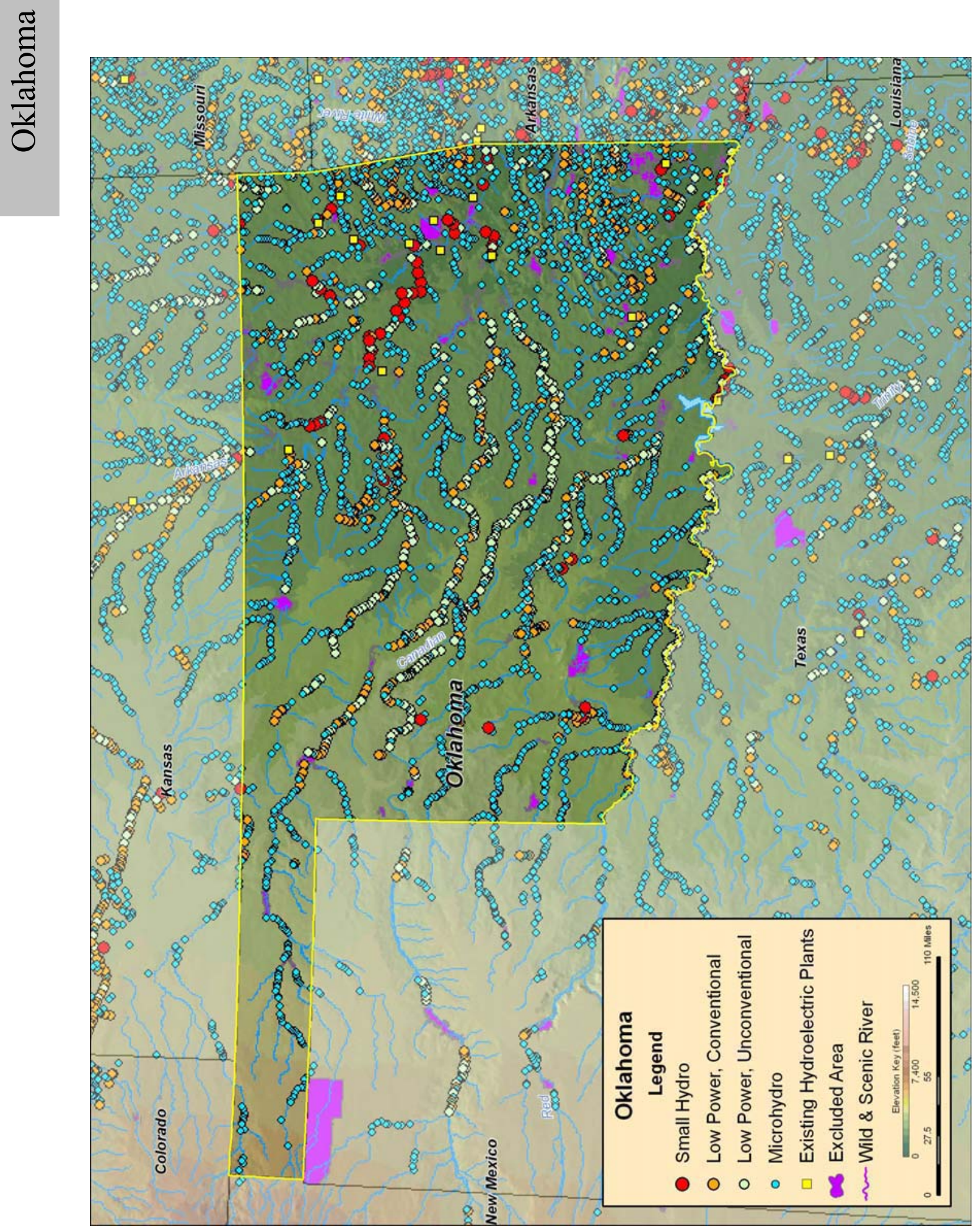

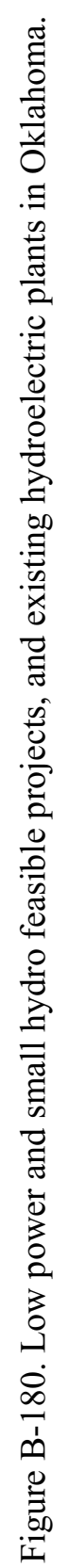




\section{B.37 Oregon}

Table B-75. Summary of results of water energy resource assessment of Oregon.

\begin{tabular}{|c|c|c|c|c|c|}
\hline Power Class & $\begin{array}{c}\text { Total } \\
\mathbf{( M W a )}\end{array}$ & $\begin{array}{c}\text { Developed } \\
(\mathrm{MWa})\end{array}$ & $\begin{array}{c}\text { Federally } \\
\text { Excluded } \\
\text { (MWa) }\end{array}$ & $\begin{array}{c}\text { Other } \\
\text { Excluded } \\
\text { (MWa) }\end{array}$ & $\begin{array}{c}\text { Available } \\
(\mathrm{MWa})\end{array}$ \\
\hline Total Power & $\mathbf{1 7 , 0 4 8}$ & $\mathbf{1 , 0 5 0}$ & $\mathbf{5 , 8 2 6}$ & $\mathbf{7 1 6}$ & 9,455 \\
\hline Total High Power & & & & & \\
\hline Large Hydro & $\mathbf{1 4 , 0 0 3}$ & $\mathbf{1 , 0 4 5}$ & $\mathbf{5 , 3 8 1}$ & $\mathbf{5 3 7}$ & 7,040 \\
\hline Small Hydro & $\mathbf{1 , 8 8 2}$ & 767 & 613 & 34 & 467 \\
\hline Total Low Power & 12,122 & 278 & 4,768 & 503 & 6,573 \\
\hline Conventional Turbines & & & & & \\
\hline Unconventional Systems & $\mathbf{3 , 0 4 5}$ & $\mathbf{6}$ & $\mathbf{4 4 5}$ & $\mathbf{1 7 9}$ & 2,415 \\
\hline Microhydro & $\mathbf{2 , 5 8 0}$ & 5 & 398 & 148 & 2,029 \\
\hline
\end{tabular}

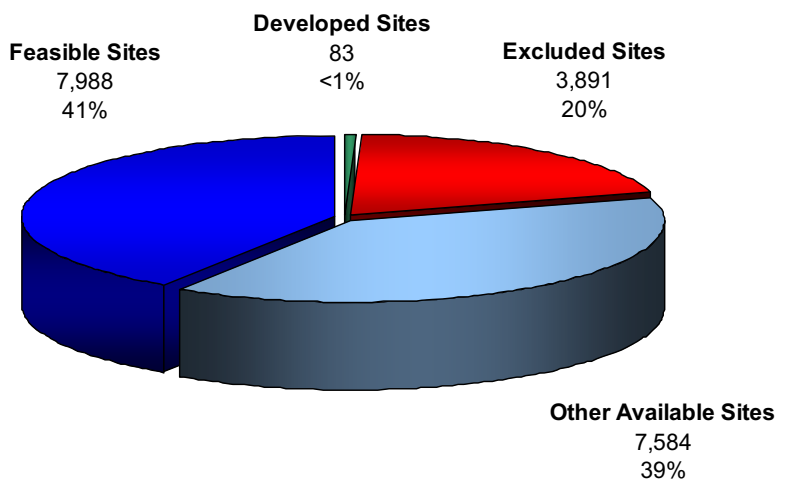

(a) Total Resource Sites 19,546

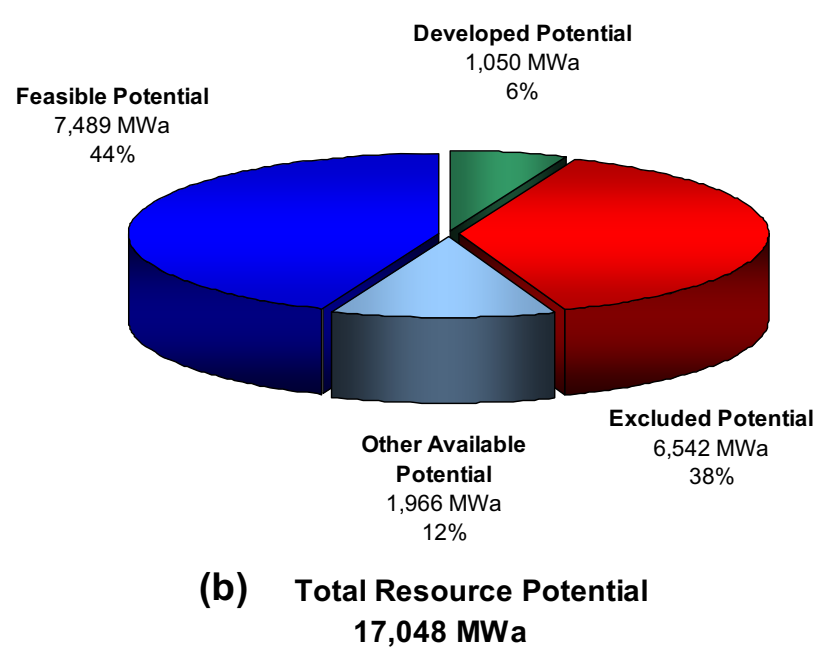

Figure B-181. Power category distribution of the (a) number and (b) total power potential of the water energy resource sites in Oregon. 
Table B-76. Summary of results of feasibility assessment of water energy resources in Oregon.

\begin{tabular}{|c|c|}
\hline Power Class & $\begin{array}{c}\text { Available } \\
\text { (MWa) }\end{array}$ \\
\hline Total Power & 9,455 \\
\hline Total High Power & 7,040 \\
\hline Large Hydro & 467 \\
\hline Small Hydro & 6,573 \\
\hline & \\
\hline Total Low Power & 2,415 \\
\hline Conventional Turbines & 2,029 \\
\hline Unconventional Systems & 84 \\
\hline Microhydro & 302 \\
\hline
\end{tabular}

\begin{tabular}{|c|c|}
\hline $\begin{array}{c}\text { Feasible } \\
\text { Sites } \\
\text { (MWa) }\end{array}$ & $\begin{array}{c}\text { Feasible } \\
\text { Projects } \\
\text { (MWa) }\end{array}$ \\
\hline 7,489 & 2,072 \\
\hline 5,858 & 1,220 \\
\hline 467 & 0 \\
\hline 5,390 & 1,220 \\
\hline 1,631 & 852 \\
\hline 1,420 & 585 \\
\hline 80 & 75 \\
\hline 131 & 192 \\
\hline
\end{tabular}

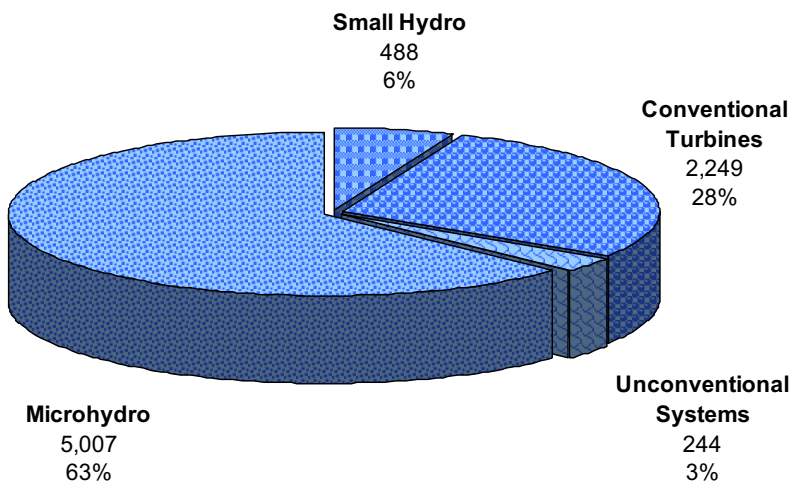

(a) Total Feasible Projects

7,988

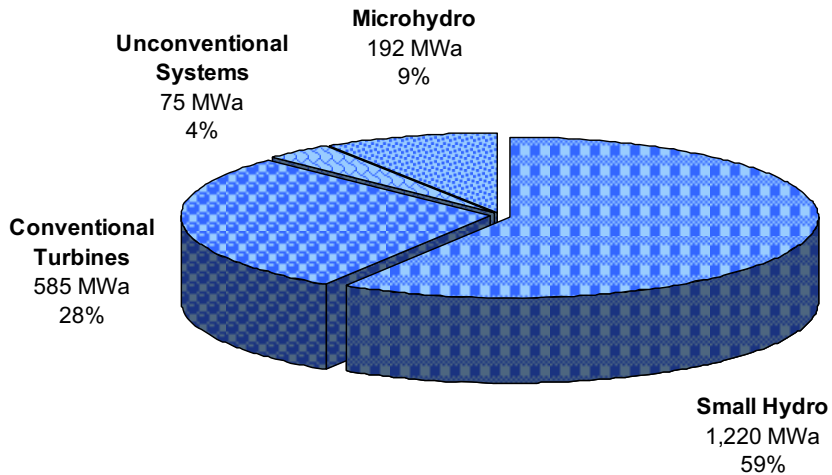

(b) Total Feasible Project Hydropower Potential $2,072 \mathrm{MWa}$

Figure B-182. Distribution of the (a) number and (b) total hydropower potential of the low power and small hydropower feasible projects in Oregon with the low power projects divided into technology classes. 

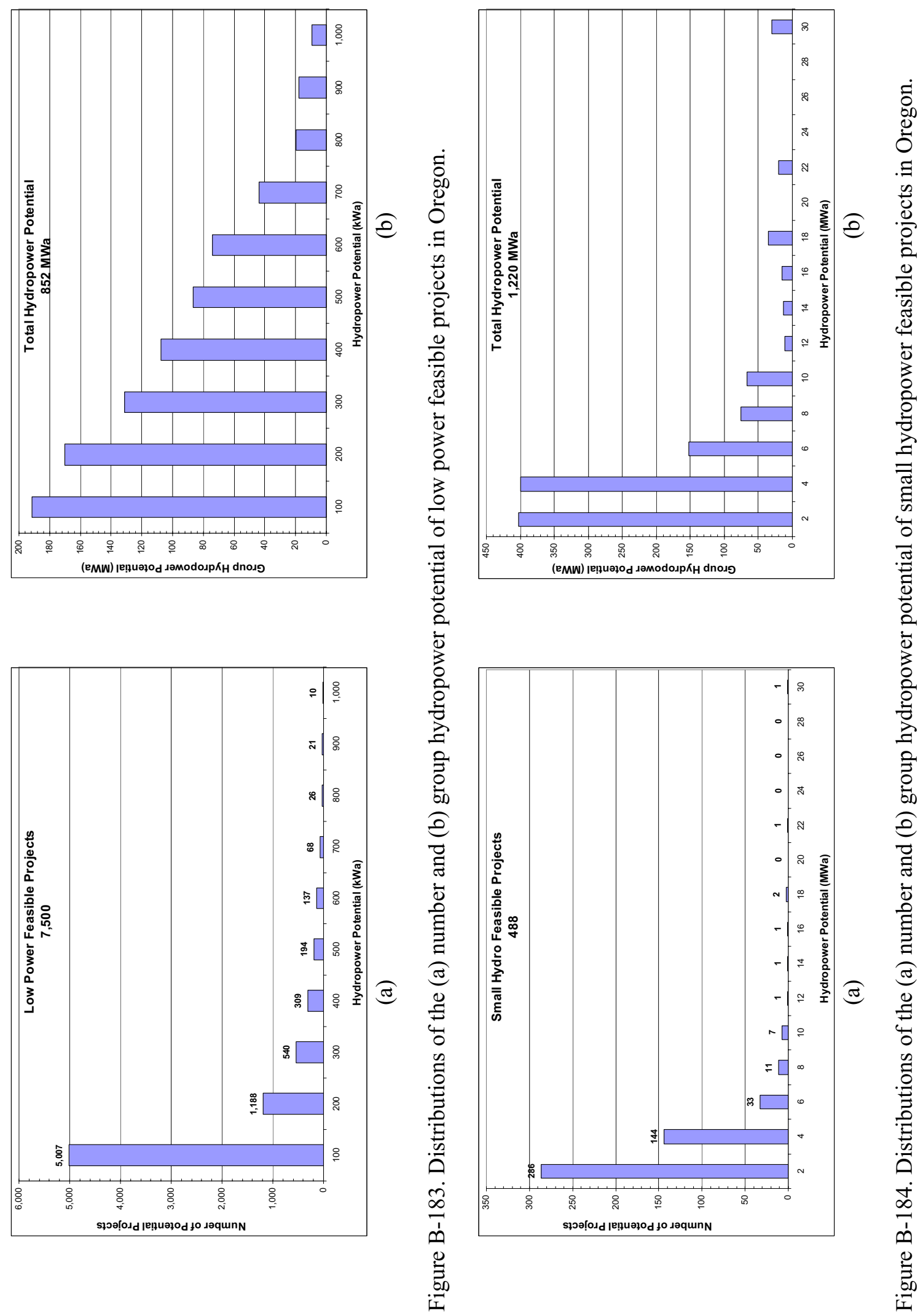

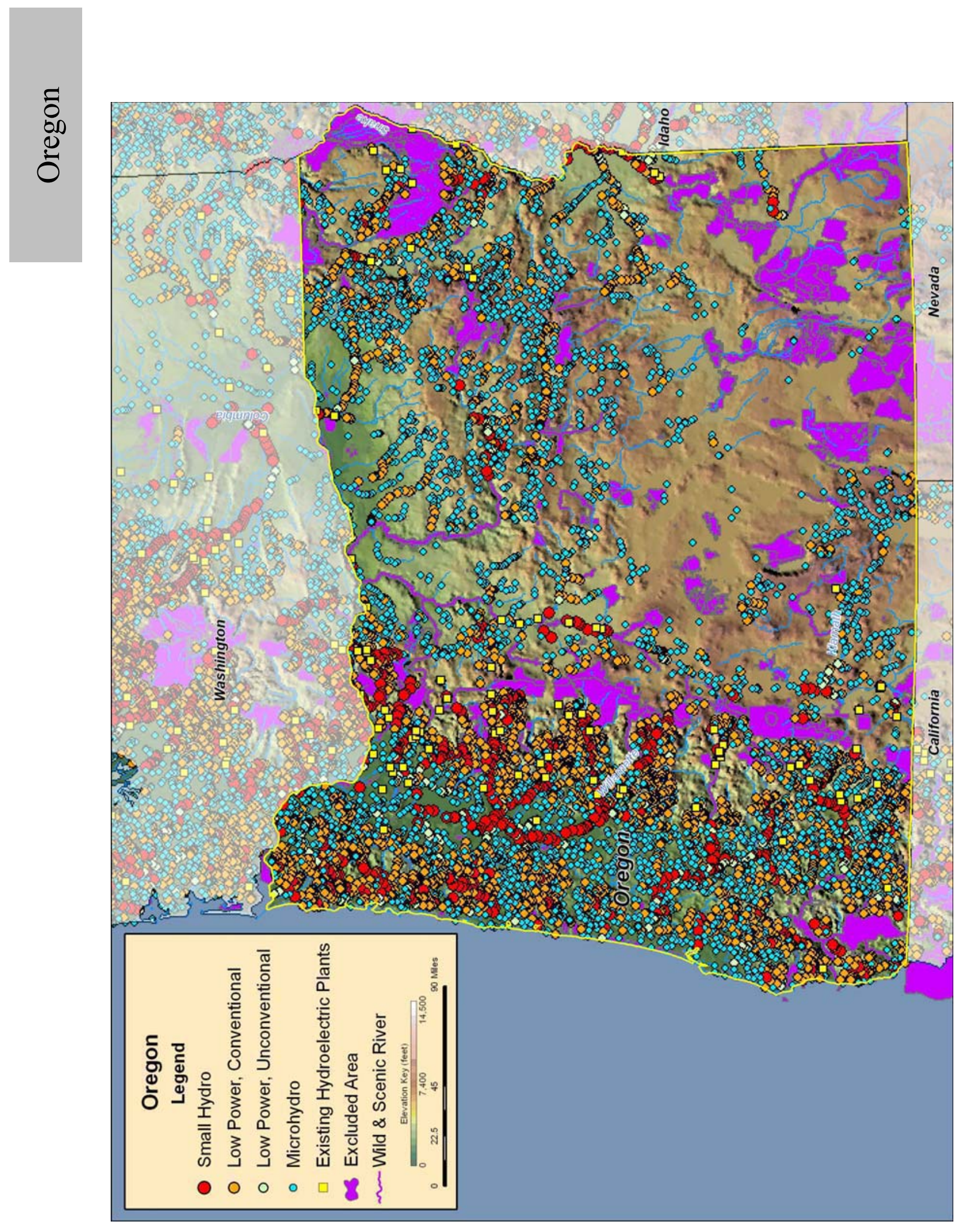

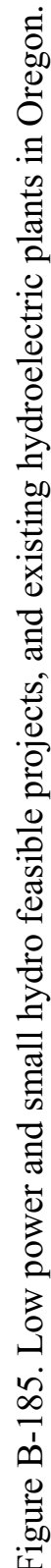




\section{B.38 Pennsylvania}

Table B-77. Summary of results of water energy resource assessment of Pennsylvania.

\begin{tabular}{|c|c|c|c|c|c|}
\hline Power Class & $\begin{array}{c}\text { Total } \\
\mathbf{( M W a )}\end{array}$ & $\begin{array}{c}\text { Developed } \\
(\mathbf{M W a})\end{array}$ & $\begin{array}{c}\text { Federally } \\
\text { Excluded } \\
(\mathbf{M W a})\end{array}$ & $\begin{array}{c}\text { Other } \\
\text { Excluded } \\
(\mathbf{M W a})\end{array}$ & $\begin{array}{c}\text { Available } \\
(\mathrm{MWa})\end{array}$ \\
\hline Total Power & $\mathbf{4 , 7 6 4}$ & $\mathbf{1 9 8}$ & $\mathbf{4 8 8}$ & $\mathbf{7 8 8}$ & 3,290 \\
\hline & & & & & \\
\hline Total High Power & $\mathbf{3 , 2 8 2}$ & 194 & $\mathbf{4 5 2}$ & $\mathbf{4 1 3}$ & 2,223 \\
\hline Large Hydro & $\mathbf{7 8 5}$ & 141 & 72 & 0 & 572 \\
\hline Small Hydro & 2,497 & 53 & 380 & 413 & 1,651 \\
\hline Total Low Power & & & & & \\
\hline Conventional Turbines & $\mathbf{1 , 4 8 3}$ & 4 & 37 & $\mathbf{3 7 5}$ & 1,067 \\
\hline Unconventional Systems & 1,169 & 3 & 30 & 329 & 807 \\
\hline Microhydro & 60 & 1 & 4 & 4 & 51 \\
\hline
\end{tabular}

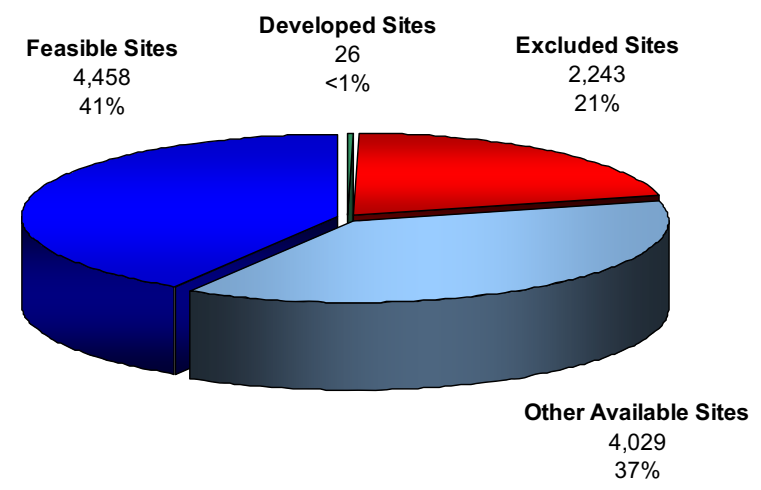

(a) Total Resource Sites 10,756

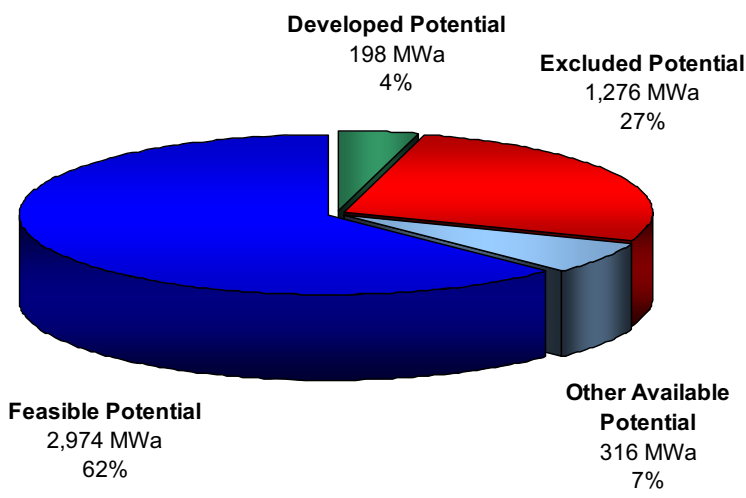

(b) Total Resource Potential 4,764 MWa

Figure B-186. Power category distribution of the (a) number and (b) total power potential of the water energy resource sites in Pennsylvania. 
Table B-78. Summary of results of feasibility assessment of water energy resources in Pennsylvania

\begin{tabular}{|c|c|}
\hline Power Class & $\begin{array}{c}\text { Available } \\
\text { (MWa) }\end{array}$ \\
\hline Total Power & 3,290 \\
\hline Total High Power & 2,223 \\
\hline Large Hydro & 572 \\
\hline Small Hydro & 1,651 \\
\hline & \\
\hline Total Low Power & 1,067 \\
\hline Conventional Turbines & 807 \\
\hline Unconventional Systems & 51 \\
\hline Microhydro & 209 \\
\hline
\end{tabular}
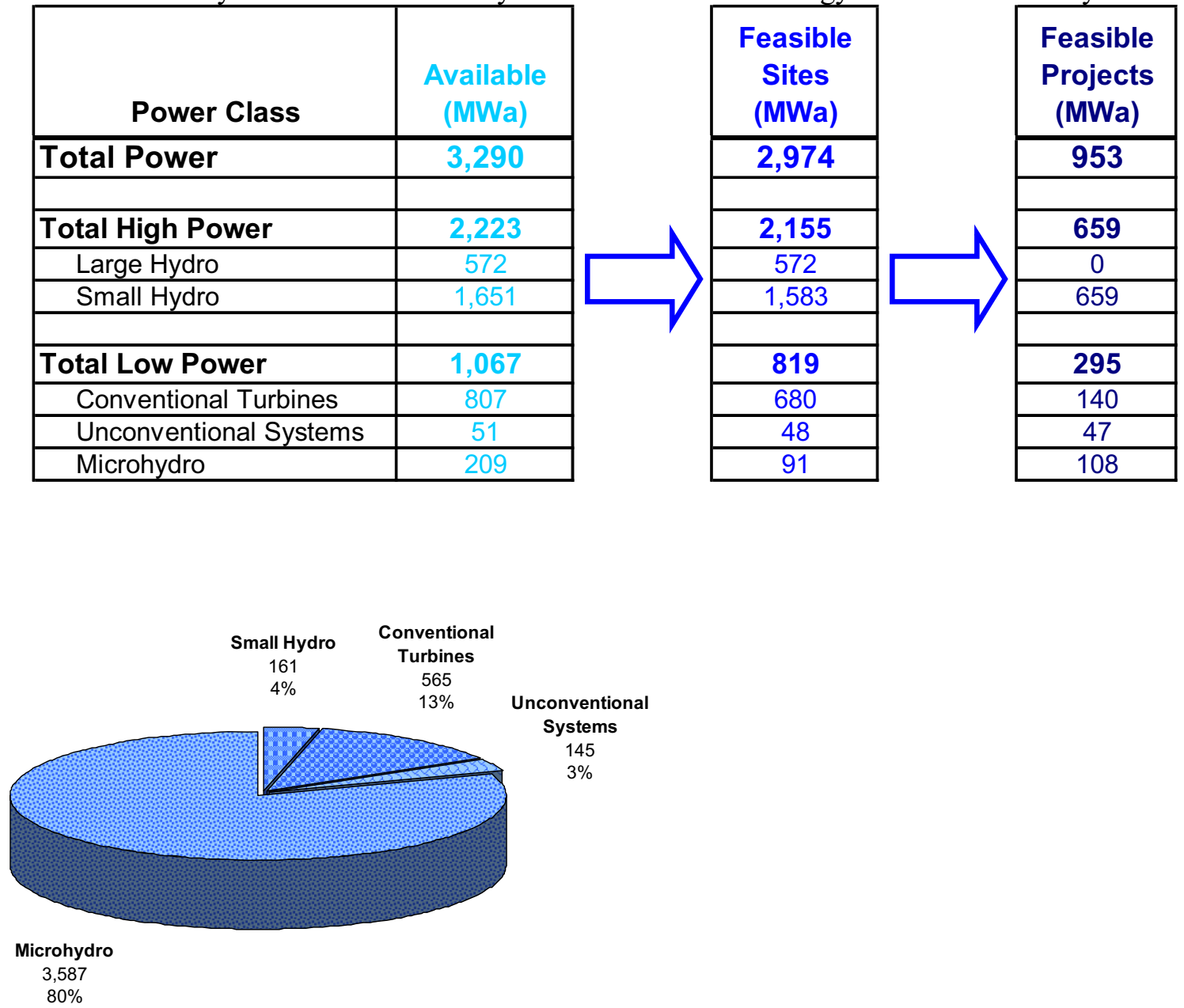

(a) Total Feasible Projects 4,458

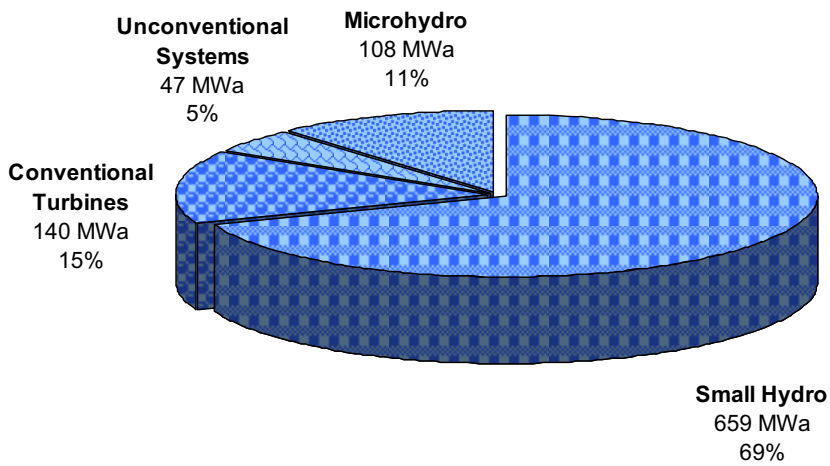

(b) Total Feasible Project Hydropower Potential $953 \mathrm{MWa}$

Figure B-187. Distribution of the (a) number and (b) total hydropower potential of the low power and small hydropower feasible projects in Pennsylvania with the low power projects divided into technology classes. 

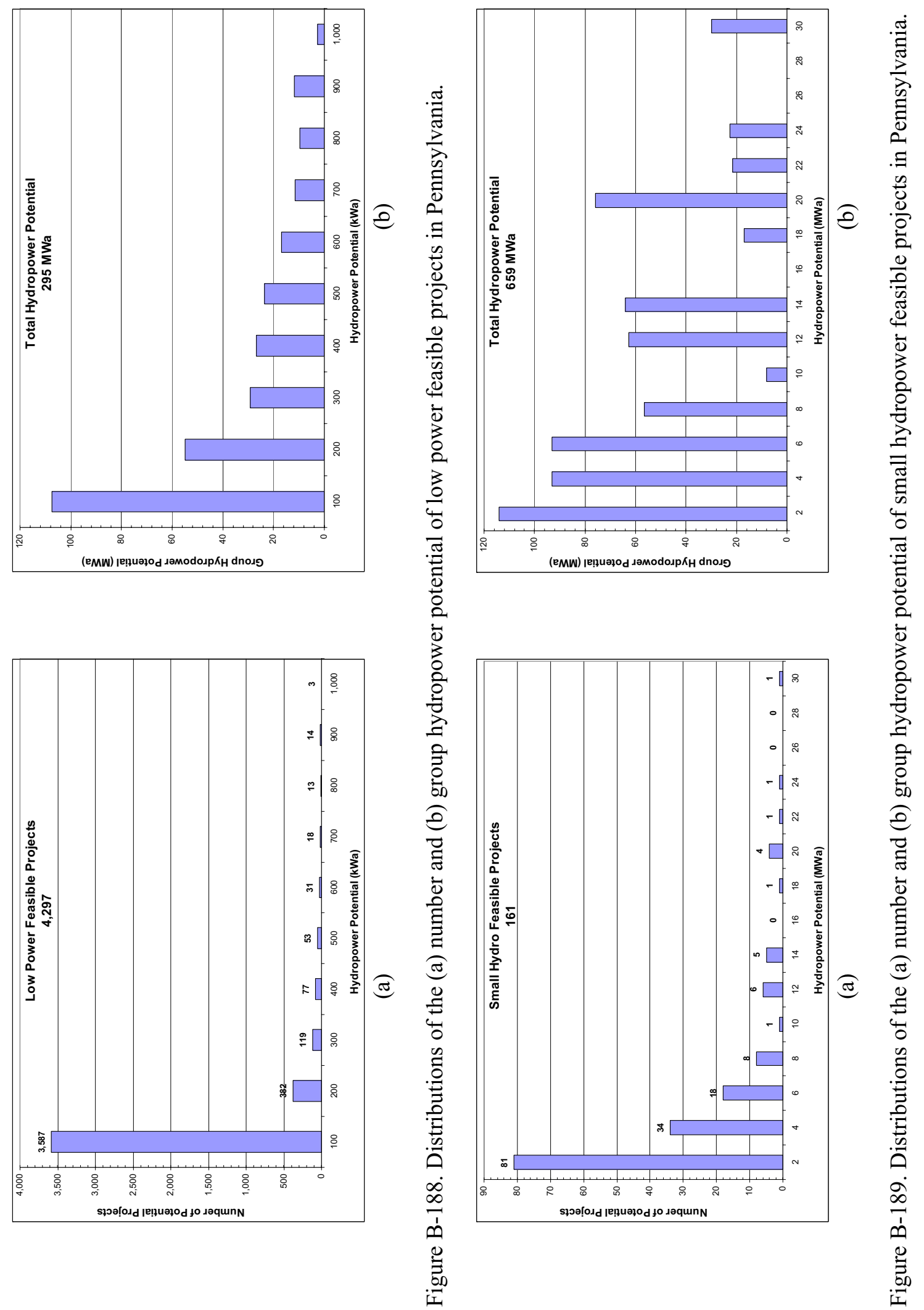


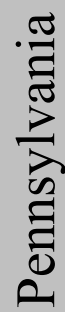

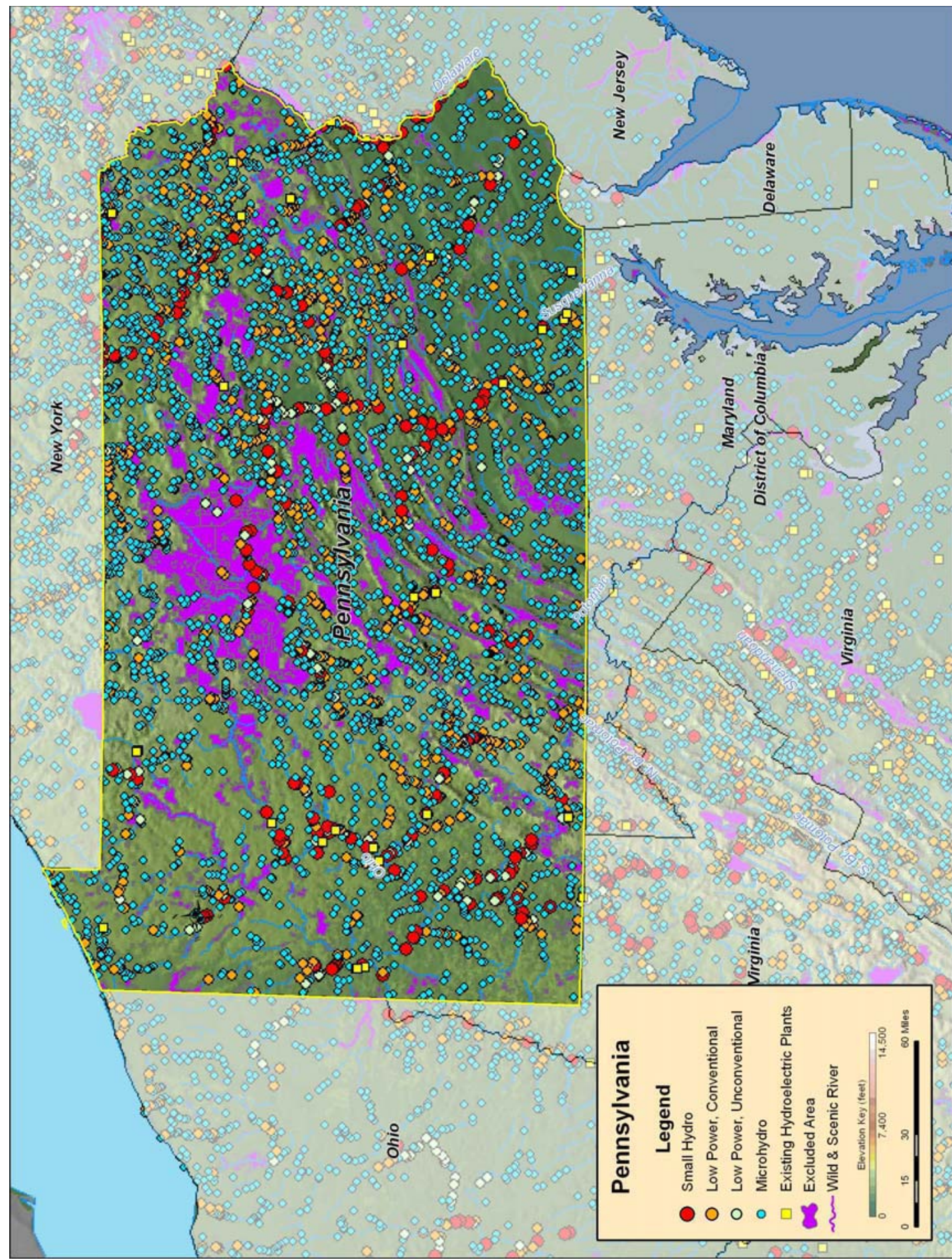

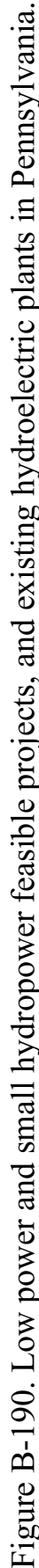




\section{B.39 Rhode Island}

Table B-79. Summary of results of water energy resource assessment of Rhode Island.

\begin{tabular}{|c|c|c|c|c|c|}
\hline Power Class & $\begin{array}{c}\text { Total } \\
(\mathbf{M W a})\end{array}$ & $\begin{array}{c}\text { Developed } \\
(\mathrm{MWa})\end{array}$ & $\begin{array}{c}\text { Federally } \\
\text { Excluded } \\
(\mathrm{MWa})\end{array}$ & $\begin{array}{c}\text { Other } \\
\text { Excluded } \\
(\mathrm{MWa})\end{array}$ & $\begin{array}{c}\text { Available } \\
(\mathrm{MWa})\end{array}$ \\
\hline Total Power & $\mathbf{3 6}$ & $\mathbf{1}$ & $\mathbf{0}$ & $\mathbf{4}$ & 30 \\
\hline Total High Power & $\mathbf{1 6}$ & & & & \\
\hline Large Hydro & 0 & 0 & 0 & $\mathbf{2}$ & 14 \\
\hline Small Hydro & 16 & 0 & 0 & 0 & 0 \\
\hline Total Low Power & & 0 & 0 & 2 & 14 \\
\hline Conventional Turbines & $\mathbf{1 9}$ & 1 & 0 & $\mathbf{2}$ & 16 \\
\hline Unconventional Systems & 14 & 1 & 0 & 2 & 11 \\
\hline Microhydro & 1 & 0 & 0 & 0 & 1 \\
\hline
\end{tabular}

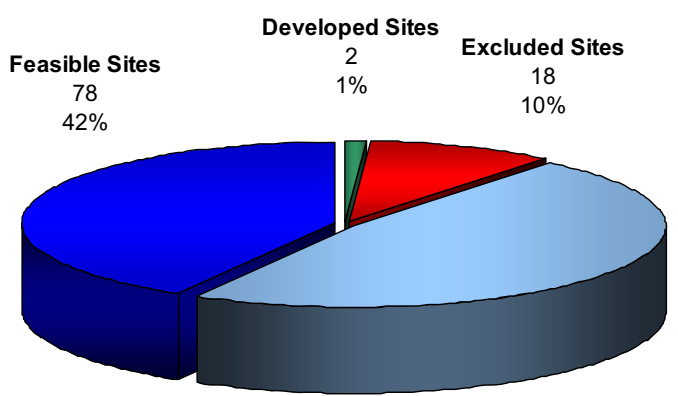

Other Available Sites

$$
89
$$

89
$48 \%$

(a) Total Resource Sites 187

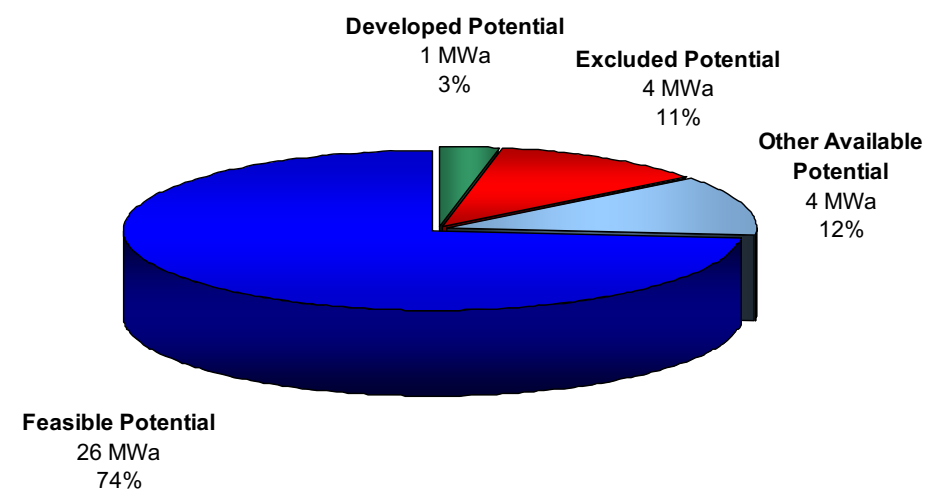

(a) Total Resource Potential $36 \mathrm{MWa}$

Figure B-191. Power category distribution of the (a) number and (b) total power potential of the water energy resource sites in Rhode Island. 
Table B-80. Summary of results of feasibility assessment of water energy resources in Rhode Island.

\begin{tabular}{|c|c|}
\hline Power Class & $\begin{array}{c}\text { Available } \\
\text { (MWa) }\end{array}$ \\
\hline Total Power & 30 \\
\hline & \\
\hline Total High Power & 14 \\
\hline Large Hydro & 0 \\
\hline Small Hydro & 14 \\
\hline & \\
\hline Total Low Power & 16 \\
\hline Conventional Turbines & 11 \\
\hline Unconventional Systems & 1 \\
\hline Microhydro & 5 \\
\hline
\end{tabular}
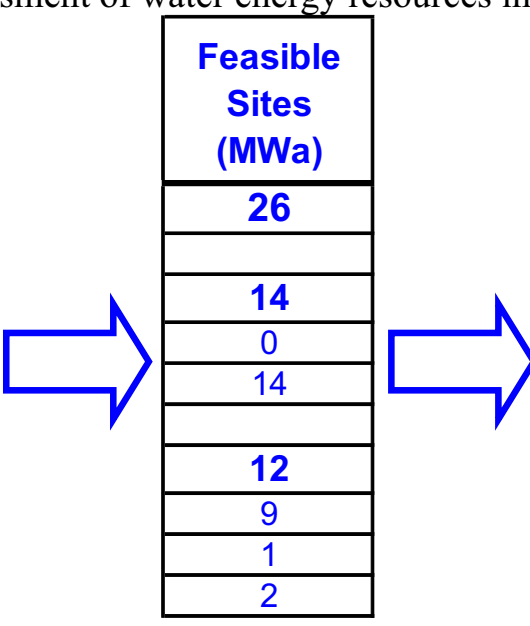

\begin{tabular}{|c|}
\hline $\begin{array}{c}\text { Feasible } \\
\text { Projects } \\
\text { (MWa) }\end{array}$ \\
\hline 7 \\
\hline \\
\hline 0 \\
\hline 0 \\
\hline 0 \\
\hline 7 \\
\hline 5 \\
\hline 0 \\
\hline 2 \\
\hline
\end{tabular}

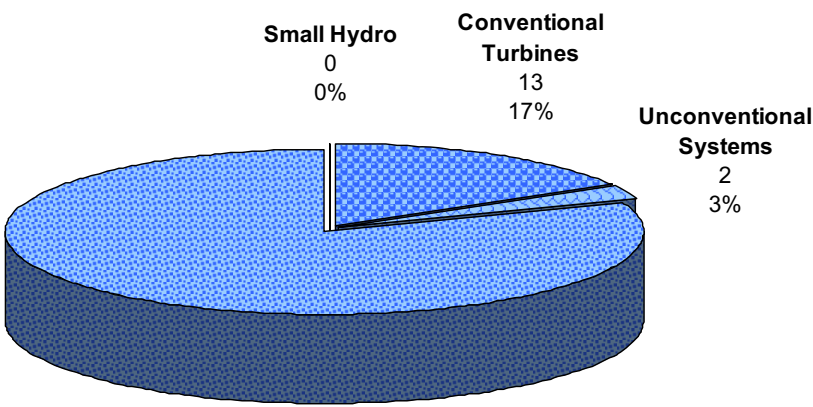

\footnotetext{
Microhydro

63

$81 \%$
}

(a) Total Feasible Projects

78

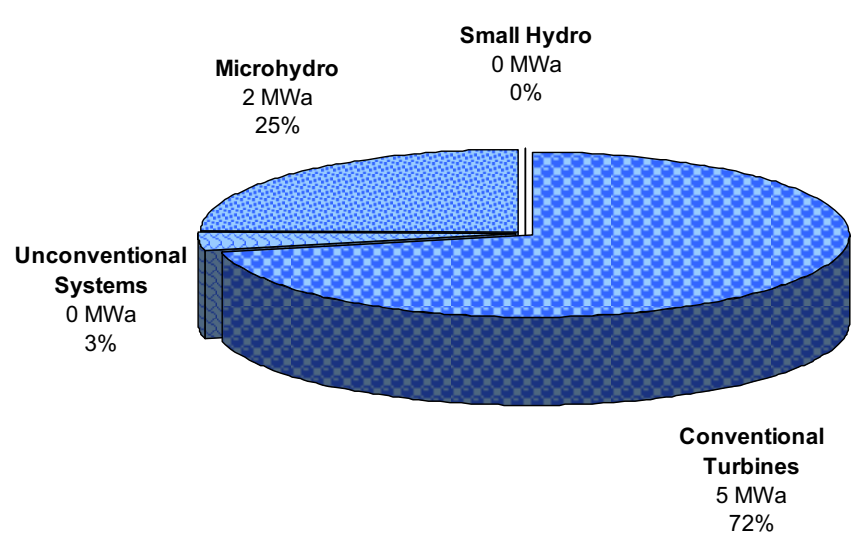

(b) Total Feasible Project Hydropower Potential $7 \mathrm{MWa}$

Figure B-192. Distribution of the (a) number and (b) total hydropower potential of the low power and small hydropower feasible projects in Rhode Island with the low power projects divided into technology classes. 

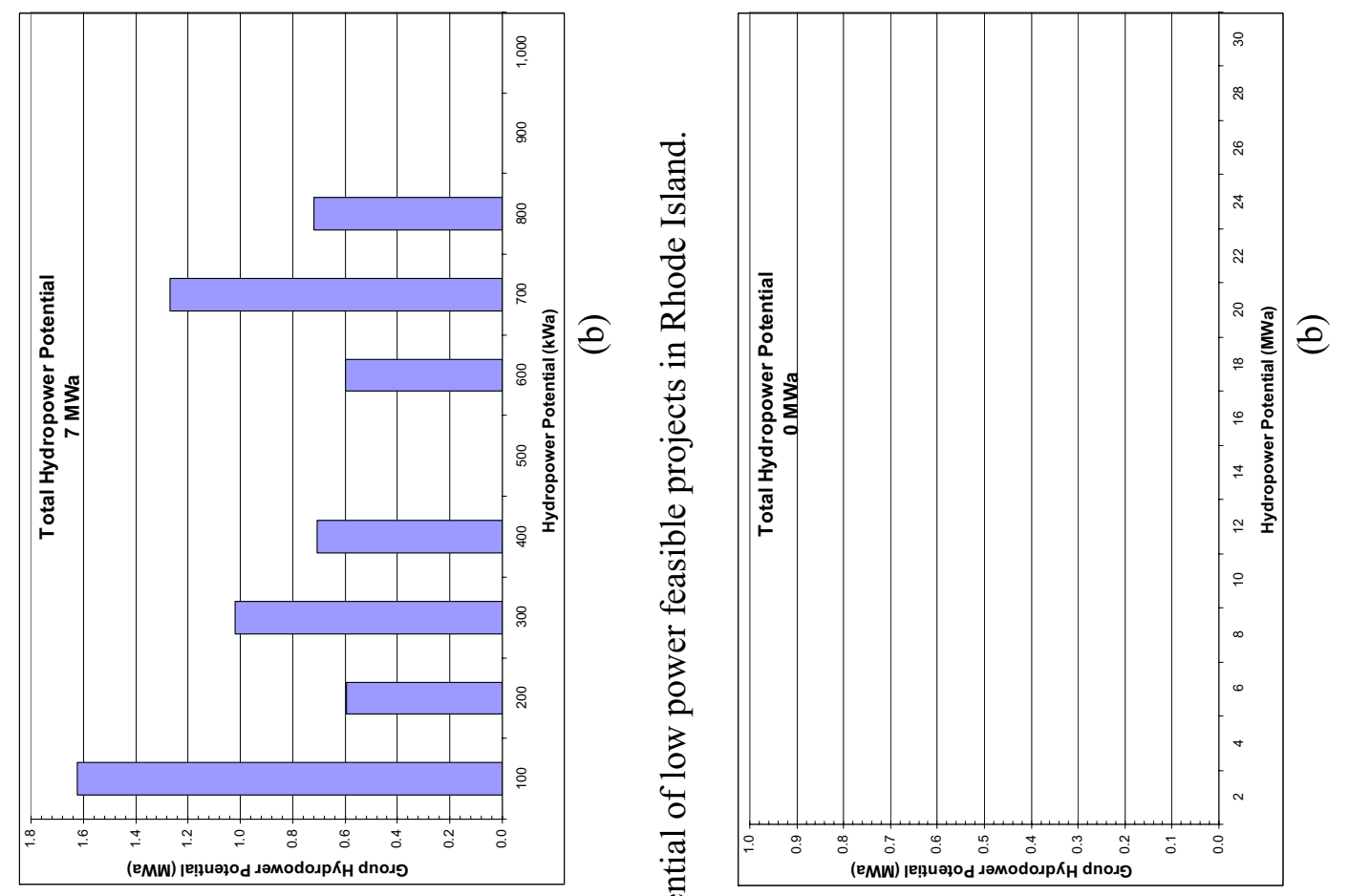

$\frac{\overrightarrow{0}}{\frac{\pi}{0}}$
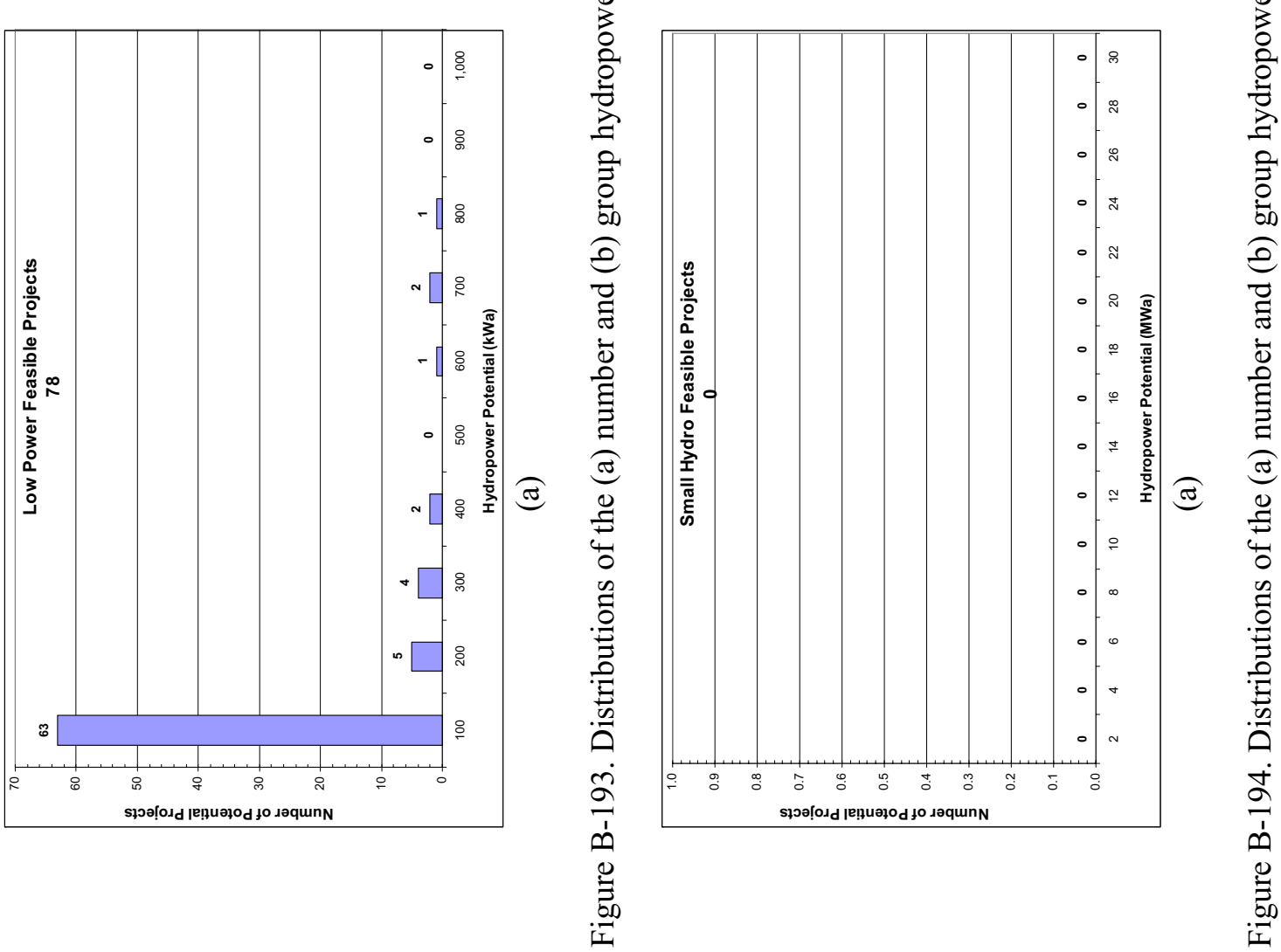


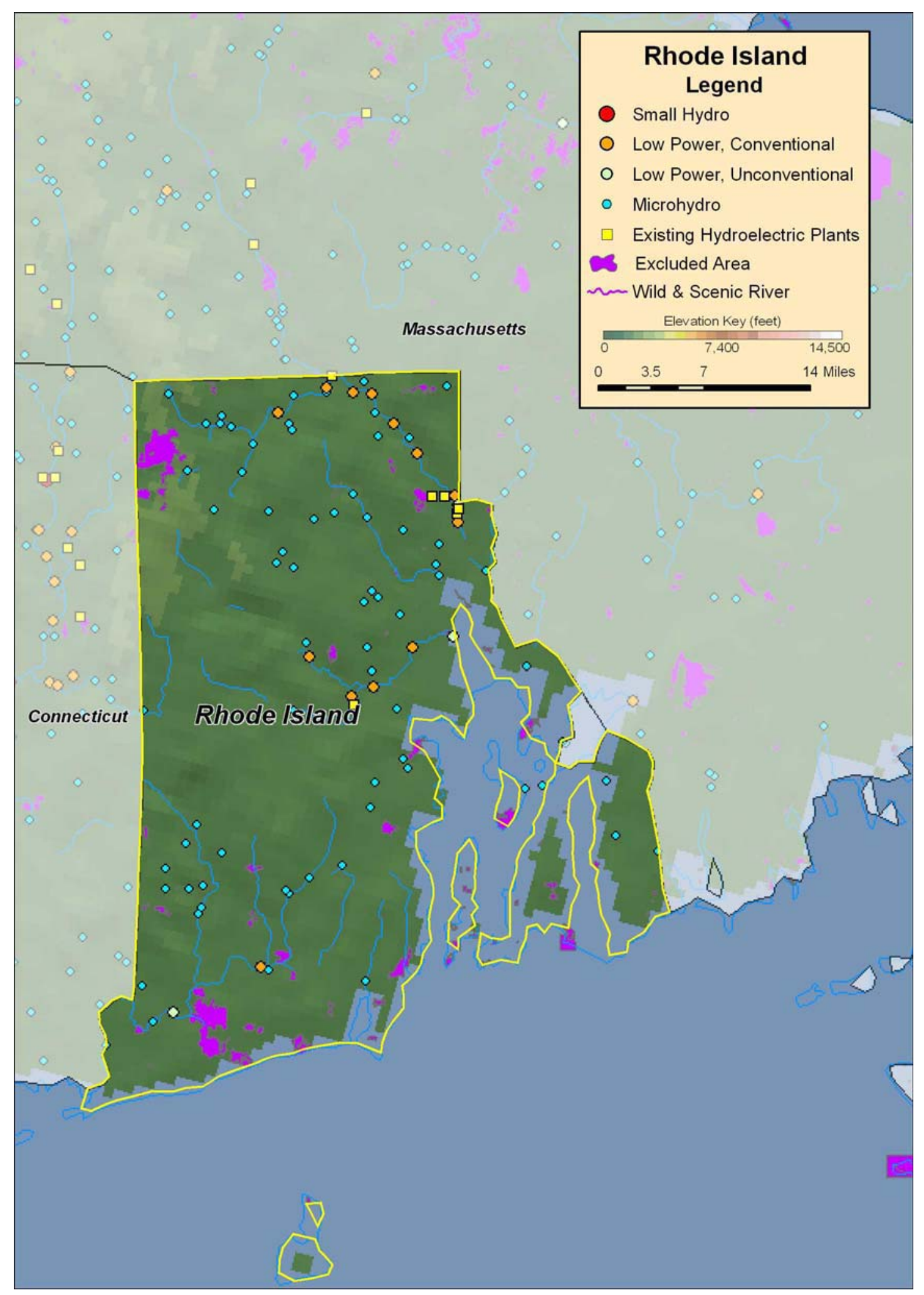

Figure B-195. Low power and small hydro feasible projects, and existing hydroelectric plants in Rhode Island. 


\section{B.40 South Carolina}

Table B-81. Summary of results of water energy resource assessment of South Carolina.

\begin{tabular}{|c|c|c|c|c|c|}
\hline Power Class & $\begin{array}{c}\text { Total } \\
\mathbf{( M W a )}\end{array}$ & $\begin{array}{c}\text { Developed } \\
(\mathrm{MWa})\end{array}$ & $\begin{array}{c}\text { Federally } \\
\text { Excluded } \\
(\mathbf{M W a})\end{array}$ & $\begin{array}{c}\text { Other } \\
\text { Excluded } \\
(\mathbf{M W a})\end{array}$ & $\begin{array}{c}\text { Available } \\
(\mathrm{MWa})\end{array}$ \\
\hline Total Power & $\mathbf{1 , 3 7 8}$ & $\mathbf{3 2 8}$ & $\mathbf{3 9}$ & $\mathbf{4 6}$ & 964 \\
\hline Total High Power & & & & & \\
\hline Large Hydro & $\mathbf{1 , 0 3 5}$ & $\mathbf{3 2 2}$ & $\mathbf{3 2}$ & $\mathbf{2 3}$ & 658 \\
\hline Small Hydro & $\mathbf{2 8 6}$ & 175 & 0 & 0 & 111 \\
\hline & $\mathbf{7 4 9}$ & 147 & 32 & 23 & 547 \\
\hline Total Low Power & & & & & \\
\hline Conventional Turbines & $\mathbf{3 4 3}$ & $\mathbf{6}$ & $\mathbf{7}$ & $\mathbf{2 3}$ & 306 \\
\hline Unconventional Systems & 159 & 4 & 4 & 12 & 139 \\
\hline Microhydro & $\mathbf{8 1}$ & 1 & 1 & 9 & 70 \\
\hline
\end{tabular}

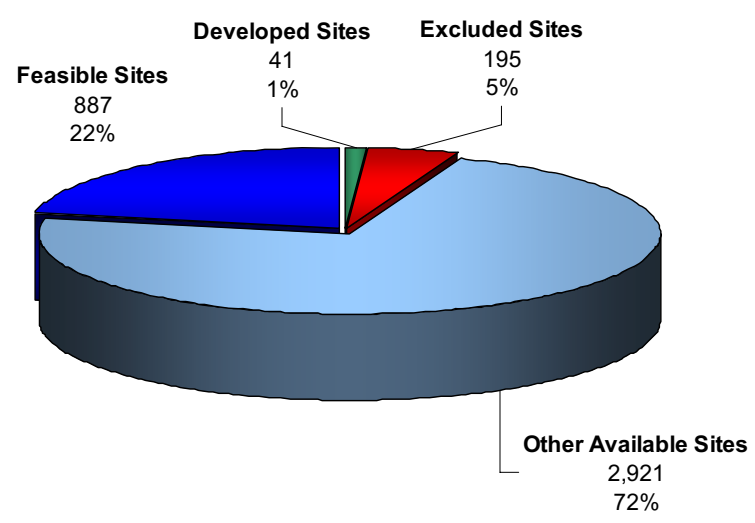

(a) Total Resource Sites 4,044

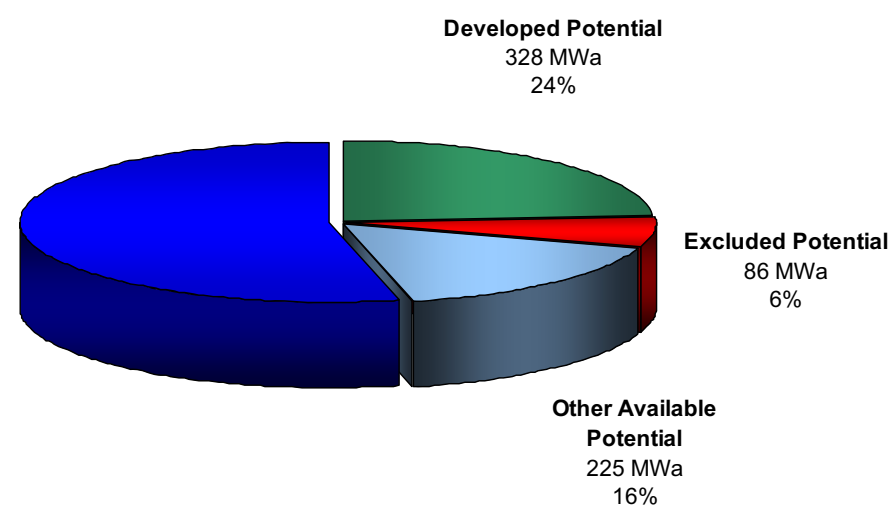

(b) Total Resource Potential $1,378 \mathrm{MWa}$

Figure B-196. Power category distribution of the (a) number and (b) total power potential of the water energy resource sites in South Carolina. 
Table B-82. Summary of results of feasibility assessment of water energy resources in South Carolina.

\begin{tabular}{|c|c|}
\hline Power Class & $\begin{array}{c}\text { Available } \\
(\mathrm{MWa})\end{array}$ \\
\hline Total Power & 964 \\
\hline Total High Power & 658 \\
\hline Large Hydro & 111 \\
\hline Small Hydro & 547 \\
\hline & \\
\hline Total Low Power & 306 \\
\hline Conventional Turbines & 139 \\
\hline Unconventional Systems & 70 \\
\hline Microhydro & 97 \\
\hline
\end{tabular}
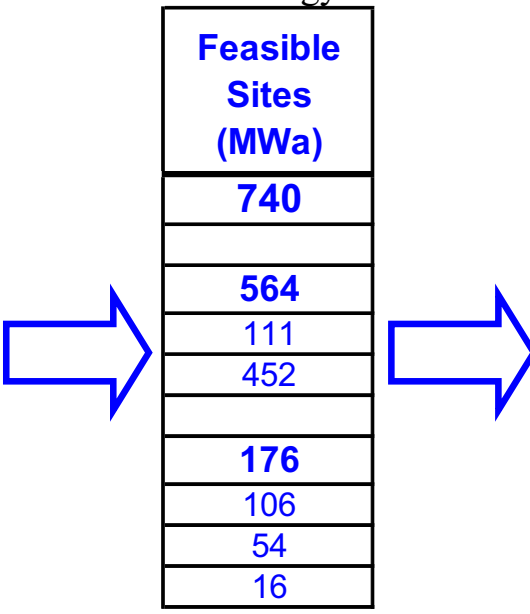

Feasible

Projects

(MWa)

211

\begin{tabular}{|c|}
\hline $\mathbf{1 5 3}$ \\
\hline 0 \\
\hline 153 \\
\hline \\
\hline $\mathbf{5 8}$ \\
\hline 11 \\
\hline 25 \\
\hline 22 \\
\hline
\end{tabular}

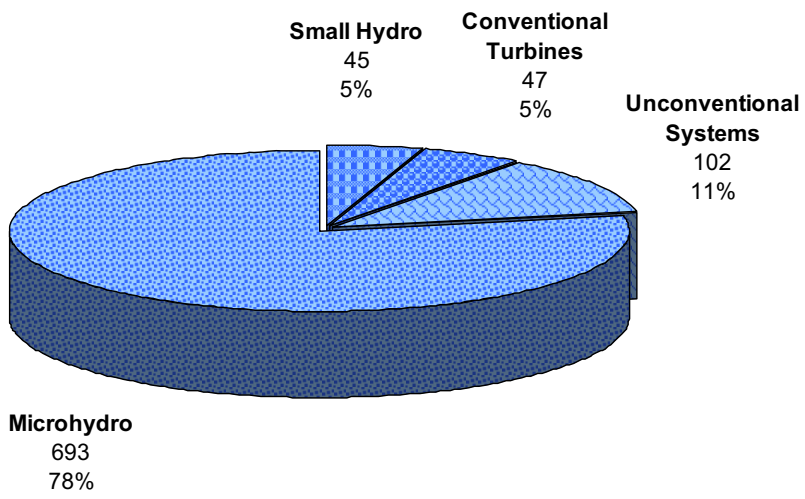

(a) Total Feasible Projects

887

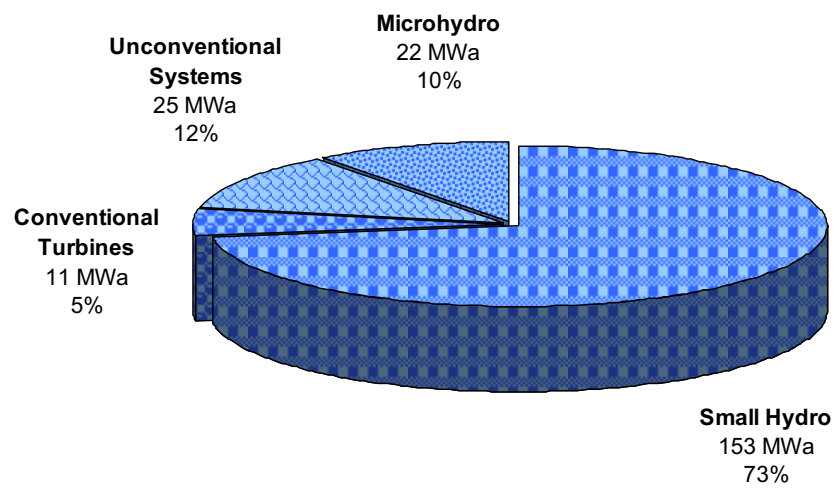

(b) Total Feasible Project Hydropower Potential 211 MWa

Figure B-197. Distribution of the (a) number and (b) total hydropower potential of the low power and small hydropower feasible projects in South Carolina with the low power projects divided into technology classes. 

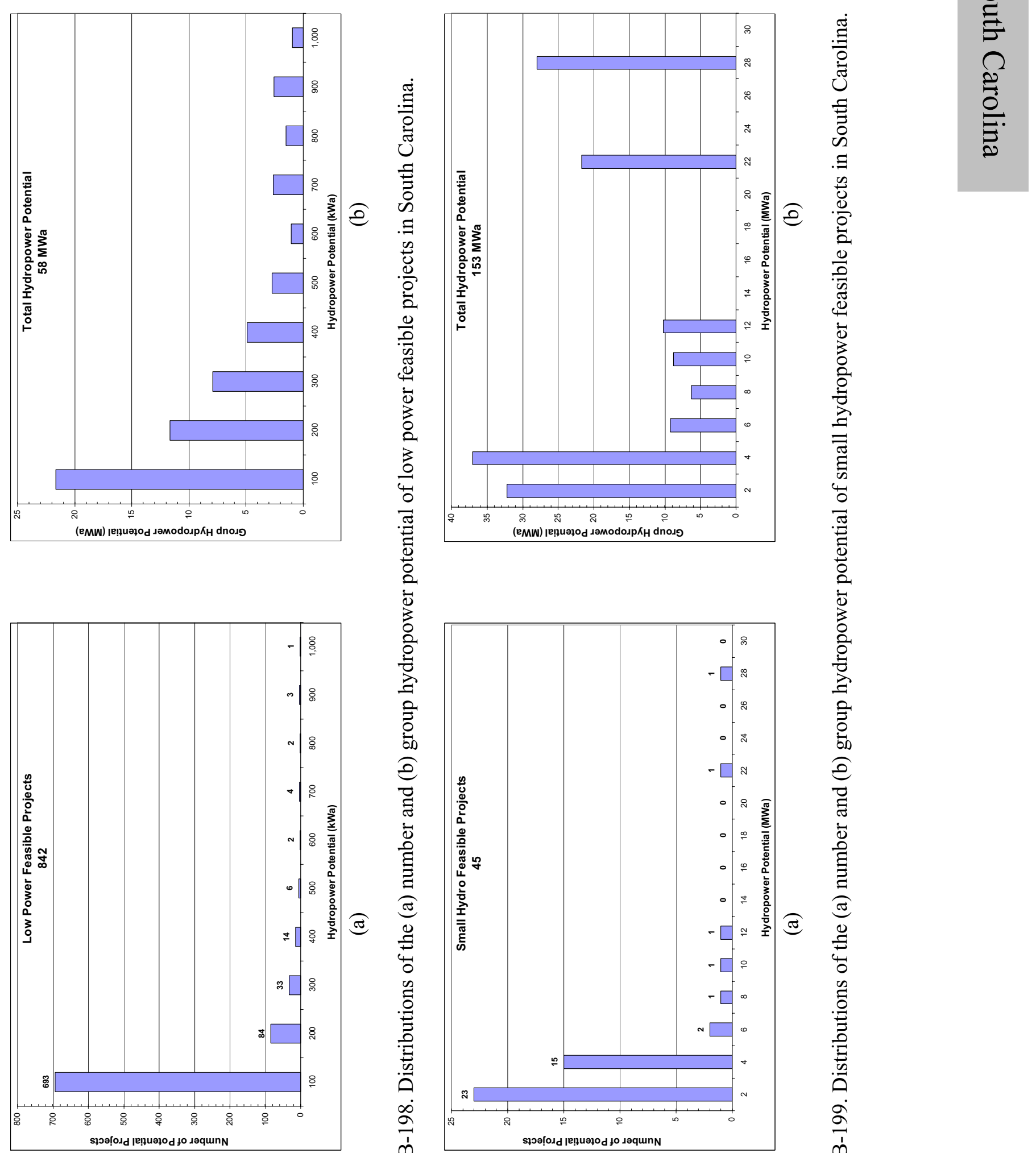

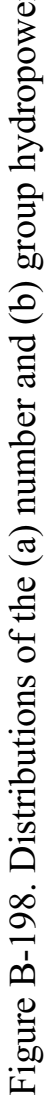

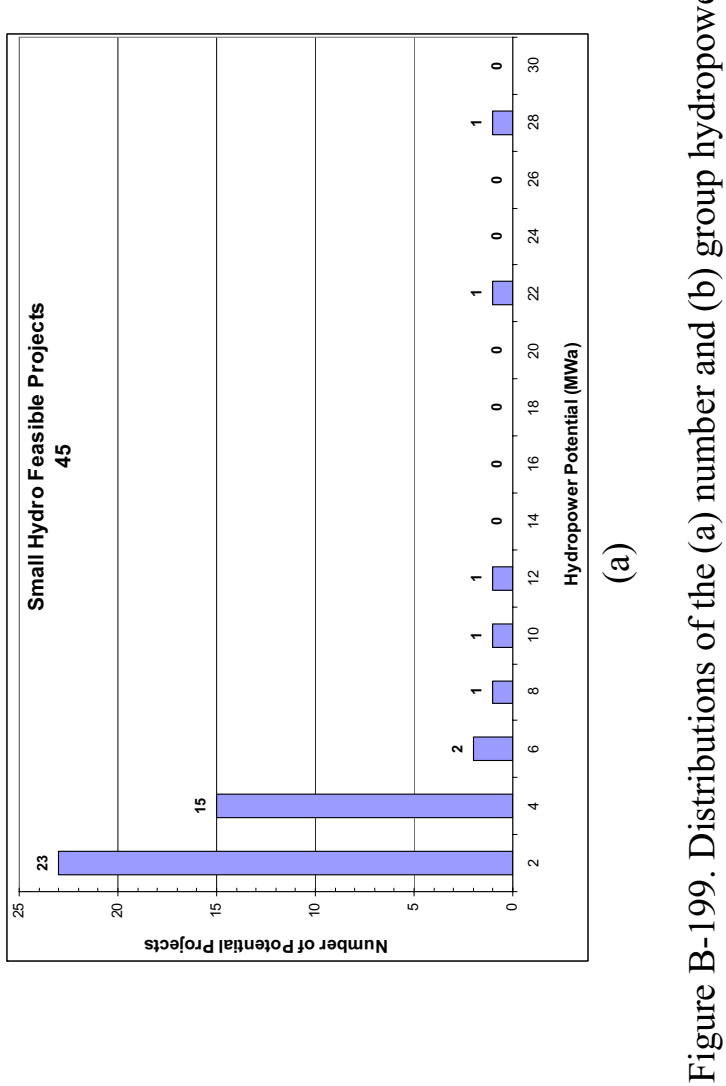



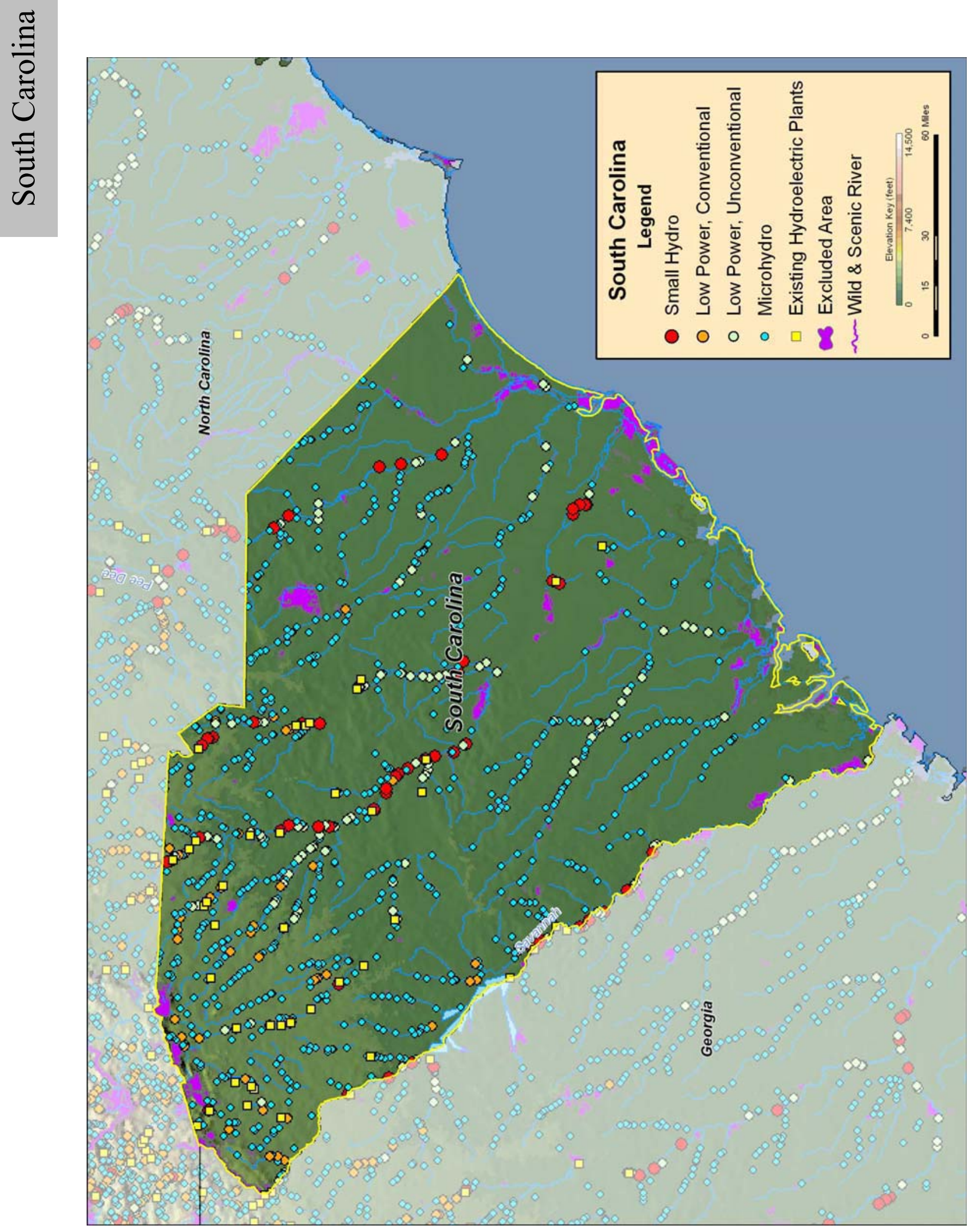

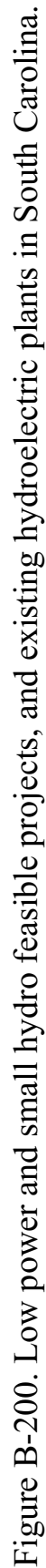




\section{B.41 South Dakota}

Table B-83. Summary of results of water energy resource assessment of South Dakota.

\begin{tabular}{|c|c|c|c|c|c|}
\hline Power Class & $\begin{array}{c}\text { Total } \\
(\mathbf{M W a})\end{array}$ & $\begin{array}{c}\text { Developed } \\
(\mathrm{MWa})\end{array}$ & $\begin{array}{c}\text { Federally } \\
\text { Excluded } \\
(\mathrm{MWa})\end{array}$ & $\begin{array}{c}\text { Other } \\
\text { Excluded } \\
(\mathbf{M W a})\end{array}$ & $\begin{array}{c}\text { Available } \\
(\mathrm{MWa})\end{array}$ \\
\hline Total Power & $\mathbf{7 9 1}$ & $\mathbf{2 1 9}$ & $\mathbf{6 1}$ & $\mathbf{5}$ & 505 \\
\hline Total High Power & $\mathbf{3 9 8}$ & 219 & $\mathbf{5 6}$ & $\mathbf{2}$ & 121 \\
\hline Large Hydro & 268 & 215 & 0 & 0 & 53 \\
\hline Small Hydro & 130 & 4 & 56 & 2 & 68 \\
\hline Total Low Power & & & & & \\
\hline Conventional Turbines & $\mathbf{3 9 3}$ & 0 & $\mathbf{5}$ & $\mathbf{3}$ & 384 \\
\hline Unconventional Systems & $\mathbf{2 2 4}$ & 0 & 3 & 2 & 219 \\
\hline Microhydro & 31 & 0 & 1 & 0 & 30 \\
\hline
\end{tabular}

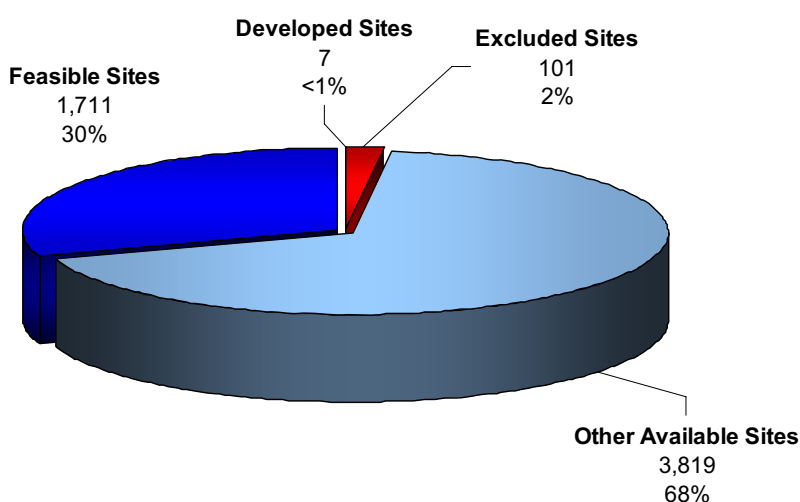

(a) Total Resource Sites

5,638

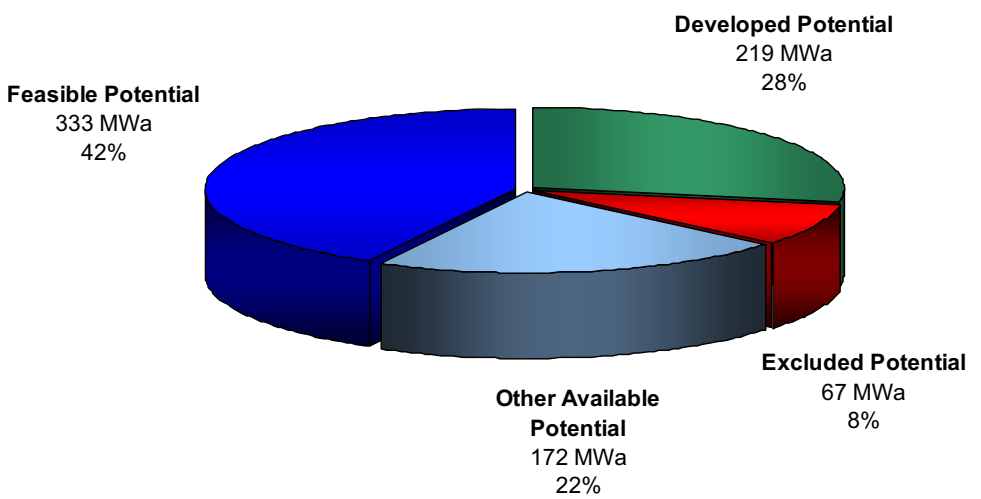

(a) Total Resource Potential $791 \mathrm{MWa}$

Figure B-201. Power category distribution of the (a) number and (b) total power potential of the water energy resource sites in South Dakota. 
Table B-84. Summary of results of feasibility assessment of water energy resources in South Dakota.

\begin{tabular}{|c|c|}
\hline Power Class & $\begin{array}{c}\text { Available } \\
\text { (MWa) }\end{array}$ \\
\hline Total Power & 505 \\
\hline Total High Power & 121 \\
\hline Large Hydro & 53 \\
\hline Small Hydro & 68 \\
\hline & \\
\hline Total Low Power & 384 \\
\hline Conventional Turbines & 219 \\
\hline Unconventional Systems & 30 \\
\hline Microhydro & 135 \\
\hline
\end{tabular}

\begin{tabular}{|c|c|}
\hline $\begin{array}{c}\text { Feasible } \\
\text { Sites } \\
\text { (MWa) }\end{array}$ & $\begin{array}{c}\text { Feasible } \\
\text { Projects } \\
\text { (MWa) }\end{array}$ \\
\hline 333 & 119 \\
\hline 108 & 23 \\
\hline 53 & 0 \\
\hline 55 & 23 \\
\hline 225 & 96 \\
\hline 150 & 44 \\
\hline 21 & 8 \\
\hline 54 & 45 \\
\hline
\end{tabular}

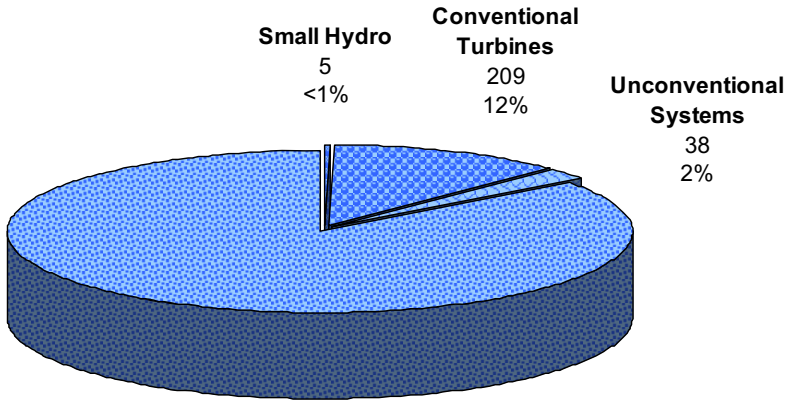

Microhydro
1,459

(a) Total Feasible Projects

1,711

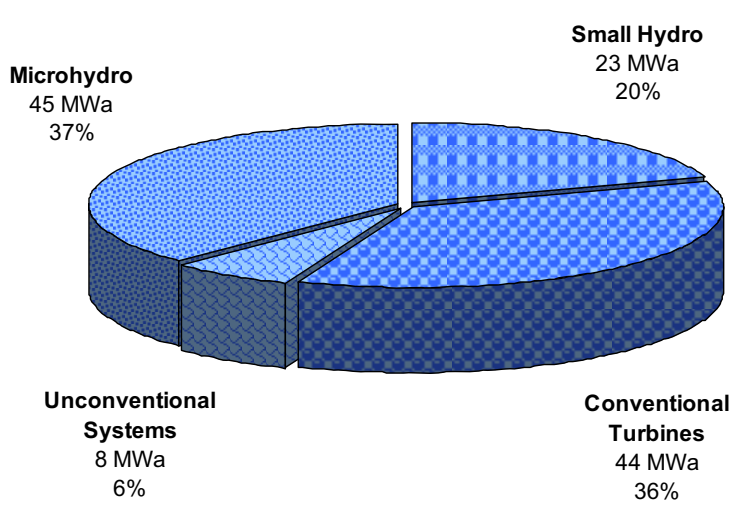

(b) Total Feasible Project Hydropower Potential $119 \mathrm{MWa}$

Figure B-202. Distribution of the (a) number and (b) total hydropower potential of the low power and small hydropower feasible projects in South Dakota with the low power projects divided into technology classes. 

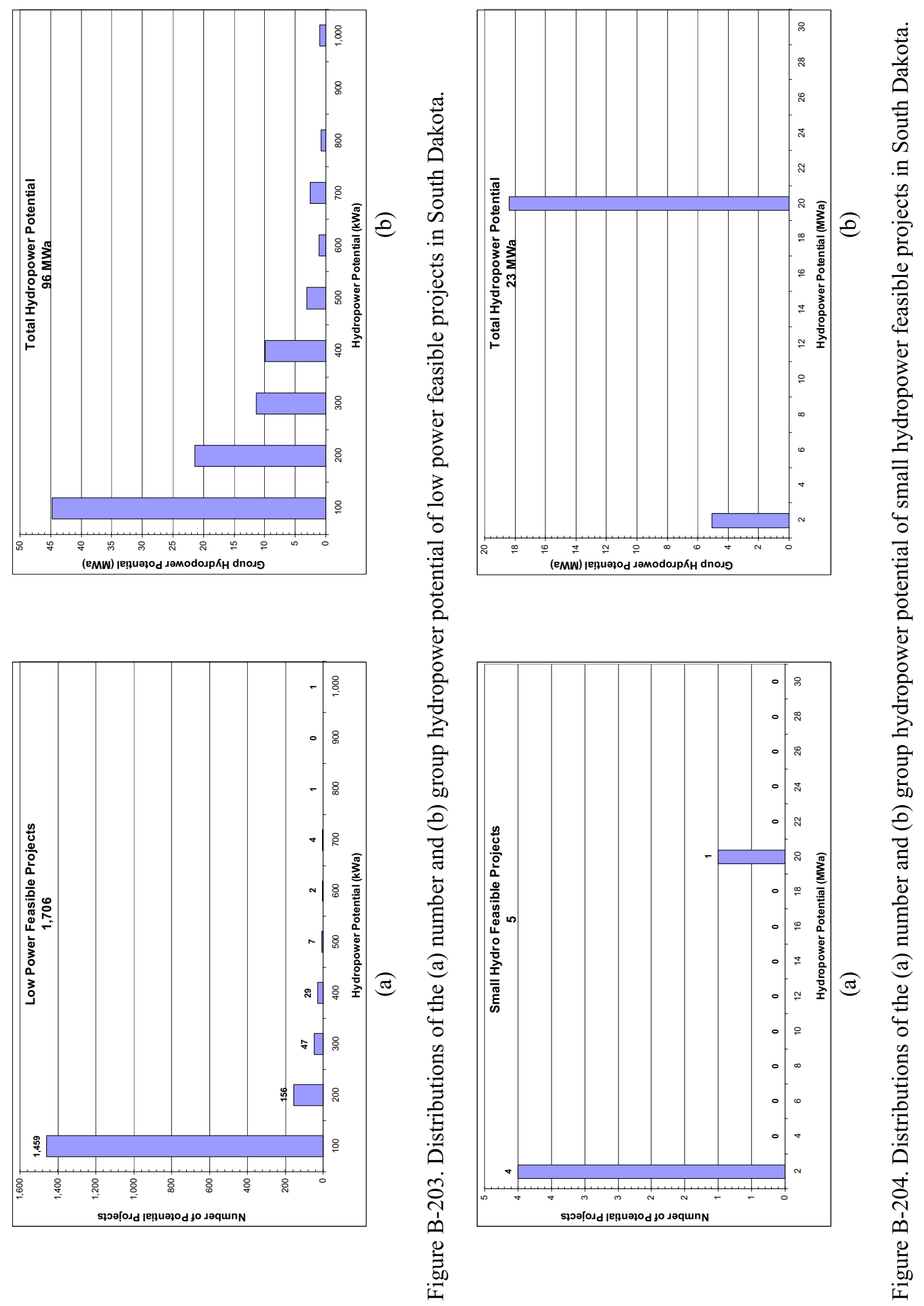


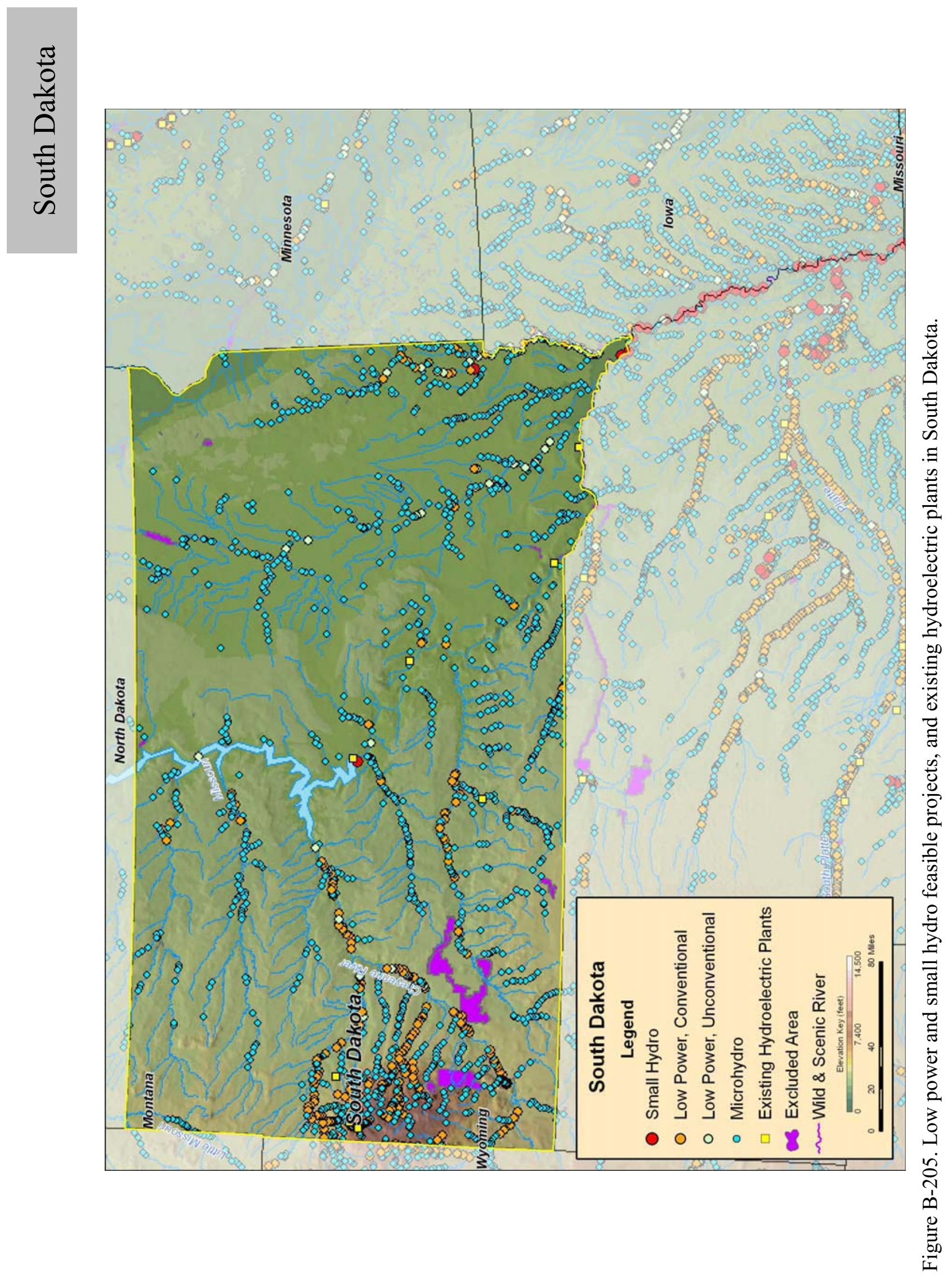




\section{B.42 Tennessee}

Table B-85. Summary of results of water energy resource assessment of Tennessee.

\begin{tabular}{|c|c|c|c|c|c|}
\hline Power Class & $\begin{array}{c}\text { Total } \\
(\mathbf{M W a})\end{array}$ & $\begin{array}{c}\text { Developed } \\
(\mathrm{MWa})\end{array}$ & $\begin{array}{c}\text { Federally } \\
\text { Excluded } \\
(\mathbf{M W a})\end{array}$ & $\begin{array}{c}\text { Other } \\
\text { Excluded } \\
(\mathbf{M W a})\end{array}$ & $\begin{array}{c}\text { Available } \\
(\mathrm{MWa})\end{array}$ \\
\hline Total Power & $\mathbf{5 , 2 9 5}$ & $\mathbf{8 4 8}$ & $\mathbf{3 3 3}$ & $\mathbf{1 1 0}$ & $\mathbf{4 , 0 0 3}$ \\
\hline Total High Power & & & & & \\
\hline Large Hydro & $\mathbf{4 , 3 9 4}$ & $\mathbf{8 4 7}$ & $\mathbf{2 6 4}$ & $\mathbf{7 9}$ & 3,204 \\
\hline Small Hydro & $\mathbf{2 , 7 7 5}$ & 683 & 44 & 0 & 2,048 \\
\hline & 1,619 & 163 & 221 & 79 & 1,157 \\
\hline Total Low Power & & & & & \\
\hline Conventional Turbines & $\mathbf{9 0 1}$ & 1 & 69 & 32 & 799 \\
\hline Unconventional Systems & 610 & 1 & 59 & 29 & 522 \\
\hline Microhydro & 83 & 0 & 6 & 1 & 77 \\
\hline
\end{tabular}

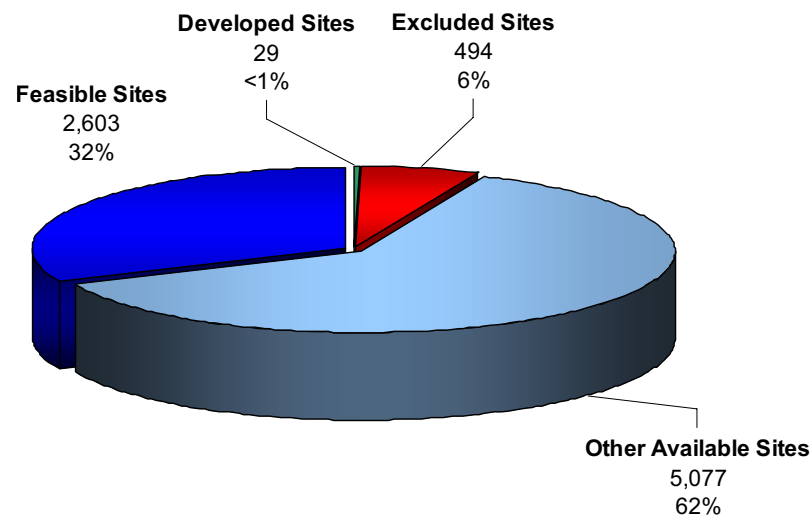

(a) Total Resource Sites 8,203

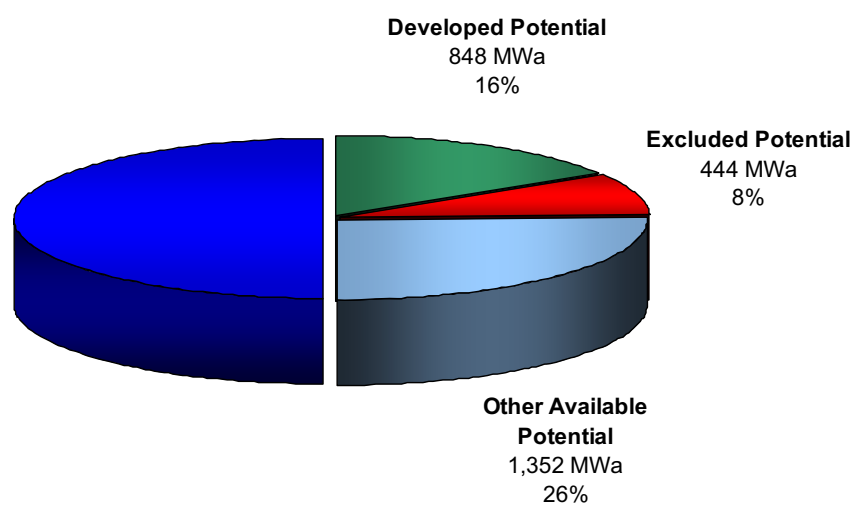

(b) Total Resource Potential 5,295 MWa

Figure B-206. Power category distribution of the (a) number and (b) total power potential of the water energy resource sites in Tennessee. 
Table B-86. Summary of results of feasibility assessment of water energy resources in Tennessee.

\begin{tabular}{|c|c|}
\hline Power Class & $\begin{array}{c}\text { Available } \\
\text { (MWa) }\end{array}$ \\
\hline Total Power & 4,003 \\
\hline Total High Power & 3,204 \\
\hline Large Hydro & 2,048 \\
\hline Small Hydro & 1,157 \\
\hline & \\
\hline Total Low Power & 799 \\
\hline Conventional Turbines & 522 \\
\hline Unconventional Systems & 77 \\
\hline Microhydro & 200 \\
\hline
\end{tabular}

\begin{tabular}{|c|c|}
\hline $\begin{array}{c}\text { Feasible } \\
\text { Sites } \\
\text { (MWa) }\end{array}$ & $\begin{array}{c}\text { Feasible } \\
\text { Projects } \\
\text { (MWa) }\end{array}$ \\
\hline 2,652 & 655 \\
\hline 2,185 & 481 \\
\hline 1,205 & 0 \\
\hline 980 & 481 \\
\hline 467 & 174 \\
\hline 352 & 64 \\
\hline 59 & 49 \\
\hline 56 & 61 \\
\hline
\end{tabular}

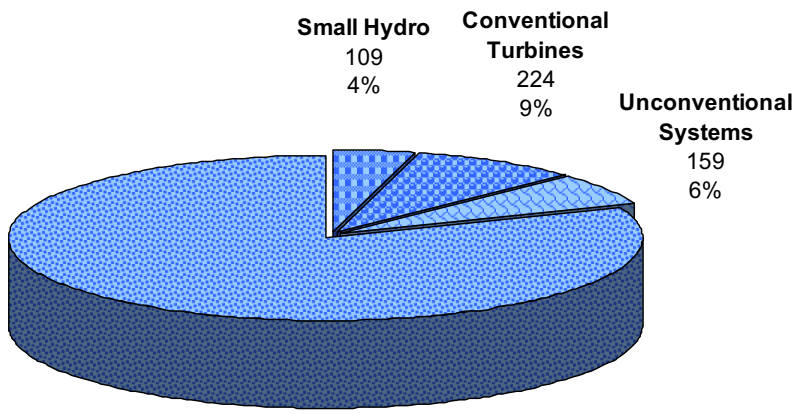

\footnotetext{
Microhydro

2,111

$81 \%$
}

(a) Total Feasible Projects

2,603

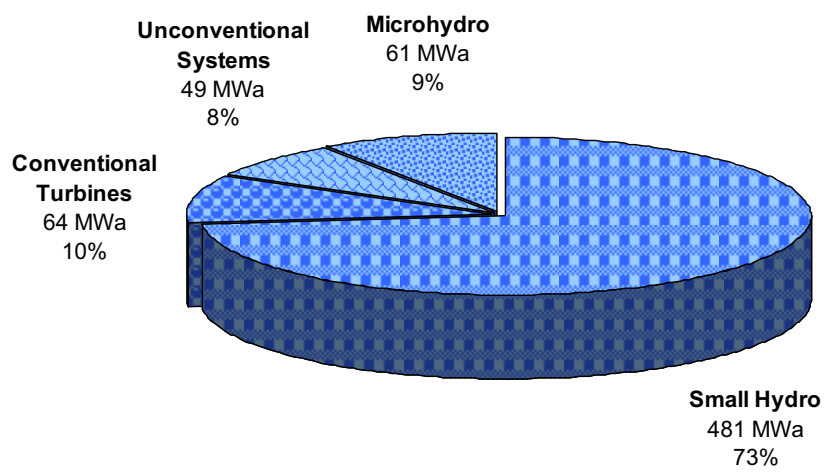

(b) Total Feasible Project Hydropower Potential $655 \mathrm{MWa}$

Figure B-207. Distribution of the (a) number and (b) total hydropower potential of the low power and small hydropower feasible projects in Tennessee with the low power projects divided into technology classes. 

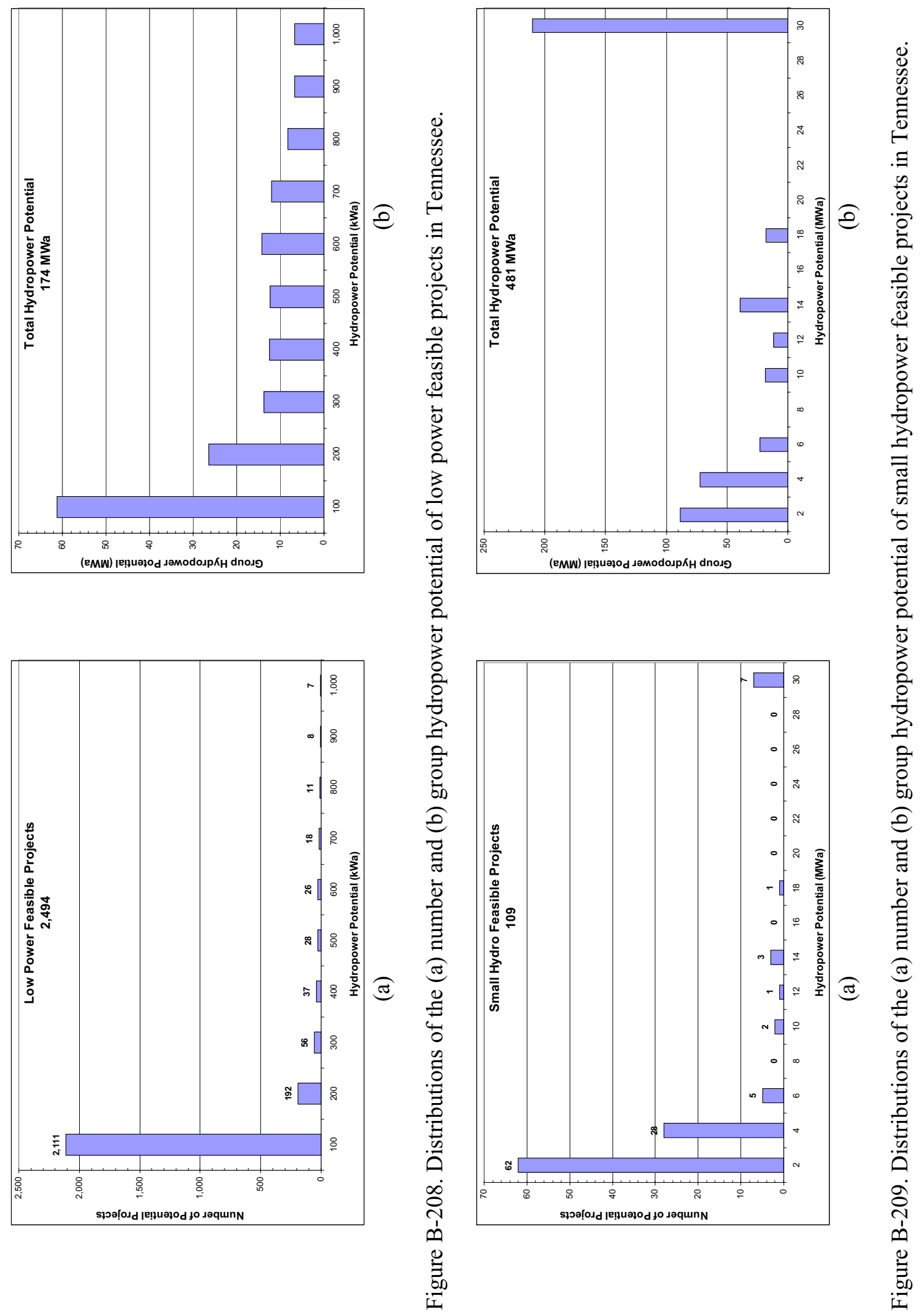

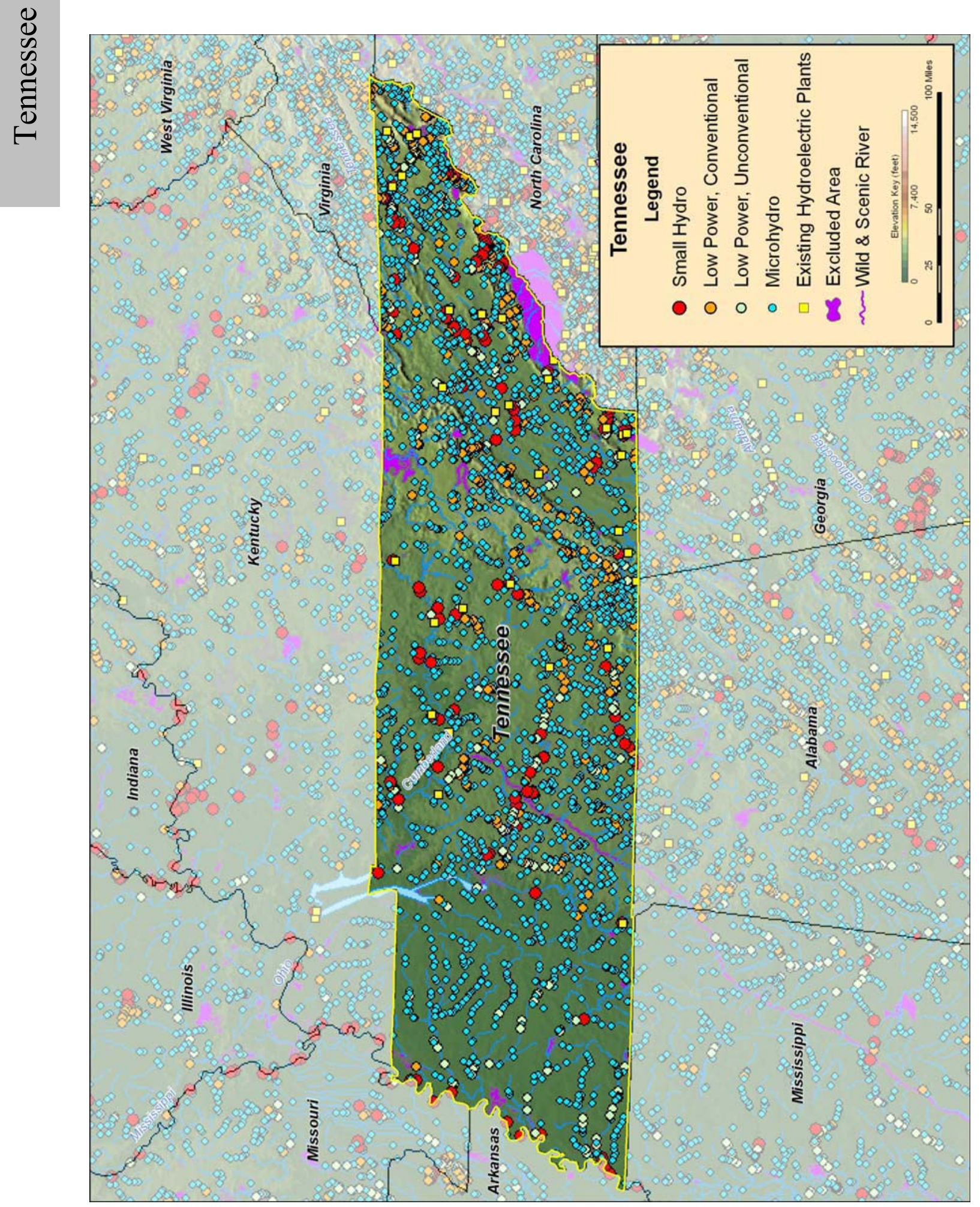

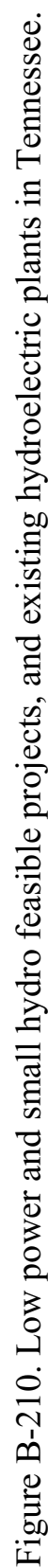




\section{B.43 Texas}

Table B-87. Summary of results of water energy resource assessment of Texas.

\begin{tabular}{|c|c|c|c|c|c|}
\hline Power Class & $\begin{array}{c}\text { Total } \\
\text { (MWa) }\end{array}$ & $\begin{array}{c}\text { Developed } \\
(\mathrm{MWa})\end{array}$ & $\begin{array}{c}\text { Federally } \\
\text { Excluded } \\
(\mathbf{M W a})\end{array}$ & $\begin{array}{c}\text { Other } \\
\text { Excluded } \\
(\mathbf{M W a})\end{array}$ & $\begin{array}{c}\text { Available } \\
(\mathrm{MWa})\end{array}$ \\
\hline Total Power & $\mathbf{2 , 3 0 4}$ & $\mathbf{1 0 4}$ & $\mathbf{9 8}$ & $\mathbf{6 1}$ & $\mathbf{2 , 0 4 0}$ \\
\hline & & & & & \\
\hline Total High Power & $\mathbf{7 0 5}$ & $\mathbf{9 7}$ & $\mathbf{7 2}$ & $\mathbf{1 5}$ & 521 \\
\hline Large Hydro & $\mathbf{3 2}$ & 32 & 0 & 0 & 0 \\
\hline Small Hydro & 674 & 66 & 72 & 15 & 521 \\
\hline Total Low Power & & & & & \\
\hline Conventional Turbines & $\mathbf{1 , 5 9 8}$ & $\mathbf{7}$ & $\mathbf{2 7}$ & $\mathbf{4 6}$ & 1,519 \\
\hline Unconventional Systems & 696 & 7 & 8 & 20 & 661 \\
\hline Microhydro & $\mathbf{2 6 2}$ & 0 & 10 & 9 & 242 \\
\hline
\end{tabular}

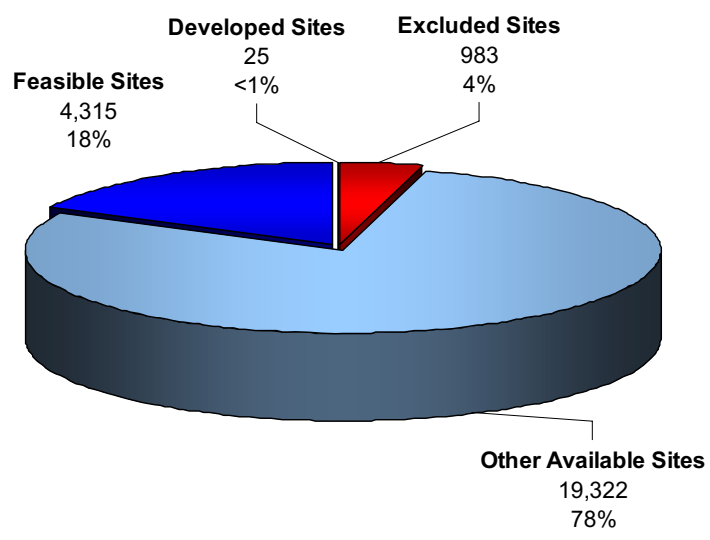

(a) Total Resource Sites 24,645

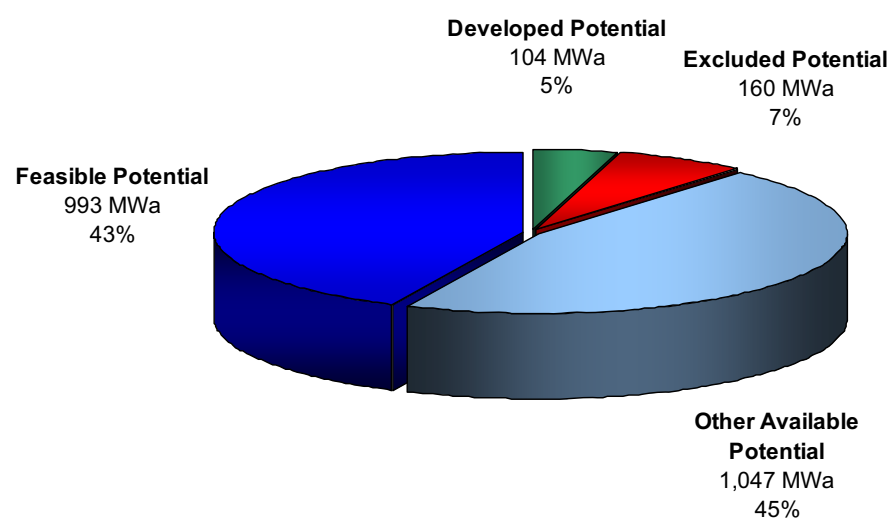

(b) Total Resource Potential 2,304 MWa

Figure B-211. Power category distribution of the (a) number and (b) total power potential of the water energy resource sites in Texas. 
Table B-88. Summary of results of feasibility assessment of water energy resources in Texas.

\begin{tabular}{|c|c|}
\hline Power Class & $\begin{array}{c}\text { Available } \\
\text { (MWa) }\end{array}$ \\
\hline Total Power & 2,040 \\
\hline & \\
\hline Total High Power & 521 \\
\hline Large Hydro & 0 \\
\hline Small Hydro & 521 \\
\hline & \\
\hline Total Low Power & 1,519 \\
\hline Conventional Turbines & 661 \\
\hline Unconventional Systems & 242 \\
\hline Microhydro & 616 \\
\hline
\end{tabular}
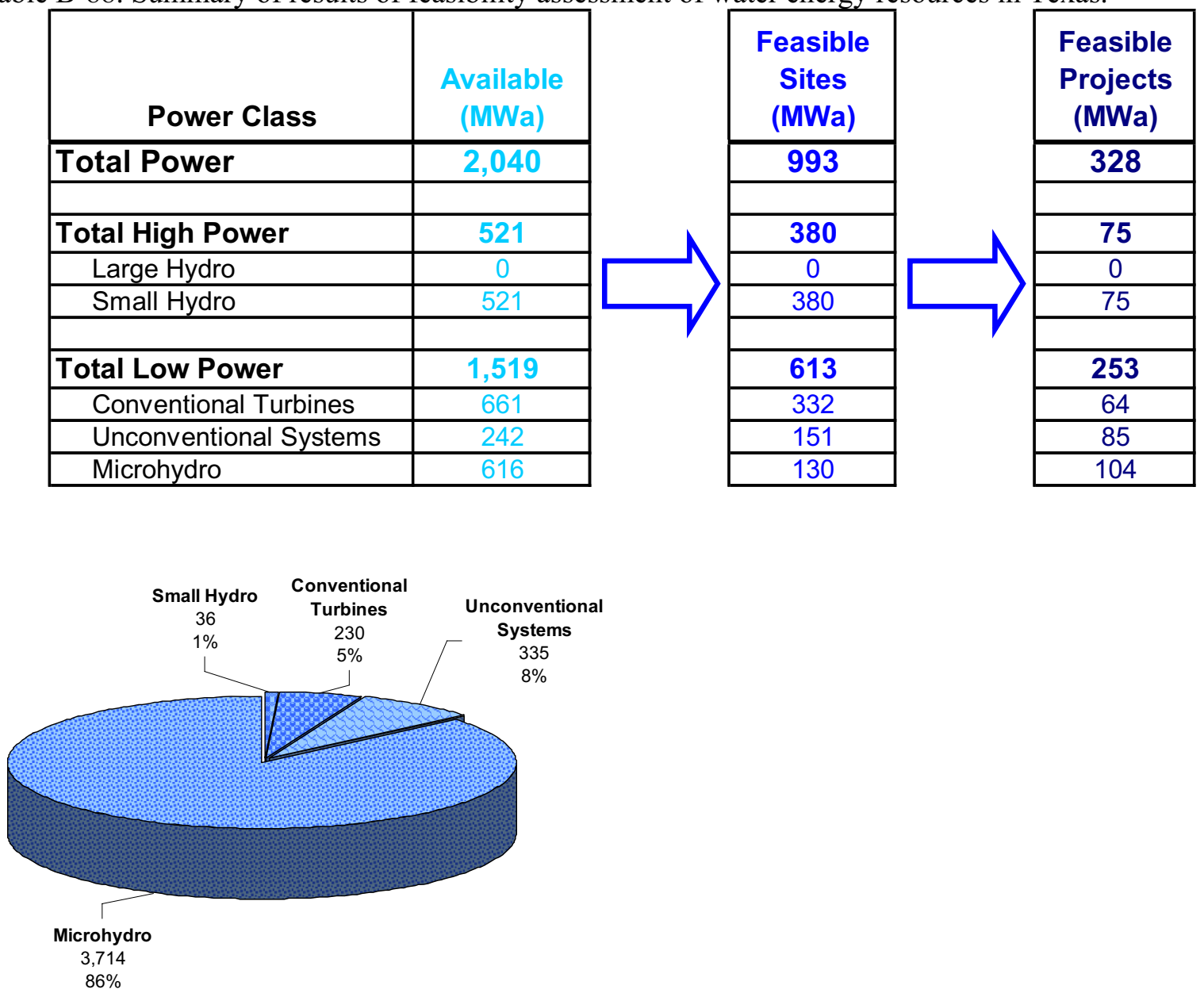

(a) Total Feasible Projects 4,315

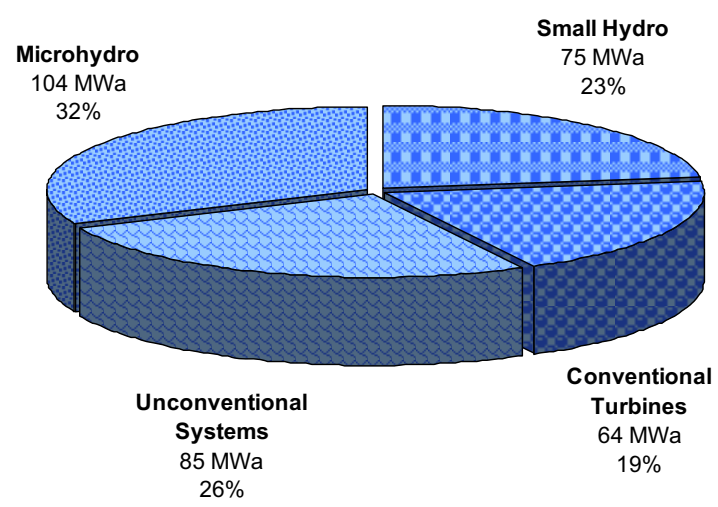

(b) Total Feasible Project Hydropower Potential $328 \mathrm{MWa}$

Figure B-212. Distribution of the (a) number and (b) total hydropower potential of the low power and small hydropower feasible projects in Texas with the low power projects divided into technology classes. 

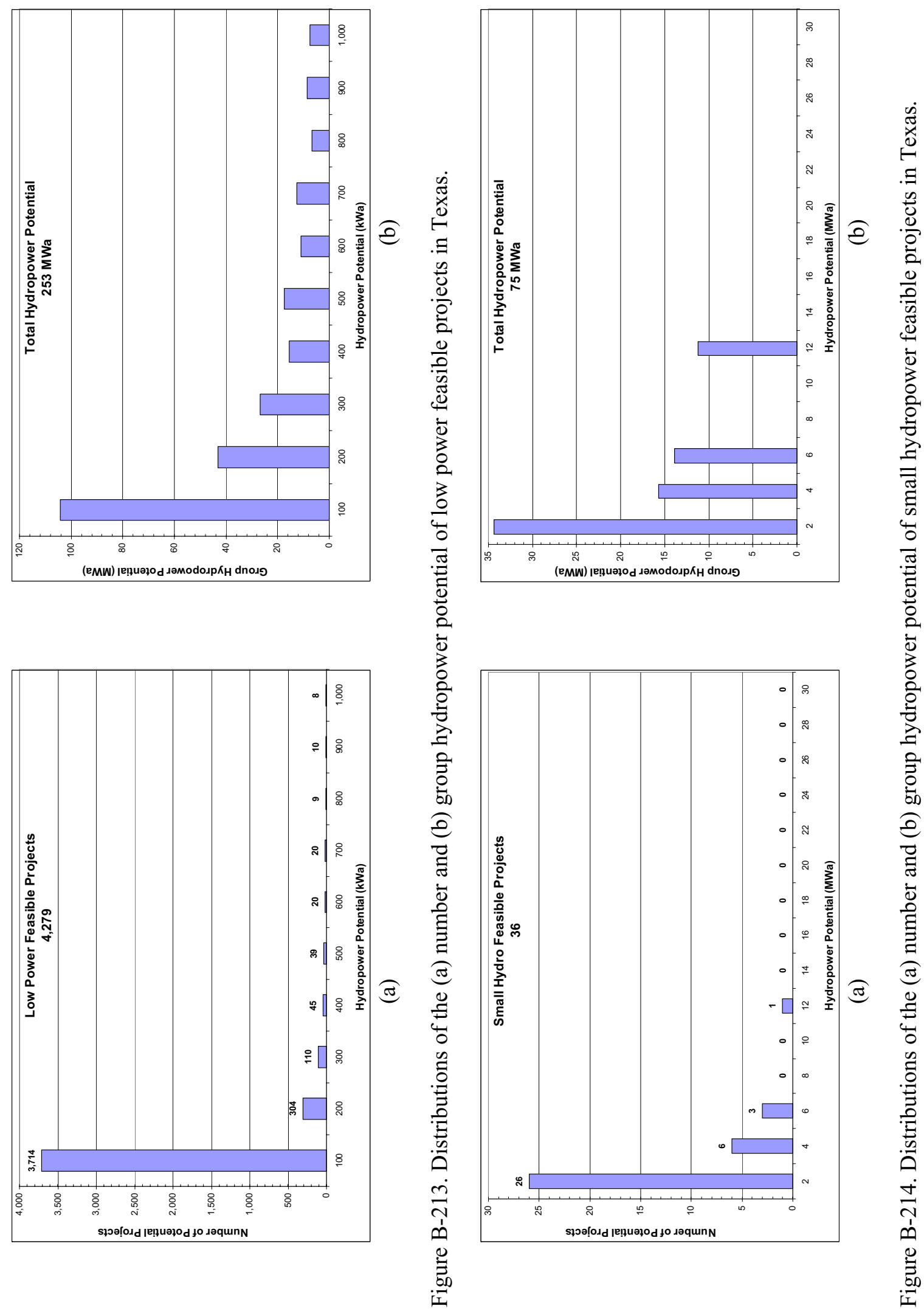

B-177 


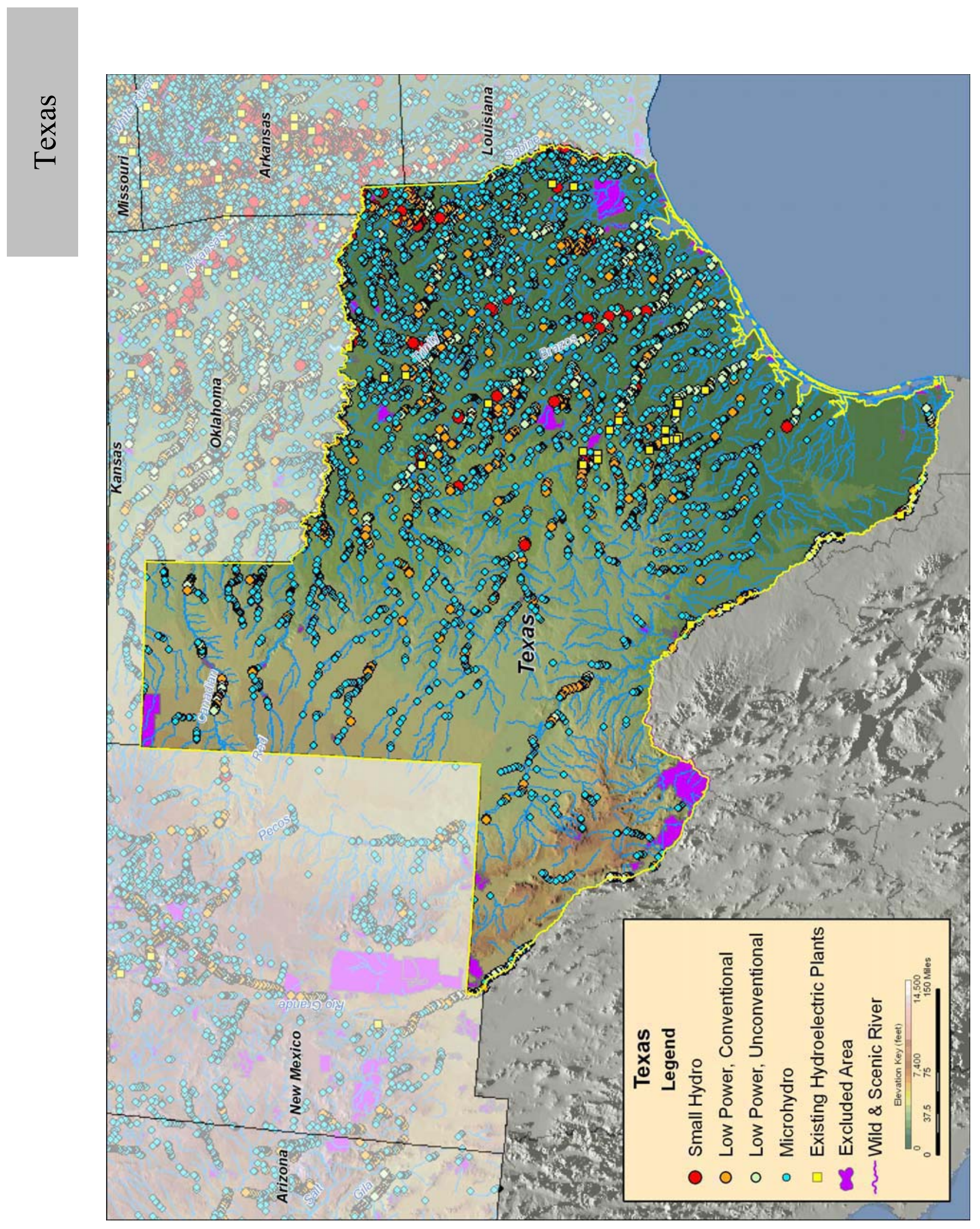

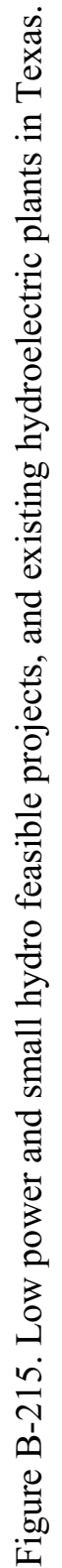




\section{B.44 Utah}

Table B-89. Summary of results of water energy resource assessment of Utah.

\begin{tabular}{|c|c|c|c|c|c|}
\hline Power Class & $\begin{array}{c}\text { Total } \\
\mathbf{( M W a )}\end{array}$ & $\begin{array}{c}\text { Developed } \\
(\mathrm{MWa})\end{array}$ & $\begin{array}{c}\text { Federally } \\
\text { Excluded } \\
(\mathbf{M W a})\end{array}$ & $\begin{array}{c}\text { Other } \\
\text { Excluded } \\
\text { (MWa) }\end{array}$ & $\begin{array}{c}\text { Available } \\
(\mathrm{MWa})\end{array}$ \\
\hline Total Power & $\mathbf{3 , 9 0 6}$ & $\mathbf{1 2 3}$ & $\mathbf{7 3 6}$ & $\mathbf{1 2 0}$ & $\mathbf{2 , 9 2 7}$ \\
\hline Total High Power & & & & & \\
\hline Large Hydro & $\mathbf{2 , 3 9 4}$ & 110 & $\mathbf{5 9 4}$ & $\mathbf{9 0}$ & 1,600 \\
\hline Small Hydro & 183 & 66 & 74 & 0 & 43 \\
\hline Total Low Power & 2,211 & 44 & 520 & 90 & 1,557 \\
\hline Conventional Turbines & & & & & \\
\hline Unconventional Systems & $\mathbf{1 , 5 1 2}$ & 13 & 142 & $\mathbf{3 0}$ & 1,328 \\
\hline Microhydro & $\mathbf{1 , 2 1 7}$ & 12 & 116 & 24 & 1,065 \\
\hline
\end{tabular}

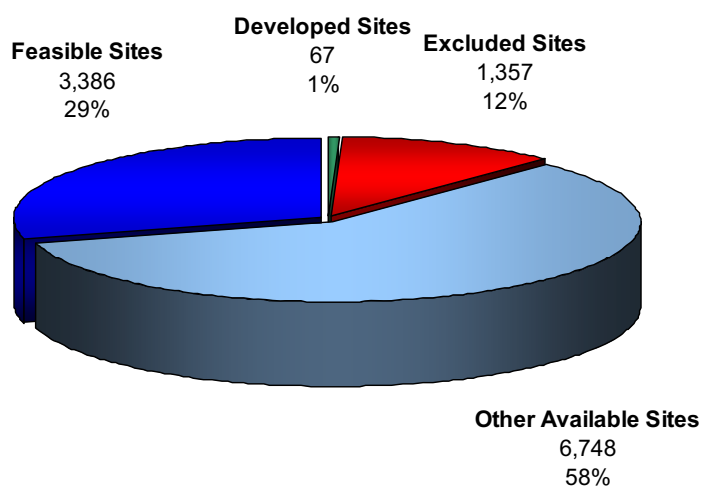

(a) Total Resource Sites 11,558

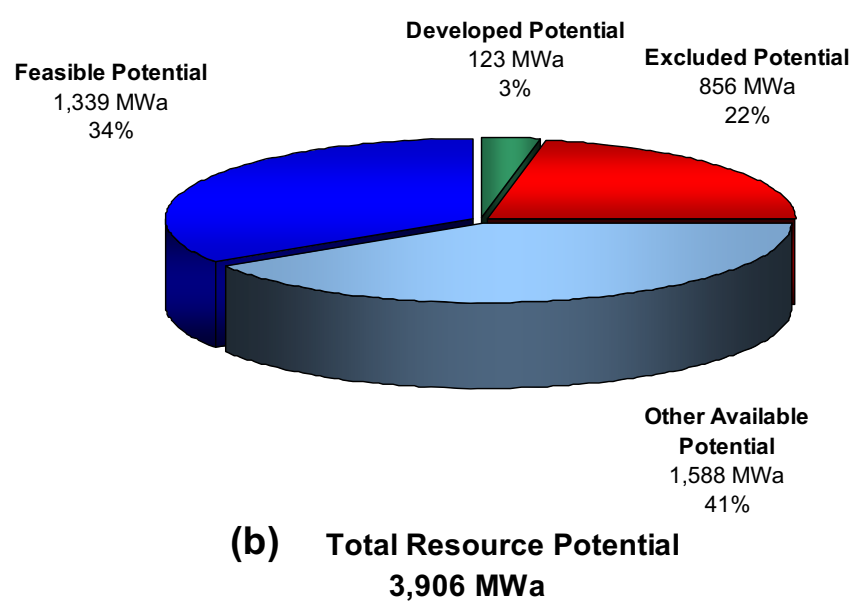

Figure B-216. Power category distribution of the (a) number and (b) total power potential of the water energy resource sites in Utah. 
Table B-90. Summary of results of feasibility assessment of water energy resources in Utah.

\begin{tabular}{|c|c|c|c|}
\hline Power Class & $\begin{array}{c}\text { Available } \\
\text { (MWa) }\end{array}$ & $\begin{array}{c}\text { Feasible } \\
\text { Sites } \\
\text { (MWa) }\end{array}$ & $\begin{array}{c}\text { Feasible } \\
\text { Projects } \\
\text { (MWa) }\end{array}$ \\
\hline Total Power & 2,927 & 1,339 & 401 \\
\hline Total High Power & 1,600 & 710 & 36 \\
\hline Large Hydro & 43 & 0 & 0 \\
\hline Small Hydro & 1,557 & 710 & 36 \\
\hline Total Low Power & 1,328 & 629 & 365 \\
\hline Conventional Turbines & 1,065 & 529 & 258 \\
\hline Unconventional Systems & 33 & 25 & 22 \\
\hline Microhydro & 229 & 74 & 86 \\
\hline
\end{tabular}

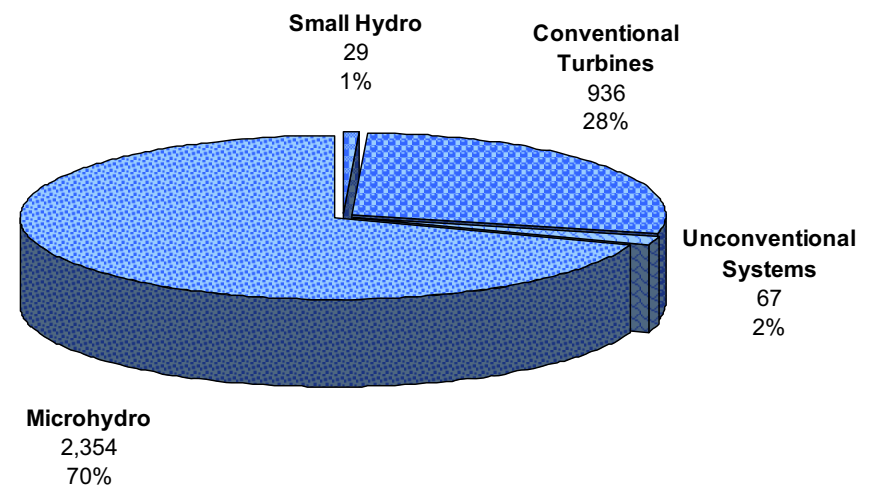

(a) Total Feasible Projects 3,386

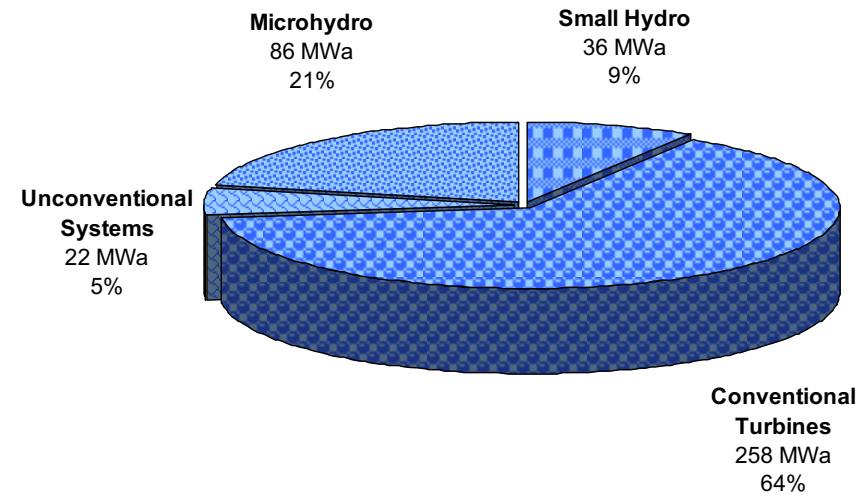

(b) Total Feasible Project Hydropower Potential $401 \mathrm{MWa}$

Figure B-217. Distribution of the (a) number and (b) total hydropower potential of the low power and small hydropower feasible projects in Utah with the low power projects divided into technology classes. 

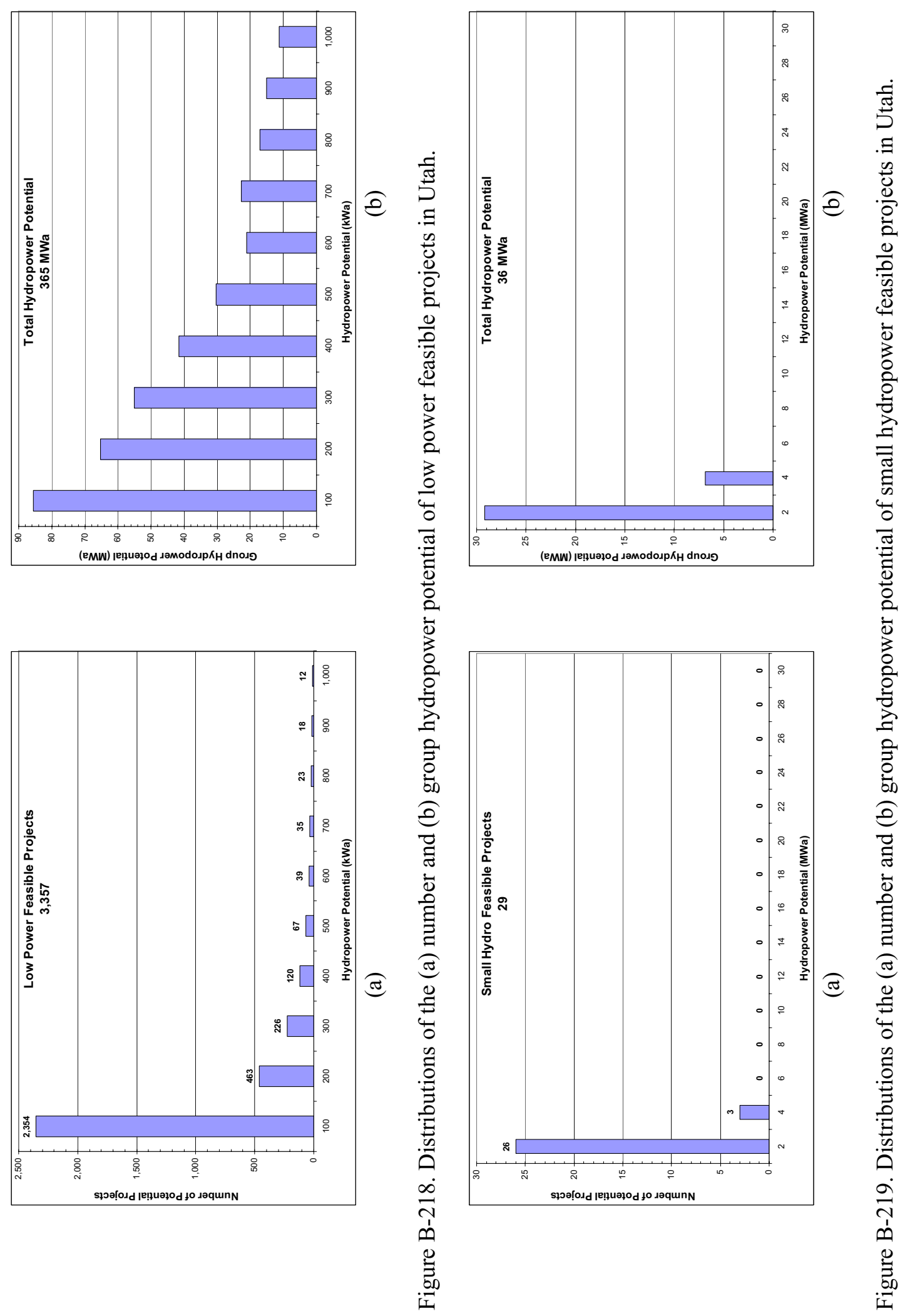

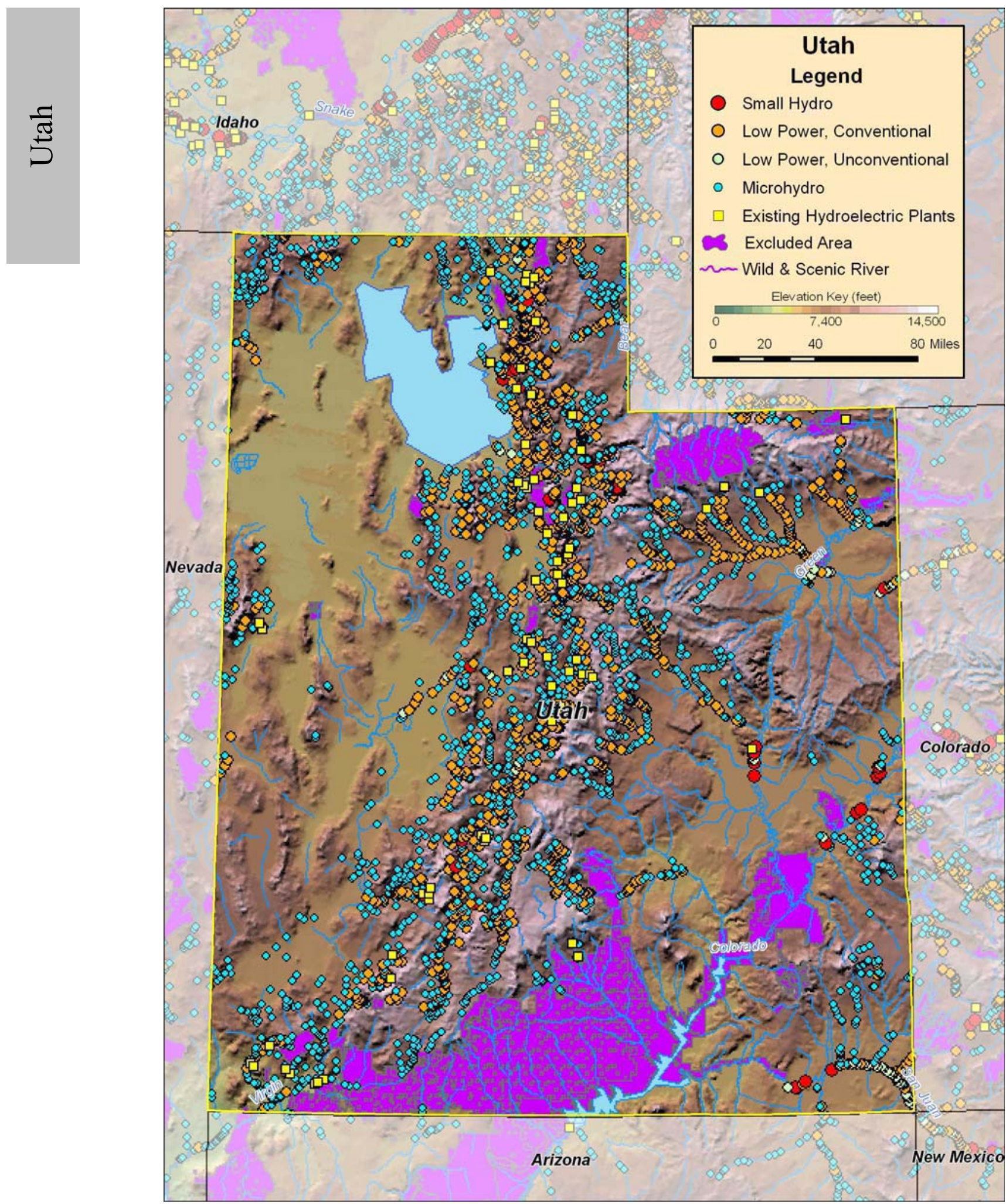

Figure B-220. Low power and small hydro feasible projects, and existing hydroelectric plants in Utah. 


\section{B.45 Vermont}

Table B-91. Summary of results of water energy resource assessment of Vermont.

\begin{tabular}{|c|c|c|c|c|c|}
\hline Power Class & $\begin{array}{c}\text { Total } \\
\mathbf{( M W a )}\end{array}$ & $\begin{array}{c}\text { Developed } \\
(\mathrm{MWa})\end{array}$ & $\begin{array}{c}\text { Federally } \\
\text { Excluded } \\
(\mathbf{M W a})\end{array}$ & $\begin{array}{c}\text { Other } \\
\text { Excluded } \\
(\mathbf{M W a})\end{array}$ & $\begin{array}{c}\text { Available } \\
(\mathrm{MWa})\end{array}$ \\
\hline Total Power & $\mathbf{1 , 2 0 2}$ & 104 & $\mathbf{3 3}$ & $\mathbf{4 3}$ & 1,022 \\
\hline Total High Power & & & & & \\
\hline Large Hydro & $\mathbf{7 4 5}$ & $\mathbf{8 5}$ & $\mathbf{2 7}$ & $\mathbf{2 6}$ & 606 \\
\hline Small Hydro & $\mathbf{9 7}$ & 54 & 0 & 0 & 43 \\
\hline & $\mathbf{6 4 8}$ & 31 & 27 & 26 & 564 \\
\hline Total Low Power & & & & & \\
\hline Conventional Turbines & $\mathbf{4 5 7}$ & 19 & $\mathbf{6}$ & $\mathbf{1 6}$ & 416 \\
\hline Unconventional Systems & $\mathbf{4 0 8}$ & 15 & 6 & 14 & 373 \\
\hline Microhydro & $\mathbf{1 5}$ & 3 & 0 & 2 & 11 \\
\hline
\end{tabular}

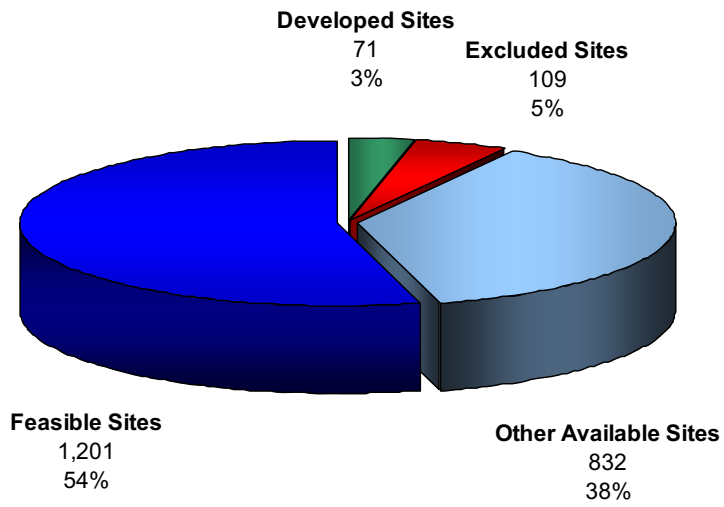

(a) Total Resource Sites 2,213

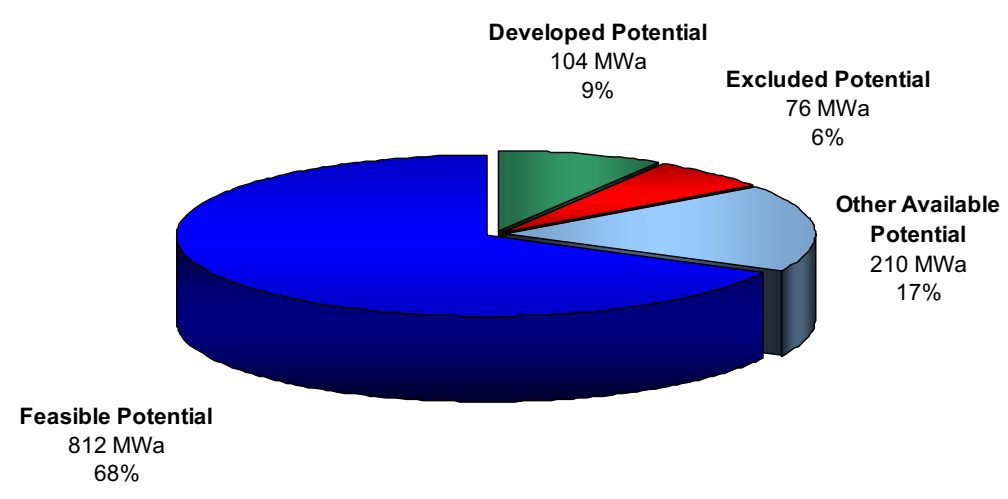

(b) Total Resource Potential $1,202 \mathrm{MWa}$

Figure B-221. Power category distribution of the (a) number and (b) total power potential of the water energy resource sites in Vermont. 
Table B-92. Summary of results of feasibility assessment of water energy resources in Vermont.

\begin{tabular}{|c|c|c|c|}
\hline & & \\
\hline Power Class & $\begin{array}{c}\text { Available } \\
\text { (MWa) }\end{array}$ & $\begin{array}{c}\text { Feasible } \\
\text { Sites } \\
\text { (MWa) }\end{array}$ & $\begin{array}{c}\text { Feasible } \\
\text { Projects } \\
\text { (MWa) }\end{array}$ \\
\hline Total Power & 1,022 & 812 & 217 \\
\hline Total High Power & 606 & 552 & 112 \\
\hline Large Hydro & 43 & 43 & 0 \\
\hline Small Hydro & 564 & 509 & 112 \\
\hline Total Low Power & 416 & 260 & 105 \\
\hline Conventional Turbines & 373 & 233 & 65 \\
\hline Unconventional Systems & 11 & 10 & 6 \\
\hline Microhydro & 32 & 18 & 34 \\
\hline
\end{tabular}

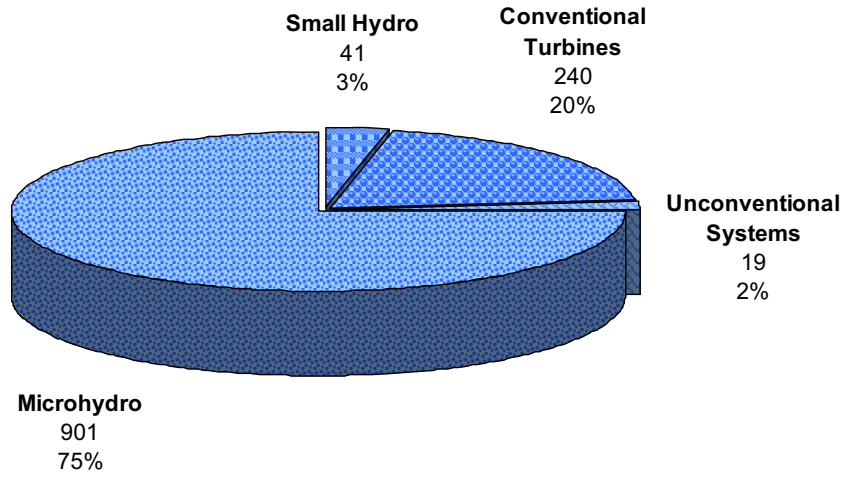

(a) Total Feasible Projects 1,201

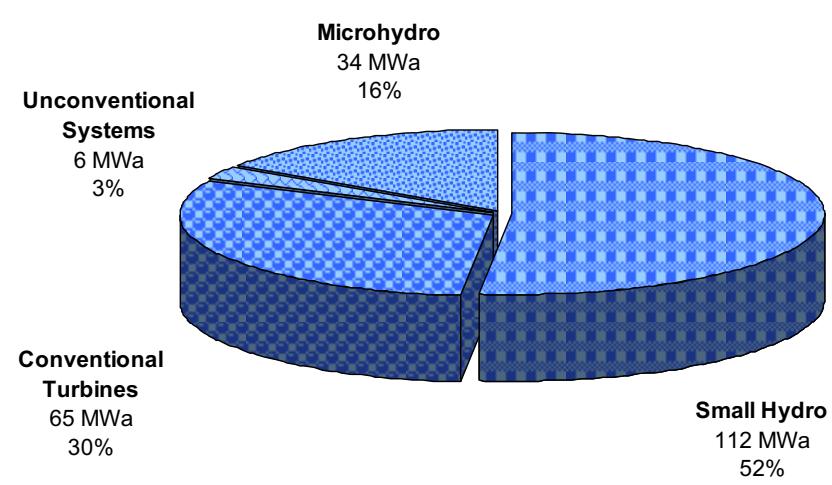

(b) Total Feasible Project Hydropower Potential 217 MWa

Figure B-222. Distribution of the (a) number and (b) total hydropower potential of the low power and small hydropower feasible projects in Vermont with the low power projects divided into technology classes. 

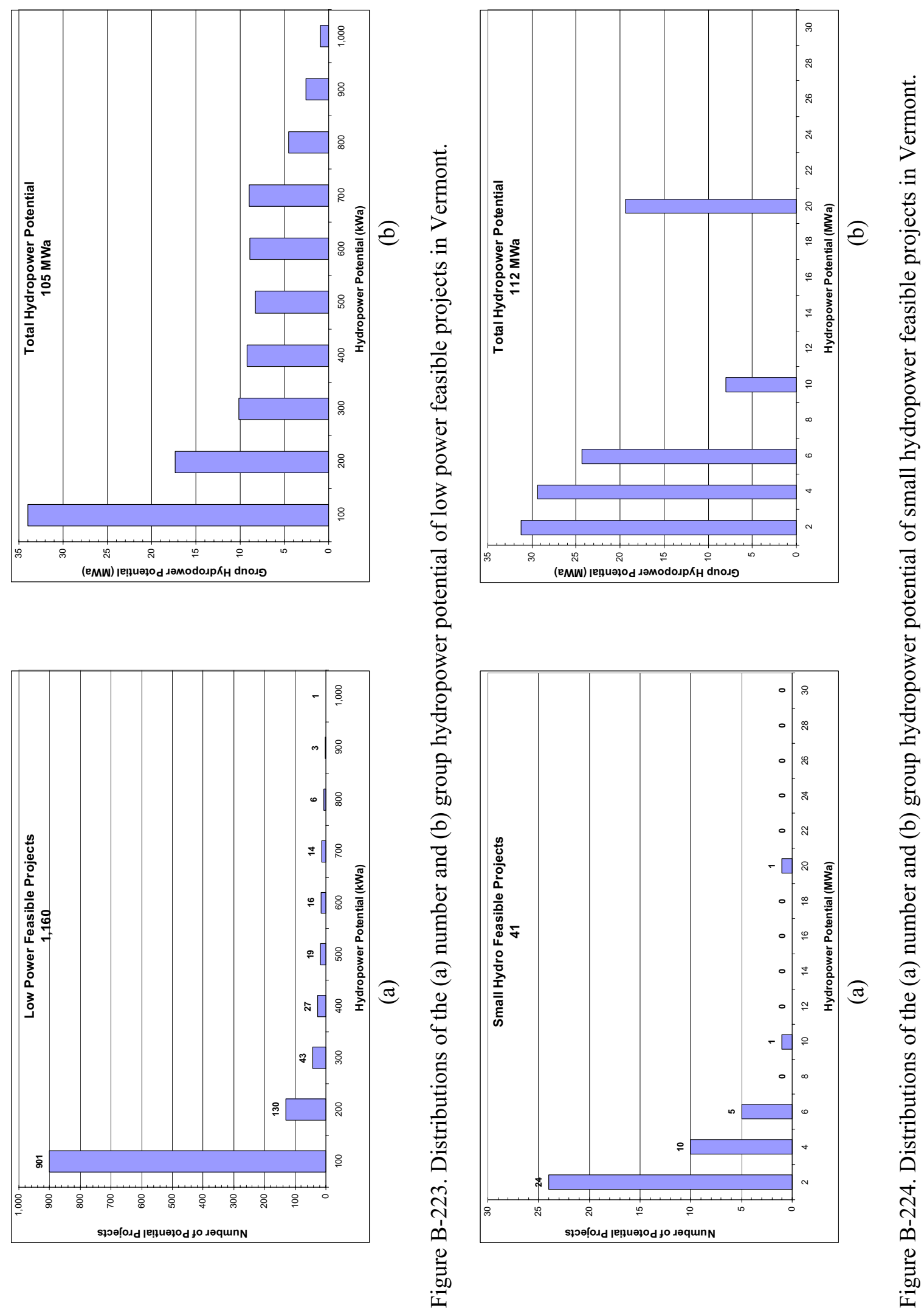


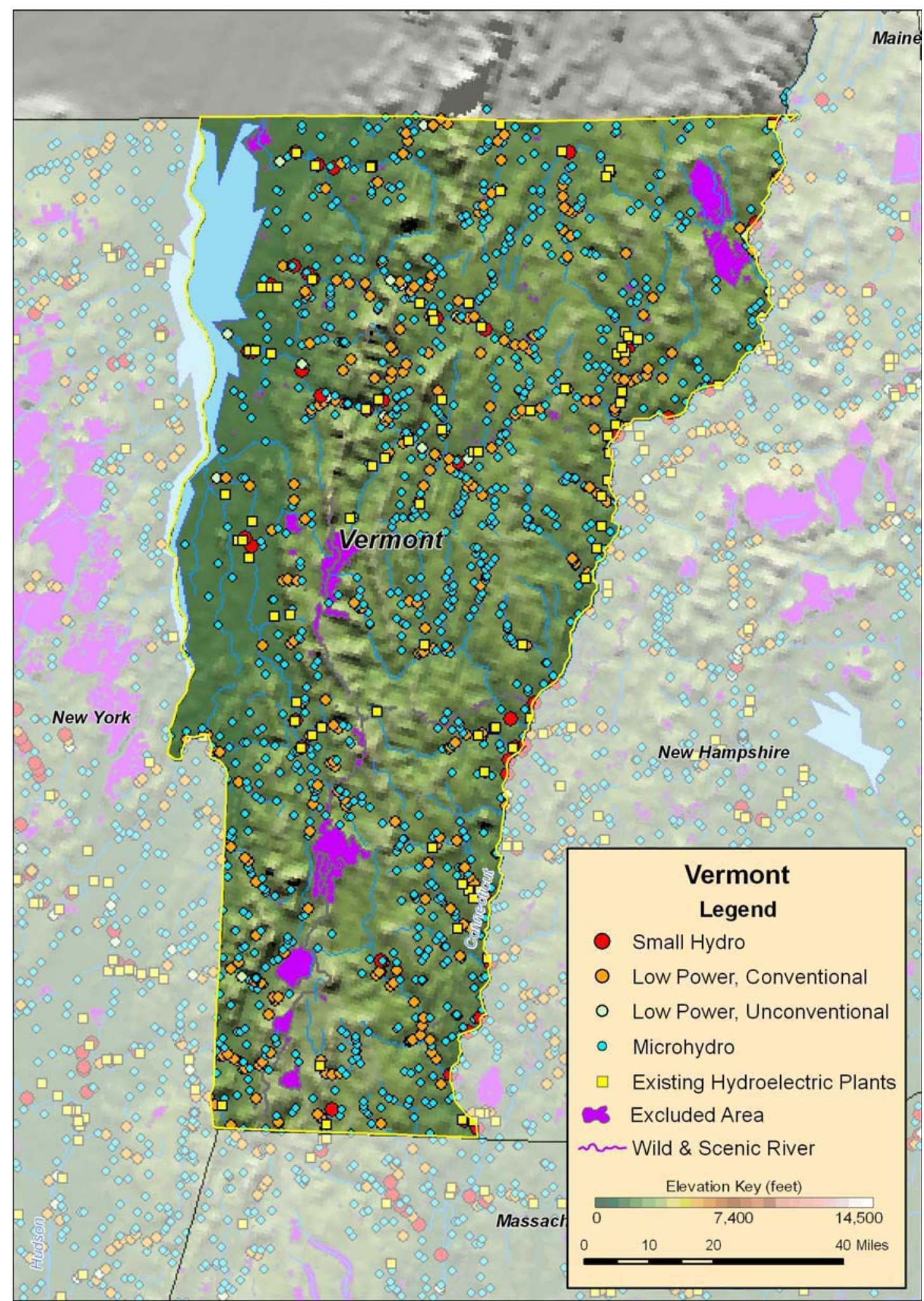

Figure B-225. Low power and small hydro feasible projects, and existing hydroelectric plants in Vermont. 


\section{B.46 Virginia}

Table B-93. Summary of results of water energy resource assessment of Virginia.

\begin{tabular}{|c|c|c|c|c|c|}
\hline Power Class & $\begin{array}{c}\text { Total } \\
\mathbf{( M W a )}\end{array}$ & $\begin{array}{c}\text { Developed } \\
(\mathrm{MWa})\end{array}$ & $\begin{array}{c}\text { Federally } \\
\text { Excluded } \\
(\mathbf{M W a})\end{array}$ & $\begin{array}{c}\text { Other } \\
\text { Excluded } \\
(\mathbf{M W a})\end{array}$ & $\begin{array}{c}\text { Availlable } \\
(\mathrm{MWa})\end{array}$ \\
\hline Total Power & $\mathbf{2 , 2 7 4}$ & $\mathbf{1 5 3}$ & $\mathbf{1 7 5}$ & $\mathbf{9 4}$ & 1,853 \\
\hline Total High Power & & & & & \\
\hline Large Hydro & $\mathbf{1 , 4 4 3}$ & 145 & $\mathbf{1 4 0}$ & $\mathbf{7 3}$ & 1,084 \\
\hline Small Hydro & 140 & 92 & 48 & 0 & 0 \\
\hline Total Low Power & 1,303 & 53 & 93 & 73 & 1,084 \\
\hline Conventional Turbines & & & & & \\
\hline Unconventional Systems & $\mathbf{8 3 1}$ & $\mathbf{8}$ & $\mathbf{3 4}$ & $\mathbf{2 1}$ & 768 \\
\hline Microhydro & 49 & 5 & 31 & 18 & 559 \\
\hline
\end{tabular}

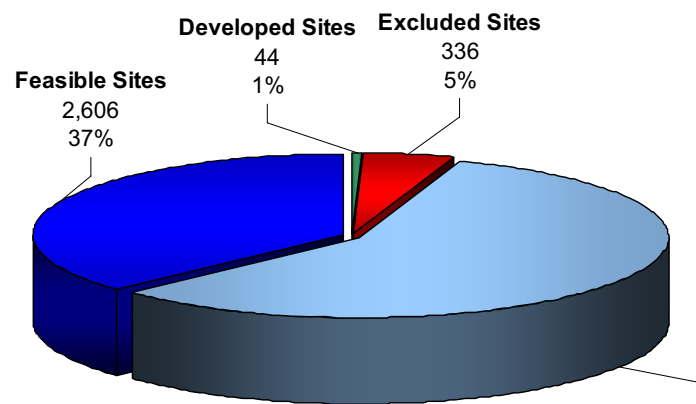

Other Available Sites

4,066

$58 \%$

(a) Total Resource Sites

7,052

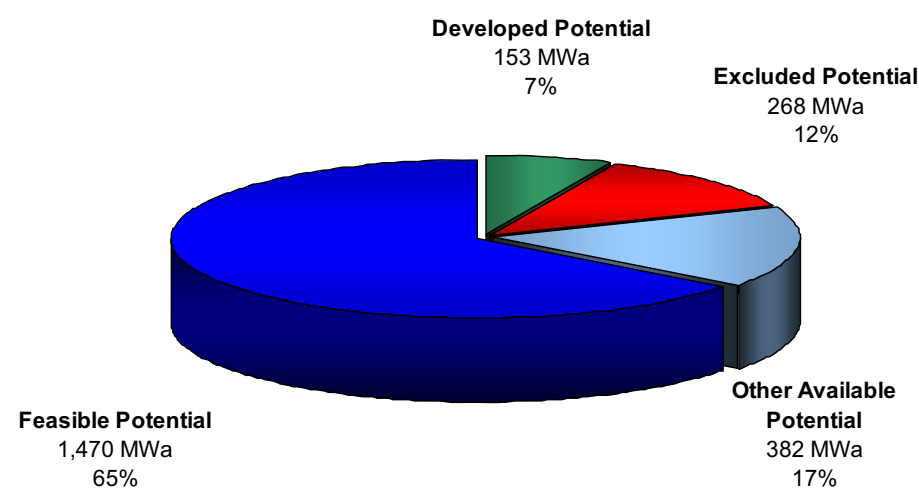

(b) Total Resource Potential 2,274 MWa

Figure B-226. Power category distribution of the (a) number and (b) total power potential of the water energy resource sites in Virginia. 
Table B-94. Summary of results of feasibility assessment of water energy resources in Virginia.

\begin{tabular}{|c|c|}
\hline Power Class & $\begin{array}{c}\text { Available } \\
(\mathrm{MWa})\end{array}$ \\
\hline Total Power & 1,853 \\
\hline Total High Power & 1,084 \\
\hline Large Hydro & 0 \\
\hline Small Hydro & 1,084 \\
\hline & \\
\hline Total Low Power & 768 \\
\hline Conventional Turbines & 559 \\
\hline Unconventional Systems & 47 \\
\hline Microhydro & 163 \\
\hline
\end{tabular}
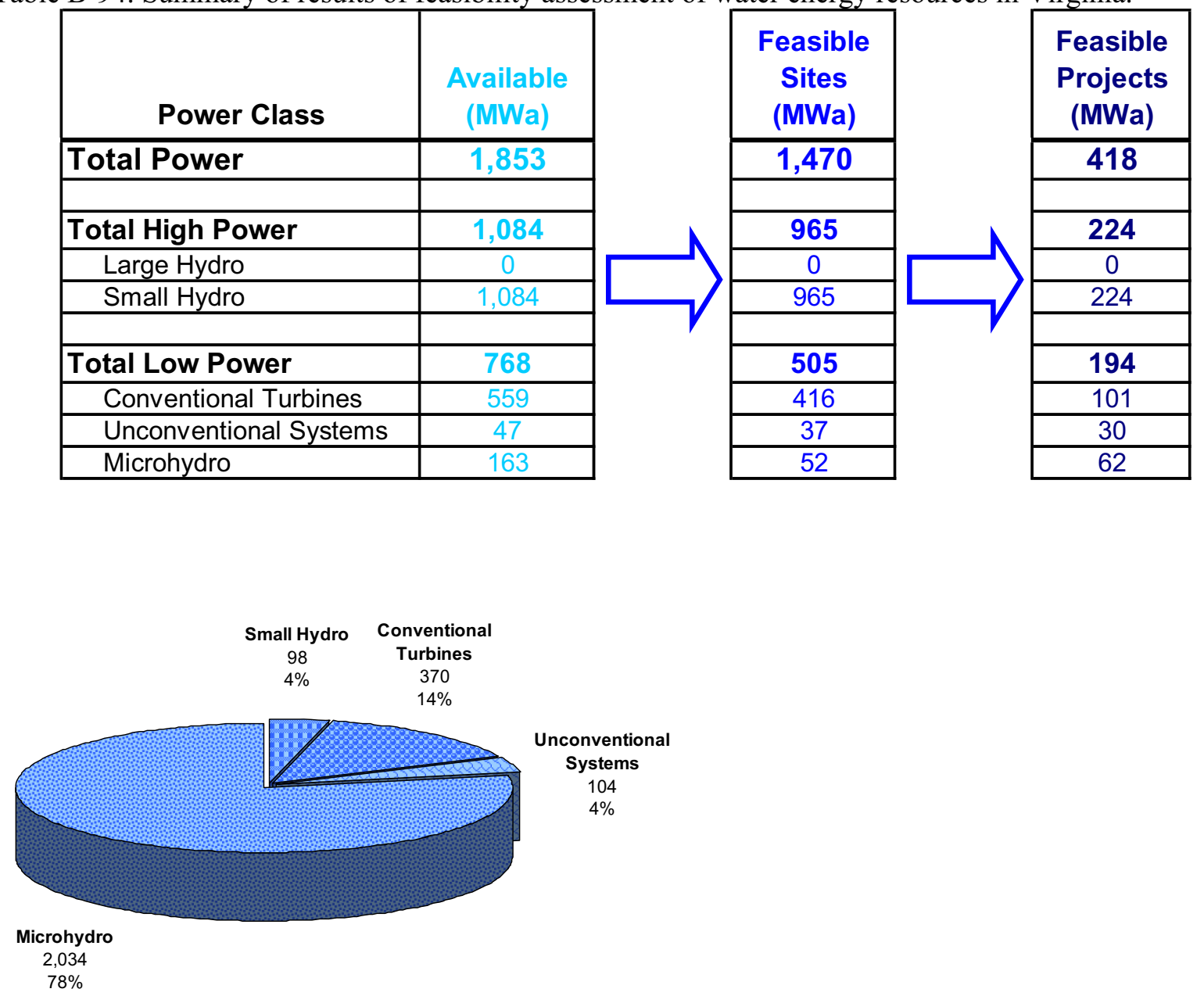

(a) Total Feasible Projects 2,606

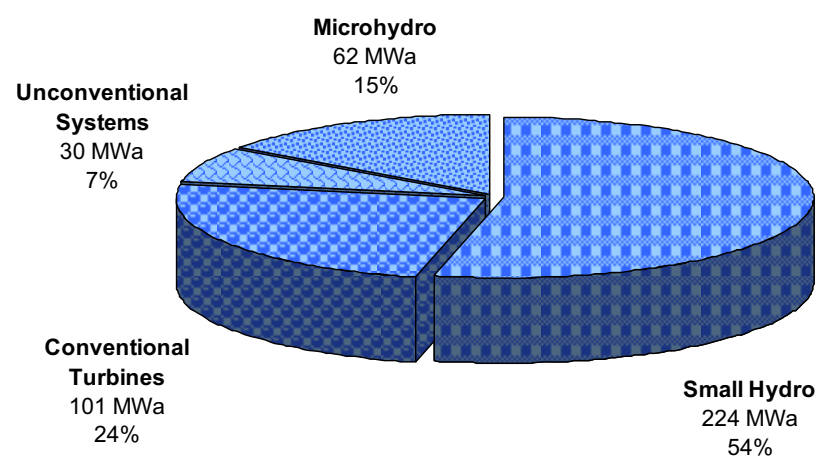

(b) Total Feasible Project Hydropower Potential $418 \mathrm{MWa}$

Figure B-227. Distribution of the (a) number and (b) total hydropower potential of the low power and small hydropower feasible projects in Virginia with the low power projects divided into technology classes. 

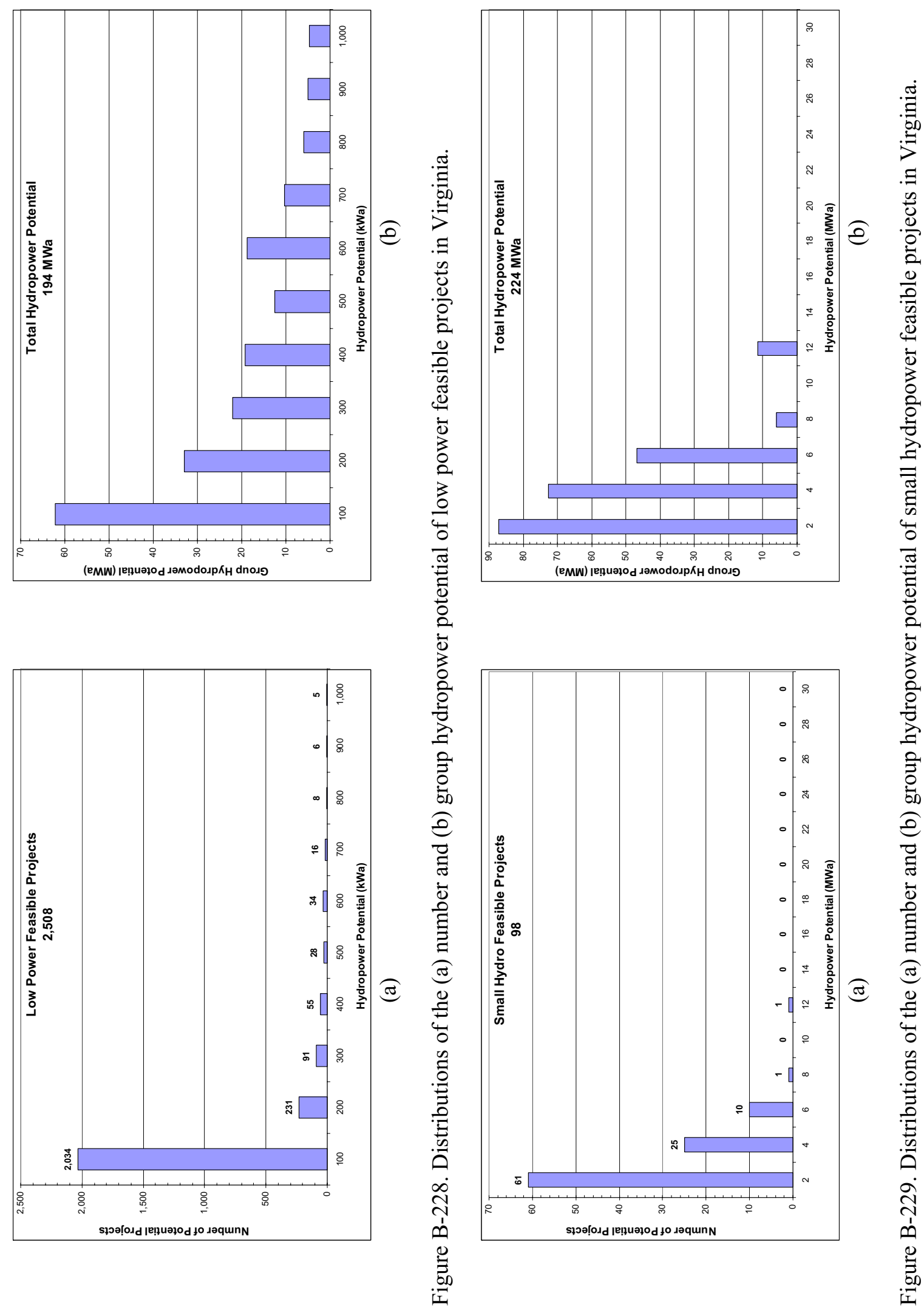


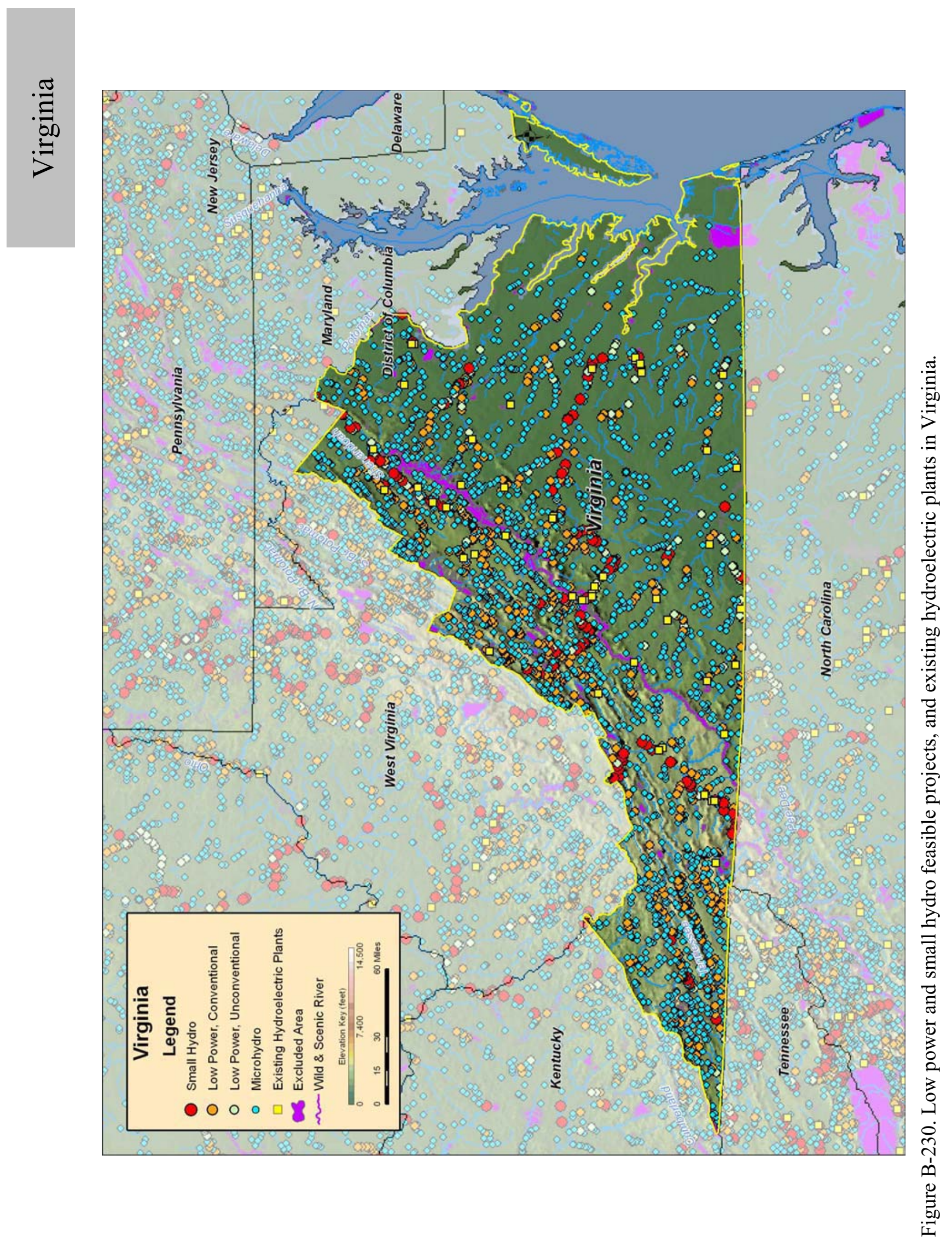




\section{B.47 Washington}

Table B-95. Summary of results of water energy resource assessment of Washington.

\begin{tabular}{|c|c|c|c|c|c|}
\hline Power Class & $\begin{array}{c}\text { Total } \\
\mathbf{( M W a )}\end{array}$ & $\begin{array}{c}\text { Developed } \\
(\mathrm{MWa})\end{array}$ & $\begin{array}{c}\text { Federally } \\
\text { Excluded } \\
(\mathbf{M W a})\end{array}$ & $\begin{array}{c}\text { Other } \\
\text { Excluded } \\
(\mathbf{M W a})\end{array}$ & $\begin{array}{c}\text { Available } \\
(\mathrm{MWa})\end{array}$ \\
\hline Total Power & $\mathbf{3 3 , 6 2 0}$ & $11, \mathbf{0 0 6}$ & $\mathbf{7 , 9 9 5}$ & $\mathbf{1 , 0 9 3}$ & 13,526 \\
\hline & & & & & \\
\hline Total High Power & $\mathbf{3 1 , 5 1 0}$ & 10,997 & $\mathbf{7 , 6 7 6}$ & $\mathbf{1 , 0 4 2}$ & 11,796 \\
\hline Large Hydro & 14,980 & 10,761 & 886 & 187 & 3,146 \\
\hline Small Hydro & 16,531 & 236 & 6,790 & 855 & 8,649 \\
\hline Total Low Power & & & & & \\
\hline Conventional Turbines & $\mathbf{2 , 1 1 0}$ & 9 & 319 & $\mathbf{5 1}$ & 1,731 \\
\hline Unconventional Systems & 1,836 & 8 & 303 & 47 & 1,477 \\
\hline Microhydro & 81 & 0 & 7 & 1 & 73 \\
\hline
\end{tabular}

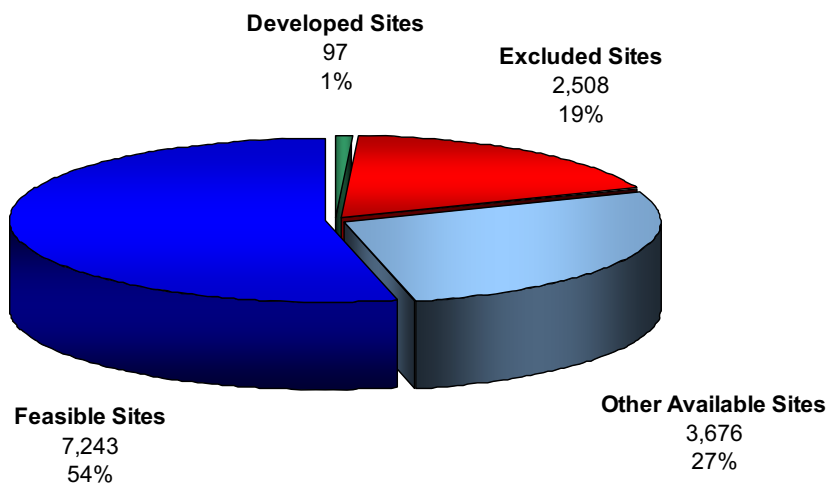

(a) Total Resource Sites 13,524

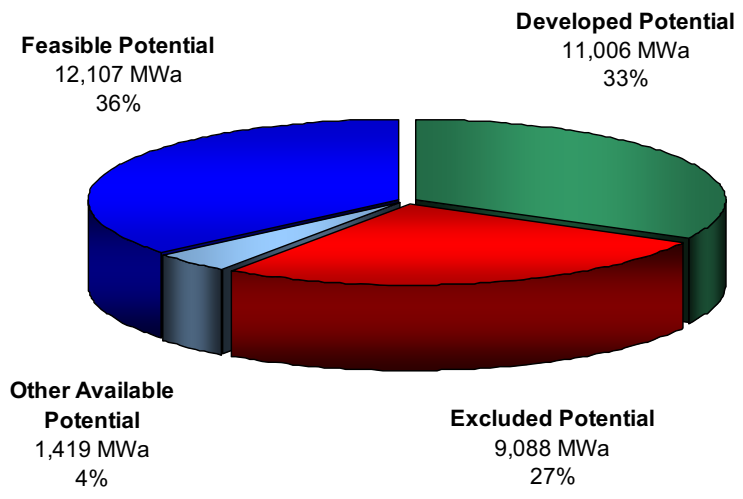

(b) Total Resource Potential 33,620 MWa

Figure B-231. Power category distribution of the (a) number and (b) total power potential of the water energy resource sites in Washington. 
Table B-96. Summary of results of feasibility assessment of water energy resources in Washington.

\begin{tabular}{|c|c|c|c|}
\hline Power Class & $\begin{array}{c}\text { Available } \\
\text { (MWa) }\end{array}$ & $\begin{array}{c}\text { Feasible } \\
\text { Sites } \\
\text { (MWa) }\end{array}$ & $\begin{array}{c}\text { Feasible } \\
\text { Projects } \\
(\mathrm{MWa})\end{array}$ \\
\hline Total Power & 13,526 & 12,107 & 3,106 \\
\hline Total High Power & 11,796 & 10,717 & 2,263 \\
\hline Large Hydro & 3,146 & 3,071 & 0 \\
\hline Small Hydro & 8,649 & 7,646 & 2,263 \\
\hline Total Low Power & 1,731 & 1,390 & 843 \\
\hline Conventional Turbines & 1,477 & 1,212 & 601 \\
\hline Unconventional Systems & 73 & 70 & 87 \\
\hline Microhydro & 181 & 108 & 155 \\
\hline
\end{tabular}

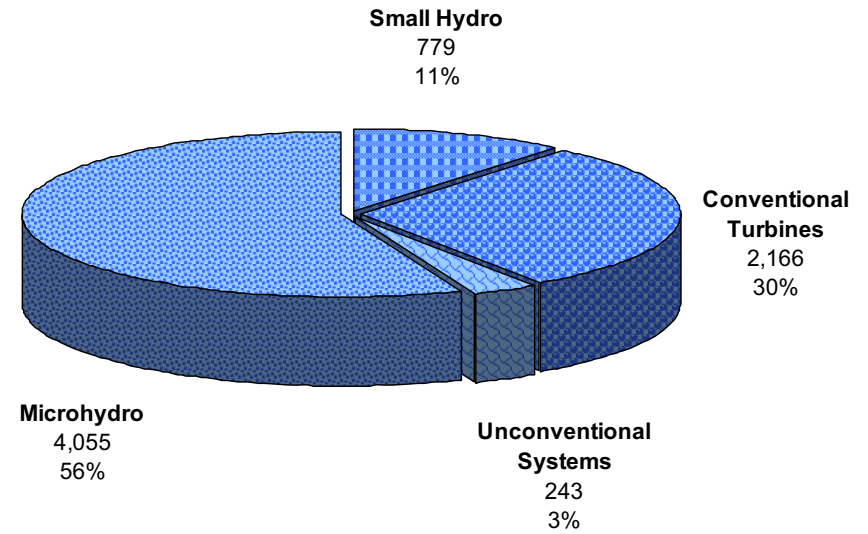

(a) Total Feasible Projects 7,243

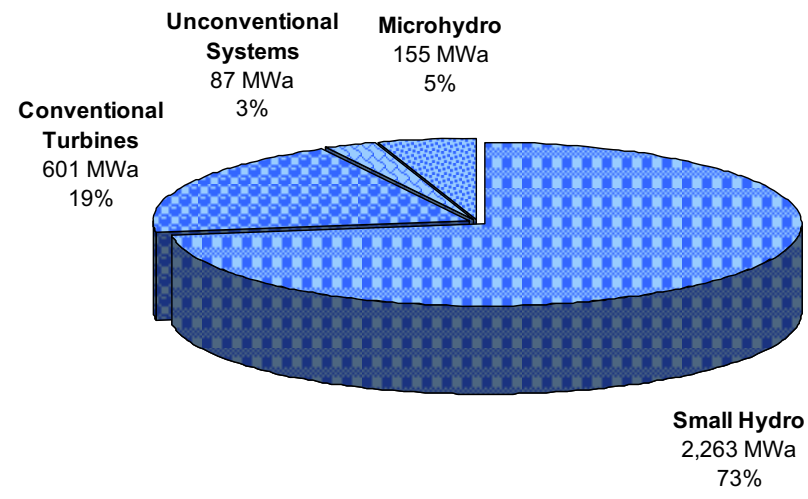

(b) Total Feasible Project Hydropower Potential 3,106 MWa

Figure B-232. Distribution of the (a) number and (b) total hydropower potential of the low power and small hydropower feasible projects in Washington with the low power projects divided into technology classes. 

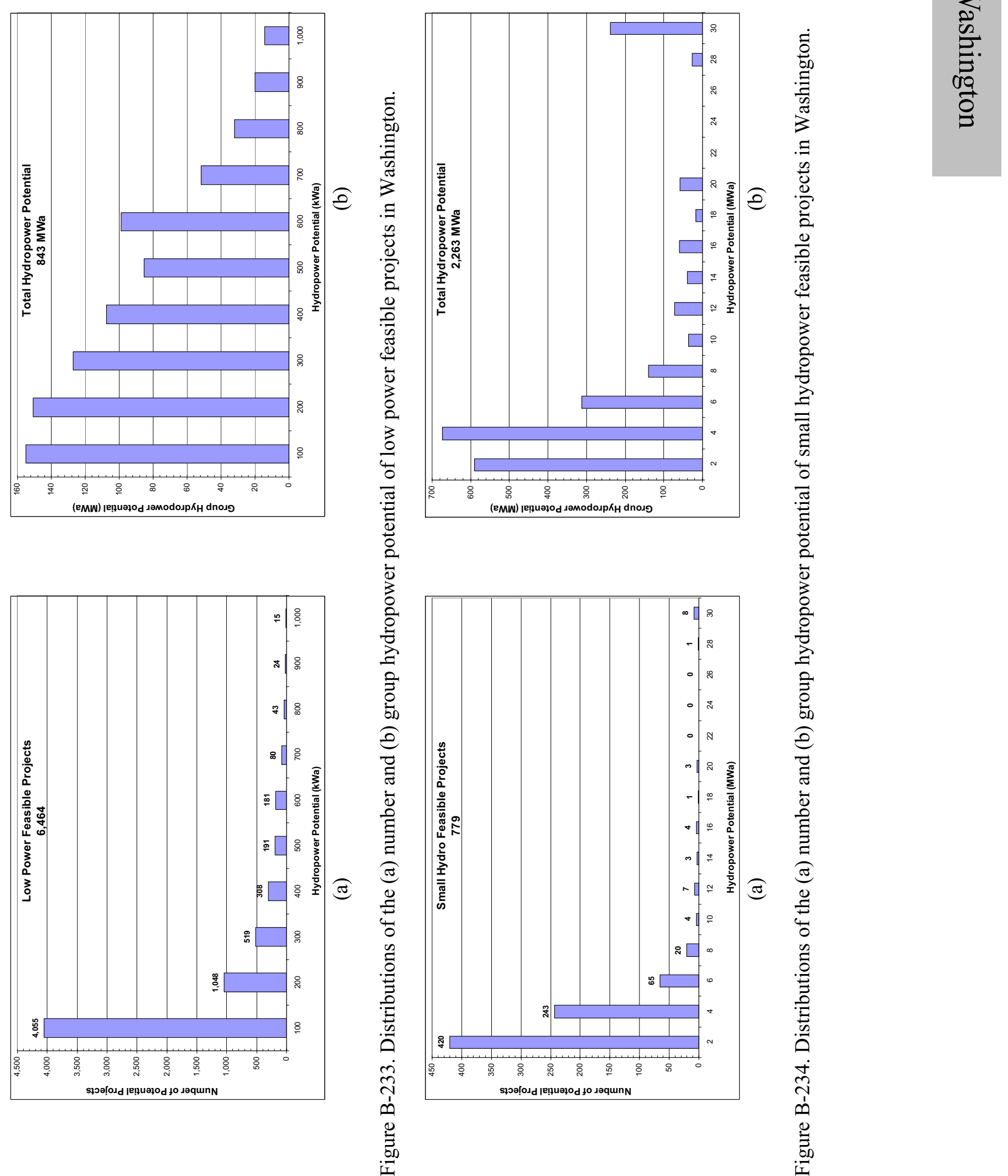

B-193 


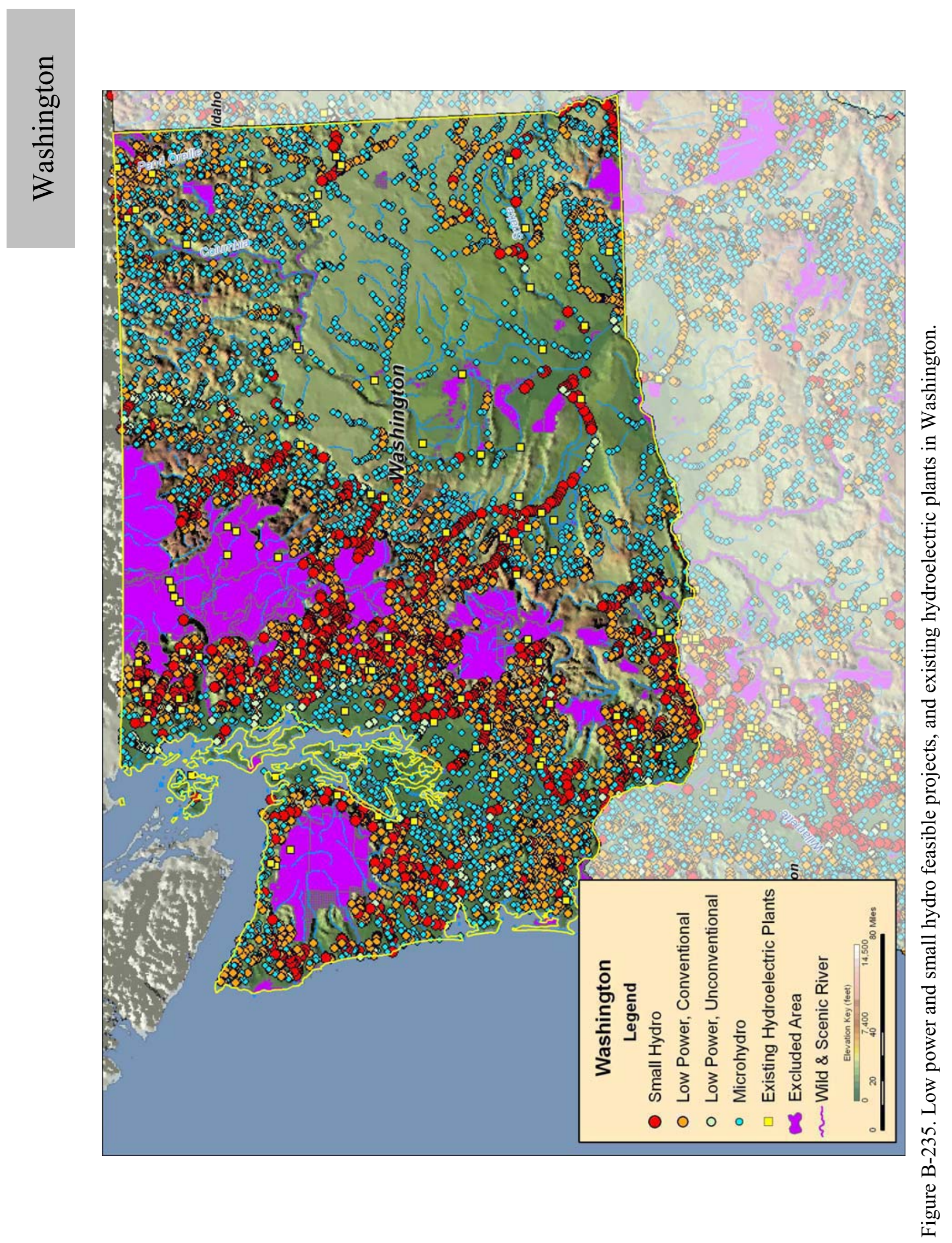




\section{B.48 West Virginia}

Table B-97. Summary of results of water energy resource assessment of West Virginia.

\begin{tabular}{|c|c|c|c|c|c|}
\hline Power Class & $\begin{array}{c}\text { Total } \\
\mathbf{( M W a )}\end{array}$ & $\begin{array}{c}\text { Developed } \\
(\mathrm{MWa})\end{array}$ & $\begin{array}{c}\text { Federally } \\
\text { Excluded } \\
(\mathbf{M W a})\end{array}$ & $\begin{array}{c}\text { Other } \\
\text { Excluded } \\
(\mathbf{M W a})\end{array}$ & $\begin{array}{c}\text { Available } \\
(\mathrm{MWa})\end{array}$ \\
\hline Total Power & $\mathbf{3 , 5 3 3}$ & 193 & $\mathbf{7 0 6}$ & $\mathbf{1 7 2}$ & 2,461 \\
\hline Total High Power & & & & & \\
\hline Large Hydro & $\mathbf{2 , 8 1 2}$ & 192 & $\mathbf{6 7 7}$ & 160 & 1,784 \\
\hline Small Hydro & 605 & 129 & 52 & 101 & 324 \\
\hline & 2,207 & 63 & 625 & 59 & 1,460 \\
\hline Total Low Power & & & & & \\
\hline Conventional Turbines & $\mathbf{7 2 1}$ & $\mathbf{2}$ & $\mathbf{3 0}$ & $\mathbf{1 2}$ & 677 \\
\hline Unconventional Systems & 569 & 1 & 27 & 11 & 530 \\
\hline Microhydro & 34 & 1 & 0 & 0 & 33 \\
\hline
\end{tabular}

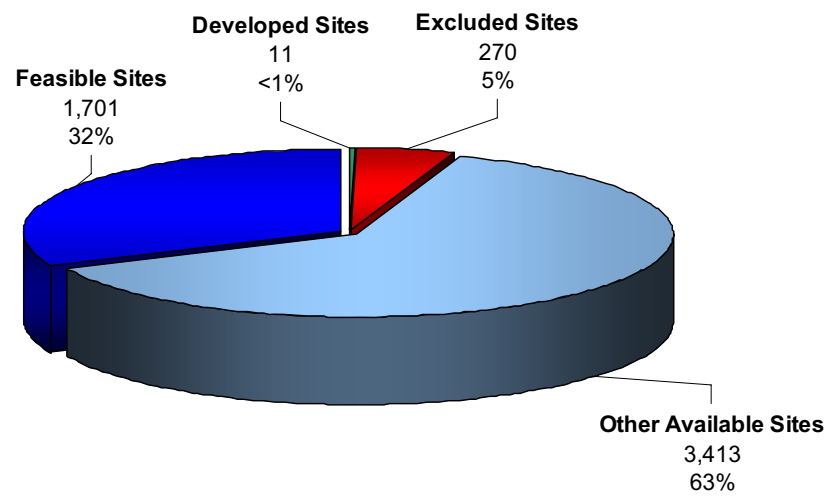

(a) Total Resource Sites 5,395

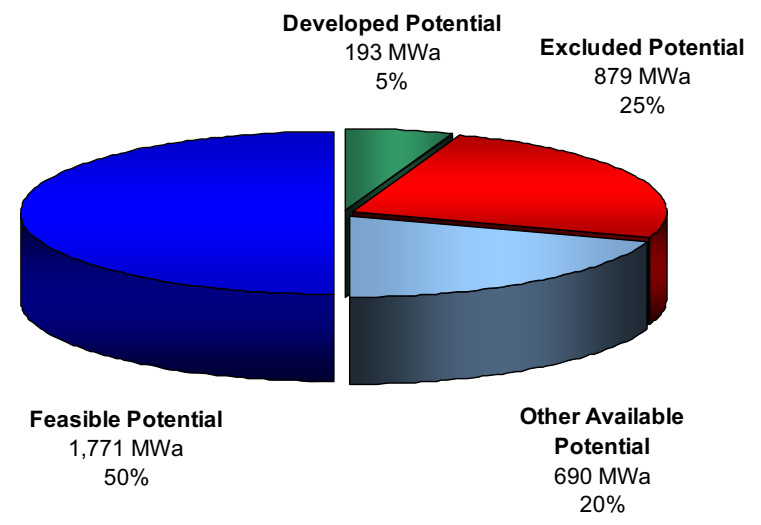

(b) Total Resource Potential $3,533 \mathrm{MWa}$

Figure B-236. Power category distribution of the (a) number and (b) total power potential of the water energy resource sites in West Virginia. 
Table B-98. Summary of results of feasibility assessment of water energy resources in West Virginia.

\begin{tabular}{|c|c|}
\hline Power Class & $\begin{array}{c}\text { Available } \\
\text { (MWa) }\end{array}$ \\
\hline Total Power & 2,461 \\
\hline Total High Power & 1,784 \\
\hline Large Hydro & 324 \\
\hline Small Hydro & 1,460 \\
\hline & \\
\hline Total Low Power & 677 \\
\hline Conventional Turbines & 530 \\
\hline Unconventional Systems & 33 \\
\hline Microhydro & 114 \\
\hline
\end{tabular}

\begin{tabular}{|c|c|c|}
\hline $\begin{array}{c}\text { Feasible } \\
\text { Sites } \\
\text { (MWa) }\end{array}$ \\
\hline 1,771 \\
\hline
\end{tabular}

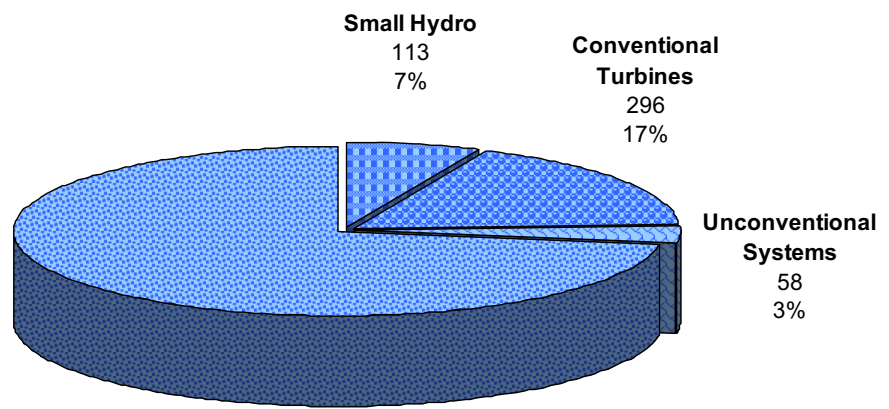

\footnotetext{
Microhydro

1,234

$73 \%$
}

(a) Total Feasible Projects

1,701

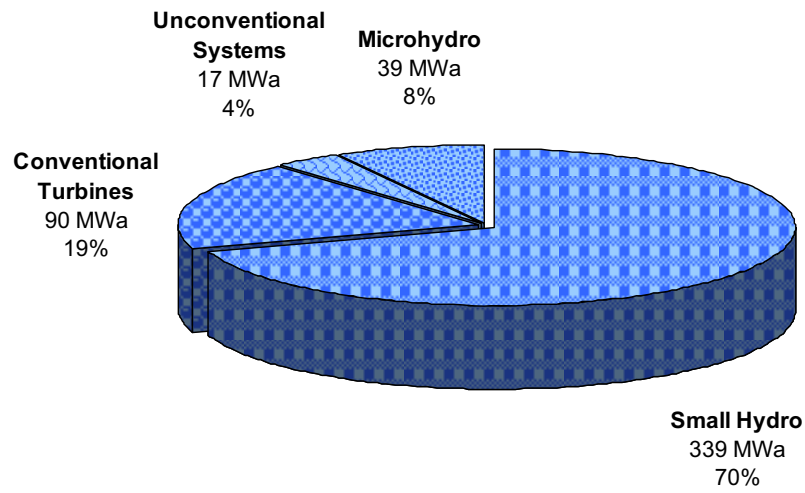

(b) Total Feasible Project Hydropower Potential $484 \mathrm{MWa}$

Figure B-237. Distribution of the (a) number and (b) total hydropower potential of the low power and small hydropower feasible projects in West Virginia with the low power projects divided into technology classes. 

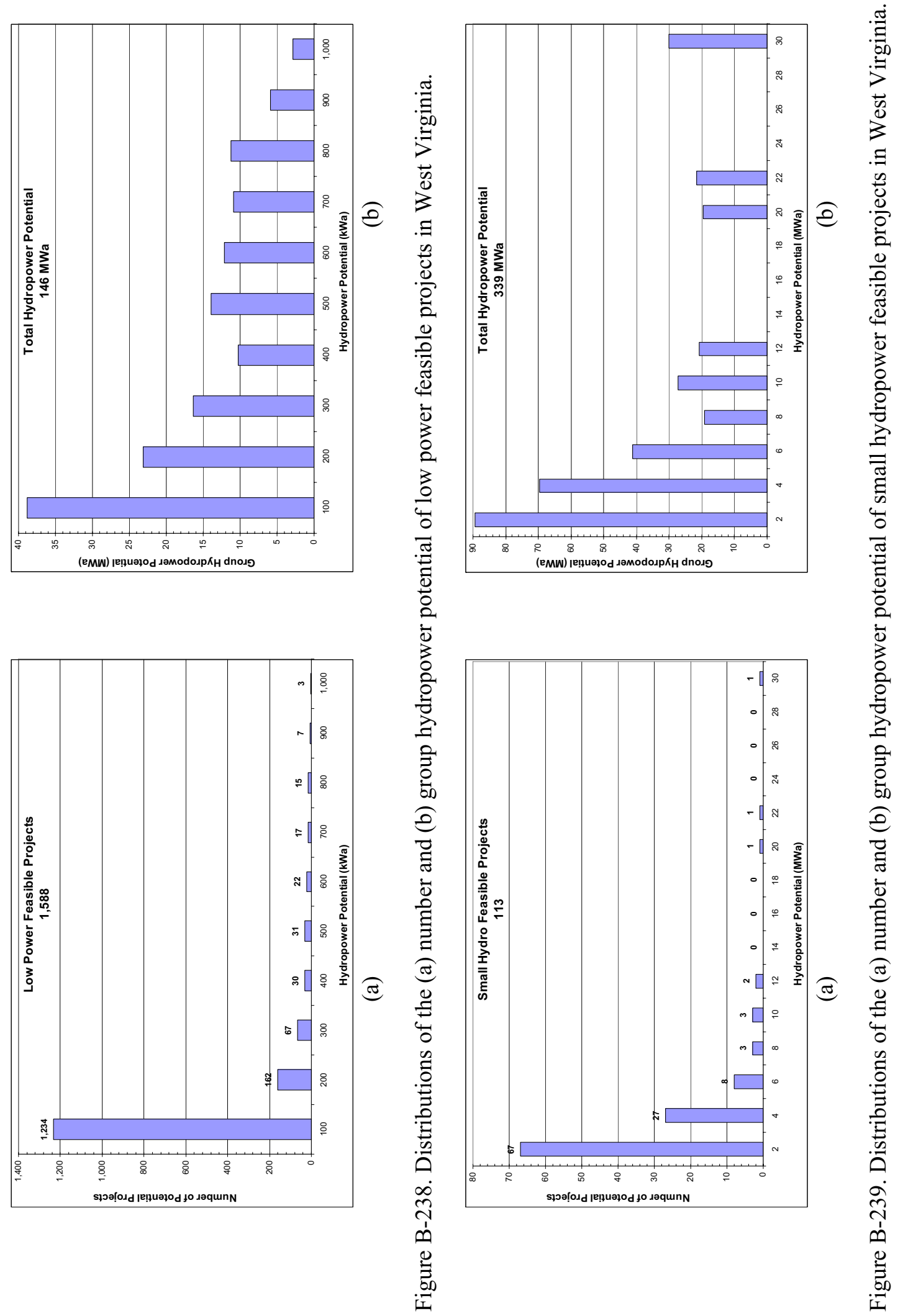

B-197 


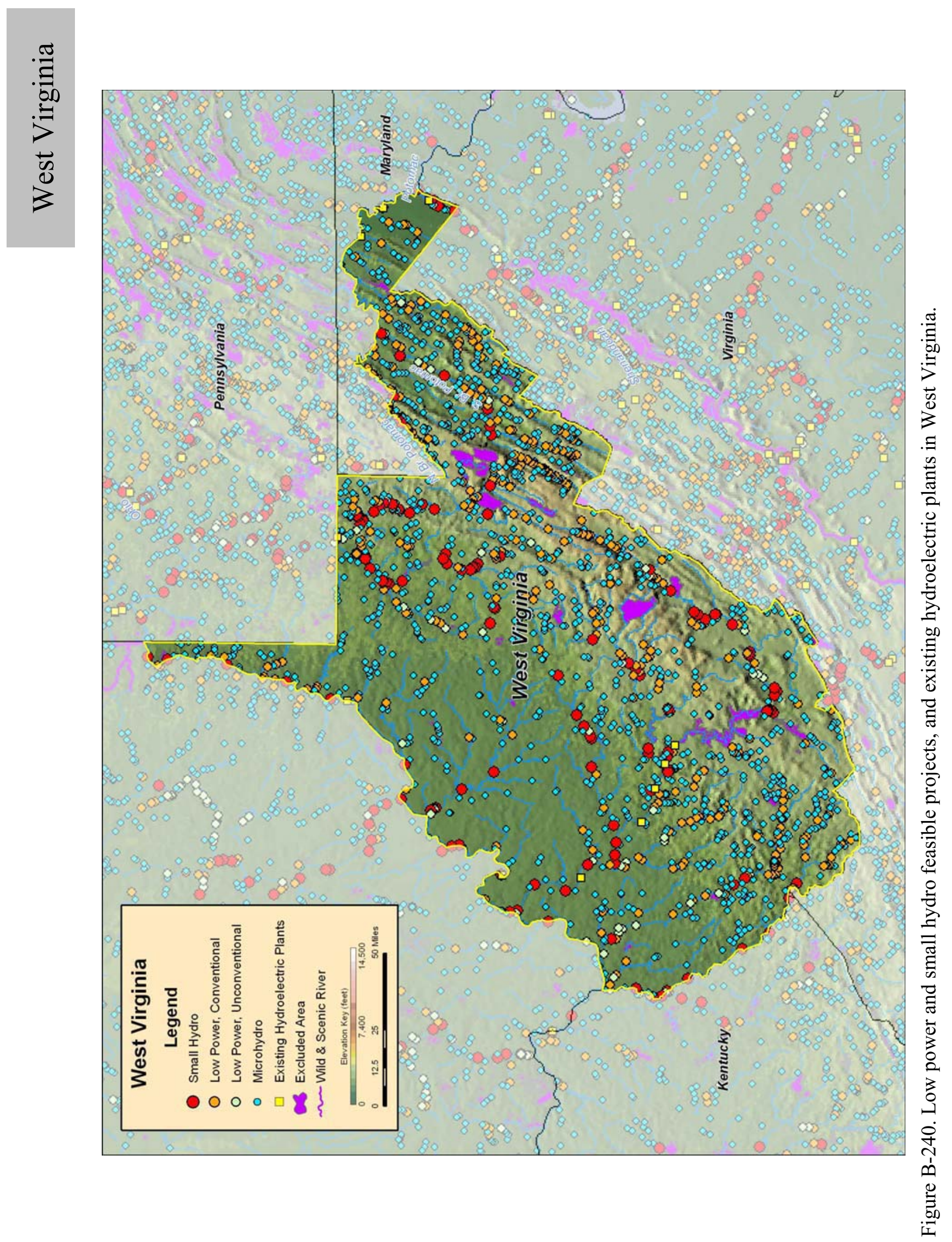




\section{B.49 Wisconsin}

Table B-99. Summary of results of water energy resource assessment of Wisconsin.

\begin{tabular}{|c|c|c|c|c|c|}
\hline Power Class & $\begin{array}{c}\text { Total } \\
(\mathbf{M W a})\end{array}$ & $\begin{array}{c}\text { Developed } \\
(\mathbf{M W a})\end{array}$ & $\begin{array}{c}\text { Federally } \\
\text { Excluded } \\
(\mathbf{M W a})\end{array}$ & $\begin{array}{c}\text { Other } \\
\text { Excluded } \\
(\mathbf{M W a})\end{array}$ & $\begin{array}{c}\text { Available } \\
(\mathrm{MWa})\end{array}$ \\
\hline Total Power & $\mathbf{1 , 5 1 5}$ & $\mathbf{2 4 5}$ & $\mathbf{6 5}$ & $\mathbf{3 6}$ & 1,170 \\
\hline Total High Power & & & & & \\
\hline Large Hydro & $\mathbf{9 4 9}$ & $\mathbf{2 3 0}$ & $\mathbf{3 7}$ & $\mathbf{2 5}$ & 657 \\
\hline Small Hydro & $\mathbf{3 3}$ & 0 & 0 & 0 & 33 \\
\hline & $\mathbf{9 1 5}$ & 230 & 37 & 25 & 624 \\
\hline Total Low Power & & & & & \\
\hline Conventional Turbines & $\mathbf{5 6 7}$ & $\mathbf{1 4}$ & $\mathbf{2 8}$ & $\mathbf{1 1}$ & 513 \\
\hline Unconventional Systems & $\mathbf{3 0 7}$ & 6 & 15 & 8 & 278 \\
\hline Microhydro & $\mathbf{7 7}$ & 7 & 9 & 1 & 60 \\
\hline
\end{tabular}

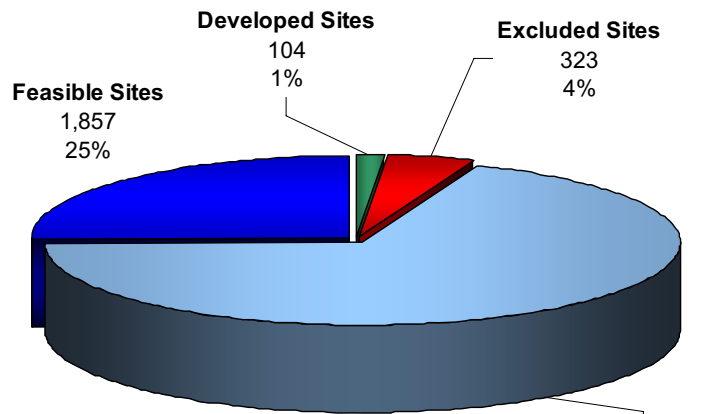

Other Available Sites

5,049

$69 \%$

(a) Total Resource Sites

7,333

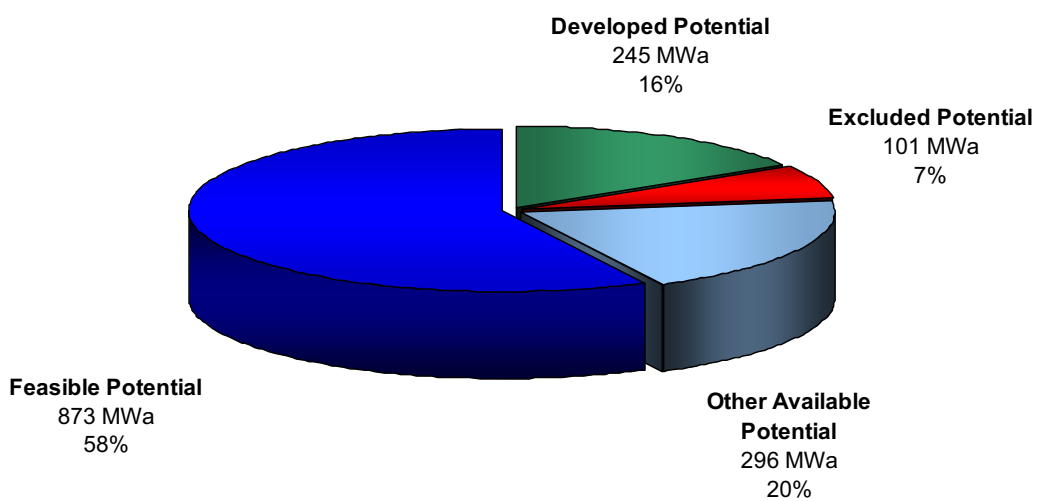

(b) Total Resource Potential $1,515 \mathrm{MWa}$

Figure B-241. Power category distribution of the (a) number and (b) total power potential of the water energy resource sites in Wisconsin. 
Table B-100. Summary of results of feasibility assessment of water energy resources in Wisconsin.

\begin{tabular}{|c|c|}
\hline Power Class & $\begin{array}{c}\text { Available } \\
\text { (MWa) }\end{array}$ \\
\hline Total Power & 1,170 \\
\hline & \\
\hline Total High Power & 657 \\
\hline Large Hydro & 33 \\
\hline Small Hydro & 624 \\
\hline & \\
\hline Total Low Power & 513 \\
\hline Conventional Turbines & 278 \\
\hline Unconventional Systems & 60 \\
\hline Microhydro & 175 \\
\hline
\end{tabular}
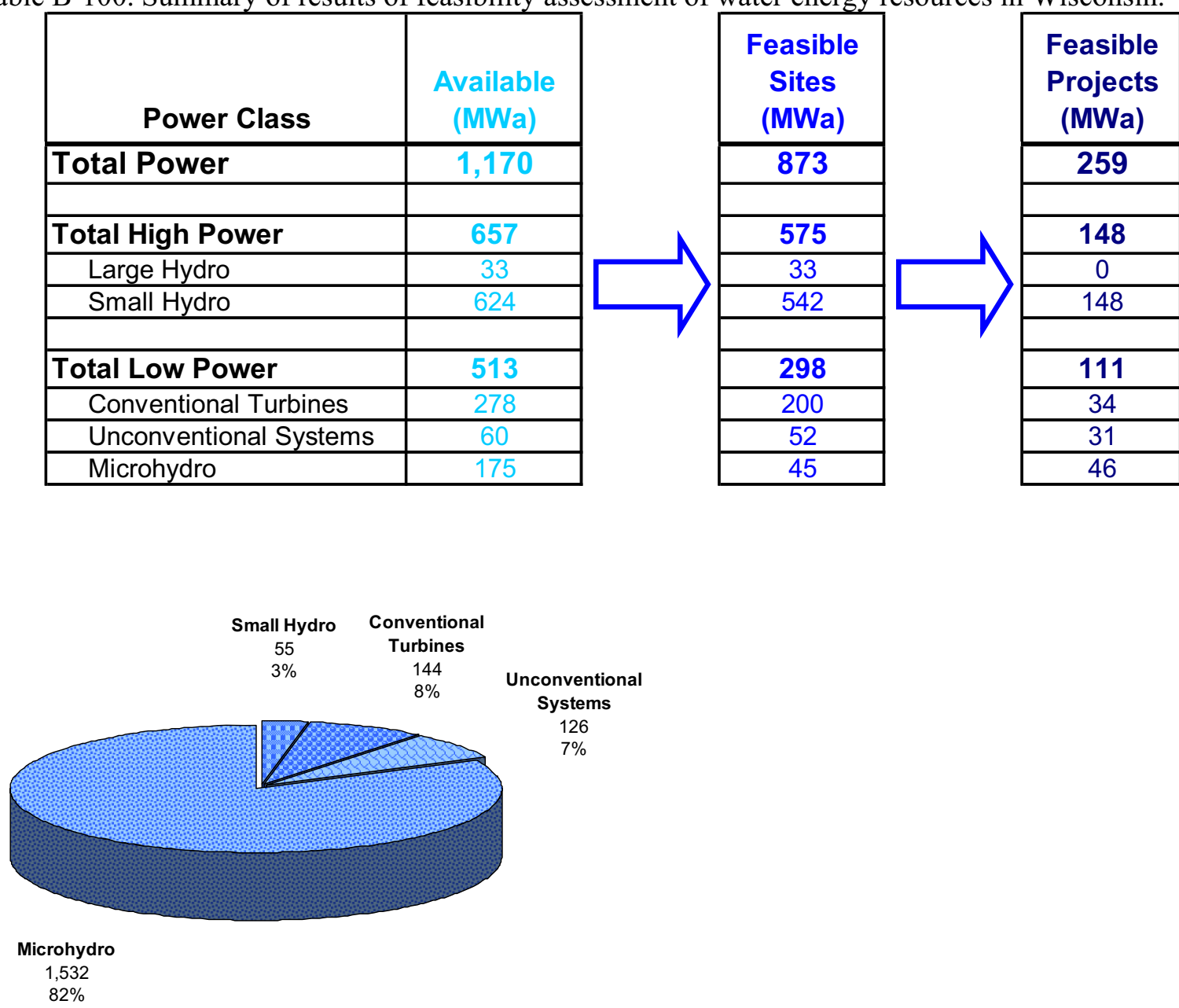

(a) Total Feasible Projects

1,857

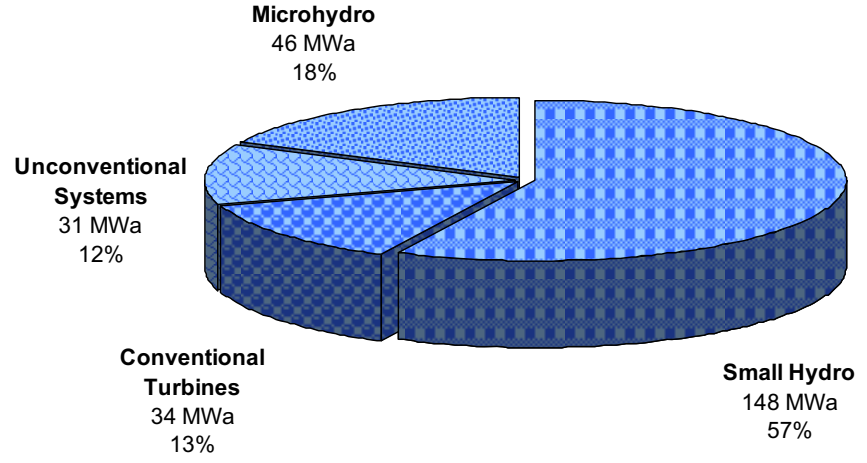

(b) Total Feasible Project Hydropower Potential $259 \mathrm{MWa}$

Figure B-242. Distribution of the (a) number and (b) total hydropower potential of the low power and small hydropower feasible projects in Wisconsin with the low power projects divided into technology classes. 

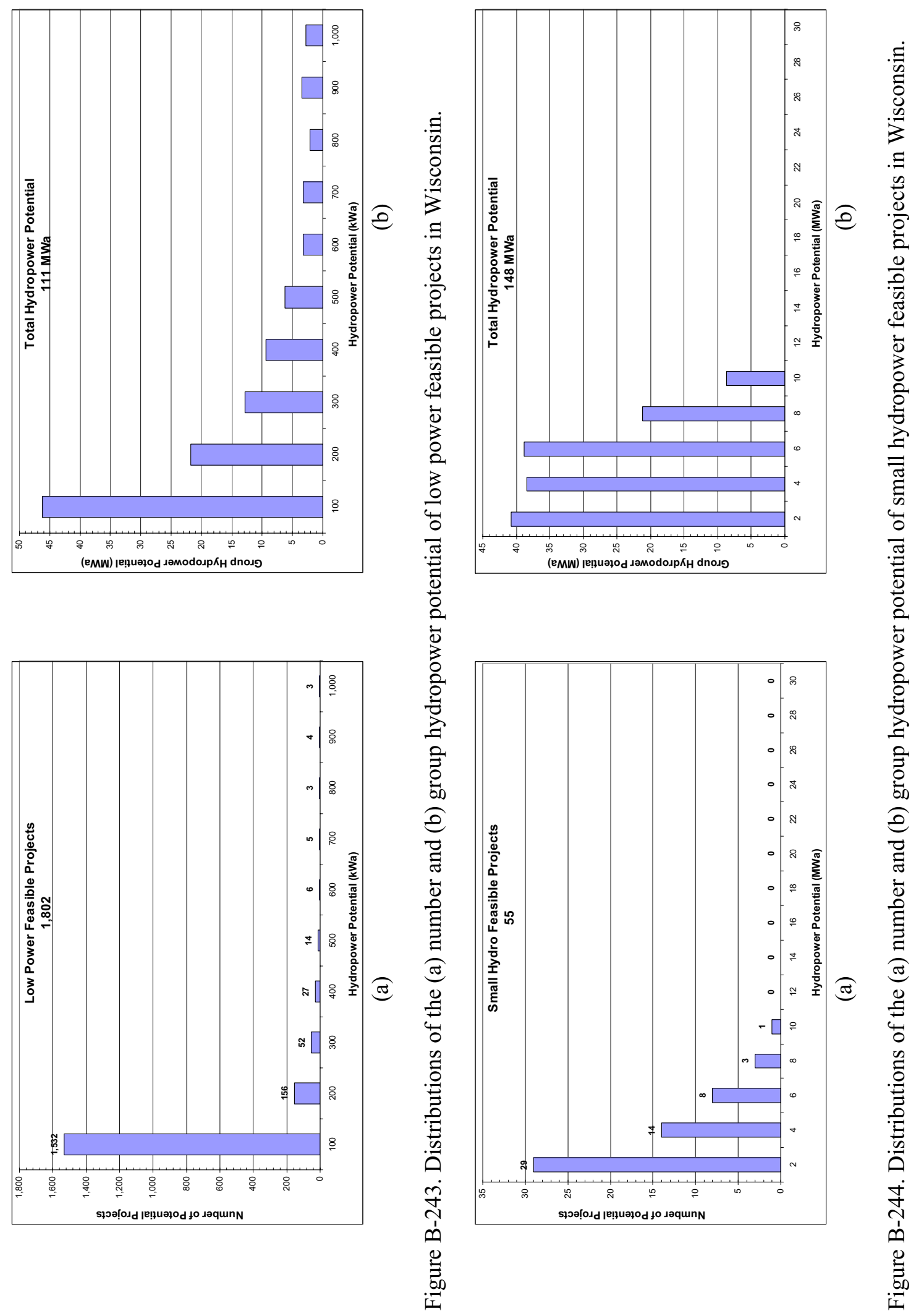


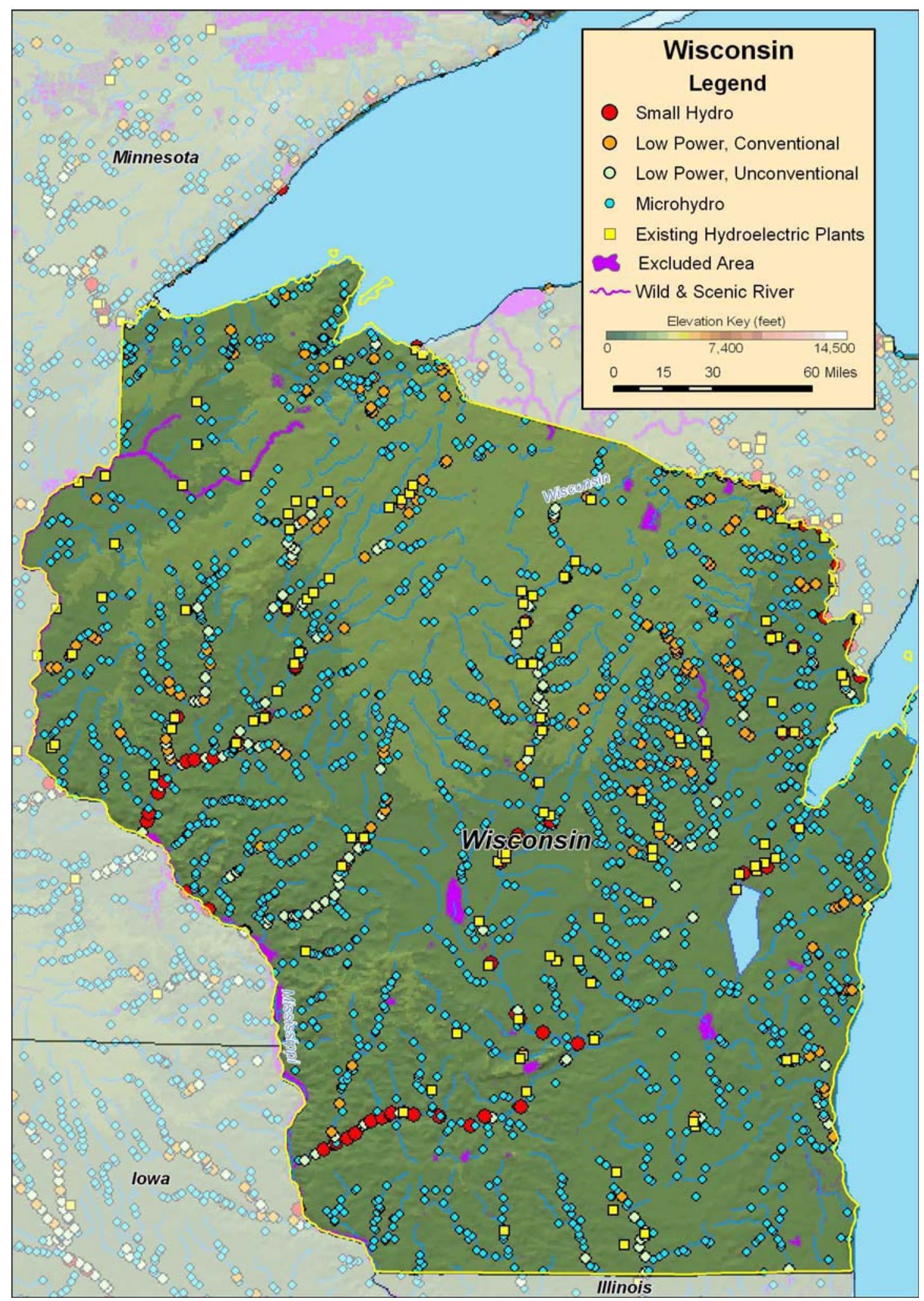

Figure B-245. Low power and small hydro feasible projects, and existing hydroelectric plants in Wisconsin. 


\section{B.50 Wyoming}

Table B-101. Summary of results of water energy resource assessment of Wyoming.

\begin{tabular}{|c|c|c|c|c|c|}
\hline Power Class & $\begin{array}{c}\text { Total } \\
\mathbf{( M W a )}\end{array}$ & $\begin{array}{c}\text { Developed } \\
(\mathrm{MWa})\end{array}$ & $\begin{array}{c}\text { Federally } \\
\text { Excluded } \\
(\mathbf{M W a})\end{array}$ & $\begin{array}{c}\text { Other } \\
\text { Excluded } \\
(\mathbf{M W a})\end{array}$ & $\begin{array}{c}\text { Availlable } \\
(\mathrm{MWa})\end{array}$ \\
\hline Total Power & $\mathbf{5 , 9 9 9}$ & $\mathbf{5 9}$ & $\mathbf{2 , 5 7 3}$ & $\mathbf{1 7 3}$ & 3,195 \\
\hline Total High Power & & & & & \\
\hline Large Hydro & $\mathbf{4 , 2 0 8}$ & $\mathbf{5 8}$ & $\mathbf{2 , 0 5 8}$ & $\mathbf{1 3 5}$ & 1,957 \\
\hline Small Hydro & 143 & 0 & 143 & 0 & 0 \\
\hline Total Low Power & 4,065 & 58 & 1,916 & 135 & 1,957 \\
\hline Conventional Turbines & & & & & \\
\hline Unconventional Systems & $\mathbf{1 , 7 9 1}$ & 1 & $\mathbf{5 1 5}$ & $\mathbf{3 8}$ & 1,238 \\
\hline Microhydro & $\mathbf{1 , 5 1 8}$ & 1 & 485 & 32 & 1,001 \\
\hline
\end{tabular}

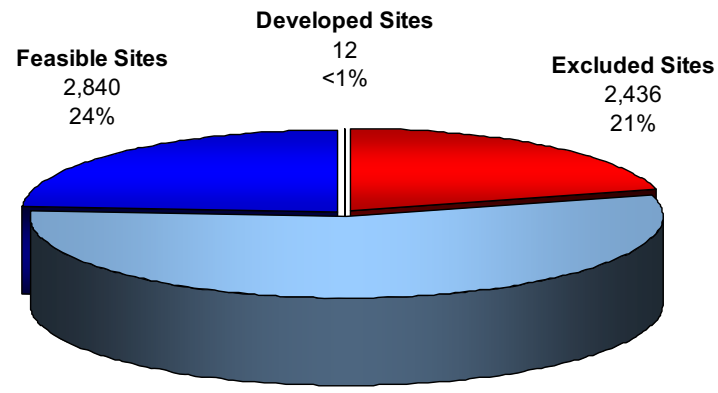

Other Available Sites

6,540
$55 \%$

(a) Total Resource Sites

11,828

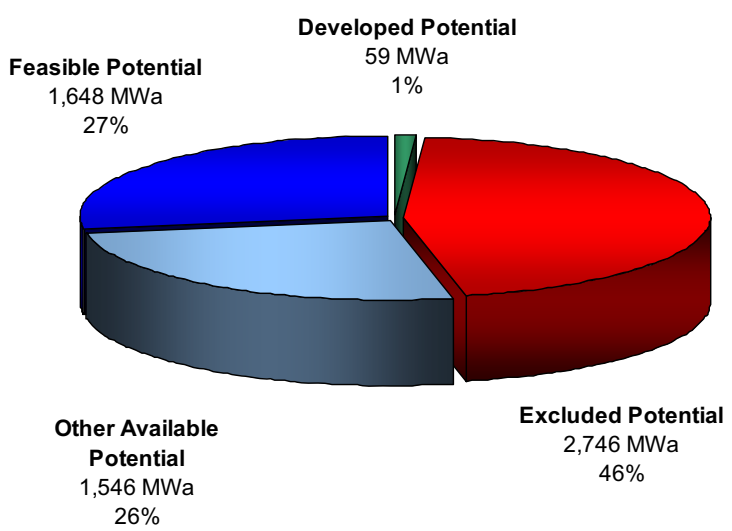

(b) Total Resource Potential $5,999 \mathrm{MWa}$

Figure B-246. Power category distribution of the (a) number and (b) total power potential of the water energy resource sites in Wyoming. 
Table B-102. Summary of results of feasibility assessment of water energy resources in Wyoming.

\begin{tabular}{|c|c|}
\hline Power Class & $\begin{array}{c}\text { Available } \\
\text { (MWa) }\end{array}$ \\
\hline Total Power & 3,195 \\
\hline Total High Power & 1,957 \\
\hline Large Hydro & 0 \\
\hline Small Hydro & 1,957 \\
\hline & \\
\hline Total Low Power & 1,238 \\
\hline Conventional Turbines & 1,001 \\
\hline Unconventional Systems & 46 \\
\hline Microhydro & 191 \\
\hline
\end{tabular}
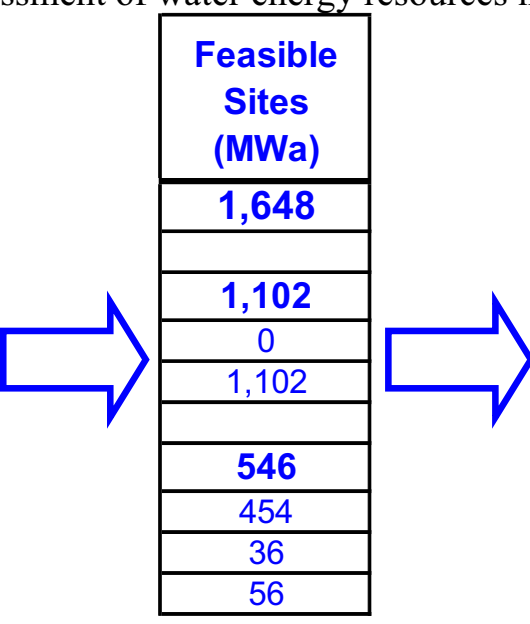

\begin{tabular}{|c|}
\hline $\begin{array}{c}\text { Feasible } \\
\text { Projects } \\
\text { (MWa) }\end{array}$ \\
\hline $\mathbf{5 0 7}$ \\
\hline \\
\hline 160 \\
\hline 0 \\
\hline 160 \\
\hline 347 \\
\hline 256 \\
\hline 20 \\
\hline 71 \\
\hline
\end{tabular}

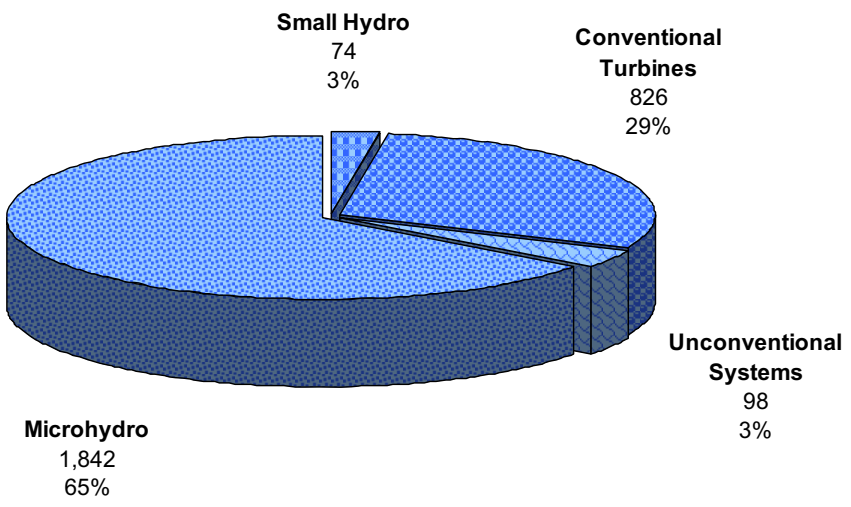

(a) Total Feasible Projects 2,840

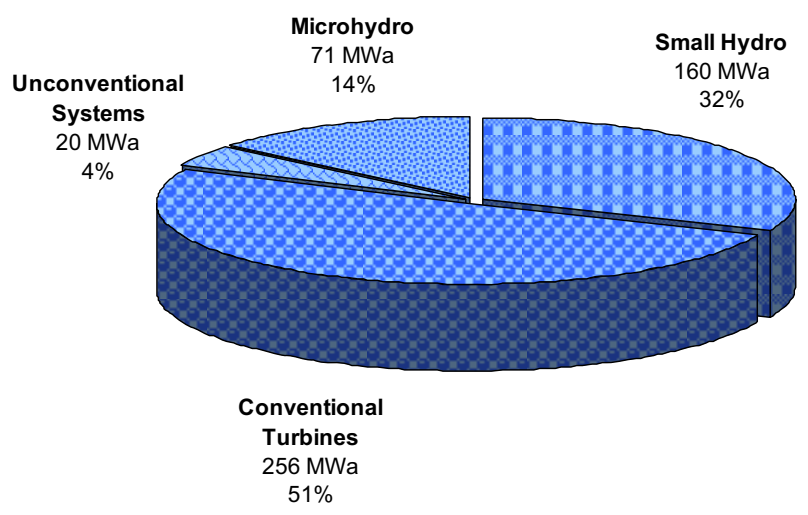

(b) Total Feasible Project Hydropower Potential $507 \mathrm{MWa}$

Figure B-247. Distribution of the (a) number and (b) total hydropower potential of the low power and small hydropower feasible projects in Wyoming with the low power projects divided into technology classes. 

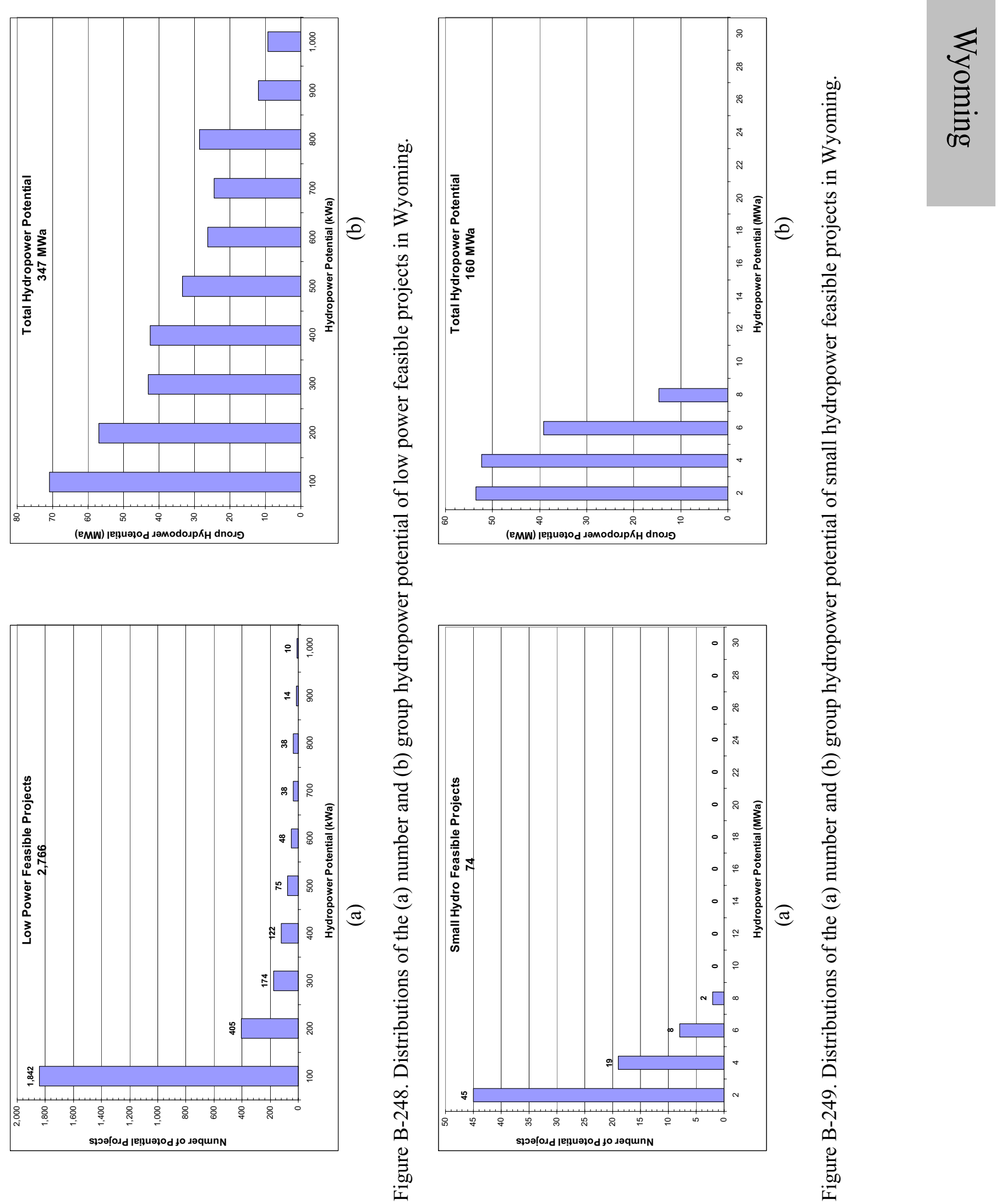

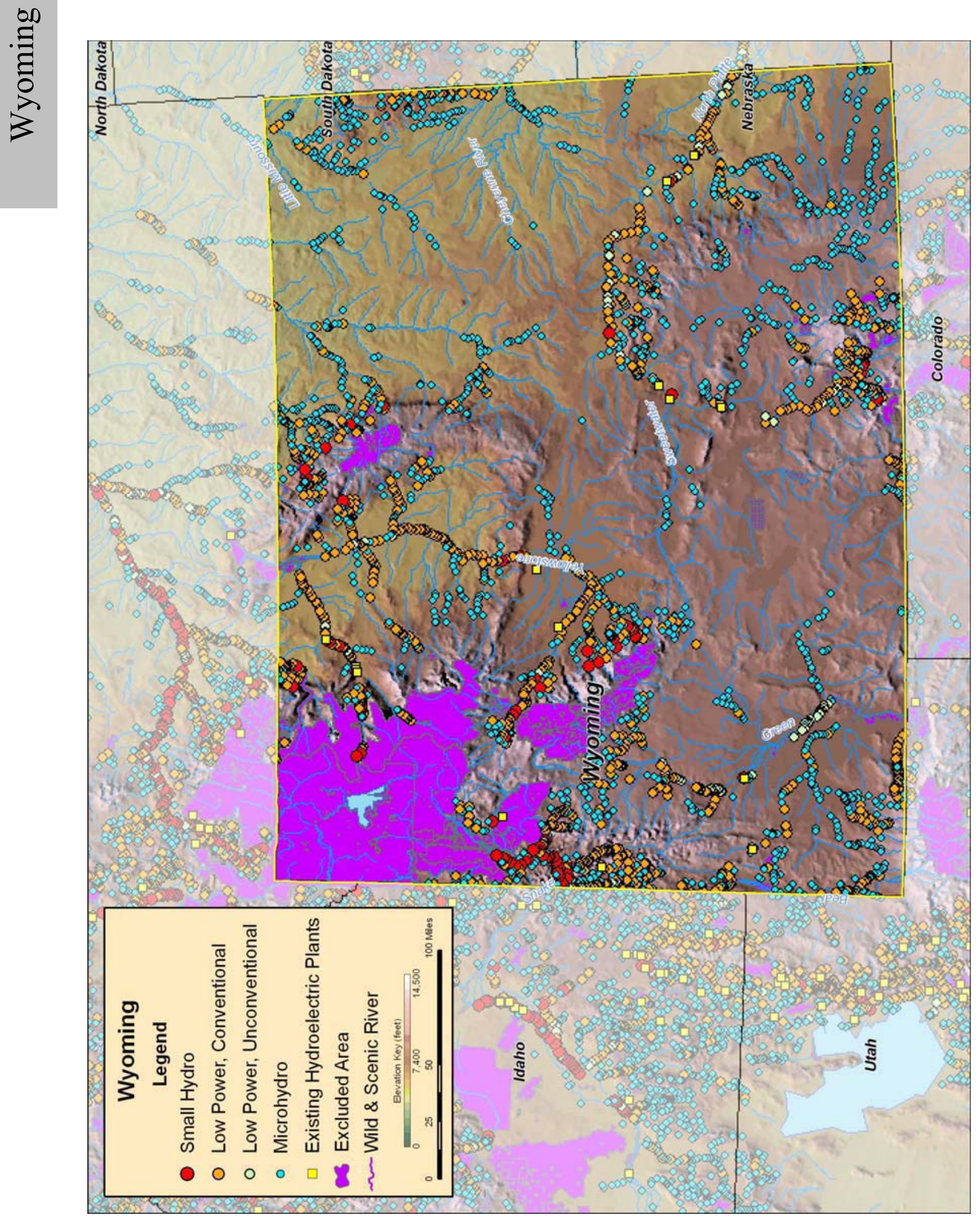

|0 